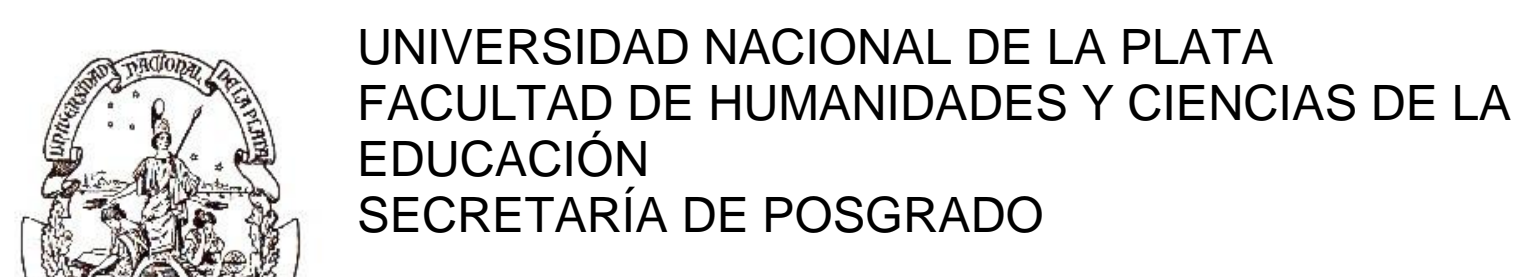

\title{
JAIME REST: \\ FUNCIÓN CRÍTICA Y POLÍTICAS CULTURALES (1953-1979)
}

De Sur al Centro Editor de América Latina

\author{
Lic. Maximiliano Crespi
}

Tesis para optar por el grado de Doctor en Letras

Director: Dr. Sergio Pastormerlo (UNLP)

Presentación: La Plata, 22 de marzo de 2013. 
Tesis Doctoral defendida el día 7 de junio de 2013.

Calificación: 10 puntos (sobresaliente, con mención honorífica y recomendación de publicación).

Título obtenido: Doctor en Letras

Jurado evaluador: Jorge Monteleone, Miguel Dalmaroni y Jorge Lafforgue. 


\section{ÍNDICE}

Introducción ……………………………………………………………………....

01. Un punto de partida (1945-1955) ……………............................. 37

Apéndice 1: Borges, Descartes y el obispo Wilkins ........... 127

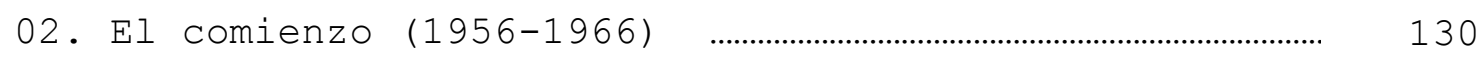

Apéndice 2: Notas para una estilística del arrabal ........... 245

03. La literatura y el mal (1966-1973) ......................................... 265

Apéndice 3: Sade y la crisis del racionalismo .......................... 335

04. La ficción crítica (1973-1976) ........................................................ 363

Apéndice 4: Los narradores argentinos y la búsqueda de

un idioma nacional ......................................................................................... 458

05. Editar, traducir, divulgar, enseñar (1976-1979)......... 472

Apéndice 5: Reflexiones de un traductor ..................................... 547

Consideraciones finales sobre el proyecto intelectual..... 567

Apéndice 6: Tierra baldía de T. S. Eliot .................................... 596

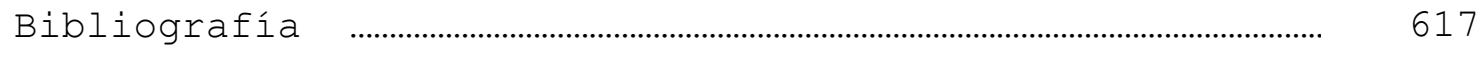


«The direction of our interests, whether intellectuak or aesthetic, is decided by the times in which we live.» 


\section{INTRODUCCIÓN}

Jaime Rest nació en Buenos Aires el 2 de julio de 1927. Según consta en su acta de nacimiento, era hijo de Isaac Rest y de Cecilia Rosenfeld, ambos de origen ruso. ${ }^{1}$ Desde muy joven, durante su infancia en Banfield, acaso influenciado por su hermano Jacobo (12 años mayor que él), exhibió -a juzgar por una serie de recortes de diarios, una colección de programas de películas proyectadas en los cinematógrafos porteños y varios libros hallados en su biblioteca personal y que datan de esa época- una afición particular por el universo de la literatura y la cultura.

Cursó sus estudios secundarios en el Colegio Mariano Moreno, del cual egresó con impecables calificaciones en el año 1946. Al año siguiente, ingresó a la Facultad de Filosofía y Letras de la Universidad de Buenos Aires, donde el 16 de diciembre de 1953 (con apenas 26 años) se graduó como Licenciado en Letras con la especialidad en Literatura de Europa Septentrional (Anglosajona) y con una tesis de licenciatura titulada "Los ensayos de Virginia Woolf", cuyo nudo reflexivo se centraba en la «función de la crítica» en los ensayos de la destacada escritora inglesa. En ese ámbito conoce y traba amistad con los tres maestros locales que

\footnotetext{
1 Salvo expresa excepción, todas las referencias biográficas de este trabajo se basan en los documentos guardados en el "Fondo documental Jaime Rest, 1927-1979", Colección 2001-3, Colecciones Especiales y Archivos, Universidad de San Andrés, Argentina, sobre el material donado a dicha institución por Guillermo Erhart del Campo (cuñado de Jaime Rest) y ordenado por el equipo de "Organización, preservación y difusión del archivo personal del escritor, traductor y crítico literario Jaime Rest" coordinado por la Lic. Silvana Lucía Piga.
} 
resultarán determinantes para su formación: el historiador José Luis Romero, el filósofo Luis Juan Guerrero y el filólogo Ángel José Battistessa.

Ejerció la docencia universitaria en la Universidad de Buenos Aires, donde -entre 1956 y 1963- fue profesor adjunto de Literatura Inglesa y Norteamericana compartiendo cátedra con Jorge Luis Borges; y también en Bahía Blanca, en el ámbito de la Universidad Nacional del Sur, donde se desempeñó como profesor titular de las cátedras de Literatura Europea Medieval, Literatura Europea Moderna y Literatura Europea Contemporánea, entre 1959 y 1975, cuando fue compulsivamente cesanteado. Pero su vida académica no se redujo sólamente a la actividad docente sino que también se dedicó afanosamente a la investigación literaria, actividad que quedó plasmada en numerosas conferencias dictadas tanto en Buenos Aires como Bahía Blanca y otras ciudades de Argentina, participó además activamente, entre los años 1966 y 1972, en las célebres Jornadas de Investigación y Enseñanza de la Historia y Literatura Argentina y de los Estados Unidos que se dictaban anualmente en diferentes sedes nacionales.

A lo largo de casi tres décadas de producción ininterrumpida, publicó una extensa y diversa obra crítica entre cuyos títulos más importantes se destacan Literatura y cultura de masas (1967), Tres autores prohibidos y otros ensayos (1968), El laberinto del universo. Borges y el pensamiento nominalista (1976), Mundos de la imaginación (1978), Conceptos de literatura moderna (1979) y El cuarto en el recoveco (póstumo, 1982). Publicó además un sinnúmero de artículos y trabajos críticos en revistas como 
Centro, Imago Mundi, Sur, Cuadernos del Sur, Revista de la Universidad de Buenos Aires, Crisis, Fausto, Marcha, Los libros, Punto de Vista y Vigencia, entre otras.

Si bien su campo de investigación académica es, en efecto, el relativo a la literatura inglesa y norteamericana, Rest desarrolló también un proyecto de investigación paralelo sobre el creciente campo de las producciones culturales masivas. Se interesó muy especialmente por las literaturas consideradas "menores", en la misma medida que no dejó de prestar atención a las diversas manifestaciones de la música popular, el teatro, el cine, la historieta. En esta línea se encamina el grueso de su trabajo de divulgación cultural periodística -donde en varias ocasiones firmó artículos con el seudónimo de Agustín Reja-, ámbito de producción en el que, además de sus colaboraciones en la prensa gráfica, sostuvo una extendida labor en radio con la producción de cerca de 52 programas emitidos en Radio Nacional entre 1956 y 1966.

Sin perder de vista esta diversidad de intereses, durante la década del sesenta y setenta participó activamente en los formidables proyectos editoriales dirigidos por Boris Spivacow, EUDEBA y Centro Editor de América Latina (CEAL); contribuyó con en el diagrama de los catálogos de proyectos como el de Ediciones Librerías Fausto, fundada por el librero Gregorio Schvartz, y la venezolana Monte Ávila Editores -con la que tomó contacto a partir de su amistad con Carlos Gardini y Héctor Libertella. En cada uno de esos proyectos colaboró desempeñando numerosas actividades, ya sea coordinando antologías, redactando prólogos e 
introducciones, supervisando y corrigiendo trabajos o realizando cuidadosas traducciones del inglés y en algún caso también del alemán .

En el año 1963, Jaime Rest se casó con su compañera de toda la vida, Virginia Erhart, profesora en Letras, investigadora y traductora, con quien compartió, tanto el profundo y genuino interés por la "alta" literatura anglosajona como el creciente fervor por las producciones de la cultura popular y masiva, hasta el final de su vida, ocurrido sorpresivamente en Buenos Aires el 8 de noviembre de 1979, cuando el crítico contaba apenas con 52 años de edad.

Los que lo conocieron personalmente aseguran que había algo de monstruoso en el rostro de Jaime Rest; sin embargo -y casi sin excepción-, agregan que era algo que el oyente olvidaba cada vez que él empezaba a hablar de literatura -como si lo monstruoso perdiese su carácter de anormalidad en los mundos imaginarios que prefiguran, a la vez, un más allá de la Norma y la Transgresión. Es probable que algo de ese encantamiento monstruoso con que en sus clases Rest fascinaba la mirada de los otros sobreviva -como figura en la alfombra- en la propia imagen que -a través de una serie irregular de evaluaciones parciales- se desprende de su proyecto intelectual. Y es probable también que algo de la condición intratable de lo monstruoso termine condicionando no pocos de los intentos por establecer las coordenadas centrales para una evaluación integral de su trabajo crítico. 
Sin duda, la multiplicidad de aristas que presentan los escritos de Rest ha dificultado -o al menos parcializado- en gran medida sus abordajes. Aun así, no es difícil observar que se le reconocen múltiples aportes y contribuciones específicas a la conformación de la crítica literaria y cultural moderna en la Argentina. Resumiendo algunos de sus aspectos fundamentales, cabe afirmar que un justo reconocimiento a esa obra crítica compleja y diversificada no puede dejar de pasar -en un orden más o menos arbitrario- sobre algunos núcleos principales de intervención: a) en primer lugar, acordando con Nicolás Rosa en que -a lo largo de arduos años de trabajo y formación académica- Rest llegó a constituirse en un singular «crítico de dos literaturas», abriendo un modo de indagación de notable consonancia con lo que años más tarde llegarían a ser los estudios de "literaturas comparadas" -prueba de ello son sus minuciosas lecturas articuladas entre literaturas europeas diversas (1955b, 1955c y 1956c), entre la literatura inglesa y la argentina (1954c, 1965a y 1967e), pero también sus estudios en torno a la cultura popular y a la "alta" literatura, realizados desde la postulación de un "punto de vista móvil" a través del cual un exigente tematismo se dispone a pensar procesos de constitución de identidades culturales y procesos de institucionalización de las literaturas nacionales, en una línea de investigación aún hoy productiva en términos críticos-; b) en segunda instancia, subrayando también sus aportes concretos como investigador precursor y analista de la llamada "cultura de masas", como introductor de los trabajos producidos en esa línea por Roland Barthes, Walter Benjamin, Theodor Adorno, Max Horkhei- 
mer y Marshall McLuhan -a quienes presentó en sus exploratorios análisis de las complejas relaciones entre cultura de masas, cultura popular y medios de comunicación en el dinámico devenir de las sociedades modernas; c) reconociendo su labor de iniciador de la corriente de los llamados "estudios culturales" en el país, no sólo como divulgador de la línea teórica más importante del llamado "culturalismo inglés" -Richard Hoggart, Raymond Williams, Frederik Jameson y figuras posteriores de la talla de Kenneth Burke, William Empson, Susanne Langer o H. E. Bates-, sino también por sus precursoras investigaciones alrededor de "La Pena de Muerte" (1962), sus estudios de la "estilística del arrabal" (1965a), sus escritos sobre "Las literaturas marginales" (1972b) - sus investigaciones sobre el cine de Michelangelo Antonioni o Ingmar Bergman (1957d y 1970g), el tango de Carlos Gardel (1979i), el modernismo transgresivo de Homero Manzi (1965a) y el «absurdo crítico» en los textos de John Lennon (1964e); d) atribuyendo valor objetivo al hecho de que, como lector atento de los aportes teóricos del formalismo ruso -a través de figuras como Víktor Shklovski, Borís Eijenbaum, Vladímir Propp y Roman Jakobson- y luego del estructuralismo -en los textos definitivos de Gérard Genette, Tzvetan Todorov y A. J. Greimas-, Rest decidiera legar una importante serie de trabajos abocados a desentrañar la dinámica que rige los múltiples procesos de formación y transformación de los géneros literarios (1971b y 1979h), deteniéndose especialmente en la problemática del ensayo (1979h y 1982), no sólo como curiosidad genérica, sino como singularidad formal y específica en la problematización y el diseño de una identidad 
cultural argentina; e) señalando, asimismo, su estratégica contribución a la formalización y establecimiento y actualización de un cuerpo fundamental de conceptos teóricos básicos para la interpretación crítica de la literatura moderna (1979a); o f) subrayando su importante labor como traductor, divulgador y gestor cultural de un contra-canon basado en la recuperación de literaturas "malditas" y "autores prohibidos" o de literaturas marginadas como el policial negro o el gótico, apuntalado en la insistencia en un modo de interrogación crítico-filosófica centrado en las relaciones que eso que es llamado "literatura" establece con los regímenes de verdad, con las estructuras del presente en el que un texto es designado y conjurado bajo ese rótulo (1968b,1970h y 1971c), ya en el desempeño de su trabajo docente, ya en su significativa contribución en proyectos culturales y editoriales como CEAL y Ediciones Librerías Fausto.

La multiplicidad de orientaciones en que diversifica su actividad devuelve ecos concretos en los rasgos característicos de su dispositivo crítico -la delimitación de sus corpus, el recorte de sus objetos, la elección de su perspectiva metodológica, etc.y parece ser, finalmente, la causa de que toda alusión a su proyecto intelectual insista en la categoría de "excentricidad" para señalar su colocación border. No es extraño, en efecto, que esta generosa y polifacética obra crítica resulte casi siempre abordada de manera parcial y que hasta el momento no haya aún un ensayo de lectura integral de la misma. El hecho no es justificable pero es de algún modo comprensible. En principio, porque el corpus de textos publicados por Rest es mucho más 
extenso y diverso de lo que suele creerse y, en consecuencia, establecer siquiera una jerarquización inicial en función de un recorte de corpus requiere ante todo un rastreo que no puede realizarse más que a partir de un demorado trabajo de archivo. Y, en segundo lugar, porque esta inclasificable "obra" no termina de cerrar del todo con ninguna "tradición crítica", al punto que si hubiera que describir el trabajo crítico restiano con justicia, más que apuntar su excentricidad y su dispersión, habría que empezar por señalar que él mismo es la prueba de un proceso de transformaciones encarnado en un proyecto intelectual; proceso cuyos efectos colaterales acaban por determinar -irónica o paradójicamente- la neutralización o la relativización de las taxonomías disciplinarias cerradas que pretenden ficharlo o asignarlo a un lugar definitivo.

Incluso las evaluaciones parciales de su trabajo crítico no son más que unas pocas. Acaso la primera referencia importante a la obra de Rest sean los breves pero sustanciosos párrafos que Nicolás Rosa le dedica en el fascículo titulado "La crítica literaria contemporánea" de la colección Capítulo. Historia de la literatura argentina, publicada por Centro Editor de América Latina en $1981 .{ }^{2}$ En este precursor trabajo -reeditado años después, bajo el título de "La crítica literaria argentina actual. Convergencias/Divergencias", en Los fulgores del simulacro3-, Rosa lee la producción restiana desde la lógica del

\footnotetext{
2 Rosa, N., "La crítica literaria contemporánea", en Zanetti, S. (ed.), Capítulo, La historia de la literatura argentina, $\mathrm{N}^{0}$ 113, Buenos Aires: CEAL, 1981.

3 Rosa, N., "La crítica literaria argentina actual. Convergencias / Divergencias", Los fulgores del simulacro, Santa Fe, Cuadernos de extensión
} 
"exceso". Luego de ubicarlo junto a Enrique Pezzoni (1926-1989) «entre la estilística y la crítica estética» como dos excéntricos respecto de los núcleos o bases teóricas que pautaron su formación, Rosa plantea el carácter excesivo de Rest en relación a varios rasgos fundamentales de su producción.

En primer lugar, subraya especialmente la productividad crítica de Rest con una enumeración ejemplificadora. Seis libros y un número indefinido de artículos y trabajos dispersos permiten a Rosa caracterizar su obra como «cuantitativamente importante en un género que, en nuestro país, se caracteriza por sus magros resultados escriturarios» (Rosa 1981: 373). En segundo lugar, sostiene que la obra restiana se exhibe también como un exceso respecto de la crítica erudita de la que proviene, en tanto su erudición se articula sobre un «refinamiento irónico» que supone un uso desconfiado de un saber acumulado cuya aplicación mecánica corre el riesgo de convertirse en un gesto de «mera documentación protocolar» (Rosa 1981: 373). El crítico rosarino percibe -con claridad meridiana- que el saber cultural acumulado que porta Rest no se presenta con «la pasión negligée de la crítica impresionista» que -como ocurre en el caso de Victoria Ocampoaparece «lateralizada por su consubstanciación con el texto o con el autor»; sino que, al contrario, se presenta como «la pasión ardiente de un saber que objetiva lúcidamente sus objetos de amor [los textos]» (Rosa 1981: 373). No sólo porque la crítica ensayada por Rest se niega sistemáticamente a tipificar esos «objetos amados», sino porque insiste -tenazmente- en mostrar su 
singularidad, subrayando su diferencia sin desdeñar el sentido de su inserción histórica. Dicho en los propios términos de Rosa, lo que la crítica restiana pone en escena es un dispositivo de «lectura histórica de las diferencias entre épocas y autores» cuyo objetivo es recobrar «su profunda historicidad, y no las meras marcas historiográficas de superficie» (Rosa 1981: 373). En tercer lugar, Rosa señala el carácter excesivo de la producción restiana con relación a su «forma genérica». «Es -apunta Rosa- un exceso instalado entre el ensayo y la crítica, un exceso entre la literatura argentina y las literaturas europeas, un exceso entre la crítica y la ficción» (Rosa 1981: 373). Esos rasgos -que Rosa vincula estrechamente a «su lectura constante de Borges y de la literatura de habla inglesa»- son los que han ido despegando la producción restiana del «ensayo libre a la manera de Virginia Woolf», refinándola y ajustándola (retórica e imaginariamente), para dar lugar a un espacio textual capaz de «franquear la distinción entre crítica y ficción» (Rosa 1981: 374). Rosa sostiene pues el argumento de que la crítica restiana es una suerte de relato complejo donde el recurso filológico de rastreo de fuentes se articula en «una tarea de pasión detectivesca» cuya metafórica constante es justamente la del tramar del texto y cuyo objetivo es, en consecuencia -en un sentido no distante del que pulsaba los ensayos de Virginia Woolf-, «reconstruir la obra en su experiencia humana traspuesta estéticamente» (Rosa 1981: 374). En el esquema propuesto por Rosa sobre el dispositivo crítico de Rest subyace, a la vez, una analogía lábil con el policial y un trasfondo decadentista que hace inevitable el nombre de Thomas 
de Quincey y la referencia a On Murder Considered as One of the Fine Arts (1827): «Lector (detective) y autor (de la obra, ¿del crimen?) encontrarán su inmixión absoluta en el espacio del goce inteligente» (Rosa 1981: 374). La crítica de Rest se presentaría pues -en la perspectiva de Rosa- como una suerte de doble invertido de la literatura borgeana, con la que comparte el deseo de poner al lector ante un «goce inteligente». De la misma manera en que los textos literarios de Borges cruzan sin restricciones e iluminan el campo del ensayo y la crítica literaria -cabe pensar aquí, a modo de ejemplo, en textos como "Pierre Menard, autor del Quijote" o "Examen de la obra de Herbert Quain"-, el texto crítico restiano se presenta ante Rosa bordeando la «ficción crítica» (Rosa 1981: 374). El ejemplo con que Rosa apuntala su hipótesis -"Elocuencia de la noche y el silencio" (1978b)- es pertinente; pero la hipótesis bien puede extenderse al grueso de la producción crítica literaria de Rest que incluye textos juveniles como "Borges, Descartes y el obispo Wilkins" (1952c), "Inadvertencia Preliminar" (1964e), "Crímenes de biblioteca" (1978b: 299-325) o "La neurastenia de Franny y el budismo Zen de Zooey" (1979c), que cada uno a su vez exhiben significativos rasgos experimentales. Por ello, es lícito sostener con Rosa que lo que subyace a los cuidados y eruditos textos de Rest es un intento por establecer un principio ético y estético fundamental: el de la crítica considerada como una de las bellas artes. De algún modo, este aspecto particular es el que determina el último rasgo de la crítica restiana: el que remite al exceso que esta supone «respecto a sus modelos mayores (Lionel Trilling, Edmund 
Wilson, Virginia Woolf)». En efecto, lo que el crítico rosarino percibe con nitidez es que con Rest se clausura casi definitivamente una línea de producción crítica «que difícilmente pueda proyectarse en etapas posteriores, a menos que reaparezca traspuesta en otras experiencias, en otros textos, en otros críticos» (Rosa 1981: 374).

En "El excéntrico Jaime Rest" (1999)", Pablo Bardauil ensaya la que acaso sea hasta aquí la única lectura transversal -aunque incompleta- del trabajo de Rest. Siguiendo rigurosamente la perspectiva de Rosa, interpreta su producción crítica bajo la hipótesis de la excentricidad, dividiendo el trabajo de la lectura en cinco apartados recortados a su vez sobre cinco "contradicciones" o pares excluyentes. Pero, antes de concentrarse particularmente en el señalamiento de los rasgos de excentricidad al interior de la producción restiana, Bardauil se detiene en dos rasgos significativos de su aspecto exterior y general: el movimiento de «inquietud constante» que pulsa las búsquedas restianas y la «discreta repercusión» suscitada por sus textos en la crítica argentina, pese a su carácter relativamente voluminoso si se lo compara con las producciones de gran parte de sus contemporáneos. En la perspectiva de Bardauil, de la segunda condición se deriva la primera característica. Es en este sentido que subraya con especial énfasis la excentricidad de Rest respecto de los diversos modos que asume su escritura -entre el ensayo y la crítica académica-, respecto de sus "intereses" -por

\footnotetext{
4 Bardauil, P., "El excéntrico Jaime Rest", en Rosa, Nicolás (ed.), Políticas de la crítica. Historia de la crítica literaria en la Argentina, Buenos Aires, Editorial Biblos, 1999. pp. 183-215.
} 
la «forma»y por «las relaciones entre arte y vida»-, el interés genuino de Rest tanto por la "alta literatura" como por la cultura de masas o su paralela y simultánea atención hacia la literatura argentina y la anglosajona. El ensayo de Bardauil se cierra con una página significativa sobre el modelo de trabajo de Rest como precursor de ciertos modelos de Estudios culturales en el país, pero no incluye su aporte como gestor cultural, editor y traductor de las teorías del culturalismo inglés al marco de un proyecto intelectual más amplio.

El primer problema con esta lectura de Bardauil es el mismo que subyace en la primigenia lectura de Nicolás Rosa: sus precisas descripciones y sus sugestivas hipótesis -retomadas y discutidas en el curso de este trabajo-, exhiben cierta fragilidad en razón de que reducen su contextualización al interior del propio proyecto crítico de Rest, dejando de lado la inscripción del proyecto intelectual en un campo de fuerzas históricas configurado en función de coordenadas sociales, culturales y políticas precisas. Al desatender o menospreciar las particulares condiciones de producción de los trabajos restianos, este modelo de lectura no consigue explicar el sentido y las razones de la "excentricidad" que el mero listado de obras publicadas por Rest expone como una fatalidad en apariencia caprichosa. Pierde de vista el componente histórico, esencial a la hora de establecer el sentido de la forma, la contextura y la táctica que subyace a esos movimientos en apariencia erráticos. En efecto, el constante «vaivén» entre «intereses presuntamente incompatibles», las contradicciones de un proyecto crítico ligado 
a un «movimiento pendular», devuelve la imagen de una pulsión histérica tanto con relación a su propio género -entre el ensayo y la crítica académica-, a sus intereses -entre la forma y por las relaciones arte-vida-, a sus objetos -entre la "alta" literatura y la literatura de masas-, por sus corpus -entre la literatura argentina y la literatura inglesa- o por sus perspectivas de enfoque -entre la crítica literaria y los estudios culturales. En una palabra, lo que esa lectura deshistorizada -que, si bien da cuenta lateralmente en su argumentación de las otras tareas desempeñadas por Rest en simultáneo a su producción crítica, no consigue tampoco integrarlas al programa de un proyecto intelectual- no llega a captar no son los rasgos de la cambiante obra, sino la deriva precisa del cambio producido al interior de ese proyecto intelectual, en el que se inscribe su trabajo crítico pero también su labor incansable como docente, gestor cultural, editor y traductor e incluso como introductor de teorías literarias y culturales particulares.

El segundo $-y$ sin dudas sustancial- problema de estas lecturas radica en que -como consecuencia de la modulación deshistorizada de su perspectiva-, en el análisis de las causa de la «discreta repercusión» de los textos restianos, no se toma en cuenta como dato efectivo el hecho de que las repercusiones de los trabajos críticos -y muy en especial los de algunos de sus enérgicos contemporáneos- extraen en un grado considerable su efectismo coyuntural de una performatividad retórica y cierta pulsión polémica, beligerante, protestativa y "denuncialista" 
(Avaro y Capdevila, 2004), por completo ajena a la ética de escritura y a la perspectiva ideológica desde la que se produce y justifica el proyecto de trabajo crítico de Jaime Rest.

Más específicos y, por ello mismo, menos integrales, dos trabajos de María Elena Torre siguen la producción de Rest en su figura de crítico literario: "Jaime Rest, un cuarto propio" $(2000)^{5}$ y "Pensar en el límite. Sobre algunos ensayos de Jaime Rest" (2002) ${ }^{6}$. En el primero de esos textos Torre concentra su atención en el uso particular que Rest hace del género ensayo tanto en el marco de la crítica cultural como de la crítica literaria. En el segundo artículo, Torre se aplica a destacar la fuerza de intervención crítica de Jaime Rest centrándose en el desglose de los trabajos reunidos en tres autores prohibidos (1968) y los ensayos escritos durante toda la década del 70 para leerlos como respuesta al contexto histórico en el que aparecen y con el que dialogan indirectamente. Ambos trabajos constituyen, sin duda, aportes significativos a la comprensión de aspectos particulares del proyecto crítico restiano y, en razón de ello, serán retomados en varias ocasiones a lo largo de este trabajo.

Resulta sin lugar a dudas curioso que en el generoso volumen colectivo dirigido por Noé Jitrik, La irrupción de la crítica. Historia crítica de la literatura argentina (1999)7, dedicado

\footnotetext{
5 Torre, María Elena, "Jaime Rest, un cuarto propio", Boletín/8 del Centro de Estudios de Teoría y Crítica Literaria, Rosario, Octubre de 2000. pp. 125-134.

6 Torre, María Elena, "Pensar en el límite. Sobre algunos ensayos de Jaime Rest", en Voz y Escritura, $\mathrm{N}^{\circ}$ 11, 2002. pp. 157-170.

7 Jitrik, Noé (dir.), La irrupción de la crítica. Historia crítica de la literatura argentina. Buenos Aires, Emecé, 1999.
} 
íntegramente a la revisión de la crítica literaria y cultural en la Argentina, apenas se consignen a propósito de la obra de Rest breves menciones o comentarios marginales en los trabajos de Susana Cella, Marcos Mayer y Américo Cristófalo. Lo grosero de la omisión -injustificable desde donde se la mire- es en apariencia salvado en el número especial sobre "La crítica literaria en la Argentina" preparado por la revista La Biblioteca. Allí, "Jaime Rest, hacia la reafirmación del hecho literario" (2006) ${ }^{8}$, un breve ensayo de Pablo De Santis reseña lo más conocido de la crítica literaria restiana en clave steineriana. Subraya, en primer lugar, en la crítica de Rest cierta «actitud amable, de quien organiza las expectativas del lector frente a un texto futuro», caracterizando su actitud pedagógica y su condición de «maestro del prólogo». Y, en segundo lugar, señala la actitud gentil y cortés que, junto a un agudo sentido de la ironía y el humor, lo convertiría -a juicio de Carlos Gardini- en «un magnífico profesor», destacado por la claridad de su dicción y su voz vibrante.

El artículo de De Santis tiene el mérito de no ser pretencioso, pero también los problemáticos límites de haber sido elaborado prácticamente en base a dos libros de Rest: Mundos de la imaginación (1978), una recopilación de artículos, y El cuarto en el recoveco (1982), un libro póstumo. Sólo desde ese recorte es posible comprender la generalización equívoca con que el autor se permite sostener, por ejemplo, que «el rastreo de la obra de

8 De Santis, Pablo. "Jaime Rest, hacia la reafirmación del hecho literario", La Biblioteca, $\mathrm{n}^{\circ}$ 4/5, Buenos Aires: verano de 2006 . pp. 174179 . 
Rest no permite advertir ninguna afición polémica» (De Santis 2006: 176). Semejante afirmación implica no sólo el necesario desconocimiento del contenido específico de su primera intervención crítica importante sobre el corpus de la literatura argentina, Cuatro hipótesis de la Argentina (1960a); sino también pasar por alto la modulación indirecta y específica que caracteriza la presencia efectiva de la polémica en muchos de sus trabajos posteriores -rasgo que es en efecto tangible tanto en intervenciones precisas como "Emotividad verbal y totalitarismo" (1958b), "El 'Caso' Lolita" (1959e) o "La Pena de muerte" (1962), como en el trasfondo de discusión de libros como Tres autores prohibidos y otros ensayos (1968b) o El laberinto del universo. Borges y el pensamiento nominalista (1976a).

Aun así, el texto de De Santis acierta en señalar un aspecto poco atendido de la obra restiana: la de mantener viva -a través de la reivindicación de géneros y literaturas marginales como el fantástico, el policial, la ciencia ficción, la historieta, el ensayo o la literatura infantil- la tensión fundamental en que surge la cultura del siglo XIX: «la dificultad de conciliar el racionalismo científico con los elementos sobrenaturales del romanticismo» (De Santis 2006: 178). La luminosa transparencia de la razón y el fondo oscuro de lo inexplicable reaparecen en esos géneros y esas "pequeñas literaturas" «a través de rupturas de la realidad, la alucinación de la ciencia o la irrupción del crimen». Tras esa imposible conjunción -que de algún modo llevan a pensar en un matrimonio del cielo y el infierno, y una atracción inevitable entre civilización y barbarie- los ensayos 
restianos se reencuentran -según De Santis- en «una doble y secreta intención» sobre la que este trabajo volverá a explayarse más adelante: «la de explicar el funcionamiento de la máquina literaria, de todo aquello que se deja ver a la luz de la lectura»; la de «señalar aquellas zonas de indeterminación, de silencio, donde la literatura dice sin decir» (De Santis 2006: 179) .

La edición en que la editorial Norma puso en circulación, bajo el título de Arte, literatura y cultura popular, dos textos de Rest ("Literatura y cultura de masas" y "La situación del arte en la era tecnológica") está precedida de una breve presentación de Victor Pesce que resume sólo aspectos superficiales y bastante difundidos de la producción restiana en torno a la problemática de la cultura de masas. Pero si el texto que encabeza el volumen que reúne dos importantes trabajos de Jaime Rest -un libro: Literatura y cultura de masas (1967a) y un extenso y sugestivo artículo "Situación del arte en la era tecnológica" (1961a)- es en apariencia baladí y se dedica a subrayar un aspecto específico aunque importante de las investigaciones restiana, no lo es en modo alguno la operación que subyace a la edición. Corre por parte del editor un título que no es el de Rest y que, sin dudas, no es para nada ingenuo. La explicación que el Profesor Pesce plantea para justificar el reemplazo del sintagma "cultura de masas" por el de "cultura popular" supone que "cultura de masas" remitiría a un concepto «demasiado contaminado a esta altura por el prejuicio que lo vincula a la industria cultural, definida 
negativamente» (Pesce 2006: 19) ${ }^{9}$. Se trata en efecto de una operación que busca disolver la ambigüedad deliberada con la que Rest define su propia colocación ante ese dinámico campo de producción. Lo cierto es que, tanto en los dos ensayos en cuestión como en otras intervenciones sobre el tema-como, por ejemplo, "Jules Feiffer: un Aristófanes de la sociedad de consumo" (1979k)-, el crítico trabaja efectivamente sobre los efectos positivos y negativos de la industria cultural en los universos del arte y la literatura; y lo hace siempre -y bajo toda circunstancia- de manera distanciada y sumamente cautelosa, es decir, despegándose deliberadamente del maniqueísmo esquemático que, en lo que hace al destino de las relaciones entre arte, literatura y cultura de masas, se dirime entre el escepticismo categórico y la idealización desmedida. Aún más: si -a lo largo de todo el ensayo- el propio Rest insiste en el concepto de "cultura de masas" es porque su elaboración parte de la idea de "masificación" que él mismo rastrea desde Oswald Spengler a Ortega y Gasset, pasando por Benedetto Croce y Vilfredo Pareto hasta llegar las contribuciones del catedrático inglés Frank Raymond Leavis. El carácter de «encrucijada» presentado en el segundo de los ensayos restianos da cuenta, al contrario, de la convicción del crítico sobre la imposibilidad concreta de sostener determinaciones completas y definitivas ante la complejidad de dichos fenómenos; por lo que la operación de Pesce -sin duda, estratégica y efectiva en función de la

\footnotetext{
9 Pesce, Víctor, "Introducción", en Rest, J., Arte, literatura y cultura popular, Buenos Aires: Norma, 2006.
} 
colocación del material editado en el ámbito preciso de la sociocultura y la comunicación social- resulta evidentemente tan discutible como loable su voluntad de rescatar esos textos restianos de un olvido por lo menos injusto.

En resumen, lo que se desprende de la mayor parte de estas lecturas es, pues, que descentramiento y dispersión son, prima facie, los atributos fundamentales con los que suele describirse el proyecto intelectual restiano. El primer término alude generalmente al hecho de que su trabajo crítico traduce, de alguna manera, una suerte de descentramiento singular, tanto en función de sus múltiples intereses como en la diversidad propia de sus modalizaciones: entre el ensayo crítico y la crítica académica, entre la cultura popular y la "alta" literatura, entre la ordenada literatura inglesa y las siempre improvisadas letras argentinas, el proyecto crítico de Rest viborea y vuelve endeble -cuando no superflua- toda etiqueta que no acabe por encallar en la remanida figuración de la "excentricidad". El segundo atributo remite por su parte a una especie de dispersión inexplicada -que sólo a una mirada superficial puede inducir la imagen de una "obra de ocasión"- y que devuelve de Rest una imagen proteica, conforme a las áreas de intervención que se le reivindiquen ("crítico de dos literaturas", "scholar riguroso", "hombre de Letras", "pedagogo locuaz y gentil", "creador de los estudios culturales en la Argentina", "destacado especialista", "comparatista" o "arqueólogo erudito", "catedrático admirable", "precursor del análisis de la cultura de masas" o "lector avant 
la lettre", etc.). El propósito central de este trabajo no es el explicar el dispositivo crítico de Rest, sino el de determinar su función específica al interior de un proyecto intelectual que incluye otras aristas -como su prolífica actividad como editor, traductor, divulgador y docente. Su objeto será pues explicar lo inexplicado -en función de tácticas, necesidades y condicionamientos materiales concretos- y dar sentido a la forma y a la configuración específica de ese singular proyecto intelectual -dispuesto como una estrategia elaborada en respuesta a un proceso histórico de creciente autoritarismo. Se tratará, en consecuencia, de explicar la configuración particular que exhibe el proyecto restiano, no como una contingencia, sino como una estrategia que dispone efectivamente de ese descentramiento táctico y de esa dispersión calculada para vehiculizar una serie de enunciados de articulación ideológica liberal-progresista en el marco de un «campo de fuerzas» dinámico y complejo, que se inscribe en un proceso histórico tumultuoso y signado fundamentalmente por la violencia, la intolerancia y el autoritarismo.

Lo que aquí se define como «proyecto intelectual» restiano remite pues a un conjunto de actividades que se extienden por casi tres décadas, desde sus primeras publicaciones en centro y su egreso de la Facultad de Filosofía y Letras de la UBA en 1953 hasta 1979, año en que la muerte interrumpió súbitamente su polifacética producción. El lapso coincide significativamente con un período particular de la historia social argentina que va desde la crisis, derrocamiento y proscripción del peronismo a la 
radicalización de la lucha armada y el terrorismo de Estado durante la segunda mitad de la década del 70. En ese lapso de violencia progresiva, la política se asume como larvada guerra civil hasta derivar -ya entrados los años setenta- en el callejón sin salida de los enfrentamientos armados. Los acontecimientos históricos y políticos que trazan cesuras concretas en ese periodo marcan la creciente espiral de violencia. Los bombardeos de Plaza de Mayo producidos en junio del '55 y el fusilamiento del General Juan José Valle y 26 de sus hombres tras un intento de insurrección al régimen de facto que había derrocado al gobierno constitucional de Juan D. Perón; los fragilísimos períodos democráticos de Arturo Frondizi y Arturo Umberto Illia que serán rematados con el golpe de Estado de Onganía en 1966 y su «shock autoritario» (abierto con la tristemente célebre "Noche de los Bastones Largos"); el movimiento de protesta popular que, con el Cordobazo de mayo del '69, condensa, en violencia emergente, la creciente resistencia al autoritarismo y tiene como trasfondo internacional una serie de procesos de radicalización social y política -que incluye revoluciones y guerras como las de Cuba, Argelia o Vietnam y revueltas articuladas entre sectores obreros y estudiantiles como el "mayo francés" de 1968-; la formación de partidos armados, los violentos acontecimientos de Ezeiza en 1973, la puesta en funcionamiento a partir de 1975 de fuerzas paramilitares de la Triple A (Alianza Anticomunista Argentina), el "paso a la clandestinidad" de los partidos y organizaciones de izquierda y el plan sistemático de desaparición de personas implementado por la dictadura militar que ocupó el 
poder en la Argentina entre 1976 y 1983, constituyen sin duda un punteo que, sin ser exhaustivo, exhibe a las claras la espiral de violencia que grava al período en cuestión. En tal contexto, el «campo de fuerza» en que se inscribe el proyecto intelectual restiano está tensado por la encrucijada abierta entre un proyecto autoritario y conservador en lo político-cultural -y liberal en lo económico- y la dialéctica modernizadora abierta con el surgimiento de la "nueva izquierda" luego del golpe de 1955 e impulsada ideológica y culturalmente por vastos sectores juveniles de las clases medias. Es por esto que para el desarrollo de esta investigación se ha optado por realizar una lectura diacrónica del proyecto restiano, organizada en una capitulación que superpone momentos específicos de dicha producción con cesuras histórico-culturales significativas.

En la solapa del Bertolt Brecht de Volker Klotz publicado en Buenos Aires por la editorial La mandrágora en marzo de 1959 se anuncia un T. S. Eliot a cargo de Jaime Rest que, por razones desconocidas, nunca vio la luz. Es probable que, de haber sido publicado, tal volumen habría estado conformado en gran medida por las investigaciones de la obra del poeta y ensayista inglés realizadas por el crítico en sus primeros años de trabajo. El período que se abre con su ingreso a la Facultad de Filosofía Letras de la UBA y se cierra con sus colaboraciones en la revista Imago Mundi es el de sus wanderjahre -período de formación y ensayo- y coincide política y prácticamente con el decenio 19451955, que comprende los dos primeros gobiernos de gobierno peronista interrumpidos por el golpe de Estado de la 
autodenominada "Revolución Libertadora". Las obras de Thomas Stearns Eliot y Virginia Woolf constituyen el centro de sus intereses en este período, donde su dispositivo crítico en formación exhibe una deliberada voluntad de profesionalización, al tiempo que muestra visos de experimentación comparatista, que se articula armoniosamente con el perfil cosmopolita, modernizador y liberal que -como ha mostrado Oscar Terán (1993: 33-57)- define el programa de Imago Mundi. Al estudio de este período se circunscribe el primer capítulo.

Si el comienzo es -como sostiene Edward W. Said- el momento en que, en un trabajo específico, un escritor toma distancia de su propia tradición -a la vez que establece, respecto de ella, complejas relaciones que no se reducen a la continuidad o el antagonismo-, el segundo capítulo de este trabajo se circunscribe a esa instancia definitoria en el proyecto intelectual restiano. El período que abarca tal inscripción se articula sobre el decenio 1956-1966, etapa en la que -como explica Carlos Altamirano- se desencadena un proceso de modernización cultural en la Argentina muy asociado a la emergencia de una serie de carreras y especializaciones en el campo universitario y a la introducción de una serie de orientaciones teóricas, ideológicas y políticas que tienen en alguna de las variantes del marxismo su punto de inflexión fundamental. En ese contexto, el comienzo del proyecto restiano se consolida a partir de una intención que define esa producción como el primer paso de un proyecto de trabajo a largo plazo y que da cuenta de un punto de comprensión -en un sentido espacial e intelectual del término- donde la 
práctica específica es asumida como intervención política en el campo de fuerzas de la cultura. La designación de ese comienzo remite objetivamente a la incorporación de la problemática de la cultura de masas, la industria cultural y los géneros "menores" a su campo de intereses y de trabajo específico. Al desarrollo de esta arista particular del trabajo restiano a los efectos de colocación que se siguen de las mismas está dedicado el segundo capítulo.

«Veo en mí una creciente fascinación por lo diabólico, lo marginal y lo maldito». Hallada entre los papeles personales de Jaime Rest luego de su muerte, esa frase sin fecha da cuenta de otro aspecto que singulariza su proyecto de investigación. ${ }^{10}$ El período que se corresponde con la radicalización de este campo preciso de intereses se corresponde con el de la embestida autoritaria y conservadora dispuesta por el proceso faccioso autodenominado "Revolución Argentina" y se extiende de 1966 a 1973. En el contexto de una escalada de persecución, censura y autoritarismo -cuya carta de presentación es la represión de julio del '66 denominada "Noche de los Bastones Largos", pero cuyo nivel de conflictividad política y social fue tal que incluso al interior del propio proceso militar se produjeran dos golpes internos, sucediéndose así en el poder Juan Carlos Onganía (1966-1970), Roberto Marcelo Levingston (1970-1971) y Alejandro Agustín Lanusse (1971-1973)-, Rest orienta su investigación sobre un espacio literario que tematiza el autoritarismo, describiendo

\footnotetext{
10 Debo la referencia a esta nota a la Licenciada Silvana Piga, actualmente encargada de ordenar los papeles personales de Jaime Rest en el sector "Colecciones Especiales y Archivo" de la Universidad de San Andrés.
} 
y develando el uso específico que el pensamiento totalitario hace de la censura, la demagogia y la retórica articulada a partir de la «emotividad verbal». En el tercer capítulo de esta tesis se examinarán pues esos significativos aspectos del trabajo crítico restiano, haciendo foco especialmente en el volumen titulado Tres autores prohibidos y otros ensayos, publicado por Galerna a mediados de agosto de 1968, y la brillante conferencia titulada El marqués de Sade y la crisis del racionalismo, dictada por Rest a comienzos de 1971, donde exhibe algunas circunstancias en que la literatura se constituye como espacio de excepción al acoger a las "partes malditas" del régimen de verdad.

El cuarto capítulo del presente trabajo es quizá el que más se acota a la descripción del modelo de indagación literaria desarrollado por Rest. Se articula sobre el período 1973-1976, donde a pesar de la restitución democrática el grado de violencia y autoritarismo creciente -que incluye el paso a la clandestinidad y la definición por la lucha armada de las organizaciones de izquierda, pero también la disposición de fuerzas de operación clandestina y paramilitar por parte del Aparato de Estado- daba las pautas del desenlace funesto que se desataría a partir del golpe de Estado del 24 de marzo de 1976, cuando la Junta Militar integrada por comandantes de las tres Fuerzas Armadas pusieran fin al endeble gobierno de Isabel Martínez de Perón. En ese contexto, Rest escribe El laberinto del universo. Borges y el pensamiento nominalista y produce el grueso de los textos que compondrán, años después, Mundos de la imaginación. Diagrama su lectura de Borges sobre la hipótesis de 
que esa literatura no se erige -como apuntaban varias lecturas de esa época- sobre un paradigma reaccionario, sino que -más biense afirma sobre una matriz del pensamiento moderno que parte de la relación subyacente entre el nominalismo filosófico, el lenguaje místico y la concepción liberal de la tolerancia. Y lee también, en consonancia con su convicción liberal, progresista y cosmopolita, una serie significativa de textos de la historia universal -algunos célebres y otros prácticamente desconocidosque describen contradicciones y aspectos específicos del imaginario social burgués que determina las condiciones mismas de la modernidad en Occidente.

La "Nota del editor" que en 1981, con de la edición de Vathek de William Beckford, cierra «la sexta serie de la Biblioteca Básica Universal del Centro Editor de América Latina íntegramente dedicada a las literaturas "marginales" o géneros "menores" o textos "olvidados"-» (1981b: XVI), rinde un sentido homenaje a Jaime Rest por su contribución precursora en la difusión de estas experiencias estéticas y culturales marginadas. El reconocimiento a tal contribución remitía, por supuesto, a su determinante labor como editor en CEAL y Ediciones Librerías Fausto, a sus trabajos de divulgación dedicados a la dinámica de los géneros, a su labor como traductor e introductor de obras y autores desconocidos, y a su contribución al establecimiento y difusión -mediante textos de divulgación o mediante su propia actividad docente- de una serie de categorías teóricas novedosas para la comprensión de las experiencias culturales modernas. A la descripción de estas múltiples actividades desarrolladas por Rest 
a lo largo de la década del 70 -y enfatizadas especialmente en el período histórico 1976-1979, sobre el fondo de un contexto de violencia generalizada, totalitarismo y represión sistematizada como terrorismo de Estado por parte de la dictadura más sangrienta de la historia argentina- está dedicado el capítulo quinto de este trabajo.

Las "Consideraciones finales sobre el proyecto intelectual" suponen por su parte un momento de examen sintético de las diferentes colocaciones de Rest desde su trabajo específico y frente al complejo y cambiante campo de fuerzas que constituía su contexto y que, de algún modo, definía sus condiciones de producción objetiva. Partiendo de la recapitulación de las conclusiones parciales dispuestas en cada capítulo de este trabajo, se trata de explicar el proyecto intelectual restiano articulado sobre una adscripción ideológica liberal, progresista, cosmopolita, antiautoritaria y democrática- de acuerdo a lo que Foucault ha descrito bajo el modelo de intelectual específico, que opera desplazando o transformando los límites objetivos de su propia especificidad e inscribiendo sus intervenciones en una dimensión microfísica -que no se impone como instancia iluminada pero que sin duda se articula estratégicamente con intereses y luchas que reverberan más allá de esos espacios específicos.

Puesto que se trata de una producción poco conocida y en muchos casos de muy difícil acceso, para evitar el tedio de citas interminables, se ha optado por producir una lectura comentada de los textos que en muchos pasajes se superpone con el ejercicio de la glosa y en otros se inscribe en la lógica del ensayo. La 
elección no es caprichosa. La glosa, aun antes que un procedimiento de escritura, es una función de la cultura. Establece respecto del texto de referencia -cuando no lo convierte en "texto de reverencia"- una relación de respeto y, al mismo tiempo, un desplazamiento sutil o apenas perceptible. La glosa cambia el texto. Lo cambia incluso sin apelar a la distorsión maliciosa o fraudulenta, con el sólo hecho de señalar un énfasis, acentuar un aspecto sobre otros, imaginar una referencia elíptica o iluminar un detalle en apariencia contingente. La glosa es pues, desde el comienzo, una lectura. Es en ese sentido que -como bien apunta Horacio González- las glosas se erigen como un «estadio vital de la cultura», en tanto «son ese nudo dramático de libertad y necesidad con que nos dirigimos a todos los materiales de la cultura»: glosar es actuar «en el juego de una libertad posible en la trama cultural que nos asedia» (González 2002: 46). Es por eso que la glosa se cubre de suspicacias cuando sus sinopsis y comentarios se invisten de traducciones sintéticas y cuando apelan a una objetividad de pureza divina. No es el caso. La glosa que se presenta aquí no es una lectura que se niega como tal, sino que se asume como un híbrido entre el comentario de lectura y la intermediación pedagógica

En razón de que el resumen que produce la glosa sustituye el texto glosado pero corre «el riesgo de una pérdida de intensidad del documento originario» (González 2002: 45), se ha determinado acompañar cada uno de los capítulos de este trabajo con un apéndice documental que restituye la singularidad del texto 
restiano. Tratando de contribuir prácticamente a investigaciones futuras, se ha optado por constituir esos apéndices con textos de difícil acceso y representativos de las diversas etapas de la producción restiana, a los que se ha accedido luego de una ardua etapa de investigación de archivo, recopilación, digitalización. En el primero de ellos se consigna la primera nota de Rest de tema borgeano, "Borges, Descartes y el obispo Wilkins" (1952c), un texto -esbozo de «ficción crítica»- aparecido en el $\mathrm{N}^{\circ} 4$ de Centro. Revista del Centro de Estudiantes de Filosofía y Letras, en diciembre de 1952. El apéndice que sucede al capítulo 2 está constituido por el artículo "Notas para una estilística del arrabal" (1965a) publicado originalmente por la imprenta del Servicio de Extensión Cultural de la Dirección General de obra Social de la Secretaría de Estado de Obras Públicas. El tercer capítulo de esta tesis es acompañado por la notable conferencia "El marqués de Sade y la crisis del racionalismo" (1971c), dictada por Rest en una de las múltiples actividades de la Alianza Francesa con sede en Bahía Blanca. El cuarto apéndice está conformado por "Los narradores argentinos y la búsqueda de un idioma nacional" (1967e), una ponencia escrita y leída en las "Segundas Jornadas de Métodos de Investigación de enseñanza de la Historia y de la Literatura Rioplatense y de los Estados Unidos", en Bahía Blanca, en junio de 1967. Para acompañar el quinto y último capítulo de esta tesis se ha optado por "Reflexiones de un traductor" (1976c) el texto confeccionado por Rest para el número doble 338-39 de la revista Sur -cuyo dossier, coordinado por el propio Rest, está dedicado a los "Problemas de la traducción"- y 
que vio la luz a fines de 1976. Finalmente, se suma una traducción inédita del poema the Waste Land realizada por Rest a comienzos de la década del 60 y empleada en sus memorables clases en la UBA y la Universidad Nacional del Sur ${ }^{11}$. La serie es sin duda cuantitativamente menor (teniendo en cuenta la extensión de la producción restiana, que se consigna en la Bibliografía que acompaña a esta tesis); pero, en términos cualitativos, da cuenta concreta de la diversidad de aspectos, intereses y modalizaciones genéricas que asume la producción intelectual restiana.

Una última consideración merece ser enunciada en el punto de partida de este trabajo: pese a su apariencia totalizadora lo que aquí se plantea es una interpretación del conjunto de aristas y aspectos específicos que componen el proyecto intelectual de Jaime Rest y, como tal, se reconoce susceptible de correcciones, rectificaciones y complementos por parte de investigaciones venideras. En cualquier caso, en él se parte de la convicción de que -como todas- la configuración particular del proyecto intelectual restiano está doblemente condicionada: tanto por una «constelación» ${ }^{12}$ de experiencias, ideas y saberes -sobre los que se define su formación específica-, como por el «campo de fuerzas» ${ }^{13}$-en que se ve obligado a interactuar y a relacionarse

\footnotetext{
11 El material en cuestión fue gentilmente cedido por la Lic. Norma Edith Crotti, alumna de la cátedra de Literatura Contemporánea dictada por Jaime Rest en la casa de altos estudios de Bahía Blanca.

12 Término astronómico con que -como bien explica Martin Jay- Walter Benjamin solía designar un «conjunto yuxtapuesto», «no necesariamente integrado, de elementos cambiantes que se resisten a una reducción por un común denominador, un núcleo central o un origen determinado». Véase Jay $1988: 5$.

13 Con la categoría metafórica de «campo de fuerza» [kraftfeld] Theodor Adorno solía aludir «a la interacción relacional de las atracciones y repulsiones que constituían la estructura transmutacional y dinámica de un fenómeno complejo». Como el de constelación, el concepto de campo de fuerza
} 
de acuerdo a la dinámica incesante de un campo cultural complejo y casi siempre amenazado por formas explícitas o encubiertas de autoritarismo. El presente trabajo -que se inscribe ciertamente en un cruce entre historia intelectual sinóptica e historia cultural- constituye pues un intento por dar sentido a las modulaciones específicas de un proyecto intelectual complejo, diversificado y no exento de contradicciones internas y tensiones irresueltas.

fue empleado por Adorno en sucesivas oportunidades, especialmente al disponerse a examinar «fenómenos culturales y sociales para captar las sutiles relaciones entre sus dimensiones naturales e históricas, particulares y universales, objetivas y subjetivas» y para explicar otras tantas relaciones al interior de las mismas (Jay 1988: 5). 


\section{UN PUNTO DE PARTIDA}

Imago Mundi, cosmopolitismo y profesionalización (1945-1955)

PERONISMO, UNIVERSIDAD Y CAMPO INTELECTUAL

Una manera eficaz de echar luz sobre una época es tratando de hacer foco en la característica y singularidad de sus emergencias. Plantear contra qué se producen, permite ver singularmente las fuerzas culturales y el conjunto de circunstancias políticas -que pueden escapar al espacio restringido del campo cultural e intelectual pero que sin duda operan de manera significativa sobre él. En un período que, como apunta Oscar Terán, tematizó los problemas nacionales «tratando de privilegiar a aquellos sujetos portadores de símbolos discursivos que por la posición que ocuparon en la red social operaron efectos ideológicos» ${ }^{14}(1986: 197)$ en el campo intelectual y cultural, resulta fundamental detenerse en la emergencia de una generación de escritores e investigadores que encarará una tarea crítica determinante dentro del entramado cultural de los '60 y '70, pero cuya formación y colocación resulta directa y singularmente marcada por el proceso de transformación política y cultural abierto por el peronismo entre 1945 y 1955 en la historia argentina.

Por una cuestión cronológica, Jaime Rest pertenece sin duda a

\footnotetext{
14 Terán, oscar, En busca de la ideología argentina. Buenos Aires: Catálogos, 1986 .
} 
esa generación cuyas opciones culturales y colocaciones políticas han sido -al menos en el comienzo- singularmente marcadas por la dura experiencia del primer peronismo. Silvia Sigal ha descrito en términos generales la política cultural del peronismo en ese momento de tensión afirmando que, en el plano de la "cultura docta", «carecía de una estrategia propia y no contaba ni siquiera con una ideología que permitiera decidir en un conflicto cultural, sea para acallar o para promover». Su política cultural se resolvía al contrario, drástica y esencialmente, en «una gestión autoritaria -directa o indirecta- que su decisión de no compartir el control de los medios masivos (radio, cine, prensa) puso rápidamente de manifiesto». ${ }^{15}$ Como consecuencia de ello, en el plano cultural, el peronismo debió soportar la militancia opositora de gran parte de los intelectuales de su época cuya ascendencia era mayoritariamente de tradición liberal. En muchas de las manifestaciones antiperonistas no tardaron en tomar un lugar cada vez más sustancial docentes universitarios y agrupaciones estudiantiles -en ciertos casos asimiladas luego a algunas de las facciones que conformaron la Unión Democrática. El peronismo no sólo hacía caso omiso de los reclamos liberales sino que además desistió de todo intento de colocar en lugares de decisión político-cultural a algunos de los intelectuales de cuño nacionalista (que veían con buenos ojos el advenimiento de Juan Domingo Perón al poder a partir de su gestión ministerial previa) y optó por integrar a la universidad y al aparato judicial

15 Sigal, Silvia, Intelectuales y poder en la década del sesenta, puntosur editora, Buenos Aires, 1991. 
agentes especialmente «conservadores tradicionales o próximos a la Iglesia». A partir de esas elecciones, el peronismo se fue ganando rápidamente la oposición de una franja ideológica que incluía desde intelectuales liberales a la izquierda ilustrada.

La postura del Ejecutivo frente a los intelectuales opositores o disidentes fue firme pero tolerante. A ellos les cupo-como apunta Sigal- una gradual marginación del espacio público. Pero «la universidad, foco de gran visibilidad, no podía gozar de una tolerancia análoga y corrió una suerte similar a la de los medios de difusión». Sigal cita pertinentemente a través de Alberto Ciria la ley 13.031, de 1947, que dejaba en claro la posición del peronismo respecto del rol y los límites de inferencia de la enseñanza superior: «Las Universidades no deben desvirtuar en ningún caso y por ningún motivo sus funciones específicas. Los profesores y alumnos no deben actuar directa ni indirectamente en política, invocando su carácter de miembros de la corporación universitaria, ni formular declaraciones conjuntas que supongan militancia política o intervención en cuestiones ajenas a su función específica, siendo pasible quien incurra en transgresión a ello de suspensión, cesantía, exoneración o expulsión, según el caso.» (Ciria, 1983: 233) $\cdot{ }^{16}$

La Universidad respondió a esta demanda no sólo declarando su lealtad mediante doctorados Honoris Causa a Juan Domingo Perón, sino también dejando entrar en sus propias cátedras líneas conservadoras que la Reforma Universitaria del '18 había

16 Ciria, Alberto, Política y cultura: la Argentina peronista 1946-1955, Buenos Aires: De la Flor, 1983. 
conseguido esquilmar: volvieron las «cátedras de filosofía en las que el tomismo era de regla o de historia donde la benevolencia hacia Rosas era altamente conveniente». Pero eso no era todo. Con escasas exigencias en los contenidos de la enseñanza, «la docencia se abrió al pensamiento católico más reaccionario o bien a profesores sin otra legitimidad que su profesión de fe política, los [irónicamente llamados] "flor de ceibo"» (Sigal, $1991: 48)$.

Las relaciones entre peronismo y cultura letrada son, en efecto, primordialmenete problemátizas y desprenden mutuamente signos de hostilidad. No sólo porque a partir de su irrupción a mediados de la década del '40 el peronismo no ha dejado de sobreimprimir su huella -incluso la de sus dificultades para articular una propuesta cultural propia- en el sistema de producción de bienes culturales; sino porque su irrupción implica una encrucijada sobre la cual se definen funciones intelectuales y colocaciones políticas. Efectivamente, como apunta Sigal, el peronismo no consiguió imponer en los círculos de la cultura "docta" «una verdadera sujeción ideológica», pero ahogó casi por completo las posibilidades de intervención crítica al interior de la estructura universitaria. No sólo porque en los espacios académicos -hasta entonces ocupados por una franja de intelectuales y profesores de origen liberal o liberal de izquierda- son compulsivamente instalados en gran medida intelectuales que provienen del campo del integrismo y nacionalcatolicismo de derecha; sino fundamentalmente porque estos nuevos docentes y autoridades universitarias se revelan rápidamente 
ajenos a todo sentido pluralista y democrático.

Los intelectuales desplazados se refugian ya en las publicaciones liberales y definidamente opositoras sostenidas a partir de recursos privados (como la revista Sur, dirigida y solventada por Victoria Ocampo, y el Suplemento Literario del diario La Nación, dirigido por Eduardo Mallea), o buscan inscribirse ya en espacios más laxos como el Colegio Libre de Estudios Superiores, la Sociedad Científica Argentina o revistas como Realidad o Imago Mundi. Es allí donde parece abrirse un espacio posible para una política cultural alternativa -que en ciertos casos incluso llegó a habilitar cierta ascendencia progresista- y que, visto en perspectiva, llegó a constituirse especialmente en las épocas más productivas de Cursos y Conferencias- una suerte de "universidad paralela", donde -como apunta Terán- pueden verse ciertas líneas programáticas para la política cultural posperonista a través de la creación de «un campo cultural que se otorga reglas de legitimación profesional propias frente a la marginación institucional y a la mediocridad de quienes controlaban las aulas» (Sigal, 1991:50). ${ }^{17}$

Los jóvenes estudiantes no están ajenos a la hostilidad. No sólo porque, además de su espacio de militancia crítica universitaria, habían perdido a sus profesores más respetados; sino porque desde el Estado se empezó a ejercer una política intimidatoria -y en ciertos casos directamente represiva- sobre los estudiantes disidentes (no peronistas, progresistas o de

17 Véase también Neiburg, F., "Elites sociales y élites intelectuales: el Colegio Libre de Estudios Superiores (1930-1961)", en Los intelectuales y la invención del peronismo, Madrid, Alianza, 1988. pp. 137-182. 
izquierda). La escalada represiva desarrollada durante la década peronista no consigue sin embargo ahogar la vida intelectual; sino que, al contrario, la obliga a diversificarse y a ocupar espacios extra-estatales, con frecuencia sobre la base de instituciones precedentes.

De manera persistente hasta la primera mitad de esa década, cuando se produce el derrocamiento del peronismo a manos de la autodenominada "Revolución Libertadora", la actitud de los sectores intelectuales liberales hacia el movimiento es pues como apunta Terán- de una "presión activa", que funciona casi como un parte aguas al interior de esta fracción cultural que hasta entonces se articulaba mediante una común oposición a la política oficial preponderantemente dirigida por sectores católicos, nacionalistas y tradicionalistas (Terán, 1986:197). La imposición estatal de ese modelo cultural conservador, la expulsión directa -o la renuncia inducida- de numerosos profesores disidentes, su reemplazo compulsivo por profesores de dudosa capacitación para los respectivos cargos, designados sin concurso y arbitrariamente, y la represión policial contra los estudiantes opositores le facilita las cosas. El ambiente opresivo cubre todas las capas y todos los espacios públicos de intervención y rápidamente hace coincidir el repudio de las facciones liberales y las del insipiente progresismo heredero de un espíritu reformista $y$, en algún punto, habilita la articulación de espacios de resistencia estudiantil (que en algunos casos incluso recibirán el auspicio benevolente de 
ciertos sectores de la elite liberal ilustrada). ${ }^{18}$

CENTRO Y LA NUEVA GENERACIÓN

Al interior del propio espacio universitario, en las pocas zonas no controladas por las autoridades impuestas por el peronismo, los estudiantes buscan expresar su incomodidad y su rechazo ante ese ambiente hostil y el avasallamiento de las conquistas ganadas por la Reforma Universitaria. La experiencia política que nace en el Centro de Estudiantes de Filosofía y Letras de la UBA, a partir de 1950 -y que cristaliza en el paso de Verbum a Centro-, da cuenta tanto de una confusión como de una necesidad de resistencia a una situación que les resultaba asfixiante. La confusión se asienta fundamentalmente en el hecho de que los jóvenes intelectuales que confluyen en centro no llegan a vislumbrar con claridad, hasta el golpe del '55, que lo que los reúne no es una afirmación ideológica común sino una identificación en la oposición al régimen peronista. No los une el amor; los une el espanto. Y la comprensión de ese hecho fundamental se deja leer en el editorial publicado en el número 10 de la revista, de noviembre de 1955, donde el fracaso de un número programado en una perspectiva «de revisionismo comprometido» es interpretado como signo de diferencias y problemas generacionales que «la conmoción [del Golpe de Estado]

18 Véase además Mangone, C. y J. Warley, Universidad y peronismo (19461955), Buenos Aires, CEAL, 1984. 
ha dejado al descubierto» ${ }^{19}$. Finalmente, y como se apuntaba en un número anterior de la revista que hace las veces de balance, no había en el origen de Centro más que el sentimiento compartido de «una inquietud, de una rebeldía y de un disconformismo con el ambiente universitario y su mediocridad» ${ }^{20}$.

Ciertamente la revista, cuyos catorce números se publican entre noviembre de 1951 y setiembre de 1959, reunía una generación que compartía una experiencia universitaria de militancia reformista y liberal. Pero esa procedencia no llegaba a materializar una homogeneidad. En Centro pueden leerse los primeros trabajos de gran parte de los jóvenes intelectuales que constituirán la franja «denuncialista» (que se proyectará como la modalidad de intervención crítica e intelectual más importante en el espectro de la cultura de izquierda en los '60). ${ }^{21}$ Allí hacen sus primeras armas Ramón Alcalde, David e Ismael Viñas, Francisco J. Solero, Carlos Correas, Oscar Masotta, Regina Gibaja, Noé Jitrik, Jorge Lafforgue, Adelaida Gigli, León Rozitchner, Adolfo Prieto y Juan José Sebreli; y allí puede verse también el proceso de radicalización de posiciones intelectuales que darán lugar a la fundación de Contorno. ${ }^{22}$ Pero, al menos durante el lustro previo al golpe militar que derrocaría a Perón, es muy difícil percibir una distinción tajante en términos ideológicos y una escisión profunda entre los que configurarán la fila denuncialista y los jóvenes intelectuales cuya afinidad electiva

\footnotetext{
19 "Editorial", Centro, n 10, noviembre de 1955. pp. 7-8.

20 "Editorial", Centro, n 9, julio de 1955. pp. 5-6.

21 Véase Avaro, N. y A. Capdevila, Denuncialistas. Literatura y polémica en los '50, Buenos Aires, Santiago Arcos, 2004.

22 Véase Croce, M., Contorno: izquierda y proyecto cultural. Buenos Aires: Colihue, 1996.
} 
llegaría a volcarse hacia el arco adyacente al liberalismo cultural en cualquiera de sus matices. Tanto es así que, junto a los artículos firmados por los que llegarán a ser los denuncialistas, se encuentran también textos de autores de extractos tan disímiles como Horacio Amigorena, Héctor P. Agosti, Ana Goutman, Rodolfo A. Borello, Gerardo A. Andujar, Adolfo P. Carpio, Rodolfo M. Pandolfi, Eduardo Jorge Bosco, Guillermo Whitelow, Ángel Jorge Casares, Juan A. Carrau. ${ }^{23}$

ESCRIBIR EN CENTRO

En ese escenario de resistencia y confusión constituido por Centro aparecen, entre 1952 y 1955, los primeros artículos del joven Rest. Los textos de Rest no son numerosos pero permiten visualizar con claridad sus diferencias -ya en el modo de enunciación y en el modelo de intervención crítica como en los intereses de investigación- respecto del imaginario revisionista que caracteriza a la franja denuncialista. Son de tres trabajos eruditos y minuciosos sobre la obra de T. S. Eliot, una breve apostilla titulada "Borges, Descartes y el obispo Wilkins" y una escueta necrológica dedicada a George Santayana.

La primera de esas intervenciones ve la luz en abril de 1952, específicamente en el número 2 de Centro, y lleva el mesurado

23 Lafleur, H., S. Provenzano y F. Alonso. Las revistas literarias argentinas (1893-1967), Buenos Aires, El 8vo. Loco Ediciones, 2006. p. 243. 
título de "Nota sobre la poesía de T. S. Eliot"24. Es la primera de una serie de exégesis que Rest ensayará sobre la obra del poeta, dramaturgo y crítico literario anglo-estadounidense Thomas Stearns Eliot, obra cuyo interés acompañará al crítico hasta sus últimos días. Rest tiene apenas 25 años y no toma riesgos serios en lo que refiere al corpus de trabajo: su primer texto está dedicado a un poeta frecuentemente vinculado al modernismo pero cuya legitimidad es ya indiscutible desde 1948, cuando fuera galardonado con del Premio Nobel de Literatura y la Orden del Mérito.

Irónicamente, la primera nota crítica publicada por Rest se recorta y reflexiona sobre el cierre de una obra. Su lectura hace pie en Little Godding, el último poema de Eliot y, a partir de él, trabaja sobre ciertos elementos de preceptiva. Rest sigue la pista de un verso del mismo que marca la paradoja de esa obra que se completa al descubrir que la línea desplegada se traduce en la figura de un círculo que da lugar a una obra entendida como una unidad consistente: «To arrive where we started / And know the place for the first time» ("Llegar al punto de partida / Y conocer el lugar por vez primera"). ${ }^{25}$ No obstante ello, Rest percibe que esa unidad que parece manifestarse a través del último poema no debe definir una operación de lectura retrospectiva («no nos debe hacer pensar en una revisión necesaria o absoluta de la poesía anterior»), sino un alumbramiento esclarecedor sobre «los aspectos presentes a lo

24 Rest, Jaime, "Nota sobre la poesía de T. S. Eliot" (1952a), Centro. Revista del Centro de Estudiantes de Filosofía y Letras, Buenos Aires, Año $2, \mathrm{~N}^{\circ} 2$, abril de 1952. pp. 46-51.

${ }^{25}$ La traducción pertenece al propio Rest. 
largo de toda la obra». Interpretar los pasos previos de esa obra sólo en función del lugar al que ha llegado al cabo atenta de manera concreta contra la pluralidad de los sentidos, parciales pero no por ello menos significativos, producidos por la crítica especializada.

Las consecuencias de esa reducción del arco de lectura bien pueden vislumbrarse por aquellas perspectivas que se han ceñido a interpretar The Waste Land, la obra fundamental de Eliot, como una mera «expresión del cristianismo que es sustancial a los Quartets». Sortear las limitaciones de los resultados que pierden de vista «el doble juego de soledad e imprecisa salvación que da vida a The Waste Land» significa, en efecto, negarse a acotar el valor y la condición particular del texto literario en función de un sentido totalizante.

Rest lee el texto literario como un espacio topográfico, como un terreno que arrastra residuos, acumula accidentes y va configurando características particulares. Ante la obra cerrada como conjunto, ve la posibilidad de producir una formulación general, capaz de dar cuenta de una sucesión: «descubrimientos sucesivos, que la precipitación o la novedad no permitían coordinar, ahora se estructuran y adquieren un significado». Pero la deriva de una continuidad no puede totalizar los momentos únicos en su condición sincrónica: si bien es posible «establecer en qué medida un accidente del terreno es continuación de otro (las colinas son, casi siempre, continuidad de los valles)»; cada uno de esos momentos del territorio no puede ser reducido «en virtud de la progresión natural». 
En el centro de la lectura restiana anida la pregunta por la posibilidad de establecer una posición alternativa a la totalización inducida por los últimos poemas de Eliot sobre el resto del texto. La articulación de dos enfoques complementarios y recíprocos -y que parecen excluirse mutuamente- supone para el joven crítico una solución de continuidad: establecer la «línea dominante» en el cierre de una totalidad, pero respetando cuidadosamente el valor singular y específico que cada texto tiene (o tuvo) al momento de su aparición.

En un movimiento análogo al que sostendrá en su lectura de Virginia Woolf, Rest extrae la posibilidad de confluencia de estos dos modelos de investigación del corazón mismo de la obra que aborda. El propio Eliot ha concebido la posibilidad de esta articulación en Tradition and the Individual Talent (1921); de acuerdo a una hipótesis que ya se puede encontrar, esbozada, en algunos de los ensayos críticos reunidos en the Sacred Wood, aparecido en 1920. Rest hace notar la manera en que Eliot piensa las complejas relaciones entre el poeta y su ámbito. El poeta sostiene Eliot- «debe desarrollar o procurarse la conciencia del pasado» que continuará desplegando y profundizando a lo largo de su carrera literaria. La razón es sencilla y desarticula cualquier mito romántico: lo que el poeta tiene para expresar no es una «personalidad» de excepción, sino un «medio particular», un medio «en el cual las experiencias se combinan en una forma peculiar y de maneras inesperadas».

Al subrayar esta frase, Rest pone en escena un matiz particular de uno de los temas más intensos y más discutidos en 
su época ${ }^{26}-y$ que de un modo directo había desestimado la producción poética como motivo de reflexión teórica en virtud a su inscripción extemporánea y a su relación con la imagen-: el que atañe a los modos de relación de la producción poética, la situación en la que surge y la perspectiva desde la cual se le adscribe un sentido.

La perspectiva de Eliot es clara: el poema es una forma «resultante de la concentración de numerosas experiencias». Pero esa concentración no se produce desde una totalización consciente - deliberada -no se trata de experiencias recordadas ni razonadas desde una tranquilidad contemplativa-, sino que «su integración se realiza más bien en una atmósfera que sólo es "tranquila" por cuanto supone esperar pasivamente el acontecimiento». En esas líneas de Eliot, Rest intuye un cierto retraimiento del poeta a la reducción de la compleja trama creativa a líneas esenciales. Esta intuición coincide con la disposición habitual de Eliot de abordar los temas y problemas culturales que atañen a la «mentalidad moderna»; ya sea en el carácter circunspecto de sus opiniones sobre los límites y proyecciones del criticismo como en su reticencia a «recortar bordes salientes» y tendencias definidas con relación a la poesía moderna.

La lectura de The Waste Land que desarrolla Rest en este primer artículo hace propia esta reticencia ante la totalización, tratando de pensar -aunque más no sea en términos esquemáticos y provisionales- una unidad de sentidos consistentes. Lee la poesía de Eliot como el protocolo de una experiencia de lenguaje

${ }^{26}$ Cfr. Sartre, J-P., ¿Qué es literatura?, Buenos Aires, Losada, 1950. 
concentrada y producida en las «fronteras de la mística y la metafísica»; pero poniendo un especial énfasis en lo que el propio Eliot ha optado por dejar irresuelto: esto es, tratando de revelar «en qué consiste la concentración de la experiencia». Esa concentración de la experiencia es sin duda un experimento con el tiempo. Dado que es imposible dar las "notas esenciales" o la "idea" de esa experiencia («cada experiencia es irreductible, porque es única»), su concentración sólo es posible al aislarla del cambio en que, sucesivas, las experiencias «se ligan para crear progresivamente la apariencia del tiempo». Sobre esa «experiencia pura», que es «revelación sensible de lo intemporal dado en el tiempo», la expresión poética traza su propia historicidad: «la concentración es poética cuando su imagen suscita la experiencia que expresa». ${ }^{27}$

La poesía de Eliot se obstina en hallar y acoger las imágenes capaces de esa experiencia. The Waste Land pone en escena dos procedimientos específicos de citación que buscan reproducir la experiencia por dos vías distintas pero íntimamente relacionadas: una es la cita - «de versos vagamente conocidos»- que procura «suscitar reminiscencias» y que ocupa una parte fundamental del poema; la otra es la que se desprende de la «rigurosa selección de estas citas en función a su capacidad de modificar la

\footnotetext{
27 La idea de experiencia que aparece con suma frecuencia en esta etapa de la producción restiana supone una ascendencia vagamente leavisiana. La noción -tomada un poco superficialmente por Rest- es no obstante de una gravitación crucial en el desarrollo del pensamiento crítico inglés. Un esclarecedor panorama crítico y analítico de las sucesivas transformaciones de dicha categoría en la tradición del pensamiento político inglés -desde David Hume y Edmund Burke hasta y Michael Oakeshott y los marxistas ingleses- puede leerse en "Política y experiencia" de Martin Jay (Cantos de experiencia. Variaciones modernas sobre un tema universal, Buenos Aires, Paidos, 2009. pp. 207-257).
} 
sensibilidad directamente».

Esos dos procedimientos -que no pierden eficacia y sobreviven incluso en los últimos movimientos de los Quartets- y sus efectos en el texto literario son los que permiten a Rest pensar la unidad poética y reflexiva que atraviesa los temas místicos y metafísicos de la poesía de Eliot. El poema es ese espacio en el que coexiste «un sentido del pasado que se da ("supone esperar pasivamente") como una experiencia» (es decir, como aquello que es posible arrancar (ex-) a lo que perece) y la huella de ese deseo de un instante puro que es «"un punto quieto en el mundo cambiante" (a still point of the turning world) donde la realidad adquiere plenitud en una "sucesión de momentos intemporales" (a pattern of timeless moments)», que son capaces de contener -en sí y al unísono- el futuro y el pasado, sin la necesidad de representaciones sucesivas que signifiquen ataduras y direcciones en el tiempo. La fugacidad de esas experiencias exige, en su paso a la experiencia poética, una condensación en «una imagen verbal exacta y ágil». El dispositivo poético de Eliot se presenta ante Rest a la manera de un ejercicio de economía y concentración: una máquina implacable que, revirtiendo la imposición sucesiva del lenguaje, es capaz de crear las imágenes poéticas que -sin margen para la contingencia o la difusión- se inscriben sobre la «necesidad apremiante» de compartir aquello que acontece como experiencia irreductible.

La segunda nota publicada por el joven Rest en Centro repite la escrupulosidad pero se diferencia considerablemente de la 
anterior en razón de su carácter específico. "La poesía de T. S. Eliot: Formación" (1952b) ${ }^{28}$, que significativamente abre el tercer número de la revista, aparecido en setiembre de 1952, es un artículo de tenor más histórico que crítico. En él Rest traza un recorrido exploratorio por la etapa formativa de Eliot teniendo como eje y referencia su relación con el imaginismo.

Bajo el sartreano título de «Situación de la poesía inglesa», Rest abre el ensayo reponiendo la doble condición de británicoestadounidense. Lee sus primerizos pasos bajo la influencia neohumanística de Irving Babitt, su conocimiento erudito de la cultura clásica, su sentido de la tradición y «esa cualidad paneuropea» que subsiste en los poetas norteamericanos radicados en Europa entre 1910 y 1920 como una prueba de los efectos que tuvo su paso por Harvard. Pero a la vez señala, por un lado, la creciente desconfianza que, ya desde sus primeros ensayos ("The Humanism of Irvíng Babbitt" y "Second Thoughts about Humanism",

28 "La poesía de T. S. Eliot: Formación" (1952b), Centro. Revista del Centro de Estudiantes de Filosofía y Letras, Buenos Aires, Año $2, \mathrm{~N}^{\circ} 3$, setiembre de 1952. pp. 1-8. En el mismo número de la revista aparecen firmadas bajo las siglas "J. R." además, en la sección Periferia, dos breves reseñas (una sobre la biografía de Nicolai Gogol realizada por Janko Lavrin, y otra sobre la antología Die Dichterbühne editada por Erich Blaschker, que da cuenta del estado de la literatura alemana de mediados de siglo), una breve recensión de dos números especiales de The Times Literary (uno dedicado al estado del pensamiento británico y el que conmemora el cincuentenario del propio suplemento) y cinco precisas necrológicas (dedicadas a Amado Alonso, John Dewey, William James Entwistle, sir Desmond MacCarthy y Carlos Alberto Leumann). En el número inmediatamente siguiente de Centro, aparecido en diciembre del '52, Rest colaborará con dos notas breves (una dedicada a "Borges, Descartes y el Obispo Wilkins" y otra a la recensión de Fifty Years of English Literature 1900-1950, del catedrático y editor del London Mercury, R. A. Scott-James); y en el número 5, de mayo de 1953, aparece publicada en la sección Periferia un breve obituario con su firma sobre "George Santayana". El hecho no es menor. El rigor disciplinario, la variedad genérica y temática que, aún en su brevedad, exhiben estas intervenciones son prueba tajante de la versatilidad, la seriedad y el grado de profesionalización de Rest en varias aristas del trabajo académico. Y de algún modo permiten pensar en qué medida explican su inclusión en el proyecto político-cultural que, en la revista Imago Mundi, generaría el historiador José Luis Romero. 
incluidos en sus Selected Essays), el joven Eliot manifiesta respecto de las figuras de ese neo-humanismo-desconfianza que se atisba en «la impaciencia con que contempla, ya residente en Inglaterra, a los que habían sido sus maestros, preocupados, al parecer, en abstraer una teoría humanística de la totalidad múltiple pero indivisible de la cultura»-; y por otro, el creciente interés del poeta por algunos de los descubrimientos londinenses, donde -como apunta Rest- «no sólo le fue revelada la eminencia Yeats a través de un bailarín japonés que representaba The Hawk's Well», sino también la existencia de su propio compatriota Robert Lee Frost.

Luego de consignar rápidamente la tensión de origen y formación en el autor de The Waste Land, Rest va al punto de su interés: el lugar ocupado por Eliot entre los poetas imaginistas y las peculiaridades de su relación, tanto con los poetas del grupo como con los precursores del movimiento, cuya dirección suele atribuirse al poeta T. E. Hulme y cuya difusión más comprometida corrió por cuenta de Ezra Pound («editor y propulsor de The Catholic Anthology, The Egoist, The Little Review»). Con ese objeto, describe la preceptiva del imaginismo resumida, en el manifiesto de 1913, en seis propósitos fundamentales: 1). uso del lenguaje común, pero empleando siempre la palabra exacta; 2). creación de nuevos ritmos, con preferencia al verso libre; 3). libertad absoluta en la elección del tema; 4). voluntad específica de presentar una imagen precisa y rechazar las generalizaciones vagas; 5). intención de producir una poesía dura y clara, por oposición a la poesía confusa o indefinida; y 6) . 
convicción de que en la concentración radica «la verdadera esencia de la poesía». Rest hace preciso hincapié en cada uno de estos puntos porque trata de ver qué rasgos particulares de su afiliación coyuntural al movimiento imaginista, que ansiaba «una renovación completa de la poesía inglesa moderna» (y entre cuyos adherentes más importantes se contaban los británicos F. S. Flint, Richard Aldington, D. H. Lawrence y Wilfred Owen, y los norteamericanos John Gruld Fletcher, Hilda Doolittle, Amy Lowell y Margaret Anderson), ha sobrevivido posteriormente en la poética de Eliot.

El paso de Ezra Pound y Eliot -presentados por Conrad Aikenpor el imaginismo no fue muy extenso temporalmente pero fue intenso en términos de adhesión poética. De algún modo sus obras fueron las que vehiculizaron los efectos propios del imaginismo sobre la poesía inglesa posterior. El imaginismo había constituido para ellos no sólo «una técnica apropiada a las nuevas necesidades», que daba cuenta del importante cambio del medio social en que se desplazaba el poeta moderno; sino también el principio activo de una «respuesta común al pasado inmediato», una respuesta que abría la posibilidad de revalidar la propia tradición poética inglesa nacional y asimilar la europea. A partir de allí era posible retomar «la influencia de Baudelaire y los simbolistas, en especial de [Jules] Laforgue y los tardíos», pero también volver a Dante, a François Villon y a los poetas provenzales e integrar estas experiencias en la propia corriente poética con el objeto de interrumpir la hegemonía de la poesía fácil e imprecisa que era cultivada y reverenciada por los poetas 
de continuidad victoriana.

El rastreo erudito de Rest sigue la propia determinación nacional-europea del imaginismo. Se opone implícitamente a las perspectivas mezquinas de un nacionalismo que, desde ciertas cátedras de la universidad peronista, perseveraba en el lugar común que considera toda la influencia no nacional como una perversión "extranjerizante". La búsqueda de precursores, no sólo se detiene en las esmeradas reflexiones de T. E. Hulme, sino que pasa por el prólogo a las Lyrical Ballads de Wordsworth, ciertos momentos de Tennyson y Browning y de Poe y Whitman, y subraya con su moderación característica- la importancia de Hopkins como referencia primigenia y da la tardía influencia de Yeats sobre Eliot. Rest se apoya en Enemies of Promise ${ }^{29}$ de Cyril Connolly para explicar la última transformación sufrida por el imaginismo antes de su desaparición como movimiento. Más que la experiencia de la guerra misma, es «la angustia de los twenties»-la transformación social y la consecuente corrupción moral desatada a partir del desarrollo industrial del capitalismo- la que promueve esa transformación en el plano literario. Entre la crisis y la guerra, el imaginismo deja de ser ya «una técnica nueva para una poesía menor»; la experiencia trágica de un mundo en ebullición lo va convirtiendo en un incontenible «cauce» que busca «expresar plenamente esa intensidad» vivida. Es el pulso mismo de la historia lo que habilita su supervivencia, con su inimitable vitalismo activo, en T. S. Eliot, en Edith Sitwell, en

29 Connolly, Cyril, Enemies of Promise, Routledge \& Kegan Paul, Londres, 1938 . 
Day Lewis y W. H. Auden, en Dylan Thomas y [Ralph] Keyes, y es también la historia la que empuja la poesía moderna de lengua inglesa a una reflexión profunda que atañe a «la problemática substancial del hombre».

El grueso del artículo se aboca a una precisa explicación de texto que traza la progresión reflexiva a través de tres célebres poemas de Eliot que han alimentado una importante discusión en torno al modernismo: The Love Song of J. Alfred Prufrock (1917), Gerontion (1920) y The Waste Land (1922).

Del primero, Rest subraya específicamente el pulso irónico que domina su reelaboración del concepto de futility, presentado por el soldado poeta Wilfred Owen en el poema homónimo. En el texto de Eliot, Prufrock se siente incapaz de realizar la creación (a la que se le ha destinado), supone que ese reiterado fracaso del hombre lo excede porque procede de fuerzas ajenas a él mismo -ya porque lo que lo detiene es la propia sociedad en que se encuentra, ya porque aun no ha llegado el tiempo destinado para la creación-y, finalmente, arriba a la conclusión de que la causa que anega al hombre no es otra que su propia falta de propósitos. Ese proceso de autocomprensión es expresado por Eliot por medio de una técnica contrapuntística que sostendrá invariablemente a lo largo de toda su producción poética como uno de los rasgos estilísticos más peculiares y que «consiste en presentar un tema, luego su contraparte $y$, por medio de un elemento débilmente ligado a los anteriores, precipitar un desenlace».

La lectura de Rest puntualiza ese procedimiento al subrayar 
de qué modo, rehuyendo la conciencia de su propia falta de propósitos, el personaje de Eliot presenta el tema en una interrogación abierta a los otros, deja por un momento «la ilusión momentánea de que aún no ha llegado el tiempo de crear» convenciéndose de que hay «todavía, esperanzas no frustradas»- y, por último, su desenlace se precipita sobre la disolución de toda certeza. El mundo exterior muestra, en la seguridad de su progreso, que el tiempo de crear es el presente que empieza indefectiblemente a «agostarse». La respuesta a la pregunta que toca al hueso de los planteos neo-humanistas de Irving Babitt surge, paradójicamente, a través de «giros cuya pretendida gravedad formal es desmentida por el avance simultáneo de observaciones triviales», o justamente en aquellos gestos con que los hombres intentan disimular «la insustancialidad de sus existencias».

No obstante, como bien nota el joven crítico, The Love Song no transmite aún «la incertidumbre con la fuerza, amplitud y serena -por no decir resignada- comprensión que adquiere en Gerontion». La brevedad del poema aparecido en 1920 «tiene la virtud de concentrar en las palabras del anciano un conjunto de imágenes complejas y sugestivas» en las que el pensamiento «se pierde en engañosos pasajes y maquinados corredores sin aparente posibilidad de rescate». Pero además, «introduciendo la preocupación por la tradición cultural dada en la historia y presente en el momento actual», Gerontion prefigura de algún modo los planteos políticos más importantes de The Waste Land. Es allí donde la tradición empieza a cobrar relevancia hasta tomar el 
núcleo mismo de su reflexión crítica y su producción poética. Eliot descubre el mundo de la gran poesía europea (de Homero a Virgilio y de éste a Dante) y lo acoge en su propio espacio textuario. Pero Rest -que da cuenta de haber leído The Idea of a Christian Society (1939) y Notes Towards the Definition of Culture (1948)- sabe que el interés de Eliot por la tradición conlleva una crítica conservadora del liberalismo y la democracia, y que ese interés es político en tanto se complementa fehacientemente con su postulación de una configuración social basada en el cristianismo. El interés de Eliot por la tradición no se reduce a un procedimiento creativo basado en una evidente «capacidad de asimilar en sus poemas versos y citas ajenos». «La naturaleza profunda de esta actitud está -como apunta Rest- muy lejos de reducirse a un aprovechamiento de las resoluciones dadas por otros poetas a sus problemas de expresión». Supone, más bien, una lucha y un diagnóstico pesimista de las transformaciones sociales que el industrialismo había desencadenado sobre la Cultura entendida como «todo un modo de vida», cuya continuidad general dependía de la articulación de una elite y una clase social en el gobierno «con la cual aquella se superpondrá e interactuará de manera constante» (Williams 2001: 203). ${ }^{30}$

Rest percibe, tanto en Eliot como en Paul Valéry, una desesperada «búsqueda del símbolo que ese pasado atesora». Sus intereses por la mitología clásica y por los temas de la tragedia griega hablan de una civilización perdida y un presente en

\footnotetext{
30 Williams, Raymond, Cultura y sociedad. 1780-1950. De Coleridge a Orwell, Buenos Aires, Nueva Visión, 2001.
} 
ruinas. Lo que está en juego es pues una sutura imaginaria en esa vuelta al pasado clásico, premoderno, ordenado y tradicional como resistencia al «sórdido culto del subjetivismo anárquico», la fetichizada «personalidad autoexpresiva», «el inmoral "dejar hacer y dejar pasar" de la economía» individualista, «la "luz interior" del protestantismo y la subversión bolchevique». ${ }^{31}$

La condición premoderna de la poesía de Eliot se afirma ya en la mitología del Rey Pescador, los cultos de la fertilidad y los temas rurales de la sangre y la tierra, como en la tradición que, aun siendo «patrimonio común de la sociedad», requiere de una elite cuya competencia articule el saber acumulado y un «código religioso social de comportamiento unificado» (Eagleton 2012: $103) .^{32}$

Se trata, como bien sintetiza Rest, de un intento desolado por conservar «ese conjunto de creencias, a veces irracionales pero vivas y directas» que, en la modernidad, «ha sido casi enteramente desplazado por la ciencia». Rest percibe que el modernismo de Eliot es profundamente antimoderno. En el antipositivismo de Eliot, lee un resabio humanista que reclama a la ciencia haber impuesto «un orden abstracto donde el hombre no halla el medio directo e inmediato para comunicarse con el hombre». Es en ese sentido que interpreta la «necesidad» de Eliot por alcanzar «el significado pleno de las ideas», por «adquirirlas por medio de la sensibilidad» (una sensibilidad conservadora que -al decir de Fredric Jameson- puede definirse

\footnotetext{
31 Eagleton, Terry, "T. S. Eliot", en Figuras de disenso, Buenos Aires, Prometeo, 2012. pp. 99-107.

32 Williams, Raymond, op. Cit. p. 194.
} 
como la «del viejo orden hidalgo agrícola inglés» que reverbera en F. R. Leavis) ${ }^{33}$, y, finalmente, por convertirlas «en símbolo y aún en mito» con tal de preservarlas.

Que la «misión del poeta» se vea acotada por la propia limitación de sus medios de comunicación no reduce su eficacia. Su tarea radica en «establecer una relación con quienes lo posean y estén dispuestos al esfuerzo de interpretarlo». Su actuación y su competencia se ratifican en la capacidad para concentrar y fundir los elementos de la tradición en imágenes de un presente puro que busca afirmarse como porvenir en el desafío de un retorno metafísico. The Waste Land es -a juicio de Rest- el más esmerado esfuerzo por articular ese reconocimiento con una ideología confiada a «la activación de la potencialidad cristiana» que Eliot percibe en el subtexto de la cultura inglesa que le es contemporánea.

Escrita durante 1953, "La poesía de T. S. Eliot: The Waste Land" $^{34}$ aparece recién en el noveno número de Centro, en setiembre del '55, cuando en la revista del Centro de Estudiantes de Filosofía y Letras empezaba a predominar una mirada crítica más radicalizada, como la que se proponía desde la revista Contorno, y cuando ya Rest era un asiduo colaborador en Imago Mundi, la publicación dirigida por el historiador liberal José Luis Romero. En ese contexto, el hecho de que el artículo de Rest ocupe un

\footnotetext{
33 Jameson, Fredric, Una modernidad singular. Ensayo sobre la ontología del presente, Barcelona, Gedisa, 2004, p. 16.

34 Rest, J., "La poesía de T. S. Eliot: The Waste Land", Centro. Revista del Centro de Estudiantes de Filosofía y Letras, Buenos Aires, Año 5, $\mathrm{N}^{\circ}$ 9, septiembre de 1955. pp. 11-29.
} 
lugar privilegiado en el volumen habla a las claras del respeto intelectual que el joven crítico se había ganado entre sus pares, aún a pesar de sus diferencias ideológicas.

El artículo no constituye en modo alguno, pese a su apariencia, un cierre de la investigación iniciada en 1952. El interés de Rest por este poema de T. S. Eliot seguirá abierto permanentemente -prueba de lo cual son tanto sus inmediatas publicaciones en Imago Mundi como el capítulo de Mundos de la imaginación titulado "Tiresias y el canto de las aves", escrito en 1967 y retomado en $1978 .{ }^{35}$

En esta ocasión Rest ensaya una minuciosa explicación de texto de matiz filológico de la obra poética más importante del fundador de la mítica revista Criterion. Pero, antes de entrar en los aspectos referidos a la presencia de la tradición literaria en The Waste Land, señala someramente las dificultades características del abordaje en relación a la competencia que exige una comprensión cabal del poema. Tal y como lo ve Rest, toda lectura del texto de Eliot que se distraiga de las notas que el autor escribió para ayudar a su comprensión, o que desconozca la referencia a las fuentes con las que el poema dialoga implícita o explícitamente, corre el riesgo de interpretar el texto como «a heap of broken images». La superficie del poema tiene la apariencia de un conjunto heterogéneo de "imágenes truncas" que semejan «la sucesión de impresiones diversas que recoge la conciencia». En función de esto, Rest emparenta el

35 Rest, Jaime, Mundos de la imaginación, Caracas, Monte Ávila, 1978. pp. $237-261$. 
texto de Eliot con el Ulysses de Joyce («la obra contemporánea donde se nota en mayor grado un esfuerzo por aprehender las modificaciones múltiples y simultáneas del acaecer tal como se dan a la experiencia») sin dejar de mencionar que esa técnica no les es patrimonio exclusivo, sino que puede encontrarse en otras obras de literatura inglesa reciente, como The Waves de Virginia Woolf.

Sin embargo, la comparación estructural dispuesta por Rest se circunscribe a Finnegans Wake (1939) y Point Counter Point (1928). Joyce, porque intentó concentrar y descubrir la trama imperceptible de la historia; Huxley porque su objetivo es el de describir la compleja sociedad de su época mediante «una elaboración musical» conceptualizada como «contrapunto», y que es muy afín al tempo en que se inscribe la versificación de The Waste Land. Como procedimiento expositivo, el contrapunto permite «comunicar directamente los significados que de otro modo el autor tendría que presentar en forma teórica». Es lo que hace que, aquellos «fragmentos aislados que integran el conjunto aparentemente caótico», aparezcan integrados en una suerte de concentración sintética. Si -como apunta Rest- los efectos poéticos del contrapunto pueden verse amenazados en la novela (especialmente por la continuidad narrativa o cronológica que une a los fragmentos), en el poema de Eliot las partes integradas por más de un fragmento muestran una cohesión impactante, en la cual es posible percibir, a la vez, «la oposición y la síntesis poética de los fragmentos». Rest remite esta técnica, que alcanza su mayor difusión con el imaginismo, no a la coyuntura del 
modernismo, sino a experiencias poéticas previas de la tradición europea, como las de Arthur Rimbaud (en Une saison en enfer) y William Blake (en The Marriage of Heaven and Hell).

El artículo de Rest se empeña en subrayar la presencia concreta de textos y técnicas de la tradición poética europea (desde el Antiguo Testamento o el Apocalipsis a la literatura y la mitología griega) en el corazón mismo de The Waste Land. La decisión de tomar como tema la sociedad contemporánea y el peso del pasado que ella soporta, es para Eliot un problema crucial y como tal lo asume ya desde 1921, cuando expone las dificultades a las que debe enfrentarse el poeta contemporáneo: «Nuestra civilización -cita Rest a Eliot- comprende una gran variedad y complejidad; y esta variedad y complejidad, cuando actúan sobre una sensibilidad refinada, deben producir resultados varios y complejos». Es por eso que el poeta se ve en la necesidad de hacerse «más y más comprensivo, más alusivo, más indirecto, a fin de forzar -de dislocar si es necesario- el lenguaje, para que signifique lo que se propone» ${ }^{36}$.

A juicio de Rest, esquemáticamente la interpretación de The Waste Land está en lo concreto determinada por dos cuestiones fundamentales: 1) por el hecho de que la articulación de los episodios del poema no es rígida, sino que cada uno de ellos propone un sentido parcial, vario y complejo; 2) porque al considerar el significado general del poema es preciso tener presente que, si lo hay, éste debe derivarse de la configuración

36 Eliot, T. S., Los Poetas Metafísicos y otros ensayos, Emecé, Buenos. Aires, 1944. p. 57. 
misma de los elementos del poema y no de las fuentes de donde éstos han sido tomados. Su lectura supone pues un rastreo erudito que abarca la mitología griega y egipcia, los cultos de la vegetación (y los que celebran la muerte y resurrección de los dioses de la fecundidad), las Upanishads, el Antiguo Testamento, la Comedia de Dante y otros textos occidentales, pero a la vez una resemantización de esas fuentes de la tradición en función de la configuración formal del poema. En vez de enfocar la lógica previsible de las influencias y la cita de autoridad, Rest ve en Eliot un modelo de apropiación y transformación de los materiales de la tradición en función de un sentido estrictamente contemporáneo, que remite al momento de decadencia moral y espiritual suscitado a partir del desarrollo del capitalismo industrial en Inglaterra.

IMAGO MUNDI: LA OTRA PROFESIONALIZACIÓN

Simultáneamente a esta serie publicaciones en Centro, y mientras redacta su tesis sobre Virginia Woolf, Rest empieza a colaborar con Imago Mundi. Esta revista, creada y dirigida por José Luis Romero, publicó sus doce números entre 1953 y 1956 y en sus páginas Oscar Terán ha leído «el rostro de una universidad alternativa a la que la política cultural del peronismo obligaba a funcionar en las sombras» (Terán, 1991:34). El consejo de redacción de la revista (conformado por Luis Aznar, José Babini, Ernesto Epstein, Vicente Fatone, Roberto F. Giusti, Alfredo 
Orgaz, Francisco Romero, Jorge Romero Brest, José Rovira Armengol y Alberto Salas) da cuenta en cierta medida de la cantidad y cualidad de los intelectuales que el gobierno peronista había excluido del ámbito universitario. La materialización de esa «universidad alternativa» hubiera sido imposible sin el apoyo del sector privado liberal. En el caso de Imago Mundi, el mecenazgo de Alberto Grimoldi permitió a los intelectuales reunidos por Romero articular sus propios intereses en relación a un conjunto de saberes que la cultura ilustrada veía en riesgo de supervivencia en el ambiente opresivo de la universidad oficial.

La coherencia interna de la revista -pese a la diversidad de voces y perspectivas que en ella recalan- es realmente admirable. Se articula tanto sobre una continuidad en términos formales como en la persistencia de colaboradores y contenidos específicos. Y de algún modo garantiza -tal como apunta Teránun doble plano de protección ante las invasiones de la coyuntura: por un lado, «un tiempo indeterminado» (en el que fuera posible afrontar «con actitud entre digna y resignada la no deseada pero ineludible perdurabilidad del peronismo en el gobierno») y, por otro, una suerte de «república internacional del saber» (cuyo espacio de interlocución se define por sobre los referentes nacionales ajenos al propio grupo y que explica el singular énfasis de la revista en lo que respecta a congresos internacionales de ciencias sociales y humanas).

Imago Mundi se mantuvo aislada de toda intervención política directa, al punto que en sus páginas no hay siquiera rastros de queja por los encarcelamientos de políticos e intelectuales 
disidentes al régimen -entre los que podían consignarse los de algunos de los integrantes de la propia revista, como Roberto Giusti o José Luis y Francisco Romero. La perdurabilidad de la misma estaba sujeta a esa omisión. La censura sólo podía evitarse con una escritura estratégica, en apariencia despegada de la coyuntura que la producía. Por eso llama poderosamente la atención que, en el número 3 de la revista, el joven Rest apareciera como la única voz disonante en el mediotono del grupo, sobre todo al reconocer e incluso celebrar -en una elogiosa reseña de la revista Encounter- «la tendencia actual a incluir los temas políticos entre las cuestiones culturales» ${ }^{37}$.

Imago Mundi, la revista que Rest confesaba fundamental en su formación intelectual, era -como su propio subtítulo lo afirmabauna "Revista de historia de la cultura" y su objetivo era la actualización de la cultura nacional y su vinculación con los focos teóricos más importantes del mundo occidental. Los artículos que tematizan directamente cuestiones nacionales son pocos y la insistencia reflexiva alrededor de la categoría de "Occidente", traduce la convicción generalizada del grupo en entender lo nacional inscrito en un arco de valores e inquietudes teóricas de una Cultura que trasciende los límites de lo local. Se trabaja -ya en el área de las humanidades como en el de las ciencias sociales- con obsesión aplicada y responsabilidad intelectual. Es en este sentido que, en este espacio constituido por intelectuales marginados, la profesionalización de las actividades intelectuales empiezan a

37 Rest, Jaime, "Encounter" (1954a), Imago Mundi, 3, Bs. As. p. 88. 
ganar legitimidad a través del ejercicio estricto de su práctica teórica y en virtud a un trabajo minucioso y comprometido, que supera con creces la exigencia de las instituciones estatales regenteadas por el peronismo.

En el marco de ese movimiento hacia la profesionalización que requiere de sistematicidad práctica y actualización teórica, la revista hace su diferencia. En la sección dedicada a las recensiones e informaciones bibliográficas se aglomeran numerosos trabajos de humanidades y ciencias sociales provenientes del extranjero. Las recensiones puntuales están tratadas con suma seriedad y rigor erudito por comentaristas especializados en las respectivas disciplinas. De lo que se trata es de proponer una forma de enseñanza alternativa a la cátedra, explorando temas específicos, dando a conocer una bibliografía actualizada y proponiendo guías de lectura impensables en las aulas universitarias de la época. ${ }^{38}$

El flagrante contraste, durante el período peronista, entre Imago Mundi y la Revista de la Universidad de Buenos Aires ( $R U B A)$ explorado por Oscar Terán pone en blanco sobre negro que los impulsos innovadores y la voluntad de actualización de la primera liquidaba cualquier sesgo de interés de los jóvenes por el tratamiento acrítico, conformista y convencional que se reproducía en la segunda. Sin embargo, no había allí siquiera un territorio para la polémica. En sí, RUBA no podía configurar un "otro" a la altura de la polémica, ni servía tampoco a Imago

38 Cfr. Sarlo, Beatriz. La batalla de las ideas (1943-1973), Buenos Aires, Ariel, 2001. 
Mundi para diseñar los límites de su propio discurso en una relación de contraste respecto de ella. Las perspectivas se confrontaban casi elípticamente, ninguneándose de manera recíproca. No obstante ello, el contrapunto era percibido de manera evidente por los jóvenes. Desde la sección "San Martín y Viamonte" de Centro, la revista dirigida por José Luis Romero era leída como un «símbolo de la azarosa -pero tal vez por elloefectiva vida espiritual del país», y, al mismo tiempo, como una «muestra de que el amor por las cosas de la inteligencia supera todos los obstáculos». Y, pese a que se la describe desde cierto utopismo que se desprende de una mirada escéptica respecto de la coyuntura (el éxito de una revista como esa exige, necesariamente, «la existencia de una vida intelectual normal y honesta», que se traduciría -según afirma la reseña- en un cierto número de lectores competentes e interesados en sus temas), se la percibe como el «símbolo inverso de la atonía e incapacidad para la vida intelectual a que han llegado nuestras llamadas Facultades de Humanidades ${ }^{39}$.

Y si, como rostro visible de otras producciones alternativas como las del Colegio Libre de Estudios Superiores o la Sociedad Científica Argentina, Imago Mundi era recibida de algún modo como una suerte de "universidad de las sombras", paralelamente, desde sus filas se promocionaba a los "alumnos" más promisorios en relación con lo previsto en su propio programa. El joven Jaime Rest es una de esas promesas tangibles en tanto -ya desde sus

39 Borello, Rodolfo, "IMAGO MUNDI", Centro, $\mathrm{n}^{\circ}$ 7, diciembre de 1953. pp. $52-53$. 
primeros artículos en Centro- revela un compromiso genuino y un trabajo profesionalizado, minucioso y erudito que se combina con un modo de enunciación formal (que exhibía como virtudes templanza y sobriedad) y una clara simpatía con la perspectiva liberal-progresista ponderada desde Imago Mundi. Rest había sido, años antes, uno de los alumnos sobresalientes de Romero y tanto sus intervenciones en Centro como el modelo de investigación sobre el que construye su tesis sobre Virginia Woolf definen la preferencia y confianza que el "maestro" revela haber depositado en él al convocarlo personalmente a colaborar de manera asidua en Imago Mundi. El joven Rest retribuye esa confianza con trabajo genuino. Publica en la revista una serie de artículos que ni por un instante se quitan al guión de la especialidad en que ha centrado su formación (la literatura anglosajona medieval y moderna) y que en cierto modo continúan el modelo de investigación ensayado en los textos más importantes de su paso por Centro.

"Sir Herbert Read y el estudio del romanticismo inglés" fechado en setiembre de 1953 y aparecido en diciembre del mismo año, es un artículo breve pero importante en términos de aporte

\footnotetext{
40 Rest, J., "Sir Herbert Read y el estudio del romanticismo inglés" (1953d), en Imago Mundi, 2, Bs. As. pp. 72-76. En el mismo número de la revista, en la sección rotulada como "Crónica", y en la que se reúnen reseñas de libros, revistas, eventos culturales y reuniones académicas de diversa índole, Rest firma una nota sobre "La muestra de arte mejicano en Londres" y una semblanza sobre el pedagogo, hispanista y traductor inglés Edgar Allison Peers. En el número siguiente de la revista, aparecido en marzo de 1954, Rest colabora con dos notas breves: en primer lugar, una reseña de la revista mensual de «literatura, arte y política» patrocinada por el "Congreso para la libertad de la cultura" presidido por Denis de Rougemont y coordinada por Nicolás Nabokov; y, en segundo lugar, una nota rigurosamente descriptiva del "número especial" de The Times Literary Supplement, dedicado al curso del pensamiento británico durante la década 1940-1950.
} 
teórico crítico. Siguiendo Principles of Literary Criticism (1924) de I. A. Richards, Rest puntualiza una distinción importante para comprender el desarrollo posterior, la naturaleza y la disposición ética de su trabajo crítico-literario. La distinción se produce al interior del propio juicio crítico. Es allí donde es posible percibir dos instancias específicas diferenciadas: la técnica («la parte del juicio que se refiere al objeto») y la crítica («la que se refiere al valor de la experiencia»). Ese diferendo remite a los signos particulares de la investigación filológica, por un lado, y la apreciación estética, por el otro; esto es: en primer lugar, un trabajo enrolado en una disciplina específica y especializada; y, en segundo lugar, una valoración subjetiva en relación a la experiencia estética del objeto en cuestión.

Puesta sobre la historia de la literatura inglesa, esa distinción decanta en dos tendencias claras: una, «de indagación técnica», cuyo origen es adscrito generalmente al Doctor samuel Johnson y a T. S. Eliot; la otra, «de índole valorativa», cuyo origen suele remontarse al pensamiento romántico, especialmente a Samuel Taylor Coleridge. Es este último aspecto el que, en Form in Modern Poetry (1932) tematiza Sir Herbert Read, quien siguiendo la perspectiva teórica de Friedrich Schelling- intuye que el arte no es «una imitación de la natura naturata», sino «una continuación de la natura naturans, el principio creativo que plasma esos objetos». Lo que el arte imita es el impulso natural de la naturaleza (no el producto de esa fuerza). Se convierte así en la «transfiguración simbólica de esta 
experiencia intuitiva, en la composición de una estructura». La reflexión de Read lleva implícita una interrogación por un problema candente en el horizonte de inscripción del texto restiano. El concepto de Gestalt surgido desde los experimentos psicológicos de Wolfgang Koehler y que, a través de los investigadores de la lógica simbólica (de Ernest Cassirer a Susanne Katherina Langer), fue introducido al ámbito de los estudios estéticos. En el voluminoso estudio de Langer que por entonces traduce junto a su esposa Virginia (y que Sur publicará en 1958$)^{41}$, Rest encuentra una definición que remite a Sir Herbert Read: existe una forma de articulación del pensamiento que no es discursiva, cuyos elementos carecen de autonomía y no son presentados en forma sucesiva sino más bien simultánea, en una estructura orgánica. Rest traslada esta reflexión del ejemplo categórico de las artes plásticas al universo de la poesía, demostrando hasta qué punto ella misma es una «unidad presentativa» cuyo sentido sólo puede extraerse de la «totalidad formal» («compuesta de sonoridad y sugestión, de exposición y reticencia»). El poema es pues el resultado de un «proceso de simbolización»-al que Read da el nombre de «orgánica»- de una situación anímica determinada.

La contraposición de la «forma orgánica» a la «forma retórica» apunta a aclarar con mayor nitidez el sentido de la investigación de Read. Rest avanza sobre este punto completando las lagunas y zonas confusas del estudio de Read y resume

41 Langer, S., Nueva clave de la filosofía. Un estudio acerca del simbolismo de la razón, del rito y del arte. Buenos Aires: Sur, 1958. Trad. Jaime Rest y Virginia Erhart. 
brevemente el contraste entre las dos nociones: la forma orgánica «consiste en la transfiguración simbólica necesaria de un estado anímico»; la forma retórica «es la elaboración de un tema de acuerdo a una configuración preestablecida». De ese modo, la primera, es una «estructura unitaria» y «simboliza una situación emotiva»; la segunda, es una síntesis desarrollada a partir de una idea general.

El carácter vago e incompleto de la teorización de Read lleva a Rest a contrastarlo con la clara conceptualización normativa de la valoración poética establecida por Johannes Pfeiffer. En Umgang mit Dichtung ${ }^{42}$, el teórico alemán traza una sistemática conceptualización. Diferencia, en principio, lo «poéticamente auténtico» (una «experiencia verdadera, realmente vivida») de lo «inauténtico o artificial de un estado "asumido" o falso». La distinción se corresponde claramente con la de «forma orgánica»y «forma retórica» ensayada por Read, pero Pfeiffer no se queda sólo en ella. Trabaja además sobre otros dos contrastes: «uno, entre la dicción original, "viva e irrepetible", y la dicción no original o estereotipada en las imágenes gastadas por la repetición; el otro, entre la poesía debidamente plasmada y la poesía meramente hablada». Las distinciones de Pfeiffer afirman el núcleo de la intuición de Read, para quien en la poesía inglesa se puede reconocer con nitidez «una continuidad fundada en el principio de "forma orgánica"» que, nacida con el romanticismo, reaparece en la noción de inscape de Gerard Manley

42 Pfeiffer, J., Umgang mit Dichtung. Eine einführung in das verständnis des dichterischen, Leipzig, Verlag von Meiner, 1938. 
Hopkins, en la teoría imaginista de T. E. Hulme y en los digitados procedimientos contrapuntísticos de T. S. Eliot. Es en este punto donde resultan de sumo interés para el joven Rest, quien en ese momento -como se ve en sus artículos aparecidos en Centro- estudia la obra del autor de The Waste Land prestando especial atención a la concentración de experiencias en la imagen poética.

La reflexión precedente se prolonga en otros textos de Imago Mundi. En setiembre del año siguiente, en la sección "Textos y documentos para la historia de la cultura", introducida por una breve nota de Rest ("Coleridge y las teorías artísticas del romanticismo inglés") ${ }^{43}$, la revista publica la conferencia "Sobre la Actividad Poética o el Arte" (On Poesy or Art) de samuel Taylor Coleridge. El joven crítico enfatiza la importancia del documento recobrado en función de su carácter testimonial con relación a los dos aspectos fundamentales del movimiento romántico subrayados en su texto sobre Sir Herbert Read: por un lado, la notable influencia de la filosofía crítica alemana (especialmente Kant y Schelling); y por otro, el desarrollo de una concepción de la actividad artística y literaria como «creación de un equivalente formal o simbólico de la experiencia que la motiva». Lo que Rest busca destacar es que, en ambos sentidos, el Romanticismo inglés se desplaza a través de «fenómenos histórico-culturales de significación destacada en el pensamiento moderno». No sólo porque en términos filosóficos el

\footnotetext{
43 Rest, J., "Coleridge y las teorías artísticas del romanticismo inglés" (1954a), Imago Mundi, 5, Buenos Aires. pp. 76-77.
} 
impulso que tiene su origen en Kant y en Schelling se proyecta sobre Hegel, Kierkegaard y Husserl y llega hasta el existencialismo de Heidegger, actualizado y difundido a mediados del siglo XX por Jaspers, Marcel y Sartre; sino porque, como teoría del arte, el ideario de Coleridge interesa profundamente a la poesía inglesa posterior. Los apuntes de Coleridge, junto al prefacio de Wordsworth a sus Lyrical Ballads, abren una perspectiva que permite la superación de los principios neoclásicos -que, presentes en Dryden, conservaban vigencia hasta ya avanzado el siglo XVIII con Pope y Johnson- y marca visiblemente la concepción poética de autores y críticos ingleses modernos. Las líneas generales de ese pensamiento están previsiblemente presentes -con diferencias atendibles- en autores como Keats, Browning y Hopkins; pero también laten bajo los argumentos de críticos hostiles del romanticismo como T. E. Hulme -quien asimila los rudimentos de ese pensamiento en la categoría de «forma orgánica»- y funcionan como precondición y fundamento de experiencias estéticas puramente modernas como las de Ezra Pond y T. S. Eliot.

Rest se niega a tomar el modernismo inglés como una ruptura radical con la tradición. Su trabajo minucioso y erudito se concentra en trazar conexiones, vasos comunicantes, referencias elípticas y relaciones subterráneas. Como resultado de ese ejercicio disciplinado y tenaz que encuentra especial acogida en las páginas de Imago Mundi ${ }^{44}$, no sólo repone las ligaduras

\footnotetext{
44 Rest colabora asiduamente en la publicación dirigida por Romero, pero es recién hacia sus últimos números que comienzan a aparecer con su firma
} 
concretas que tensan en términos poéticos la experiencia modernista y la tradición romántica; también explora las transformaciones en la concepción de poesía en el pasaje de lo medieval a lo moderno. "Chaucer y el concepto de poesía: lo medieval y lo moderno"45 plantea los términos de esa exploración centrándose en la transformación operada por el cambio de perspectiva historiográfica producido por A short History of the English People, de John Richard Green, en 1874. El quiebre que este acontecimiento implica en la historia de la historiografía inglesa es notable: se vuelve tangible un «creciente interés por la historia social, en general, y por la historia cultural y económica, en particular». Lo popular deja de ser una mera escenografía o un ingrediente secundario frente a «la política, la guerra y las personalidades a quienes correspondían los papeles principales de la vida pública». El cambio es paulatino y empieza a materializarse a partir de los trabajos y estudios historiográficos, políticos y constitucionales de William stubbs, Edward Freeman y el propio Green. Pero fue este último quien estableció más nítidamente un nuevo criterio de exposición histórica desplazando el énfasis de «la narración detallada de los episodios bélicos y de la diplomacia» a «los hombres, las ideas y los ideales que revelan o afectan la vida nacional». Rest subraya especialmente el hecho de que la literatura pueda ser

artículos de extensión considerable en la parte central de la revista. Hasta 1955, sólo ha publicado en la revista textos breves o reseñas de extensión razonable como la dedicada, en el número 6 (de 1954), a Le mouvement doctrinal du IX au XIV siécle, el tomo 10 de la Histoire de l'Église fundada por Agustin Fliche y Víctor Martin; o la dedicada a "Wycliffe y los lolardos", en el número 9, aparecido en 1955.

45 Rest, J., "Chaucer y el concepto de poesía: lo medieval y lo moderno" (1955a), Imago Mundi, 8, Buenos Aires. pp. 13-34. 
tomada como documento de la cultura: «como testimonio de la vida, el pensamiento y los ideales, la literatura adquirió una importancia documental notable» -escribe. Se interesa especialmente en ese modelo de «historia social» en que la literatura -a partir de la centralidad que adquiere la obra de Geoffrey Chaucer en el texto de Green- ocupa un lugar fundamental. Sigue la línea de investigación que se abre con el libro de Green y se prolonga en los estudios de Coulton, Eileen Power o Trevelyan, quienes leen a chaucer a partir de las relaciones que su obra mantiene con su época. Esos trabajos demuestran de manera categórica que la obra de Chaucer da testimonio de una serie de «factores que afectaron en el siglo XIV a todo el mundo europeo y de una manera peculiar a Inglaterra, factores que han ejercido una profunda atracción sobre los historiadores de la sociedad y de la cultura». La crisis económica, política, religiosa y moral de esa Inglaterra desguazada por las consecuencias de la Guerra de los Cien Años y la Peste Negra no pasaron sin marcar la literatura de su época. «Como era de esperarse -apunta Rest-, esos acontecimientos se reflejaron en la literatura» ${ }^{46}$. Pronunciada en una revista que no se pronuncia sobre la coyuntura crítica que reverbera tanto en los planos político y económico como en el cultural, el moral y el religioso, la frase no deja de resultar sugestiva. Ciertamente, tanto The Canterbury Tales de Chaucer como Piers Plowman de William Langland confirman en cierta medida la contundente afirmación del joven Rest. Reelaborando los tópicos

46 El subrayado es mío. 
populares de su época, tanto Langland como Chaucer consiguen «describir el complejo mundo de su época».

El carácter estructural de la obra de Chaucer le permite además retomar uno de los puntos más trabajados por Rest en este período sobre el corpus de la literatura inglesa: el carácter orgánico de las obras. El joven Rest apela a la teorización de Coleridge -concentrada en la Conferencia On Poesy or Art, recuperada y traducida por Rest para el número 5 de Imago Mundipara explicar la forma orgánica de la obra de Chaucer, puesto que esta «involucra una rica gama de matices sometidos a una idea predominante que, sin sacrificar la variedad, impone cierta unidad de efecto». Pero la lectura no se acota meramente a eso. En cada uno de los relatos de Chaucer, Rest subraya y diferencia los estratos sociales de pertenencia de los narradores, las costumbres de clase y la heterogeneidad de voces que el texto concentra, tipifica y presenta vívidamente. Y se detiene especialmente en el hecho de que el carácter popular de la obra de Chaucer se haya sostenido a través del tiempo, teniendo en cuenta las transformaciones acaecidas en la idea misma de poesía (desde su acepción medieval a su sentido moderno). Pero su interés fundamental radica en subrayar, no ya la célebre «validez literaria de Chaucer como narrador hábil, escritor entretenido, penetrante observador de su época o innovador técnico notable», sino sus «cualidades específicamente poéticas». Para ello, retoma las notas y comentarios de Dryden, Coleridge, Matthew Arnold, T. S. Eliot y Sir Herbert Read a propósito de The Canterbury Tales. A partir de allí, traza una definición particular de la poesía 
moderna en virtud a la -explícita o implícita- identificación vivencial del poeta con la situación expuesta en su poesía. Que esta definición se corresponda -en la perspectiva de Auerbachcon la «gravitas de la literatura clásica» no la hace menos incómoda a la hora de interrogar la invariable popularidad de la literatura de Chaucer. En primer lugar, porque a esa obra «le falta, en efecto, cierta cualidad propia de la poesía más elevada»; y, en segundo lugar, porque «la concepción poética moderna de identificación vivencial no es -según los términos empleados por Arnold- real (constante y necesaria) sino histórica (contingente; válida sólo en determinados períodos)».

Frente a esa definición consagrada bajo el auge del romanticismo, la noción medieval de poesía se resolvía de manera menos específica y de acuerdo a una caracterización más amplia: comprendía prácticamente toda la literatura concebida como tal, «pues en la Edad Media sólo se componían en prosa las obras que tenían un propósito funcional o extraliterario, como los sermones y las crónicas». Y el hecho de que prácticamente toda la literatura del período -lírica, cómica, alegórica y narrativaesté escrita en verso tampoco contribuye a trazar distinciones específicas. Es por eso que Rest lee el valor específicamente poético de Chaucer a partir de su «intención de perfeccionar una poesía cuyo verso fuera un medio ágil y flexible para la narración pura de textura neutral, sin la compenetración vivencial intencional que puede percibirse en la poesía moderna». Subraya el hecho de que sus personajes consigan «desenvolverse y dialogar con plena libertad sin que el verso resulte 
obstructivo». Pero además se detiene con especial atención en la cualidad de las imágenes que -en función de su nitidez condensada- «parecen aproximar los objetos y destacarlos afectivamente».

Para Rest es claro que Chaucer consiguió perfeccionar al grado sumo la poesía medieval. The Canterbury Tales exhibe pues una poesía que -a diferencia de la identificación vivencial que caracteriza a la poesía moderna- materializa «una forma narrativa impersonal, en la cual el poeta describe y comenta los sucesos sin estar comprometido o identificado afectivamente con ellos». Su técnica poética consigue establecer un equilibrio admirable entre el lenguaje cotidiano y popular y el verso poético. Que su poética se produzca en un constante vaivén entre la narración y el diálogo, garantiza que su versificación no sea estilísticamente ingenua o carente de dignidad. De hecho -como bien apunta Rest-, es en función de esto que la de Chaucer tal vez sea la única en el contexto inglés que, «por su elaboración, flexibilidad y pureza, pueda compararse con el extraordinario verso dramático de las últimas piezas shakespeareanas o con el atrevido verso lírico de Donne».

No obstante ello, Rest reconoce en Chaucer una serie de notas renacentistas y salientes rasgos modernos. En primer lugar, nota que alimentándose de corrientes poéticas medievales -como la alegoría, el romance y la comicidad- su poesía llegó a perfeccionarlas y trascenderlas instaurando una forma nueva, sumamente compleja y desarrollada, «cuya fluidez y flexibilidad deben mucho a las innovaciones métricas de los poetas que 
preceden y anuncian el esplendor humanístico del Renacimiento». En segundo lugar, porque -tanto en Troilus and Criseyde como en The Canterbury Tales- se aparta del propósito medieval de narrar los sucesos de una fábula y su narración «cae sobre la pintura o el relieve de los caracteres, como luego sucederá en la literatura de ficción y dramática moderna». En tercer lugar, porque la obra de Chaucer -como la de Dante, pero también como la de Eliot- obtiene su singularidad al constituirse como «un abigarrado entrecruzamiento de rasgos medievales y modernos».

En el corolario de esa caracterización minuciosa de la obra chauceriana, Rest subraya un punto importante que permite pensar la inscripción de su propio trabajo en un régimen disciplinario riguroso y acumulativo. Los hechos culturales, su historia y su comprensión, están ligados a «una evolución del pensamiento». Se trata de un saber progresivo, que avanza a través de «desaciertos e incertidumbres de apreciación», en la indagación profunda de las condiciones que determinan «el proceso histórico-cultural», ya se trate de las «que permitieron el advenimiento del fenómeno incomprendido», o de las propias «ideas de quienes no pudieron comprenderlo»

En "La cárcel corporal: una imagen y su perduración en las concepciones antropológicas" $(1955 \mathrm{c})^{47}$, el joven Rest prosigue el desarrollo de sus investigaciones previas en torno a la obra de T. S. Eliot centrándose especialmente en los procesos de

47 Rest, J., "La cárcel corporal: una imagen y su perduración en las concepciones antropológicas" (1955c), en Imago Mundi, 10, Buenos Aires. pp. $19-53$. 
composición y comprensión de las imágenes poéticas. Este texto, aparecido luego de una breve reseña a propósito de "Wycliffe y los lolardos" $(1955 b)^{48}$, supone una profunda exploración filosófica y un rastreo temático centrado en la imagen poética de la «cárcel corporal» que aparece hacia el final de la última parte de The Waste Land y que retoma una fábula cuyo origen Rest remonta al Upanisad Bhradaranyaka.

Los imperativos morales del texto oriental «datta, dayadhvam, damyata; dad, simpatizad, controlaos» ciñen la escena poética del hombre encerrado en su prisión, en tanto en el proceder que presuponen se prefigura la llave de la cárcel. En un modelo que anticipa metodológica y recursivamente a las investigaciones actuales de las literaturas comparadas, Rest rastrea y coteja las imágenes poéticas del encierro corporal a partir de un tipo de interrogación que caracteriza su trabajo crítico: la interrogación filosófica. En tanto comparte con Langer la idea de que la imagen poética es una forma de pensamiento, se permite leer en ella la persistencia de una reflexión genuina, que marca las experiencias poéticas europeas.

Rest va a Dante, al episodio del Conde Ugolino en el XXXIII del Infierno en La Divina Comedia, como va a Appearance and reality de Francis Herbert Bradley, quizá el último gran representante de la tradición filosófica del idealismo inglés, para dar sentido a la imagen poética propuesta por Eliot. La obra de Bradley permite crear un contexto metafísico: la imagen

\footnotetext{
48 Rest, J., "Wycliffe y los lolardos" (1955b), en Imago Mundi, 9, Buenos
} Aires. pp. 68-71. 
poética de Eliot sólo es comprensible en virtud de «la situación de aislamiento en que se halla el hombre debido a la impenetrable insularidad de su experiencia». Tanto Dante como Bradley le permiten a Rest empezar a proponer un sentido para la imagen de The Waste Land: «lo que Eliot quiso destacar es que el alma humana -o el hombre en su totalidad- está en un confinamiento semejante al de quien se halla acerrojado en una prisión». Que Eliot conciba la existencia como un irremediable aislamiento del individuo en un claustro de insuperable subjetividad, facilita a Rest asociar su imagen poética a la imagen filosófica de Bradley «del hombre acerrojado en su prisión». Pero el hecho de que para Eliot tal encarcelamiento no se derive de la encarnación corporal sino de la finitud misma de la existencia, impide que en the Waste Land pueda establecerse una conexión lineal entre la «prisión existencial» de Bradley y la idea platónica de la «cárcel corporal». En función de ello, y siguiendo a eminencias en el tema como Rodofo Mondolfo, Werner Jaegger y Étienne Gilson, Rest traza un paciente recorrido que sigue esa imagen en su progresión desde la poesía y el pensamiento grecorromano hasta su supervivencia en la tradición del idealismo occidental contemporáneo, reconociendo su resistencia a «los embates del cristianismo medieval» e iluminando especialmente su renovado vigor «en la poesía y filosofía renacentistas». La pesquisa deriva en la perduración de aquel empecinado dualismo en el pensamiento moderno. Rest sostiene que, pese al hecho de que el tópico de la «cárcel corpórea» haya perdido vitalidad, el dualismo ha sobrevivido en la oposición entre «substancia anímica 
pura e inmortal» y «substancia corpórea turbia y perecedera», el consecuente confinamiento al que está sometida el alma encarnada. El hecho de que, luego del Renacimiento, se haya acentuado una tendencia a considerar espíritu y materia como dos substancias de análoga jerarquía y dignidad (y en estrecha relación), ha contribuido a introducir la idea de armonía y equilibro, que permite pensar otras dualidades modernas como interior/exterior, objetivo/subjetivo y forma/contenido.

Presentando esa tención en una imagen, Eliot consigue concentrar un elemento importante del pensamiento moderno. No sólo compromete en ella la amalgama del dualismo cartesiano que divide lo existente en res cogitans y res extensa. La imagen del encarcelado insinuada en numerosas citas y alusiones de The Waste Land, se vuelve tangible en el Rey Pescador de la leyenda del Grial, quien permanece confinado en su pecado a la espera de una redención externa que lo libre de sus padecimientos. Pero una versión menos mesiánica de la misma imagen aparece ya en el epígrafe de la obra, donde Eliot cita a Petronio y refiere a la Sibila de Cumas, «encerrada -prisionera- en una redoma» y cuyo único deseo es morir. Sin embargo, como apunta Rest, no es la muerte lo que deshace la cárcel sino el enfrentamiento y la superación de la forma límite de la angustia. En este punto, la reflexión modernista coincide con uno de los tópicos centrales del pensamiento moderno de corte existencial, donde la angustia es un estado de tránsito de la existencia inauténtica a la autenticidad. Ese tópico, que en el sartrismo de Contorno se resuelve -de una manera un tanto voluntarista-como el paso de la 
existencia alienada a la existencia libre, presenta en Eliot un matiz menos optimista. La profecía de Tiresias a propósito del encuentro de los amantes en el mundo moderno deja cierto sabor amargo. La dactilógrafa y el empleado parecen condenados a una existencia inauténtica. La escena -explica Rest- es hosca e infecunda. La mujer admite el acto sexual sin deseo, pasivamente. El hombre -sin el menor cuidado en las respuestas afectivas o personales de la mujer- reduce su deseo a la posesión. Rest lee en esa resignación -es decir: en esa canallada- «la encarnación del estrato mediocre e inerte de nuestro mundo», donde el sexo es una mera sublimación y un escape de la realidad, una escena donde sólo se puede descargar la tensión física.

Lo que Eliot quiere mostrarnos -asegura Rest- son los efectos de una existencia inauténtica, relativa al «linaje de questi sciaurati, che mai non fur vivi», es decir, aquellos que -según Dante- se mostraban incapaces por su cobardía y su indolencia, aún para cometer «el mal suficiente» para ser admitidos entre los condenados. Retenidas en el vestíbulo del Infierno, estas existencias inauténticas remiten a la alienación particular que produce el mundo moderno en términos morales. El argumento de Eliot -sugiere Rest- borra toda ambigüedad en su punto de vista: el hombre moderno «puede vivir arrastrando una existencia vegetativa y animal», pero «la jerarquía existencial plena de su dignidad y condición distintivamente humanas sólo puede alcanzarla al admitir la trascendencia de sus actos».

En este punto, el humanismo de Eliot se articula -en la 
lectura restiana- sobre un fundamento existencialista. La escena de los amantes habla menos del sexo moderno que de la ausencia del amor. Si el amor es esa forma de trascendencia del otro en uno mismo, y viceversa, el sexo en los términos que lo presenta la imagen poética no es más que el resultado inmediato de la alienación y el egoísmo posesivo que caracterizan el mundo moderno. Es una experiencia traumática, que no enriquece el espíritu ni lo libera, sino que expone la medida de su miseria. El amor -Sartre lo expone claramente en la perspectiva existencialista- no puede reducirse al régimen de la posesión. Supone el deseo de una libertad en tanto libertad. ${ }^{49}$ E implica como lo plantea Jaspers, a quien Rest se obstina en emplear como referencia de autoridad- un sentimiento de simpatía que «designa un movimiento de compasión y comprensión», que implica «trascender hacia la persona amada y aún trascender la misma persona amada». En una palabra -como apunta Rest-, en el imaginario de Eliot esa simpatía implica comunicación, una comunicación que no se restringe únicamente a la persona amada sino comunicación «con el mundo entero, que de tal modo ser recobra de su esterilidad por obra de la incandescencia creadora del espíritu liberado». El "Simpatizad" de la referencia eliotiana a las Upanishads aparece pues, finalmente, resemantizado. La simpatía es un valor moral que transforma al mundo al arrancar los sujetos de la angustia y al producir el pasaje de la existencia inauténtica a la autenticidad.

The Waste Land constituye así -en la interpretación restiana-

49 Sartre, J-P., El ser y la nada, Barcelona, Altaya, 1996. pp. 389-392. 
un diagnóstico y una respuesta moral a la encrucijada vital del mundo moderno. Señala dos tendencias que paulatinamente manifiestan sus efectos como resultado del triple proceso de capitalismo, secularización y democracia que define la modernidad: una, es «la senda que lleva a la salvación (es decir: a la autenticidad existencial) a través de la angustia admitida y aceptada por el hombre prudente»; la otra, que ni siquiera llega a constituirse en una forma de condenación, es «la senda de la inercia, del "escapismo", el camino seguido por quienes rehúyen la aceptación de la angustia y tratan de ignorarla o acallarla», sin tomar conciencia de que ella misma es «condición fundamental e inevitable de la existencia humana y de su perfeccionamiento». Como se ve, luego de un rodeo erudito y minucioso por los textos de la tradición, Rest lee a Eliot prestando especial atención a tópicos que se revelan coincidentes con los más frecuentados por los autores de Contorno. El amor, la comunicación, la alienación, el egoísmo posesivo del hombre moderno son los temas del David Viñas lector de Ezequiel Martínez Estrada $^{50}$, el Rozitchner lector de Mallea ${ }^{51}$, el Masotta lector de Arlt ${ }^{52}$. Lo que cambia es el carácter de su resolución, sobre todo teniendo en cuenta la estrecha vinculación entre moral y política. La diferencia remite también a sus fuentes teóricas. Mientras Contorno piensa desde la gradual articulación entre

\footnotetext{
50 Weinbaum, Raquel [David Viñas], "Los ojos de Martínez Estrada", en Contorno, (Buenos Aires), $\mathrm{N}^{\circ}$ 4, diciembre de 1954, pp. 1-2.

51 Rozitchner, León, "Comunicación y servidumbre: Mallea", en Contorno, (Buenos Aires), $\mathrm{N}^{\circ}$ 5/6, 1955.

52 Masotta, Oscar, Sexo y traición en Roberto Arlt, Buenos Aires, Jorge Álvarez, 1965. Cabe tener en cuenta que los ensayos reunidos en ese libro fueron escritos y publicados por Masotta en publicaciones vinculadas al grupo.
} 
existencialismo ateo y marxismo que teje Jean-Paul Sartre en Qu'est-ce que la littérature? (1948), Rest lo hace a través de la interpretación del pensamiento de Martin Heidegger de Alphonse de Waelhens ${ }^{53}$ y a través de la variante cristiana del existencialismo propuesta por Karl Jaspers ${ }^{54}$.

"La crisis contemporánea y el espíritu en el testimonio de dos poetas: T. S. Eliot y Paul Valéry" (1956c) ${ }^{55}$ aparece en el último número de Imago Mundi. Se trata de un número doble (11-12) y su salida coincide con el mes del bombardeo a Plaza de Mayo en lo que se suponía un intento de asesinato y golpe de Estado al presidente Juan Domingo Perón. Y el artículo de Rest vuelve a poner en escena su especial interés por la percepción literaria de la crisis producida por «el mundo moderno».

Esta vez Rest realiza una lectura comparada de corte temático entre la percepción de Eliot -sobre cuya obra viene trabajando desde 1952- y la que Paul Valéry presenta tanto en Le cimetière marin como en su prolífera producción ensayística. El núcleo reflexivo de la intervención sigue las cartas de Valéry sobre La crise de l'esprit y se circunscribe a las reacciones del «hombre europeo» que debe abordar un proceso de transformaciones cuyas consecuencias no es capaz de prever. Pronunciada a comienzos de 1919, la frase de Valéry con que Rest abre su ensayo («La

\footnotetext{
53 De Waelhens, Alphonse, La filosofía de Martin Heidegger, Madrid, Editorial del Consejo Superior de Investigaciones Científicas, 1952.

54 Rest cita en el texto específicamente la edición italiana de La mia filosofía (Torino, Einaudi, 1948).

55 Rest, J., "La crisis contemporánea y el espíritu en el testimonio de dos poetas: T. S. Eliot y Paul Valéry" (1956c), en Imago Mundi, 11-12, Buenos Aires. pp. 134-182.
} 
oscilación del navío ha sido tan fuerte que hasta las lámparas mejor sostenidas finalmente se han volcado» ${ }^{56}$ ) señala la percepción de la conmoción histórica que el hombre europeo ha debido afrontar en las dos primeras décadas del siglo Xx; es decir, en lo que va desde la sangrienta Primera Guerra Mundial desatada entre julio de 1914 y noviembre de 1918, y la consolidación del proceso revolucionario en Rusia. Luego del armisticio y el cese de la fase bélica, el desasosiego económico -que Rest ratifica en el diagnóstico estrictamente contemporáneo de Keynes $^{57}-$ se presenta a la mirada de los intelectuales burgueses como un panorama sombrío. «Confusión», «desconcierto», «derrumbe» son los sustantivos con que tropieza la descripción restiana de la ya «maltrecha sociedad europea». Sin embargo, Rest no ata únicamente esa «desazón» europea a causas que se remontan más allá de la Gran Guerra y el caos económico. La hipótesis de Valéry que Rest sigue tímidamente sostiene más bien que esos acontecimientos provenían de la «crisis del espíritu», que asediaba al hombre moderno tanto en términos individuales como colectivos. Lo que ese hombre enfrenta -para seguir las palabras de Valéry- es una crisis más sutil, intelectual, «que por su propia naturaleza adquiere apariencias más engañosas, (puesto que se desenvuelve en el reino mismo de la simulación) ${ }^{58}$. Luego de la guerra ya nada permanece ajeno al mundo moderno, los imperios que se derrumban, las ruinas y la catástrofe pasan del relato mítico

\footnotetext{
56 Valéry, P., "Primera Carta sobre la Crisis del Espíritu", en Política del Espíritu, Buenos Aires, Losada, 1940. p. 28.

57 Keynes, J., The economic consequences of the peace, London, Macmillan \& Co., 1919. p. 235.

58 Valéry, P., "Primera Carta sobre la Crisis del Espíritu", en Política del Espíritu, Buenos Aires, Losada, 1940. p. 26.
} 
al relato histórico y la «perspectiva intelectual» se revela transformada por completo. «El abismo de la historia -dice Valéry- es suficiente para contener al mundo entero». Francia, Inglaterra y Rusia exhiben su fragilidad. La palabra occidental se muestra sobrepasada en su voluntad de «responder de algún modo a la creciente angustia engendrada por el amenazante caos» que -a corto o largo plazo- parece devorarlo todo. Los cambios se sucedían en el ámbito estético e intelectual casi al mismo tiempo que las transformaciones sociales, políticas y económicas alteraban al mundo. No obstante -como apunta Rest-, la crisis, lejos de producir un estancamiento o una anulación del espíritu, generó una agitación intelectual que confluyó en una vorágine creativa. Nuevas corrientes de pensamiento y sensibilidad estética germinaron del caos, como si hubiesen permanecido «latentes» desde antes de la guerra, esperando manifestarse en el periodo inmediatamente posterior a la conflagración. «La experimentación artística que anunció al mundo un cambio profundo de mentalidad estética occidental -escribe Rest- acaso sólo pueda explicarse en función de esta crisis general del espíritu y de la cultura europeos». El modernismo y las nuevas orientaciones formales, surgidos en la primera mitad del siglo xx, están pues estrechamente ligados a «la conmoción intelectual y la crisis cultural que impregnaban el ambiente coetáneo».

Que Rest opte por analizar las actitudes que tanto Paul Valéry como T. S. Eliot manifestaron ante la crisis que les fue contemporánea, no es casual. No sólo porque en su consideración se trata de «los dos poetas contemporáneos más notables»; sino - 
fundamentalmente- porque, a su juicio, sus propios posicionamientos ante la crisis «se oponen, se complementan y, por sobre todo, parecen nacer de un criterio compartido» en lo que respecta a «las causas primordiales de la inquietante situación que enfrentaba la cultura europea al cabo de la primera guerra mundial». Ambos coinciden en la opinión de que «en el mundo moderno se advierte una honda confusión que ha engendrado una crisis generalizada del espíritu». Para ambos las raíces mismas del desconcierto son múltiples y actúan unas sobre otras, pero entre ellas coinciden en destacar las decisivas «conmociones político-culturales» y las «concepciones renovadoras de la ciencia». Ambos coinciden en que el «desorden mental» que dio a la crisis su gravedad y profundidad fue -como apunta el diagnóstico de Valéry- la «coexistencia, en todos los espíritus cultos, de las ideas más desemejantes, los principios más opuestos en lo referente a la vida y el conocimiento». ${ }^{59}$ En esa condición íntima de la modernidad que es la contradicción y la inconsecuencia también radica la «fase crítica». Sobre esa paradoja se asienta la imposible estabilidad de un mundo asediado por tendencias, pensamientos, costumbres y creencias incompatibles que se ignoran entre sí. Es por ello que Valéry puede sostener que la modernidad del hombre moderno radica en su capacidad para convivir con una multiplicidad de contradicciones

59 Valéry, P., "Primera Carta sobre la Crisis del Espíritu", ed. cit. p. 29. El propio Valéry refrendaría esta hipótesis en su conferencia sobre "La Política del Espíritu", de 1932, al señalar que: «en multitud de espíritus se ve coexistir la fe y el ateísmo, la anarquía en los sentimientos y alguna doctrina de orden en las opiniones. La mayoría de nosotros tendrá sobre un mismo asunto varias tesis que se sustituyen en nuestro juicio sin dificultad, en una misma hora de tiempo, de acuerdo con la excitación del momento.» (Valéry, P., Política del Espíritu, ed. cit. p. 72). 
que esperan aparecer una tras otra desde «la penumbra de su propio pensamiento». Que esas contradicciones e inconsecuencias pasen muchas veces desapercibidas sigue resultando para Valéry algo significativo. En su perspectiva, «la tolerancia, la libertad de confesión y opinión» llegan siempre en las instancias tardías, puesto que «sólo puede concebirse y penetrar las leyes y las costumbres en una época avanzada», «cuando los espíritus se han enriquecido y debilitado progresivamente con sus diferencias intercambiadas», mientras la intolerancia es sin más «la virtud terrible de los tiempos puros...». ${ }^{60}$

Rest sigue el «perspicaz diagnóstico» de Valéry en sus consecuencias filosófico-existenciales. Advierte que, si bien la multiplicidad de ideas acrecienta «las posibilidades seminales del pensamiento», también puede contribuir negativamente alimentando la confusión colectiva. Parafraseando a Heidegger, Rest anota que, en tal «contexto de ebullición», los individuos pueden tanto abordar auténticamente su proyecto («abriéndose a la perspectiva del riesgo y la aventura intelectual y la creación espiritual») ○ pueden precipitarse «individualmente hacia el ilusorio refugio de la "existencia inauténtica": inercia, irresponsabilidad, autoconmiseración, desaliento, "escapismo"» y otra serie de «actitudes nacidas de una voluntad demasiado débil para buscar una forma de superar la confusión».

Como respuesta a esta carencia de fortaleza espiritual para sortear la crisis -que, a juicio del propio Rest, se presenta

\footnotetext{
60 Valéry, P., Política del Espíritu, ed. cit. p. 73. Cursivas y puntos suspensivos en el original.
} 
como «una tremenda e insalvable realidad negativa, amenazadora y acaso mortal para los valores de nuestra tradición occidental que juzgamos más queridos y dignos de conservación» ${ }^{61}-$, el joven crítico plantea dos soluciones divergentes que, a su entender, son la muestra tangible de una profunda y simétrica «autenticidad existencial»: la encarnada fe en la condición moral de Eliot y la aspiración de claridad a que se aferra la lucidez cartesiana de Valéry.

El punto de vista anglo-católico de Eliot -que, como apunta uno de sus comentadores, roza casi el «totalitarismo eclesiástico» ${ }^{62}$ - se asienta en varios de sus trabajos ${ }^{63}$ y puede resumirse en las conclusiones conservadoras que guardan las últimas líneas de Notes towards the definition of culture (1948), donde el laureado poeta inglés concluye que la obligación primordial de la Europa contemporánea consiste en «tratar de salvar algunos de aquellos valores de los que somos custodios comunes: el legado de Grecia, Roma e Israel, y el legado de Europa a través de los últimos mil años», puesto que -a su juicio- «en un mundo que ha presenciado tanta devastación como el nuestro, estas posesiones espirituales también están en inminente peligro» ${ }^{64}$. Rest percibe en la afirmación eliotiana dos aspectos innegables: por un lado, la amenaza de un derrumbe cultural y, por otro, la necesidad de remediar la situación. Es en virtud de ello que inscribe en la línea de los paliativos al

\footnotetext{
61 El subrayado es nuestro.

62 Cfr. Hyman, S., The armed vision, New York, Vintage, 1955.

63 Rest remite aquí, especialmente, a Thoughts after Lambeth, de 1931, y a The idea of a Christian society, de 1939.

64 Eliot, T. S., Notas para la definición de la cultura, Buenos Aires, Emecé, 1982. pp. 199-200.
} 
grueso de la producción en prosa de Eliot, mientras que circunscribe en la descripción del estado de situación a su producción poética. Lee pues, con rigor minimalista, The Waste Land en esa clave y concluye que el poema constituye «la enunciación más profunda y amplia -aunque tal vez críptica- del primer aspecto: la situación espiritual de nuestro tiempo y la naturaleza de los peligros que acechan a la cultura de Occidente». Y llega así a sostener que, finalmente, la idea rectora del poema «señala que los males de la sociedad actual son el reflejo del desconcierto y la debilidad individuales» y que, en ese sentido, sólo pueden ser superados en tanto cada hombre particular adquiera para sí «la certidumbre y el vigor éticos que le permitan sobreponerse al egoísmo en que ha caído debido al temor y al desaliento».

Como en un cierre de investigación, Rest funda y consolida su interpretación de The Waste Land como «un cuadro de frustración y desconcierto», retomando, ampliando y completando los numerosos aspectos del poema tratados en los sucesivos ensayos aparecidos previamente en Centro e Imago Mundi. Su contraposición con la perspectiva de Valéry le permite deslindar aspectos, cualidades y valores específicos. Observa así que, mientras Eliot es presa de un temperamento romántico que lo obliga a descreer incluso de la esperanza en una recuperación de la confusión y la angustia de su época, Valéry se revela en cambio «imbuido del aplomo del equilibro clásico» y, sobrepuesto a cualquier desilusión, se atiene a dictaminar con sobriedad y sin desesperación que l'Éurope est finie. Frente a la nostalgia conservadora de Eliot, 
la mirada de Valéry propone actuar sobre el presente en función del porvenir. Pero en su deseo no hay vestigios de restauración, sino un proyecto progresista, racionalista y liberal, asentado sobre una "política del espíritu" que sea capaz de convertirse en un "soberano bien". Es en razón de este proyecto que concluye su diagnóstico apelando no sólo a la «voluntad de lucidez» y «la nitidez del intelecto», sino también -y fundamentalmente- al «sentimiento de grandeza y del riesgo, de la aventura extraordinaria en que el género humano, al alejarse tal vez de las condiciones primarias y naturales de la especie, se ha empeñado, marchando no sé hacia dónde». ${ }^{65}$

Que ambos hicieran confluir las líneas generales de su diagnóstico y sus paliativos en el corazón mismo de sus producciones poéticas no es un dato menor. Rest acentúa el hecho de que Valéry se impuso «el arduo y sostenido esfuerzo de conciliar el encantamiento propio de la poesía con la más estricta claridad intelectual». Lo consiguió, al final de una progresiva maduración artística, en Le cimentière marin, concebido en la posguerra de 1918. En ese sentido, representa tanto la «voluntad de producción» de su autor, como the Waste Land traduce análogamente la de Eliot. Ambas piezas, a menudo rechazadas por su supuesta dificultad de lectura, manifiestan un contraste notable. El sentido agónico y místicamente creyente de la composición de Eliot es simétricamente proporcional al caudal y la variedad de alusiones veladas que, más que una lectura, demandan «una exégesis que aclare la oscuridad de sus referencias

65 Valéry, P., Política del Espíritu, ed. cit. p. 106. 
significativas y recónditas». Le cimentière marin se presenta, en cambio, como una «pura transparencia», al punto que -como apunta Rest- «los tropiezos que presenta su interpretación surgen precisamente de este exceso de claridad». Clásica hasta la transparencia, la poesía de Valéry no hace lugar a «ingredientes románticos» ni deja que el residuo emocional confunda «los tenues hilos conductores que dan sentido y conformación al poema».

La apelación final de Rest -que parece aceptar su modernidad en la aceptación imparcial de los opuestos- subraya el valor de las obras que se interrogan por el destino y la deriva de «nuestro incierto mundo», en tanto son capaces de conferir a «nuestro tiempo una dimensión singular en el devenir cultural». Como casi todos los textos de Imago Mundi, Rest habla de Occidente, de Europa y del mundo moderno como de su propio mundo. El hecho traduce un ademán de identificación que, a la distancia, resulta sin dudas notable. Lejos de cualquier inscripción vernácula, nacional o marginal (en relación a un centro), el crítico piensa el destino y los avatares particulares del hombre europeo y el mundo moderno como sí su propia modernidad borrara por completo la condición histórica, social y política de su propio espacio de inscripción. Lee a Eliot y a Valéry como artistas «acuciados por un desgarramiento interior nacido de nuestra ubicación histórica en un punto de intersección del tiempo y la eternidad». Y los presenta como ejemplos universales de un «arte contemporáneo» que «no se ha entregado a la expresión de un flojo y blando sentimentalismo», sino que -por el contrario- «ha escogido la dureza y la transparencia de la imagen 
cristalina, reconcentrada» y ha volcado sus esfuerzos en vencer la «excesiva dependencia subjetiva» $y$ en conferir a la propia creación poética las huellas de «la tenuidad evanescente y cambiante de esta trama compleja y casi inaprensible -mundo exterior, sedimento cultural, experiencia- en que nos hallamos irremisiblemente cautivos».

La referencia a lo nacional, lo local y lo vernáculo termina siendo, en la perspectiva crítica de Rest, un residuo de existencia inauténtica. Su posicionamiento se liga rápida y definitivamente a la argumentación borgeana de "El escritor argentino y la tradición" (1951) que reduce todo localismo al folklore y a la mera afectación. En razón de eso lee los experimentos estéticos del alto modernismo como nacidos de una misma crisis y, por ende, enrolados en la tarea de alcanzar un equilibrio entre «un sentido universal e intemporal» y la «experiencia del individuo perecedero». Esta experimentación creadora que da cuentas del desgarramiento de la condición moderna remite claramente su apogeo hacia 1920 y es, como sugerirá Virginia Woolf, un esfuerzo por vencer la precipitada temporalidad y arrebatar un girón de eternidad en la experiencia estética que configura el arte moderno.

VIRGINIA WOOLF, EL ENSAYO Y LA FUNCIÓN CRÍTICA

La referencia final a la explicación del «arte sutil» de Virginia Woolf permite introducir aquí el contenido formal de una 
investigación paralela realizada por Rest a lo largo de estos mismos años, y que se materializa en dos textos aparecidos durante 1953. Se trata de una exploración rigurosa y formal sobre la producción ensayística de Virginia Woolf. En el extenso recorrido, que se materializa en su Tesis de Licenciatura en Letras -presentada y defendida el 16 de diciembre de 1953 en la Facultad de Filosofía y Letras de la Universidad de Buenos Aires- sigue por lo demás la lógica de la mayoría de las intervenciones de Rest de la época: el corpus se recorta en términos generales sobre la tradición textual de la literatura de lengua inglesa -que ha elegido para su especialización- y en términos específicos sobre la producción de una autora que bien puede incluirse en los que los críticos sajones definen como alto modernismo literario.

Que el texto, discreta y descriptivamente titulado Los ensayos de Virginia Woolf (1953b) ${ }^{66}$, permaneciera inédito por ciertas trabas institucionales, no aminora su importancia, su centralidad y valor específico en la producción crítica de Rest. No sólo porque -a comienzos de 1956- su autor concede la publicación de un resumen del mismo en el número 238 de la revista Sur $^{67}$; sino también porque -en términos generales y con leves modificaciones- el texto será recobrado más de veinte años después, propia decisión de Rest, en Mundos de la imaginación

\footnotetext{
66 Rest, J., Los ensayos de Virginia Woolf. Tesis de licenciatura. Facultad de Filosofía y Letras, Universidad de Buenos Aires, 1953. Para el presente trabajo hemos consultado la copia mimeográfica del material conservada en la Biblioteca Central "Prof. Augusto Raúl Cortázar" de la Facultad de Facultad de Filosofía y Letras de la Universidad de Buenos Aires.

67 Rest, J., "Virginia Woolf y la función crítica", en Sur, 238, enerofebrero, 1956. pp. 45-59.
} 
como un trabajo que conserva interés en función de sus «actuales preocupaciones» (1978b:12) ${ }^{68}$. El trabajo en cuestión hace del ensayo literario su objeto y, en este sentido, es la primera interpelación de un problema de investigación cuyo interés acompañará a Rest hasta en sus últimos escritos teóricos y críticos, y que pasará por diversas configuraciones textuales canónicas y vernáculas, desde el magisterio de Thomas De Quincey a las aguafuertes de Roberto Arlt.

Pese a que -de manera más definida que las intervenciones que a la par van apareciendo en Centro e Imago Mundi- se adecúa formal y estilísticamente a los códigos retóricos académicos, el texto excede largamente los límites del prototipo monográfico. A juzgar por la bibliografía empleada y las notas a pie de página, da cuenta también de que, efectivamente, los wanderjahre -período de formación y ensayo- restianos están marcados por las derivas de la crítica sajona de la época: al punto que F. R. Leavis, David Cecil, C. M. Bowra, Theodore Spencer, Edmund Wilson, Robert Liddell, Andrew Wright, C. S. Lewis, Lionel Trilling, Ciryl Connolly y -especialmente- T. S. Eliot constituyen la constelación de sus referencias teóricas matriciales durante los años de estudio universitario que se corresponden con el período signado por el primer gobierno peronista. Escrito en un estilo sobrio y austero, el trabajo crea su propio vacío de investigación tomando un corpus de textos marginalizados e invierte la lógica de lectura y la jerarquización crítica

68 Rest, J., Mundos de la imaginación (1978b). Caracas: Monte de Ávila. pp. $211-236$. 
consensuada al interior mismo de la obra de la autora de To the Lighthouse. Rest circunscribe su estudio de los ensayos literarios de Woolf con un objetivo fundamental, explicitado en su misma presentación: se trata de quitar los ensayos de Woolf del lugar marginal y accesorio que hasta allí les había dado la crítica respecto de la imponente y ampliamente celebrada obra literaria de su autora. Es por ello que la pregunta con que el joven crítico encara la investigación es -al menos inicialmentecasi de orden ontológico y se proyecta como descripción: el objeto de la indagación apunta a establecer «qué son», «en qué consisten» esos "textos marginales", y no meramente a señalar la razón de su contenido, es decir, «de qué tratan» (1953b:1) ${ }^{69}$.

No es arbitrario que el tesista opte por este modelo de búsqueda arguyendo que «un reconocimiento temático» de «la cuestión del ensayo» en Woolf llevaría a creer que -como en muchos casos tocan problemas literarios- lo que se trata es de poner en discusión la dimensión y la modalidad crítica de esos ensayos. Desde el comienzo, Rest reconoce las dificultades que este tipo de examen podría presentar al señalar que «no hallaríamos en Virginia Woolf esa "consistencia" y esa "riqueza" propias del crítico sistemático» (1953b:2), que visiblemente se revela en autores como Johnson y Coleridge. Las comillas que aprietan los términos «riqueza»y «consistencia» no son irónicas. Con ellas, Rest hace referencia a la distinción trazada por David Daiches, quien distingue el ensayo woolfiano del espacio

69 Rest, J., Los ensayos de Virginia Woolf, ed. cit. En adelante se cita esta versión con el número de página entre paréntesis en el cuerpo del texto. 
disciplinario riguroso que la crítica ha construido para sí pensándose como un «ejercicio sistemático» de lectura. ${ }^{70}$ La crítica -conjetura el joven Rest- se ajusta a un determinado sistema, el texto ensayístico de Woolf «es demasiado flexible e indirecto para que podamos aceptar su existencia». El deslinde territorial determinado por el crítico obedece a razones específicas. La tesis se presenta en un rígido espacio institucional, donde la crítica empieza a constituir, a partir de un trabajo de adopción y adecuación de herramientas conceptuales, una disciplina que gana su autonomía y su valor a partir de su retirada de la «comunicación impresionista» de la lectura. La crítica -apuntará Rest más adelante- busca explicar funcionamientos, no transmitir efectos o impresiones de lectura. Por ello despegará los textos de Woolf de la crítica con una frase de referencia nietzcheana: «Virginia Woolf escribe sobre libros como escribiría acerca de un paisaje: describiendo una experiencia» (1953b:2) .

Luego de un exhaustivo estado de la cuestión -que se detiene fundamentalmente en la dispersión y las dificultades de reunir el corpus completo de los ensayos de Woolf y que repasa someramente las intervenciones críticas que se han desembarazado rápidamente de ellos aduciendo su condición secundaria («segunda siega») respecto de la obra estrictamente literaria de la autora-, Rest señala la excentricidad de los temas para borrar todo rasgo de especificidad crítica literaria. La pintura, el teatro, el

70 El texto referenciado por Rest en este punto es Daiches, D., Virginia Woolf, Norfolk, New Directions Books, 1942. 
cinematógrafo, las figuras excéntricas, la pesca, los viajes, el paisaje, la naturaleza, las calles de Londres y la expedición nocturna para cazar polillas en el bosque, pueden ser los temas de los ensayos de Woolf. Como tema, una literatura o un libro no tienen pues en esa serie arbitraria un lugar privilegiado. Son simplemente formas de la experiencia vital de Woolf que de un modo prosaico hace cuerpo en sus ensayos.

Para Rest, lo que hace estrictamente al ensayo woolfiano es su modalidad de tratamiento de esos temas: ese carácter prosaico que se sostiene a nivel cualitativo en dos aspectos: el estilo y la forma. Pureza y perfección son los atributos demandados para la constitución del estilo; la forma, por su parte, «debe ser cuidadosamente trazada» ya que su objeto es el de producir un «efecto unitario que impone $-y$ al que se presta- la dimensión limitada del ensayo», de modo que no sólo se realce la «belleza de conjunto», sino que también sea dable subrayar «determinado sentido que prevalece en la composición» (1953b:3). La subjetividad lectora de Woolf se imponía a los textos de sus contemporáneos y presentaba a Rest la propia exigencia que subyace a sus ensayos: la escritura del ensayo debe tender «a una prosa que fuera prosaica» (1953b:4).

En Woolf, el carácter «prosaico» de la prosa adquiere la dimensión de un deseo que define su pulsión y, en algún punto, se le otorga un sentido similar al que posee lo «poético» en referencia al poema: en el ensayo literario, «la prosa -escribe Rest- ha de emplearse artísticamente, "sin finalidad práctica"», fuera del régimen utilitario que la vuelve «una bestia de carga 
que ha de acomodarse a toda clase de trabajos» (1953b:4-5). Así como la novela se sostiene en la historia, el ensayo se sostiene en una escritura que se apropia de un saber. Pero «no basta que el autor tenga una erudición profunda», sino que esa erudición haya sido incorporada en términos de escritura («es necesario que la haya asimilado y sepa fundirla en una visión donde cada elemento contribuya a presentarnos su concepción como un todo orgánico» (1953b:4). El ensayo produce sus mayores logros (en términos de efecto) cuando la escritura consigue articularse sobre «un equilibrio constante entre el tema que expone y la intención que lo mueve». En este sentido, Woolf apunta que el ensayo «ha de ser personal», pero entendiendo la personalidad como una modalidad de ser, como una modulación particular de la relación entre el tema, el estilo, la forma y la intención. La personalidad no remite pues a una «conexión entre el escritor y su existencia extraliteraria» (1953b:4), sino a una modalidad de ser de la escritura que debe ser capaz de impregnar cada palabra transformándola en algo nuevo.

Dominar el arte de la prosa, acercarse al siempre huidizo «triunfo del estilo», suponen un horizonte claro en el que se sabe -porque se da por sobreentendido- qué es la prosa bien escrita. En The Modern Essay (1922) esas cualidades son enumeradas breve y tajantemente: exactitud, veracidad, imaginación. Sobre esos tres atributos se apoya la tradición de la prosa literaria inglesa desde el periodo isabelino hasta la propia Virginia Woolf. Sin embargo, Rest hace notar cierta decadencia en la prosa del ensayo literario de lengua inglesa, 
cuyas causas se desprenden del grueso de su investigación de tesis. Con el objeto de describir la variedad que abarca esa prosa cuyo apogeo se había extendido por casi cuatro siglos, Rest contrapone dos modelos. Lee paralelamente y en contrapunto un ensayo de Francis Bacon sobre la muerte ("Of Death") y el de Virginia Woolf sobre la polilla ("The Death of the Moth"), entendiendo que ambos guardan sobrada semejanza aun dentro de sus diferencias. Del contrapunto, Rest extrae sus conclusiones acerca del lugar de la erudición en el ensayo literario. En el caso de Bacon se observa un poderoso saber erudito acerca de la muerte y de lo que de ella se ha dicho a través del relato de la muerte estoica de figuras venerables del pasado. El ensayo marca pues una distancia clara respecto del lector, al que supone pasivo de un saber que le es dado. En el caso de Woolf la operación es más interesante y menos jerarquizada en el orden pedagógico. Woolf ofrece en el sencillo relato de la polilla que muere, un saber que no se transmite sino que se reconoce y se hace propio. Cuando Woolf mira propone una proximidad con la mirada del lector («Estamos a su lado, y ella lo sabe», escribe Rest). Lo invita a ver lo que imagina. No impone su autoridad en la relación pedagógica; crea una escena en la que el saber debe ser desprendido por el lector como lo haría de una escena de su propia cotidianeidad. Lo increíble es que la polilla de Woolf «comunica lo mismo» que Galva, Tiberio o César Augusto en el poblado texto del autor del Novum Organum. En la diferencia de método y de ethos entre ambos modelos ensayísticos se hace visible la distancia entre la prosa isabelina (impersonal, 
general, abstracta) y lo prosaico de la prosa de Woolf, definida por un carácter personal, particular y concreto en la actualidad. En todo caso, en ese arco que se abre entre el ensayo erudito de Bacon y el ensayo prosaico de la autora de Between the Acts, se define el generoso continente del ensayo literario de lengua inglesa.

Como última peculiaridad del ensayismo woolfiano, Rest señala como una particularidad notable la distancia que este modelo específico toma respecto de la usual propensión del género a «fijar cierto principio general acerca del asunto que trata». El ensayo de Woolf no parte del tema; llega a él a partir de la indagación particular y minuciosa de una anécdota o una situación específica. Es por ello que su ensayo se resiste a establecer una norma. En sus ensayos, Woolf procede como novelista: ofrece «todos los elementos que permitirían deducir cierto criterio, pero sin declararlo». En ese sentido, tampoco fija el título de cada ensayo de acuerdo al tema sino en el detalle que lo liga a la situación particular. El hecho de que esos ensayos sean muchas veces poco más que «resúmenes, sumarios o selecciones de los textos utilizados» $y$ que muchas veces no aporten «ninguna investigación nueva u original» (1953b:10), sirve a Rest para establecer en ellos una preeminencia de lo literario por sobre lo crítico o lo filosófico. Woolf saca su mayor provecho de aquello que muchas veces se tiene por la limitación más pesada del ensayo: su brevedad. La configuración acabada de un texto ensayístico pautado por la brevedad produce un «efecto unitario» a la vez que permite que el sentido propuesto pase por el orden 
de la sugerencia y no por la afirmación propia del dictamen. Sobre estas pautas el ensayo de Woolf se distancia del procedimiento crítico y se aproxima a la configuración literaria breve. Se trata de un ensayo que, si bien se funda en una referencia o situación precisa, su mayor cuidado recae en la manera en que la imaginación literaria de la autora la procesa y la transforma, «atando cabos sueltos y descubriendo encuentros» (1953b:11). El ensayo se convierte así una experiencia literaria que incorpora lo que la crítica o la filosofía rechazarían. Allí caben la complejidad, la contradicción, la paradoja, la digresión, el «indicio secreto». Pero, por sobre todo, el ensayo está pulsado por una voluntad de interrogación abierta (y no de respuesta). El resultado de ello es que los cuadros producidos por Woolf en sus ensayos quedan siempre incompletos, suspendidos entre la fascinación de la escena y «la duda acerca de lo que suscita tal fascinación» (1953b:15).

Pero la distinción profunda que, amparándose en la experiencia de Woolf, Rest establece entre ensayo y crítica literaria no es casual ni mucho menos ingenua. Constituye el núcleo autorreflexivo de la tesis y su importancia es tal que Rest dedica el capítulo final de la misma a dicha distinción. Es allí donde deslinda la propiedad creativa de la lectura en el ensayo de la propiedad analítica de la lectura crítica. Y es allí donde las hipótesis de Woolf se encuentran con el posicionamiento liberal de Rest respecto de la lectura: si «la crítica ha de servir al lector» (1953b:32), y no éste a aquella, «la función de la crítica» es la de constituir un «complemento de la lectura, no 
su tirano». La crítica debe contribuir, en la perspectiva restiana, a «ampliar el conocimiento y la comprensión» que faciliten al lector la «recreación» del texto literario. En virtud de ello, el crítico debe demostrar su probidad detentando «ciertas calificaciones» (1953b:33). La función y el valor de la crítica están pues ligados a una intermediación pedagógica: el crítico debe "clarificar" las ideas y las preguntas que han surgido a la lectura del lector común. Parafraseando a Woolf, tanto Dryden como Johnson son valiosos en la medida en que «iluminan» las ideas que pueblan «las nebulosas profundidades» de la imaginación del «lector común». Pero la crítica -aclara Woolfsólo cumple con su función en tanto el lector común se acerque a ella cargado de preguntas y sugestiones «ganadas honestamente» en el curso de su propia lectura (1953b:33).

La idea de «lector común» remite en principio a una sensibilidad y una imaginación singulares. No sólo porque en él encarna una potencia que radica en la posibilidad de inscribir la lectura no en un más allá de los guiones de la Crítica; sino porque, por su propia condición, sólo el «lector común» es capaz de producir sentidos nuevos, formas de vida no presentidas en la tensión del texto y la vida. La idea de «lector común» woolfiana -cuya espíritu sobrevive aún en planteos contemporáneos como el de la «crítica patética» imaginada por Roland Barthes ${ }^{71}$ - tiene rasgos determinantes: remite a las condiciones objetivas de una experiencia activa, que salta el cordón policial impuesto por la

\footnotetext{
71 Cfr. Barthes, R., La preparación de la novela. Notas de cursos y seminarios en el Collège de France, 1978-1979 y 1979-1980. Buenos Aires, Siglo XXI, 2005.
} 
«aristocracia del espíritu» (que condena la lectura a ciertos charcos de sentido donde el agua suele quedar estancada más de lo debido). De ese modo, expone al texto a una relación que se define en términos de pura intensidad: que hace de la experiencia de lectura ese instante de indecisión en que el texto toca la vida y la vida activa el texto.

Rest apunta de este modo contra dos errores claves en los que suele incurrir la crítica: el de arrogarse -en forma autoritariala verdad de la lectura y el de convertirse -por voluntad oportunista o por desidia negligente- en un discurso judicial con el derecho a establecer valoraciones capaces de sentar precedentes prescriptivos y proscriptivos. En razón a este último punto se apoya en Woolf para ironizar sobre la imposibilidad y la necedad de juzgar o establecer valoraciones en términos tajantes y definitivas, como por ejemplo cuando se pretende juzgar si Hamlet es «superior» a Lear, O viceversa: «por adornadas de pieles y togas que estén, admitir autoridades en nuestras bibliotecas y permitirles que digan cómo debemos leer, qué debemos leer, qué valor otorgar a lo que leemos, es destruir el espíritu de libertad que alienta estos santuarios» (1953b:32). En la perspectiva del joven Rest, la crítica debe contribuir a «ensanchar la comprensión del lector» (1953b:33). Tras ese objetivo pedagógico, el crítico se encuentra con su función «explorando de tal modo la obra investigada que se descubra su forma», «se ilumine su significado»y se proyecte sobre el ámbito vital en que fue concebida. La crítica debe pues «hacer sentir» al lector, no la obra, sino «el acto creativo de que es 
resultante» (1953b:33). Debe poner al lector común ante «el rasgar de la pluma, las dudas e inquietudes del escritor, los pregones callejeros o los gritos de los niños en la habitación contigua, que lo interrumpieron» (1953b:33). No es difícil leer en ese fraseo la configuración de una crítica de corte tradicional, que trabaja en el vaivén de una relación particular entre «vida y obra», movimiento pendular que no por ello se acota al biografismo ni se desentiende de los riesgos que asume, al punto de señalar que la «personalidad»y la vida del autor pueden también llegar a constituir «un obstáculo para la comprensión artística», ya que parte de reconocer que «los grandes artistas desde los poetas griegos a Shakespeare- son también los más impersonales.» (1953b:33).

Para Woolf, como para Rest, la relación «arte y vida» tratada sustancialmente en el apartado "Life itself" (1953b:815)- constituye el núcleo de la lectura. Ambos «están estrechamente entrelazados»: «el arte es una interpretación esencial e intensificada de la vida» y como ella se nos ofrece en toda su complejidad, contradicción y misterio (1953b:15); la crítica debe pues -en consecuencia- asimilar en su enfoque de la literatura las circunstancias que permitan sostener esta identificación y ofrecer las herramientas para su comprensión: por ello, partiendo de una confesión de ignorancia de corte casi cartesiano, debe encargarse de situar al lector común en el espacio y en el tiempo de la obra y debe procurar señalar las diferencias concretas de estas coordenadas con las de la lectura. El ensayo literario de Virginia Woolf sigue esta relación entre 
vida y arte pero lo hace en el interior de una experiencia imaginativa diferente de la que compromete a la crítica. Sin embargo, la crítica debe ser capaz de reconocer en él una disposición ética de la lectura que le permita quitarse al autoritarismo del juicio: en su interpretación de los textos de Geoffrey Chaucer, por ejemplo, «Woolf no nos guía, no impone autoridad; pero ayuda a definir las cuestiones que suscita la lectura de Chaucer y nos ofrece las respuestas que ella les ha dado» (1953b:35) .

El ensayo de Woolf es, en efecto, algo menos y algo más que una crítica. Hay algo menos en tanto no puede hallarse en ella un juicio categórico, sea este de encomio o descalificación. En algún punto, hasta puede ser confiada a una «anticrítica», en el sentido que Leigh Hunt, el crítico y ensayista amigo de Keats y de Shelley, propuso para los ensayos críticos de Charles Lamb: una crítica que -en tanto se niega al «enjuiciamiento y la ponderación de autores»- llega a comprender tanto, a reconciliarnos con tantas cosas, que «neutraliza todo excepto la aceptación y la admiración» (1953b:35). Lo que hay de más es el encuentro con una obra en el mundo, con un autor comprometido o asediado por sus circunstancias: «el arte como una forma más sutil y perfecta de la vida». De ese modo, la crítica se reencuentra con una función creativa al dar lugar -partiendo siempre de la lectura de la obra- a una «figura completa», que incluye «el retrato de un hombre», «el boceto de una época»y «una teoría del arte de escribir» (1953b:35-36).

El hecho de que Rest republique, en formato resumido, con 
leves modificaciones $y$ de manera independiente este último capítulo en la revista Sur tampoco es casual. Bajo el título de "Virginia Woolf y la función de la crítica"72, el texto aparece publicado en el número siguiente al titulado "Por la reconstrucción nacional" y escrito como celebración del golpe de Estado que derrocara el 16 de septiembre de 1955 al gobierno democrático de Juan Perón. ${ }^{73}$ La decisión de publicación es pues una toma de posición que no ofrece demasiadas dudas. A comienzos de 1956, unos meses antes de que vea la luz el número especial de Contorno que revisa críticamente la experiencia peronista como experiencia de clase, Rest publica su artículo más trabajado artículo que, sintomáticamente, hace especial hincapié en los aspectos referidos a la autonomía y la especificidad del hecho literario- en la revista que sin mediatintas vitorea a la autodenominada "Revolución Libertadora". Derrocado el peronismo, no era difícil esperar una reconfiguración del campo intelectual con relación a las instituciones educativas estatales. Los intelectuales liberales -como los reunidos alrededor de revistas como Imago Mundi o Realidad- y más todavía aquellos que se habían declarado abiertamente opositores al régimen peronista -como los que orgánicamente hacían Sur y colaboraban ocasionalmente en el suplemento cultural del diario La Nación- corrían con ventaja para ocupar los espacios que los despidos de la Libertadora dejarían vacantes. En lo que respecta al grupo comandado por Romero, cabe señalar que además se trataba de intelectuales que 72 Rest, J., "Virginia Woolf y la función crítica". Sur, 238, 1956. pp. 4559 .

73 Véase Sur, Revista bimestral. "Por la reconstrucción nacional", $N^{\circ} 237$, Buenos Aires, noviembre de 1955. 
habían dado pruebas tangibles de estar capacitados para asumir cargos en sus disciplinas específicas. Habían adquirido en esa formación lateral a la universidad peronista un capital cultural específico que, junto a la abstención calculada de pronunciamientos políticos coyunturales, los candidateaba casi naturalmente a ocupar esos cargos. En su mayor parte se inscribían políticamente -sin una militancia fervorosa- en algunos de los matices del liberalismo antipopulista. Ese hecho no los congraciaba directamente con la ideología reaccionaria de las fuerzas que encabezaban el gobierno de facto; pero, a los efectos de producir una universidad sumisa y antiperonista, cumplían los requisitos ideológicos para asumir la responsabilidad de hacer del campo universitario un espacio comprometido específicamente con la división social de los saberes y las disciplinas profesionalizadas.

Lo que se jugaba en esos reemplazos constituía pues un hecho que excedía los nombres propios y las necesidades específicas de la coyuntura. El proceso de autonomización del campo universitario aleja a esos mismos intelectuales de la posibilidad de intervención política. Los vuelve gradualmente «maestros seleccionados y especializados»y, en razón de ello, se les otorga «una carrera burocrática e ingresos regulares» que como apunta Bourdieu- los libera en la jaula que los tiene presos. Es así que llegan rápidamente a conocer mejor que nadie una parcela específica del saber y que, «al profesionalizarse y dotarse de una metodología específica, tienden a romper con las tradiciones mundanas de la crítica» (Bourdieu 2008:53-55). 
El acercamiento de Rest a la vertiente liberal más dura del campo intelectual es gradual pero sintomático. No se reduce a gestos de sobria cortesía; sino que incluye textos específicos como "Virginia Woolf y Victoria Ocampo" (1954c) ${ }^{74}$, donde el joven Rest celebra con fervor desmedido Virginia Woolf en su diario (1954) de la directora de Sur o Cuatro hipótesis de la Argentina ${ }^{75}$, donde el joven crítico despliega una discutible defensa de Eduardo Mallea, blanco fijo de la crítica ideológica practicada por los contornistas. Sin embargo, fue el propio José Luis Romero, Rector interventor de la Universidad de Buenos Aires a partir de 1955 -ante quien el joven Rest había probado largamente su competencia y profesionalismo en las páginas de Imago Mundi- quien lo designó para acompañar a Jorge Luis Borges en la cátedra de Literatura inglesa y norteamericana en la etapa de «desperonización e innovación» universitaria (Neiburg 1988: 215-251). Rest desempeñó su cargo junto al autor de Historia universal de la infamia desde 1956 hasta 1963. Su indiscutible profesionalismo, su acentuada especialización y el prestigio cultural que le prodigaba la cátedra lo convirtieron paulatinamente en un experto ampliamente reconocido y consultado con relación a temas afines a su competencia disciplinaria. En función de ello y su generosa disposición, llegó a contribuir en adelante a la realización de numerosas traducciones, ediciones,

\footnotetext{
74 Rest, J., "Virginia Woolf y Victoria Ocampo" (1954c), en Oeste. Revista Literaria, Año $X, \mathrm{~N}^{\circ}$ 17, Buenos Aires, setiembre de 1954. [sin paginar]. 75 El texto, escrito a mediados de la década del '50, sería publicado recién, a instancias del propio director del suplemento Cultural del diario La Nación, en Bahía Blanca: Rets, J., Cuatro hipótesis de la Argentina (1960a). Bahía Blanca: Cuadernos de Extensión Universitaria, Universidad Nacional del Sur.
} 
revisiones y correcciones en el ámbito específico del área mencionada, en proyectos editoriales tan disímiles como Sur, Monte Ávila, Centro Editor de América Latina o Ediciones Librerías Fausto.

El texto de Rest que resume las ideas centrales de su tesis de grado parece, sin embargo, subrayar la necesidad de acortar esa distancia que indefectiblemente impone la profesionalización. Su apelación a la categoría de «lector común» -y a la articulación de arte y vida que se produce en la experiencia de la lectura- van en esa dirección. Pero, a la vez, en la misma medida en que lo hace su tesis, deja leer entre líneas -en la única forma que era posible plantear una polémica en ese contexto: en el juego de alusiones e insinuaciones que hace posible la propia retórica académica- el movimiento de una actualización metodológica en lo referente a la investigación literaria.

En ambos textos, Rest deja constancia pues de la necesidad de reconocer la «autonomía que en relación con su propio autor adquiere la obra de arte una vez completada» al tiempo que se inclina por una concepción del discurso literario como una articulación eminentemente formal, como una construcción de carácter específico. Con este ademán, el joven crítico procura tomar distancia, a la vez, de la tradición de la crítica liberalidealista y de las reducciones de la tendencia marxistamaterialista. Se trata, claro está, como bien apunta Bardauil, de escapar a la encrucijada definida por la oposición sociologismo marxista/idealismo burgués. Pero además de configurar una 
alternativa posible al biografismo de la "crítica tradicional", al impresionismo (que en Sur practicaban figuras como la propia Victoria Ocampo) y a las distintas variantes del sociologismo "vulgar" o "mecanicista" (como el practicado por Jorge Abelardo Ramos o Juan José Hernández Arregui, para citar dos ejemplos). Y era, finalmente, también la prueba concreta de una voluntad manifiesta por tomar -en el sentido estricto del términorecursos de la crítica estilística (para la cual la forma es lo central de la experiencia estética) y de la crítica sociológica "no mecanicista" como la practicada en Contorno (que reconocía en el estudio de la forma un punto fundamental de la lectura política de la obra). ${ }^{76}$ Sin dejar de pensar la relación autor/obra, Rest propone una crítica que se apoya en una lectura en la que la relación entre ambos deja de ser directa, inmediata y causal, dando lugar a una idea de autonomía de carácter relativo, que obliga al crítico a plantear ante todo la modalidad de ser de la relación que en la lectura se funda como mediación.

El primer ensayo que trata de materializar esa disposición ética de la lectura se publica el mismo año en que aparece su tesis de grado, en el número 10 del Boletín de Estudios Germánicos. ${ }^{77}$ Se trata de un sobrio ensayo de diez páginas sobre la poética narrativa de Woolf, construido casi en su totalidad sobre los materiales marginados de su lectura de los ensayos de

\footnotetext{
76 Véase sobre este punto Croce, M., Contorno: izquierda y proyecto cultural. Buenos Aires: Colihue, 1996.

77 Rest seguirá refinando esta reflexión sobre la función de la crítica en muchos de sus trabajos posteriores. Vale la pena detenerse además, en lo que respecta a esta primera etapa de la producción restiana, en el notable trabajo titulado "Thomas de Quincey ante el magisterio de la prosa" (La Biblioteca, IX, 2, 1958. pp. 144-154).
} 
la escritora inglesa. Rest subraya especialmente el carácter provisional y tentativo de la indagación desde la misma definición de su título, "Notas sobre Virginia Woolf" (1953c) ${ }^{78}$, pero propone una lectura sólida y meditada, que se recorta sobre el tópico de la relación entre literatura y experiencia. La solidez aparece refrendada doblemente al identificar el carácter complementario de este texto y el núcleo reflexivo de su tesis.

En un claro gesto por limpiar puntos de partida ambiguos o confusos, Rest comienza por despegar el carácter específico de las novelas de Woolf. Señala que las suyas no son argumentales, puesto que no es posible observar en ellas la «hipertrofia creativa del "carácter"» con que se modela un «mundo imaginario» (1953c:118). Tampoco se trata -escribe Rest- de novelas «de tesis», ni de «interpretación de la sociedad». Se trata más bien de novelas de un riguroso carácter formal y, en función de ello en la perspectiva restiana-, aparecen definidas como una superficie textual que presenta «sólo trazos impresionados por partículas luminosas sobre una placa sensible» (1953c:118). Esas «placas» son los «personajes» de Woolf. Están compuestos no por características ni por tipicidades, sino por pequeñas partículas que «constantemente varían y se reordenan», en una suerte de constelación móvil donde unnas cuantas suscitan a otras o se alteran a sí mismas». Estas «placas» suponen una perspectiva gnoseológica que pone en escena «una sutil conciencia de existir», surgida a partir del encuentro con «la dureza de los

78 Rest, J. (1953c), Notas sobre Virginia Woolf, Buenos Aires, del Boletín de Estudios Germánicos, $\mathrm{N}^{\circ}$ 10. (separata) 
objetos» que modulan, por afecto, la sensibilidad (1953c:118).

Sin embargo, y pese a que permanecen aislados en cada placa (y es casi imposible sostener que mantengan relaciones entre sí), los personajes de Woolf -como bien apunta Rest- no se mueven como objetos, ni «es posible decir que se relacionen»; puesto que, ante todo, «conservan una impenetrabilidad que solamente puede ser modificada -nunca superada- por la relación que produce la experiencia» (1953c:118). Son, en efecto, «formas y figuras» que se desplazan y transforman a partir de la experiencia; es decir, a partir de lo que son capaces de arrancar de lo que perece en sus propias vidas. Toda su consistencia está pues «sujeta al poder de un flujo cambiante». De ahí que, en la perspectiva restiana, el problema fundamental que pone en escena la novelística de Woolf sea finalmente el del tiempo. El tiempo, manifestándose, como un flujo inestable, como un peso físico que roe silenciosamente la realidad, teje la «frágil trama de recuerdos» que toma la forma de una «conciencia». Pero además, en su propia movilidad, se manifiesta como «la dimensión de los objetos, grado de proximidad o lejanía que éstos distan de la ubicación de la experiencia actual que los conjura» (1953c:119). Sólo el tiempo da lugar a la experiencia. Sólo en virtud de su capacidad configuradora aquello que arrancamos a lo que perece, aquello que el instante deja tras de sí como una huella frágil, tiene lugar. He ahí lo que Virginia Woolf entiende por experiencia y en virtud de lo cual asume su literatura como una necesidad.

Dar lugar a la experiencia de la pérdida es en efecto dar 
lugar a una suerte de belleza frágil y fugitiva como la vida misma: «La vida -escribe Rest- es efímera, carece de finalidad. La actividad creadora, igualmente, está desprovista de depósito. Su contenido se borrará de inmediato» (1953c:220). El desafío poético de Woolf consiste entonces en tratar de acoger «los retornos de aquel pasado que ha muerto», entendiendo que ese acogimiento en el espacio literario representa a la vez la imposibilidad de su retorno real, puesto que se graba sobre «experiencias que estaban condenadas a disgregarse». Woolf funda una literatura justo en un umbral de pérdida. Su narrativa surge pues y define su propio espacio en «la experiencia actual más próxima que tenemos de la muerte». Pero lo hace no en un intento de recaptura nostálgica, sino «anulando definitivamente toda posibilidad de que pueda volver a repetirse». El «distanciamiento irremisible» de lo perdido en el recuerdo aparece ligado a dos procedimientos específicos en el orden de su composición literaria: uno consiste en «el enrarecimiento de las imágenes recuperadas del tiempo», y el otro en la disgregación de la unidad temporal mediante la presentación de «partículas aisladas», distribuidas «de manera discontinua y en una duración indeterminada» (1953c:221).

\section{SERIEDAD, ESPECÍFICIDAD, PROFESIONALIZACIÓN}

Haciendo referencia a esta primera etapa de su trabajo crítico Rest remitía con franqueza a dos nombres propios significativos en la constelación que determinaba sus lecturas: 
el de F. R. Leavis y el de Theordore Spencer. La referencia es fidedigna. No sólo porque ambos aparecen explícita y frecuentemente citados en la voluminosa masa crítica que de manera generosa ofrecen sus eruditas investigaciones; sino también porque, tanto el fundador de la mítica revista scrutiny como el autor de Shakespeare and the nature of man, dan a Rest las claves fundamentales para la configuración formal y la razón inmanente a su propio dispositivo crítico.

Podría parecer extraño que el nombre del poco conocido poeta y académico norteamericano Theordore Spencer aparezca reconocido por Rest como uno de sus referentes fundamentales en el período correspondiente a sus wanderjahre. Pero no es así. La influencia de Shakespeare and the nature of man, su obra más importante traducida al español por Losada en 1954-, se nota particularmente en los trabajos de formación del joven Rest. En principio, porque el perfil académico de spencer supone cierto carácter modelo en el contexto de la profesionalización académica que el joven crítico pugna por alcanzar. El autor de Shakespeare and the nature of man, se graduó de la Universidad de Princeton en 1923, y obtuvo su doctorado de la Universidad de Harvard cinco años después. Luego enseñó en esa prestigiosa institución desde 1927 hasta 1949. Fue nombrado en 1939 Profesor de Literatura Inglesa en la Universidad de Cambridge. En 1942, dictó la serie de conferencias de Lowell sobre la obra de William Shakespeare; y, a partir de la investigación sobre la que se diagramaron esas conferencias, compuso su libro más importante, aparecido en Cambridge a mediados de 1951. 
Pero es Shakespeare and the nature of man $(1954)^{79}$ lo que más impacto generará en Rest. Es allí donde Spencer traza las coordenadas fundamentales de la investigación literaria que más interesan al joven crítico argentino. Según expone detalladamente Spencer en el prefacio de su minucioso ensayo, tres son «las principales maneras de estudiar la expresión de la experiencia humana en las artes»: en primer lugar, «estudiar el fondo histórico -intelectual y emocional- que el artista pudo utilizar»; en segunda instancia, «estudiar el artificio, el instrumento artístico que [el artista] empleó»; y, finalmente, estudiar «el producto logrado, con relación a lo que creemos que es la verdad de la experiencia humana como conjunto» (Spencer 1954: 9).

En esa articulación «pretenciosa» se inscribe el libro de Spencer sobre Shakespeare. Y en ese mismo propósito de dar cuenta del contexto histórico, la técnica específica y la verdad social que a través de esa técnica se expresa, se inscribe la investigación que Rest desarrolla sobre la obra de T. S. Eliot. Es el diagrama de una investigación que se despliega, no sobre un aspecto específico de la obra, sino a partir de un presupuesto «amplio y fundamental» capaz de visualizar el punto de vista subyacente a la experiencia estética particular.

Se trata pues, tanto en spencer como en el joven Rest, de captar la articulación del arte y la vida, de manera que las dos primeras instancias de la investigación -el relato histórico y el

\footnotetext{
79 Spencer, T., Shakespeare y la naturaleza del hombre, Buenos Aires, Losada, 1954. En adelante todas las referencias a este texto se hacen sobre esta edición.
} 
análisis técnico- confluyan para dar lugar a la comprensión de la imagen del mundo y del hombre que subyace a la letra literaria. Así como para Spencer el autor de King Lear fue capaz de presentar «en una forma artística aceptada por su público, las experiencias individuales de los seres humanos con relación a sí mismos, a la sociedad y a las fuerzas que lo condicionan» (Spencer 1954: 254), la obra de T. S. Eliot representaba para Rest una suerte de síntesis poética de la encrucijada existencial del hombre moderno ante un mundo en permanente transformación. Como el Shakespeare de Spencer, el Eliot de Rest escribía ante un mundo cambiante en el que «viejas teorías sobre el hombre se derrumbaban por los nuevos descubrimientos que agrandaron el abismo entre lo que el hombre debía ser y lo que efectivamente era» (Spencer 1954: 253). Por eso mismo, se abocó a «estudiar y tratar de comprender la visión que de la vida tenía el poeta», planteando a su literatura una interrogación filosófica y cabal, señalando y describiendo especial y rigurosamente sus complejas pero estrechas relaciones con los dilemas más importantes «del pensamiento contemporáneo», y tratando siempre de clarificar «el desenvolvimiento de su personalidad artística a través de la forma poética y su verdad universal» (Spencer 1954: 10).

Del influyente crítico británico Frank Raymond Leavis, el joven Rest toma el modelo de una ética de trabajo. Representante saliente de la «crítica de Cambridge», Leavis era un defensor a ultranza de un riguroso estándar intelectual, al punto que atacaba sin miramientos ni contemplaciones el elitismo aficionado 
que caracterizaba al grupo de Bloomsbury. En función de ello, su cátedra en el Downing College de Cambridge y la revista Scrutiny en especial llegaron a convertirse en un foro fundamental para el examen y la evaluación de la literatura que le era estrictamente contemporánea, pero también y fundamentalmente llegó a constituirse como un espacio de revisión del canon tradicional en razón de criterios rigurosos, sentidos en términos de «seriedad» o «gravedad» [《seriousness»].

New Bearings in English Poetry (1932), la primer obra citada por Rest como referente en su formación, aun siendo el primer volumen importante de crítica publicado por Leavis, materializa ya ese ethos de seriedad. El trabajo, dedicado al análisis de textos de Gerard Manley Hopkins, William Butler Yeats, T. S. Eliot y Ezra Pound, que -como apunta Michael Bell-con frecuencia suele ser considerado erróneamente precursor para la escuela americana New Critics ${ }^{80}$, busca identificar los logros esenciales y nuevos en la poesía moderna. Pero, más que en su novedad interpretativa, donde se ratifica la seriedad propia de la crítica que el joven Rest imagina como modelo, es en su voluntad manifiesta de afirmar posiciones críticas propias, sólidamente sostenidas en función de argumentaciones precisas y centradas en los textos literarios.

La segunda referencia de Rest no es menos importante. Se trata sin más de The Great Tradition (1948), la importante intervención crítica de Leavis sobre la tradición de la novela inglesa. Los ensayos reunidos en ese volumen -publicados en su

80 Bell, M., F. R. Leavis, Routledge, New York, 1988. 
mayoría previamente en Scrutiny- se ocupan casi exclusivamente de las experiencias narrativas de Jane Austen, George Eliot, Henry James y Joseph Conrad. Polémicamente, Leavis excluye o margina de la columna vertebral de la tradición novelística inglesa a los autores por entonces indiscutibles como Charles Dickens, Laurence Sterne y Thomas Hardy. Rest reconoce el impacto del libro de Leavis. Lee y cita fervorosamente -tanto en sus clases de la cátedra de Literatura Inglesa y Norteamericana como en sus publicaciones del período- la edición de Chatto \& Windus, publicada en Londres en 1950. Pero no son los enunciados específicos del trabajo crítico los que lo marcan, sino la rigurosidad indeclinable de sus explicaciones de texto -técnica característica del trabajo de lectura restiana, recordado y reconocido por alumnos y colegas tanto en sus artículos como en sus clases ${ }^{81}-$ y la sobriedad y la gravedad [«seriousness»] sobre la que se constituye su ethos de enunciación crítica. La influencia de este ethos no se redujo sólo a los estudios de la literatura inglesa; muchos departamentos universitarios ingleses y americanos se formaron sobre el modelo ejemplar de Leavis, Scrutiny y su ideario revisionista. Ya de sus propias lecturas del autor de Revaluation (1936) o de las diversas escuelas críticas por él influenciadas, el joven Rest se revela -tanto ética como metodológicamente- muy próximo al primer Leavis, es decir: aquel que, bajo una inobjetable influencia de T. S. Eliot, se esfuerza por reexaminar la poesía inglesa de los siglos XVII y

81 Cfr. Sarlo, B., "Sobre literatura y política" (entrevista de Pablo Chacón), en Letras Libres, setiembre de 2011. pp. 58-62. 
Xx. Se aferra a esa idea arqueológica de la crítica literaria. Pero lo hace sin incurrir en provocaciones ruidosas, confiando en los efectos de largo alcance de un lento y minucioso trabajo de remoción de escombros idiosincrásicos, de exposición comparativa y de disolución taxonómica, como si todo el tiempo tratara de hacer de su propia crítica una crítica del juicio. En ese sentido, Rest se distancia reservadamente de Leavis, quien sobradamente insistió en que la valoración debía ser la principal ocupación de la crítica. ${ }^{82}$ Pero lo sigue, sin dudas, en su convicción de que la literatura debe ser leída a partir de sus relaciones con la sociedad -en tanto «realidad viva», en funcionamiento- y en su certeza de que la crítica literaria debe contribuir -porque la incluye tanto en sus visiones como en sus revisiones- a la formación crítica de la sensibilidad contemporánea.

Como las primeras obras de Leavis, estos primeros trabajos de Rest exhiben, a la vez, lo que Eagleton ha definido como «un reconocimiento melancólico» de la tradición y una férrea voluntad por profesionalizar la crítica como disciplina específica. ${ }^{83}$ El doble ademán supone un intento de superación -a través del refinamiento disciplinado de una técnica- de la "crítica tradicional", estancada en el impresionismo, el biografismo y la estilística escolar; pero también -mediante una retórica de la explicación comparada- de una crítica populista, de pedagogía ideológica, intolerante y mecanicista, que se resolvía en la

82 Véase al respecto especialmente "The Idea of Criticism" de R. P. Bilan (en The Literary Criticism of F. R. Leavis, Cambridge, Cambridge University Press, 1979. pp. 61-84).

83 Eagleton, T., La función de la crítica, Barcelona, Paidos, 1999. p. 90. 
figura del dictamen valorativo de corte judicial y que no dudaba en poner el referéndum por encima de la experiencia de la lectura. En esa encrucijada, Rest se aferra a una profesionalización especializada -y siempre ávida de actualizaciones (por ende, siempre abierta a las transformaciones)- que confiaba en el poder y el valor de la seriedad. En ella se apoyaba tanto su silenciosa reacción contra la devoción amateur por las "bellas letras" -reproducida por los estratos más duros de la elite patricia-, como su propia inscripción crítica en un humanismo liberal que pusiera alguna resistencia a las imposiciones de la industria cultural capitalista.

Como en la «práctica crítica» que Leavis trataba de llevar adelante en Scrutiny, en el núcleo mismo de la crítica restiana subyace una tensión irresuelta que bien puede leerse en términos de contradicción. Está, ciertamente, el trabajo de investigación erudita y rigurosa -cuyo ejemplo más tangible es la serie de artículos sobre the Waste Land- sobre la que se construye un plus de legitimidad del especialista que se traduce en la profesionalización académica. Pero está también la apelación constante al ensayo literario y a la función creativa de crítica que recobran la experiencia de la lectura como resistencia a las formas tecnocráticas y academicistas de la crítica que imponen una discontinuidad entre la literatura y la vida social. La tensión entre lo amateur y lo profesional, entre el «lector común» y el especialista, supone indefectiblemente la tensión entre sociabilidad e individualismo. Que Rest no haga de esta 
contradicción un tema de reflexión específica no supone que le sea particularmente invisible. Desde su propia inscripción en el proyecto intelectual implícito en Imago Mundi, acepta que la profesionalización tiene sus costos: hacer de la crítica un discurso analítico riguroso significa hablar a un lector diferente del «lector común». ${ }^{84}$ Hacer de la lectura un proceso de definición y discriminación de valores culturales a partir de la exégesis textual supone también la existencia de una escucha particular, capaz de seguir los meandros de una reflexión crítica especializada y disciplinada. Rest sabía pues que el escrupuloso empirismo de su técnica crítica redituaba una apariencia de profesionalidad eficiente, pero no ignoraba que ese tono y esa retórica tenían un destino preciso en una comunidad específica y prácticamente imaginaria. Buscaría en consecuencia una suerte de síntesis al dirigirse deliberadamente a un «lector enterado, [aunque] no necesariamente especialista» ${ }^{85}$ y al producir trabajos que no «aspiren a exponer hipótesis novedosas o intrincadas» sino a plantear con la mayor claridad posible las «problemáticas» inscriptas en las diferentes literaturas. ${ }^{86}$

Del mismo modo, trató de ejercer su propia práctica crítica como una alternativa a un cientificismo positivista (que rápidamente se ahogaba en generalidades ineficaces) y a un

\footnotetext{
84 Escribir de modos diferentes -dice Williams- significa no sólo dirigirse a subjetividades diferentes, sino también «vivir de modos diferentes. Significa asimismo ser leído de modos diferentes, dentro de relaciones diferentes, y a menudo por gentes diferentes.» (Williams, R., Marxismo y literatura, Barcelona, Península, 2000. p. 235).

85 Rest, J., Conceptos de literatura moderna, Buenos Aires, CEAL, 1979, p. 7.

$86^{\circ}$ Rest, J., Novela, cuento, teatro: apogeo y crisis, Buenos Aires, CEAL, 1971, p. 8 .
} 


\begin{abstract}
amateurismo impresionista y caprichoso (que construía singularidades evanescentes). Tomó de estos polos en contradicción dos puntos de afirmación para su crítica: lo técnico y lo humanista. Las usó como fuerzas complementarias cuando se las tenía por antagónicas. En ese sentido consiguió sus mayores logros cuando, interrogando rigurosa y formalmente los textos literarios, fue capaz de producir sentidos en la relación entre literatura y sociedad. Los resultados de esa articulación no siempre fueron exitosos; pero la propia búsqueda expone sintomáticamente un gesto de inquietud e inconformismo. Como Leavis, Rest buscaba $-y$ en la oscilación de esa búsqueda produjo su propia profesionalizaciónuna alternativa viable que le permitiera producir una intervención crítica liberal, progresista y tolerante, capaz de sortear los límites concretos de las posiciones extremas de la estilística y el marxismo, del cientificismo y el subjetivismo, del formalismo y la frivolidad.
\end{abstract}




\section{APÉNDICE $\mathrm{N}^{\circ} 1$}

\section{BORGES, DESCARTES Y EL OBISPO WILKINS ${ }^{87}$}

Como lo revela Tlön, Uqbar, Orbis Tertius, Borges ha observado que la creación de mundos es, en primer lugar, de orden filológico y, por lo tanto, principalmente lingüístico. No tiene nada de extraño, en consecuencia, que le preocupe la aplicación de los principios cartesianos a la formación de un lenguaje analítico; tampoco que asocie el nombre de Descartes con Essay towards a Real Character and a Philosophical Language del obispo Wilkins. Aquí, sin embargo, es necesario establecer si fue la influencia directa de Descartes la que actuó sobre el obispo Wilkins, como supone Borges, o no. Es muy probable que la respuesta sea negativa. El libro de Wilkins es de 1668; anteriormente, un escocés, George Dalgarno de Aberdeen, autor de un lenguaje para sordomudos y de una taquigrafía para todas las lenguas, publicó su Ars Signorum o Universal Character and Philosophical Language. Su sistema aplica el principio de clasificación lógica de las "nociones" propuesto por Descartes. Todo el conocimiento fue ordenado por Dalgarno en diecisiete categorías, cada una indicada por una consonante (K: temas políticos; N: objetos naturales); estas diecisiete categorías se dividían, a su vez, en subclases indicadas por una vocal griega o latina (Ke: asuntos jurídicos; Ki: asuntos criminales; Ku: guerra). Estas subclases eran, por su parte, di-

\footnotetext{
87 "Borges, Descartes y el obispo Wilkins" (1952c), Centro. Revista del Centro de Estudiantes de Filosofía y Letras, Buenos Aires, Año $2, \mathrm{~N}^{\circ} 4$, diciembre de 1952. pp. 47-50.
} 
vididas en grupos simbolizados por consonantes y éstos en otros designados por vocales, lo que daba una palabra polisilábica que indicaba un objeto, individuo, relación o proceso particular. Por ejemplo, el elefante, el caballo, el asno y la mula eran llamados Nń Ka, Nń Kń, Nń Ke, Nń Ko. Wilkins, que estaba relacionado con la Royal Society, tuvo, indudablemente, conocimiento de esta obra, que fue recomendada al rey por algunos miembros de las universidades de Cambridge y Oxford, según hay testimonio. El profesor Frederick Bodner, de cuyo libro The Loom of Language (New York, 1944; pp. 449 y ss.) tomo las noticias precedentes, ha dedicado varias páginas al análisis comparativo de los planes de racionalización lingüística propuestos por Dalgarno y Wilkins, y los puntos en que este último se apartó de las opiniones de aquel - las desarrolló. No me ha sido posible hallar otras referencias acerca de Dalgarno. Las de Wilkins son, en cambio, numerosas. Se halla citado en los diarios de sus contemporáneos Evelyn y Pepys, y el editor del primero de éstos ha incluido, al pie de la primera información que de él se da, una nota biográfica de relativa extensión (10 de julio de 1654; pp. 292/3 del primer tomo de la edición de Everyma' Library). El admirable libro de Douglas Bush, English Literature in the Early Seventeenth Century, 1600-1660, da en las páginas 270-271 una noticia breve pero fundamental de esta figura que tan pronto provoca el interés como causa el desconcierto. Wilkins fue un hombre de religión y filosofía; entre sus obras una, sobre prédica, es muy recordada; se titula Ecclesiastes. Entre sus trabajos científicos hay unos sobre los viajes a la luna. Bush indica, en la página 607 de su libro, una biblio- 
grafía sumaria sobre Wilkins. Entre los estudios de su teoría lingüística menciona el de Lancelot Hogben, citado por Borges, y el de E. N. Andrade, en Annals of Sáence.

El Essay towards a Real Character and a Philosophical Language ha sido reproducido parcialmente en la obra de F. Fechmer, Beiträze Zur Geschichte der Frangösischen und englischen Phonetik und Phonographie (Heilbronn, 1899). 


\section{EL COMIENZO}

\section{$(1956-1966)$}

SUR: PAREDÓN Y DESPUÉS...

En una lúcida nota destinada a esclarecer la concepción del intelectual que se configura en el proyecto de Sur, María Teresa Gramuglio no duda en reconocer el carácter fundamental de la referencia a la crítica literaria inglesa. ${ }^{88}$ Pese a no aparecer explícitamente declarada en los primeros números de la revista, la concepción del intelectual que se deja entrever en las primeras décadas de la publicación -sostiene Gramuglio- se encuentra en estrecha relación con la propuesta por The Criterion dirigida por T. S. Eliot.

Una nota sin firma, aparecida en la sección "Calendario" del número 36 de Sur (de febrero de 1939), avala en cierto sentido la conjetura de la crítica. En ella se informa el cierre definitivo de The Criterion y se destaca especialmente el «papel importantísimo» que la revista de Eliot jugara para la historia de la literatura contemporánea. Ante todo porque la revista representaba «un raro exponente de generosidad, de probidad intelectual y artística», en un tiempo de «fanatismo políticos»y de posiciones acomodaticias. Ajenas a todo «mezquino interés

88 Gramuglio, María Teresa. "Las minorías y la defensa de la cultura. Proyecciones de un tópico de la crítica literaria inglesa en Sur", Boletín/7, Centro de Estudios de Teoría y Crítica Literaria, octubre de 1999. pp. $71-77$. 
personal», las páginas de The Criterion -afirma la reseña anónima- permanecieron sobre todo «incontaminadas» y en función de eso consiguieron convertirse en «uno de los pocos refugios del pensamiento contemporáneo», donde colaboraban asiduamente «las plumas más célebres de la lengua inglesa» y donde se dio a conocer «al público británico la obra de escritores tales como Proust, Valéry, Jacques Rivière, Cocteau, Ramón Fernández, Maritain, Wilhem Worringer, Max Scheler, E. R. Curtius».

Que el elocuente elogio del reseñista se cierre con una cita a las palabras de despedida que Eliot publica en el último número de la revista ilumina un nuevo aspecto de la semejanza, en tanto aclara la función y la condición marginal de las elites ilustradas. En el paisaje sombrío de tiempos aciagos, Eliot vaticina las dificultades y la importancia de la función social que deben asumir esas elites letradas: es probable que, durante mucho tiempo -escribe allí el autor de The Waste Land-, «la continuidad de la cultura habrá de ser mantenida por un muy pequeño número de personas». Y es de esperarse -continúa el fundador de la revista- que no sean los grandes órganos de opinión, sino «los pequeños y oscuros diarios y revistas (aquellos que son leídos casi exclusivamente por sus propios colaboradores) quienes conserven vivo el pensamiento crítico y alienten a los autores con talento original» (Sur 1939:81).

En la semblanza encumbrada de la reseña, se puede vislumbrar con bastante claridad la fisonomía del propio proyecto de Sur; en la apelación a las palabras de Eliot (que la directora de la revista volverá a citar, en 1948, aludiendo a la situación 
política de la revista bajo el peronismo) ${ }^{89}$, no es difícil percibir la coartada que pretende dignificar y legitimar el lugar de la elite al otorgarle una función política: la de arrogarse el lugar de la protectora abnegada de la Cultura. La propia directora y mecenas de Sur, Victoria Ocampo, señalaría en varias oportunidades tanto el interés de hacer de la revista un órgano de integración de una «elite de escritores» que funcionara como una «Aristocracia del Espíritu» ${ }^{90}$, como la voluntad de contribuir a la creación de «la elite futura» acercando al lector argentino lo más refinado de la literatura y la cultura universal. ${ }^{91}$ Sur no anunció su programa en un manifiesto explícito, pero -tal como advierte Gramuglio-, ya su número inaugural presenta el esbozo que permite visualizar su presupuesto objetivo fundamental: no se puede crear nada auténticamente nuevo en «el encierro de una sola cultura y una sola lengua»; sólo se puede hallar «la voz propia» a partir de «una relación activa con todo el ámbito americano y con Europa» (Gramuglio 2001: 343$)^{92}$.

El sobreentendido de que la necesaria tarea de difundir lo mejor de la cultura moderna está reservada a cierta elite ilustrada y minoritaria justifica ideológicamente los términos del proyecto. En este punto, resulta realmente sintomático que el primer texto de la revista sea precisamente una carta (de Victoria Ocampo a Waldo Frank) y la rememoración de un viaje. La

\footnotetext{
${ }^{89}$ Cfr. Sur, $\mathrm{n}^{\circ}$ 169, noviembre de 1948. pp. 7-9.

90 Una «aristocracia cuyos miembros tienen siempre estrecho parentesco, como en otros tiempos las familias reinantes» (cfr. Sur, $n^{\circ}$ 75, 1940).

91 Cfr. la presentación de Victoria Ocampo al número especial por el vigésimo aniversario de la revista (Sur, $n^{\circ}$ 192-193-194, 1950).

92 Gramuglio, María Teresa. "Una década dinámica. Transformaciones, posiciones y debates en la literatura argentina en los años treinta", Nueva Historia argentina, tomo 7. Buenos Aires: Sudamericana, 2001. pp. 333-380.
} 
propia revista llegó a constituir el nudo indiscutible de una compleja trama epistolar que puso en escena -como señala King- el funcionamiento efectivo de una red de relaciones que remitía a una comunidad de intereses y preocupaciones que, como quería Ortega y Gasset, era capaz de conectar a las elites intelectuales «por sobre las diferencias de sus pertenencias nacionales y sociales» (King 1989:63) ${ }^{93}$.

Que un joven como Rest, proveniente de una clase media ascendente, antiperonista y recién titulado con una especialización en literatura inglesa se sintiera secretamente interpelado e incluso deseara -consciente o inconscientementeformar parte de esa hipotética «elite futura», no era ciertamente raro. Rest se había formado leyendo Sur, donde había conocido a casi todos los escritores y ensayistas ingleses por quienes prodigaba una admiración fiel y respetuosa (sólo por citar algunos, Thomas De Quincey, T. S. Eliot, Virginia Woolf y Georges Orwell habían aparecido en sus páginas); pero también allí leería por primera vez en español a críticos y referentes académicos como F. R. Leavis, David Cecil, C. M. Bowra, Theodore Spencer, Edmund Wilson, I. A. Richards, Robert Liddell, Andrew Wright, C. S. Lewis, Lionel Trilling y Ciryl Connolly. Tampoco llama la atención que Rest reconociera en la revsita de Victpria Ocampo, no sólo una afinidad manifiesta con The Criterion, sino también y fundamentalmente- una publicación que realmente se inscribía en la constelación de las grandes revistas europeas nacidas en el

93 King, John, Sur. Estudio de la revista argentina y de su papel en el desarrollo de la cultura. 1931-1970, México, Fondo de Cultura Económica, 1989. 
período de entreguerras como Revista de Occidente o la polémica Scrutiny. También allí se materializaba una crítica de la modernidad capitalista que por entonces empezaba a traducirse políticamente en las democracias de masas y en el ascenso de los totalitarismos, y socialmente en la imposición cada vez más declarada del utilitarismo, la técnica y las ciencias positivas.

La elite intelectual de Sur se pretendía independiente y portadora de la tarea crucial de mantener los valores morales y culturales amenazados por el vertiginoso cambio social. Y de alguna manera la revista encarnaba en una versión vernácula y secularizada las funciones de la clerisy teorizada originalmente por Samuel Taylor Coleridge y reformulada luego por T. S. Eliot, especialmente en The Idea of a Christian Society (1939) -texto que Rest había estudiado con detenimiento en sus trabajos publicados en Imago Mundi. Este último -por quien Rest sentía una admiración tal que le convirtió muchas veces en objeto de burlas irónicas en el mismo seno de Sur $^{94}$ era el último eslabón de la crítica de la sociedad moderna en la tradición inglesa. En él confluía la tradición crítica inaugurada por William Blake y el romanticismo inglés, retomada luego por Thomas Carlyle, revitalizada en Samuel Taylor Coleridge y completada orgánicamente por Mattheu Arnold. Eliot encarna la persistencia de esa crítica como «una figura mediadora privilegiada» (Gramuglio 1999: 76), al punto que en muchos casos Sur hace propias algunas de ellas ya sea por citas, referencias o

94 Cfr. Bioy Casares, A., Borges, Barcelona, Ediciones Destino, 2006. p. 300 . 
reelaboraciones de sus tópicos fundamentales.

El joven Rest se acerca pues a Sur a partir de 1956. En un principio, cuando la revista -en la voz de su directora y las de sus colaboradores más orgánicos- no escatima elogios para la "Revolución Libertadora", lo hace tímidamente, contribuyendo con reseñas menores o marginales (siempre en el ámbito específico de su formación académica) ${ }^{95}$; y, luego, a partir de que el frondizismo se avizora como salida al militarismo, de manera más comprometida, con algunos textos que vale la pena analizar con especial detenimiento ya que permiten vislumbrar una serie de posicionamientos e intereses que contribuyen a caracterizar la formación de la perspectiva político-ideológica del joven crítico, especialmente su intención de ampliar el ámbito de incumbencia de su propia práctica.

El primero de ellos, "Ingmar Bergman: presencia humana y dimensión imaginaria del cine sueco" (1957d) ${ }^{96}$, es especialmente

95 Las reseñas de esta índole publicadas por Rest en el periodo son: "Forster y su 'Paso a la India'" (Sur, 239, Buenos Aires, 1956b. pp. 5277), "Geografía ultramundana del medioevo" (Sur, 245, mar/abr, Buenos Aires, 1957b. pp. 82-90), "Howard Match, 'El otro mundo en la literatura medieval"" (Sur, 245, mar/abr, Buenos Aires, 1957c. pp. 90-99), "Schultz de Mantovani, 'El árbol guardavoces"" (Sur, 251, Buenos Aires, marzo/abril de 1958a. pp. 88-96), "Helen Ferro, 'Los testigos'" (Sur, 257, Buenos Aires, marzo/abril de 1959b. pp. 77-79), "Federico González Frías, 'El oficinista Pedreiras y otras pesadillas vulgares'" (Sur, 257, Buenos Aires, marzo/abril, 1959c. p. 77), "Susana Bombal, 'Green Wings" (Sur, 258, Buenos Aires, mayo/junio, 1959d. pp. 79-85), "Presencia de Güiraldes: Última biografía Dora P. de Etchebarne, Collantes de Terán, Horacio Jorge Becco" (Sur, 263, Buenos Aires, marzo/abril, 1960c. pp. 55-59), "Sobre las hadas; ensayos de literatura infantil" (Sur, 263, Buenos Aires, mar/abr., 1960d. pp. 62-64), "Fernando de Elizalde, 'El camino'" (Sur, 266, Buenos Aires, set/oct., 1960e. pp. 70-71), "Carmelo Bonet, 'La crítica literaria'" (Sur, 266, Buenos Aires, set/oct., 1960f. pp. 71-73), "Emilio Sosa López, 'La novela y el hombre'" (Sur, 266, Buenos Aires, set/oct., 1960g. pp. 7475), "Peter G. Earle, 'Unamuno and English Literature'" (Sur, 273, Buenos Aires, nov/dic., 1961b. pp. 57-58) y "María Rosa Vacaro, 'Los maestros de antes, hoy: Chaplin, Reoir, Clair, John Ford'" (Sur, 273, Buenos Aires, nov/dic., 1961c. pp. 82-83).

96 Rest, J., "Ingmar Bergman: presencia humana y dimensión imaginaria del 
sustancial en términos críticos, puesto que pone de manifiesto la condición filosófica de la interrogación crítica restiana. Que su objeto específico no sea la literatura no es de extrañar. Su paso por Imago Mundi le ha dado las pautas, no sólo de la posibilidad, sino más bien de la necesidad de volver la interrogación crítica sobre los diversos objetos y fenómenos de la cultura que problematizan y de algún modo reproducen la encrucijada moderna. El cine de Ingmar Bergman permite al joven Rest poner a la crítica en un lugar superador tanto de los juicios de la prensa cultural como de la apreciación del público. Paradójicamente, esa superación se da a partir de la asunción de sus propios límites: es decir, en el reconocimiento de su perplejidad ante el propio fenómeno estético.

Bergman es particularmente interesante para Rest justamente porque «tanto su técnica como su temática -es decir: los fundamentos de su arte- revelan una elaborada complejidad que resulta intencionalmente ambigua» (1957d: 81). Es esa deliberada ambigüedad («procedimiento característico de toda ironía, de todo conceptismo») la que bloquea los juicios simplistas del «apurado crítico» y del espectador «poco adentrado en las exigencias metodológicas». La crítica moderna -en su ascendencia socrática y, sobre todo, cartesiana- se apoya, al contrario, para Rest, en una regla áurea: la del saludable «reconocimiento de que uno no ha entendido». Es así que se dispone a insistir en su examen de la obra, asumiendo las dificultades que importa el juicio que sobre ella se pueda verter. La crítica implica pues una 
«cuidadosa inquisición» de la cual el cine rara vez se vuelve objeto. Y la dificultad que presenta el cine de Bergman es, en este sentido, particularmente notable: "ya sea por exigencias profesionales o por esa perentoria demanda intima que imponen la vanidad y el respeto propios», en su intento por «"comprender" pronto», imponen a esa evidente ambigüedad «un esquema» que, en vez de facilitar la interpretación de la obra, la clausuran en una simplificación.

Por lo general, esa simplificación se consuma -observa Resten la reducción a un tema (en el caso de Bergman, mayoritariamente, al tema del amor -en especial, de la frustración o del fracaso amoroso). Rest examina con minucia la producción de Bergman y ratifica la endeblez del esquematismo temático. Seguir el tema sin atender a las modificaciones que sobre él operan los recursos técnicos y procedimentales es percibir apenas la superficie de un texto y una textura que la crítica devuelve a la «genuina complejidad de lo ambiguo».

En cada uno de los films analizados percibe una operación formal que desestabiliza la consistencia del tema. En Puerto (1948) lo que licúa la consistencia es la incertidumbre con que se diluye la trama, en tanto pone en escena la ambigüedad característica del cine de Bergman: «la vida es demasiado compleja, demasiado rica, demasiado variada para que la agote una decisión o la resuelva una trayectoria, ya sea alentadora o pesimista» (1957d: 82). Juventud, divino tesoro (1950) se desarma también a partir del final, cuando la historia de amor idílico se abre a la doble interpretación, dando a entender, cuando la 
protagonista afronta la muerte de su amado y luego acepta «un insatisfactorio sucedáneo del amor», que «el empañado cristal erótico nunca podrá recuperar su transparencia primigenia» (1957d: 82) y que -tarde o temprano- deberá afrontar su propia ambigüedad. Desprovista de todo clima idílico por «el desajuste y la desintegración moral del mundo familiar» de los amantes, Un verano con Mónica (1952) se concentra en lo erótico en su acepción más primitiva y «en toda su vehemencia física» (1957d: 82), pero -empujada por una infidelidad- la historia amorosa deriva en «una disgregación definitiva»; de modo que, «con una historia áspera y un pulcro virtuosismo técnico», Bergman consigue -según explica Rest- imponer la «idea que lo fascina»: «no hay esperanza, no hay concesiones»; «por difícil y amarga que sea la vida no hay más remedio que aceptarla en sus contrastes, en sus contrasentidos, en su intrínseca ambigüedad» (1957d: 82). En contraste con sus realizaciones previas, Noche de circo (1953) se sitúa en un tiempo y un espacio fabuloso e incierto, y su manera de frustrar la significación cerrada es su carácter delirante, al propiciar -como Kafka y como Carroll- la «intromisión de lo absurdo o lo alucinatorio» en la ficción y de narrar la historia desde «perspectivas que modifican y distorsionan la realidad» (1957d: 85). En La sed (1949) es la técnica del contrapunto que marca la ficción la que articula las tres historias que ponen en escena la deriva de un mundo en crisis, lleno de miserias («ruinas de ciudades bombardeadas que perduran como fantasmas crepusculares, rostros cansados que se contemplan en espejos, muchedumbres hambrientas pidiendo comida 
en estaciones ferroviarias»), un mundo del cual es muy difícil escapar y sobre el cual sólo es posible reconocer «la ambigüedad extrema, inescrutable» (1957d: 87). Secretos de mujeres (1952) articula, en una secuencia acumulativa, también tres historias una risueña, una emotiva y una trágica- en las que la trama amorosa parece predestinada a malograrse, pero que a la vez, paradójicamente, se cierran sobre un final que «desemboca en la resignación y la serenidad», en un clima de sosiego.

Como antes en T. S. Eliot y en Paul Valéry, Rest lee en la ambigüedad que presentan los films de Bergman un signo y un testimonio de la confusión y la crisis de valores que compromete al hombre moderno. Reconoce en ellos una poética que responde indirectamente al efectismo del arte que se justifica en una pedagogía de las masas. Pero fundamentalmente ve traducirse en él la insistencia de una búsqueda filosófica y existencial de la condición humana en la que no se esquilman ni menosprecian «sus fastidios, su inverosimilitud, sus distorsiones» (1957d: 88). La soledad del hombre moderno, su «desesperada búsqueda de comunicación», su «necesidad de responder a las abrumadoras preguntas de la existencia», sus «contradicciones y la intromisión de lo absurdo» en el mundo moderno, quiebran la consistencia del tema amoroso en Bergman. Pero es la «aceptación irremediable, ni resignada ni discutible, de la vida en todo su caudal de posibilidades», es decir, en su «honda e inextricable ambigüedad», lo que lo neutraliza como valor y como emblema de moralidad. Devuelve así la propia obra a una condición de insistencia significante, que no dice ni comunica nada a nadie 
sino que -en su marca diferencial- es genuino testimonio de la ambigüedad del sentido.

El segundo texto importante en términos teórico-críticos publicado por Rest en Sur es "La 'reconciliación' de la filosofía moderna (con motivo de un libro de Sussane K. Langer)" (1958b). ${ }^{97}$ Se trata de un extenso comentario a propósito del libro que, junto a Virginia Erhart, ha traducido para la editorial de Victoria Ocampo: Una nueva clave de la filosofía. Un estudio acerca del simbolismo de la razón, del rito y del arte de la ensayista Sussane $\mathrm{K}$. Langer. ${ }^{98} \mathrm{El}$ artículo tiene una intención precisa: deslindar el ámbito de inscripción de la investigación humanística -y en especial literaria- en el marco disciplinario del saber moderno. Es en razón de ello que parte de Mysticism and Logic de Bertrand Russell para visualizar los dos móviles elementales del pensamiento filosófico moderno. Ambos conducen a sistemas divergentes pero complementarios: «por una parte, los que derivan de la religión y la ética; y por otra, los que derivan de la ciencia» (1958b: 42). Rest discute el carácter dicotómico de esos procesos mentales -que derivan respectivamente la "especulación" científica, por un lado, y la "intuición" ética, religiosa, metafísica y estética, por el otro- que pautan las diversas modalidades del saber moderno, desde la antropología y la psicología hasta la gnoseología y la teoría

97 Rest, J., "La 'reconciliación' de la filosofía moderna (con motivo de un libro de Sussane K. Langer)." (1958b), en Sur n 252, Buenos Aires, mayo/junio de 1958. pp. 41-51.

98 Langer, S., Una nueva clave de la filosofía. Un estudio acerca del simbolismo de la razón, del rito y del arte, Buenos Aires, Sur, 1958. 
del lenguaje.

No es casual que Rest se interese por el tema. Si esas «dos formas primarias de la actividad intelectual» definen en última instancia «la capacidad humana para captar, fijar y comunicar el pensamiento, el conocimiento y la experiencia», una crítica empeñada en pensar la relación entre literatura, pensamiento y experiencia no puede más que asumir su compromiso sobre el saber moderno planteado por el libro de Langer. Sobre todo porque al definir la modalidad de ser de esas formas primarias resulta inevitable reconocer, por una parte, un tipo de «organización sintética (es decir, analizable)» que se manifiesta como lenguaje, y por otra, «una forma de estructuración compleja (es decir, no analizable) cuyas características pueden inferirse examinando las representaciones visuales» (1958b: 42). Como se ha visto en sus lecturas de Eliot y Woolf, Rest se interesa especialmente por esta última forma de organización: tiene la convicción de que las imágenes poéticas ponen en escena una relación concreta entre pensamiento y experiencia. Pero en ningún momento se desentiende de la primera, no sólo porque sobre ella se configura gran parte de la "prosa de tesis" que pauta la literatura de su época, sino también porque sobre ese tipo de estructuración se articula su propia intervención crítica -cuya prosa arrastra, como atributo más saliente, una sólida voluntad de claridad y exactitud.

La síntesis permite fijar el pensamiento en forma discursiva, a partir de una combinación relacional que devuelve un significado comprensivo, intrincado y amplio. Pero las 
estructuras complejas son capaces de organizar una trama inteligible cuyos elementos sólo poseen significación en la integridad del conjunto, de modo que es imposible descomponer la cohesión estructural sin que en esa descomposición se pierda el sentido, tal como sucede en las representaciones visuales, «cuyos elementos de luz, sombra, matiz y proporción se ofrecen simultáneamente -no sucesivamente-», consiguiendo abarcar, en un único acto de percepción, figuras complejas y plenas en detalles y rigurosidad.

Si es cierto que el conocimiento es un proceso creador, que como apunta Rest- se empeña en organizar el caos de las experiencias sensibles, también lo es que no hay conocimiento inmediato. Todo el conocimiento está formalizado por esos dos tipos de estructuración $y$, en este sentido, es siempre de carácter simbólico. En ese fundamento se elabora la filosofía del arte del romanticismo (desde Schelling y Coleridge hasta Herbert Read), que concibe la producción estética como un proceso de «"conformación" de la experiencia».

Rest ha estudiado especialmente este aspecto y toma partido al describir los riesgos que implicaría el descartar una de las modalidades de estructuración de la experiencia en función de un predominio absoluto de la restante. Siguiendo a Langer, describe los resultados inminentes del fundamentalismo hegeliano que, acaso sin proponérselo directamente, «favorece el avance incontenible de una marea de irracionalismo, fundada en premisas voluntaristas, historicistas e intuicionistas» (1958b: 44). En este punto, Rest critica desde una argumentación moral de corte 
liberal tanto a Hegel como a Marx por las consecuencias políticas de sus filosofías de la historia. Entiende que «con sus teorías de que el Estado no se halla sometido a obligación moral alguna y de que el "espíritu del mundo" encarna en cada época en una nación rectora», Hegel es el precursor involuntario de «los mitos políticos modernos implicados en las doctrinas totalitarias, ya sean de índole derechista, izquierdista, "mixta" o "fluctuante"» (1958b: 44). Según Rest, ciertos enunciados de la especulación hegeliana -que, paradójicamente, frente a la filosofía romántica precedente, reivindicaba un sistema de conocimiento basado en la Idea o Concepto-, bajados a la praxis, fueron capaces de constituir también «el germen del irracionalismo político». Sobre todo porque en él el lenguaje discursivo ha perdido de vista los valores morales y ha olvidado que su función es la de convertirse en «el instrumento de una política sana», en tanto la precisión y la claridad discursiva, «sin ser la panacea de la política universal, son, no obstante, el medio más adecuado para prevenir la irreflexiva elaboración de ideologías totalitarias» (1958b: 45) .

Rest percibe con claridad que el pensamiento discursivo no garantiza resultados en lo que refiere a la regulación de las relaciones humanas. Ante todo porque el discurso, que es específicamente apto para enunciar leyes científicas, no asegura eficacia a la hora de conformar los preceptos destinados a orientar la conducta humana. Las leyes científicas suponen una enunciación descriptiva; la legislación político-social es normativa por antonomasia. El enunciado de la ley científica 
declara un determinismo (es decir, una necesidad de orden físico); la recomendación contenida en todo precepto moral o político presenta una determinación (es decir, un convenio arraigado en la idiosincrasia de cierta comunidad).

Si de lo que se trata es de pensar la alternativa contemplada en un «conocimiento ético» (1958b: 46), lo que debe prevalecer a nivel social es la conciencia de que se puede emplear el lenguaje en dos funciones diferentes: como «discurso» y como «magia verbal». En cualquier caso, no se debe confundir la estela de su incumbencia: «el discurso -escribe Rest- es el mecanismo que debe emplearse para legislar en materia de conocimiento científico y para regular cuanto concierne a las relaciones político-sociales» (1958b: 45-46); la «magia verbal» por su parte «no tiene objeto científico o práctico» y «sólo puede emplearse con fines poéticos o religiosos» (1958b: 46). En el reconocimiento de su esencia y su función social se juega más que una confusión. Rest -que ha leído con provechosa atención las reflexiones de Orwell y de Cassirer sobre el tema- lo avizora en una frase transparente: el totalitarismo -escribe- es «principalmente una táctica lingüistica que consiste en anular o tergiversar los significados del discurso con el fin de suscitar - impedir (según convenga al régimen) reacciones emotivas en la masa» (1958b: 46). Es esa operación maliciosa la que hace surgir la propaganda, es decir, el procedimiento por el cual se consigue «dar apariencia de objetividad y exactitud discursivas al empleo de la magia verbal» (1958b: 46) .

El pensamiento moderno se ha alimentado sucesivamente de 
estas dos modalidades de estructuración mental. Rest distingue en función de la gravitación de uno u otro- el desenvolvimiento de los últimos siglos en tres etapas: 1) «el análisis "científico" y "racionalismo" de los siglos XVII y XVIII» que cierra con Hume; 2) el romanticismo alemán «de orientación "ético-metafísica", en el siglo XIX»; y 3) una etapa de «restablecimiento de la filosofía "científica" en base a la análisis lógico, en la primera mitad del siglo XX» (1958b: 48). Pero es en la segunda mitad del siglo XX cuando -a juicio de Rest- empieza a manifestarse una orientación que tiende hacia una síntesis integral, que habilita una comprensión del «ámbito íntegro de la mente humana» en un esquema coherente y completo.

Ernest Cassier, John Dewey y Alfred North Whitehead son los nombres que Rest señala en esta última orientación de la filosofía. Pero es el primero de ellos el que constituye un precursor fundamental para el desarrollo reflexivo que Langer expone en su libro. La cultura es para Cassirer -tal y como lo afirma Rest- «un proceso creador que consiste en "dar forma" a la experiencia humana, a fin de captarla, fijarla y comunicarla». Que esa experiencia sólo puede ser comprendida cabalmente «con el auxilio de símbolos que sirven de intermediarios en el proceso intelectivo» (1958b: 48), es lo que viene a iluminar el libro de Langer. Pero también viene a examinar en detalle la reestructuración antropológica que supone el hecho de que la inteligencia humana no se reduce exclusivamente a su capacidad para crear y disponer de una racionalidad discursiva, sino que debe incluir también su capacidad simbólica. 
Los símbolos que el hombre emplea para traducir y traducirse sus propias experiencias son «formas significativas» y abarcan tanto las que remiten a las secuencias discursivas como a las formas de pensamiento no discursivo. La capacidad simbólica compromete pues al arte, la religión, los rituales y las especulaciones ético-metafísicas al convertirlas también a ellas en formas significativas. Es esta articulación complementaria de las dos tendencias prerenacentistas la que efectúa la «reconciliación» que el título del ensayo de Rest anticipa. Philosophy in a New Key desarrolla una meticulosa «teoría comprensiva»y es -a juicio de Rest- «la exposición más completa del simbolismo considerado como un proceso característico de la mente humana» (1958b: 49).

La capacidad de percibir la alusión in absentia se materializa a través del elemento específico que Langer denomina «símbolo». Ya en su versión proyectiva (discursiva) o en su versión presentativa (gestáltica), el símbolo es siempre significativo. En consecuencia, tanto el arte como la religión o los rituales suponen modalidades semánticas que exigen, cada una a su vez, «leyes de "racionalidad" propias» (1958b: 50). La importante investigadora en lógica simbólica sostiene que la virtud de dicha teoría general se basa en que permite incorporar a la experiencia intelectual no sólo la razón sino también «la imaginación y los sueños, el mito y los rituales, así como la inteligencia práctica». Pero Rest no se contenta con eso y lleva más allá la teorización de Langer: sostiene que la sola admisión del pensamiento no discursivo abre la posibilidad para una 
teoría del entendimiento que culmina naturalmente en una crítica del arte» (1958b: 50).

Los efectos de estas posiciones gnoseológicas y antropológicas en el horizonte de la modernidad no son nuevos para Rest. Sus lecturas de F. R. Leavis e I. A. Richards, sobre todo en relación a las determinaciones de la práctica crítica, van en esta dirección. ${ }^{99}$ El debate entre ambos a propósito de la incumbencia de la ciencia y su relación con la práctica crítica era la base desde la cual Rest leía el libro de Langer como una reconciliación promisoria. Tanto Richards como Leavis compartían lo que Eagleton define como «una visión sombría de la civilización moderna», pero sólo el primero consideró que «una crítica y una psicología basadas en la ciencia» podrían constituir el antídoto más certero contra «los efectos más degradantes de una sociedad tecnológico-científica» (Eagleton 2012:80). Leavis, por su parte, rechazaba vehementemente en carácter totalizador y utilitarista de la civilización «tecnológico-benthamiana».

Ambos se oponían a todo sueño de especificidad absoluta y confiaban en que el arte y la literatura eran capaces de producir «efectos socialmente redentores»; pero se aferraban «por diferentes motivos a una continuidad entre el arte y la experiencia común» (Eagleton 2012:80). Para Richards, como para Valéry, la ciencia y la tecnología eran fácticamente inevitables (tanto como lo era tener que lidiar con sus consecuencias históricas). El arte y la literatura estaban, a su juicio,

99 Ver Capítulo 2. 
acorralados por la modernidad científico-técnica y reducidos cada vez más a la tarea de «suplementar sus deficiencias emocionales». Su función empezaba a ser pues «más emotiva que cognitiva», al punto que el auge de la propia emotividad estética era precisamente la ratificación de la hegemonía positivista en la trama discursiva de la sociedad moderna. En la estela de T. S. Eliot, Leavis exhibía un rechazo militante por «el monopolio positivista del conocimiento» e incluía abiertamente al arte como un modo específico de conocimiento.

Como lo muestra su tesis sobre Virginia Woolf, Rest simpatiza con este último punto de vista y reconoce en el arte una particular modalidad de experiencia perceptiva. Pero, como Richards, está convencido además de que la transformación producida por el mundo moderno sobre la experiencia humana implica irremediablemente la gestación de nuevos modos de apropiación y comprensión de los fenómenos estéticos y culturales. Si el arte y la literatura constituyen formas de experiencia de esa transformación del mundo, la práctica crítica debe necesariamente reexaminar sus propios fundamentos para ser capaz de afrontar las nuevas exigencias.

El autor de Principles of Literary Criticism había creído encontrar en el modelo científico la salida a una disciplina que languidecía en un puro efecto de expresión elegante. Rest no optaba por una adscripción tan radical, pero empezaba a confiar en el modelo de una práctica crítica sistematizada y rigurosa (una crítica que, como veremos más adelante, fuera capaz de 
enlazarse con una teoría de la comunicación) ${ }^{100}$. Defendía una crítica que realizara inferencias y propusiera conjeturas a partir de la «explicación de texto», pero siempre reconociendo y subrayando el carácter eventual de sus afirmaciones, en razón de la naturaleza plural y la ambigüedad intrínseca al lenguaje poético. Para Rest, la «explicación de texto» no fue nunca -como para Richards- esa suerte de utopía comunicativa que sueña con «transportar una experiencia mental total y completa de una mente a la otra», sino la manera en que el lector produce un sentido en una relación entre un texto y un contexto de inteligibilidad. En ese punto, la práctica crítica era claramente asumida por Rest como una «actividad creativa», en tanto debía su propio carácter ficcional a la ambigüedad que corrompe todo intento de establecer un significado para las imágenes con que se compone la experiencia literaria.

Lo que la crítica de Rest replica de la de Richards es el hecho de asumirse -ante todo y bajo cualquier concepto- «enemiga del reduccionismo y de la rigidez dogmática» (Eagleton 2012:79). Si se vuelve gradualmente rigurosa y erudita, no es sólo en función de su colocación académica, sino primordialmente por su propia convicción en la necesidad de atender a la complejidad y la flexibilidad de lo que Richards había definido como un «significado múltiple». Pero -vale la pena aclararlo- no por ello Rest piensa que el lenguaje literario carezca de significado o que lo rechace abiertamente, ni mucho menos. Al contrario: está convencido de que el significado es inestable precisamente en

100 Véase Capítulo 4. 
razón de su carácter eminentemente contextual. Ligada a la experiencia teórica de Imago Mundi, este último punto se vuelve enriquecedor a la hora de pensar su propio antichauvinismo y su abierto interés por la diversidad cultural y por la lectura comparada. Rest $-y$ es uno de los objetivos de esta tesis dar cuenta de este hecho- lee las literaturas más lejanas y los textos de las culturas más distantes sabiendo que la lectura produce siempre un sentido situado, que pone al descubierto tanto la relatividad cultural del valor como la superstición implícita en la necesaria sumisión de una literatura a una realidad nacional. Leer es -para Rest- producir una relación allí donde antes no la había; escribir la lectura es comunicar la posibilidad de vida de esa relación. La crítica restiana, en su carácter creativo y en su disposición ficcional, imprime sus enunciados políticos en un régimen deliberadamente alusivo; pero a la vez pone al descubierto la potencia política de la enunciación crítica: se pueden hacer cosas nuevas con palabras ajenas.

En este punto, es notable el hecho de que el siguiente texto importante que Rest publique en Sur sea justamente "Emotividad verbal y totalitarismo" (1958d). ${ }^{101}$ Aparecido en el número 255 a fines de 1958, y recuperado luego en 1968 como cierre a Tres autores prohibidos y otros ensayos, es un texto que responde, de manera alusiva pero notable, a la coyuntura del peronismo (en que 101 Rest, J., "Emotividad verbal y totalitarismo" (1958b), en Sur n 255,
Buenos Aires, noviembre/diciembre. pp. 14-24. 
fue concebido) ${ }^{102}$ y que funciona de manera efectiva frente a las formas de totalitarismo de la dictadura militar autodenominada "Revolución Argentina", que -encabezada por Juan Carlos Onganía-, tras derrocar en el golpe de Estado del 28 de junio del 1966 al presidente electo Arturo Illia, se alzaría en el poder hasta 1973.

Que el conciso y esclarecedor ensayo de Rest se abra con el epígrafe del Cratilo de Platón, es parte del ejercicio irónico descrito por la pregunta retórica ${ }^{103}$. El texto está íntegramente dedicado a describir la presencia y la remanencia de los signos y las operaciones lingüísticas del totalitarismo. Por ende, ratifica su propio objeto en ese singular «poder de las palabras» que el epígrafe plantea en el interrogante.

Retomando el tema fundamental del libro de Langer (reseñado en la nota previa $\left.{ }^{104}\right)$, la intervención de Rest comienza precisamente con una refutación de cualquier imagen inocente del lenguaje. Rest no niega la «función instrumental de las palabras»; al contrario: la ve especialmente confirmada en el hecho de que el lenguaje se adecúa a las «nuevas circunstancias, a medida que las condiciones sociales se transforman como consecuencia del progreso intelectual y científico (1958b: 14). Pero no duda en advertir rápidamente que el lenguaje está lejos de ser un instrumento sumiso, pese a que el hombre lo emplee como

\footnotetext{
102 El primer boceto de este texto se encuentra en un cuaderno guardado en el Archivo Rest donde hay borradores de notas aparecidas en su versión pública entre 1954 y 1957.

103 «Pero permitidme que os pregunte, ¿cuál es el poder con que cuentan las palabras?» Platón, Cratilo, 435 D.

104 Rest, J., "La 'reconciliación' de la filosofía moderna (con motivo de un libro de Sussane K. Langer)." (1958b), en Sur $\mathrm{n}^{\circ}$ 252, Buenos Aires, mayo/junio de 1958. pp. 41-51.
} 
«su servidor» y el propio desarrollo de la humanidad lo transforme y adecúe a las nuevas necesidades. Es por lo menos falaz -apunta Rest en un parágrafo de notable anticipación estructuralista- «sostener que la vida precede al lenguaje, que los cambios experimentados por la vida determinan y modifican la estructura del lenguaje» (1958b: 15), sin reconocer que la vida es, al mismo tiempo, continuamente transformada por él. El lenguaje es un instrumento en la misma medida en que lo es un arma de doble filo: «no sólo posee valor comunicativo; también cuenta con un intenso poder sugestivo, con una honda capacidad evocadora» (1958b: 15). Que las palabras signifiquen siempre algo más que lo que estrictamente dicen es precisamente la condición por la cual su poder de seducción es tan real como su peligrosidad. Tras la función semántica de las palabras se presenta muchas veces la función emotiva. Cuando ambas funciones confluyen de manera genuina en un ademán «grato y revelador», lo que se revela es el efecto poético. Pero en otras oportunidades advierte el crítico- esa doble función es empleada con otros fines, al punto de entrañar «una corrupción del pensamiento que en nuestro tiempo ha sido cultivada por los regímenes de corte totalitario» (1958b: 15) .

Que el totalitarismo pueda encarnar -y encarne efectivamenteen una determinada «técnica verbal» se explica por la fuerza intimidatoria y coercitiva del propio lenguaje que, «empleado por un demagogo o un fanático, es capaz de dominar y transformar la vida» (1958b: 16). Si se lo usa con deliberada perversión -apunta Rest- el lenguaje es capaz de infundir consecuencias nefastas, 
propiciar confusiones, generar obstáculos al pensamiento, ya sea introduciendo arbitrariedades y supersticiones o evocando «oscuros temores y atávicos prejuicios de honda fijación en nuestro ánimo» (1958b: 16).

Esta potencia evocativa del lenguaje se ratifica plenamente en la eficacia eufemística. ${ }^{105}$ Rest ve en la estrategia alusiva del eufemismo una potencia que -como la escritura entre líneas descubierta por Leo Strauss- es capaz de resistir de manera efectiva las imposiciones de la censura totalitaria, y no duda en ejemplificar el hecho haciendo referencia (alusiva) a uno de los casos locales que replican en intención, absurdo y arbitrariedad los dictámenes de carácter totalitario. La alusión irónica de Rest es a la disposición del Decreto Ley 4161 (sancionado por el gobierno de facto encabezado por los militares Pedro Eugenio Aramburu e Isaac Rojas en marzo de 1956), que en su primer artículo prohibía expresamente toda «utilización de imágenes, símbolos, signos, expresiones significativas, doctrinas, artículos y obras artísticas, [...] representativas del peronismo», e incluía una extensa lista de vocablos proscritos, entre los cuales figuraban "peronismo", "peronista", " justicialismo", "justicialista", "tercera posición", y otros. ${ }^{106}$ Rest presenta su ejemplo, en el corazón mismo de Sur, con

105 «El eufemismo -escribe Rest- consiste en no emplear el término exacto que designa a una persona, cosa o suceso, por temor de atraer lo nombrado hacia nosotros. En reemplazo del término que correspondería adoptar, se utiliza entonces un sustituto, de alusión más indirecta, moderada o decorosa» (1958b: 16).

106 El texto completo del Decreto Ley 4161 de la autodenominada "Revolución Libertadora" puede leerse online en http://www.elhistoriador.com.ar/documentos/revolucion libertadora/decreto 4 161.php. Última consulta: 16/11/12. 
diplomática ironía: «hace no mucho tiempo -apunta-, cuando se acudió a la perífrasis para soslayar el nombre de un ex gobernante, los periódicos argentinos elaboraron el eufemismo "mandatario depuesto"» (1958b: 16). Pero no fue sólo la prensa gráfica la que probó la eficacia del eufemismo en referencia al nombre de Perón. Rest señala también dos usos particulares que imprimen además un matiz burlesco: el de «mandatario indispuesto» concebido por el humorista Juan Carlos Colombres "Landrú" en las revistas Vea y Lea y Tía Vicenta, y el de «mandatario abolido» ensayado por Jorge Luis Borges en la revista Ficción. La referencia a estos dos declarados antiperonistas no es para nada casual. Rest sabe que -usado estratégica y deliberadamente- el eufemismo ocurrente deja ver tanto la ideología como los deseos del que lo produce y que, en efecto, pone en evidencia tanto una ocurrencia como una represión.

El ensayo refracta claramente que Rest viene de leer con suma atención la obra narrativa de George Orwell -otro maestro de la crítica alusiva- y de reflexionar especialmente las ideas que el escritor británico despliega en su memorable ensayo "Politics and the English Languaje" (1950). ${ }^{107}$ Como Aldous Huxley, escribe con la intención de «poner el dedo en la llaga lingüística de los graves problemas políticos que enfrenta su época» (1958b: 21). Es por ello que se detiene especialmente en los discursos movidos por un estricto interés persuasivo -incluyendo aquellos casos en que «el propio orador se persuade a sí mismo de que sus argumentos son válidos, objetivos y de buena fe» (1958b: 19).

107 Orwell, G., Shooting an Elephant, Londres, 1950. pp. 84-101. 
Señala que, en este tipo de discursos, cuanto menos concretas y claras son las apreciaciones tanto más desconfiable resulta la totalidad del argumento. No sólo porque gradualmente se vuelve más patente la intencionalidad del orador por deslumbrar al auditorio, sino porque ese «brillo superficial del discurso» sólo busca neutralizar el sentido crítico del oyente. Producido deliberadamente y atado a la mera intensión persuasiva, el discurso se vuelve demagógico.

La demagogia -escribe Rest, en un párrafo que no ha perdido un ápice de actualidad-es, en esencia, un procedimiento verbal y político. «Consiste en proclamar de manera aparentemente persuasiva que se defiende al pueblo y que se lucha contra las acechanzas de una minoría tiránica que está en el poder o que trata de encaramarse en él» (1958b: 19). Pero eso no es todo. Para hacer más efectivo su ataque contra su adversario, el demagogo emplea recursos lingüísticos específicos. La «táctica verbal» del demagogo es tan compleja como firme es su convicción en la necesidad de dividir el mundo en términos binarios. No duda pues en afirmar que «su causa es progresista, democrática, justiciera, patriótica, realista; que su aspiración es crear un orden nuevo, una nación nueva, un plan racional, una doctrina nacional» (1958b: 19) ${ }^{108}$; ni vacila en calificar a sus adversarios, «en forma indiscriminada y promiscua, de reaccionarios, rojos, oligarcas, vendepatrias o políticos viejos» (1958b: 19) ${ }^{109}$. La alusión directa a la retórica persuasiva de la

108 Cursivas en el original.

109 Cursivas en el original. 
pedagogía peronista clásica es más que evidente en este pasaje del texto. Se ven allí los signos concretos de la diatriba política en que se afirman los regímenes totalitarios que, no sólo cuenta con numerosas concentraciones populares que siguen al histrión en su ejercicio de su sermón, sino que además empieza encontrar una alianza sin precedentes en los «grandes sistemas audiovisuales de difusión, que permiten la ininterrumpida reiteración de slogans propagandísticos» (1958b: 19). Rest percibe pues que el totalitarismo político es un modo particular de pedagogía de las masas. Las dictaduras modernas se apoyan, a su juicio, en una técnica lingüística de persuasión y denigración del adversario. La demagogia, «variedad depravada del arte de injuriar», es esa técnica que busca producir y manipular estados colectivos de emotividad con fines políticos concretos.

Los ejemplos empleados por Rest a este respecto señalan aspectos específicos de la manipulación demagógica. La paradoja introducida por el término «democracia popular» es otro ejemplo de ese tipo de operaciones. De acuerdo al análisis de Rest, el evidente pleonasmo no obedece a una necesidad de «robustecer el caudal significativo» del término democracia, sino a una estrategia retórica por la cual se querría significar que se hace referencia a una "democracia auténtica", en contrapunto elíptico a lo que sea la democracia a secas. Del mismo modo, cuando el discurso demagógico apela, por ejemplo, a los adjetivos "verdadero" o "auténtico" para calificar la democracia, la libertad o la justica, lo que se busca es persuadir al pueblo de que durante años ha sido presa de los engaños de sus adversarios 
y que, en consecuencia, él nunca ha gozado realmente de los beneficios sociales que esos términos implican. En los regímenes totalitarios, el demagogo insiste en sostener incansablemente que «las libertades vigentes durante los gobiernos pretéritos no fueron libertades auténticas, que la verdadera libertad es la presente o será la futura, cuando se haya eliminado toda oposición a su régimen» (1958b: 21). De ese modo, el demagogo saca provecho del sofisma y la tergiversación verbal.

A lo largo de todo el ensayo, Rest no habla de política estricta sino de sus modalidades de intervención específica en el lenguaje. Sigue en muchos momentos las bases de esa «estilística del engaño» con que, en sus ensayos, Orwell comenzó a desenmascarar «las argucias de la mala política» y que, en sus ficciones, desnuda a través de «demoledoras parodias del lenguaje empleado por las dictaduras para confundir y doblegar el pensamiento claro y la libertad individual» (1958b: 21). Y apunta -acertadamente- que las observaciones orwellianas a propósito de «la descomposición verbal y la insensatez lógica que se advierten en los sistemas totalitarios» (1958b: 22) han sido estudiadas de manera más orgánica por el filósofo alemán Ernest Cassirer en su obra póstuma Myth of the State $(1947)^{110}$, donde hace especial hincapié en las operaciones de manipulación lingüística desarrolladas bajo el régimen nazi. Pero el interés fundamental de Rest no radica en rechazar tal o cual ideología política sino en poner en evidencia los procedimientos de naturalización a los que apela el totalitarismo.

110 Cassirer, E., El mito del Estado, México, FCE, 1947. 
Si todas las dictaduras invocan necesariamente tácticas lingüísticas de manipulación es -piensa Rest- porque su poder y perduración se apoyan «no tanto en un abierto empleo de la fuerza cuanto en un clima de fanatismo y temor que se alcanza por medio de un recurso (también) primordialmente lingüístico: la propaganda» (1958b: 22). Pero los demagogos no sólo apelan a los procedimientos de manipulación para infundir en las masas una emotividad que les es favorable; también emplean sutiles recursos lingüísticos para evitar estados de emotividad colectiva «inconvenientes para sus fines totalitarios» (1958b: 22). Un claro ejemplo de ello se da en los momentos en que los regímenes despóticos deben justificar discursiva y públicamente el uso de la violencia -ya para contener eventuales revueltas, ya para ampliar efectivamente su campo de dominio- y deben lograr hacerlo, a la vez, sin que «la masa popular llegue a identificarse con los grupos perjudicados o maltratados por el encono gubernativo». Los procedimientos lingüísticos de la voz pasiva con agente elíptico, la caracterización despersonalizada de los pacientes de la acción represiva y el empleo deliberado de un léxico vacío y abstracto cristalizan por completo la información y neutralizan toda connotación afectiva y todo efecto compasivo o empático.

Los diversos procedimientos de tergiversación verbal, «que constituyen una especie de evasión a través de la cual somos trasladados a un enrarecido mundo de conceptos abstractos y neutros» (1958b: 22), sirve a los regímenes totalitarios para auto-justificarse públicamente pero no le garantiza en modo 
alguno una eficacia plena y definitiva. «La instauración plena del totalitarismo requiere -como apunta Rest- la eliminación del pensamiento libre» (1958b: 24). En función de ese objetivo concreto dispone un conjunto de técnicas lingüisticas de manipulación articulado sobre un dispositivo propagandístico. Es por eso que entre los rasgos específicos de la técnica totalitaria no es menor el lugar y la función concreta de «la táctica lingüística que respalda sus procedimientos» (1958b: 24). Que por la razón de la insistencia la propaganda termine imponiéndose al punto de que, «por pereza mental, las masas permitan que un demagogo piense -o simule pensar- por ellas», no impide que surjan formas de resistencia. Incluso el hecho de que la propaganda demagógica consiga imponerse, exige que, en cierta medida, los pueblos se hagan también «cómplices de los tiranos en la instauración de regímenes totalitarios». Finalmente, como bien señala Rest, «el derecho a pensar no debe [ni puede] ser regulado discrecionalmente por los gobiernos; es el pueblo quien [puede y] debe hacer a diario profesión de renovar sus ansias de libertad» (1958b: 24$)$.

La siguiente intervención importante de Rest en esta época de Sur es su respuesta a la encuesta realizada por la revista de Victoria Ocampo a propósito de "El caso 'Lolita' (Encuesta)" $(1959 e)^{111}$. Encabezada por su propia directora, la encuesta se inscribe en una serie -escrupulosamente estudiada por Nora Avaro

111 Rest, J., "El caso 'Lolita' (Encuesta)" (1959e), en Sur n² 260, Buenos Aires, set/oct. pp. 66-68. 
$(2002)^{112}$ y Judith Podlubne $(2003)^{113}$ - que se concentra en discusiones en torno a la relación entre "Moral y literatura"114. Como en las ocasiones previas, en el $n^{\circ} 260$ de Sur los consultados son fundamentalmente autores, críticos y traductores afines a la revista y se expresan con relación a un hecho concreto de censura y prohibición. El tema del debate es -según apunta la propia directora de la revista- el decreto de la Municipalidad de Buenos Aires «que califica de "inmoral' la novela Lolita de Vladimir Nabokov», editada ese mismo año por la editorial sur, y que determinó su secuestro. Luego de «varios juicios de autores extranjeros sobre la obra» (Graham Green, Lionel Trilling, Alberto Moravia, Dominique Aury, Robert Kemp, Colin Wilson y Kleber Haedens), la revista publica «las declaraciones que al respecto hicieron la Sociedad Argentina de Escritores y un grupo numeroso de intelectuales». En la categoría de «intelectuales», expresaban su opinión al respecto Victoria Ocampo, Juan Adolfo Vázquez, Jorge Luis Borges, Eduardo González Lanuza, Carlos Mastronardi, Silvina Ocampo, Carmen Gándara, Ernesto Sábato, María Rosa Oliver, Alicia Jurado, Guillermo de Torre, Manuel Mujica Lainez, Carlos Viola Soto, Alicia Marta Justo, Ernesto Schóo, Luis Justo, H. A. Murena, Jaime Rest, Eduardo Mallea, Enrique Pezzoni, José Blanco Amor y Virgilio

\footnotetext{
112 Avaro, N., "Sur en debate: moral y literatura", ponencia presentada en el III Congreso Internacional de Teoría y Crítica Literaria, Rosario, Agosto de 2002 (mimeo).

113 Podlubne, J., "Moral y literatura en Sur: un debate tardío", en Boletín/11 del Centro de Estudios de Teoría y Crítica Literaria, Rosario, Diciembre de 2003. pp. 42-58.

114 Las discusiones precedentes a la que aquí hacemos referencia son "Moral y literatura" (en Sur $n^{\circ}$ 126, abril de 1945, pp. 63-84) y "Literatura gratuita y literatura comprometida" (en Sur n 138, abril de 1946, pp. 105121) .
} 
Piñera. Excede los límites específicos de este trabajo un análisis comparado de cada una de las intervenciones vertidas en este sentido. Pero interesa subrayar la intervención particular de Rest porque a través de ella empieza a madurar la conciencia de una potencia de acción intelectual apoyada en la especificidad de la formación.

La intervención de Rest sobre el "caso Lolita" se extiende apenas en tres páginas que responden con lucidez las tres deslucidas y casi retóricas preguntas formuladas por la encuesta: «1. ¿Cree Ud. que un poder político deba ejercer la facultad de censurar obras literarias? 2. ¿Cuáles son los límites y el criterio con que esa facultad debe ejercerse? 3. ¿Cree Ud. que en el caso Lolita, de Vladimir Nabokov, esa facultad ha sido ejercida con acierto?». Se trata de un puñado de párrafos precisos y cargados de erudición, en los que Rest se empeña en subrayar, no sólo la larga y desafortunada historia de la censura literaria (desde los juicios a Gustave Flaubert por Madame Bobary y a Charles Baudelaire sobre Les fleurs du Mal hasta las numerosas acusaciones de inmoralidad recaídas sobre obras de William Blake y D. H. Lawrence respectivamente) sino también el hecho concreto de que todo intento de censura «puede convertirse en un instrumento de tiranía, en un medio eficaz para menoscabar la libertad»y, en consecuencia, es justamente la coerción que entraña la censura la que debe tenerse por «la mayor de las inmoralidades» (1959e: 66).

Con relación estricta a la pornografía (una de las falaces acusaciones recaídas sobre la obra de Nabokov), Rest apunta que 
sólo pueden ser definidas como tales aquellas obras cuyo «objeto manifiesto» sea «estimular pensamientos o deseos lascivos». Pero exceptúa puntualmente aquellas experiencias estéticas que emplean los elementos sexuales, no con fines meramente obscenos, sino ligados a un «valor estético formal (como el desnudo pictórico o escultórico) o una significación humana (como a menudo suele advertirse en la literatura)» (1959e: 67). Sin embargo, no por ello la literatura no queda absolutamente exenta a la perversión. Citando las investigaciones de George Orwell, Alex Comfort y Richard Hoggart, Rest señala la presencia de una «subliteratura» que combina «sexualidad y violencia» y cuyo objeto es «obtener un clima de sadismo que sirva de evasión o de sucedáneo vital para las masas de población sedentaria que vegetan en las oficinas o fábricas de los grandes núcleos urbanos». Pero no demora en afirmar que tal subliteratura es «un flujo de obras perecederas que carecen de individualidad y que sin cesar se suceden unas a otras»y que, por ello mismo, «ni el más complejo mecanismo de censura bastaría para ponerles un dique» (1959e: 67) .

Lo que Rest percibe tras esa «masa anónima y amorfa», que «debe ser combatida», no es -claro está- un propósito estético, sino más bien un emprendimiento con estrictos fines comerciales. Es una literatura dirigida a los «sectores menos avisados»y eso es lo que la hace todavía más «perniciosa»: en tanto busca «halagar la procacidad imaginativa de quienes conservan la ingenuidad de la juventud o de la escasa ilustración»y «pretende adular los apetitos de las grandes masas de población», «Configura una forma de demagogia» (1959e: 67). En tal sentido, 
más que avalar o rechazar cualquier intento de prohibición o censura de textos, el fundamento de un cambio concreto supone, para Rest, atacar el problema desde sus raíces, en los fundamentos estructurales de la sociedad misma, y contribuir a «mejorar el nivel cultural de los más vastos grupos de ciudadanos» (1959e: 67) .

De manera elusiva e incisiva, Rest parece rechazar uno a uno los términos mismos del cuestionario planteado desde la revista dirigida por Victoria Ocampo. Desplaza el eje del debate hacia los temas que más repercuten en sus interese de investigación. Finalmente, ni se opone ni apoya la censura. Con astucia sutil, considerando la extensa lista de errores cometidos en el pasado, plantea que la de la censura o no de una producción estética o cultural es una cuestión cuyo debate sólo puede ser considerada al interior de un espacio especificado por una burocracia técnica calificada con probidad (historiadores, filólogos y críticos literarios) y que, bajo ningún sentido, su proposición o su decisión debe ser facultad de otros poderes. Respondiendo sin responder (siendo incluso indirecto al contestar la primera pregunta del cuestionario: "¿Cree Ud. que un poder político debe ejercer la facultad de censurar obras literarias?"), Rest pone en evidencia la impropiedad del interrogatorio surgido por el atropello de un decreto de la Municipalidad de Buenos Aires que, tras declarar la «inmoralidad» de Lolita, determinó su inmediata salida de circulación y el secuestro de los ejemplares distribuidos en librerías. Indirectamente, sin darle y sin quitarle la razón a la censura, Rest desautoriza al poder 
político en su intervención y descompone la legitimidad de la discusión. Lo que se corrobora en ese movimiento es pues un intento de poner límites al Poder (represivo) desde el poder (productivo) de la especificidad. De ese modo, se neutraliza la legitimidad de una decisión que solapa su arrogancia y que naturaliza su incumbencia bajo la superstición de una "defensa de la moral pública". Bajo la cobertura de una cuestión que concernía a todo el mundo (porque lo ilegítimo de la decisión era estricta y fundamentalmente su agente), el crítico hace funcionar y pesar su posición específica en el orden del saber, para dejar en evidencia la impropiedad de lo actuado desde el Poder.

A fines de 1957 la editorial sur publica, por primera vez en lengua hispana -en traducción de Héctor Vaccaro-, a otro de los referentes teóricos importantes de Rest. La edición de Literatura y sociedad del catedrático estadounidense Edmund Wilson coincide con el momento más intenso de las lecturas políticas del joven crítico. Es por esa época que estudia los principios del socialismo democrático, cuyo sentido reformista no duda en elogiar. Simpatiza con los fundamentos históricos que impulsaba la "Sociedad Fabiana" fundada hacia 1884 en Londres, el movimiento socialista conocido por constituir los cimientos y la trayectoria del socialismo moderno inglés encarnado por el Partido Laborista británico. Hacia 1960, a la luz de This little band of prophets: The British Fabians de Anne Jackson 
Fremantle ${ }^{115}$, lee los folletos The True Radical Programme (1887) y Socialism for Millionaires (1901) de Bernard Shaw y se siente interpelado por el contenido subyacente a ficciones científicas de Herbert George Wells como The Time Machine (1895). Su ideal político es difícil de determinar, pero se inclina cada vez más hacia el modelo de una democracia social, basada en la tolerancia liberal y el reformismo práctico y progresista. En ese contexto, la función crítica e intelectual se supone específica pero a la vez política. Remite a una suerte de elite que trabaja y toma decisiones sobre un espacio específico del saber moderno que repercute socialmente porque su tarea es la de iluminar el sentido histórico de los textos literarios. En la lectura de Literatura y sociedad -donde Wilson estudia con detenimiento el sentido de la política en Flaubert, las contradicciones ideológicas entre praxis política y praxis literaria en Shaw; y especialmente las relaciones entre "marxismo y literatura" y "la interpretación histórica de la literatura"- Rest afianza su convicción en la necesidad de leer los textos literario con rigor científico y comprensión humanista, pero también ratifica su intención de leer la producción literaria poniendo especial atención a la relación (íntima pero no determinista) entre literatura y sociedad, esto es, contemplando en su interpretación aspectos sociales, económicos y políticos.

La función intelectual se define pues, para Rest, en una línea de desmitificación cada vez más pronunciada. En ese

115 Fremantle Jackson, A., This little band of prophets: The British Fabians, New American Library, 1960. 
sentido, sus referencias a los trabajos de Orwell, Hoggart y Raymond Williams se articulan con la serie de trabajos que exponen la estrategias discursivas del totalitarismo. Como Wilson, Rest asume su función específica convencido de que la actividad intelectual «en cualquier campo en que se desarrolle, es un intento por dar significado a nuestra experiencia -es decir, de hacer más practicable la vida- pues entendiendo las cosas nos es más fácil subsistir y circular entre ellas» (Wilson 1957: 216) $)^{116}$.

Ni el modelo de una crítica rigurosa, ni la comprensión humanista, ni -menos aún- la perspectiva crítica cada vez más orientada al culturalismo se articulan fácilmente en el programa de Sur. El carácter hegemónico en el espacio de la cultura letrada del que gozaba la revista de Ocampo empieza a declinar hacia los '60 y esa declinación pronunciada tiene por causas evidentes -tal y como lo afirma Podlubne-, no solamente «el natural envejecimiento biológico de sus miembros y colaboradores históricos», sino en especial «el envejecimiento social del programa intelectual de la revista» (Podlubne 2012: 48) ${ }^{117}$. Las dificultades concretas para enfrentar, tanto las profundas transformaciones sociales suscitadas en la segunda mitad del siglo XX, como los efectos culturales de dichas transformaciones, hicieron que la revista perdiera gradualmente influencia en el campo cultural. Que, como respuesta a ese paulatino declive, la

\footnotetext{
116 Wilson, E., Literatura y sociedad, Buenos Aires, Sur, 1948.

117 Podlubne, J., "Sur en los 60. Hacia una nueva sensibilidad crítica", en Badebec. Revista del Centro de Estudios de Teoría y Crítica Literaria, $\mathrm{N}^{\circ}$ 2, marzo de 2012 . On-line en: http://www.badebec.org/badebec_2/sitio/pdf/Podlubne.pdf
} 
revista apelase al éxito obtenido en su primera década de existencia (Gramuglio 2010: 202), aferrándose y defendiendo en términos generales los valores morales y el estilo de intervención de la llamada "Crítica Tradicional", no fue menos perjudicial. En términos generales -y concediendo a Podlubne el reconocimiento de ciertas «tracciones que agitan la publicación» (2012)- se puede afirmar con Oscar Terán que «mientras [la crítica literaria] se torna paulatinamente más profesional -y sobre la cual pronto han de influir las propuestas estructuralistas-, Sur permanece atenida básicamente a un estilo tradicional de abordaje del hecho literario» (Terán 1991: 87). Lo que en ella se publica como "crítica" carecía de repercusión real porque, en rigor, y a juicio de Nicolás Rosa, mayormente se trata de una maquillada variante del comentario. Salvo honrosas excepciones (entre las que se pueden subrayar las intervenciones sutiles de José Bianco, la precisión erudita de Ángel Batistessa, la consistencia filológica de María Rosa Lida de Malkiel, la lucidez repentina de Daniel Devoto y el delicado textualismo de Enrique Pezzoni), se trataba -como apunta Rosa- de una crítica de fachada, que se erige en tautologización de la obra (a la que mistifica sacralizándola), que presupone al crítico como un lector privilegiado por una suerte de don o especial percepción estética que le permite hacer las veces de «catalizador de sentido, donde se recomponen en medidas arbitrarias el gusto, el refinamiento y la solvencia de una ecuanimidad "naturales"» (Rosa 1971:6) ${ }^{118}$. Lo que la exégesis del texto sacralizado realiza no es

118 Rosa, N., "Sur o el espíritu y la letra", Los Libros, 15/16 (1971): 4-6. 
en ningún punto un cuestionamiento; sino fundamentalmente una traducción y, finalmente, acaba por reducir toda la verdad de la obra a «su inaccesible misterio» (Rosa 1971:6).

Pero no sólo bajo los pretendidos y muchas veces logrados "volados victorianos" -caros, como diría Viñas, a una aristocracia de le bon goût- la crítica tradicional tratará de solapar su incapacidad teórica y metodológica para afrontar los hechos culturales de una sociedad en plena transformación. En términos de contenido, optará también por borrar gradualmente todo lastre y toda referencia política y social en sus interpretaciones, a fin de aminorar la condición problemática. Que semejante modelo "crítico" se apoye retóricamente en una "libertad" mistificada (porque sólo existe como abstracción), sólo ratifica lo solapado de su operación ideológica: en este sentido, la adhesión encomiosa a una militancia de "flexibilidad" -so pretexto de una supuesta "amplitud de espíritu"- no es menos sintomática que su reticencia corporativa a adoptar "esquemas teóricos" bajo el mitificado argumento de que así es más factible «abarcar mejor toda la "riqueza" de la literatura» (Rosa 1971:6).

CUATRO HIPÓTESIS DE LA CULTURA

Es claro que, ya por estos años, los intereses de Rest y los de Sur van por caminos diferentes. Casi no llama la atención pues que su presencia en la revista sea cada vez más esporádica y más circunstancial en la década siguiente. Sin embargo, tardíamente, 
en junio de 1960, aparece Cuatro hipótesis de la Argentina, que ve la luz en Bahía Blanca, publicado por la Universidad Nacional del Sur, a instancias de su rector interventor Vicente Fatone y el escritor oriundo de esa ciudad Eduardo Mallea. ${ }^{119}$

Escrito durante los años inmediatamente posteriores al Golpe de Estado del '55, es el primer texto de largo aliento publicado por Rest de manera independiente $y$, como tal, resulta sin dudas significativo a la hora de evaluar los antecedentes de su proyecto crítico intelectual. Ante todo, cabe que señalar que se trata a primera vista $-y$ en consideración de su subtítulo explicativo ("Reflexiones sobre la interpretación de nuestra realidad en la Argentina")- de un pronunciamiento y una toma de posición en una "batalla cultural" que lo preexiste y a la que, considerando la fecha de aparición del texto, casi asiste a la manera de lánguido estertor. Rest se presenta en sociedad con estos cuatro ensayos que suponen, desde la primera página, una colocación concreta en la puja que a comienzos de la década del '50 se libraba entre la "Critica tradicional" (con sede en la revista Sur y el suplemento cultural del diario La Nación) y la "nueva crítica" que, bajo el influjo de un existencialismo sartreano con clara ascendencia marxista, empezaba a legitimarse desde Contorno.

Rest polemiza elíptica pero notoriamente con los contornistas. Su trabajo es estrictamente contra-parricida. Recupera a Sarmiento, al que los contornistas marginan en función

119 Rest, J., Cuatro hipótesis de la Argentina, Bahía Blanca: Cuadernos de Extensión Cultural - Universidad Nacional del Sur, 1960. En adelante se cita la presente edición con el número de página entre corchetes en el cuerpo del texto. 
de una reivindicación progresista de Alberdi; retoma a Mallea, a quien Contorno transforma en cabeza de turco de todas sus críticas ideológicas a lo más rancio de la "crítica tradicional", a Martínez Estrada, a quien el grupo liderado por los hermanos Viñas critica con dureza al punto de dedicarle un número especial de la revista, y a Julio Mafud, como heredero de una articulación posible de estos tres momentos específicos del ensayo de interpretación nacional.

En el Facundo Rest reconoce un libro crucial. No sólo por su voluntad de «examinar los conflictos suscitados a causa de nuestro advenimiento como nación independiente» y proponer soluciones eventuales a partir de «la interpretación de la realidad social del país»; sino porque, siendo la primera gran hipótesis de interpretación del «ser nacional», «trata de explicar las discordias intestinas apelando a una hipótesis mediante la cual pretende definir la fisonomía de nuestra sociedad» (1960: 3). Pero en Sarmiento lo que ve es un precursor. No sólo porque casi una veintena de años antes de la aparición de la Histoire de la littérature anglaise de Hippolyte Adolphe Taine, el examen que propone en Facundo se adelanta en materia de análisis social a los conceptos básicos que habría de proponer este investigador francés; sino porque su proyecto de «revelar el carácter dominante de la sociedad argentina» -eso que en Taine no dudaría en llamar la faculté mâ̂tresse-, y de hacerlo precisamente «mediante un estudio general de las fuerzas que incidieron en su constitución: el ámbito físico, los caracteres humanos, las manifestaciones gregarias elementales y su 
incidencia en la vida política y social, la situación coetánea», constituye el punto de partida inexcusable de los sucesivos intentos de «interpretación de la realidad nacional» argentina.

Rest no duda en explicar y justificar el «ánimo polémico» del trabajo a partir de sus propias condiciones de producción. Si Facundo es «el libro de un hombre totalmente comprometido en la turbulenta situación que juzgaba», y no el intento de establecer la eficacia de «una metodología mediante el ejemplo práctico», su valor se potencia por constituir un denodado esfuerzo por comprender «un vasto y angustioso proceso social», y de establecer los términos de su explicación «con urgencia de una manera simple, inteligible, desprovista de las múltiples contradicciones que era inevitable hallar en semejante objeto de estudio» (1960: 5). Signado por la necesidad -justifica Rest-, Sarmiento se vio obligado a «reducir las complejidades y de concentrar la totalidad de su indagación y de su argumentación en una fórmula clara, evidente, a la vez comprensiva y comprensible». Su objetivo era enunciar una teoría, no avanzar hacia una demostración. Y esa teoría no podía evitar traducir a su vez, singularmente, el desconcierto que el propio sarmiento sentía, «al igual que sus contemporáneos cultos», ante el curso de una historia cuya comprensión requería seguramente más tiempo que el que tenía a su mano.

Que el propio Sarmiento tuviera plena conciencia de la precariedad y de la simplificación que entrañaba su intervención (a la que él mismo definiría como «un trabajo hecho de prisa») ratifica, para Rest, el valor de su sentido histórico. Es por eso 
que su comprensión genuina exige «un análisis de su ubicación en la época y en las circunstancias que vivió» así como también de «la proyección que su pensamiento ha tenido en el desarrollo de nuestras ideas» (1960: 6).

El análisis de Rest se liga a una serie de interrogantes entre los que es preciso subrayar especialmente dos: el primero, se atiene a la hipotética posibilidad de que «la aptitud de Sarmiento responda a una constante del pensamiento argentino reflejado en nuestra literatura; es decir, la búsqueda de definición», como si esta fuere la «peculiaridad permanente de nuestra literatura»; el segundo, se circunscribe a la posibilidad de que «la búsqueda de definición se ha observado en el pensamiento argentino de los años recientes», y comporta acaso «una respuesta a los mismos estímulos que obraron en Sarmiento» $(1960: 6)$.

Es claro que el análisis de Rest convoca y dialoga -de manera alusiva pero concreta- con la compleja experiencia del fenómeno peronista. Lee la situación de Sarmiento en una encrucijada histórica de una nación dividida, «a mitad del camino entre la Asociación de Mayo y la caída de Rosas», cuando una sucesión de intentos progresistas se ha malogrado en la aventura de imponer un proyecto político liberal como organización definitiva. Un país dividido en dos fuerzas opuestas e irreconciliables: de un lado, las «minorías ilustradas» de procedencia urbana, «que proponían un régimen centralizador que favoreciese una conversión liberal, orgánica, destinada a promover el adelanto de las instituciones y el desarrollo de las inexploradas riquezas 
materiales y espirituales del país»; del otro lado, los «grupos populares» de origen rural, «que habían permanecido hasta la madurez en pequeñas comunidades aisladas en medio de la campaña y que, por consiguiente, respondían a una concepción política tradicional, autoritaria y autónoma». Un país que se dirime entre un sector que -con un criterio «positivo, previsor» e «inspirado por una honda fe patriótica en el porvenir de la nación»- aspira «a la libertad civil sometida a fórmulas ya experimentadas en otros países»; y otro que -en tanto «elemento negativo»- «retrasó el desenvolvimiento cultural y social», «entregó el poder a caudillos con frecuencia iletrados» y «provocó un manifiesto retroceso en la marcha de nuestro fortalecimiento económico» (1960: 11). Esta imagen de un país desdoblado replica con bastante precisión la que sobre el peronismo se hacían por entonces las capas liberales. Sin demasiados rodeos, el propio Rest asume, presuroso, su abierta solidaridad con este sector: «la perspectiva histórica -declara- nos pone de parte de las minorías ilustradas» (1960: 11), precisamente porque «representa, para nuestro juicio, el porvenir en la Argentina: sólo la fe liberal que las inspiraba pudo ser capaz de construir un país, extrayéndolo del desierto, la adversidad y el olvido» (1960: 12). Que este grupo cometiera la «imprudencia irreparable» de pretender implantar «esquemas políticos sumamente adelantados, plenamente democráticos y respetuosos de la libertad individual», sin adaptarlos previamente a la «tendencia naturalmente federalista» (justificada en una superstición telúrica que superponía «extensión territorial» y «aislamiento mutuo» de los 
habitantes), hizo que finalmente la «inspiración unitaria y centralizadora» acabara por frustrar todo intento de organización nacional.

Rest no duda en subrayar la insuficiencia de la buena voluntad cuando se trata de política. Rompe con todo voluntarismo y con toda mixtificación al aclarar que, «por más que semejante observación desagrade a nuestro espíritu liberal», para evitar cualquier pecado de ingenuidad es preciso reconocer que «la política es la teoría de lo perfecto y la práctica de lo posible», por lo menos en lo que atañe al ordenamiento social. Rest actualiza sintomáticamente el enunciado de Maquiavelo en relación a su propio contexto cuando apunta que esta «verdad que obstinadamente nos negamos a reconocer», es la que tampoco «quisieron aceptar los fundadores de nuestra nacionalidad» (1960: 12). En ese no reconocimiento del carácter estratégico de la política Rest centra el estancamiento conflictivo de una situación histórica: de un lado, las fuerzas inorgánicas pero dinámicas «expresaban en la acción su voluntad de autonomía y autocracia» y «constituían un retrógrado que era incapaz de agrupar su ideario en una concepción coherente, pero respondían a una realidad que no podía ser ignorada»; del otro, «los núcleos doctrinarios a quienes la ortodoxia teórica impedía no sólo comprender, sino -inclusive- tomar en cuenta el motivo que justificaba la existencia de sus oponentes». Este diagnóstico de una sociedad dividida en compartimientos estancos, cada uno de los cuales se atribuía a sí mismo la única concepción nacional que era auténtica y razonable $-\mathrm{y}$, por consiguiente, consideraba 
imprescindible excluir totalmente de la vida política a sus adversarios- se parece bastante a los que desde Contorno se planteaban en la revisión de la etapa peronista; sobre todo la perspectiva de Oscar Masotta quien -retomando a Sartre- no dudaba en usar la paradoja para definir los límites de cada una de las perspectivas: unos equivocados en su manera de tener razón, otros tenían razón en su manera de estar equivocados. ${ }^{120}$

La reticencia a comprender la situación del otro empujaba el conflicto de los sectores no a la división en dos bandos sino, lisa y llanamente, a la existencia de «dos Argentinas que mutuamente se excluían». Rest lee pues al Facundo como un intento por enfrentar el problema, tratando de hallar «una fórmula que explique la división» y que establezca las condiciones de «un reencuentro nacional». Como en la lectura de Langer, la conciliación no es forzadamente sintética sino ligada en una comprensión que sólo es posible en la tolerancia de la diferencia y en el reconocimiento de una complementariedad enriquecedora. Es por eso que Rest plantea el acierto fundamental de Sarmiento en su lucidez para «admitir los dos elementos de la disyuntiva en un pie de igualdad»; pero subraya el error del escritor sanjuanino en la elección de los vocablos escogidos para describir las dos fuerzas. "Civilización" y "Barbarie" quizá no fueran los términos más felices o convenientes «para implicar contenidos tan intrincados», puesto que se ofrecen a una discriminación simplista de la que el mismo Sarmiento no puede exentarse. Como

120 Cfr. Masotta, O., "Sur o el antiperonismo colonialista", Contorno, 7 /8, Julio de 1956. 
bien apunta Rest, «la "civilización" -denominación que abarca las tendencias liberales y progresistas de las ilustradas minorías urbanas- sin demoras adquirió un valor favorable: era la posibilidad fecunda, el porvenir estable»; mientras que «la "barbarie" -designación identificada con la irrupción autocrática, federalista y escasamente instruida de las masas populares-» tomó rápidamente un matiz peyorativo: remitía al estancamiento y la disolución (1960: 14). La incomprensión y el menosprecio de esta última fuerza -que para Sarmiento «poseía raíces que penetraban mucho más profundamente en la tierra de lo que podían inferirse»- eran las que terminaban por boicotear una y otra vez el diagnóstico de nuestra dicotomía político-social. Es por eso que Sarmiento sabía que la definición del conflicto era urgente a riesgo de incurrir en cierto previsible esquematismo, sobre todo en una mirada fuertemente comprometida con la causa de la minoría ilustrada que combatía la barbarie, para la cual ella configuraba una suerte de «dolencia cultural» que debía ser combatida «por medios pacíficos, con el auxilio de una política educativa adecuada». Pero, sin embargo -tal y como lo señala Rest-, no llegó a percibir el desacierto terminológico ya que el vocablo "barbarie" resultaba por lo menos inapropiado y menospreciativo, cuando en realidad «pretendía englobar manifestaciones reales de la vida nacional, por más que fuesen aristocráticas, insulares, inorgánicas e iletradas» (1960: 16).

Sarmiento es -a juicio de Rest- un «cabal exponente de la minoría ilustrada que se expatrió durante la tiranía de Rosas», pero es también y fundamentalmente una superación de esa misma 
minoría en tanto consiguió superar «la inercia del grupo». Fue el primero en hacer suya la máxima maquiaveliana de que la política es la teoría de lo perfecto pero, a la vez, la práctica de lo posible. En principio porque, en lugar de «limitarse meramente a propiciar regímenes ideales sin considerar su validez práctica tal como había hecho la orientación liberal desde la emancipación hasta bien avanzada la tiranía-», consiguió dar «un paso decisivo» en la superación del conflicto haciendo foco en «el significado estructural» de la vida política nacional y en «los hechos concretos que habían precipitado la confrontación de dos bandos». Comprender cabalmente la naturaleza de ese enfrentamiento implicaba poner en evidencia que, «al reclamar mutuamente su validez única y exclusiva», en cada uno de esos bandos se traducía la presencia de «dos tendencias igualmente representativas de modalidades ideológicas cuya vigencia efectiva en nuestro desenvolvimiento como nación parece poco menos que incontestable» (1960: 16). El hecho de que la interpretación de la "barbarie" que se ofrece en Facundo incurra en algunas confusiones que distorsionan la perspectiva, no impugna empero su valor específico.

Lo que sí subraya Rest en Sarmiento con especial atención es el reduccionismo sobre el cual se funda la homología QuirogaRosas como «exponentes de la incultura autocrática», enfrentados apenas como «figuras intercambiables» -sólo distinguibles en virtud del «egoísmo con que cada una desea alcanzar el dominio absoluto de los despiadados instrumentos mediante los cuales es posible adueñarse de un poder sin restricciones» (1960: 17). 
Sobre este punto -y no casualmente- Rest cita explícitamente la lectura de Sarmiento producida por Ezequiel Martínez Estrada, autor cuya polémica interpretación del fenómeno peronista -en una clave que se asemeja notablemente a la que Rest evalúa como posible a partir de Sarmiento- le mereciera un distanciamiento irreparable del ala más marcadamente liberal de Sur: el falso federalismo de Juan Manuel de Rosas -dispuesto táctica y demagógicamente como mediación para establecer y perpetuar un poder despótico que tenía a la tiranía como un fin en sí mismo-, no podía impugnar la existencia real y auténtica de las fuerzas populares que encarnaban en el poder efectivo de Facundo Quiroga y que reaparecerían nuevamente ratificadas en el espíritu mismo del Martín Fierro.

En la perspectiva restiana, si Facundo configura «un aporte perdurable a nuestra literatura», lo es en tanto «documento social». Pero también, en su «aguda penetración»-capaz de sintetizar la realidad de nuestros conflictos y la formación de nuestras instituciones- constituye un antecedente irrenunciable a la hora de evaluar los posteriores ensayos de interpretación nacional.

En su intento por probar que la abierta por sarmiento es una constante del pensamiento argentino en su permanente intento por dar una definición de nuestra realidad, Rest recala en los primeros trabajos de Eduardo Mallea. La elección no es casual: el autor de Historia de una pasión argentina -escribe Rest- «está vinculado a Sarmiento por lazos de parentesco y de admiración, y su trayectoria literaria se caracteriza por una prolongada 
búsqueda de la realidad argentina» (1960: 18) y, desde su conferencia titulada Conocimiento y expresión de la Argentina de 1934 en adelante, «prácticamente toda su producción crítica e imaginativa ha renovado sin cesar su inquietud por el destino actual de nuestra sociedad» (1960: 19).

El concepto básico que Rest percibe en el pensamiento de Mallea es la noción de "patriciado". En la órbita de la obra de Mallea el término designa a un «sector humano, frecuente pero no necesariamente identificado con una clase social añeja y descollante, que tiene por "misión" guiar el país por un sendero de autenticidad y de rectitud» (1960: 19). Semejante designación, se presta -como bien apunta Rest- a varias y justificadas suspicacias. No sólo porque alude a un sector aristocratizante «que domina las esferas económica y cultural de una comunidad»; sino porque además implica una idea de sociedad que, si bien no necesariamente debe estar sometida a un régimen nobiliario, «no obstante se caracteriza por una rígida estratificación de clases sociales». Rest reconoce claramente que, en una concepción del mundo que deposita en el predominio del "patriciado" la guía y la conducción moral y política de un país, asoma una ideología elitista -como la enunciada por Vilfredo Pareto en su Sociología Generale, o como la que se desprende de las Notes towards the definition of cultura de T. S. Eliot- que no está lejos de la que «en Italia recogió el fascismo durante su permanencia en el poder» (1960: 20). Sin embargo, ateniéndose a «la equidad del juicio», se apresura a afirmar que sería erróneo calificar de fascista a Mallea, en especial porque -pese a que hay en su obra 
momentos de briosa «exaltación de la nacionalidad» (que no le impiden reconocer la «profunda crisis» en que se encuentra el país)- su definición ideológica difiere de la del fascismo pero se revela «conservadora», cuando no directamente reaccionaria.

A lo largo de sus trabajos, Mallea plantea -según Rest- la necesaria recomposición de la matriz moral de la nación a partir de su propia clase. El problema del país es el problema de la clase: el «patriciado tradicional», constituido por las familias e abolengo, atraviesa un hondo proceso disgregatorio y se encuentra en una etapa de declinación, que factores diversos y difíciles de ponderar hayan precipitado el relajamiento de sus virtudes y favorecido la desintegración de sus cualidades morales. Ese es el asunto que se reitera en casi toda la novelística de Mallea, pero que está expuesto hasta la transparencia en Fiesta en noviembre -aparecida el año siguiente al reconocido «fraude patriótico» con que Agustín Pedro Justo le cediera la presidencia del país a Roberto Marcelino Ortiz, en los años de corrupción, hostigamiento y represión popular que la historia denominaría la "Década Infame".

La corrupción de la clase patricia aparece pues, en Mallea, homologada a la corrupción de la nación. Pero eso no es todo. Como bien apunta Rest, esto no se traduce en una mirada pesimista: en la obra de Mallea la dolencia se torna notablemente manifiesta en razón de que es contemplada por alguien a quien no le aqueja el mal: «un observador que posee la pureza necesaria para poder contemplar la marcha» (1960: 20). Que esos observadores aparezcan muchas veces «identificados en algunos 
ensayos con el escritor mismo», sería el síntoma de que -al interior de esa clase angustiada- hay ciertos espíritus que mantienen la esperanza: son aquellos que «se sienten desgarrados pero conservan la fe y creen que aún es posible restablecer los valores auténticos de nuestra sociedad». La restauración anhelada por Mallea se apoya, en fin, tanto en esos pocos «espíritus patricios y puros» como en aquellos que, «sea cual fuere su origen y su condición social, sientan y vivan en consonancia con un ideario de dignidad, de genuina hombría, de fecunda feminidad» (1960: 21)

Rest subraya con especial atención que -de manera análoga a lo que ocurre en el Facundo- Mallea se basa en «una interpretación dicotómica». La dicotomía en la que recala Mallea diferencia una "Argentina Visible" y una "Argentina Invisible". El nudo teórico de esa división aparece desarrollado en Historia de una pasión argentina, de $1936^{121}$. El libro de Mallea se diferencia de Facundo en que el orden de problemas que reconoce es estrictamente moral, y no atañen «a la contextura antropogeográfica o institucional» (1960: 21) del país. Por otra parte $-y$ contrariamente a lo que registra Sarmiento-, en la perspectiva de Mallea, «una apariencia de estabilidad social y de continuidad política» no llega a cubrir por completo «un malestar un tanto inexplicable», que se presenta en la conciencia más que como un aspecto del mundo circundante. Es por eso que el método que lo caracteriza no es «objetivo y casi científico» como el sarmientino; sino, más bien, «subjetivo y autobiográfico». Y -

${ }^{121}$ Mallea, E., Historia de una pasión argentina, Buenos Aires, Sur, 1936. 
puesto que «su testimonio no está destinado a fundamentar la acción sino que es solamente un examen íntimo, el enunciado de una pasión» (1960: 21)- los temas que entreteje «con fervor y capacidad evocativa» en su reflexión se traducen afectivamente en su propia subjetividad en tres nodos recurrentes: la mujer, la ciudad y la soledad.

La "Argentina Visible" representa -en la perspectiva de Mallea- «un conjunto de apariencias» (una superficie deslumbrante pero sin profundidad) y se traduce como un «conjunto de formas y de luces, de figuras humanas y de vehículos, de dinamismo y de euforia -verdadera o simulada-», es decir, como «una realidad seductora, una suerte de canto de sirena que trae y captura a los hombres que no poseen la voluntad necesaria para descender hasta estratos más íntimos y meditativos» (1960: 23). La "Argentina Invisible" es, por el contrario, en la interpretación de Rest, «la vigilia pensativa en las horas de la madrugada», «la transformación de las visiones diurnas en el alimento de la quieta reflexión nocturna, cuando todo permanece en calma salvo la angustia, el sufrimiento»; «es "la tierra auténtica, la tierra profunda y su hombre" es el trabajo anónimo y sin codicia», «el "descontento creador" en busca de una superación que no aspira a recompensas» (1960: 23). Esta última Argentina no es perceptible al sentido de un observador cualquiera. Sólo el que está empapado en los valores y en la moral del patriciado puede percibir su presencia -y es probable que ajeno a esa sensibilidad la tome por «inexistente en razón de que se ha multiplicado el deseo de figuración, la exterioridad, coincidente con el gradual 
desenvolvimiento material de nuestra realidad superficial» (1960: 23).

Que la dicotomía que percibe Mallea pueda ser poco exacta, sobradamente lírica o excesivamente personal y evasiva -y, por ende, irreductible a la terminología estricta y científica del sociólogo- no impugna su valor. Aun cuando en ella entrañe -como apunta Rest- más «una catadura moral» que «una distribución geográfica», obliga no obstante a reconocer «ciertas coordenadas telúricas, originadas en el encontrado ritmo de la vida rural y urbana»: la Argentina visible -la que no nos deja ver nuestro verdadero arraigo en la Argentina Invisible- es un espejismo citadino: el carácter cosmopolita de la ciudad produce «evasiones inauténticas, facilidades técnicas, sujeciones a un temporalismo del reloj que es indiferente a la periodicidad de la naturaleza»; mientras que «en la campaña perdura el contacto directo con la tierra, la conservación continuada de las tradiciones, la estabilidad duradera de un orden moral» (1960: 24). Frente a la ciudad tomada por las «masas inmigratorias de hombres distantes que han podido ingresar en el país»-pero que o bien «permanecen insensibles a la realidad que nos circunda» o bien han sido víctimas de «la negligencia de la "Argentina Visible" que hizo caso omiso de sus deseos de arraigamiento»-, Mallea opta por el ámbito rural. Esta inversión de la naturaleza de la dicotomía sarmientina es un signo particular de una misma ideología operando en relación a la coyuntura histórica que la determina: «abandonar la ciudad y trasladarse al interior -escribe Rest con cierto dejo de ironía- es también aquí el símbolo de un repliegue 
hacia las moradas más auténticas del alma» (1960: 24).

Rest emplea la caracterización de la obra de Mallea que realiza Patrick Dudgeon para dar cuenta de que, en su novelística, lo que prevalece es «un significativo testimonio de las zozobras morales del hombre contemporáneo» y una propuesta de resolución a la que pueden hacérsele objeciones ciertas de evasión o «enclaustramiento en una suerte de "torre de marfil"» (1960: 25). Esas objeciones -escribe Rest- provienen en gran medida de la «generación más joven», surgida hacia 1955, que no ha vacilado en enjuiciar severamente a Mallea. Rest habla de un modo distante de esos autores con los que ha compartido las páginas de Centro, como si buscara -desde su mirada equilibrada, tolerante y mesurada- tomar distancia de su propia generación. Tal voluntad de distanciamiento respecto de la generación a la que el uruguayo Emir Rodríguez Monegal bautizó como la de "Los parricidas"122 -y que Horacio González no vaciló en calificar como "Generación del '55"123 en función de una cesura histórica precisa-, se verifica tanto por la posición indulgente que el joven Rest asume respecto de la obra de Mallea, cuanto por su incapacidad para rebatir las argumentaciones vertidas por David Viñas y León Rozitchner a propósito de la novelística del director del suplemento cultural de La Nación. Rest replica la posición paternalista de los "altos nombres" de los grupos hegemónicos de la cultura -a los que Contorno ha juzgado por su traición- al negarse a sostener un debate intelectual que los

122 Cfr. Rodriguez Monegal, E., El juicio de los parricidas. La nueva generación argentina y sus maestros, Buenos Aires: Deucalión, 1956.

123 Cfr. Horacio González, Retórica y locura. Para una teoría de la cultura argentina, Buenos Aires: Colihue, 2002. 
comprometiera políticamente. Se pone en la vereda opuesta a los "jóvenes" (que tienen exactamente su misma edad) y -no pudiendo rebatir los argumentos de la crítica ideológica desatada por los contornistas- sostiene que el conflicto entre Mallea y esta joven generación «no deriva tanto de la ideología cuanto de la cronología». Reduce el sentido de la crítica a «un gesto de rebeldía» y lo inscribe como el último eslabón de «un proceso de gradual depreciación» del que ha sido víctima la obra narrativa de Mallea. Más aún: en el despliegue de su defensa, Rest no vacila en declarar que, desde su punto de vista, «la airada denuncia contra Mallea» carece en el fondo de legitimidad ya que, con «palabras rayanas en la diatriba», esos críticos acusan a Mallea de ser lo que él nunca hubiera negado ser: «un reaccionario que "prefirió seguir en el juego burgués"» (Rozitchner 1955: 34) ${ }^{124}$. En su perspectiva, es preciso desestimar «el calibre de injurias» para hacer foco en «el significado del antagonismo», puesto que «hay críticos insospechadamente avanzados y exentos de toda connotación "reaccionaria" o "burguesa" que han mencionado con respeto y cordialidad el pensamiento de Mallea» (1960: 26). Que no se trate en este caso de críticos nacidos antes de 1915 y que hayan alcanzado la madurez después de 1940, es un dato que -para Rest- no puede pasarse por alto puesto que, en su óptica, lo que ha transformado el sentido de las obras de Mallea es la historia misma, al desencadenarse «en el país sucesos graves y turbulentos que han

124 Rozitchner, L., "Comunicación y servidumbre: Mallea", Contorno 5/6, Buenos Aires, septiembre de 1955. 
provocado una especie de fisura en el desenvolvimiento intelectual, una discontinuidad en la evolución de la cultura» (1960: 26). Los acontecimientos socio-históricos son los que han producido ese «cambio en las actitudes y en la sensibilidad que excede los criterios meramente políticos». La referencia a las transformaciones políticas y sociales producidas por el peronismo explican tanto la pérdida de actualidad de la literatura y el pensamiento de Mallea como el desamparo que motiva las críticas de la joven generación tienen una razón histórica: la impotencia del novelista y la desilusión de sus críticos se explican por esa «Catástrofe» que el novelista intuyó aun cuando «no podía prever el curso de esa acción destructora» (1960: 26).

La evaluación final de Mallea realizada por Rest no es categórica y parece hacer gala de un equilibrio armonioso. Rescata, como saldo positivo, el hecho de no reducir la realidad a la mera e indiferente exterioridad, obligando a sus lectores a pensar ese desastre también en la propia intimidad, «a fin alcanzar el aplomo espiritual que nos capacite para la acción responsable y auténtica» (1960: 27). Y señala también como aspecto particularmente negativo la «impotencia» que ese repliegue intimista supone con respecto a los acontecimientos históricos inmediatos.

Rest prolonga su contextualización de Historia de una pasión argentina describiendo los conflictos de clase entre el patriciado criollo y las masas inmigrantes que ansiaban ser reconocidas políticamente. De la Ley Sáenz Peña a la «ficción democrática» de la Década Infame la corrupción del patriciado se 
presenta, a los ojos de Mallea, como una situación cada vez más dramática en consideración de sus efectos políticos y morales de desprestigio.

Las transformaciones sociales y los acontecimientos políticos han producido, a la vez, un «estado de malestar y de apatía» cuya peligrosidad se potencia «a causa del influjo que en ciertas mentalidades desorientadas ejercían por aquel entonces los experimentos totalitarios de algunas naciones europeas» (1960: 37). Es la situación histórica la que determina la «honda resonancia» de la crisis «en los espíritus», «provocando una suerte de flaqueza moral», alentando un «patriotismo de circunstancias» que -como apunta Rest- «se pone o se saca como la ropa dominguera», y que se encuentra «en pleno auge» en Europa aunque, en rigor, carece por completo de autenticidad (1960: 37). Esta es la realidad a la que responden las inquietudes de Mallea pero también las de Ezequiel Martínez Estrada. La correspondencia señalada por Rest entre el autor de Historia de una pasión argentina y el de Radiografía de la pampa no es, pese a sus «notorias diferencias», del todo caprichosa. Mientras en sus ensayos Mallea «se esfuerza en conservar la fe»-pese a que su narrativa presente a veces «una especie de vértigo suscitado por el abismo de la nada en que parece desvanecerse la ilusión de una Argentina auténtica»-, Martínez Estrada, en cambio, insiste en que «nuestra realidad es o bien esa "barbarie" que combatió Sarmiento o un vacío que tratamos de disimular con el auxilio de la mentira o del engreimiento» (1960: 38). La diferencia estriba en que Martínez Estrada, por contraste a Sarmiento y a Mallea, no 
plantea la presencia de una dicotomía en la integración de la sociedad argentina. Para él no hay, pues, «dos Argentinas»; hay una sola y única realidad que no admite dobles interpretaciones. La fuerza que rige esa realidad es la que proviene de «los grupos humanos de la campaña» y de ese modo se halla «configurada y establecida», invariablemente. La tesis estradiana -escribe Restlleva implícito «un determinismo absoluto e irremediable, una actitud netamente fatalista»: no nos deja más alternativa que la de reconocer la constitución de nuestra nacionalidad como «un fenómeno azaroso en que imperó el espíritu de aventura y en el que nunca prevaleció un criterio de organización y orden» (1960: 38). Para Martínez Estrada, el "alma dilatada y sin forma" del hombre de las pampas se negaba a aceptar regulaciones y veía en toda codificación una suerte de servidumbre; pero, a la vez, era portador de ese miedo primario que «nos asalta ante la amenaza de un peligro cuya naturaleza exacta desconocemos» (1960: 39) . El reemplazo de una auténtica vertebración normativa por «seudoestructuras»-que, diagramadas sobre seudovalores, determinan desde el ámbito cotidiano a la vida política- responde a esa ambigüedad $y$ a ese miedo primitivo. Pero esas seudoestructuras funcionan con cierta anomalía y se mantienen siempre en un equilibrio precario; en consecuencia, la situación del país se vuelve «sumamente inestable e incierta» y sus habitantes, tratando de olvidar o negar el estado de incertidumbre en que viven, se aferran a cualquier ilusión que pueda distraerlos del desasosiego. Para Martínez Estrada, es el intento mismo de «ocultar la barbarie natural» tras una 
«artificiosa civilización» lo que desfigura la realidad. Si cualquier concepción dicotómica de nuestra existencia es engañosa y toda división de nuestras estructuras es falsa -porque «hay una sola realidad, que es la realidad inorgánica, rústica y anárquica»-, toda interpretación apoyada en esos dualismos razona Rest- «está destinada a fracasar, a causa de su carácter ilusorio» (1960: 40).

La de Martínez Estrada es pues la tercera hipótesis sobre la realidad argentina que Rest reconoce «formulada igual que las dos anteriores en un período de crisis». Su signo característico se define en que -a diferencia de aquéllas- esta hipótesis «rechaza el dualismo y formula un monismo de neto perfil pesimista». Pensada como reelaboración y rectificación de la hipótesis sarmientina, la hipótesis estradiana se inscribe además -razona Rest- en un tono apocalíptico que no siempre ha sido bien recibido. Acaso «persuadido de que su visión superaba la de sus compatriotas», Martínez Estrada ha sostenido su vaticinio «con entonación apocalíptica, a semejanza de Tiresias o de un profeta del antiguo testamento». No obstante ello, tanto el polémico ¿Qué es esto? como Las 40 prueban para Rest el hecho de que «sus anuncios conservan plena lucidez y acierto» (1960: 41). Con estas palabras que no admiten grado de ambigüedad o de duda Rest aprueba la interpretación que Martínez Estrada produce del peronismo y, en ese punto, se distancia visiblemente de la posición que a su respecto toma el grueso de los integrantes de Sur. ${ }^{125}$

125 Durante este mismo periodo, que coincide con el fallecimiento de Martínez Estrada, Rest retomará -con tono evocativo- la obra del autor de 
Que en los momentos de mayor crisis institucional republicana la hipótesis de Martínez Estrada tome mayor presencia y reclute mayores seguidores, no es sorprendente para Rest. Con la caída de las falsas ilusiones su perspectiva retorna. Su dimensión profética -explícitamente reconocida y retomada, entre otros, por Héctor A. Murena- adquiere así nuevos visos de actualidad. Pero, mientras que la hipótesis estradiana es más sólida y más aceptable que «el desesperado esfuerzo salvador de Eduardo Mallea», al punto de que Radiografía de la pampa (1933) ${ }^{126}$ es aceptada incluso «en la plenitud de su fatalismo», Rest percibe con claridad lo defectuoso de este particular monismo: «deja la sensación de que nuestra realidad no pertenece al orden dinámico de los fenómenos sociales sino que se encuentra por encima de todo lo transitorio, en el inerte ámbito de lo ontológico» (1960: 43). Vale la pena subrayar la exigencia historicista que Rest plantea al telurismo profético de Martínez Estrada, cuyos momentos de aprobación se apoyan necesariamente en las crisis históricas en que amenaza la catástrofe de la disgregación.

Con las masas incorporadas ya como un componente crucial en el desenvolvimiento histórico de la nación, veinte años después de Radiografía de la pampa e Historia de una pasión argentina, un nuevo momento de crisis da lugar a una serie nueva de interpretaciones. Se trata de autores nacidos hacia el 1900 que

Radiografía de la Pampa, en dos textos de homenaje y revalorización integral de su obra: "Evocación de Martínez Estrada" (Sur, n² 295, Buenos Aires, julio/agosto, 1965. pp. 69-72) y "Trayectoria de Ezequiel Martínez Estrada" (en AAVV. Homenaje a Ezequiel Martínez Estrada, Bahía Blanca: UNS, 1965).

126 Martínez Estrada, E., Radiografía de la Pampa, Buenos Aires, Babel, 1933. 
registran en su producción «los cambios, las nostalgias o la crisis». Son «interpretaciones fabuladas o lúdicas» que con frecuencia señalan «una notoria tendencia localista a evocar modalidades de la vida porteña» (1960: 44). En Evaristo Carriego (1930) y en sus elucubraciones sobre el tango y las historias de cuchilleros, Jorge Luis Borges «transpone la realidad inmediata del hombre de los suburbios, del paisaje y de las situaciones en término de mito o leyenda»; en El estruendo de las rosas (1948), bajo el irónico disfraz de novela detectivesca, Manuel Peyrou deja «translucir entre líneas una acerba crítica al totalitarismo»; en Adán Buenosayres (1948), Leopoldo Marechal, intenta «una suerte de fabulosa "suma" porteña, mezcla de odisea y añoranza» (1960: 45). Pero eso no es todo. Luego y -como bien apunta Rest- desde perspectivas de mayor «objetividad y espíritu científico», ven también la luz por esa fecha novedosas investigaciones «sobre nuestra historia y sobre nuestras estructuras sociales». Rest destaca especialmente dos de ellas: en primer lugar, Argentina: imágenes y perspectivas (1956) ${ }^{127}$ de José Luis Romero, que subraya «nuestra tendencia natural a formular definiciones para esclarecer la causa de los repetidos momentos críticos que ha vivido el país»; y, en segunda instancia, Política e massa. Estudo sôbre a integração das massas na vida politica dos paises em desenvolvimento (1960), en cuyo último capítulo se describen las circunstancias que dieron lugar al «reciente interludio tiránico» y se hace foco en lo que su

127 Romero, José Luis, Argentina: imágenes y perspectivas, Buenos Aires, Raigal, 1956. 
propio autor define como «la integración de las masas en la vida política y el totalitarismo» (Germani 1960: 112-113) ${ }^{128}$.

La última hipótesis de interpretación de la realidad nacional expuesta por Rest es la de Julio Mafud en El desarraigo argentino $(1956)^{129}$. Llega a éste luego de un interesante rodeo en el que expone su perspectiva respecto de su propia generación. Replicando el argumento expuesto en el pasaje dedicado a las críticas recibidas por Mallea, Rest argumenta que, al no haber pasado por «la experiencia totalitaria» con edad suficiente sino «apenas salidos de la adolescencia», los jóvenes se han puesto a la defensiva extremadamente y han adoptado «el propósito parricida»; esto es, «la intención de liquidar definitivamente las ataduras con un pasado que aspira a ponerle exigencias sin comprender su responsabilidad en la crisis nacional» (1960: 46). Deja abierta la referencia histórica al referirse a esas «últimas décadas» en que imperó una «ensordecida retórica patriótica» que atribuía al país «grandezas y virtudes hiperbólicas» ausentes en los hechos. Arremetiendo contra esa ficción y también contra la que la precedía, la «generación rebelde» sólo acepta -y con marcadas reticencias- al Martínez Estrada más crítico de las nociones vigentes hacia 1930. De esa diferenciación generacional, Rest extrae la existencia de «un nuevo frente de lucha» en el que, de un lado se enfila «la generación que alcanzó madurez y expresión antes de 1943» y que puja con ahínco «por restablecer

\footnotetext{
128 Germani, G., Política e massa. Estudo sôbre a integração das massas na vida politica dos paises em desenvolvimento, Belo Horizonte, Facultad de Dereito - Universidade de Minas Gerais, 1960.

129 Mafud, J., El desarraigo argentino: clave argentina para un estudio americano. Buenos Aires, Américalee, 1959.
} 
el equilibrio liberal»; y, del otro, se enrola «la juventud que se ha denominado "parricida"» y que «durante la lucha contra la dictadura [peronista]» estuvo junto a la generación precedente pero -luego del Golpe de Estado del 16 de septiembre de 1955- se distanció de sus predecesores en razón de su convicción en la necesidad de ver la realidad argentina en términos enteramente nuevos. «Para estas nuevas figuras de nuestra historia cultural escribe Rest-, la tiranía peronista ha sido un mal; pero consideran añadir dos advertencias a este juicio» (1960: 47). Por un lado, comparten la hipótesis de Martínez Estrada, para quien el peronismo fue «engendrado por factores preexistentes, por circunstancias políticas y sociales» previas. Y por otra parte, advierten también que su caída «no puede implicar su abrogación histórica», sino que -habiendo sido «incorporada inevitablemente al destino nacional»- es preciso hacerse cargo tanto de sus efectos como de sus causas, de sus calamidades y sus fundamentos. Para estos jóvenes -entre los cuales Rest no duda en incluir al grupo de la revista Contorno, cuya «tendencia "integracionista" de reconciliación nacional» (1960: 48) se frustra a partir de la "traición frondisista"-, la restauración del régimen republicano no puede reducirse a un mero retorno a las condiciones previas al mismo; ni siquiera se acota al contrario, para este grupo la recuperación democrática y republicana debía ya a «un enriquecimiento de nuestra experiencia política» a partir de la compleja experiencia peronista; sino que supone la expectativa de una transformación radical de la sociedad misma en términos estructurales. 
El libro de Mafud se presenta a Rest como una versión moderada de esta posición conciliadora. La propuesta de Mafud supone como objetivo la «real integración» de aquellos vastos y marginados sectores sociales que «han permanecido desarraigados, inarticulados; se han sentido ajenos al mundo que los rodea» (1960: 48). El indio exterminado, el gaucho despojado, el inmigrante marginado, el hombre-masa omitido, son algunos de esos personajes que, perteneciendo a los extractos más populares, han sido abandonados a su precaria situación por las clases dirigentes. El diagnóstico de Mafud sobre los errores del pasado no es de atribución telúrica sino de acción efectiva: «un error de sistema». Rest subraya especialmente el carácter abierto que surca la propuesta de Mafud: al presente, la nación es menos una realidad que una posibilidad; y, como tal, puede realizarse o frustrarse. Su destino depende estrictamente de que se sepa «aprovechar la experiencia» del pasado, se pueda «admitir a todos los grupos sociales o políticos en un pie de igualdad», y se consiga superar las limitaciones del temperamento a partir de «una comunicación real y simpática». El valor objetivo del libro de Mafud, escrito bajo la influencia de Simone Weil y Erich Fromm, consiste -a juicio de Rest- en que «confiere a nuestros problemas una dimensión universal» y cosmopolita: la crisis nacional se articula así sobre las crisis del hombre contemporáneo y las sociedades modernas que deben afrontar transformaciones estructurales.

Como bien señala Rest, para Mafud la crisis nacional sólo puede afrontarse con expectativas a partir de tres tareas o 
requisitos fundamentales: 1) la aceptación de la realidad nacional y su estilo de vida, 2) la integración de los diversos estratos sociales en una ámbito de reconocimiento y respeto mutuo y 3) el «reordenamiento de las instituciones en función de las necesidades» (1960: 50). Es preciso comprender e incorporar el aspecto «bárbaro», puesto «que no es posible superarlo mediante la agresión a determinados sectores sociales». Como bien escribe el propio Mafud, «el problema de civilización y barbarie no era un problema de exclusión, sino de asimilación». La posición de Mafud es liberal y conciliatoria. Se basa en el principio de tolerancia y autodeterminación. Rest simpatiza concretamente con esta ascendencia e incluso contempla con cierto asentimiento el carácter reformista que Mafud parece evidenciar en lo referente a la estructuración institucional. Un genuino «reordenamiento que permita la convivencia de todos los grupos sociales e ideológicos» implica -apunta Rest- «modificar la naturaleza de las instituciones que regulan nuestra vida de relación» (1960: 51). Son las instituciones, «creadas para salvaguardar los derechos individuales», las que deben adecuarse a la realidad social que deben regular, y no a la inversa. Es preciso adecuar las instituciones para evitar que su imposición deba hacerse por la violencia, de facto, avasallando los poderes legales y desconociendo los derechos ciudadanos. La reestructuración del orden socio-político propuesta por Mafud y saludada por Rest implica la consolidación de «instituciones que posean un carácter funcional y orgánico», «que expresen cabalmente las necesidades del individuo»y que se adecúen a los requerimientos particulares 
de la existencia colectiva, «en lugar de restringir la fluidez de la sociedad y la capacidad de transformación progresiva» (1960: 52). Tales instituciones deben propiciar, en el mayor grado posible, la participación de los actores sociales; y, por lo tanto, deben presentar «un fortalecimiento del espíritu federalista, del sindicalismo, del régimen municipal, del movimiento cooperativo». Rest afirma en Mafud lo que es, en sustancia, el catálogo fundamental de su convicción socialistaliberal. Y agrega, a título particular, que esas instituciones deberían asumir una posición respetuosa respecto de «la propia tradición» para llegar a consolidarse y «perdurar el tiempo suficiente como para transformarse, a su vez, en tradiciones». Pero es preciso evitar -agrega- confundir esa tradición con «el vocinglero encasillamiento en un supuesto apego seudofolklórico, aderezado con discursos de circunstancias sospechosas de "nacionalismos" importados». La auténtica tradición implica pues -a su juicio- «algo más que un vínculo con el pasado; es también una perspectiva hacia el porvenir» (1960: 52); y, como tal, no constituye un anquilosamiento conservador en doctrinas estáticas sino, como bien había visto T. S. Eliot, una actitud dinámica que le permita transformarse sin interrumpir la progresiva continuidad histórica.

Cuatro hipótesis de la Argentina es en efecto el texto más polémico de esta primera etapa. Lo es tanto en relación al recorte y las colocaciones que Rest asume en su desarrollo, como la elección de un tópico particular -el ensayo de interpretación de la realidad nacional- que, si bien ya empezaba a declinar, se 
sostenía en su fundamento político. Pero, además, deja entrever ya la acertada intuición restiana de que lo nacional de una cultura no es una esencia sino una construcción que se define por el tratamiento específico que se hace sobre la propia lengua. Es lo que manifiesta el propio epígrafe de D. H. Laurence con que Rest encabeza su investigación (You know quite well life doesn't start with a form. It starts with a new feeling, and ends with a form): se trata de una búsqueda que comienza en una instancia sensible y se resuelve en una forma. Se inicia con un nuevo sentimiento, y termina con una forma. ${ }^{130}$ En este punto, prefigura en gran medida lo que constituye el nudo crítico de sus últimas inquisiciones, dedicadas específicamente al ensayo, donde -más que las discusiones que comprometen al tema y al ensayo como género- lo que se subraya más enfáticamente es esa suerte de «disposición ética» de la escritura que define su función por su destino social y sus modos de elección (política e histórica) en términos de morales de lenguaje.

LITERATURA Y CULTURA DE MASAS

\footnotetext{
130 Y en este sentido es que se entiende su progresión tópica en textos críticos como "Notas para una estilística del arrabal", Buenos Aires: Servicio de Extensión Cultural de la Dirección General de Obra Social de la Secretaría de Estado de Obras Públicas, 1965), "Los narradores argentinos y la búsqueda de un idioma nacional" (la conferencia escrita y leída en las "Segundas Jornadas de Métodos de Investigación de enseñanza de la Historia y de la Literatura Rioplatense y de los Estados Unidos", en Bahía Blanca, en junio de 1967) e incluso el "Prólogo a El juicio del Siglo de Joaquín V. González" (Buenos Aires: CEAL, 1979).
} 
En el prólogo a Navegaciones: comunicación, cultura y crisis, Aníbal Ford recuerda una escena fundamental en su formación teórica. Relata allí la determinante aparición de Jaime Rest como «gran maestro e interlocutor». Pero eso no es todo. Ford subraya muy especialmente la función magisterial de Rest para una generación que compartía cierta inquietud respecto de los temas y problemas vinculados a «las relaciones entre la cultura, los medios, las tecnologías, la política, la historia social» (Ford 1994: 18131. Más aún, en la consideración del autor de La marca de la bestia, Rest fue, sin dudas, «el creador de los estudios culturales en la Argentina». En lo que respecta a este punto, su perspectiva coincide con Beatriz Sarlo quien, en más de una ocasión, ha descrito a Rest como uno de los principales introductores de los trabajos teóricos ingleses y norteamericanos precursores en esa línea de investigación. ${ }^{132}$ Como bien afirma Ford, Rest no sólo fue quien recomendó a esos jóvenes investigadores textos capitales como Mass culture. The Popular Arts in America (1957), el famoso reader de Bernard Rosemberg y David M. White, y The Uses of Literacy. Media, Communication, and Culture in America (1957) ${ }^{133}$ de Richard Hoggart, sino que también los puso ante el primer esbozo de análisis crítico de la cultura de masas en un manual de literatura, el de Boris Ford, publicado

\footnotetext{
131 Ford, A., Navegaciones: comunicación, cultura y crisis, Buenos Aires: Amorrortu, 1994 .

132 Turner, Graeme, British Cultural Studies: An Introduction. Boston: Unwin Hyman, 1990 .

133 Hoggart, R., The Uses of Literacy: Aspects of Working-Class Life with Special Reference to Publications and Entertainments, Harmondsworth, Penguin Books, 1957.
} 
en Harmondsworth por Penguin Books en 1961. En ese volumen se incluía puntualmente el ensayo "Mass communication in Britain"134, de Hoggart, que de algún modo ratificaba el sistema de relaciones que los jóvenes investigadores argentinos estaban viendo funcionar «entre literatura y medios, en relación o no con los estudios de sociología de la literatura» (Ford 1994: 19).

A través de trabajos como Notas para una estilística del arrabal (1965a) ${ }^{135}$ o la nota introductoria a su traducción de los poemas de John Lennon ${ }^{136}$, el propio Rest marcaba ya la avanzada de esta línea de intervenciones. Había aprendido de la mano de José Luis Romero a ver la historia en una perspectiva socio-liberal, «desde las transformaciones sociales, desde la gente y no desde los héroes» $y$, cuando ya por los 160 se asumía como «un "fabiano", un socialista antiperonista» (Ford 1994: 19), su inquietud y su erudición se enfocaban ya en el desarrollo específico de saberes que contribuían a estudiar y comprender los «procesos culturales profundos», incluidos aquellos derivados de la propia experiencia del peronismo.

Es altamente significativo que el primer texto argentino importante dedicado a la problematización de estas cuestiones sea de un autor perteneciente al circuito académico, pero notablemente formado -según la opinión de Jorge B. Rivera

\footnotetext{
134 Hoggart, R., "Mass communication in Britain", en Ford, B. (ed.), The Modern Age, Harmondsworth, Penguin Books, 1961.

135 Rest, J., Notas para una estilistica del arrabal (1965a). Buenos Aires: Servicio de Extensión Cultural de la Dirección General de Obra Social de la Secretaría de Estado de Obras Públicas.

136 Rest, J., "Introducción", en (Lennon, J., John Lennon, en su tinta, Buenos Aires, Bocarte, 1964).
} 
$(1987)^{137}$ - como científico social. Es la colocación excepcional de Rest -nuevamente a medio camino entre dos esferas de investigación distantes- lo que le permite encarar el desafío de un profundo "estado de cuestión" en "Situación del arte en la era tecnológica" (1961a) ${ }^{138}$. En ese extenso y riguroso ensayo, Rest sintetiza las principales tesis e hipótesis centrales elaboradas por autores como Vance Packard, Walter Benjamin, Richard Hoggart y de manera muy especial por los colaboradores del clásico volumen colectivo Mass culture: the popular arts in America, coordinado por B. Rosenberg y D. M. White, sobre la producción artística y difusión mecanizada, el impacto social de los medios masivos, la manipulación de mensajes y las consecuencias estéticas de la incidencia de la tecnología y los medios de comunicación en la producción artística.

El aporte de Rest en este campo de investigaciones es realmente precursor y define de manera estratégica el comienzo de su proyecto intelectual; esto es -como sostiene Edward W. Said en Beginnings. Intention \& method- es el punto preciso en el cual, en un trabajo específico, el escritor se separa de todos los demás trabajos de la tradición a la vez que establece complejas relaciones -ya sea de continuidad o antagonismo o de diferencia específica- con los trabajos ya existentes. El comienzo supone pues, según Said, la designación de una intención que define esa producción como el primer peldaño en la materialización de un

137 Rivera, J. B., La investigación en comunicación social en la Argentina, Buenos Aires, Puntosur, 1987.

138 Rest, J., "Situación del arte en la era tecnológica" (1961a), Revista de la Universidad de Buenos Aires, 5ta época, $\mathrm{N}^{\circ}$ 2: 297-338, Buenos Aires, abril-junio. pp. 297-338. 
proyecto de trabajo a largo plazo. "Situación del arte en la era tecnológica" (1961a) -que será rigurosamente continuado con "Alcances literarios de una dicotomía cultural contemporánea" (1965b)- constituye tal comienzo en el proyecto restiano en tanto señala una nueva disposición en el imaginario del crítico. Se instituye como una instancia que tiene «el carácter de una actividad materializada en un lugar y un tiempo determinados», y resulta eventualmente situable en el marco de coordenadas históricas y sociales precisas que definen sus condiciones de posibilidad, existencia y circulación concreta (Said 1985: 17$50)^{139}$.

El trabajo tiene la virtud de constituir, en primer lugar, una temprana sistematización de la problemática y de las reflexiones producidas en torno al auge de los medios de comunicación masiva a lo largo de los 40 y los 150. Pero su acierto más importante radica en el hecho de no condenar (necesariamente) la mutua influencia de los medios y tecnologías de comunicación masiva y el ámbito de la producción estética. Lúcidamente, Rest resume su posición en una perspectiva moderada y progresista, advirtiendo que los medios en sí son ante todo instrumentos cuyos efectos "positivos" están prioritariamente supeditados a una adecuada socialización y a una acción pedagógica concebida en términos de estricta racionalidad.

En la novedosa indagación el joven crítico sigue en líneas generales investigaciones previas de autores cuya formación es

${ }^{139}$ En todos los casos, la traducción de los fragmentos me pertenece. 
eminentemente literaria y su repercusión se percibe más notablemente en autores que, también formados en el campo de la literatura, se sienten especialmente interesados en la investigación de la comunicación, los medios masivos o la cultura popular (Héctor Schmucler, Eduardo Romano, Aníbal Ford, Juan Sasturain, Beatriz Sarlo, Victor Pesce, etc.). El hecho no es menor. Supone una tendencia que delata una laguna de especificidad de ese campo hasta entrados los años '70. Pensando la formación de este espacio disciplinario, uno de sus mayores cultores, define esta aparición como un "fenómeno" particular, surgido a partir de la confluencia de intereses de unos pocos actores de la enseñanza superior de la literatura, «frente a la comparativa abundancia de científicos sociales que en otras latitudes se dedicaron a explorar la misma problemática» (Ribera 1987: 55) .

La elección de Rest por esta línea de investigación implicaba pues cierta incomodidad y dificultad. Formado en un contexto académico tradicional, que privilegiaba fundamentalmente la convención de un recorte de "grandes obras" y "alta literatura" en la conformación de un "canon natural" -que rápidamente se superponía con la literatura a secas-, decide orientar su investigación de la cultura de masas. Pero eso no es todo. Opta además por hacerlo poniendo especial atención a temas y problemas de competencia extra-académica como las condiciones de producción, de circulación y consumo de los bienes culturales. Se interesa por textos considerados como "no literarios" y deliberadamente excluidos de oficio de los programas vigentes en 
las universidades. Concentra su atención en ese espacio definido con una «categoría chandala» (cultura de masas) en que, tal y como señala Jorge B. Rivera, estarían comprendidas, "naturalmente", «la totalidad de las denominadas "literaturas marginales", las formas "no escritas" y múltiples expresiones de las "culturas populares")» (Ribera 1987: 56).

La precariedad epistemológica sobre la que se producen estas investigaciones precursoras se hace patente en las referencias bibliográficas. Los propios trabajos de Rest configuran corpus bibliográficos caóticos, eclécticos y no jerarquizados que, por su misma heterogeneidad, impide prácticamente la discriminación entre materiales accesorios y textos auténticamente modernizadores y científicos en la materia. Rest trabaja pues casi a ciegas pero convencido de la creciente importancia adquirida por la problemática cultural que, en continua transformación, muestra no sólo múltiples aristas inexploradas sino también, y fundamentalmente, aspectos particulares que permiten comprender o al menos replantear fenómenos y procesos socio-culturales de vital gravitación en la configuración política e ideológica de su tiempo. En una palabra, Rest intuye que a partir de estas producciones culturales de masas se reconfigura no sólo la comprensión de los fenómenos y productos de la propia literatura, sino también los que atañen a la conformación y legitimación de procesos políticos e ideológicos.

En su perspectiva, la orientación hacia esa problemática constituye una suerte de movimiento exógeno, relacionado con ambos tipos de búsquedas y requerimientos operativos. En primer 
término, lo que se plantea como necesidad: la redefinición o el ajuste de los conceptos mismos de literatura y cultura que comienzan a procesarse desde fuentes extra-académicas muy diversas. Esta transformación hace confluir las necesidades de lo estético como experiencia social en el mundo moderno como la inminencia de la actualización teórica derivada del formalismo y del estructuralismo, los aportes significativos de la antropología moderna, el historicismo populista, las álgidas polémicas desarrolladas al interior del marxismo a propósito de cuestiones de arte y literatura, las corrientes estéticas de vanguardia, y los importantes debates filosóficos prodigados sobre la ideología y lo ideológico. Rest da cuenta del importante caudal de textos y autores que se aproximan y pronuncian con relación a los procesos culturales señalados: la lista va del propio Karl Marx a Antonio Gramsci, de Lukács a Benjamin y Adorno, de Lèvi-Strauss a Eco y a Morin, de Bachelard y Sartre, a Althusser y Barthes. También pone en evidencia la creciente atención que los críticos e investigadores de la literatura empiezan a depositar en cuestiones que deslinda, plantea y problematiza específicamente la sociología de la literatura, cuyos textos fundamentales acabarán por constituirse en soportes y puntos de partida en el desarrollo de investigaciones ancladas en nuevos territorios. Los trabajos de Robert Escarpit, Lucien Goldmann, Richard Hoggart, Arnold Hauser, Ian Watt, Mihail Bakhtin, Edmund Wilson, David Daiches, Raymond Williams, Kenneth Burke, William Empson, Susanne Langer, H. E. Bates y otros se convierten en puntos de partida teóricos y metodológicos que 
permiten a Rest trazar las nuevas directrices de una concepción más inclusiva de la literatura, pero también le permiten incorporar temas y fenómenos culturales tradicionalmente excluidos de ese campo específico en los ámbitos académicos. ${ }^{140}$

El sistema de la literatura ya no es para Rest un recorte simplista y estereotipado de textos venerables y consagrados, sino un entramado mucho más complejo y dinámico, cuya hibridez constitutiva exige -de cualquier intento de comprensión genuinael auxilio de múltiples disciplinas como la filosofía, la lingüística, la teoría de la comunicación, el psicoanálisis, la semiología, la sociología del conocimiento, la crítica políticocultural y la psicología social. Que el juego de relaciones interdisciplinarias suponga casi siempre el descubrimiento de nuevas problemáticas y perplejidades, no inhabilita que sólo merced a su confluencia sea dable hallar algunas respuestas provisionales pero importantes en relación a cuestiones fundamentales de la configuración cultural moderna.

Rest se interesa gradualmente por producciones culturales en gran medida despreciadas. Lee novelas policiales, folletines, historietas, guiones cinematográficos, canciones populares, radioteatros, etc. Percibe que en otras latitudes esas producciones empiezan a tornarse relevantes para los investigadores: se las estudia con el objeto de dimensionar su contribución con relación a cuestiones técnicas y teóricas de alta complejidad. Jóvenes de su propia generación, como Oscar 140 En ese sentido hay que evaluar la importancia de esa singular investigación cultural desarrollada por Rest a propósito de la Pena de Muerte. Cfr. Rest, J., "La Pena de Muerte", en Revista de la Universidad de Buenos Aires, 5ta época, Año VII, N 3, Buenos Aires, 1962. 
Masotta, Adolfo Prieto y Eliseo Verón, emprenderán una investigación similar y -ya sea desde perspectivas semiológicas como sociológicas- ponen estas producciones culturales bajo la horma teórica de categorías novedosas como las de estructura significativa y producción, los conceptos de ambigüedad, redundancia, textualidad, iconicidad, mercado, traslación lingüística, verosimilitud y metalenguajes, entre otros). ${ }^{141}$

Desde ese primer umbral de ruptura constituido desde el espacio de la literatura -que, con excepción del trabajo de Adolfo Prieto en Sociología del público argentino, aún tiene poco que ver con la problemática de los medios y sus temas vinculados y derivados-, la reflexión sobre la cultura de masas se va definiendo y encaminando por carriles concretos, hasta imponerse en una idea de crítica como análisis de las interrelaciones entre los sistemas de la literatura y otros sistemas (económico, político y social). Se trata de un modelo de práctica crítica que considera especialmente el contexto histórico en que se inscriben tanto las producciones culturales como sus propias condiciones de producción y consumo. El trabajo de Rest se apunta pues a este perfil de investigación al centrar su atención en el papel del receptor como mercado y al considerarlo como factor determinante

\footnotetext{
141 Trabajos realizados desde el campo de la literatura como Crisis y resurrección de la literatura argentina (1974), de Jorge Abelardo Ramos, Sociología del público argentino (1956), de Adolfo Prieto, Imperialismo y cultura (1957), de Juan José Hernández Arregui, Literatura argentina y realidad política (1964), de David Viñas, y Conciencia y estructura (1968), de oscar Masotta, a pesar de sus muchos puntos discutibles y polémicos, constituyen indudablemente una formulación de lo político-cultural y de lo literario que marcaron notablemente el desarrollo de la reflexión crítica argentina ulterior en términos de análisis de la cultura.
} 
en los procesos de transformación que se producen en el sistema de la literatura y la cultura en general, donde enfrentan sus condicionamientos políticos y económicos reales (la manipulación demagógica, la censura, el pago condicionado, las presiones del mercado, etc.) que se verifican en el plano de las demandas de la industria cultural.

Durante las décadas del '60 y el '70, Rest profundizará pues un pasaje gradual desde una crítica académica estrictamente literaria a una práctica orientada hacia la investigación de lo político-cultural. Esto se corrobora en la gravitante influencia que empiezan a cobrar en su proyecto crítico, sobre este proceso transferencial, la exploración de lo cultural como significado y mercancía, el estudio de su producción, distribución y consumo, y las condiciones políticas e ideológicas que determinan la naturaleza específica de las producciones culturales masivas en un contexto histórico determinado. Géneros menores, literaturas marginales y otras formas menospreciadas de la cultura popular empiezan a tomar un lugar cada vez más central en sus investigaciones. Su reflexión sobre esos temas se vuelve más sutil y pormenorizada. Lee las producciones particulares de la cultura popular en una suerte de desconstrucción crítica que le permite reelaborar su propia reflexión sobre los medios y los modos de reproducción y difusión cultural masiva y subrayar la relevancia inusitada que adquieren en el proceso de comprensión de lo social entendido como un complejo tejido de relatos. ${ }^{142}$ Sin embargo, las investigaciones de Rest siempre se realizan

142 Cfr. Hall 1984. 
en la articulación de una doble mirada de los objetos abordados: por un lado una aproximación literaria -que enfoca flexiones y puntualizaciones no necesariamente convencionales sobre el propio sistema de la literatura- y una aproximación más general -que barre los aspectos más amplios de lo político-cultural y sus múltiples cauces y sistemas. Esta condición está claramente presente tanto en sus inquisiciones sobre la «estilistica arrabalera» de Homero Manzi como las dedicadas al non-sense y el absurdo en la poética de John Lennon. La mirada restiana se desarrolla en función de esas dos variables en el juego improvisado de una compleja operatoria epistemológica en la que las fuentes teóricas y críticas son abordadas con un sentido eminentemente instrumental.

A diferencia de otras intervenciones de corte ideológico más parcializado, las exploraciones de Rest siguen con cierta distancia objetiva los procesos productivos de la industria cultural y los mecanismos y estrategias de afirmación políticoideológica. Se trata pues de establecer las directrices de una perspectiva analítica que -aun cuando por momentos se revele en una relación empática con sus objetos- se desarrolla, a partir de los casos, en busca de generalizaciones y sistematizaciones que ponen especial acento en lo interdisciplinario, planteando lecturas relacionales y entrecruzadas de los diversos sistemas que componen el tejido discursivo de la producción cultural de una sociedad determinada.

Pero lo que se produce en el proyecto crítico restiano no es un desvío ni un cambio de objeto de investigación sino una 
«ampliación de campo de intereses», que parte de lo «estrictamente literario» y procede a una «integración analítica de la por entonces difusa parafernalia de los medios masivos, las literaturas "marginales" y la comunicación (en un sentido global)» (Ribera 1987: 70). Sin imponer jerarquías ni prejuicios conservadores, a veces leyendo comparativamente sus operaciones específicas, Rest trata con la misma seriedad, con la misma actitud escrutadora y con el mismo distanciamiento crítico las más diversas producciones de la cultura, y se aboca laboriosamente a subrayar -como se ve en sus lecturas particulares- relaciones contigüidad y adherencia entre las formas aparentemente más distantes y más dispares de la experiencia cultural.

Publicado en 1961 en la Revista de la Universidad de Buenos Aires, "Situación del arte en la era tecnológica" (1961a) ${ }^{143}$ tiene indudablemente un carácter precursor en la bibliografía académica argentina sobre cultura y medios masivos. Pero es también un texto que marca una nueva orientación en las investigaciones restianas. En primer lugar, porque hasta ese punto las intervenciones de Rest se han manifestado casi exclusivamente desde el ámbito especializado de la literatura inglesa: sus colaboraciones en Imago Mundi, La Biblioteca, Revista de la Universidad de Buenos Aires y Sur se reducen a temas de

143 Rest, J., "Situación del arte en la era tecnológica" (1961a), en Revista de la Universidad de Buenos Aires, 5ta época, No 2, Buenos Aires, abriljunio. pp. 297-338. 
literatura y cultura anglosajona ${ }^{144}$, a lo que habría que agregar algunas de sus incursiones precursoras en el terreno de las literaturas comparadas. Pero su interés por el novedoso campo de los medios se evidencia hacia 1958, cuando prepara su traducción de Philosophy in a New Key de Sussane K. Langer ${ }^{145}$ y, al año siguiente, cuando lee Culture and Society de Raymond Williams ${ }^{146}$ y The Uses of Literacy: Aspects of Working Class Life de Richard Hoggart ${ }^{147}$. Esas lecturas -que aparecen visiblemente marcadas en su intervención en la mesa redonda organizada por la revista Señales sobre el tema "Los medios masivos de comunicación"148, en la que además participan la escritora Fryda Schultz de Mantovani y Basilio Uribe- redimensionan en cierta forma su campo de intereses y preocupaciones en una línea de investigación teórica y análisis que se prolonga en Literatura y cultura de masas (1967) y Conceptos de literatura moderna (1979).

Pero eso no es todo. De su paso por Imago Mundi, Rest no sólo ha aprehendido un modelo de investigación en materia de historia de la cultura e historia social del propio José Luis Romero. Allí

\footnotetext{
144 Rest seguirá publicando incluso durante esta "época culturalista" numerosos trabajos referidos a su especialidad, en estricta consonancia con su actividad docente en la Universidad de Buenos Aires donde -entre 1956 y 1963- ejercería el cargo de "Profesor Asociado" en la cátedra de Literatura Inglesa y Norteamericana junto a Jorge Luis Borges. Entre esas publicaciones cabe mencionar especialmente: "Thomas de Quincey ante el magisterio de la prosa" (1958c), Una traducción de William Blake" (1958e), "Thomas Taylor: influjo platónico en el romanticismo inglés" (1959), "Cartomancia y poesía" (1960b), "Un Shakespeare para nuestro tiempo" (1964a), "Wesker y su trilogía dramática" (1965c) y "Shakespeare y la imaginación impersonal" (1966) .

145 Langer, S., Una nueva clave de la filosofía. Un estudio acerca del simbolismo de la razón, del rito y del arte, Buenos Aires, Sur, 1958.

146 Williams, R., Culture and Society, London, Chatto and Windus, 1958.

147 Hoggart, R., The Uses of Literacy: Aspects of Working Class Life, London, Chatto and Windus, 1957.

${ }^{148}$ Cfr. Señales, núm. 125, Buenos Aires, octubre de 1960. pp. 7-10.
} 
también ha templado su temprana vinculación con las investigaciones más sociológicas de David Daiches, Edmund Wilson, Harry Levin, F. R. Leavis y Ian Watt. Es a partir de esas influencias teóricas que pone en relación la serie específica de lo literario -sin omitir o descuidar su especificidad artísticacon la de lo social. En ese cruce singular percibe en qué medida ciertas categorías ausentes en el análisis académico -tales como "mercado", "público", "circuito de lectura", "profesionalización", "desarrollo tecnológico", "géneros 'menores'", entre otros- resultan productivamente fundamentales para comprender la génesis, la circulación y la función de la obra de arte o de la literatura en general en el complejo espacio de la cultura.

Su sostenido interés por la sociología del conocimiento notable en sus investigaciones de la experiencia literaria en Virginia Woolf y T. S. Eliot- se articula, paradójicamente, con una concreta voluntad de rescatar a la literatura, incluyendo en su interior manifestaciones y formas excluidas o relegadas por su carácter socialmente masivo y popular. Rest se aproxima a las denominadas "literaturas marginales" con herramientas de la teoría literaria, pero también con categorías y conceptos teóricos forjados por investigadores sociales. Y en esa doble articulación describe de manera simultánea el tejido cultural en que se insertan las obras, sus valores poéticos específicos y su función social.

Formado en el canon tradicional de la "alta literatura" anglosajona pero atraído por la incipiente problemática de la 
cultura de masas, Rest se formula en "Situación del arte en la era tecnológica" (1961a) la pregunta sobre el impacto de las masas y la tecnología en el porvenir de esas viejas y prestigiosas matrices culturales del pasado. Tanto en este ensayo como en "Alcances literarios de una dicotomía cultural contemporánea" (1965b), revisa y sopesa rigurosamente contribuciones teóricas de Walter Benjamin, Richard Hoggart, Bernard Rosenberg, David Manning White, D. W. Brogan, Daniel Bell, Dwight MacDonald, Raymond Williams, Theodor W. Adorno, Edgard Morin y Robert Escarpit, entre otros. Esa constelación de investigadores y críticos procedentes del funcionalismo, de la Escuela de Frankfurt y de la sociología francesa, le brinda un panorama complejo que lo obliga a tomar una posición cautelosa frente a los usos y efectos de los medios masivos sobre la cultura. Los medios en sí -apunta el crítico- no son ni dejan de ser peligrosos: «son meros instrumentos cuyos efectos positivos o negativos dependen, exclusivamente, del empleo que se les dé» (1961: 336). Tal posicionamiento, que a nuestros ojos parece recatado en su neutralidad, era -en boca de un crítico literario de formación académica como Rest- un gesto «heterodoxo y hasta audaz para la época» (Ribera 1987: 72).

La originalidad de los planteos y el ordenamiento realizado por Rest de la problemática literatura - cultura de masas tecnología, a comienzos de la década de 1960, se enfatiza por su excepcionalidad. Descontando un aislado trabajo de corte sociológico de José Enrique Miguens (aparecido en el volumen 
colectivo Argentina 1930-1960, editado por Sur en 1961) ${ }^{149}$ y un par de notas con un énfasis más definidamente literario publicadas por Ángel Rama en el semanario Marcha de Montevideo ${ }^{150}$, los trabajos de Rest suponen el primer relevamiento integral de la problemática de la difusión mecanizada. La estructuración misma de "Situación del arte en la era tecnológica" (1961a) devuelve esa imagen de primera exploración y "estado de cuestión". Como bien apunta Víctor Pesce, Rest realiza un trabajo histórico, riguroso y desprejuiciado, que enfoca el problema sin juicios a priori, y que en cierta medida se anticipa a las experiencias de la teoría de la recepción que cobrarían auge años después. El texto de Rest dialoga con un contexto histórico internacional en el que está implícita la llamada "teoría de la manipulación" y el momento más estratégicamente especulativo de la Guerra Fría. En lo que respecta al contexto vernáculo el texto de Rest se desmarca con astucia de un dispositivo de lectura política de las coyunturas que cristalizaba recurrentemente en la idea de "dominación" ideológica. Esta idea, apoyada en una concepción cuantitativa y acumulativa del poder, daba lugar a la llamada "Teoría de la manipulación de los medios", según la cual, los medios (o la comunicación) son capaces de manipular las conciencias individuales y de ese modo también la "realidad". Implícitamente esta perspectiva entraba en diálogo concomitante

\footnotetext{
149 Miguens, J., "Un análisis del fenómeno", en AAVV., Argentina 1930-1960, Buenos Aires, Sur, 1961. pp. 329-353.

150 Rama, A., "Literatura y sociedad" (Marcha, Montevideo, 4 de mayo de 1962) y "La sociología del conocimiento" (Marcha, Montevideo, 11 de mayo de 1962). En estas notas el crítico uruguayo repasa la compleja problemática de la relación literatura-sociedad a propósito de la edición en español tres libros: Arte y sociedad de A. Ievgorov, La crítica literaria de Jean Filloux y Sociología de la literatura de Robert Escarpit.
} 
con el mentado adaggio político que homologaba la "realidad" a la "única verdad" y que, en su formulación posterior a la caída del peronismo, prácticamente se sostenía en la suposición de que la "realidad verdadera" era precisamente "la realidad prohibida o excluida". Sin suscribir a esa unicidad categórica (de la necesaria verdad de la realidad) y entendiéndola más bien como una construcción social y colectiva, la progresión de estos temas en la propia obra de Rest resulta irrecusable al evaluar los trabajos reunidos en Tres autores prohibidos (1968), donde se deja en claro que, cuando hay temas prohibidos, autores censurados, fuentes proscriptas, la verdad de la crítica se materializa en su capacidad para denunciar y poner en evidencia los mecanismos en que se ejecuta la exclusión.

Sin embargo, la propia "teoría de la manipulación" se asienta justamente sobre la hipótesis de que la verdad de la comunicación reside en la operación de remisión del mensaje a sus condiciones de producción. La ratificación de su verdad es pues una operación de referencia. La verdad del mensaje se corrobora cuando la operación de lectura remite eficazmente los mensajes a sus condiciones materiales de producción. La presunción que subyace a esta teoría encarna en la idea de que los medios son un instrumento de manipulación de las masas porque pueden operar por referencias falsas, que desvían estratégicamente al mensaje de su origen .

El ensayo en cuestión ratifica (a través de sus citas explícitas y sus glosas) además que Rest es uno de los primeros lectores de la llamada Escuela de Birmingham y su mirada coincide 
con esa serie de investigaciones que aspiran a comprender y explicar la articulación entre clase social y práctica cultural desde una perspectiva que trasciende lo estrictamente socioeconómico. En el apartado inicial del artículo, titulado "Producción artística y difusión mecanizada", Rest examina los «profundos cambios» a que está sujeta la disposición estética contemporánea a partir de la transformación y el crecimiento inusitado de los medios masivos de comunicación. Deja deliberadamente al margen «los desacuerdos relativos al comportamiento moral», para limitarse a examinar «únicamente las transformaciones sufridas por los medios de difusión cultural como consecuencia directa del progreso tecnológico» (1961a: 298). Se trata de examinar cómo el modo de producción capitalista dispone de «una vasta y compleja organización» destinada al esparcimiento y a los momentos de ocio, hasta impregnar sin excepciones «la totalidad de nuestra existencia diaria» (1961a: 299). Para ello -apunta Rest- el modo de producción dispone de un conjunto de recursos técnicos que han modificado por completo «los vínculos específicos de difusión cultural», creando «objetivos y problemas nuevos»: «un nuevo nivel de educación media, nuevos arquetipos de comportamiento colectivo, nuevos campos artísticos, nuevos símbolos de prestigio social» (1961a: 299), etc. La aplicación de esos recursos a la difusión artística entraña -para Rest- dos aspectos fundamentales: 1) la necesidad de considerar «en qué medida el empleo del vehículo mecánico modifica la calidad del objeto estético en su relación con el espectador» (mayor divulgación pero no necesariamente condiciones 
óptimas para la relación entre artista y público); 2) la obligación de tener en cuenta que, como consecuencia de la reproducción masiva, «el objeto estético se convirtió fundamentalmente en mercancía sujeta a las fluctuaciones de la oferta y la demanda» (1961a: 299). Rest pone en discusión la relación ambigua entre arte y propaganda, tanto a través de la creciente estetización de los mensajes publicitarios como mediante el empleo publicitario de las obras de la cultura reproducidas masivamente. Examina usos y abusos de las obras en la pedagogía de las masas y da cuenta de la pérdida de calidad que la reproductibilidad puede implicar para las producciones estéticas. Pero, además de esos problemas concretos, Rest reconoce un fenómeno compensatorio: la tecnología ha dado lugar a «nuevas perspectivas para la difusión cultural» -perspectivas que, «debidamente utilizadas», permiten visualizar «un perceptible adelanto» en la educación estética del público a gran escala. La encrucijada no admite pues soluciones fáciles. Al tiempo que los procedimientos mecánicos de difusión transforman los modos de producción estética (haciendo que las obras de la cultura lleguen a un público mayor), el arte se convierte en «una mercancía o dispositivo publicitario, que sacrifica su calidad y autonomía para satisfacer las aspiraciones multitudinarias» (1961a: 303).

Luis Juan Guerrero, André Malraux y Walter Benjamin son las fuentes de referencia que Rest enfatiza para una mise au point de la cuestión; pero no duda en subrayar los «significativos progresos» en el estudio sociológico de los medios empleados para 
la difusión cultural, sobre todo en los trabajos de Erik Barnouw, Reuel Denney, F. C. Barlett, Ian Watt, Robert K. Merton, Paul Lazarsfeld y en el trabajo panorámico compilado por Bernard Rosenberg y David Manning White. Subraya especialmente el valor de las investigaciones sociológicas que producen un saber progresivo sobre la «comunicación de masas» sin perder de vista la problemática del uso propagandístico y el «encausamiento de la opinión pública» (1961a: 304). En su perspectiva, es de suma importancia el carácter socialmente inclusivo que supone el auge de la comunicación masiva de las expresiones estéticas. Subraya el hecho de que «el desarrollo de los procedimientos mecánicos de difusión ha coincidido, aproximadamente, con el avance de la enseñanza elemental de los sectores populares» (1961a: 307). Pero Rest no es ingenuo. No cree que se trate de una consecuencia necesaria, ni que necesariamente se pueda esperar de ese hecho cultural un beneficio social progresivo. Se apoya en el «admirable trabajo» de Richard Hoggart para ejemplificar el hecho apuntando que «la alfabetización ha sido acompañada por un abaratamiento de las publicaciones populares", pero que eso «se logró no sólo mediante la reducción del precio unitario a causa del aumento de circulación, sino también mediante el descuido de la presentación artística y del contenido literario» (1961a: 307). Como bien lo exponen las especulaciones de George Orwell sobre los "semanarios juveniles"151 citadas por Rest y el propio The Uses of Literacy de Hoggart, ese proceso de empobrecimiento

151 Orwell, G., Critical Essays, London, 1951 (Ensayos críticos, Buenos Aires, Sur, 1948. pp. 76-110). 
no produce más que alienación: «crea un hábito de malsana pasividad»y «estimula la pereza mental, al punto de entorpecer la voluntad y el espíritu crítico»; circunstancia que -a juicio de Rest- «fácilmente transforma al individuo en instrumento indefenso de cualquier designio vituperable» (1961a: 307). Es en razón de esto que, en lo fundamental, la reflexión restiana sobre la cuestión del arte en la era tecnológica se centra especialmente sobre dos facetas importantes: por un lado, la de examinar cómo las transformaciones tecnológicas redimensionan la relación entre arte y sociedad; y por otro, la de las mutaciones efectivamente producidas en el cambio de la estética como resultado del impacto del avance científico en el quehacer estético.

En el segundo apartado de su ensayo, dedicado al "Alcance social de la difusión mecanizada", Rest se aboca a describir el cambio de época que produce el auge progresivo de los medios masivos de comunicación. Señala puntualmente el hecho de que, en esa transición, la difusión del arte queda gradualmente supeditada a un proceso cada vez más industrial -regido por exigencias de una lógica productiva de serialidad, donde los dispositivos mecánicos sirven para elaborar productos en gran escala, destinados a un consumo mercantilizado, rápido y masivo. En ese contexto de producción, el objeto estético puede llegar a cualquier sector de la sociedad, pero corre el riesgo de transformarse en mero "bien de consumo" y de bastardear su propia función estética. Releva además históricamente ejemplos positivos de la secularización y la difusión mediados por los cambios 
tecnológicos (como la introducción de la imprenta) y, correlativamente, los efectos que la ampliación del público receptor fue capaz de producir históricamente en las producciones estético-culturales -como la demanda de la lectura femenina, que estimuló poderosamente el desarrollo de la novela moderna a través del folletín. Nota asimismo que los aspectos negativos de la industria cultural están tan vinculados a la oferta como a la demanda, en tanto las exigencias del público al que se apunta (entretenimiento, evasión de las preocupaciones cotidianas, estímulo temporario) van casi siempre en desmedro de la exigencia en la calidad artística. Rest ve en este hecho un potencial desperdiciado, puesto que -empleados en una función cultural de instrucción informativa o de educación formativa- los procedimientos mecánicos de producción y difusión masiva son capaces de modificar costumbres, criterios morales y normas de conducta. En ese punto radica, para Rest -y esta es una de sus obsesiones temáticas fundamentales-, tanto su potencia como su peligrosidad: siguiendo ejemplos de la literatura, el cinematógrafo y la televisión, Rest ratifica sus temores de que los medios masivos de comunicación y difusión cultural pueden ser empleados en una táctica demagógica, espuriamente interesada en fortalecer el instinto de rebaño con el objeto de facilitar la «captación de masas»y hacer posible la instauración de regímenes populistas totalitarios (de diversa ideología).

Desde una perspectiva socialista liberal, Rest sabe que en las sociedades elitistas y articuladas alrededor del Estado es determinante la forma en que se gesta la producción ideológica y 
cultural en y desde la sociedad y la que se impone en y desde el Estado. Sabe que entre una y otra se juegan dos matices bien diferentes de acción política. Eso es lo que en términos generales lo enfrenta al peronismo, con quien comparte no obstante el rechazo por una estructura social como la heredada del sistema oligárquico, cerrada por completo a la participación de las masas en las decisiones políticas y culturales. Mientras el paternalismo populista que reviste el peronismo piensa y dispone del Estado como una gestión de asistencia a las masas, el socialismo liberal desde el que Rest elabora su punto de vista es, al contrario, un movimiento ascendente, de abajo hacia arriba, que supone una reestructuración radical del Estado y de la sociedad toda. En ese sentido, tal y como explica Portantiero, el populismo -entendido como una ideología y una práctica política- se revela como un principio articulador de demandas explícitamente opuesto al del socialismo. El populismo, como modelo de organización social y estatal, coloca la elaboración de una política de masas en un plano endógeno, recuperando la memoria histórica colectiva capaz de fusionar, como mito, demandas de clase, de nación y de ciudadanía en un movimiento que recoge la herencia paternalista y caudillista de la política tradicional, que pone la asistencia en lugar de la reivindicación y neutraliza la conciencia que precede a la lucha de clases. De alguna manera, Rest intuye que el éxito y la perpetuación del populismo por sobre el socialismo radica en un falseo estratégico que consiste -como bien percibe Portatiero- en «elaborar "desde arriba" lo "nacional popular", fusionando la cultura de masas con 
la política moderna; tradición con innovación» (Portantiero 1988: $132-133)$

Al resumir las "Consecuencias estéticas de la difusión mecanizada", Rest subraya la seriedad y las dificultades que el problema entraña en virtud a su excesiva extensión y a la variedad disciplinaria que compromete su estudio. En cualquier caso, el crítico deja en claro que, así como todos los productos culturales elaborados por la tecnología moderna (desde una silla a un automóvil) cuentan con algún valor estético, también sus complejos mecanismos operan al interior del campo artístico tradicional. Lo hacen fundamentalmente de dos maneras: en tanto su repercusión modifica en efecto la actividad creadora del artista y en tanto su intervención permite difundir las obras ya existentes en espacios antes impensados. Esto último, facilita que «toda persona medianamente interesada en las artes, con escaso esfuerzo y sin grandes desembolsos, tenga acceso directo a una vasta congregación de materiales»; y, en consecuencia, hace posible al mismo tiempo una apertura significativa a un grado de conocimiento y comparación tal que -en el vaticinio restiano- «se halla en condiciones de provocar un cambio sin precedentes en la sensibilidad estética» (1961a: 329).

Luego de un recorrido por los avances tecnológicos en materia de soporte y reproductibilidad técnica, Rest acepta la idea de que el "museo imaginario" supone una mayor y mejor accesibilidad al caudal de las obras de arte tradicionales; pero -en una advertencia que recuerda a la melancolía benjaminiana en torno a la pérdida del aura- advierte también que, en esencia, «toda 
reproducción sólo nos transmite la obra en la medida forzosamente imperfecta en que ésta ha podido ser trasladada más allá de su presencia efectiva» (1961a: 331). Y al enfrentar el interrogante acerca de si el propio dispositivo tecnológico puede ser considerado un ámbito artístico independiente -haciendo coincidir realmente el medio y el mensaje-, Rest sostiene que, para que eso sea factible, el dispositivo tecnológico debe responder a las propias «exigencias indispensables» de todo objeto estético: debe alcanzar por sí mismo el grado de «autonomía, unidad formal perfecta y trascendencia significativa» (1961a: 329) que hace a la auténtica obra de arte. Tras un largo recorrido por las producciones de Sergei Einsenstein, Alain Resnais, Jean Renoir, Ingmar Bergman, Robert Bresson y Michelangelo Antonioni, llega a la conclusión de que sólo el cine ha conseguido establecerse dentro de estos exigentes parámetros, al punto de que ha conseguido «examinar -con firmeza pero sin crueldad- las evasivas y las búsquedas de una sociedad perpleja y desarraigada» (1961a: 335) .

En las "Conclusiones" del trabajo, Rest se distancia equidistantemente de los apocalípticos (que ven sólo los signos negativos de avance de la tecnología sobre el ámbito de la cultura y las artes) y de los voluntaristas (que sólo ven los signos positivos y que interpretan todos los cambios como necesarios en función de una idea impoluta de progreso). Si es cierto que la modernidad atraviesa una etapa de crisis, es claro que no se sale de ella con una posición reaccionaria y poco realista que pretenda abstraer el ámbito de lo estético fuera de 
las transformaciones sociales y tecnológicas, pero tampoco se puede augurar una salida deseable de esa coyuntura crítica abandonándose a una disposición complaciente y resignada a cualquier tipo de cambio. La crisis es reconocida siempre en términos cosmopolitas: no se restringe a la modernidad periférica sino a la "cultura occidental" misma. ${ }^{152}$ Los cambios ocasionados por los modos de producción modernos, sostenidos en el avance tecnológico, son los que -apunta Rest- han «modificado totalmente las condiciones de nuestra vida», han acotado las distancias temporales y espaciales y han usuprimido barreras nacionales y culturales» (1961a: 336).

Que esas transformaciones hayan producido cambios positivos en el desarrollo de las artes desde los hallazgos creativos del grupo Bauhaus a la música experimental de Alois Hába y Pierre Boulez, no lo exime de presentar su grado de peligrosidad con relación a su poder de atracción sobre las masas. El cine, la radio, la televisión y la prensa no son en sí mismos peligrosos, pero tampoco están exentos de serlo; lo que determina sus efectos positivos o negativos -dice Rest siguiendo los términos acuñados por Hoggart- son sus usos. El hecho de que estos usos estén ligados a capitales concentrados, recursos económicos que «están

\footnotetext{
152 La idea de "cultura occidental" con que trabaja Rest es la que se respira en las páginas de Imago mundi y que su director, José Luis Romero, define como «una concepción del mundo y la vida que se expresa en infinidad de formas y que tuvo origen localizado en cierto ámbito territorial y por obra de determinados grupos sociales. Por algún tiempo sólo allí se desarrolló y por obra de esos grupos; su tendencia fue más bien a acentuar las diferencias con las culturas vecinas y a circunscribir el ámbito de su desenvolvimiento. Pero a partir de cierto momento, la cultura occidental se torna expansiva y sus portadores comienzan a difundirla más allá de las fronteras dentro de las que se había originado, y con tanta ilusión que pareció justificarse la ilusión de que se había tornado universal» (Romero 1953: 8-9).
} 
en manos del Estado, de las grandes empresas comerciales o de ciertas instituciones inspiradas en propósitos de hegemonía ideológica», representa para Rest el origen de su peligrosidad, ya que potencialmente pueden convertirse en «útiles herramientas para quienes desean orientar la opinión pública de buena o mala fe, con fanatismo o espíritu comprensivo» (1961a: 336). Desde su socialismo liberal y democrático, Rest afirma, con cierto aire de denuncia muy poco frecuente en sus escritos: «grupos sumamente poderosos están en condiciones de interferir con armas más arteras y eficientes que la mera violencia física». En su perspectiva, las «tácticas publicitarias» restringen la independencia intelectual, regimentan el pensamiento y regulan las actitudes colectivas; y en consecuencia, son capaces de establecer «un logrado índice de dominio sobre la comunidad» (1961a: 337). En este punto anidan las reticencias de quienes señala confesionalmente Rest- «hemos sido educados en las concepciones modernas basadas en la democracia y en la creencia de que la libertad y el bienestar de cada hombre constituyen el fin supremo a que debe aspirar la acción colectiva» (1961a: 337). Y en este punto también abriga su esperanza en la posibilidad «acaso utópica»- de que «una adecuada socialización de estos mecanismos difusores conduzca a una acción pedagógica más racional» capaz de «elevar el nivel cultural de la colectividad en su índice medio» (1961a: 337).

Las «posibilidades creadoras» y los «riesgos intelectuales» que la difusión mecánica trae aparejados confirman la «ambigüedad de la situación» que el trabajo de Rest se propone describir. El 
augurio de un futuro en que «la cultura íntegra acabará por reordenarse de una manera revolucionaria» se superpone con la eventual amenaza que motiva el desconcierto y la alarma. El vaticinio de una total y armoniosa articulación de los elementos tecnológicos en el campo estético aparece supeditado a que sea posible evitar el uso de la tecnología con fines espurios y demagógicos, esto es, con el propósito de «estimular la pereza mental y de anular por completo la función individualizadora del pensamiento» (1961a: 338) .

"Alcances literarios de una dicotomía cultural contemporánea" (1965b) ${ }^{153}$, aparecido originalmente en el número 19 de la Revista de la Universidad de La Plata, y republicado dos años después con leves ampliaciones- bajo el título de Literatura y cultura de masas (1967a)"154, sigue la línea de "Situación del arte en la era tecnológica" (1961a). Huelga decir que su tema específico es la dicotomía "Cultura de masas vs. Cultura de élite". Un dato importante se desprende del hecho de que la totalidad de la revista dirigida por Noel H. Sbarra esté dedicada a los efectos y relaciones producidos por la vigencia de esa dicotomía. El tema está definitivamente instalado como discusión necesaria y potente en el campo intelectual. Junto al texto de Rest aparecen textos de N. Rodríguez Bustamante, Ernesto Epstein, Jorge Romero Brest, Gregorio Weinberg, Nicolás Babini, Juan Carlos Gené, Edmundo E. Eichelbaum, Tulio Fornari y Horacio J. Pereyra. En el propio

153 Rest, J., "Alcances literarios de una dicotomía cultural contemporánea" (1965b), en Revista de la Universidad de La Plata, 19, La Plata. pp. 23-52. 154 Rest, J., Literatura y cultura de masas (1967a). Buenos Aires: Centro Editor de América Latina. 
texto introductorio, firmado por sbarra, se declara que las interrogaciones y los enfoques que reúne el volumen «se formulan sobre una realidad concreta del mundo contemporáneo» (Sbarra 1965: 6). Los ámbitos diversos que abarca el volumen comprometen varios aspectos de las múltiples aristas en que puede recorrerse la cuestión. La música, el teatro, el cine, la publicidad, la producción y el consumo son algunos de esos aspectos.

En su actitud panorámica, el texto de Rest toca casi todas estas aristas. Pero, a diferencia de lo que ocurre en "Situación del arte en la era tecnológica" (1961a), donde el tono era moderado y exploratorio, en este caso, la toma de posición en favor de la cultura de masas es más decidida, acaso -como apunta Pesce- en razón de que se trata de un debate que «prácticamente ya ha terminado por instalarse», con colocaciones definidas ideológicamente. En un tiro por elevación a las posiciones conservadoras, que suponen que el destino de la Cultura depende de la guarda de una élite ilustrada, Rest despacha con cierta ironía los diagnósticos de Ortega y Gasset en La rebelión de las masas y de F. R. Leavis en Mass civilization and minority culture, ambos publicados en 1930. Opta por relativizar la gravedad de las versiones "apocalípticas" con referencia a las relaciones entre literatura y cultura de masas, y se opone drásticamente a las posiciones que se sostienen en una opción elitista. En su perspectiva, el origen del fenómeno denominado "cultura de masas" -por oposición a "cultura elevada" o clásicaradica en la acción convergente de diversos factores: 1) «el impacto de la mecanización originada por el avance científico- 
tecnológico» (cuyo influjo va de lo específicamente industrial a lo social en general); 2) el «desarrollo de sistemas para intensificar la producción y comercialización a gran escala de objetos manufacturados» (lo que incluye las necesarias estrategias propagandísticas para estimular el consumol; y 3) el «surgimiento de un vasto mercado consumidor» de artefactos, objetos culturales, ideas y programas políticos. Pero el principal denominador de estas transformaciones sociales radica para Rest- en la «marea de democratización», cuya «consecuencia más significativa» es concretamente «el acceso de los estratos más nutridos de la comunidad a beneficios que anteriormente se reservaban para círculos egregios» (1965b: 25). Como se ve a lo largo del trabajo, la ambigüedad empieza a resolverse. No es que Rest desconozca ahora los riesgos y aspectos negativos de la masificación, sino que sobre ellos se impone la necesidad de «reconocer los derechos de los sectores mayoritarios, con anterioridad marginados», a los efectos de favorecer «una estructuración más justa de la sociedad y una distribución más equitativa del bienestar» (1965b: 25) .

El acento del análisis restiano está, en efecto, estrictamente puesto en el concepto de democratización. La elección no es azarosa. Ese es el concepto sobre el que los adversarios de la "cultura de masas" evitan prolijamente pronunciarse «ya sea por inadvertencia o con plena intención, a fin de ocultar ante sí mismos y ante los demás las implicaciones político-sociales conservadoras y clasistas de su actitud» (1965b: 25). Luego de considerar argumentos de David Manning 
White y del propio Hoggart, se inclina por apoyarse en las conclusiones de Culture and Society: 1780-1950 de Raymond Williams para sostener que la aparente inestabilidad de la época nace del «desconcierto de la "pretérita clase ociosa", asediada por una "nueva fuerza social" que le arrebata el gobierno de la cultura y que se proyecta hacia el porvenir como posible vehículo de una socialización» (1965b: 27) .

Rest toma concreta distancia de las visiones pesimistas del porvenir cultural planteadas por críticos como Dwight MacDonald y Bernard Rosenberg. Su punto de vista coincide -desde una perspectiva menos alarmista y menos maniquea- con las críticas desarrolladas por D. W. Brogan, Jacques Barzun y Daniel Bell. Ilustra con casos concretos los hallazgos y contribuciones de los géneros "menores", desarrollados paralelamente al propio desarrollo de los medios masivos en que se reproducen: el cine de Antonioni, Einsenstein y Orson Welles; los teleteatros de Paddy Chayevsky; las historietas o "tiras cómicas" de Chic Young, Charles M. Schulz, Quino o Jules Feiffer (donde con un humor corrosivo «se enjuician los aspectos más problemáticos de la actualidad política, social y cultural»); la science fiction de Jules Verne, H. G. Wells, C. S. Lewis O Ray Bradbury; y el "género policial" desde G. K. Chesterton, E. C. Bentley y Dorothy Sayers a Dashiell Hammett, Peter Cheney, Ian Fleming, Mickey Spillane, Eric Ambler o James Cain (1965b: 36-41).

Luego de descartar, mediante un largo y minucioso análisis, los «presuntos aspectos negativos» de la cultura de masas, Rest se plantea el problema de la relación entre el intelectual 
formado en pensamiento humanístico y las nuevas y complejas producciones de la cultura de masas. Contra todas las miradas nostálgicas y conservadoras, pero sin olvidar que la "cultura de masas" está sin duda «ligada a circunstancias aciagas» (una «nivelación comparativamente rastrera del gusto», una serie de «tácticas amenazadoras utilizadas para controlar la opinión», a los usos de «una fascinación psicológica aborrecible», «a la pereza mental de quienes son incapaces de pensar por cuenta propia»y, finalmente, a «procesos de diversa índole -desde técnico-científicos hasta políticos- que a la larga suponen una merma de la libertad individual»), Rest plantea una defensa de la "cultura de masas" bajo el argumento de que ella es capaz de producir un crecimiento en los «índices de bienestar colectivo» (1965b: 49). Se pregunta -no sin cierta ironía- si el rechazo de la "cultura de masas" de las "minorías selectas" y "egregias" no es realmente una postura que «supone un pesimismo sin atenuantes» tras el cual se oculta una deliberada voluntad de «mantener la mirada fija en el pasado» con «un consciente propósito de alienación» (1965b: 49). Rest percibe con lucidez que la negativa a inteligir y a comprender los aspectos democratizadores del proceso es intencional: «es un esfuerzo destinado a recuperar por contraste la condición de élite por el mero hecho de "ser diferente" (para lo cual se acude al argumento de que el futuro no puede abrigar posibilidades o esperanzas)» (1965b: 49-50) .

La resistencia a la democratización es pues ideológica. Como apunta Charles Percy Snow, los humanistas «se resisten a admitir el cambio en nombre de un legado cultural que consideran 
perjudicado» $y$ en nombre del cual ellos mismos «justifican su función y su lugar privilegiado». ${ }^{155}$ Esto no implica, sin embargo, la caducidad de la actividad humanista; sino más bien todo lo contrario: en una sociedad signada por la presencia y la incidencia activa de «la ciencia y la técnica -recursos neutrales que indistintamente pueden utilizarse con buenos 0 malos propósitos- es fundamental la cooperación humanística a fin de conformar un hombre moralmente capacitado en el empleo de estos instrumentos» (1965b: 50).

Rest concibe la legitimidad de la "cultura de masas" como respuesta social concreta a un campo estético que cada vez más deliberadamente elige su público en un contexto de formación profesional. Su propia concepción liberal y progresista del humanismo -no como «un legado estático» sino como «un comportamiento dinámico»- lo obliga a oponerse a toda actitud evasiva. Ese humanismo es -apunta- «una posición de compromiso y lucha que se ha caracterizado por la participación activa del intelectual en los problemas de su tiempo» (1965b: 51). Esta frase, que declara su referencia sartreana, aparece particularmente ilustrada por Rest con las Mythologies de Roland Barthes. Eso no es casual. Rest ejemplifica la función intelectual a partir de un compromiso específico con una práctica que deliberadamente aborda -con «lucidez y sensibilidad crítica»«el estudio de la mecánica literaria que es propia a la "cultura de masas"» (1965b: 51). El intelectual humanista en que piensa Rest es «un hombre de su tiempo». Incide sobre él abordando

155 Snow, C. P., The Two Cultures, London, Cambridge University Press, 1959. 
críticamente -desde el espacio de saber específico de su formación- las cuestiones problemáticas de su época, sin cuidarse de «conservar las "manos limpias", para convertirse en un "bienpensante", para excluirse del momento actual y de las responsabilidades sociales que presuntamente entraña la condición intelectual» (1965b: 52).

Muchos de sus trabajos dedicados a producciones de la "cultura de masas" se inscriben en esta perspectiva éticopolítica. Sus incursiones críticas por casos concretos de géneros "menores" y "literaturas marginales" y que van de los cancioneros populares ${ }^{156}$ y el cine comercial ${ }^{157}$ a la literatura infantil ${ }^{158}$, de la literatura rosa (estudiada especialmente por Virginia Erhart) ${ }^{159}$ a la de literatura de terror ${ }^{160}$, de la ficción científica a las utopías de anticipación ${ }^{161}$, de la literatura policial ${ }^{162}$ a la novela gótica ${ }^{163}$, y de la historieta ${ }^{164}$ a la literatura erótica ${ }^{165}$, dejan ver el rigor, la severidad y el

156 Cfr. Rest, J., Notas para una estilística del arrabal (1965a). Buenos Aires, Servicio de Extensión Cultural de la Dirección General de obra Social de la Secretaría de Estado de Obras Públicas.

157 Cfr. Rest, J., "Ingmar Bergman: presencia humana y dimensión imaginaria del cine sueco" (1957d), en Sur, $\mathrm{n}^{\circ}$ 246, Buenos Aires, mayo/junio. pp. 8089 .

158 Cfr. Rest, J., "Sobre las hadas; ensayos de literatura infantil" (1960d), en Sur $n^{\circ}$ 263, Bs. As., mar/abr. pp. 62-64.

159 Cfr. Erhart, V., "Corín Tellado: la cenicienta en la sociedad de consumo", en Crisis XIV, Buenos Aires, 1974.

160 Cfr. Rest, J., "Prólogo a Carmilla y otras alucinaciones" (1975c), en J. Sheridan Le Fanú, Carmilla y otras alucinaciones, Buenos Aires: Ediciones Librerías Fausto. Trad. Virginia Erhart y Jaime Rest.

161 Cfr. Rest, J., "Zamiatin y sus herederos ingleses" (1978b), Mundos de la imaginación, Caracas, Monte Ávila. pp. 193-210.

162 Cfr. Rest, J., "Diagnóstico de la novela policial" (1974a), en Crisis, $\mathrm{XV}$, Buenos Aires. pp. 30-39.

${ }_{163}$ Cfr. Rest, J., "Introducción a El monje" (1975d), en Matthew G. Lewis, El monje, Buenos Aires, Ediciones Librerías Fausto.

164 Cfr. Rest, J., "Jules Feiffer: un Aristófanes de la sociedad de consumo" (1979k), en Punto de vista, año II/ $N^{\circ}$ 7/ Buenos Aires, noviembre. pp. 2829.

165 Cfr. la primera parte de Rest, J., Tres autores prohibidos y otros 
compromiso con ese imaginario del intelectual en la materia misma de su trabajo.

En Notas para una estilística del arrabal (1965a) ${ }^{166}$, por ejemplo, donde hace foco en las relaciones entre la lírica del tango y lengua popular, Rest sostiene que la exploración de las relaciones entre modos de vida y formas del lenguaje puede realizarse en «los estratos más corrientes y elementales de la investigación lingüística», siguiendo «el desarrollo de las flexiones, la evolución de los valores semánticos, las insinuaciones de la etimología, el alcance de las reglas sintácticas o de los preceptos gramaticales» (1965a: 1). Pero también manifiesta su convicción en la necesidad de examinar dicha confluencia tanto «en niveles más complejos y evasivos, como la emotividad de los giros idiomáticos en sus empleos políticos, literarios o "mágicos"», como bajo la lupa de «una suerte de sociología del lenguaje» presta a advertir, en los diversos matices de esas formas lingüísticas, «distinciones de clase social o de nivel cultural» (1965a: 1). Es claro que para Rest todo estudio cultural -al trabajar él mismo sobre los usos del lenguaje- debe reconocerse, no como «una disciplina estática y anquilosada» ni como un simple «proceso de disección»; sino más bien como «el examen de un flujo dinámico», que «nutre nuestro pensamiento», «perpetúa nuestras ideas», «facilita nuestra

ensayos (1968b). Buenos Aires: Galerna. Véase además "Retrato del moralista como cínico" (1970f), en Los Libros, n 8. Bs. As., mayo de 1970. pp. 10 y 26. Y también "Estudio preliminar a El Supermacho de Alfred Jarry" (1979j), en Alfred Jarry, El Supermacho. Buenos Aires, Stilman Editores. pp. 7-26. 166 Rest, J., Notas para una estilistica del arrabal (1965a). Buenos Aires, Servicio de Extensión Cultural de la Dirección General de Obra Social de la Secretaría de Estado de Obras Públicas. 
comunicación» y llega incluso a «burlar nuestras pretensiones de gobernarlo» e incluso «a dominarnos a su arbitrio» (1965a: 2). La complejidad y la potencia de lo cultural radican en su carácter lingüístico. Los lenguajes y las formas culturales -que a veces pueden ser dúctiles y efectivas- también pueden constituir «un obstáculo en una prisión insuperable» o «un seductor tembladeral». Se desenvuelven en «un plano social y comunicativo» cuyo fundamento mismo es la «relación de los individuos o de los grupos entre sí» (1965a: 2) .

Frente a la "lengua literaria", que «tiende a uniformarse de acuerdo con regulaciones gramaticales y estéticas que la fijan dentro de cánones conservadores y la convierten en una suerte de Iingua communis» (1965a: 2), las formas culturales masivas incorporan la vitalidad de la sociedad misma en el tejido de sus lenguajes. Cuando junto a la "lengua culta" aparecen «modalidades que han surgido y se desarrollan de manera espontánea, nutridas por la atmósfera social de los estratos más vastos y típicos de la región», la intersección entre ambas formas da lugar a nuevas expresiones culturales que consiguen una potencia de aceptación masiva incuestionable.

Rest percibe con claridad que la lengua popular -su slang pero también sus argots- es gradualmente incorporada a las formas culturales. El lunfardo mismo - «jerga cerrada y de sedimentación políglota» (1965a: 3)- da pruebas fehacientes de esta potencia al ceder constantemente a la lengua popular giros o términos cuya significación se difunde masivamente; lo que lo obliga a transformarse incesantemente con el objeto de excluir y 
reemplazar aquellas formas que le fueron expropiadas. La economía política del lenguaje popular -sugiere Rest- sigue la lógica de la cultura misma. Apropiación y divulgación masiva de formas producidas tanto en espacios marginales como en los más elitizados. De ese modo crece y se estandariza cubriendo imaginativamente incluso las zonas tabuadas o transgresivas de la trama cultural -como las de la delincuencia y la sexualidad.

Rest demuestra que la «vigencia cultural» de las letras de tango de mayor llegada a las masas radica precisamente en su capacidad de articulación entre la "alta cultura" y la "cultura popular". La metafórica y sutil «incidencia de influjos cultos»y la insistente estetización de los «lenguajes marginales» producen esa forma cultural citadina, que ha sido -como bien apunta el crítico- capaz de estimular tanto «la reflexión sociológica» como la «inquisición filológica». Los abordajes poéticos de Jorge Luis Borges, Julio Cortázar o Daniel Devoto, y los "metafísicos" de Ezequiel Martínez Estrada, suponen -para Rest- exámenes parciales que sólo pueden ser completados en una exploración transversal y multidisciplinaria del fenómeno. La «indagación estética de las letras de tango» supone pues una evaluación de sus formas en relación a la tradición poética de la "alta cultura" -como la que el propio Rest desarrolla al poner en evidencia «la prosapia culta» de las populares letras de Homero Manzi- y, al mismo tiempo, supone reconocer sus inflexiones particulares con relación a formas lingüísticas marginales sobre las que se erige su emotividad poética y su efectiva vigencia cultural.

Rest se interesa especialmente por esta ambivalencia 
intrínseca a las formas culturales masivas. Reconoce en la «metáfora» un mecanismo fundamental para «el desenvolvimiento y en la expresividad del lenguaje popular», ya que -como apunta el teórico alemán Wolfgang Kayser- su carácter eminentemente activo permite una ampliación constante de la potencia de significación. Lo que la metáfora nos revela -cita Rest- es «que las palabras no sólo poseen significado propio sino energías sugestivas, valores sociales, ideas secundarias de todo género» (1965a: 6). En la metáfora hay un desplazamiento, una forma de violencia verbal que se torna productiva. Es en esos desplazamientos y en esas violaciones a la norma lingüística donde se produce ese «seductor tembladeral» del que nace la poesía.

En el intento por expresar tanto la complejidad como la sutileza de las emociones, el poeta «debe violentar o transfigurar la lógica idiomática, a fin de exigir a las palabras la intensidad que sólo es propia de la poesía» (1965a: 4). En este sentido es que Rest ratifica el valor de la producción literaria de John Lennon, como producción cultural definida entre la literatura del absurdo y la comicidad. Así como en la «estilística del arrabal» planteaba conexiones entre el tango de Manzi y la poética de François Villon -no por obra de una improbable intertextualidad sino por el reconocimiento de operaciones poéticas similares-, en la realmente singular "Inadvertencia preliminar"167 a su traducción de John Lennon in his own write (1964), aparecida en 1967 bajo el título de John

167 Rest, J., "Inadvertencia preliminar" (1967d), John Lennon en su tinta (Traducción, prólogo y notas de Jaime Rest), Buenos Aires, Bocarte. pp. 1318 . 
Lennon en su tinta, Rest inscribe la producción poética lenonniana en la tradición de una de «las corrientes más auténticas y elementales» de la literatura de lengua inglesa. Siguiendo a Christiane Rochefort y Rachel Mizrahi -los traductores de la obra al francés- declara que lo que su traducción proporciona es «un libro vagamente sugerido por otro que algo tiene que ver con la lengua inglesa» e inscribe su prosapia en «aquella literatura que cultiva el absurdo y que ha llegado a constituir un género propio denominado nonsense» (1967d: 14).

A juicio de Rest, los textos de Lennon constituyen un nuevo avatar poético en esa corriente singular en que el absurdo se alimenta eficazmente de «una elevada proporción de sugestión semántica, porque sus palabras, frases y meras conexiones lingüísticas aparentemente (cf. Freud) causales están impregnadas de sentido» (1967d: 14). En esa inscripción radica pues su dimensión crítica, puesto que con ese vocablo inglés -escribirá Rest en Conceptos de literatura moderna- se designa a los «enunciados carentes de sentido o reveladores de una índole absurda que parece negar los principios lógicos, el empleo significativo de las palabras o el propósito socialmente comunicativo del lenguaje» (1979a: 95). Se trata -agrega el crítico- de una tendencia que durante mucho tiempo se juzgó como «un área menor y disparatada de la actividad artística» que «un conjunto de fenómenos literario y extraliterarios ha venido a reivindicar sus alcances» en su capacidad desautomatizadora, su potencia para romper con la naturalización de «experiencias cuyo 
reconocimiento explícito habitualmente fue reprimido o disimulado de manera deliberada o inadvertida» (1979a: 96).

Pero eso no es todo. Tras la referencia vaga a «algún crítico inglés, en un periódico literario londinense», Rest describe el procedimiento literario de Lennon como «un nuevo intento de "joycear" el lenguaje» (1967d: 15). El carácter activo y creativo de la experimentación joyceana de Ulysses y Finnegans Wake está puesto en su deliberada intención de explorar abiertamente «no lo que el lenguaje es sino lo que puede ser». Esa misma pulsión poética reaparece, a juicio de Rest, en los escritos de Lennon -y en su «propósito manifiesto» de «aprovechar la comicidad del absurdo» (1967d: 13)- de manera tal que el crítico no duda en traer a colación a «Lewis Carroll (con sus portmanteau words que "reúnen dos significados en una sola palabra") 》 y a «Edward Lear (con su superabundancia de limericks incluidos en su célebre Book of Nonsense)» (1967: 15), como distingudos precursores de esta poética popular.

Aprovechando la referencia a Joyce, Rest cita a Borges con el objeto de plantear las dificultades intrínsecas a toda traducción del inglés que se estime realizar sobre el texto original de una literatura de corte experimental: «la lengua inglesa posee abundancia de palabras monosilábicas y cuenta con un eficaz mecanismo de composición verbal que permiten crear nuevos vocablos sintéticos carentes de toda artificialidad» (1967d: 16). Pero no se queda allí. Se ve obligado además a subrayar una nueva circunstancia particular que tiene que ver precisamente con el fundamento crítico de la poética lennoniana. Escribe Rest: 
«Quienes hayan escuchado a los Beatles -personalmente, en el cine - en grabación fonográfica- recordarán sus peculiaridades fonéticas, propias del lenguaje popular inglés»; todo lo contrario del «lenguaje culto» que «tiende a oscurecer los sonidos (sobre todo los vocálicos)». En virtud de esto que acontece en el registro de la oralidad es muy difícil -apunta el traductor- reproducir el «burlesco tono crítico» de muchas de las composiciones de Lennon respecto del «lenguaje de kis betters, de los snobs, de los locutores de la BBC, de los oxonienses, del queen's English» (1967d: 16).

Rest subraya muy especialmente la coincidencia de estas operaciones paródicas en el plano lingüístico y las caricaturizaciones de los referentes culturales de la poesía de Lennon. Las múltiples referencias a hechos, circunstancias o personajes conocidos en el espectro cultural inglés son repuestos por Rest en unas atentas notas que devuelven el carácter socialmente crítico del texto poético (el crecimiento de la densidad de población negra de origen colonial en la metrópolis inglesa y los consecuentes conflictos raciales, las pujas políticas, la creciente influencia ejercida por los sindicatos y otras formas de organización obrera y popular). Pero, al mismo tiempo, una mirada tenaz sobre los textos mismos repone la presencia de una parodia meditada de composiciones poéticas clásicas («algo de Shakespeare, mucho de Wordsworth») y la deliberada experimentación sobre formas lingüísticas estandarizadas -a través de pasajes que «deforman frases hechas o giros muy frecuentes en Inglaterra cuyo valor literal sorprende 
porque ha quedado oculto tras el sentido metafórico habitual» (1967d: 17). Como mucho de la producción cultural masiva, la poética de Lennon es más compleja de lo que aparenta.

La eventualidad de que Samuel Beckett saludara calurosamente estos textos de Lennon, abre a Rest la posibilidad de situar los textos de este último en el contexto de un fin de ciclo en que «el estancamiento de esquemas de conducta y personalidad» ha perdido tanta fuerza y significación como el lenguaje mismo. En ese contexto, «la confusión del significado se torna directamente proporcional a la búsqueda desesperada de una expresión inteligible» (1967d: 17-18). La conclusión de Rest es casi de corte borgeano. El lenguaje ha perdido toda inocencia. Es un instrumento maleable con diferentes fines; pero es también ese mecanismo que nos manipula al disponer la sintaxis de la realidad misma, puesto que evidentemente «somos incapaces de construir una realidad coherente que estemos en condiciones de gobernar y expresar» (1967d: 18). La «intensidad agresiva» que exhiben los poemas de Lennon en su superficie, no es la de la denuncia (que amanece en Shaw y en Brecht), sino más bien la de la burla lúdica; sin embargo, viene risueñamente a subrayar un aspecto trágico y fundamental de la condición moderna: que «nuestras propias palabras -escribe Rest- se han tornado abstractas o vacías, al punto en que hablamos sin decir nada» (1967d: 18).

El hecho de que Rest decida examinar particularmente las producciones de la cultura popular -en lugar de leerla sólo a través de grandes grupos genéricos para generalizar más eficazmente sus apreciaciones- no es un dato menor. Al contrario: 
habla a las claras de su interés genuino por estas manifestaciones culturales. Lúcida y generosamente, su posición se superpone en este punto con la de Richard Hoggart, quien en referencia a tales manifestaciones no ha dudado en sostener que «si simplificamos excesivamente sus relaciones con la sociedad, no logramos ver lo que esas expresiones tienen para decir sobre la naturaleza de la cultura y la sociedad» (Hoggart 1974: 191) ${ }^{168}$. Semejante actitud de apertura, que busca incorporar las transformaciones genéricas y estéticas en la producción cultural, se expresará aun -como se verá más adelante- tanto en "Las literaturas marginales" (1972b) ${ }^{169}$ como en el generoso Conceptos de literatura moderna $(1979 a)^{170}$. Allí Rest trabajará con un concepto abierto de literatura e incorporará en su amplio espectro un léxico sobre conceptos literarios y culturales que incluye temas y aspectos no siempre considerados en su importancia real como los que comprometen a la literatura marginal, las pautas de lectura, la literatura popular, la cultura de masas y los medios de comunicación. Esos aspectos aparecerán en Rest rigurosamente elaborados y convertidos en artículos específicos, ligados a conceptos teóricos como "Ciencia Ficción", "Costumbrismo", "Narrativa detectivesca", "Fábula", "Literatura Fantástica", "Floklore", "Humor", "Lectura" y "Marginalidad". Y es al interior de estos dos textos donde Rest

168 Hoggart, R., "Los estudios culturales contemporáneos: literatura y sociedad", en Bradbury, M. y D. Palmer, Crítica contemporánea, Madrid, Cátedra, 1974. pp. 187-208.

169 Rest, J., "Las literaturas marginales" (1972b), Capítulo. La historia de la literatura mundial, 2, Buenos Aires: Centro Editor de América Latina.

170 Rest, J., Conceptos de literatura moderna (1979a). Buenos Aires: Centro Editor de América Latina. 
puntualiza además las dificultades involucradas en la definición misma del concepto de "marginalidad", sobre todo al señalar la necesidad de desarrollar análisis más integrales y menos prejuiciosos de los géneros y las obras incluidos en ese campo.

En estas y otras intervenciones posteriores, Rest trabajará sobre una inversión de la hipótesis adorniana según la cual el arte moderno fue una reacción estratégica al surgimiento y el avance de la cultura de masas. En su óptica, la cultura de masas -en su condición estrictamente popular- nace como respuesta a un campo estético que se vuelve cada vez más excluyente, más "selecto" y más exigente en términos de competencia específica. Cuanto la literatura moderna más se interna en la anomalía, en la disonancia y en la abstracción autorreferencial, más las formas de la cultura de masas se legitiman por la aceptación popular. A medida que las obras de arte se separan de cualquier forma de sociabilidad y voluntad comunicativa, la cultura popular crece, se desarrolla materialmente y se apropia de formas nuevas. Cuanto más las obras modernas enrarecen sus texturas, trastornan sus sintaxis, fragmentan su visión y pulverizan el significado, más las obras de la cultura de masas «sellan su pacto con las clases populares». Esas obras «hablan su idioma», «tocan sus problemáticas sociales» O «sencillamente entretienen» (1972b: 8). En función de ello, Rest se empeña en señalar, para cada caso, los antecedentes de esas "nuevas" formas culturales en el corazón de la tradición y la "alta cultura": para la "ciencia ficción", el Frankestein de Mary Shelley; para la narrativa policial, la novela romántica; para la literatura infantil, las obras de 
Swift, los hermanos Grimm y Carroll, y así sucesivamente. Pero la mirada de Rest no es por ello ingenua. Los límites críticos de las producciones culturales masivas están específicamente condicionados por los medios masivos que las producen y reproducen. La cultura de masas introduce el proceso de intercambio y mecanización que rige el sistema capitalista en la esfera misma del entretenimiento popular. Es por eso que, cuando ensaya sus estudios en casos específicos de la "cultura de masas", las "literaturas de consumo" y las "literaturas marginales", Rest siempre lo hace contemplando especialmente los aspectos sociológicos e ideológicos del problema. Reconoce los valores positivos y los peligros que entraña este tipo de formación cultural: sabe que ella misma corre el riesgo de ser reducida a un sutil instrumento de manipulación de las masas, es decir, un nuevo engranaje en la economía política capitalista en virtud de la cual es obligada a renunciar a todo su potencial crítico. Hace especial hincapié en la iniciativa y los avances sustanciales desarrollados por «investigadores sociales, psicólogos y pedagogos» antes que de los «estudiosos de la poesía» (1979a: 85). Pero no por ello desprecia el aspecto estético. Al contrario: está convencido de que tales producciones, al ser únicamente definidas y valoradas por su marginalidad, son implícitamente condenadas y menospreciadas -en relación a un "centro" supuestamente más valioso y significativo socialmente: la Literatura con mayúsculas. Sabe que «sólo con gran resistencia y en forma bastante anárquica ha sido posible rescatar ciertos aspectos de la producción irremediablemente 
menospreciada con el calificativo de "marginal"» (1979a: 86). Pero confía, sin embargo, en su valor específico al punto de afirmar que «con el advenimiento del fenómeno llamado cultura de masas» han llegado a proliferar «especies narrativas a las que se atribuye un mero propósito de entretenimiento» que «con frecuencia exceden ese ámbito y alcanzan valores artísticos y culturales notables» (1979a: 109).

La confluencia de una mirada atenta a los aspectos sociológicos, y a la vez preocupada por la condición estética de las formas estudiadas, marca de manera singular los análisis culturales de Rest. Si aun así no consigue explorar todos los matices que las producciones de la cultura de masas exhiben, ello no se debe a sus prejuicios ni a su cerrazón metodológica, sino al hecho concreto de que las suyas son investigaciones las que empiezan a abrir un campo inexplorado $y$ de una vastedad inagotable. Es, como apunta Aníbal Ford, «un pionero» precisamente porque su trabajo pone en juego la necesidad de crear un mínimo escenario teórico-crítico pero también ético para las investigaciones posteriores.

En efecto, y como podrá claramente observarse en sus posteriores investigaciones literarias, lo cultural no será para Rest nunca un «objeto de estudio» específico, circunscripto y preconstituido; constituye, más bien, un nivel de análisis, un registro permeable, si no a la acción específica de los procesos históricos y políticos de la sociedad, al menos a ciertos aspectos de la constitución ideológica de la formación social. En consecuencia, lo cultural no serán pues los productos específicos 
sino los modos de producción, circulación y apropiación del patrimonio simbólico de la sociedad. Se trata de una renovadora dimensión de enfoque de los fenómenos que, estratégicamente, Rest incorpora a su dispositivo crítico con el objeto de habilitar en sus lecturas la posibilidad de asignar sentidos a determinados aspectos de los procesos históricos, políticos y culturales de la sociedad.

Lo cultural es en efecto, en esta perspectiva, lo que revela sintomáticamente formas de manipulación a través de la demagogia - la propaganda. Pero es también el espacio donde es dable reconocer formas genuinas de la experiencia cultural popular. Rest intuye -por su experiencia acumulada como historiador cultural- tan bien como Hoggart que el «arte de masas» es un prisma capaz de evocar momentos de crisis, establecer las claves de «una respuesta a las necesidades de cambio e innovación». Pero sabe también que puede funcionar como «catalizador o represor de deseos o miedos informes o poner en escena en un nivel -de ordinario inconscientemente- muchas de las disputas de la sociedad consigo misma» (Hoggart 1974: 195). En una palabra, lo cultural es para Rest un complejo territorio de lucha, donde se establecen tácticas y colocaciones políticas que ocurren al nivel de lo específico de la práctica crítica, en la composición, la configuración, la transformación y legitimación de sentidos que la lectura produce con relación a los fenómenos concretos de la cultura. 
APÉNDICE $\mathrm{N}^{\circ} 2$

\section{NOTAS PARA UNA ESTILÍSTICA DEL ARRABAL ${ }^{171}$}

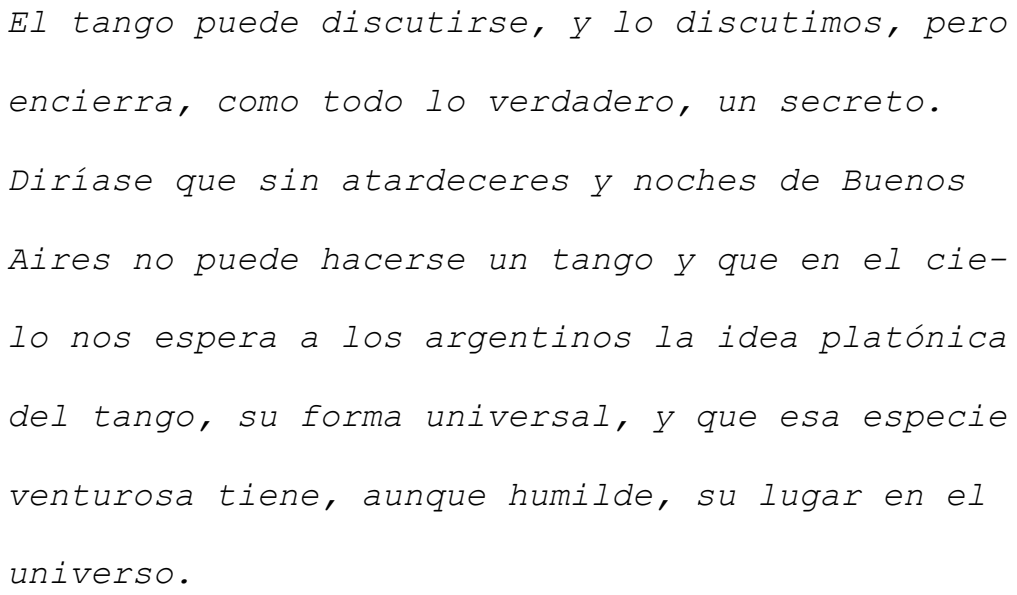

\section{Lunfardo y lenguaje popular}

En el constante comercio que desenvuelven entre sí la innumerables manifestaciones de la existencia humana, uno de los aspectos más seductores es el que abarca el influjo recíproco de las formas y los modos vitales. Tal vínculo podría explorarse en los estratos más corrientes y elementales de la investigación lingüística, como el desarrollo de las flexiones, la evolución de los valores semánticos, las insinuaciones de la etimología, el alcance de las reglas sintácticas o de los preceptos gramaticales. Pero también es posible examinar esa confluencia en niveles más complejos y evasivos, como la emotividad de los giros idiomá-

\footnotetext{
171 Notas para una estilística del arrabal (1965a). Buenos Aires: Servicio de Extensión Cultural de la Dirección General de Obra social de la Secretaría de Estado de Obras Públicas.
} 
ticos en sus empleos políticos, literarios o "mágicos". Y existe, asimismo, una suerte de sociología del lenguaje que advierte distinciones de clase social o de nivel cultural fundadas en los matices de nuestro uso verbal y que se propone evaluar los alcances de mudanzas y desenvolvimientos expresivos cuyo origen inmediato debe buscarse en ciertos fenómenos que se observan en los sectores populares de la vida ciudadana. Por consiguiente, el estudio del lenguaje no es una disciplina estática y anquilosada ni un mero proceso de disección: es el examen de un flujo dinámico que nutre nuestro pensamiento, que perpetúa nuestras ideas, que facilita nuestra comunicación, que inclusive burla nuestras pretensiones de gobernarlo y llega a dominarnos a su arbitrio. Más que un animal nacional, como supuso Aristóteles, el hombre es, como opina Ernest Cassirer, un animal lingüístico. Su conocimiento y su capacidad de concebir y de transformar el mundo se fusionan en la ductibilidad de este instrumento que permite asentar verificaciones y observaciones. Pero esa ductibilidad no es ilimitada, ni ese instrumento es completamente dócil. En ciertas ocasiones, el lenguaje se convierte en un obstáculo en una prisión insuperable; otras veces, constituye un seductor tembladeral; y en algunas oportunidades, para expresar la complejidad o la sutileza de las emociones, debemos violentar o transfigurar la lógica idiomática, a fin de exigir a las palabras la intensidad que sólo es propia de la poesía. El estudio del lenguaje tiene mil facetas de increíble variedad; el fenómeno verbal entraña un milagro en el que se conjugan múltiples circunstancias e incontables requerimientos. La existencia humana se desenvuelve en un plano social y co- 
municativo que se fundamenta en la relación de los individuos o de los grupos entre sí. Este lazo de unión entre los hombres lo aporta el lenguaje, de modo que nuestro universo íntegro se afirma, primordialmente, en bases de orden verbal. Las formas esenciales de nuestra existencia se identifica con el habla: ante todo, somos seres capaces de expresarnos por medio de la palabra.

En esta estrecha vinculación del habla con la vida, se observa en las lenguas una manifiesta propensión a fragmentarse geográficamente o profesionalmente, sin por ello perder la total unidad espiritual que las caracteriza; surgen así los dialectos y las expresiones argóticas. La lengua literaria tiende a uniformarse de acuerdo con regulaciones gramaticales y estéticas que la fijan dentro de cánones conservadores y la convierten e una suerte de lingua communis. Pero en el área lingüistica de todo idioma se advierte una tendencia del habla a fraccionarse en jergas especializadas o en dialectos locales de uso habitual y popular. Juntamente con la lengua culta, existen modalidades que han surgido y se desarrollan de manera espontánea, nutridas por la atmósfera social de los estratos más vastos y típicos de la región. Generalmente, estas formas locales del lenguaje son muy emotivas y de gran colorido. Casi siempre, esta lengua popular se halla en estrecho contacto con otro vocabulario singular, que es el lenguaje de los maleantes. No obstante, en los grandes centros urbanos -donde el hampa se desarrolla con vitalidad y donde se producen mezclas bastante complejas de hablantes que proceden de distintas zonas dialectales o de países que emplean distintos idiomas- la diferencia entre lenguaje popular y lenguaje delictivo se 
halla claramente trazada. En Londres, por ejemplo, se distingue entre slang, o lengua coloquial de carácter vulgar, y cant, o jerga secreta del hampa. De igual manera, el francés parisino tiene su langage populaire y su argot. El argot es una lengua artificial creada con el solo objeto de que únicamente pueda entenderla un determinado círculo de personas; en cambio, el langage populaire reúne las formas idiomáticas usadas corrientemente en la conversación diaria. En Madrid, se diferencia el caló, o jerga del populacho, de la germanía, o lenguaje delictivo. En Buenos Aires existe, asimismo, un habla arrabalera, usada por los estratos populares y suburbanos de la ciudad, y u lenguaje lunfardo, característico de la truhanería. El lunfardo es una jerga cerrada y de sedimentación políglota. Como muestra, tomemos un ejemplo propuesto por José Edmundo Clemente, autorizado investigador de las modalidades lingüísticas porteñas. Sea la frase: "Dequera, la yuta". Este giro, alguna vez empleado por los maleantes, traspuesto al lenguaje corriente significa: "Cuidado, la policía". Dequera es una deformación del inglés take care, "cuidarse"; yuta es síncopa de "yunta" y alude a la circunstancia de que los empleados policiales actúan en pareja. Así como términos de origen inglés, el lunfardo también incluye portuguesismos -en su mayoría procedentes del Brasil-, numerosos italianismos de aporte inmigratorio y giros de procedencia francesa, además de vocablos castellanos empleados en un sentido distinto del corriente. Esta diversidad de procedencias y esta singularidad semántica del habla delictiva tiene su explicación en el hecho de que se trata de una jerga secreta que los maleantes emplean para comunicarse entre 
sí, con el propósito de que no los entiendan quienes sean ajenos al ambiente criminal. Por lo tanto, todo giro o término lunfardo cuya significación se populariza deja de integrar el lenguaje del delito en razón de que ha perdido su carácter secreto. En consecuencia, el lunfardo -y todas las otras jergas de maleantestienden a transformarse constantemente con el objeto de excluir y reemplazar aquellos usos que han dejado de pertenecer en forma exclusiva a los círculos marginales de la sociedad para los que fueron originalmente acuñados. En cambio, esos giros argóticos desechados suelen incorporarse al habla popular y cotidiana.

Por su parte, el lenguaje popular es una jerga que se destaca por su carácter robusto, generalmente de intenso matiz sexual y de expresión vívida e imaginativa. En el pasado, los lexicógrafos ignoraban púdicamente este vocabulario, y aún ahora muchos investigadores tratan de soslayar su expresión franca y vigorosa. Sin embargo, es en este nivel popular donde se percibe con mayor claridad el proceso de configuración lingüística en su dinamismo creador y en su espontaneidad. Aún en sus expresiones de carácter más subido, el pueblo demuestra un natural sentido de la metáfora como acercamiento a la cálida y palpitante imagen de la realidad expresada por las palabras. Probablemente, en ese lenguaje popular, más que en cualquier forma de expresión culta o eufemística, se advierte el calor y el interés humano que entraña el estudio del habla y sus matices afectivos. De esa jerga popular -de su vocabulario, de su sintaxis y de las frases hechas que emplea emana un espíritu hondamente comunicativo, tanto en el elogio cuanto en el agravio. Por ejemplo, tal vez bastaría un solo tér- 
mino para evocar la fuerza del vocabulario porteño; es la palabra pibe, que la lengua castellana -con su innegable riqueza- sería incapaz de reemplazar satisfactoriamente porque ningún vocablo literario o culto registra esos afectivos tan simpáticos y tan profundos. Su femenino, piba, no desprovisto de un acentuado matiz sensual, expresa una ternura viril, desprovista de todo melindre. En resumen, que nuestros giros suburbanos adquieren una expresividad rica y llegan a constituir una suerte de raíz cultural cuyas palabras callejeras son, para nosotros, el reflejo fiel de cierta trascendencia metafísica que el hombre argentino percibe en la realidad substancial del mundo circundante.

Una demostración palmaria del vigor que posee nuestro lenguaje popular la hallamos ejemplificada en el empleo de metáforas. Muchas veces, la designación propia de un objeto es menos inmediata, gráfica y sensible que la designación traslaticia. Así, por ejemplo, en el habla porteña resultó mucho más vívido denominar el papel moneda por su color o por su dibujo que por su valor. Todavía se recuerdan los canarios, referidos al matiz cromático de los billetes de cien pesos, y en la actualidad el término fragata es una de las designaciones empleadas para los billetes de cien mil pesos, en razón de la imagen que los ilustra. Estas denominaciones no están exentas de cierto sentido irónico, surgido probablemente a causa del monto comparativamente abultado que tales sumas de dinero suponían para el hombre de recursos exiguos. También existen frases hechas de carácter metafórico, entre las que podrían citarse algunas de manifiesto corte turfístico, como "salir de perdedor" o "entrar no placé". En la revista poli- 
cial L.C., la sigla lunfarda de "ladrón conocido", Evaristo Carriego publicó en 1912 unas décimas que registran varios giros hípicos de arraigo popular, como: "No hay como correr parejo / Para estar bien en carrera". Y también: "Cuando uno se abre en el codo, / Ya no hay caso: ise la dan! En la campaña se emplearon numerosas frases hechas de índole metafóricas que han sido asimiladas por el vocabulario ciudadano. Eleuterio Tiscornia, en su edición de Martín Fierro de José Hernández, explica algunas. Por ejemplo, "hacerse humo", lo cual significa escapar sin dejar rastros como humo que se desvanece; "apretarse el gorro", lo que equivale echar a correr pues en tal ocasión es necesario sujetarse el sombrero con la mano para que la resistencia del aire no lo arranque de la cabeza. "Hacerse una manganeta", en el sentido de jugar una mala pasada, se origina en el empleo del lazo y alude al animal ya apresado al que se confiere cierta libertad aparente para luego reducirlo de un tirón y por sorpresa. De igual modo, el giro "tener jabón" y el más chabacano "jabonearse" tienen cabida en el Martín Fierro, I, 550: "No soy manco pa la guerra / Pero tuve mi jabón". Según apunta Tiscornia, este uso ya contaba con antecedentes españoles en el verbo jabonar con el significado de tratar mal de palabra o reprender a una persona. Giros ciudadanos como "hacer sebo" (en el sentido de haraganear), "adornar" (en el sentido de sobornar con dinero) y "apoliyar" (en el sentido de dormir) son, asimismo, metafóricos. La metáfora es uno de los mecanismos fundamentales en el desenvolvimiento y en la expresividad del lenguaje popular. No en vano, el teórico alemán Wolfgang Kayser, acreditado investigador literario, señala que 
"la metáfora es uno de los medios más activos para ampliar el ámbito del significado y para poner en movimiento al que penetra en él". La metáfora nos revela "que las palabras no sólo poseen significado propio sino energías sugestivas, valores sociales, ideas secundarias de todo género".

\section{Las letras de tango y su vigencia cultural}

El habla popular constituye, por excelencia, un lenguaje oral, que es recogido por la letra impresa de manera incompleta y deformada. El auténtico hablante de la jerga arrabalera rara vez deja asentada su expresión por escrito, y cuando lo hace tiende a esforzarse en imitar las modalidades cultas. El producto de semejantes esfuerzos resulta, consecuentemente, bastante híbrido. Eso lo podemos advertir si examinamos la forma más próxima al lenguaje popular que ha quedado registrada literariamente: la letra de tango. En esta forma típica de la lírica urbana rioplatense observamos prontamente la incidencia de influjos cultos, por lo general distorsionados y parciales. En ciertas ocasiones, percibimos una notoria propensión hacia la cursilería, aportada por cierto gusto un tanto sensiblero que prevaleció a fines del siglo XIX y durante las primeras décadas del siglo XX como subproducto casi extraliterario de la estética modernista. La influencia francesa, puesta en circulación por malas traducciones o por poetas de vasta repercusión popular, se refleja en el empleo de manifiestos galicismos que había adquirido una supuesta dignidad 
culta. Así hallamos confundidos en letras de tango vocablos orilleros, italianismos y palabras afrancesadas, como sucede en estos versos: "Decís que sos un tipo de rango y vento / Y andás como la oruga, a medio hacer". Adviértase la tendencia casi aforística del segundo verso, rasgo típico de la elocución popular en el ámbito hispanohablante (recuérdese, al respecto, el uso que Sancho hace de los refranes en El Quijote); al mismo tiempo, obsérvese el empleo del voseo en la segunda persona del singular. A más de ello, cabe señalar que tipo es un vocablo singularmente porteño, en su sentido de "hombre" o "individuo", vento, por su parte, es un italianismo que denomina metafóricamente al dinero, que es igual al viento, pues siempre se escurre con facilidad de nuestras manos, sin que lo podamos retener; finalmente, rango, pese a su ya lejana incorporación hispánica (cfr. Corominas, Diccionario etimológico, IV, 28; s.v. "ringlera"), es un indudable galicismo, aunque disfruta de bastante aceptación y prestigio culto en los sectores populares.

Sin embargo, a pesar de su frecuente caída en tales elaboraciones híbridas, las letras de tango no dejan de contar con notables aciertos expresivos. Salvados los prejuicios lingüísticos y éticos que a menudo nos separan de la imparcialidad, cabe reconocerle al tango giros de notoria fuerza verbal que espontáneamente se ajustan al precepto estético de que la poesía debe expresar el pensamiento por medio de imágenes vívidas y epítetos precisos. Hay una multitud de expresiones afortunadas de nuestro lenguaje popular que han perdurado registrados en el tango. Por ejemplo, la mujer venida a menos es trazada en colorida metáfora: "Y maña- 
na cuando seas descolado mueble viejo "; o el ocaso del matón que purgó sus pendencias en la cárcel es recordado en una nostálgica alusión al ocio vespertino del hombre envejecido: "Hoy ya libre 'e la gayola y sin la mina, / Campaneando un cacho 'e sol en la vereda".

En suma, el lenguaje arrabalero recogido por el tango -ya sea auténticamente popular o elaborado- es un reflejo verbal de los múltiples influjos que han obrado en el desarrollo ciudadano. Basta con unos pocos versos para que el lingüista o el sociólogo cuenten con un aporte informativo nada desdeñable. Sea, por ejemplo, esta estrofa de un tango que gozó de considerable popularidad: "Vos te creés que porque hablás de 'ti', / Fumás tabaco inglés, / Paseás por Sarandí / Y te cortás las patillas / A lo Rodolfo / Sos un fifí. / Porque usás la corbata carmín / Y allá en el 'Chantecler' / Las vas de bailarín / Y te mandás la biaba de gomina / Te creés que sos un rana / Y sos un pobre gil". Observemos, nuevamente, la aplicación del voseo a la segunda persona del singular: creés, fumás, paseás, cortás, usás, mandás, sos; inclusive tratarse de "ti" y "tú" resulta peyorativo, poco viril; además, señalemos el empleo de un vocabulario típico: fifí, biaba y rana son términos característicos de nuestro lenguaje popular; también gil, que no está desprovisto de antecedente hispánicos; a esto se añade la mención de lugares -como el "Chantecler"- que gozaban de prestigio elegante, y se insinúa la difusión del cine -todavía mudo- cuya cifra era entonces Rodolfo Valentino. Aquí, como en todo testimonio escrito, las palabras documentan la historia íntegra de una época. La perduración de los hechos sociales 
se transforma, con el tiempo, en una pura y exclusiva perduración verbal. Un procedimiento exegético similar puede aplicarse a innumerables letras de tango, tarea que permite extraer tipos humanos, actitudes vitales y rasgos lingüísticos perfectamente definidos.

No hay duda de que las letras de tango han estimulado con frecuencia la reflexión sociológica o filológica, las más de las veces por medio de la improvisada y precaria labor de aficionados muy entusiastas pero insuficientemente disciplinados en la investigación erudita. En cambio, el examen estrictamente estético o literario de dichos textos hasta el presente no contó con una consideración adecuada, pese a que ciertos aspectos tanguísticos a menudo han tenido eco profundo y significativo en los escritores argentinos de más aguda sensibilidad expresiva, como Jorge Luis Borges y Julio Cortázar, o en indagadores dotados de una sutil capacidad perceptiva para valorar el quehacer poético, como Daniel Devoto. La poderosa tentación de caer en una especie de hermenéutica ontológica o metafísica del tango como testimonio del advenimiento urbano en la Argentina-según el modelo que cultivó Martínez Estrada-suele alejarnos del hecho creativo que entrañan estas composiciones: la dimensión poética que a veces poseen, ya sea por su refinamiento y sortilegio formal, ya por su singular fuerza imaginativa y su hondura de intuición. En pocas ocasiones -si acaso en alguna- se ha encarado el estudio de estas piezas líricas en términos estrictamente literarios, y casi nunca se ha tratado de indagar sus posibles fuentes o de enriquecer su significación a través de un adecuado cotejo con materiales poé- 
ticos de origen culto. Una de las contadas excepciones ha sido la circunstancial observación de un escritor mejicano de incomparable perspicacia crítica -Alfonso Reyes- que en cierta oportunidad aproximó un verso de Baudelaire (Sois sage, ô ma Douleur, et tienstoi plus tranquille) al porteñisimo equivalente hallado en un tango (Araca corazón, callate un poco), Tulio Carella, por su parte, ha puntualizado -de modo más bien general e indeterminado pero, sin duda, inteligente- coincidencias temáticas con autores clásicos, entre las que cabe destacar afinidades con el carpe diem horaciano y con el Vivamus, mea Lesbia, atque amemus de Catulo. Sin embargo, estas apreciaciones resultan desacostumbradas y muy infrecuentes, quizá porque los argentinos sufrimos de un complejo de inferioridad, originado en una falta de raíces culturales que se hace más notoria en las ciudades, donde el flujo inmigratorio todavía no se ha sedimentado suficientemente; a causa de ello, ni por asomo nos atrevemos a asumir abiertamente modalidades urbanas que se aceptan y enaltecen en países europeos: hasta el presente, sólo se han realizado esfuerzos dispersos para estudiar nuestro lenguaje argótico y popular, a diferencia de lo sucedido en Francia e Inglaterra gracias a eruditos como Dauzat o Partridge, o inclusive en los Estados Unidos por obra de H.L. Mencken; los hombres de teatro, en el área rioplatense, hasta hace muy poco tiempo se resistían al natural empleo escénico del voseo; nuestra Academia de Letras parece más dispuesta a imponer los usos lingüísticos del arrabal madrileño que a admitir los giros de la orilla porteña, cuando no confunde -en ponencias enviadas a congresos especializados- las funciones perfectamente dife- 
renciadas de la lengua literaria y del habla cotidiana (por supuesto con el propósito arbitrario y extemporáneo de dictaminar por decreto la extinción de esta última); y como corolario de esta última enumeración, resulta explicable que las letras de tango sean ignoradas porque eufemísticamente se pretende anular de ese modo la existencia de aquello que jamás es mencionado (según procedimientos supersticiosos harto conocidos en la magia verbal). No se trata de cultivar el pintoresquismo localista -cuya amenaza, por cierto, debe combatirse- sino de aceptar las formas de expresión natural cuando ello se justifica y de reconocer lo que tienen de vital y poético, si caer en actitudes pusilánimes o chauvinistas. La producción de Carlos Gardel, por ejemplo, ha sido elogiada por el popular cantor francés Charles Aznavour, en cuyas composiciones a veces uno cree descubrir ciertos influjos sintomáticos de nuestro máximo representante del cancionero urbano. Ahora bien, en Francia no se ha dudado en incorporar a una de las más afamadas series de literatura poética los textos de Aznavour y también los de Georges Brassens, igualmente representativo del gusto popular; pero acaso esto ha sido posible porque París hace ya cinco siglos que tiene, en la figura de Francois Villon, un poeta totalmente identificado con el lenguaje del pueblo, cuyas preocupaciones y miserias conocía y cuyos empleos argóticos no desdeñaba; pero, claro está, debemos reconocer que el tiempo ha borrado en Villon estos rasgos y lo ha convertido en un clásico cuyas peculiaridades idiomáticas suscitan el interés de sesudos y doctos estudiosos (ventaja de la que todavía no gozan los autores de letras de tango). Pero si nos despojáramos de sus- 
picacias tal vez hallaríamos en algunas letras de tango -en el plano de la expresión popular- méritos comparables a los que solemos atribuir a nuestra literatura culta (si acaso inclusive no mayores). Cuando se piensa en el abrumador ejercicio del verso exento de convicción creativa -tan frecuente en la producción nacional, por imitación de formas que con anterioridad escritores extranjeros emplearon con mucho mayor acierto y autenticidad-, para el oído habituado a percibir la intensidad poética resulta manifiesta la calidad de Enrique Santos Discépolo o de Homero Manzi; lo que se necesita es estudiar sus obras con apropiado rigor. Por muy menor que pueda considerarse tal poesía, no debemos olvidar que esta cualidad ha sido característica de la lírica popular urbana, por lo menos en sus orígenes: Villon se describía a sí mismo como un pauvre écolier; y pese a su formación "clerical" y a su conocimiento del latín, los anónimos autores de los Carmina Burana no pasaban de ser considerados vagantes. En consecuencia, por humilde que nos parezca, es necesario reconocer que la producción de Discépolo posee indudable afinidad con la ternura y compasión de Villon, en lo que respecta a la imagen que nos ofrece del sufrimiento y de la miseria humana en los sectores más oscuros de la sociedad; y por añadidura, su tango Cambalache es un documento poético de extraordinaria perspicacia que no cuenta con parangón en la litera culta. En cuanto a Homero Manzi, quizá sea el escritor de mayor vigor y de más auténtica evocación urbana en su generación, con la sola excepción de Borges; un análisis serio y detenido de unas cuantas composiciones suyas muy probablemente 
lo sitúe entre los más representativos poetas argentinos del siglo XX.

\section{La letra de tango y su prosapia culta}

En sus comienzos, el tango fue culto de coraje y exaltación verbal del temperamento pendenciero. En cierto modo, viene a prolongar la tradición orillera - no gauchesca- que ya se había insinuado en el episodio del baile en que Martín Fierro mata al negro y, posteriormente, en las crónicas de Eduardo Gutiérrez, Hormiga Negra y Juan Moreira. Pero el mundo de este malevaje orillero se halla en su apogeo hacia 1870 y se extingue antes de terminar el siglo, a medida que los arrabales de la Gran Aldea son asimilados al orden y a la vigilancia de la ciudad cosmopolita donde hasta la delincuencia requiere de técnicas más organizadas y menos atrevidamente heroicas. A la par que el tango va llegando a la madurez, en las primeras décadas de nuestro siglo, se va extinguiendo el mundo casi fabuloso del malevaje arrabalero, de los bailongos suburbanos, de los inquilinatos céntricos, de las mujeres que eran motivo de riña, memorables en cafetines de moda. En cierto momento se llega a dudar de que este mundo heroico haya existido en modo alguno; tal vez, como la Ilíada o la Odisea, sea la fábula de un universo puramente imaginario en el que la realidad sólo interviene de vez en cuando. Es natural que así nos parezca -y que tal vez así sea- pues la época áurea del tango, entre 18910 y 1930, coincide con los recuerdos postreros, y por lo 
tanto nostálgicos e idealizados, del arrabal porteño anterior a 1890. este hecho trae aparejada una curiosa coincidencia, al reiterar en la letra de numerosos tangos el tradicionalísimo tema del ubi sunt, que a través de la literatura clásica, de la tradición bíblica y de la latinidad medieval se perpetua hasta el prerrenacentismo de Villon (tal como lo señaló bibliográficamente Étienne Wilson en Les idées et les lettres, págs. 31-38, si bien omitió, quizá por descuido, uno de los ejemplos más tempranos, que se encuentra en los Tragicorum Graecorum Fragmenta, ed. A. Nauck, $\mathrm{n}^{\circ}$ 372), y que halla expresión castellana en las Coplas de Jorge Manrique: "¿Qué se fizo el rey Don Juan? / Los infantes de Aragón, / ¿Qué se fizieron? / ¿Qué fue de tanto galán? ¿Qué fue de tanta invención / Como trujeron?"; y más adelante: "¿qué se fizieron las damas, / Sus tocados, sus vestidos, sus olores? / ¿Qué se fizieron las llamas de los fuegos encendidos / de amadores?". Esta pregunta halla eco en el recuerdo malevo del tango porteño: "Tiempo viejo, / Caravana fugitiva, / ¿Dónde estás?". O si no: "Puente alsina, / ¿Dónde está ese malevaje?". Y también: ¿Dónde están aquellos hombres y esas chinas, / Vinchas rojas y chambergos que Requena conoció?". Pero tal vez el más memorable ubi sunt que registra la lírica porteña es aquel tango Tiempos viejos: "¿Te acordás, hermano, qué tiempos aquellos? / ... / ¿Dónde están los muchachos de entonces? / Barra antigua, de ayer, ¿dónde estás? / ... / ¿Te acordás las mujeres aquellas? / .. / ¿Te acordás, hermano, la rubia Mireya / Que quité en lo de Hansen al loco Cepeda?". Aquí el tango ingresa en una de las grandes preocupaciones humanas: el carácter efímero de todas las cosas, la condición 
precaria de nuestra existencia. Las palabras se convierten en medida de la fugacidad que de día en día va estrechando nuestro horizonte y ensanchando nuestros recuerdos. Este no es, empero, el único tema clásico de la poesía -casi un topos, según la denominación griega utilizada por Ernest Robert Curtius- que registra el tango. Asclepíades y Meleagro, en epigramas eróticos que recoge la Antología Griega (V, 7 y 8), invocaron a la lámpara como testigo de encuentros amatorios con una pérfida mujer que ha quebrado las promesas de fidelidad; del primero de estos autores, André Chenier extrae el tema de la elegía que denomina La lampe: "Et toi, lampe nocturne, astre cher á l'amour, / Sur le marbre posée, ô toi qui jusqu'au tour, / De ta prison de verre éclairais nos tendresses, / C'est toi qui fus témoin de nos douces promesses". Lo mismo refiere el enamorado del tango Mi noche triste, "amurado" en lo mejor de su vida, cuando evoca idéntica situación: "y la lámpara del cuarto / También tu ausencia ha sentido, / Porque su luz no ha querido / Mi noche triste alumbrar".

Sin embargo, una de las exploraciones temáticas más apasionantes a que se prestan las letras de tango como retoños de una prosapia culta puede ejemplificarse en el tradicional motivo poético de la luna, cultivado en la literatura europea desde tiempo inmemorial. Una muestra cabal de la evocación lunar extraída de la poesía anónima que escribieron en latín los "clérigos vagabundos" del amanecer burgués, a fines de la Edad Media, ha sido empleada por Carl orff en el comienzo de su experimento coral en que reúne una selección de Carmina Burana: "O fortuna, / Velut Luna / Statu variabilis, / Semper crescis / Aut decrescis". Esta 
analogía de la diosa Fortuna todopoderosa con la luna -que en el curso de sus fases sucesivas crece o disminuye en volumen- ejerció poderosa fascinación en la imaginería de Jules Laforgue, aquel poeta francés nacido en Montevideo que integró el círculo de seductoras figuras menores del movimiento simbolista a fines del siglo pasado y que fue -pese a la brevedad de su existenciauno de los más interesantes precursores de la poesía europea contemporánea, admirable maestro de una tesitura plena de fantasía y espíritu irónico, una de cuyas obras más memorables es el conjunto de composiciones reunidas con el esclarecedor título de L'imitation de Notre-Dame la Lune. En una de sus letanías, Laforgue retoma manifiestamente el tema expuesto en los Carmina Burana y renueva la comparación de la voluble fortuna con la variedad de formas que adopta la luna: "Ah! la belle pleine Lune, / Grosse comme une fortune!". Y en otro poema, el mismo autor confiesa su predilección casi excluyente: "Ah! la Lune, la Lune m’obsede... / croyez-vous qu'il y ait un reméde?". El descubrimiento de la vigencia estética que tiene la luna en la obra de Laforgue habría de proyectarse en toda la poesía ulterior de habla hispana: en la Argentina, el tema es introducido a través del movimiento modernista que actúa como vehículo difusor del simbolismo francés; el autor más representativo que recoge la melancólica conmemoración lunar y la incorpora a nuestra poesía es Leopoldo Lugones, especialmente en su Lunario sentimental; a partir de esta vertiente, el asunto se difunde y arraiga en los grupos vanguardistas surgidos hacia 1920; de tal modo, hallamos en la producción juvenil de Borges alguna resonancia lunar: "He cantado lo eterno: la clara 
luna volvedora y las mejillas que apetece el querer". En Borges, la presencia de la luna sirve para rememorar con añoranza la imagen de la distante Buenos Aires, evocada desde Europa; posiblemente, tal es el significado que posee el título de uno de sus primeros volúmenes poéticos: Luna de enfrente. Este recurso de apelar a la luna para revivir con nostalgia el suburbio porteño, recordado desde la distancia espacial o temporal, es un típico procedimiento que adoptan las letras de tango. Al respecto, varias composiciones que popularizó Gardel sirven de conveniente ilustración. En el comienzo de Melodía de arrabal hallamos: "Barrio plateado por la luna, / Rumores de milonga / Es toda tu fortuna", formulación que reitera el vínculo entre los elementos ya conectados en la lírica medieval latina de carácter profano y en nuestra primera cita de Laforgue. Por su parte, Lejana tierra mía recoge la presencia lunar de este modo: "Silencio de mi aldea / Que sólo quiebra / La serenata / De un ardiente Romeo, / Bajo una dulce / Luna de plata". Pero en la literatura argentina este motivo quizá alcanza su mayor fuerza evocativa y entonamiento a través de Homero Manzi, en algunas de sus letra de tango. En su incomparable Sur escribe: "Las calles y las lunas suburbanas / Y mi amor en tu ventana, / Todo ha muerto, ya lo sé". Finalmente, el tema reaparece en varios versos de Barrio de tango, como "un ladrido de perros a la luna" o "barrio de tango, luna y misterio". Aquí, la referencia lunar adquiere plenitud poética; ante semejante intensidad expresiva, nada parece tan acertado como la opinión de Horacio A. Ferrer en El tango, su historia y evolución, cuando señala que "la buena literatura que el tango ha pro- 
ducido" no sólo posee un auténtico acento popular, sino que también, por añadidura, está entre nuestra mejor poesía ciudadana.

Estas descuidadas páginas de exégesis sólo han pretendido demostrar la posible indagación estética de las letras de tango, desenvuelta al más elevado nivel de exigencia erudita, pero aún se aguarda la aparición de quien emprenda el amplio, exhaustivo y ambicioso estudio que apenas nos hemos limitado a insinuar. 


\section{LA LITERATURA Y EL MAL}

\section{(1966-1973)}

A mediados de la década del '60, más precisamente en lo que va del golpe de Estado del General Juan Carlos Onganía (1966) al Cordobazo (1969), se produce en el campo intelectual argentino una serie de mutaciones importantes en función de acontecimientos políticos concretos tanto en el plano nacional como internacional. Esas transformaciones incluyen desde una reconfiguración considerable en el modelo sobre el que se perfilan las colocaciones de los intelectuales de izquierda a una profunda transformación en el tejido mismo de relaciones del campo intelectual entero.

El golpe de Estado del 28 de junio de 1966, que puso fin a la presidencia de Arturo lllia e inauguró el período de lo que se llamó la Revolución Argentina, gozó al comienzo -como apunta Romero- de cierto crédito político por parte de los partidos tradicionales -«con la excepción de los radicales, socialistas y comunistas»- en función de «la indefinición inicial entre las diversas tendencias que coexistían en el gobierno» (Romero 2001: 169). Sin embargo, el "shock autoritario" que siguió a la implantación de Onganía en el poder -quien rápidamente, con el aval del "Estatuto de la Revolución Argentina" adosado a la Constitución, disolvió el parlamento y los partidos políticos («cuyos bienes fueron confiscados y vendidos, para confirmar lo 
irreversible de la clausura de la vida política»)- dio cuentas claras de sus objetivos e intenciones. Tras la concentración plena de los poderes, comenzó una suerte de encorsetamiento de la sociedad misma. La persecución y represión del comunismo -cuya "amenaza" se hacía más tangible a medida que se afianzaba el proceso de la Revolución Cubana- «se extendió a todas aquellas expresiones del pensamiento crítico, de disidencia o hasta de diferencia». El blanco principal de la embestida autoritaria fue la Universidad, la que era consideraba como el «lugar típico de la infiltración, la cuna del comunismo, el lugar de propagación de todo tipo de doctrinas disolventes y el foco del desorden». En consecuencia, las universidades fueron drásticamente intervenidas y se acabó con toda posibilidad de autonomía académica. Pero eso no fue todo. El 28 de julio de 1966 se produjeron los trágicos acontecimientos represivos de la llamada "Noche de los Bastones Largos", cuando la policía irrumpió en varias Facultades de la Universidad de Buenos Aires y apaleó brutalmente a alumnos y docentes. «A este impromptu, grave, simbólico y premonitorio, siguió un movimiento importante de renuncias de docentes», algunos de los cuales siguieron sus carreras en el exterior mientras otros «procuraron trabajosamente reconstruir, subterráneamente, las redes intelectuales y académicas, por lo general en espacios recoletos, que alguien comparó con las catacumbas» (Romero 2001: 170).

Mientras a las cátedras universitarias se van incorporando compulsivamente «grupos tradicionalistas, clericales y autoritarios» y mientras la censura se extiende rápidamente a 
otros órdenes sociales hasta abarcarla por completo (Romero 2001: 171), Rest redoblará su apuesta intelectual tanto en función de sus temas como en la orientación de su actividad docente. En un artículo titulado "Raymond Williams: una relectura", Beatriz Sarlo recuerda, en un pasaje que vale la pena citar in extenso, la inscripción de Rest en el contexto represivo: «Sólo otro argentino conocía a Williams entonces: Jaime Rest, con quien conversábamos frecuentemente porque también él aislado en medio de la represión, alimentaba la esperanza de seguir pensando en Argentina, en los pasajes de una débil red intelectual desprotegida y subterránea» (Sarlo 1993: 13) 172.

En rigor, el cambio en el modelo intelectual que se produce en ese contexto puede ser descrito como el pasaje de una concepción humanista de izquierda fundamentalmente matrizada por la figura de Jean-Paul Sartre a un modelo intelectual antihumanista y científico cuyas intervenciones se apoyan en el legado teórico de la antropología, la lingüística y el psicoanálisis estructuralista (Terán 1991: 105-110). Se trata de un intelectual que acentúa su función comprometiendo su especificidad. El trabajo de Rest -quien viene de subrayar, en las páginas finales de Literatura y cultura de masas (1967), su admiración por la «lucidez y sensibilidad crítica» del Roland Barthes de Mythologies- sigue progresivamente también este camino. La aparición en 1968 del volumen titulado Tres autores prohibidos y otros ensayos viene sin dudas a corroborarlo.

172 Sarlo, B., "Raymond Williams: una relectura", en Punto de Vista, $\mathrm{N}^{\circ} 43$, Buenos Aires, 1993. 
Aparecido bajo el sello Galerna en agosto del 68, Tres autores prohibidos (1968b) ${ }^{173}$ reúne y conjuga dos líneas de investigación de importancia gravitante en el proyecto crítico restiano. El libro se estructura en dos partes definidas: en primer lugar, la dedicada a los "tres autores prohibidos" (Sade, Cleland y Lawrence) y, a continuación, los "otros ensayos de literatura y sociedad". El "otros" da cuenta indudable de que Rest concibe también a los primeros como ensayos recortados sobre la misma relación. En términos generales, la primera parte está estructurada sobre cuatro artículos y se concentra fundamentalmente en el problema de la censura; mientras que la segunda -compuesta por tres trabajos selectos por el autor entre su producción previa para acompañar y complementar a los primeros- se enfoca particularmente en los peligros de la propaganda y la pedagogía de las masas. En cualquier caso, y «pese a la índole heterogénea de los temas tratados», los textos elegidos por Rest para formar parte del libro dan cuenta de una inscripción liberal, progresista y abiertamente anti-totalitaria. Estrictamente vinculada a los temas desarrollados en "Situación del arte en la era tecnológica" (1961) y "Alcances literarios de una dicotomía cultural contemporánea" (1965), la segunda parte del libro, se abre con tres epígrafes significativos. El primero de ellos es de Carroll y está tomado de Alice in Wonderland: «Todo tiene moraleja; la cuestión es pescarla». El segundo, más extenso, pertenece a F. R. Leavis y

173 Rest, J., Tres autores prohibidos y otros ensayos (1968b). Buenos Aires: Galerna. 
reza: «Todavía pienso, empero, que la mejor forma de estimular una discusión provechosa consiste en mostrarnos tan claros con nosotros mismos como sea posible acerca de lo que vemos y juzgamos, en buscar y establecer las pautas esenciales referentes al campo de interés enfocado y en enfocarlas con toda la claridad que podamos (así fuera para expresar desacuerdo, si ello fuera necesario)». El tercer epígrafe pertenece al poeta William Blake: «La oscuridad no es el manantial ni de lo sublime ni de cualquier otra cosa» (1958b: 103). Carroll, Leavis y Blake son convocados no casualmente- para abrir un apartado dedicado a los beneficios de la comunicación franca. Rest, que ya ha leído a Williams, sabe que «cualquier teoría real de la comunicación es una teoría de la comunidad» (Williams 2001: 258). Es consciente de la relevancia de las técnicas de la comunicación de masas ya que ellas pueden convertirse en "técnicas de dominación".

"Actualidad del realismo" -surgido a partir de la recensión de dos textos dedicados al tema y aparecidos en 1963 (uno del vienés René Wellek ${ }^{174}$ y otro del norteamericano Harry Tuchman Levin ${ }^{175}$ )- abre el apartado que se recorta sobre la relación cultura y sociedad. Reelaborado en función del libro, el ensayo no conserva ninguna de las convenciones del género reseña e incluso dispersa su foco introduciendo otros textos y otras voces que contribuyen a pensar el realismo como un tópico importante en la problemática relación que compromete su tema. Al tanto de las investigaciones de Roman Jakobson, Rest enfoca el problema del

\footnotetext{
174 Concepts of Criticism, Yale University Press, 1963.

175 The Gates of Horn: A Study of Five French Realists, Nueva York, Oxford University Press, 1963.
} 
realismo en sus múltiples significaciones (lo lee como aspiración de una obra hacia el verosímil, como percepción de una obra en tanto verosimil, $y$, finalmente, como la suma de rasgos característicos de una escuela artística del siglo XIX y su proyección en el XX) ${ }^{176}$. No se plantea como un resumen de los trabajos que aborda, ni como una redacción que recoge textualmente sus contenidos; sino que, al contrario, se despliega más bien a partir de un comentario de corte analítico sobre los materiales abordados, desde el cual se examinan las tesis esgrimidas por cada autor y se analizan sus conclusiones destacando las repercusiones y la contribución que cada texto representa para el campo de estudios sobre el tema. Sin embargo, la pregunta tácita que lo pulsa es sin duda la que circunscribe el interrogante por las condiciones de posibilidad de la "actualidad" del realismo en tanto poética de género, entendiendo el carácter variablemente histórico del concepto: «en la medida en que cada período histórico ha tenido una concepción de la realidad con características propias» (1979a: 128-131).

En primer lugar, lo que Rest se propone impugnar es cierta vulgata crítica que considera al realismo como una poética desfasada o un «estilo de época». Discute con argumentos sólidos el cuestionamiento de la validez poética del realismo en función de su relación denotativa y referencial. Pone en descubierto la inconsistencia de las acusaciones que sus censores han enarbolado ante esa forma poética aliada al testimonio de ciertos rasgos

176 Jakobson, R., "El realismo artístico" [1921], en Todorov, T., Teoría de la literatura de los formalistas rusos, Madrid, Siglo XXI, 1970. pp. 99109. 
sintomáticos de la sociedad. En defensa de esa poética de género y de su validez estética, Rest trae las argumentaciones de los propios Flaubert y Baudelaire, para quienes la perfección formal de la obra literaria no estaba necesariamente reñida con «la más precisa descripción y crítica del ámbito social» (1968b: 106) .

Lo singular del planteo restiano es que la percepción de cierto "retorno del realismo" está dada, no por el descubrimiento de nuevas producciones literarias en el interior de esa corriente, sino en función de «un grado considerable de interés» que parece haber recobrado el tema «entre investigadores de muy diversa orientación» (1968b: 105). El hecho de que el "proceso" abierto sobre y contra el realismo por numerosos perceptistas e historiadores de las artes (que anudaban su vigencia y su caducidad al uso pedagógico del que había sido objeto, en su versión socialista, en la Unión Soviética) no haya conseguido terminar con el interés por el problema del realismo es el punto de partida de la indagación restiana. Lo que importa es saber cómo y por qué el realismo literario, que parecía condenado a una perduración estertórea, anómala, artificial y vinculada a procedimientos exangües, ha encontrado condiciones sociales de subsistencia y sobrevida en el imaginario de la crítica y la teoría.

Remontándose a su "surgimiento" en la narrativa canónica del siglo XIX, especialmente a las novelas de Stendhal o Balzac, y a la pintura de Courbet o los devaneos teóricos de Champfleury o Duranty, Rest subraya la necesidad de indagar en los vínculos entre «las condiciones objetivas en que se halla inserta la 
existencia humana en una época y un lugar determinados y su fiel e inmediata representación artística» (1968b: 105) para reconocer las necesidades, las demandas y los límites históricos que subyacen a la adscripción a esta poética de género. Pero, si Rest discute las hipótesis que insisten en denostar al realismo, no muestra tampoco condescendencia con aquellas perspectivas que lo ponderan por oposición al "decadentismo" de las vanguardias. A las reduccionistas y restrictivas apreciaciones del teórico húngaro George Lukács opone la inventiva vanguardista de Bertolt Brecht, para quien el realismo no es una «"forma de representación" orientada a reproducir fielmente situaciones verosímiles», sino «un método destinado a encaminar las reflexiones» del auditorio o del lector hacia problemas actuales de su sociedad (1968b: 107-108). Siguiendo la hipótesis brechtiana, Rest plantea que, de hecho, muchas de las expresiones literarias del siglo XIX habitualmente consideradas como "realistas" (sólo preocupadas por evocar de manera verista sus escenarios) bien pueden no serlo realmente, en tanto busca suscitar en el lector no una disposición crítica y distanciada sino que, al contrario, pretenden producir una ilusión de realidad. En la perspectiva brechtiana, Rest afirma que el realismo ilusionista "distrae e hipnotiza" en la medida en que retiene al público en situaciones particulares que favorecen la identificación sentimental en vez de presentar conflictos típicos que exijan del lector el "efecto de distanciamiento" (Verfremdungseffekt) y el consecuente enjuiciamiento crítico. Para Rest, en el realismo brechtiano es más importante la 
estructura del suceso que el suceso mismo en su particularidad. Se trata de representar poniendo en escena ante todo el carácter representacional de la escena; dejando expuesto el procedimiento y procurando establecer el "distanciamiento dramático", que Brecht definía bajo la noción de verfremdung en su teoría del "teatro épico". Ante las «interpretaciones estrechas» del realismo lukacsiano, la perspectiva brechtiana -sostiene Restpermite pensar las experiencias poéticas contemporáneas conforme a formas más flexibles y dinámicas. ${ }^{177}$

Esta posición que, expuesta a mediados de la década de 1960 no es por cierto muy osada, revela no obstante un hallazgo importante que de algún modo anticipa lo que años después sostendrá Louis Althusser en "Idéologie et appareils idéologiques d'etat (notes pour une recherche)"178. Rest sostiene aquí que la dimensión realista no consiste en una disposición a calcar determinadas situaciones, sino a ofrecer una «transposición imaginaria» que excede el simple carácter informativo y que tiende a desencadenar en el lector una respuesta de corte militante o reflexiva. El hecho de que para Rest tal «transposición imaginaria» exceda «el simple carácter informativo» obliga a pensar en una modalidad performativa o por lo menos connotativa que remite al sistema ideológico con el que los autores se representan a sí mismos, en forma imaginaria, sus propias condiciones de existencia reales. Si hay una realidad que la posición realista asume es la de que de esta «transposición

\footnotetext{
177 Cfr. Brecht, B., El compromiso en literatura y arte, Barcelona, Península, 1973.

178 Paris, La Pensée, nro.151, junio 1970.
} 
imaginaria» compromete su punto de vista y sus propias condiciones de existencia, en tanto se representan a sí mismos las condiciones de representar su realidad. De modo que lo que el realista (se) representa no es sólo el mundo real, sino ante todo su modo de relacionarse con el mundo que representa. Lo que, a diferencia de Althusser, Rest no dice es que la "transposición imaginaria" constituya necesariamente una "inversión", un "falseo" o una "deformación", pero deja entrever que ella misma, que bien puede ser vivida por el autor como «una evidencia inmediata» $^{179}$, puede desencadenar en el lector reacciones diversas: su respuesta -apunta Rest- puede ser «militante o reflexiva» (1968b: 109) .

Lo que Rest señala es la adecuación teórica del concepto creado en el siglo XIX en función de una descripción de las nuevas experiencias estéticas. Mimesis: Dargestellte Wirklichkeit in der abendländischen Literatur (1942), la obra del gran filólogo, romanista y crítico literario alemán Erich Auerbach, ejemplifica claramente esa mutación teórica que tiende a una «restauración valorativa» del realismo. Entendido como un estudio sobre «la representación de la realidad», el monumental trabajo de Auerbach replantea el lugar central del realismo en la literatura europea, desde Homero a Virginia Woolf; pero supone, al mismo tiempo, un desplazamiento del uso que del término se hace en la tradición aristotélica. Rest percibe con lucidez la operación auerbachiana de actualización teórica justamente por su intencional soslayo de la Poética aristotélica, donde el

179 Althusser, L., Posiciones, Barcelona, Anagrama, 1977. pp. 112-113. 
estagirita identificaba el objetivo del acto creador con la "imitación" del «comportamiento humano concreto en el ámbito propio de la acción» (1968b: 110). Descubre que lo que Auerbach busca sortear es el hecho contundente de que la "mímesis" aristotélica y el "realismo" moderno son «paralelos pero antagónicos»: la primera «puntualiza que el artista sólo puede alcanzar una seriedad plena mediante la exposición de figuras egregias y casi sobrehumanas», mientras que, por el contrario, el segundo insiste en que es en el «hombre común y en las peripecias de su vida diaria» donde se hallan los motivos de composición de «más elevada dignidad creativa». Lo que Auerbach intenta evitar es el problema del cambio de perspectiva moral en el desarrollo de la poética de género: «el reemplazo de Príamo (héroe clásico) por César Birotteau (comerciante burgués)». Saltando ese escollo moral el teórico berlinés puede sostener su hipótesis: demostrar la perduración del realismo como tendencia estética que aspira a «reproducir la realidad en forma minuciosa e inmediata». Apoyado en ejemplos múltiples y de distintas épocas Auerbach sostiene la eficacia general de su hipótesis en el mismo ademán que enfrenta las nuevas particularidades del fenómeno que examina. Los hallazgos que en la indagación auerbachiana puntualiza Rest son significativos como las conclusiones que de ellas extrae. ${ }^{180}$

En primer lugar, que el "realismo social" sólo puede ser encarado con propósitos artísticos serios «en una comunidad predominantemente democrática», donde hayan perdido valor y

\footnotetext{
180 Véase al respecto, Auerbach, E., Mímesis: la representación de la realidad en la literatura occidental, México, Fondo de Cultura Económica, 1950.
} 
actualidad las «nociones carismáticas de precedencia que establecen un desnivel social insalvable» (1968b: 111). Esta hipótesis de cierta ascendencia weberiana articula plenamente con la perspectiva liberal defendida por Rest en otros planos, al punto que le permite sostener que la evocación verista de la existencia en los sectores burgueses o proletarios tomó un matiz cómico «hasta tanto logró afianzarse el predominio de las clases medias, cuyo ascendiente no se origina en criterios de linaje» (1968b: 111). El ejemplo que denota el fin de la tragedia clásica y la instauración de las teorías dramáticas de Diderot es claro: a medida que fue perdiendo actualidad el género que exaltaba la supuesta heroicidad de los sectores egregios, se fue tornando cada vez más imprescindible «la consideración digna y grave de los conflictos humanos que se desenvuelven en los niveles plebeyos» (1968b: 111) .

En segundo lugar, Rest percibe en el juicio de Auerbach -que plantea a Stendhal como el primer autor «consciente y premeditado del realismo social con actitud seria y crítica»- una hipótesis discutible si se considera con cierto detenimiento la obra de novelistas anteriores como Jane Austen. Considera que indirectamente la hipótesis auerbachiana no hace más que ratificar la «tesis ortodoxa» según la cual se explica el surgimiento del realismo "clásico" como «un recurso para enjuiciar el orden instaurado en Francia a partir de la Revolución de 1789» (1968b: 111). El hecho de que esta hipótesis coincida con la del húngaro George Lukács -y por algunos de sus seguidores como Jean O. Fisher- anima en Rest la idea de que la 
visión de conjunto que ofrece Auerbach lo ubica sin duda entre los «precursores inmediatos» de los estudios que sostienen la vigencia de las poéticas realistas en la modernidad. Sin las operaciones de desplazamiento operadas en el intenso estudio del filólogo alemán, serían pues inimaginables las contribuciones posteriores de pensadores marxistas como Galvano della Volpe o Paul Garaudy, quienes sostienen dicha vigencia discutiendo las hipótesis lukacsianas -por considerarlas excesivamente estrechas y tradicionalistas por su adhesión irrestricta al realismo "clásico" del siglo XIX- y proponiendo, en contrapunto, «una concepción sans rivages», que toma por realista toda experiencia creativa que se plantee «evaluar las condiciones objetivas de la sociedad» en que aparece aun cuando «formalmente parezca distorsionar las apariencias externas del mundo» (1968b: 112113). Lo que de algún modo traduce el paso -no menor- de una definición estrictamente poética del realismo al de una intención práctica que deja en segundo plano la perspectiva formal.

Los hallazgos restianos hasta aquí son contundentes pero no concluyentes. A su juicio, si bien ha sido empleado desde mediados del siglo XIX por la perceptiva literaria para circunscribir los procedimientos destinados a trazar, con cierta intención crítica, «una representación verista -casi fotográficade las condiciones objetivas en las que se mueve el hombre moderno», el "realismo" se ha ido desplazando hasta cubrir toda producción imaginaria en la que prevalezca «la voluntad de exponer y examinar la conducta humana y sus motivaciones en relación con las pautas que gobiernan la sociedad contemporánea 
al autor» (1968b: 113-114). El paso de un realismo de técnica poética a un realismo de voluntad ideológica se sostiene sólo en virtud de una operación de lectura en la que sobreviven no singularidades textuales sino caracterizaciones generales: las obras se juzgan a partir de las "circunstancias típicas" que exhiben y en función de los perfiles tipológicos en que se enrolan sus personajes (transformados mecánicamente en personificaciones).

En consecuencia, Rest percibe que si «no se ha logrado una evaluación uniforme con respecto a los alcances del concepto» es porque su ámbito oscila entre la perspectiva ética y la poética. Ya se ponga el acento en el nivel descriptivo o el prescriptivo, ya se lo traslade al ademán voluntario del «enjuiciamiento social» o se lo constriña a «la configuración estrictamente poética» (1968b: 114), el realismo aparece tensado por una pluralidad de criterios en pugna. Como resultado de cada uno de ellos, y en función de diversos matices de perspectiva, el realismo constituye hasta aquí la encrucijada de cinco formulaciones de abordaje fundamentales: a) como «movimiento literario» (la perspectiva de algunos historiadores como George J. Becker); b) como «estrategia "crítica"» (en la línea sociológica lukacsiana que de algún modo continúa Harry Levin); c) como «método creativo de conocimiento» (la posición abierta y defendida por Brecht); d) como «constante histórica» (tras los pasos concretos del propio Auerbach); y e) como rasgo intrínseco de todo discurso auténticamente poético (tal y como empiezan a considerarlo a partir de su «lectura semántica» autores como 
Galvano della Volpe).

La imposibilidad de unificación de un significado para dos fenómenos se explica a partir de esa misma tensión entre dos niveles diferentes: de un lado, se aspira a «lograr una eficacia puramente descriptiva»; del otro, se apunta a una «actitud crítica con respecto a la sociedad» (1968b: 116). Lejos de la ortodoxa perspectiva de un Duranty -para quien el realismo era una técnica precisa y gráfica que el artista refinaba para reproducir minuciosamente y al detalle situaciones vividas- la perspectiva lukacsiana -que se apoya definidamente en el propósito de «enjuiciar las estructuras del mundo burgués»produce la categoría de "realismo crítico" para deslindar su propuesta de la del realismo "clásico". Su verismo es una herramienta, una técnica poética acorde con sus objetivos políticos. El objeto de la "crítica" de ese realismo no es el realismo mismo sino la realidad que ponía bajo su lupa. Rest apunta que, dentro de los límites de esa funcionalidad, Lukács no contempla el hecho de que, para ser auténtica, la crítica debía recaer también sobre la realidad de su técnica. Que el nuevo realismo crítico no someta a crítica sus propios fundamentos es lo que le impide reconocer que lo que hace al arte realista no es «la aplicación mecánica de esta o aquella técnica imitativa» ni tampoco «la mera trasposición imaginaria de esquemas sociológicos», sino una «captación original de ciertas estructuras cuyo impacto en el espectador está encaminado -como diría Coleridge- a suscitar esa "voluntaria suspensión de la incredulidad"» (1968b: 119) que es la razón de toda «convicción 
poética»: que el realismo es una actitud que el artista asume a través del estilo.

En la perspectiva restiana, ya el propio realismo "clásico" entraña un doble compromiso: uno de índole filosófica y otro de carácter expresivo. En el primer caso, se trata de definir una concepción de realidad a partir de la interdependencia del hombre y las circunstancias sociales y naturales a las que está ligado sobre una hipótesis que considera su realización a un nivel secular y mundano. "Desde el sistema idealista de Platón hasta la interpretación atomística de Wittgenstein, sin excluir el cogito cartesiano o los restantes vericuetos de la inagotable exploración intelectual, el objetivo constante de las fatigas eruditas -escribe Rest- siempre apuntó a la condición última de la realidad»; pero los resultados de esos esfuerzos han sido siempre hallazgos parciales: la realidad bien puede ser una sola, pero las interpretaciones que de ella se han dado son múltiples y variadas -de ahí que el realismo, como bien apunta Karl Mannheim en Ideologie and Utopie, signifique también «diferentes cosas en diferentes contextos» (1968b: 120-121). Más aún: si, como apunta Philip Wheelright en Metaphor and Reality, «sólo mediante una arbitraria limitación del vocablo "realidad" es posible admitir que un tipo de experiencia se denomine real», las restantes experiencias -consideradas "irreales"- están también sujetas a esa limitación inicial.

El concepto de realidad es pues «la premisa especulativa básica que define la mentalidad de cada época». Se identifica por entero con la cosmovisión que coetáneamente regula las 
condiciones de lo pensable: toda "concepción del mundo" es indefectiblemente realista en la medida en que «delimita las fronteras implícitas de la "noción de realidad" vigente» (1968b: 122). Es por ello que todo cambio profundo de mentalidad está forzosamente ligado a una transformación radical y simultánea del concepto mismo de realidad. Rest lee la desintegración del realismo clásico en la modernidad no como una transformación de orden poético sino como una mutación gradual pero concreta en la concepción burguesa de la realidad que ha entrado en una crisis «apocalíptico-pesimista». Rastrea el síntoma de esa crisis inminente en «la disposición antiburguesa de Flaubert» (1968b: 124), lo sigue a través del esteticismo decadentista finisecular y del afán descriptivo que pulsa las producciones naturalistas. Pero el punto de saturación de esos síntomas iniciales es sin lugar a dudas la explosión de la vanguardia -cuyo desafío a los fundamentos de la sociedad burguesa «abarca desde el rechazo del mundo objetivo hasta la irrupción poética del absurdo, que se opone a la representación coherente de las formas materiales, del comportamiento social y de las nociones temporales y causales». Aun así, comprueba Rest, ese arte no deja de ser realista «en la medida que responde al estado crítico de la cosmovisión vigente» (1968b: 124-125) .

En lo concerniente al segundo compromiso de la poética realista, Rest remite el núcleo de la problemática a la naturaleza expresiva o simbólica del mismo. Se trata de saber «de qué recursos o convenciones universalmente aceptados ha de valerse el creador para fijar la noción de realidad, a fin de que 
en la obra de arte quede atestiguada con eficacia». Para examinar este carácter específico Rest parte de la articulación entre el auge del movimiento realista y la filosofía cientificista, para recaer en la idea de que el único e impreciso modo de explicar el «realismo secular» consiste en apelar al célebre razonamiento de Wittgenstein acerca de la expresión simbólica general: «lo que la imagen debe tener en común con la realidad a fin de que pueda representarla a su modo es la forma de la representación». Sólo es posible aspirar a lo que Ian Watt llama un «realismo formal», capaz de abocarse a exponer «anécdotas novedosas, personajes plenamente individualizados, sucesos contemporáneos y verosímiles, circunstancias minuciosamente reconstruidas, coordenadas espaciales y temporales precisas» (1968b: 127) utilizando el lenguaje apropiado. Pero en ese espacio de absoluta denotación no hay lugar para la imaginación literaria ni para la alusión connotativa. Rest percibe con claridad el error de incurrir en semejante reduccionismo y lo ejemplifica citando a Cervantes, quien -ya en el prólogo a la primera parte del Quijote- advertía que «el novelista, por necesidad, ha de excluir los adornos redundantes y los artificios retóricos, a fin de elaborar un estilo pragmático y concreto» (1968b: 128). La ironía borgeana casi se hace evidente: si el realismo tiene por objeto trazar un mapa de la realidad social, yendo por la senda denotativa, sólo conseguirá un mapa absurdo, cuya proyección replicaría en tamaño y densidad a la realidad que pretende representar. La literatura realista debe pues definirse por una forma de proyección verbal e imaginaria de la realidad que 
presente -discursivamente- episodios ficticios pero verosímiles. Sólo así la poética realista se distancia del método científico naturalista, cuyo discurso es solamente en apariencia referencial. Del lado de la simulación, la poética realista desata la mistificación naturalista que emplea el verismo de los recursos descriptivos como un fin en sí mismo y los incorpora a la función poética.

Ya en el meollo de su ensayo, Rest reintroduce los trabajos de Wellek y Levin en un contrapunto erudito que no deja de poner en evidencia el modelo ideológico que anima ambas interpretaciones. Rest lee y desarma la clave ideológica que soporta "The Concept of Realism in Literary Scholarship", el sesudo ensayo aparecido en Concepts of Criticism que René Wellek parece haber elaborado con «empeñosa diligencia y profundo desasociego» (1968b: 131). ${ }^{181}$ La ironía restiana señala como "infortunio" el hecho de que el crítico austríaco se sienta incomodado por su objeto de lectura al punto que llegue a «confundir el problema artístico [del realismo] con prejuicios políticos manifiestos (en entera conformidad con los preceptistas del realismo socialista, a quienes tanto desdeña)» (1968b: 131) . Yendo al grano, Rest puntualiza que el enfoque propuesto por Wellek se ve "deformado" por su "desmedida aprensión" respecto de «las opiniones de [Friedrich] Engels y [Georgi Maksimiliánovich] Malenkov», a lo que habría que agregar su afirmación explícita de que «el realismo subsiste en la actualidad por influjo casi exclusivo de las vastas masas soviéticas de ignorantes apenas

181 Yale University Press, 1963. pp. 222-255. 
alfabetizados (vast masses only recently admitted to literacy)» (1968b: 131). Rest critica fuertemente también el enjuiciamiento que Wellek hace de la tipificación (al insistir en que simplifica excesiva y perjudicialmente la riqueza de matices humanos y la complejidad de los personajes imaginarios), sosteniendo lúcidamente que aún la más grotesca tipificación suele ser un «recurso de gran eficacia estética»-como en la commedia dell'arte, donde la caricatura apunta a caracterizar «en un individuo los rasgos propios de un sector social» (1968b: 132). Y finalmente se detiene en la cuestión de la «historicidad realista» -a partir de la cual se supone que la composición artística debe «reproducir las auténticas condiciones de vida» vigentes de la sociedad en que se desempeña el autor en cuestiónpara dejar en claro que, si bien esta posibilidad existe potencialmente, ningún autor está obligado a ofrecer en su obra testimonio fiel de los acontecimientos que hacen a la historia específica de su época (1968b: 134).

Por contraste, el estudio de Harry Levin sobre el "realismo clásico" resulta -a los ojos de Rest- más "agudo y perspicaz" que el de Wellek. Los ensayos de Contexts of Criricism (1957), dedicados a Cervantes y el Quijote, a Proust y a Balzac, y el "meduloso análisis" de la novela realista francesa del siglo XIX desplegado en The Gates of Horn. A Study of Five French Realists (1963), centrado enteramente en las obras de Stendhal, Balzac, Flaubert, Zola y Proust, constituyen el grueso del corpus teórico en el que Levin examina la experiencia realista «en relación con las condiciones sociales» en que se inscribe. Rest subraya la 
lucidez de Levin al enfocar el problema del realismo como «cualidad inherente a la naturaleza específica de la novela», al punto de constituir el rasgo fundamental y distintivo de tal expresión genérica frente al resto de la producción ficticia en prosa. Apoyado en el dictum de Walter scott de que es el género que presenta por antonomasia «el curso habitual de los acontecimientos humanos y las condiciones modernas de la sociedad», Levin opone la novela a la narrativa romancesca -el romance inglés- que se atiene a registrar «peripecias maravillosas e insólitas» (1968b: 138). Tal y como lo hará más tarde Terry Eagleton, siguiendo los pasos de Raymond Williams, Levin hace del tema de la novela realista, y de la «trama baladí» que la sostiene, el núcleo de una investigación que remite a las condiciones de existencia cotidiana en la burguesía de clase media y que traspone poéticamente su propia imagen en «una visión casi mítica». Rest subraya con claridad que esta hipótesis de Levin coincide en términos generales con la idea lukacsiana de que la novela es «el género peculiar de la sociedad burguesa», ya que en ella «se exponen, examinan y transfiguran» los deseos y los miedos de esa clase social. ${ }^{182}$ Pero esa exposición, ese examen y esa transfiguración de aspiraciones y temores se producen en la novela realista en la medida en que ella misma está destinada a indagar, a través de la «convención literaria», la «convención social». Su objetivo es hacer una crítica y es por eso que exhibe y juzga las bases económicas y el conjunto de «aspectos

182 Cfr. Lukács, G. Problemas del Realismo (México, Fondo de Cultura Económica, 1966) y Significación actual del realismo crítico (México, Era, 1963). 
pragmáticos que sustentan la convivencia en un sistema». Rest percibe a través del trabajo de Levin muchos de los puntos que desplegarán E. P. Thompson, Richard Hoggart y Raymond Williams en su indagación culturalista. La novela realista clásica es el espacio que da cuenta de una transformación social e histórica muy precisa. Allí «el matrimonio -con una carga social y financiera más que erótica- ha sustituido al amor cortés», allí «el ciudadano común ha desalojado al gentil-hombre palaciego»y, finalmente, allí también empieza a tomar un lugar preponderante el individualismo «transformado artísticamente en estudio de caracteres». ${ }^{183}$

A través del trabajo de Levin, Rest arriba a su hipótesis particular: la novela es el resultante histórico de la tensión entre dos fuerzas antitéticas. Por un lado, insiste en persuadir al lector de que lo que se ofrece es un cuadro real y no ficticio; pero al mismo tiempo, por el otro, no deja de seducir con cierto encanto propio del cuento de hadas. Tanto el subterfugio imaginativo como el sedimento de realidad histórica con que constituye su tipificación social, juegan un rol determinante en el nacimiento del género. Levin, a quien Rest describe como «confeso admirador de Cervantes», pone al Quijote como enclave histórico fundamental para el desarrollo del realismo novelesco, pero se cuida bien de señalar la preeminencia de Inglaterra en el siglo XVIII y de Francia en el siglo siguiente. Esa corrección no es azarosa y Rest no duda en señalar

183 Véase, sobre este punto específico, el minucioso estudio del origen, la forma y los procedimientos de la novela burguesa en Novela, cuento, teatro: apogeo y crisis, Buenos Aires, CEAL, 1971. pp. 11-51. 
su origen: el itinerario de desarrollo «del capitalismo burgués aproximadamente 1789 a 1939- corresponde, no por accidente, al apogeo de la novela realista» (1968b: 138). El hecho de que Levin dedique las últimas páginas de su estudio a señalar el declive de la novela como forma narrativa hegemónica, siembra en la lectura restiana ciertas dudas en función de los argumentos sostenidos por el teórico norteamericano. La pérdida del preciado "equilibrio" entre un absorbente interés por la realidad y un distanciamiento que garantice su objetivación imaginaria parece ser el argumento más sólido del diagnóstico de Levin. En muchos casos, la inmersión en el acontecimiento histórico impide el «desapego»y es de ese modo que «el campo narrativo de la pieza testimonial consciente el indispensable margen de ficción» (1968b: 139). Lo que Rest ve es que, paradójicamente, el «exceso de realidad» termina por constituir el «factor decisivo» en la crisis del "realismo clásico", para dar lugar al nacimiento de «un nuevo realismo», cuya proyección constituye el núcleo de examen del último apartado.

Que Rest vaya al origen del realismo clásico para tratar de reconocer lo que de él sobrevive en las experiencias literarias del presente, no es casual. Capitalismo, democracia y secularización constituyen el triple proceso que acompaña el nacimiento y desarrollo del realismo clásico y la novela moderna. El refinamiento de la técnica verista y la marcada actitud de crítica social obligan a pensar tanto en los ecos de la Revolución Francesa como en las teorías dramáticas de Diderot, para quien «la dignidad trágica del hombre común y la vida 
cotidiana en las clases medias y en los sectores populares» (1968b: 139) debía ser objeto de la indagación estética moderna. Tanto la historia como las series discursivas coetáneas traman las condiciones de posibilidad de una poética de género. Es por eso que, sin perder de vista los orígenes de la novela inglesa, Rest se apoya en las investigaciones de Margaret Schlauch para subrayar que desde sus tempranas apariciones el realismo literario en las lenguas europeas modernas estuvo vinculado a cierta preocupación por «las relaciones personales entre los individuos, a nivel de un ámbito social definido» ${ }^{184}$, sin que el «concepto central de verosimilitud» deje de ser capital en su desarrollo ${ }^{185}$. La captación de lo típico como procedimiento y la disposición al rechazo o la aceptación del verosímil llevan a establecer una distinción tangible entre dos especies narrativas: la novela («la minuciosa evocación de sucesos posibles») y el romance («que no se arredra ante la incorporación de hechos inverosímiles o improbables»). Pero la importancia que se otorga a la verosimilitud determina que el escritor imagine su propia producción no ya como una ficción sino a la manera de un documento de la realidad. La insistencia en ese punto compromete a la forma de la novela en razón de su destino. La exaltación de la verosimilitud está estrechamente ligada a una actitud de crítica y menosprecio de lo fantástico, lo sentimental y lo misterioso -en ese punto, el Quijote sería a las novelas de

\footnotetext{
184 Schlauch, M., Antecedents of the English Novel, 1400-1600, Londres, Oxford University Press, 1963.

185 A través del propio Cervantes retomado por Henry Fielding, Rest reafirma categóricamente dicho concepto argumentando que el realismo se cuida de llegar al hombre que no es capaz de admitir sino aquello que está en condiciones verosímiles de realizar él mismo.
} 
caballería hispánica lo mismo que Joseph Andrews a la sensiblería de Pamela de Richardson, o Northanger Abbey de Jane Austen a las narraciones góticas de Mrs. Radcliffe. A la luz de la militancia verista, lo fantasioso y lo sentimental aparecen, no sólo como síntomas concretos de «imperfección creativa», sino también como «un desatino que puede perturbar la mente, deteriorar las costumbres, socavar los principios morales» (1968b: 147). En este punto, Rest describe y subraya la superstición ideológica que lo llevará a indagar -en los años siguientes- en las literaturas del mal, los géneros marginales y los autores malditos. El realismo clásico es una poética de género que se justifica como disposición ética pero es también una fuerza que motoriza el despliegue de la literatura moderna en su complejo devenir histórico. Los síntomas iniciales bien pueden remitirse a las más tempranas manifestaciones del "verismo burgués" pero sus secuelas llegan incluso a las expresiones más complejas y genuinas de "realismo crítico" que denuncia abiertamente la inoperancia poética de los procedimientos clásicos sin perder de vista sus objetivos.

Rest, que publica estos apuntes sobre la "actualidad del realismo" a pedido de Ángel Rama, en el semanario Marcha, está pensando en experiencias renovadoras del realismo como las de Juan Carlos Onetti y Roberto Arlt, en las que el escritor demuestra contar «no sólo con un agudo sentido crítico sino también con una singular percepción creativa, que le permite ordenar los elementos del mundo imaginario expuesto en adecuada perspectiva» (1968b: 151). Teniendo en cuenta que las categorías 
estéticas del realismo se caracterizan por su variedad y su dinamismo («al punto que es posible sostener - de conformidad con Sartre- que el realismo nace de sus mismas contradicciones, originadas en la riqueza de sus medios»), Rest apunta que el realismo está menos en los hechos referidos que en el modo de tratar con ellos, «ya que la autenticidad de la descripción no radica sino en la forma» (1968b: 151-152). Las nuevas formas del realismo -que reemplazan las esclerosadas consignas del realismo "clásico"- nacen a partir de que este último se convierte en un movimiento deliberado y programático, es decir, a partir de que el realismo clásico encuentra sus límites y entra en crisis terminal, como efecto de circunstancias internas y condiciones históricas generales. El «impacto del romanticismo» y sus aspiraciones poéticas, el paulatino «desgaste de la mentalidad individualista y liberal» (1968b: 153) de las estructuras burguesas, y la aguda "conmoción" originada por las profundas transformaciones históricas que se producirían desde comienzos del siglo $x x$ en adelante, dieron origen -junto a una serie de factores intrínsecos importantes (como su severo rechazo de la lírica y del componente fabuloso)- a una nueva manera de pensar la propuesta estética realista. En un abanico que recuperaba para sí desde el naturalismo de Zola a Proust y desde Joyce a Virginia Woolf, la «disgregación realista» implicó un cambio de objeto de la finalidad crítica: la experiencia de desgarramiento, alienación y frustración de la vida moderna pasó a ser el blanco de su crítica. El realismo -y en este punto la obra onettiana al igual que la arltiana podrían configurar, según Rest, ejemplos 
esclarecedores- fue despojándose del lastre impuesto por el programa implícito del realismo clásico. El desplazamiento del personaje tipológico al enfoque de los personajes excepcionales y transmigrantes (locos, raros e infames), el desliz hacia un universo marginal y canallesco (que incluye el juego, la delincuencia, la prostitución) a través de una mirada desencantada (que no oculta su pulsión paródica o por lo menos irónica respecto del uso que de esos mismos tópicos había hecho el realismo socialista más lacrimoso), el nuevo realismo es crítico de lo social en términos generales a la vez que lo es de sus propias modalidades estereotipadas. El realismo, como poética de género, conquista así su propia autonomía frente a las narrativas de la tierra y el realismo socialista; se descubre como un trabajo de creación de una lengua literaria y abandona el recurso estereotipado a un verosímil apoyado en el "color local". Pone en cuestión su propio dispositivo narratológico apelando a recursos provenientes de las experiencias vanguardistas del primer modernismo -rompe con la presunción de objetividad del narrador omnisciente y con el registro estrictamente descriptivo. Construye su verosímil pero incorporando incluso -en la vertiente faulkneriana- las técnicas del monólogo interior, los narradores parciales y el armado de una trama compleja a partir del cruce de puntos de vista y empieza a reconocer -en su propio interior- un espacio para lo incierto, lo engañoso y lo ambiguo. El realismo clásico se desintegra en función de la erosión que sobre su preceptiva operan las «nuevas tendencias creativas y críticas». Se transforma al transformarse el «criterio de realidad» de la 
modernidad. Rest lo subraya fehacientemente haciendo pie en la aseveración de Alain Robbe-Grillet, según quien, a partir de la segunda mitad del siglo XX, todos los escritores se tienen a sí mismos por realistas: «ninguno pretende jamás ser abstracto, ilusionista, quimérico, fantasioso o impostor» (1968b: 155).

Pero el hecho de que la noción burguesa de realidad -de fundamento secular, cotidiano y objetivo- haya entrado en un proceso de progresiva disgregación, no ha contribuido a una liquidación del realismo, sino más bien a su propia multiplicación. Que el concepto de "realidad" se haya relativizado «como consecuencia de la crisis sufrida por el pensamiento moderno» y haya favorecido el resquebrajamiento de la estructura intelectual de la sociedad burguesa, condujo además a que la actividad poética -fiel a su permanente función testimonial- se dispersara en una «multitud innumerable de realismos, inspirados por las tendencias más contradictorias» (1968b: 156). Ya sea con mayor o menor grado de anclaje en la tradición del realismo "clásico", Rest reconoce en el «realismo social» de Brecht, el «realismo lingüístico» defendido por Cesare Pavese, Julio Cortázar y el grupo de críticos vinculados a la revista Tel Quel -entre los que cabe mencionar a Roland Barthes y Jean Ricardou-, el «realismo humanista» O «integral» defendido por T. S. Eliot en su célebre conferencia titulada "Poetry and Drama", el «realismo subjetivo» cuyos exponentes más visibles son James Joyce y Virginia Woolf, el «realismo literal» que Susan Sontag lee en la significación literal de idiotismos y frases 
hechas en Ionesco'186, o el «realismo objetivista» ensayado por Robbe-Grillet en Dans Labyrinthe y L'année dernère à Marienbad, el arduo trabajo realizado al interior de una tradición que se fue desarrollando siempre a partir de «experiencias operativas»y «no de preceptos o dogmas que en definitiva coartan o delimitan las posibilidades de creación» (1968b: 160) ${ }^{187}$.

Tanto el debilitamiento del referente como determinación del verosímil, como la crisis de la representación en el sentido clásico, empujan finalmente a Rest a reconocer que «el realismo "clásico" es un capítulo definitivamente cerrado en la historia de las concepciones artísticas», al tiempo que lo ponen ante el hecho de que, en esa capitulación, se abre a la vez un nuevo comienzo. Nacido de la crisis del realismo "clásico", el «nuevo realismo» es consciente no sólo de sus deseos sino también de sus propios límites. Se enfrenta sí a dos de sus más lamentables errores: el voluntarismo y la pedagogía. La literatura «jamás es gratuita»y, «sea cual fuere la intención o el punto de vista del escritor, no cabe duda de que su intento poético es tanto más pleno y significativo cuanto más hondamente penetra en las dimensiones primordiales de su horizonte, de su realidad» (1968b: 161); pero las formas de esa inquisición no pueden ser ya

186 Rest cita aquí de manera precursora, en 1967, la edición inglesa de Contra la interpretación: Sontag, S., Against Interpretation, Nueva York, Delta Books, 1966. pp. 118-119.

187 «De paso -acota Rest-, convendría señalar que el enfoque preceptivo del realismo socialista sigue el camino inverso al que recorrieron Marx y Engels, quienes solían juzgar la validez realista de la obra de arte a partir de la autenticidad estrictamente poética, no de la evaluación ideológica; tómense en cuenta, al respecto, los juicios elogiosos de estos opinantes sobre Shakespeare y Balzac» (1968b: 160). Cfr. Marx, K. y F., Engels, Sobre la literatura y el arte, Editorial Calomino, La Plata, 1946. Trad. Pedro Peralta. 
lineales, ni pueden obedecer ciegamente al simple cálculo de una verticalidad pedagógica. Lo que el nuevo realismo pone en escena -y es por ello que con justicia puede hacerse legítimo acreedor de las contribuciones «de un Mallarmé o un Ionesco»- es la necesidad de reflexionar sobre la modalidad de irrupción de la realidad sobre sus propios medios reproductivos. Porque, si «no hay obra de arte legítima que se desvincule por completo de las condiciones históricas en que fue concebida», el nuevo realismo no puede menos que dar cuenta de la crisis representacional y estética en que se inscribe. De tal modo, la referencia final a Giulio Carlo Argan no es arbitraria. Como bien apunta el historiador y crítico de arte italiano en Salvezza e caduta nell'arte moderna (1964), realismo no es ya «representar objetivamente la realidad o interpretarla, sino estar dentro de la realidad; dentro de la realidad natural, dentro de la realidad histórica y social, no menos que dentro de la realidad natural, dentro de la realidad no sensible, no menos que dentro que aquella aprehendida a través de los sentidos» ${ }^{188}$. El nuevo realismo se sabe «indefectiblemente -como diría Joyce- una epifanía de la realidad» (1968b: 161). No pretende ya, como el "clásico", capturar o fijar la realidad, pero no se resigna a serle indiferente (porque sabe que no podría serle indiferente). Sabe que no está destinado a resolver sus problemas, pero no por ello renuncia a la difícil y comprometida tarea de plantearlos.

188 Argan, Giulio Carlo, Salvación y caída del arte moderno, Buenos Aires, Nueva Visión, 1966. p. 109. 
El segundo ensayo que compone el apartado lleva por título "El cine, testigo de nuestro tiempo". No es la primera vez que el cine convoca la sensibilidad crítica de Rest. Su interés declarado por ampliar el campo de investigaciones en esta dirección puede comprobarse tanto en el lugar que ocupan estas producciones en "Situación del arte en la era tecnológica" (1961a) y "Alcances literarios de una dicotomía cultural contemporánea" (1965b) -reeditado como Literatura y cultura de masas (1967a) ${ }^{189}$ - como en el artículo dedicado a los films de Ingmar Bergman publicado en Sur analizado en el capítulo 2 de esta investigación (1957d) ${ }^{190}$. Desde esos antecedentes que atribuyen a las producciones cinematográficas un estatuto marginal (que refuta los prejuicios despectivos al potenciarlo en funciones que las producciones literarias más sofisticadas del modernismo parecen ir resignando), "El cine, testigo de nuestro tiempo" dialoga significativamente con el resto de los ensayos que componen el libro.

Pero el carácter testimonial que Rest percibe en el cine es el mismo que percibe en las literaturas de T. S. Eliot y Paul Valéry. En su perspectiva, tanto uno como otros son textos que encarnan y -por eso mismo- revelan «la tragedia del hombre moderno». De algún modo, como sugiere el epígrafe de Alexander Astruc, el cine es el heredero de la ficción que hace pie en esa condición trágica que toca a todos los hombre por igual.

El trabajo de Rest se empeña en desarmar críticamente los

189 Rest, J., Literatura y cultura de masas (1967a). Buenos Aires: Centro Editor de América Latina.

190 Rest, J., "Ingmar Bergman: presencia humana y dimensión imaginaria del cine sueco" (1957d), en Sur, n²46, Buenos Aires, mayo/junio. pp. 80-89. 
«prejuicios» y «reproches» que las «versiones apocalípticas» y las descalificaciones de «intelectuales nostálgicos» reproducen y naturalizan la condición mercantil de dicha producción cultural. Rest lamenta -no sin cierta ironía- que estas posiciones preconcebidas resulten ciegas a las transformaciones irreversibles que los medios de comunicación masiva producen en la vida social y en las configuraciones estéticas de la modernidad. Y -apoyado en el riguroso trabajo de Albert Huntsubraya particularmente el hecho de que en su corta vida ya ha sido capaz de ofrecer «obras de mérito real, dignas de un adecuado estudio que prestaría considerable utilidad para una mejor comprensión de este novedoso ámbito poético» (168b: 164).

Claramente -como apunta María Elena Torre-, Rest exhibe, en esta disposición abierta y atenta a las transformaciones, «ese espíritu permeable a la dinámica de la historia que pretende descolocar al pensamiento cristalizado» (Torre 2002: 166). La hipótesis de Rest supone discutir y determinar la función y significación del cine en el marco de la cultura de masas. Asume el riesgo que entraña la falta de «perspectiva» en razón de la proximidad con esa forma de expresión estética que considera capaz de «reflejar nuestros sentimientos e inquietudes con respecto al mundo que nos circunda» (1968b: 165). Y plantea al respecto «una problemática central de la crítica literaria: el tema del valor de una obra en relación con el contexto» (Torre 2002: 166).

El repaso de Rest por las diversas posturas teóricas, que dan lugar a formulaciones siempre parciales y «provisionales», 
subraya especialmente la tensión constitutiva del cine, que se dirime entre un fuerte componente comercial e industrial y sus propias y ambiciosas pretensiones estéticas. Retoma los planteos teóricos de Paul Valéry y André Malraux y vuelve a discutir los argumentos del crítico Dwigth MacDonald a quien en Literatura y cultura de masas (1967a) había descrito, a partir de «un lenguaje exaltado e imprudente», como una suerte de representante típico de esa «élite intelectual "débil y desintegrada"» que empieza a ser «arrollada en todos los campos de la batalla cultural» (1967a: 20) .

La comparación de las técnicas y procedimientos cinematográficos frente a los que hacen a la producción teatral y novelística busca delimitar las condiciones y la productividad significante de esta forma estética en su diferencia. Los aportes específicos de Galvano della Volpe y Siegfried Kracauer le permiten ratificar la proximidad formal entre los mecanismos narrativos del cine y la novela. Pero además le permiten trazar un singular paralelismo entre los efectos buscados en ambos campos a partir del parecido entre la verosimilitud novelística y el verismo cinematográfico. Este cotejo y aproximación entre condiciones de producción, procedimientos estéticos y efectos específicos no es casual. Siguen una metodología comparativa de las investigaciones restianas. Y lo que busca es desmitificar finalmente el valor de un arte por sobre otro en razón de argumentos que ponen a la condición mercantil como eje de diferenciación: es por eso que Rest va a los orígenes non sanctos de la novela inglesa y da cuenta de su expansión en función de la 
ampliación del público lector (derivada de la aglomeración demográfica producida en espacios urbanos por el desarrollo industrial y comercial), cuando la propia novela «se convirtió en una suerte de industria a menudo reprobada por críticos literarios o censores morales» (1968b: 174).

Sólo desde esta perspectiva desmitificadora el crítico argentino concede el abordaje de un tema tan escabroso y tan sensible como el de la relación -nunca cómoda, casi siempre conflictiva- del cine con el público que asegura el circuito económico que requiere su financiación. En función de esto apunta- hay que comprender su atención a la demanda estética y temática de los sectores más vastos de la sociedad. Rest nota lúcidamente que el auge de esta forma de expresión cultural está indisolublemente ligada a una sociedad en transformación, «a causa del proceso disgregatorio que aqueja a la burguesía» y que afecta a sus lenguajes y manifestaciones estéticas en la misma medida que exhibe los límites concretos «de la concepción del mundo instaurada por dicha clase» (1968b: 175). En su perspectiva, el cine se erige como «testimonio», sólo en tanto «recoge el legado de la novela y lo prolonga en medio de las vicisitudes de una época de perturbaciones, cambios y "masificación" (fenómeno, éste último, que ha desconcertado al individualismo de la mentalidad burguesa)» (1968b: 175) .

Porque si, como apuntaba en "Alcances literarios de una dicotomía cultural", aún no están dadas las condiciones específicas para establecer «en qué medida el público determina la calidad del material que se le proporciona o en qué medida el 
gusto colectivo es manejado y orientado "desde arriba" a través de los vehículos difusores mismos» (1965a: 27), no es a causa de la ausencia de herramientas teóricas o voluntad crítica; sino fundamentalmente porque la propia perspectiva crítica está inmersa y constitutivamente afectada por la inestabilidad causada por ese mismo progresivo movimiento de disgregación y transformaciones dinámicas. A juicio de Rest, se trata de una encrucijada histórica «donde la actitud crítica, con todos sus riesgos y todas sus virtudes, supera en empuje a cualquier afirmación, a cualquier certidumbre» (1968b: 176).

Su convicción de que un adecuado empleo de los medios masivos de comunicación puede contribuir a «la gradual elevación del gusto popular» se encuentra aquí manifiesta frente a un uso malicioso del mismo. No duda pues en afirmar que uno de los «peligros» fundamentales que afronta el cine es el de ser convertido en un «mero pasatiempo» que produce una «anulación de la personalidad» desde una «engañosa apariencia realista que invita a la fácil identificación sentimental, en desmedro del juicio crítico» y que facilita la «instauración de una verdadera atmósfera hipnótica» (1968b: 177). La referencia explícita a Brecht viene a definir una colocación frente a esa antinomia problemática entre el cine como entretenimiento y evasión y la reflexión crítica a partir del uso de los mecanismos de verosimilización: Rest opta por una configuración poética que procure «estimular la facultad crítica del espectador» aun creando de manera artificial «un mundo imaginario exento de "ilusión de realidad" y, por lo tanto, peculiarmente apto para 
enjuiciar el ámbito real de la sociedad con lucidez intelectual y sin peligrosas identificaciones sentimentales» (1968b: 177). Sin perder de vista «la predisposición realista del cine»-que siempre puede constituir una forma «perturbadoramente engañosa» al dirigirse a un «auditorio multitudinario»-, Rest apunta que esta nueva producción cultural «demuestra ser testigo y juez severo de nuestra época de disolución e inestabilidad social» al orientarse al «examen del hombre en su actual desamparo ideológico, en sus búsquedas, en sus fracasos, en sus posibilidades» (1968b: 178) .

El análisis que el propio Rest describe como «rápido y superficial», se cierra con breve muestrario de producciones cinematográficas que cumplen con la premisa de «documentar» ese estado de incertidumbre, intemperie y desamparo que caracteriza la vida moderna. En ese contexto, destaca especialmente las obras de Ingmar Bergman y Michelangelo Antonioni, porque ambas describen «la situación del individuo en la vida social contemporánea, especialmente a través del vínculo que se establece en la relación erótica» (1968b: 179). Al leer estas nuevas formas de expresión en articulación cultural con la tradición medieval y con algunas obras literarias modernas como las de Cesare Pavese, Paul Valéry o T. S. Eliot -cuya actitud vacilante ante la deriva moderna hemos descrito en capítulos anteriores-, Rest busca hacer emerger la singularidad del acto crítico como respuesta a «la incertidumbre que circunda la condición humana» en el contexto histórico y cultural de la modernidad. 
En ese punto -y como bien afirma Torre-, el valor concreto del ensayo radica, no sólo en su disposición a la apertura de nuevas líneas de investigación «en los estudios literarios y culturales de la crítica argentina de los sesenta», sino también en «el planteo anticipado de futuras disputas acerca de las relaciones entre cultura letrada, cultura popular y vanguardia» (Torre 2002: 168). Pero eso no es todo. Ratifica también la convicción restiana para iluminar los fenómenos estéticos abordándolos desde un nivel de análisis histórico-cultural a partir del cual emergen en su diferencia y especificidad. Y pone al lector, finalmente, ante la certeza cuyas reminiscencias borgeanas resultan inocultables: lo que define el valor específico de las producciones culturales de una época no es un conjunto de prescripciones con que la obra se produce ni el conjunto de mecanismos con que se materializa su reproducción, sino la manera en la que esas producciones son leídas. ${ }^{191}$

La sección se cierra con el artículo "Emotividad verbal y totalitarismo", publicado originalmente en sur en 1958 y confeccionado por Rest como una respuesta elíptica al peronismo. Sobre este ensayo, que ha sido examinado con detenimiento en páginas anteriores, vale la pena decir que se resignifica

\footnotetext{
191 En su "Nota sobre (hacia) Bernard Shaw", incluida en Otras inquisiciones (1952), Borges plantea singularmente esta idea: «La literatura no es agotable, por la suficiente y simple razón de que un solo libro no lo es. El libro no es un ente incomunicado: es una relación, es un eje de innumerables relaciones. Una literatura difiere de otra, ulterior o anterior, menos por el texto que por la manera de ser leída: si me fuera otorgado leer cualquier página actual -ésta, por ejemplo- como la leerán el año dos mil, yo sabría cómo será la literatura el año dos mil» (Borges 1998: 238-239).
} 
políticamente en el contexto de la edición del libro. En contrapunto con la escalada autoritaria prodigada por el gobierno de facto de Onganía, el texto de Rest -que en términos generales podía inscribirse en una posición liberal democrática- adquiere el carácter de una crítica progresista en presente ante ese régimen que se obstinaba en «acallar cualquier ámbito de expresión de las tensiones de la sociedad, y aun de las opiniones mismas» con el objeto de «diseñar sus políticas con tranquilidad, sin urgencias -la revolución no tiene plazos, se decía- y con un poderoso instrumento estatal en sus manos» (Romero 2001: 171).

Al describir -bajo una inspiración manifiestamente orwelliana- una actitud general de los «lenguajes políticos» ${ }^{192}$, vinculada a usos específicamente propagandísticos y demagógicos, este ensayo de Rest funcionaba como crítica específica a la naturalización belicosa del discurso populista bajo el peronismo; pero reeditado aquí exhibe también la manipulación implícita tanto en la censura autoritaria de la "Revolución Libertadora" como en el silenciamiento totalitario mediante el cual la "Revolución Argentina" pretendía encubrir sus resistencias. El ensayo se resemantiza en los diferentes contextos de opresión autoritaria. Un ejemplo claro de ello es que, después del golpe de Estado de 1976 -en un ejercicio paradójicamente retroactivo-, el libro fuera considerado nuevamente "peligroso" y convertido

\footnotetext{
192 Como recuerda Orwell en uno de sus memorables ensayos sobre el tema, «el lenguaje político, y con algunas variantes esto es cierto en todos los partidos políticos, desde los conservadores hasta los anarquistas, está destinado a hacer que las mentiras parezcan verdades y el crimen algo respetable, y dar a lo que es puro viento una apariencia de solidez» (Cazando un elefante, Buenos Aires, Kraft, 1955. p. 98).
} 
objeto de la censura y la persecución política. ${ }^{193}$

En el "Prefacio" del libro, Rest afirma sin vacilaciones su convicción de que existen «conexiones muy estrechas» entre la persecución de autores y la compulsión ideológica a través de las estrategias lingüísticas de poder. «Las estrategias verbales del totalitarismo -escribe categóricamente- no están desvinculadas de las interdicciones artísticas». La hipótesis restiana reafirma su fundamento liberal al describir la censura como «uno de los recursos más utilizados para imponer regulaciones intelectuales y para coartar la formación de un juicio independiente» (1968b: 8). Dedicados a las obras de John Cleland, el marqués de Sade y D. H. Lawrence, los ensayos que conforman la primera parte del libro ratifican la hipótesis de que la censura como «recurso del poder» es una de las preocupaciones fundamentales de su trabajo crítico. Se interesa por lo que es como hecho efectivo, pero también por su poder de coacción intimidatoria de otras eventuales transgresiones. Pero fundamentalmente reconoce que en la censura lo que se busca reprimir es una potencia que viene a trastocar los fundamentos históricos de las convenciones sociales, morales y religiosas.

En la perspectiva de Rest, lo realmente necesario no es censurar esas obras cuya virulencia y voluntad de transgresión resultan prácticamente inadmisibles, sino más bien de clarificar sus sentidos últimos y subyacentes. La crítica tiene -para Rest-

193 Véase al respecto: Biblioteca de Libros Prohibidos, Archivo Provincial http://www.apm.gov.ar/sites/default/files/biblio.pdf. 
la obligación de dar cuenta de estas obras porque ella misma es concebida como una de las disciplinas que desarrollan la libertad del hombre» (1968b: 9). Y, aunque se empeña en acentuar la premisa ética según la cual «toda obra de arte es una compleja estructura simbólica dotada de valor polisémico», Rest no duda en reconocer que -aun en su carácter de especulación provisional y parcializada- «la crítica está llamada a desentrañar, actualizar y enriquecer» su horizonte significativo (1968b: 10) .

La determinación restiana de abordar esta serie de autores prohibidos se resignifica políticamente si se considera la naturaleza de su contexto de investigación. Como apunta Oscar Terán en Nuestros años sesenta, durante todo este período «son recurrentes los operativos de seguridad en su inagotable tarea de secuestrar libros, revistas, periódicos, allanar editoriales o prohibir películas». En ese contexto, la censura se ejerció vertical y arbitrariamente «toda vez que se consideró estar en presencia de desviaciones respecto de los patrones que aquellos discursos tradicionalistas habían establecido como norma». La represión apuntaba tanto a los "desvíos políticos" como a los "descarríos morales y sexuales", al punto que se llegó inclusive a «promover una célebre campaña de moralidad sexual encabezada por un jefe policial [el comisario Marguide]» (Terán 1993: 156) que -como bien recuerda el poeta y militante del Frente de Liberación Homosexual (FLH) Néstor Perlongher- no excluían violentos operativos de razzia en los lugares de reunión y encuentro de homosexuales y que frecuentemente determinaban medidas como la clausura de los baños públicos, irrupciones en 
los cines, bloqueos en los subtes y múltiples variantes de atropello a las libertades de la sociedad civil (Perlongher 1983: $8-9)^{194}$.

En semejante contexto de autoritarismo, la determinación de plantear un análisis crítico en torno a «la actitud asumida [por las obras de Cleland, de Sade y de Lawrence] con respecto al sexo» es decididamente provocativa pero también sutilmente meditada. Cada una de las obras examinadas por Rest representa, a su juicio, un estadio particular de la cultura occidental: en primer lugar, la obra de Cleland da cuenta del «secularismo jovial y optimista implantado por la burguesía en su época de plenitud»; en segundo lugar, la de Sade traduce de algún modo «la consolidación de una idea absoluta del Mal, de neta estirpe maniquea, que se canaliza en estallidos de intolerancia y arbitrariedad»; y, en tercer lugar, lo que se percibe en Lawrence es «un vigoroso enfoque cristiano que intenta renovar en el hombre moderno la conciencia religiosa, a través de un "realismo del mal" que considera al pecador un individuo que por lo menos ha vencido la indiferencia moral» (1968b: 9) .

Los cuatro ensayos que componen la sección sitúan las experiencias literarias tanto en sus condiciones de producción como en la contingencia de su recepción. Titulado con la irónica frase de Marghanita Laski, "Ese librito tan divertido...", publicado originalmente en 1964 en el semanario Marcha de Montevideo y escrito con motivo de las reediciones inglesa y

194 Perlongher, N., "Entrevista", en el suplemento "Cerdos y peces", El Porteño, año 2, $\mathrm{N}^{\circ}$ 22, Buenos Aires, octubre de 1983. pp. 8-9. 
norteamericana de Fanny Hill (1749), da cuenta exacta de esta metodología de investigación. Rest recorre rápidamente -pero con datos precisos- la larga historia de censuras y proscripciones que -ya «en versiones francesas, alemanas, italianas y portuguesas» (1968b: 17) e inclusive en la «sospechosamente anónima» traducción española- el texto de Cleland debió atravesar en sus más de dos siglos de existencia. El hecho de que su «nombre olvidado y clandestino llegase a ocupar un sitio prominente en los periódicos, entre las noticias de actualidad» (1968b: 18) no deja de exhibir -a juicio del crítico- un síntoma sobre su naturaleza específica pero también de los prejuicios morales de la sociedad burguesa. El texto introductorio de Peter Quennell, ese «erudito conocedor de la historia social dieciochesca en sus más tortuosos y disimulados vericuetos» (1968b: 18), también publicado en la revista Encounter, es -según Rest- un texto fundamental y necesario en tanto repone histórica y críticamente las condiciones de aparición y recepción de Fanny Hill. El crítico se apoya en él para subrayar el hecho de que la novela fue escrita a pedido del editor (que le solicitó escribiera «un relato libertino que pudiese suscitar el interés de una concurrencia literaria comparativamente nutrida») en el contexto de un importante aprieto económico del autor. Que denunciado por las autoridades e interrogado por el Consejo Privado de la Corona- el propio Cleland abdicase de los valores de su propio libro (alegando en su deposición que «los apuros financieros lo habían convertido en un emborronador asalariado e impúdico»), resulta -a juicio de Rest- altamente significativo, 
tanto de las presiones de la «moral pública» de la época como de la propia miopía de Cleland ante su obra -puesto que, como sugería Oscar Wilde, su literatura «nunca más volvió a alcanzar el nivel de perfección exhibido en Fanny Hill» (1968b: 21). La operación restiana no es ingenua. En primer lugar, se trata de desmitificar el prejuicio victoriano naturalizado de la oposición entre arte y trabajo: lo que se busca es demostrar que, por el sólo hecho de haber sido producida como contraprestación en una relación puramente comercial, el valor de la obra no es necesariamente desdeñable. En segundo lugar, se trata de despegar al autor de la obra, quitándole al primero la autoridad para decidir sobre el valor específico de la segunda.

Rest subraya especialmente que -a excepción de este pequeño inconveniente que no pasó a mayores- «Fanny Hill no fue juzgada en su época [como] una obra definitivamente pornográfica». Constituía, antes bien, «un caso limítrofe» que -más que «estimular la corrupción»- «documentaba los decadentes hábitos de la sociedad contemporánea» (1968b: 23). Se esmera en hacer notar el hecho de que la narración, «aunque detallada en las descripciones eróticas, nunca cae en un lenguaje grosero y siempre conserva cierta pulcritud y levedad en el estilo». Es por ello que -afirma el crítico- «el efecto de conjunto es grácil y no peca de innecesaria depravación o excesiva morosidad» (1968b: 23). Rest desarrolla un resumido examen argumental de la novela a fin de demostrar que, en rigor, lo que ella presenta es pues «un verdadero catálogo de los extravíos más diversos en el comportamiento erótico, pero sin que la narración se regodee en 
ultrajes y violencias». Es en este punto donde el crítico subraya la relación específica entre la literatura de John Cleland y la de Samuel Richardson. En este último, pese al evidente «aparato moralizador desplegado en beneficio de la masa lectora procedente de las clases medias», ya mostraba cierta ambigüedad en la moral de la fábula aun cuando la «interpretación social propuesta es demasiado esquemática y contradictoria» (1968b: 25): la clase alta es siempre presentada como irremediablemente «disoluta y corrupta» por oposición al «decoro» exhibido por las clases populares. En este sentido, la literatura de Cleland-como la de Laclos y la del propio sade- se inscribe en el «voluminoso anecdotario de frivolidad erótica» de su época.

En síntesis, de acuerdo a la perspectiva restiana, «Fanny Hill, más que pornografía, es testimonio» (1968b: 26). Se sobrepone a las convenciones reiterativas del género con «un ritmo ágil y una extensión mesurada». Elabora sus descripciones «en un estilo armónico, cristalino y pleno de sobriedad» y se revela portadora de las más notables «virtudes formales que suele exhibir la admirable prosa inglesa dieciochesca». Y la «ausencia de morbosidad» y de «escenas innecesariamente crueles o enfermizas» se articula -en su óptica- con el cuidado y la austeridad de la prosa en función del objetivo genuino de presentar las heterogéneas situaciones en que se resuelve la erótica de la época.

La argumentación de Rest sobre este punto es tan precisa como estratégica. Manifiesta que el interés por la pornografía es una consecuencia -no una causa- de la censura: cuando «el consenso 
público se vuelve intolerante y coercitivo y apela a medios compulsivos de censura» -nota- «surge una vasta industria de la pornografía clandestina que documenta un grado considerable de hipocresía moral». La censura hace surgir pues «una perversión generalizada de los impulsos amatorios y una evidente represión psíquica que busca canalizarse en un regodeo malsano, en una complacencia del pecado y en el deseo de causar o recibir daño» (1968b: 28). Es en ese momento que surge «el erotismo de la crueldad» que se extiende desde el Marqués de Sade a Jean Genet o Georges Bataille, autores que ejemplifican lo que -siguiendo a Lukács- Rest define como un «asalto a la razón»iluminista que se materializa en «el avance de esa mentalidad totalitaria cuyo máximo refinamiento es el campo de concentración, la cámara de gas o la técnica para el lavado de cerebro» (1968b: 28).

Siguiendo los sugestivos argumentos de Mario Praz en La carne, la morte e il diavolo nella litteratura romantica (1948) ${ }^{195}$, Rest sitúa la aparición de esta tendencia en la «actitud melancólica, pasional e hipersensible» que gravitó en el advenimiento del romanticismo. Pero agrega que -presumiblementela insistencia en la disposición censora a lo largo del tiempo tenga que ver con las determinaciones clasistas de la propia

195 Rest frecuentó asiduamente las investigaciones de este catedrático de Literatura italiana en las Universidades de Liverpool y Manchester, Knight Commander of the British Empire, Doctor Honoris Causa en Cambridge y la Sorbona. En muchos pasajes de su obra sigue especialmente las hipótesis desplegadas en La carne, la morte e il diavolo nella litteratura romantica [La carne, la muerte y el diablo (en la literatura romántica)] (1948) y su continuación titulada Il patto col serpente. Paralipomeni di La carne, la morte e il diavolo nella litteratura romantica [El pacto con la serpiente. Paralipómenos de La carne, la muerte y el diablo (en la literatura romántica) ] (1972). 
moral. Se apoya en Sartre para señalar que la vigencia de la censura esté posiblemente «ligada a la creciente influencia de las clases medias -de la pequeña burguesía, en particular-», a las que el autor de La nausée atribuye el «oficio de opinión»: «la clase alta y el proletariado -resume Rest- son lo que son o lo que se muestran capaces de hacer; los sectores intermedios, en cambio, tratan siempre de "parecer"». Y es precisamente en razón de que «obliteran su espontaneidad para "guardar las formas"», que las clases medias pequeñoburguesas llegan a percibir como indispensable la defensa de «las llamadas "buenas costumbres"»y apoyan las disposiciones que se empeñan en «perseguir las transgresiones por inocentes que sean, aun cuando toleren que a menudo tales normas puedan quebrarse clandestinamente» (1968b: 29). Rest pone en evidencia que es en esa doble moral de las clases medias burguesas donde se apoya el poder autoritario para encontrar legitimidad y disponer sus programas de censura, expurgación, persecución y prohibición. E incluso llega a deslizar la hipótesis -no del todo improbable- de que la misma interdicción, más que una restricción efectiva de la circulación de los «materiales libertinos», es capaz de transformarse en un eficaz motor para intensificar la «lubricidad impotente» de la sociedad burguesa. De este modo, citando agudamente la reflexión de John Calder (el editor de Tropic of Cancer de Henry Miller), Rest deja entrever la complicidad y la hipocresía propias del régimen coercitivo que, operando sobre la actividad artística, resulta «un eficaz estímulo de cierta rendidora actividad mercantil, pretendidamente subrepticia» (1968b: 30). 
La reseña del escándalo y los vericuetos legales que llevaron a la reedición de Fanny Hill en 1963 aparece descrita rauda pero estratégicamente. Rest lleva el asunto a su repercusión en dos niveles: 1) «el específicamente vinculado a la actividad y crítica de índole literaria» y 2) «el que abarca la habitual discusión acerca de la autoridad que una repartición gubernamental -sea esta jurídica o administrativa- pueda tener en el ejercicio de funciones censoras» (11968b: 31). Su posición se define -al igual que lo hace en su intervención a propósito de "El 'caso' Lolita"- rechazando todo tipo de censura, defendiendo la «libre circulación de materiales artísticos que posean cualidades estéticas o científicas relevantes, sea cual fuere su contenido» (1968b: 34) y alegando que, en el caso extremo de que sea necesario establecer condicionamientos a la difusión de algunos materiales, esa actividad sólo puede ser encarada por especialistas rigurosamente formados y avalados por su genuino desempeño en el primero de los ítems, y nunca debe quedar en manos de los agentes mencionados en el segundo.

En "La polémica de Sade con el demiurgo" y "Una nota aclaratoria: la época de Cleland y Sade", ambos aparecidos también originalmente en el semanario Marcha de Montevideo, Rest sostiene la clave de lectura. Ambos textos insisten en problematizar las articulaciones histórico-sociales del iluminismo partiendo de la hipótesis de que en el corazón mismo del "Siglo de las Luces" se desarrolló «un vasto sector de penumbra» que aún está por descifrarse: «sociedades secretas consagradas a prácticas extrañas, corporaciones masónicas, 
indicios de una renovación de viejos y subrepticios cultos satánicos», testimonios de descomposición moral y social y un fuerte impulso hacia la «delectación en lo irracional y lo clandestino» (1968b: 53). Esta hipótesis está sin duda en estrecha conexión con las reflexiones de Michel Foucault.

Se sabe -porque el autor de Les mots et les choses ha echado luz sobre esta trayectoria secreta- que lo que la modernidad llama literatura es una forma derivada de la leyenda y que, a su vez, en la leyenda se parte de un cierto equívoco, una cierta confusión entre lo ficticio y lo real. En el origen, lo legendario, cualquiera sea su núcleo de realidad, no era en suma nada más que lo que se decía de determinado acontecimiento que merecía la gloria legendaria. Si el héroe existió realmente la historia lo recubre con tantos prodigios, lo enriquece con tantos atributos imposibles que es -o casi es- como si no hubiese existido. Y si es puramente imaginario, la leyenda trasmite de él tantos y tan insistentes relatos que adquiere el espesor propio de la existencia. He ahí un origen para la leyenda dorada, en la cual se habilitan sutiles pero efectivos traspasos y transacciones entre historia y ficción.

No obstante, y como bien apunta Foucault, existe también una leyenda que beneficia a aquellos cuya fama es determinada por el espanto o escándalo que generan, y cuya incomprensible gratuidad es desplazada rápidamente al horizonte de lo patológico o de lo mera y gratuitamente maligno. Es la fama que trae la infamia. Gilles de Rais, Aretino, Sade, Lacenaire o Cleland han hecho fama de su infamia a causa de las atrocidades que narran, los 
recuerdos abominables que infunden, las maldades que se les atribuyen o del respetuoso terror que han inspirado o aún inspiran a través de sus textos. Y si bien su infamia es el costo exacto de su fama, es preciso apuntar que esa fama escandalosa es también un modo de esconderlos, de reprimirlos bajo la célebre artimaña de la carta robada. ${ }^{196}$ De modo que, así como ha creado esa tecnología disciplinaria que es el ritual de la confesión en el que se obliga a todos y a cada uno a decirlo todo para borrarlo todo, de contar hasta los más mínimos y exhaustivos detalles para que el relato mismo sea el conjuro significante por el cual el pecado significado sea borrado luego por obra de la penitencia y el arrepentimiento, Occidente también ha encontrado un pozo ciego al cual arrojará -exorcizándolo- todo residuo, todo material indócil, todo exceso en los enunciados de la verdad. Es la operación moderna de un régimen de verdad que rearticula sus funciones y sus dispositivos. De manera que aquellos enunciados que eran reconociblemente insoportables para el régimen de verdad, y para los que el medioevo prescribía abiertamente la hoguera, la modernidad (no más inclusiva que su predecesora, pero sí más utilitaria) los desplazará a la literatura. De modo que, ahí sí, lo demás será literatura. Lo demás, lo que sobra, el exceso: la literatura.

Es claro que desde la función de la fábula -en un sentido literal: lo que merece ser dicho- en la que occidente accedía a

\footnotetext{
196 Está además el silencio impuesto sobre la "leyenda negra" tan lúcidamente descrito por Foucault en "La vida de los hombres infames", un ensayo escrito como presentación a un libro homónimo que compilaría textos de seres anónimos (en términos literarios) cuyos testimonios literales narran las causas de su exclusión social sin ningún tipo de embelesamiento o artificio literario. (Foucault 1996).
} 
un discurso que superponía lo literario y lo fabuloso (se salía de los más concretos y reales embrollos mediante proezas, milagros, la providencia o la gracia), a una literatura de la fábula oscura, en la que lo maravilloso mismo será proscrito o desplazado a un segundo plano, se ha producido un cambio que habla también -en el revés de la trama- de una transformación en el régimen de verdad que funciona como soporte último de la legibilidad de los enunciados. Nace para la literatura -dice Foucault- un nuevo destino: su tarea no consiste ya en celebrar lo imposible, sino en hablar de aquello que había permanecido oculto, aquello no debía o no podía leerse como enunciado. Sorda, solapadamente la literatura es enviada (¿obligada?) a decir lo indecible dentro del régimen de verdad imperante. Esa va a ser la ética inmanente al discurso literario de ahí en adelante y será también la garantía de continuidad de la verdad cartesiana. La literatura -ese paraíso en que vaga perdido todo genio malignoserá el lugar en el que todo puede ser dicho sin que nada pese es decir, sin que ninguno de los enunciados implique un costo o un riesgo cierto para el régimen de verdad: finalmente, sólo es literatura. De este modo, como apunta Foucault, sus funciones ceremoniales (en las que celebraba el heroísmo, la fuerza y la gracia del poder) cesarán para dar paso a una dicción de lo más prohibido de lo prohibido, de lo más escandaloso. ${ }^{197}$

\footnotetext{
197 «Una especie de exhortación -dice Foucault-, destinada a hacer salir la parte más nocturna y la más cotidiana de la existencia, va a trazar -aunque se descubran así en ocasiones las figuras solemnes del destino- la línea de evolución de la literatura desde el siglo XVII, desde que ésta comenzó a ser literatura en el sentido moderno del término. Más que una forma específica, más que una relación esencial a la forma, es esta imposición, iba a decir esta moral, lo que la caracteriza y la conduce hasta nosotros
} 
He ahí la relación estrecha entre la literatura con el dispositivo de poder articulado sobre un régimen de verdad. Ceder la indecisión entre lo verdadero y lo falso -que la fábula mantenía de manera irresuelta- a cambio de una decidida vocación de no verdad (mentir diciendo la verdad y mentir diciendo la mentira): en ese movimiento hacia la ficción, la literatura articula plenamente con un régimen de verdad occidental cuyo modo de coacción (de represión) es hacer pasar por el orden (disciplinario) del discurso aquello de lo que quiere liberarse. Para decirlo de un modo brutal y acaso también excesivo: la literatura ha llegado a ocupar el lugar del confesionario. Destinada al relato de la trasgresión más escandalosa y desvergonzada, a decir lo inconfesable, ella misma llegará a configurar un estado de excepción, el lugar en que la ley es trasgredida abiertamente a condición de devolverla indemne a los enunciados de la verdad.

Pero, ¿qué pasa cuando los enunciados de esa literatura son interpelados críticamente fuera el territorio de excepción que ella misma comporta en función de la verdad? ¿Qué cuando un crítico se siente tentado a hablar de eso sobre lo que ha sido impuesta una prohibición y una amenaza de sanción a aquel que ha decidido hablar? ¿Qué cuando "eso", que pretendía ser exorcizado a través del dispositivo, es tomado deliberada, insolentemente como núcleo de su investigación? ¿Qué se pone en juego cuando la crítica se obliga a hablar de aquello que ha sido desplazado al

en su inmenso movimiento, la obligación de decir los más comunes secretos. La literatura no absorbe para sí esta gran política, esta gran ética discursiva: ni tampoco se conduce a ella enteramente, pero encuentra en ella su lugar y sus condiciones de existencia» (Foucault 1996:173). 
territorio de lo inefable, al territorio del Mal (en términos absolutos)? ¿Qué efectos acarrea y qué riesgos implica obligarse a pensar ahí donde otros prescriben el silencio o proscriben lo impensable?

Sobre estas preguntas se despliega esta etapa de investigación restiana dedicada a "las literaturas del mal". Desde estos ensayos recogidos en Tres autores prohibidos (1968b) a El marqués de sade y la crisis del racionalismo (1971c) ${ }^{198}$, pasando por su "Retrato del moralista como cínico" (1970f) ${ }^{199}$, "Satanás, sus obras y sus pompas" (1970h)200, "Las agonías del romanticismo" (1971a) ${ }^{201}$, Rest sostiene su tematización del mal en la literatura. Lo hace subrayando siempre las particulares condiciones de producción y aparición de esa literatura que trae consigo no sólo la marca de lo maldito, lo maldecido, lo impensable, sino también de todo aquello que por su "naturaleza" sería suspecto de maldición. Interroga a las literaturas del mal para tratar de ver qué es lo que ellas hieren al punto de ser desplazadas al territorio de lo patológico, al conjuro de la enfermedad.

La literatura del mal es pensable, comprensible y acaso también explicable en función de sus relaciones con el complejo contexto que le es contemporáneo; es decir, en función de sus luchas políticas, de sus deseos sociales y de los imaginarios y

198 Rest, J., El marqués de Sade y la crisis del racionalismo (1971c). Bahía Blanca: Alianza Francesa.

199 Rest, J., "Retrato del moralista como cínico" (1970f), en Los Libros, nº 8. Bs. As., mayo de 1970. pp. 10 y 26.

200 Rest, J., "Satanás, sus obras y sus pompas" (1970h), en Los Libros, n 14. Bs. As., dic. de 1970. pp. 10 y 26.

${ }^{201}$ Rest, J., "Las agonías del romanticismo" (1971a), en Los Libros, n 17. Buenos Aires, marzo de 1971. 
cosmovisiones, esto es, del régimen de verdad que aprueba, refuta - -en tanto el contexto funcione como condición prácticamente negativa- del que huye. Hablar públicamente de lo que no se habla, aun cuando ese hablar implique hacerlo bajo amenaza de sanción por parte de los poderes de (la verdad de) turno: he ahí la enseñanza que la literatura del mal transmite a la crítica y que Rest retoma siguiendo a Mario Praz pero en una perspectiva definidamente culturalista que recuerda al modelo de investigación desarrollado en los ensayos de Raymond Williams. La operación crítica se ciñe estrictamente a lo anunciado en el prólogo: se trata de manejar «las cuestiones [de la literatura] como si fueran problemas de historia (ya sea de la cultura, de la sociedad o muy particularmente de las ideas» (1968b: 10), sin perder de vista la condición provisional de la exploración misma. Investigar el pasado significa siempre hacerlo desde un punto de vista móvil desde el que sólo puede tomarse «una imagen parcial». Sin embargo, aun desde esa perspectiva particular y provisoria es posible para el «investigador del pasado» -en función del recorte y la valoración específica de datos y documentos- «volver a escribir la historia de un mismo acontecimiento» (1968b: 51).

Rest lee pues la compleja trama sociopolítica y cultural del siglo XVIII a través de la «literatura libertina». Es allí donde se perciben sus fisuras, sus lagunas profundas y su desintegración inminente. El iluminismo nace con el germen de su propia destrucción y ese germen es una «profunda revolución ideológica que se ha prolongado desde el Romanticismo hasta nuestros días» (1968b: 51). En el horizonte de esa exploración no 
hay lugar para las simplificaciones lineales, ante todo porque se parte de la certeza de que «todo período histórico es complejo y contradictorio» y «todo proceso de cambio entraña ventajas y prejuicios» (1968: 60). Es por ello que su exploración sigue un definido «criterio dialéctico -que ofrece una visión de mayor amplitud o equilibrio, pero que dogmatizado también puede resultar parcial y constrictivo-» con el objeto de explorar «posibilidades históricas desatendidas» (1968b: 51). Con ese «método de investigación que permite comprender y aceptar los procesos de cambio», Rest aborda la problemática del mal y la literatura en la narrativa de Sade y en la poesía de Blake.

Trabaja sobre esa suerte de «contracorriente subterránea» del iluminismo que ha recibido el estigma de la prohibición, la censura o el tabú. La convicción de que en esa prohibición se signa una represión, guía una detenida investigación acerca de las condiciones de producción y difusión de sus obras. Rest reconoce la trascendencia de ese nudo problemático al indagar en la compleja relación que une la obra como producción específica y el contexto de producción social en que ésta encuentra su horizonte de posibilidad pero también un orden de significación concreta. Las obras de Sade, Cleland o Aretino hablan de su época en tanto testimonios del modo en que han sido rechazadas, censuradas y prohibidas; es decir: por el modo en que han sido conjuradas como mal en términos patológicos.

Ciertamente, estas literaturas no narran ni representan otra cosa que los modos de su huida, su expulsión, su destierro del horizonte de verdad dominado por los discursos de la razón 
iluminista. Sin embargo, como lo literario también puede definirse por los modos en que es recusado por esos discursos, cabe afirmar que acaso lo maldito de la literatura del mal es precisamente lo que acoge como insoportable en tanto noliteratura.

La «imaginación alucinada del Marqués de Sade» es el punto de inflexión más dramático de esa «contracorriente» que exhibe el lado oscuro del paradigma iluminista. Rest se detiene especialmente en esa «obra de crueldad» y se compromete en la «espinosa tarea de rehabilitar al Marqués de Sade»-como antes lo habían hecho Heine, Bataille, Klossowski, Blanchot y Foucault, entre otros- porque está convencido de que, en su complejidad y en su condición transgresora, habita una «filosofía de la libertad». Más aún: parece intuir que bajo la superficie perturbadoramente violenta de ese pensamiento hecho literatura se esconde la clave de «apertura a las tendencias intelectuales y poéticas del mundo moderno» (Torre 2002: 162). Es por eso que plantea respecto de esa obra paradigmática la posibilidad de una triple lectura en función de su complejidad: una «estrictamente literal y anecdótica», una «destinada a estudiar la coherencia intelectual» de los diversos momentos de esa obra y, finalmente, una enfocada a evaluar la complementariedad entre los nudos problemáticos de la obra y sus «procedimientos específicamente artísticos» (1971c: 7) .

Sin descuidar su articulación ficcional, Rest interroga ese «sistema de pensamiento» que se articula sobre «las descripciones del comportamiento más impúdico y brutal y las más lúcidas 
disertaciones de carácter doctrinario o filosófico» (1968b: 39) y que de algún modo traduce la contracara exacta de la utopía racionalista. Nota con perspicacia que lo que la obra de Sade pone en evidencia es precisamente que el «concepto de mal» no se circunscribe a una redención de lo imperfecto sino que «es una noción absoluta y autónoma» (1968b: 69), capaz de ejercer su «poderosa fascinación» no sólo sobre los poetas. El dato no es menor si se tiene en cuenta que, desde su perspectiva socialista liberal y democrática, Rest pone en relación esa poderosa fascinación con los desbordes de la «irracionalidad totalitaria, cuya presencia ha perturbado de manera decisiva el curso de la historia contemporánea» (1968b: 61). En estas indagaciones, se muestra bastante cercano a Adorno y Horkheimer puesto que, al tratar de comprender la dialéctica misma del iluminismo, enfrenta la encrucijada de un pensamiento desgarrado de su propio régimen de verdad, obligado a inscribirse en una suerte de umbral indeciso entre la naturaleza y la cultura, la ley y la transgresión.

Las cuestiones relativas a la censura literaria y la propaganda totalitaria -que recorren de cabo a rabo Tres autores prohibidos- resultan claramente reconocibles en la conferencia sobre "Sade y la crisis del racionalismo". Pero lo que subyace a la investigación restiana es una suerte de desafío crítico que visto en perspectiva, en un contexto represivo como el que propulsaba la dictadura de Onganía- describe un proceso de oscurecimiento social que coincide con el afianzamiento de la burguesía como grupo dominante. Su indagación sobre las estrechas 
conexiones existentes entre «la persecución de autores y la compulsión ideológica» da cuenta del oscurecimiento de su propio contexto. Porque si la tesis de Rest insiste en confrontar el totalitarismo -para el cual «la censura es uno de los recursos para imponer regulaciones intelectuales y para coartar la formación de un juicio independiente»-, el libro mismo se inscribe en esa tensa encrucijada histórica de modernización y tradicionalismo que es el campo intelectual argentino. La decisión autoritaria de hacer de la censura un instrumento de represión y compulsión ideológica se contraponía a una profunda y creciente radicalización -hacia el marxismo- en los modos de concebir el futuro mismo de una sociedad dinámica y un mundo en constante ebullición.

Lo que se escondía bajo ese dispositivo censor era acaso el temor real a la «radicalización de las masas», a las que el propio gobierno es incapaz de enfrentar y que, en sus momentos de revuelta, puede inclinarse hacia el temido comunismo «hermanándose con los movimientos populares» (Terán 1991: 170). La confluencia de los temas y problemáticas específicas de la "cultura de masas" y los de la censura, la propaganda y la demagogia autoritaria son en este sentido sintomáticas del carácter modernizado del perfil crítico restiano. Su abordaje franco sobre aquellos textos (y autores) que la prohibición censura -y que el tabú social contribuye a conjurar-, su decisión de encausar su investigación bajo «criterio dialéctico» no dogmático y su convicción en la necesidad de historizar las producciones culturales -describiendo las condiciones histórico- 
materiales de producción, circulación y consumo de dichos materiales- va en esa misma dirección. En ese sentido, la historización de la prohibición y la censura permite a Rest visualizar con cierta nitidez las políticas de exclusión que la burguesía opera bajo la gastada extorsión de la "moralidad" (cuando pretende imponer como natural el régimen de verdad en que se consolida su propia hegemonía).

Sin perder de vista la multiplicidad, la ambigüedad y la incertidumbre que produce en el lector el texto sadiano, Rest lee esa literatura extrema como una antiteología del mal, como una ficción que responde desde el ateísmo más radical a la liturgia cristiana de la salvación. Como su estrictamente contemporáneo Francisco de Goya, Sade presenta el mal radical como lo impensado de la propia razón moderna. Rest reconoce las dificultades inmanentes al examen objetivo de esta obra: «cuestionarlo -anota lúcidamente- entraña cuestionar los fundamentos mismos del mundo en que vivimos y nuestra propia situación en la historia» (1971c: 1). La obra de Sade es la expresión misma de la complejidad del momento que determina su emergencia. Es por ello que sostiene que esa obra compleja no puede ser comprendida en toda su dimensión sin tomar como eje el momento de invención del sujeto en la Ilustración como sujeto de la razón moderna, sin contemplar la coyuntura concreta del acontecimiento revolucionario como zona de convergencia de ese nuevo sujeto en ciernes, y sin tener en cuenta la realidad efectiva de lo que Bernard Sichère ha definido como «una violencia opaca representada por la secuencia extrema del Terror» (Sichère 2007: 157). 
Es claro que para Rest el problema del mal en la literatura debe ser examinado en términos críticos e históricos y el tratamiento que exhibe respecto del texto de Sade así lo demuestra. Subraya expresamente su contemporaneidad con Rousseau y con la corriente materialista de la Ilustración y señala expresamente la contemporaneidad de sade con las contradicciones históricas y sociales que dieron lugar a la Revolución Francesa. Intuye que el texto sadiano se produce de algún modo como respuesta a la dramaturgia de esa época convulsa. Surge -escribe Rest siguiendo a Apollinaire- de un profundo «disconformismo, no sólo social sino también -y con bastante frecuencia- metafísico» (1971c: 2). No lo reduce a una «alegre apología del goce libertario» ni lo minimiza en función de su condición literaria. Para Rest, el texto sadiano es esa literatura que acoge la apología del goce libertario y la atrocidad feroz desatada por el libertino. El goce y el horror, el deseo y la crueldad: en esa articulación monstruosa e impensada por la razón moderna anida el fundamento de la fascinación que produce su obra. Sade es lo monstruoso: es el nacimiento de esa subjetividad atea y sin rostro que se manifiesta bajo las imágenes del placer extremo, es el advenimiento del rostro negado por la Ilustración pero que la constituye secretamente en lo más íntimo, su parte maldita.

Pero-como bien apunta Rest- no es la única emergencia de esa fuerza sublimada por la modernidad. Ahí están también situadas «las historias "góticas" inglesas», allí se corrobora el «auge de las novelas libertinas francesas», «el florecimiento de los relatos de [Nicolás Edme] Restif, de [Pierre Ambroise 
Choderlos de] Laclos, de [William Thomas] Beckford, de [JacquesAntoine] Révéroni, barón de Saint-Cyr. En todos ellos -escribe el crítico- «el ingrediente demoníaco y los indicios de una devastadora ruptura moral confluyen en variada proporción» (1971b: 4). Allí se funda el origen de una persistente línea de tematización del mal donde asumen «un mérito relevante» obras precisas como Vathek, Les Liaisons dangereuses, The Monk o los poemas de William Blake y los Caprichos de Goya. Sin embargo, la fuerza de Sade excede largamente la de esas obras y radica -para Rest- en una serie de cualidades muy precisas: 1) «en una poderosa capacidad de estimular la fantasía»; 2) «en la fascinación con que logra imponer un ámbito de alcances quizá restringidos pero casi ilimitado en sus posibles variaciones de violencia y desenfreno»; 3) «en la coherencia intelectual del "sistema" subyacente en ese sostenido desborde cuya superficie tal vez pueda dejar en la mirada distraída una impresión totalmente caótica» (1971: 5).

La confluencia del abordaje literal, su contextualización articulada sobre un sistema filosófico coherente y el reconocimiento de sus particulares condiciones estéticas permite a Rest dar cuenta de la complejidad filosófica y literaria de la obra sadiana. Pero es su historización precisa lo que le permite inscribirla como una respuesta cabal al proceso abierto en las postrimerías del siglo XVIII. El crítico subraya el parecido del régimen del relato sadiano con el estilo de las disertaciones racionalistas. De ese modo, lleva al límite la hipertrofia del racionalismo neoclásico. Para Rest, Sade ilustra -de manera 
contundente- el límite último del sistema empirio-racionalista de la Ilustración. Presenta una ruptura que va mucho más allá de la «mera descomposición de un sistema especulativo en boga»; y señala -más bien- «la quiebra de una mentalidad»: la de la nueva filosofía que «se abría paso desde las entrañas medievales hasta alcanzar un decisivo predominio en el pensamiento científico moderno, al proporcionar un método para interpretar y aprovechar las leyes de la naturaleza» (1971c: 8). Sade, por el contrario, venía a decir que la naturaleza era precisamente aquello que se situaba por completo fuera de la ley, la convención y la norma. Es por ello que su literatura es de algún modo el síntoma literario más cabal de la crisis y «la bancarrota del racionalismo mecanicista». En sus categóricas disertaciones teóricas «prevalece un ateísmo y un utopismo social que permiten entrever considerable afinidad con la tendencia que estaba prevaleciendo entre los partidarios del racionalismo»; pero, a su vez, la dimensión imaginaria de su obra, «con el desborde de crueldad desorbitada y sin atenuantes, parece nacer de estímulos irracionales y dinámicos» (1971c: 10). Este último punto ha llevado a una serie de autores que va desde Geoffrey Gerer y Alan Hull Walton a Theodor Adorno y Max Horkheimer a percibir en su literatura un anticipo del nazismo como modelo de pensamiento y como ejercicio del terror. En respaldo de estos últimos, Rest agrega que se trata tanto de «la historiografía anticipada de las virtudes públicas reconocidas en la era totalitaria» como de «una consecuencia casi inevitable del iluminismo burgués» (1971c: 11). Si la obra de Sade entraña «una postura revolucionaria», lo 
hace precisamente en virtud de esa ambigüedad explícita respecto del régimen de verdad en que se inscribe. La fascinación que ejerce radica también en esa condición revulsiva que Baudelaire atribuye a esas experiencias en las que «hay algo de infame y de agradable a la vez». La liberación de fantasmas atávicos que su obra presupone excede largamente los límites de «la literatura licenciosa», característica del secularismo burgués. No expone como la serie de textos que va del Decamerón a Fanny Hill- un erotismo «fresco, grato, exento de violencia» como «una manifestación de la alegría de vivir»; sino que más bien insiste minuciosamente en el relato del «comportamiento perverso y la humillación del objeto erótico» que parece afirmarse en «un deseo de soberanía mediante la cosificación del otro» (1971c: 17).

En razón de ello, la «implacable interdicción» que ha caído y sigue pesando sobre la obra de sade es directamente proporcional a la virulencia de su denuncia. Es -escribe Rest- «la respuesta previsible que la sociedad da a quien se propuso desenmascararla públicamente en su comportamiento más feroz y alarmante». Su prohibición y su censura no configuran más que «un exasperado intento de amordazar a uno de los pensadores más audaces de los siglos recientes» (1971c: 17). Tanto la «tesitura corrosiva» de sus «teorías políticas, sociales y religiosas» como el desplegado vigor de su «dimensión imaginativa» se articulan -a juicio de Rest- en un propósito esencial y altamente loable: «quebrar la atmósfera represiva imperante, engendrada en esa época como secuela de los esquemas intelectuales mecanicistas» (1971c: 18).

Rest lee la obra de Sade $-y$ las «literaturas del mal» en 
general- historizando sus condiciones de producción. Pero también -en virtud de su perspectiva culturalista- en sus formas de circulación y recepción específicas. De ahí que no pueda más que situarlas en una encrucijada de libertad o compulsión que de algún modo remite a las condiciones concretas de su propia lectura. Es notablemente consciente de que «si la ortodoxia intelectual y el paradigma moral se ajustan a un criterio mecanicista» inflexible, la necesidad inminente de «una apertura dinámica» corre el riesgo de resolverse «indisolublemente en una concepción del mal, en un ofuscamiento de la razón, en las presentes obras y pompas del demonio» (1971c: 10). Insiste pues en historizar esas literaturas porque esa historización le permite dar cuenta ante todo de las condiciones reprimidas en la censura. De ese modo, su operación crítica busca despegar a esas literaturas malditas del corto horizonte del sentido común naturalizado que, en clave maniquea, absolutiza el mal como si sus manifestaciones concretas no fueran historizables -es decir: explicables sociológica y culturalmente- sobre la base de sus condiciones materiales. ${ }^{202}$

Censurar el mal no lleva a ningún destino. La censura no garantiza su abolición. De lo que se trata es de pensarlo, de volverlo pensable, comprensible y, acaso, evitable; y no meramente temido. Como sade $-y$ en esta intuición hay que valorar la lúcida lectura de Pierre Klossowski ${ }^{203}$ en la que el crítico

\footnotetext{
202 Prueba clara de este compromiso con la explicación es la investigación que Rest lleva adelante en su largo ensayo histórico titulado "La Pena de muerte" (Rest, 1962).

203 Klossowski, P., Sade mon prochain preceded by Le philosophe scélérat, Paris, Editions du Seuil, 1947.
} 
hace pie-, Rest se toma en serio el mal porque se toma en serio sus implicancias y sus consecuencias sociales. Es por ello que se obliga a lidiar con esos «fantasmas atávicos» y esas «zonas de penumbra» que muchas veces resultan insoportables. Entiende que la crítica debe justamente hablar de aquello que la pone en peligro, y que ella misma debe ponerse en peligro en pos de una comprensión de aquello que el maniqueísmo religioso o político no hace más que cristalizar en el tabú (volviéndolo acaso más temible -y más temido- por inexplicable) .

Su perspectiva liberal no se reduce a la pose, ni se conforma sólo con sostener declarativamente un enunciado antitotalitario más o menos consensuado políticamente. Rest opta, al contrario, por enfrentar al totalitarismo haciéndolo objeto de la propia práctica intelectual. Es por ello que su interrogación crítica recae tanto sobre lo censurado como sobre las condiciones concretas que hacen posible la censura. Se opone a que haya un "eso" de lo que no debe hablarse, pero también de un "eso" de lo que no puede hablarse. Y semejante determinación no puede más que sostenerse en la convicción de que la censura misma es fundamentalmente y ante todo- un habla: el decir que impone (autoritariamente) una indecibilidad.

El habla inquisidora del tabú social, el habla represora de la censura política, el habla genuflexa a la Verdad Divina. ¿Hay un habla más poderosa y más afectada de verdad histórica que aquella que nos sustrae -0 que intenta sustraernos- la posibilidad de hablar, la posibilidad de pronunciar palabra sobre aquello que un mandato ha sellado -y clausurado- en la figura del 
mal? En este tramo fundamental de su trabajo crítico, Rest viene a preguntarse no sólo por las condiciones de aparición del mal y lo maldito, sino también por las de la maldición y la censura. Las preguntas implicadas serán entonces: ¿desde dónde algo es maldito (maldecido) o bendito (bendecido) sino desde la sustracción misma de sustancia histórica, esto es: desde el borramiento de las condiciones históricas de la verdad -el "régimen de verdad" - que encarna? ¿No será que a través de cada maldición -como a través de cada sacralización- lo único que se juega es una omisión: una quita (la del pensamiento crítico) en la que lo único que se afirma es el régimen de verdad imperante? Hablar del mal, de lo maldito, de la maldición a riesgo de ser uno mismo -como Sade- objeto de maldición; hablar del texto como de un hecho maldito: mal leído, mal dicho, maldecido; hablar del mal, del malestar, el malentendido, el maldito y la maldición. Ese es el desafío asumido por Rest en un contexto en que le habría sido seguramente más redituable restringirse a cuidar una merecida parcela en un "campo académico" -alambrado con precisión de terrateniente inglés- ${ }^{204}$ o dedicarse abiertamente al universo en expansión de la "cultura de masas" -que ya en los años ' 60 se perfilaba económicamente rentable-- ${ }^{205}$. En vez de eso, en un horizonte de hostilidad e intolerancia intelectual como el que abrió el golpe de Estado de 1966, Rest ha insistido en pensar

\footnotetext{
204 Aspecto que durante este período Rest descuidó sin marginar del todo. Entre los textos relativos a esae área de investigación que publicó por entonces cabe mencionar: "Función del mito clásico en The Weste Land": Tiresias como 'persona' del poeta" (1967d), "A lightning before death: elaboración de un tema en tres cuentistas" (1968d), El teatro inglés (1969b), "Prólogo a Moby Dick o la ballena blanca" (1970b) y "El teatro de habla inglesa" (1972a).

205 Cfr. Pesce, 2007.
} 
las literaturas del mal y la censura como si en ello se jugara algo perversamente único, a saber: una suerte de articulación entre un intenso proceso de modernización socio-económica y un régimen definidamente totalitario en términos culturales e ideológicos. Acaso la particular inscripción histórica de la propia investigación restiana haya contribuido a que, pensando metonímicamente, algunos ensayistas como Horacio González no hayan podido evitar señalar un parentesco oculto y acaso monstruoso con las lecturas de la «afirmación por el mal» en el clásico trabajo de Oscar Masotta sobre la narrativa de Roberto Arlt, pero también con el freudiano «malestar en la cultura»y con la celebradísima frase irlandesa en que el peronismo aparece como el «hecho maldito del país burgués»: el mal como conjuro de aquello que en el imaginario burgués no puede ser explicado si no en la delación de las contradicciones sobre las que se erige -y sostiene- su propia verdad histórica. ${ }^{206}$

Lo que se pone en evidencia en la lectura que Rest hace de las literaturas de Sade, Cleland, Lewis, Aretino, Beckford o De Quincey es el modo de intervención específica del texto en su contexto. A partir de esta determinación fundamental es posible comprender también el meditado dispositivo subyacente a su propia investigación: en la crítica restiana existe desde el comienzo la convicción de que la maldición es el rictus que encubre una operación ideológica de exclusión. Sigue la misma operación a través de la cual la censura se impone, advirtiendo que la

206 Cfr. González, H., Retórica y locura. Para una teoría de la cultura argentina, Buenos Aires, Colihue, 2002. 
maldición es la caución misma sobre la cual la censura se realiza. Y es por ello que las estrategias verbales del totalitarismo -larval en la (auto) censura burguesa de las clases medias- no están en absoluto desvinculadas de las interdicciones artísticas sobre las que se pauta su doble moral.

Rest liga pues su práctica específica a un imperativo transgresivo que enfrenta su propio riesgo de sanción. Piensa lo prohibido, lo censurado, lo reprimido porque está decidido a pensar el régimen mismo de la prohibición, la censura y la represión. Por ello se compromete en la tarea de «pensar el mal», su funcionamiento, sus características, su pulsión, su utilidad y sus usos, es decir, sus "razones", siempre remitiéndolos a sus condiciones históricas. Pero también se obliga a pensar a través del mal; a pensar en la maldición, qué es lo que la provoca y qué es lo que aquello que lleva el estigma del mal ha herido para ser objeto de semejante marca; pensar a través del mal y lo maldecido en el pasado las condiciones de la maldición presente -la lógica histórica sobre la que se asienta- y acaso también las proyecciones de la maldición por venir.

Rest trabaja sobre la hipótesis de que la presencia de lo maligno -como categoría ética y estética- y la consecuente respuesta censora terminan por funcionar como índice de la articulación del pensamiento autoritario en el discurso burgués. Es por eso que su investigación se sitúa justamente donde la prohibición detiene el pensamiento presentando un absoluto intratable. El propio conteo que Rest hace por los argumentos de 
rechazo de la obra del "Divino Marqués"207 permite ejemplificar hasta qué punto la literatura sadiana, antes que criticada rigurosamente, habría sido instituida como tabú ominoso o como aberración patológica -al punto que el propio nombre de Sade llegó a ser considerado «sinónimo de insanía, de envilecimiento, de obscenidad, de furia impúdica y desvergonzada» y la confesión de haberlo leído llegó a constituir una «demostración suficiente de depravación, de falta de decoro, de predisposición malsana» (1971c: 2). Contra esta negación crítica, Rest elabora una lectura lúcida que, apoyada en una fuerte historización crítica, expone el modo en que la obra sadiana describe la difícil transición del sobrenaturalismo medieval al secularismo moderno en la articulación «aparentemente estable» del racionalismo iluminista: democracia, capitalismo, secularización y positivismo aparecen pues en Sade como el límite de la capacidad de exacción y enajenación del cuerpo del otro. Rest corrige de ese modo las aseveraciones que sostienen que sade es «el primer teórico del nazismo», explicando claramente que el infierno concentracionario no estaba predicho en sus textos literarios, sino en la articulación aberrante sobre la que la modernidad desarrollaba su propio régimen de verdad. Sade es la parte maldita de aquel régimen de verdad que lo excluye: denuncia que la «autonomía metafísica de la ley científica» cartesiana contiene las celebradas investigaciones newtonianas y los principios

207 La serie de defensores de sade se extiende históricamente -a través de excepciones- de Apollinaire a Blanchot. Los nombres más encumbrados de esa lista, Rest subraya especialmente la presencia de Charles Augustin SainteBeuve, Charles Swinburne, Charles Baudelaire, el Conde de Lautréamont, Fiodor Dostoievski, Gustave Flaubert, Aldous Huxley, André Bretón, Georges Bataille, Pierre Klossoowski, Paul Eluard y Michel Foucault. 
contractales de Rousseau, pero también el modelo de exacción absoluta cuya lógica -apoyada en la articulación de las leyes de la naturaleza del más apto- es también la lógica del exterminio.

Sobre esa determinación crítica del Iluminismo Rest desarrolla también otras inquisiciones como las dedicadas a la literatura inglesa del periodo decadentista, las referentes al moralismo cínico que lee en los Diálogos picarescos de Aretino (1970a), en su vindicación de La carne, la muerte y el diablo en la literatura romántica de Mario Praz (1970b y 1971a), en su singular pasión por el gótico a través del irlandés Joseph Sheridan Le Fanú (1975a y 1975b) y Matthew G. Lewis (1975d), en su defensa del cinismo mordaz y corrosivo de Richard Garnett (1977b), en su valoración del mundo sobrenatural de M. R. James (1977d), en su recuperación de las aventuras delictivas de A. J. Raffles -el «doble siniestro de Sherlock Holmes») en la imaginación de Ernest William Hornung (1976d) y en su provocativa vindicación de El Supermacho de Alfred Jarry (1979j). En todos esos casos, sin perder de vista el hecho de que la obra de arte es una «compleja estructura simbólica dotada de valor polisémico», Rest asume que la función crítica está llamada a desentrañar, actualizar y enriquecer «unos pocos significados» históricos, historizables -a su vez- ellos mismos. Pero precisamente por esa capacidad de faltar a la vez a la verdad y a la mentira, la obra literaria -que resiste las reducciones de la superstición política, la sociológica y la histórica- ${ }^{208}$ funciona

208 La referencia implícita es a la lectura deleuziana de Spinoza. Véase al respecto la concisa y clara descripción de Alberto Giordano (1999: 9-17). 
igualmente, a través de sus lecturas, como un prisma que permite recomponer, junto con la historia de la obra, una historia de la verdad narrada en los modos de su recepción o su rechazo.

En resumen, lo que revela esta particular arista de la obra restiana es su determinación singular y estratégica, al interrogar críticamente esa forma límite de lo pensable que es el mal -«la crueldad gratuita, el afuera de la ley, el más allá de la razón». Potenciada en su carácter provocativo por un contexto de radicalización represiva, esta determinación por indagar en las literaturas del mal no busca solazarse en su "buena conciencia", declarando su atrocidad o su indecibilidad; comprometerse en la tarea de volverlo más comprensible y, acaso por ello mismo, menos aterrador. Con ese horizonte en vista, interroga las condiciones de producción, recepción y rechazo de las obras que problematizan esas «zonas sombrías»; se pregunta qué es lo que ha hecho posible que semejante potencia destructiva haya sido implementada, organizada y dispuesta a la luz de un régimen de verdad centrado en la racionalidad científica y la lógica utilitaria. Lee las literaturas del mal reconociendo que en el punto en que una obra es maldecida, estigmatizada y censurada, hay algo concreto que -como alguna vez escribió Roland Barthes- ha sido herido y que es recusado en (a través de) la maldición y la censura. Y lo hace desde la convicción de que ese "algo" es, precisamente, aquello sobre lo cual la crítica debe obligarse a hablar. 
APÉNDICE $\mathrm{N}^{\circ} 3$

\section{EL MARQUÉS DE SADE Y LA CRISIS DEL RACIONALISMO 209}

Alfred Cobban, una de las máximas autoridades inglesas en Historia de Francia, escribe en su reciente libro In Search of Humanity: "El placer por la crueldad ha llegado a ser considerado una perversión sexual más o menos por accidente histórico pues se asocia con el Marqués de Sade, quien atraía muchachas a su casa con el propósito de realizar experimentos científicos que incluían la flagelación y casi el envenenamiento. El suyo fue un caso apenas leve, y sólo resulta notable porque este individuo escribió un tratado para demostrar que su método expresaba una tendencia natural que no merecía reproches. Otras obras fueron escritas más tarde para demostrar que le marqués era un moralista prominente e incomprendido. Este lamentable personaje sin duda estaba bastante loco, pero no inventó el sadismo sino que se limitó a proporcionarle nombre. El régimen nazi, en Alemania, fue una exhibición de sadismo colosal, pero lo novedoso no era la naturaleza del hecho sino la magnitud de su aplicación. Debemos admitir que la crueldad es un ingrediente de la naturaleza humana y que es posible hallarlo en todos los pueblos y épocas".

Este pasaje, escrito hace muy pocos años, es no sólo interesante por la información a la vez sintética y comprensiva que nos

209 El marqués de Sade y la crisis del racionalismo (1971c). Bahía Blanca: Alianza Francesa. 
proporciona, sino también porque destaca el interés actual que suscita el Marqués de Sade y porque pone en evidencia la respuesta ambigua que su obra provoca en nuestros días. La actitud de este extraño creador resulta a la vez abominable y ejemplar, y de alguna manera refleja nuestra profunda incertidumbre para evaluar un testimonio que el hombre contemporáneo no se siente capacitado para juzgar con objetividad, porque cuestionarlo entraña cuestionar el mundo en que vivimos y nuestra propia situación en la historia. Pese a ello, el propósito de la siguiente exposición apunta esclarecer este episodio dieciochesco que posee un significativo ascendente en el siglo que habitamos.

No es posible afirmar taxativamente -como lo hizo Apolinaireque en el curso del siglo XIX la obra de Sade haya permanecido olvidada por completo, ya que su impacto puede trazarse o al menos sospecharse en una sugestiva nómina de autores que, por lo general, se caracterizaron por alguna manifestación de disconformismo, no sólo social sino también -con bastante frecuencia- metafísico. Pero no cabe duda de que el reconocimiento público del Divino Marqués -acompañado de una notable proliferación de comentarios y estudios y de una abundante labor erudita- es el resultado del interés que ha ido creciendo a lo largo de nuestra propia centuria. Exceptuadas las opiniones que formularon los iniciados -entre los que parece justo incluir nombres tan destacados como Petrus Borel, Swinburne, Baudelaire, Lautréamont, tal vez Dostoievski e inclusive Flaubert-, la mayoría de los juicios se empecinaba en abominar de esta singular producción, en contadas ocasiones con conocimiento de causa pero las más de las veces con 
absoluta ignorancia. Con su habitual perspicacia, no siempre advertida en nuestros días, Sainte-Beuve afirmaba en 1843 que Sade se había convertido en uno de los influjos más profundos que se podía entrever entre quienes encarnaban en aquel momento la renovación y avanzada de la literatura moderna, pero al mismo tiempo añadía que el enfoque adecuado, pero al mismo tiempo añadía que el enfoque adecuado de este poderoso ascendiente resultaba velado por una clandestinidad que, si bien no llegaba a ser total, bastaba para impedir una conveniente evaluación del asunto. Desde fecha temprana, el nombre de Sade llegó a ser sinónimo de insanía, de envilecimiento, de obscenidad, de furia impúdica y desvergonzada, de composiciones que eran detestables (o que las buenas costumbres reclamaban proclamar estridentemente como detestables); leerlo -o, de conformidad con una manifiesta duplicidad moral, confesar que se lo había leído- era una demostración suficiente de depravación, falta de decoro, de predisposición malsana. Gustave Lason, en su clásica Historie de la littératura francaise, podía permitirse en 1894 la omisión total del autor de Justine. Pese a las notorias excepciones que hemos enumerado, el criterio que prevalecía entonces era el mismo que Fréderic Soulié -un folletinista contemporáneo de dumas pére- había enunciado en 1837: la obra de Sade no era más que una "frenética y abominable colección de todos los crímenes y de todas las suciedades". Lo que correspondía era o bien refugiarse en una púdica ignorancia o asumir una airada denuncia de la literatura irreverente. En su autobiográfico The Middle Years, Henry James refiere una anécdota acerca de Tensión que en alguna medida ilustra ambas actitudes: 
en el curso de una recepción, una de las invitadas aludió a su conocimiento de cierta mademoiselle Laure de Sade (cuyo nombre de pila, por lo demás, permite sospechar razonablemente un parentesco cercano con el marqués); el laureado poeta victoriano, allí presente, al parecer sólo oyó el apellido y se consideró obligado a lanzar una fulminante y extensa diatriba contra el infame escritor francés; ello determinó, para gran regocijo de James, que el grupo de personas reunidas -constituido en su abrumadora mayoría por señoras de considerable elegancia y respetabilidad- quedara perplejo, en virtud de que nadie demostraba poseer ni la más remota noticia del individuo anatomizado.

En decisivo contraste con los juicios emitidos en el siglo pasado, nuestra óptica ha sufrido una completa inversión, hasta llegar a la tesis enunciada por Maurice Blanchot, que acaso resulta un tanto sorprendente fuera de su contexto: "Entre el hombre normal que encierra al hombre sádico en un callejón sin salida y el sádico que hace de ese mismo callejón una salida, es el segundo el que sabe más sobre la verdad y la lógica de su situación, el que tiene una comprensión de ella más penetrante, al punto de que puede auxiliar al hombre normal para que se comprenda a sí mismo, al modificar las condiciones de toda comprensión". De algún modo, Sade se ha convertido en nuestro semejante, en nuestro hermano. Para comprobarlo, no tenemos más que recorrer las páginas que Etiemble le ha consagrado en la "Historia de la literatura francesa" que incorporó la Enciclopédie de la Pléiade, quizá uno de los testimonios más esclarecedores de las orientaciones críticas que al presente aspiran a ser canonizadas; allí, 
en un juicio que busca la delicada reconciliación entre la censura y el elogio, hallamos la afirmación de que este excéntrico creador cuenta "al menos con el mérito de sistematizar hasta el absurdo aquello que Rousseau expuso como caso individual". La evaluación actual de sade, por consiguiente, ya no puede sintetizarse -explícita o implícitamente- en un aforismo más o menos desdeñoso, en una desaprensiva omisión, en un ligero examen de los posibles desarreglos fisiológicos o mentales que según se suponía eran los únicos causantes de sus perturbadoras invenciones literarias.

Nuestra visión de la obra de Sade se ha tornado inevitablemente compleja y minuciosa. Ante todo, se ha llegado poco menos que a comprobar la falsedad de los argumentos que trataban de presentar estos escritos como un mero subproducto de las obsesiones y desequilibrios sexuales que habrían aquejado a su autor; al libertinaje y a las perversiones -que sade indiscutiblemente exhibía- se les atribuyó una importancia exagerada, ya que apenas si excedieron el nivel medio de aquella época, que sin duda se caracterizó por una notoria propensión hacia la conducta licenciosa, depravada y atroz; sin desconocer la magnitud de los extravíos que lo perturbaron, no parece razonable que las fantasías de este escritor sean juzgadas exclusivamente como documento patológico, ya que desde un punto de vista literario, en el peor de los casos, sólo correspondería interpretarlas como un intento de configurar en términos poéticos ciertas perturbaciones psíquicas acaso no, más agudas que las observadas en textos de Dostoievski o de Kafka, en tanto que curiosamente no se ha destacado en grado 
satisfactorio el trasfondo "sádico" que revela Dickens en ciertos momentos de Oliver Twist, cuando se demora en los detalles del brutal fin que padece Nancy y del suceso en el que muere el perro perteneciente a Sikes. Por añadidura, no debemos olvidar que el periodo en el que sade escribe sus narraciones principales corresponde al de la mayor difusión de las historias "góticas" inglesas, al auge de las novelas libertinas francesas, al florecimiento de los relatos de Restif, de Laclos, de Beckford, de Saint-Cyr, en los cuales el ingrediente demoníaco y los indicios de una devastadora ruptura moral confluyen en variada proporción. En función de un criterio estrictamente creativo, resulta incuestionable el hecho de que estas orientaciones fructiferaron en varias piezas de mérito relevante, como Vathek, Les liaisons dangersuses o The Monk, tan dispares entre sí en elaboración y propósitos. Estos autores y obras -así como también Blake y el Goya de los Caprichos- anunciaban una crisis que se desenvolvía a niveles muy profundos, si bien casi siempre solemos limitarnos a considerar sus exteriorizaciones más accesibles, como el proceso revolucionario francés y la difusión de las doctrinas románticas. Por su naturaleza misma, se trataba de un fenómeno explosivo que debía conducir necesariamente a la exageración y aún a la oscuridad; y quizá lo que convierte a sade en una figura tan singular y desconcertante es la circunstancia de que en una etapa muy propensa a desorbitarse, sobrepujó en mucho a sus contemporáneos en la medida de exageración; pero conviene agregar que esta cualidad a menudo ha estado íntimamente ligada a la genialidad de ciertos artistas, vínculo que en el presente caso tal vez estemos apenas 
descubriendo. De cualquier modo, nos hemos ido acostumbrando a una percepción más discriminada y aguda de las composiciones de Sade, a un distingo más certero de sus variedades y matices, lo cual ha significado el definitivo abandono de juicios anteriores en los que se confundía sin apropiada diferenciación el conjunto de escritos, congregados con absoluto desafecto en un esquema unitario de aberraciones. Por cierto, sus creaciones más caudalosas no lo presentan como a un autor equilibrado en la exposición - cuidadoso en el estilo, pero una observación análoga puede aplicarse a los principales novelistas del siglo pasado -Balzac, Dickens, Dostoievski-, que se destacaron no tanto por la prolijidad formal cuanto por el vigor de los "mundos imaginarios" a los que dieron vida. Además es posible considerar que la experiencia abarcada por sade es sus anécdotas resulta parcial y hasta restringida, si bien cabe señalar asimismo una actitud parecida en escritores como Kafka o Beckett. La fuerza de Sade, en cambio, radica en ciertas cualidades perfectamente definidas: una poderosa capacidad de estimular la fantasía; en la fascinación con que logra imponer un ámbito de alcances quizá restringidos pero casi ilimitado en sus posibles variaciones de violencia y desenfreno; en la coherencia intelectual del "sistema" subyacente en ese sostenido desborde cuya superficie tal vez pueda dejar en la mirada distraída una impresión totalmente caótica. Con el auxilio de múltiples recursos que había elaborado la narrativa francesa del siglo XVIII o que le proporcionaba el ejemplo de Samuel Richardson, Sade crea una escritura enteramente original que -a juicio de Henri Coulet- consigue prevalecer, en un estricto pleno lite- 
rario, por el sortilegio que comunica al asunto y por la intensidad de convicción que transmite al lector, al punto de que el lenguaje adquiere una suerte de furor mágico. En verdad, las realizaciones más eficaces trasuntan una estrategia episódica y reiterativa que, con los debidos recaudos, puede compararse a la técnica acumulativa desarrollada por Bosh y Bruegel en sus composiciones pictóricas con el propósito de configurar una atmósfera grotesca y absurda, que en la lectura -en razón del carácter temporal que es propio de la narrativa- engendra una sensación de crescendo, a causa de la inercia acumulada con una insistencia que no decae ni se interrumpe. La índole de los sucesos referidos puede llegar a engendrar en el acondicionamiento moral del lector un proceso reactivo de disgusto o desasosiego, pero simultáneamente es innegable la presencia de cierta euforia o deslumbramiento poético, de una comunicativa exhuberancia que fluctúa entre el humor rabelesiano y un frenesí imaginario casi dionisiaco. A esta especie pertenecen, en particular, la última Justine y la historia de Juliette, cuya caudalosa estructuración épica permite acumular hasta el vértigo los efectos reiterativos. En un sector aparte conviene ubicar Les 120 journées de Sodome que, en lugar de elaborar una trama abierta nos enfrenta con un mundo cerrado por completo no sólo física y materialmente sino también en virtud del ordenamiento establecido de los sucesos; si alguna comparación esclarecedora conviene proponer, podemos sugerir que el clima imperante aquí surge de una mezcla entre la utopía clásica y el sistema sin fisuras de los relatos en los que una barrera impenetrable permite que regiones secretas sean aisladas de toda 
relación con el mundo circundante (situación que es posible trazar desde remotos cuentos de hadas hasta la narrativa kafkiana). En otro grupo debemos reunir los "diálogos filosóficos", representados por Dialogue entre un pretre et un moribond y por La philosofhie dans le boudoir, en los que el asunto libertino se combina de manera conspicua con intensiones discursivas, orientadas a exponer las observaciones morales, políticas y religiosas de Sade, especialmente concentradas en el opúsculo que Dolmancé lee en la segunda de estas obras, la pieza doctrinaria justamente célebre que se conoce con el título de "Francais, encore un effort si vous voulez etre républicains". La abundante producción de Sade se completa con narraciones breves, dramas, escritos políticos, una amplia correspondencia, varias novelas históricas y el "relato filosófico" Aline et Valcour. Esta sostenida labor creadora permite desestimar sin demora la vieja leyenda de que la producción de Sade poseyó una función puramente supletoria, como vía de escape para las fantasías extravagantes que no pudo poner en práctica a causa de sus frecuentes y prolongados encarcelamientos; sin embargo, para demostrar la naturaleza conciente y reflexiva de su actividad literaria poseemos, además, ,el interesantísimo ensayo sobre la novela que escribió como introducción a Les crimes de I'amour. Esta breve disquisición revela un vasto y meditado conocimiento del género, desde el período clásico grecolatino hasta Matthew Gregory Lewis: ante todo, admira sin retaceos el Quijote; elogia La princesse de Cloves, Manon Lescaut y La nouvelle Helö̈se; destaca el aporte de Voltaire; celebra con entusiasmo a Richardson y Fielding, los grandes autores del siglo 
XVIII inglés; advierte con claridad el estrecho vínculo entre el proceso revolucionario y The Monk o las "historias góticas" en general; por último, formula una interpretación extremadamente lúcida de la novela moderna, cuya tarea consiste en trazar "un cuadro de las costumbres seculares" tan valioso para el pensador y el erudito como las más serias investigaciones históricas. En síntesis, es lícito sostener que el Marqués de Sade se presta, por lo menos a tres lecturas diferentes: la primera, estrictamente literal y anecdótica, dio origen a insatisfactorias interpretaciones sobre las supuestas aberraciones mentales del autor; la segunda, destinada a estudiar la coherencia intelectual, ha suscitado en los últimos tiempos una entusiasta revaluación crítica; la tercera, que aún aguarda una atención más detenida y concreta, deberá conducirnos a la estimación de los procedimientos específicamente artísticos. Puesto que el texto los admite, los tres enfoques son valederos; pero no resultan igualmente apropiados: el primero origina una lamentable confusión, al poner excesivamente énfasis en la praxis de acciones que por lo general sólo fueron imaginadas; el segundo, mucho más perspicaz, todavía conserva demasiadas ataduras con la realidad operativa; únicamente el tercero asume con plenitud la dimensión de pura fantasía que entrañan estas invenciones.

Con bastante insistencia se ha puntualizado que la morosa exposición de atrocidades y la delectación de la crueldad ejercida de manera gratuita -como una satisfacción casi estética- son indicios de que sade demostraba una sostenida preferencia (o estaba forzosamente dominado) por una veta de absoluto irracionalismo. 
Tal afirmación contenga probablemente una parte de verdad, pero para determinar con suficiente aproximación la medida de acierto conviene recordar que este autor no exhibe simpatía por las corrientes místicas y ocultistas que habían ganado terreno en las postrimerías del siglo XVIII representadas por figuras tan dispares como Cagliostro, Swedenborg y los "gnósticos de la revolución" -sino que, por el contrario, parece identificarse con las expresiones más radicales de un racionalismo hipertrofia había engendrado la disolución de sus propias premisas y estaba desencadenando una reacción de agudo escepticismo. Las extensas formulaciones discursivas que sade suele introducir en las obras de ficción para exponer sus ideas revelan un indudable parentesco con el estilo de las disertaciones racionalistas, e inclusive la argucia de neta estirpe aristotélica que fragua para justificar sus escritos -con la inveterada referencia a las emociones purificadoras- nos descubre una estricta racionalidad neoclásica: "¿En qué forma puede imaginarse el terror, si no es a través del crimen triunfante? ¿De qué manera surge la piedad, si no es mediante la imagen de la virtud amenazada". El problema consiste en que, llevado hasta sus últimas consecuencias, el realismo empirio-racionalista de la ilustración había llegado -en particular por obra de Hume- a una encrucijada que no parecía tener la más mínima posibilidad de hallar una salida convincente. El inevitable resultado de esta situación consistió en que el vacío ocasionado por la crisis fue rápidamente cubierto por tendencias idealizantes e idealistas. La gravedad de este proceso radica en que la ruptura no significaba la mera descomposición de un sistema 
especulativo en boga sino que constituía la quiebra de la mentalidad misma cuya acción había permitido elaborar un instrumento que, cualesquiera fuesen sus limitaciones, poseía una eficacia excepcional para comprender ciertos aspectos fundamentales del mundo material. De conformidad con esa actitud empirioracionalista, la "nueva filosofía" -como hubo de llamarla John Donne- se abrió camino desde las entrañas medievales hasta alcanzar un decisivo predominio en el pensamiento científico moderno, al que proporcionó un método para interpretar y aprovechar las leyes que en apariencia regían la naturaleza. Este método -muy vinculado a las pautas del secularismo burgués- tuvo origen en la suposición de que la realidad sensible se halla regulada por principios inteligibles, de modo que la mente humana puede reconstruir las estructuras del universo físico con sólo ordenar los datos empíricos de acuerdo con los criterios lógicos que gobiernan el pensamiento. A esa interpretación no sólo se le reconoció provecho sino que desde fecha temprana se le atribuyó también una validez metafísica y autónoma, como si emanara de las cosas mismas; lo que condujo -tal vez por influencia de residuos neoplatónicos- a fortalecer la tesis de que la naturaleza respondía a una organización inteligible y deliberada; y aún se llevó más lejos el argumento, al afirmar que las leyes naturales -así como habían sido enunciadas- eran inmutables y, consecuentemente, que el cosmos responde a una estructuración cerrada cuyo funcionamiento se ajusta exclusivamente a un mecanismo de conservación, no a un proceso de transformación. Estas hipótesis contaron con el sólido respaldo filosófico que les otorgó Descartes y demostraron in- 
cuestionable utilidad en los estudios de física y cosmografía que culminaron en la codificación de Newton. En cambio, no se consiguió un aprovechamiento igualmente satisfactorio en biología, disciplina que comenzó a forjar una teoría propia acerca del crecimiento orgánico, importantísima en el desarrollo de las ideas románticas. Pero el mayor efecto coercitivo se hizo sentir en el arte y en el pensamiento social. Con indebida asiduidad, la eficacia científica de una doctrina suele tener consecuencias devastadoras en la perceptiva poética, que en el presente caso apeló a la rigidez normativa del neoclasicismo para remedar la tendencia legisladora imperante. Por su parte, en el campo de las concepciones políticas y sociales, el racionalismo ejerció cierto influjo benéfico, en la medida en que apuntó hacia pautas especulativas más equilibradas, entre las que sobresalió el principio contractual de Rousseau; sin embargo, tales ventajas quedaron totalmente anuladas en la práctica, a causa de los esquemas mecanicistas que se negaron a acoger una interpretación abierta y dinámica del cambio social. En consecuencia, se perfiló una honda contradicción que fue adquiriendo caracteres alarmantes a medida que se agudizaba la descomposición de la vida dieciochesca, hasta llegar a un punto crítico con el estallido de la Revolución Francesa. Por lo demás, David Hume, en sus demoledoras investigaciones sobre el entendimiento humano, se lanzó de lleno contra la autonomía metafísica de la ley científica, que se había convertido en expresión inmodificable de una voluntad poco menos que divina; a su vez, Voltaire personificó en el profesor Pangloss los excesos y desvaríos a los que conducía la rigidez normativa en el 
ámbito del comportamiento; y el problema, a partir de 1750, se puede rastrear en un vasto sector intelectual: se había producido la bancarrota del racionalismo mecanicista y gradualmente iban adquiriendo empuje los criterios dinámicos y las intuiciones irracionalistas. Justo en ese punto crucial está ubicado Sade: en sus disertaciones teóricas prevalecen un ateísmo y un utopismo social que permiten entrever considerable afingidad cn la tendencia que estaba prevaleciendo entre los partidarios del racionalismo, pero su dimensión puramente imaginaria -con el desborde de una crueldad desorbitada y sin atenuantes- parece nacer de estímulos irracionales y dinámicos. En este último sentido, ilustra un desenvolvimiento que Blake, en The marriage of Heaven and Hell, testimonió con notable clarividencia: si la ortodoxia intelectual y el paradigma moral se ajustan a un criterio mecanicista, la necesidad de una apertura dinámica de algún modo acabará por quedar atrapada indisolublemente en una conmoción del mal, en un ofuscamiento de la razón en las presuntas iras y pompas del demonio.

En esta situación se concentra buena parte de la ambigüedad inherente al pensamiento de nuestra época, ya que en el último siglo y medio la idea de dinamismo ha llegado a expresarse por igual, en términos de igualdad o de compulsión. Al mismo tiempo, estrechamente asociado a la noción de dinamismo, ha sido considerado por algunos pensadores religiosos -Bloy, Péguy, T. S. Eliotprácticamente como una toma de conciencia más valiosa, desde la perspectiva de una moral trascendente, que la habitual respetabilidad convencional cultivada en la indiferente sociedad contempo- 
ránea. Tal vez esta valoración cristiana del mal sea razonablemente certera, y conviene recordar que ya está insinuada en Dante con la expulsión infernal de "quienes torpemente vivieron sin vituperio ni alabanza"; sin embargo, es necesario reconocer que satanás no sólo se ha vuelto ingénu -como proponía Baudelaire- sino también ingénieux: ya no se refugia junto a sus servidores en aquelarres secretos sino que se pasea por las calles, interviene en la vida pública, persuade a los que están más convencidos y seguros de su propia misión redentora y aguarda, con ilimitada paciencia, su posible canonización. A causa de estas complejas circunstancias, Sade ocupa un lugar notabilísimo como clave de un proceso y aún contradictorio, cuyo desenvolvimiento ha llegado hasta el presente.

Entre los estudiosos ingleses del Divino Marqués se suele destacar con frecuencia la relación entre el sadismo y las prácticas violentas o intolerantes de los regímenes políticos que han convertido en sistema el campo de concentración, la cámara de gas, el lavado de cerebros y los más diversos e inhumanos refinamientos en materia de tortura física o moral. En el prólogo a una nueva edición de su Life and Ideas of he Marquis de Sade, Geoffrey Gerer declara que la primera redacción de este libro, en 1933, fue guiada por el propósito de examinar algunos aspectos del "monstruoso régimen" que el hitlerismo acababa de instaurar en Alemania, y agrega que en aquel momento tuvo múltiples oportunidades de establecer "paralelos entre los actos y opiniones de los personajes sádicos y de muchos dirigentes nazis y fascistas". De manera análoga, en el extenso comentario que precede a su ver- 
sión inglesa de Justine, Alan Hull Walton -con su reiterado criterio personal y hasta arbitrario de enfocar y anotar las obras que traduce- ha señalado que "es posible trazar una extensa lista de semejanzas entre la conducta nazi y ciertos episodios de las obras que compuso Sade; como ejemplo, podemos tomar el tratamiento que Roland, el falsario, da a las muchachas que tiene encerradas en su castillo; ello se aproxima -especialmente en la forma desarrollada en la última Justine- al imperio del terror que el Tercer Reich empleaba contra los pobladores de sus campos de concentración; los perversos y despiadados experimentos biológicos realizados en estas prisiones acaso estén en deuda con las proposiciones del médico Rodin en la primera versión de Justine, proposiciones que este individuo pone en práctica en la redacción final; y los castigos, flagelaciones y pensamientos del Marqués de Bressac y de los monjes libertinos -también en Justine- quizá tengan su contraparte en la historia secreta del nazismo". Inclusive Aldous Huxley, que subraya el trasfondo revolucionario de Sade y recuerda al mismo tiempo su actitud humanitaria durante el Terror, no puede evitar la afirmación de que este autor padecía de "una perversión estrictamente sexual". Es lícito sospechar que la crítica inglesa se ha visto arrastrada, en su evaluación, por ciertos residuos de moral victoriana; pero también hallamos una conclusión análoga en los alemanes Max Horkheimer y Theodor W. Adorno, cuando en su Dialektik der Aufklärung sostienen que los vicios privados, en Sade, constituyen "la historiografía anticipada de las virtudes públicas reconocidas en la era totalitaria", a lo cual añaden la hipótesis de que ello era una consecuencia 
casi inevitable del iluminismo burgués, también manifiesto en las ideas de figuras tan dispares como Kant y Nietzsche. En respaldo a tales apreciaciones, cabe agregar que hasta la detallada y minuciosa de la forma en que se hallaba la vida de las reclusas en el convento libertino de Justine y en el castillo de Les 120 journées de sodome hace pensar en los reglamentos y prácticas establecidos en los campos de concentración.

Estos juicios, empero, contrastan drásticamente con las interpretaciones que propone un representativo sector de la crítica francesa de nuestro siglo, encabezado por Apollinaire, quien consideró a Sade una especie de apóstol de la libertad, según lo declara en un ensayo de importancia decisiva en el proceso de rehabilitación de la obra sadiana: "amaba, ante todo, la libertad; sus actos, su sistema filosófico, todo atestigua su acendrado amor por la libertad, de la que se vio privado por tanto tiempo". Esta tesis ha sido respaldada por un nutrido grupo de escritores, entre los que se destacan personalidades conspicuas del superrealismo. Uno de los más prominentes defensores es, sin duda, el poeta Paul Eluard, quien puntualizó, en una conferencia dictada en Londres el 24 de junio de 1936, que "Sade ha querido restituir al hombre civilizado la fuerza de sus instintos primitivos, ha querido emancipar la imaginación amatoria de sus objetos mismos, ha creído que por este camino -y sólo por él- podría nacer la verdadera igualdad". El mismo disertante subrayó que el autor de Justine aspiraba a recuperar la autenticidad de la existencia, tarea a la que más tarde se sumó Lautréamont; "ambos libraron la más encarnizada lucha contra todos los artificios, así groseros 
como sutiles, contra todas las trampas que nos tiende esa falsa e indigente realidad que degrada al hombre"; por lo tanto, en reemplazo de la mezquina fórmula "Sois lo que sois", se abría de este modo el mundo de libertad que está implícito en la afirmación de que "Podéis ser otra cosa"; ya que Eluard concluía apuntando que, por haber proclamado esta aspiración, sade se vio perseguido y relegado a la soledad, si bien su ejemplo no quedó estéril pues fue recogido y renovado por la acción del superrealismo contemporáneo. Esta línea interpretativa culmina, en cierto modo, con la sostenida labor erudita de Maurice Heine, que consideró a Sade uno de los más agudos espíritus renovadores, deseoso de configurar un hombre más pleno, creado con el auxilio de una revolución moral cuyo triunfo deberá preceder a toda transformación social y política, si acaso se desea que los cambios tengan hondura y permanencia necesarias para instaurar un mundo de mayor amplitud y caudal. Opiniones análogas hallaremos en André Bretón, en Georges Bataille, en las cuidadas ediciones y en los minuciosos comentarios de Gilbert Lély (que culminaron en una documentada Vie du Marquis de Sade). Por su parte Maurice Blanchot ha señalado que "en sade hay un moralista de la más pura tradición", una inteligencia "capaz de elaborar un humor extraño, en el que su estilo afecta una helada jovialidad, una suerte de inocencia fría e los excesos, que resulta preferible a toda la ironía de Voltaire y que no es posible hallar en ningún otro escritor francés". En cambio, Michel Foucault, en su Historie de la folie a l'age classique, observa: "En Sade, como en Goya, la sinrazón continúa velando en su noche; pero, por esta vigilia, se une a poderes nue- 
vos; el no ser se convierte en poder de anonadar. A través de Sade y de Goya, el mundo occidental ha adquirido la posibilidad de sobrepasar su razón mediante la violencia, y de recuperar la experiencia trágica más allá de las promesas de la dialéctica". Por último, Jean-Jaques Brochier retoma esta idea y se propone la apoteosis de este autor al que se declaró maldito en el pasado: "Sade, en su tiempo, pone en juego todo el pensamiento occidental y lo destruye frenéticamente, para facilitar la aparición de otro pensamiento, que no surgirá hasta después de la Revolución".

La confrontación de las dos líneas exegéticas desemboca de manera inevitable en una paradoja. Sin embargo, tratar de superar esta situación mediante un comprimido entre ambas orientaciones sólo resultaría válido en parte, porque la comprensión de Sade necesariamente exige que admitamos cierto grado de arbitrariedad; es decir, cierta dosis de ruptura con todo molde convencional que pretenda constreñir nuestro empuje imaginativo, que nos impida concebir -aunque sea lejanamente- una absoluta libertad de pensamiento y de acción. En todo caso, cuanto podemos hacer es aceptar las contradicciones y rescatar a esta extraña figura que las encarna, pues la antinomia advertida en su obra es, de algún modo, cifra del desenvolvimiento seguido por la cultura europea moderna, en el afán de ordenar sus logros al mismo tiempo que los va destruyendo para precipitarse hacia objetivos nuevos e imprevistos. La producción de Sade entraña una postura revolucionaria y, en tal sentido, cabe aplicarle la observación que Baudelaire formuló acerca de todo vuelco radical: en él "hay algo de infame y de agradable a la vez". Por consiguiente, renunciemos por el mo- 
mento a un balance demasiado estricto y limitémonos a enunciar unas pocas evaluaciones posibles de la significación que le va siendo reconocida a este autor. Fundamentalmente, debemos subrayar que esta rehabilitación no se origina en un cambio de actitud ante el hombre sade son ante su obra: lo importante no consiste en negar o desconocer las aberraciones del individuo (a las que se puede considerar trasparentadas en las preferencias temáticas), sino en advertir -como lúcidamente lo hizo Lionel Trilling en un examen de relaciones entre arte y neurosis- que la auténtica virtud poética radica en la capacidad de configurar las experiencias, al margen de que sean o no consideradas "normales". Al respecto, conviene recordar que se ha juzgado a sade como precursor de Freud -y también, por supuesto, de Kraft-Ebing y de Havelock Ellis-, en la medida en que expuso con abrumadora fuerza e inclusive se propuso catalogar, en Les 120 journées de Sodome, la nómina más nutrida e inquietante de perturbaciones sexuales que registra la literatura; pero corresponde agregar que esta condición de precursor, atribuida a Sade, modifica significativamente el alcance de las corrientes psicológicas que al presente consideramos más actualizadas; los extravíos que enumera sade nacen, sin lugar a dudas, de inquietudes y angustias intrínsecas a la naturaleza humana misma, pero la toma de conciencia de estos problemas anímicos parece vinculada de manera sintomática a fenómenos culturales que se han desencadenado en los últimos doscientos años y cuya detonación probablemente tuvo origen la crisis producida en el curso del siglo XVIII: el secularizado hombre moderno construyó un sistema mecanicista para explicar el ámbito en que 
se hallaba inserto quizá porque su permanencia en una estructura cerrada le confería una sensación de seguridad, le garantizaba hasta cierto punto un dominio factible del mundo circundante y le permitía concebir metas concretas de realización individual; cuando este esquema se hubo desarrollado hasta su plena madurez, la racionalidad misma que había permitido construirlo prosiguió su labor crítica hasta provocar el derrumbe de cuanto había erigido; ello determinó una atmósfera de desamparo que -a partir del periodo romántico- puso en libertad fantasmas atávicos y facilitó la irrupción de impulsos que un orden intelectual más rígido había logrado detener; una de las consecuencias de este proceso fue la quiebra del precario equilibrio represivo que, según Freud, el principio de realidad ejerce sobre el principio de placer, como base del comportamiento civilizado; de este modo sería posible explicar el homo sadicus en un momento determinado de la historia; aún más, podría agregase que el concepto de salvación última que se han propuesto por igual los movimientos religiosos y las corrientes ideológicas -ya sea como supervivencia póstuma o como objetivo social- sirvió en el pasado para mediatizar, a través de formulaciones escatológicas, la satisfacción plena de las aspiraciones humanas; pero, como consecuencia de la ruptura producida, estos deseos han buscado una respuesta inmediata, aunque más no fuera al nivel de la fantasía, tal como quedó documentado en la obra del divino Marqués. Interpretada de esta manera, la profunda revolución acaecida nos enfrentaría con una curiosa actualización del carpe diem, cuyo explícito enunciado e inevitable corolario la abrogación de toda esperanza puesta en el futuro- hallamos en 
un revelador pasaje de La philosophie dans le boudoir, atribuido a Mademe de Saint-Ange: "Aprovecha el tiempo más feliz de tu vida, pues los años felices de nuestros placeres son demasiado cortos. Si la fortuna nos acompaña en nuestros goces, deliciosos recuerdos consuelan y distraen en nuestra vejez. Pero si hemos perdido la oportunidad, amargas lamentaciones y espantosos remordimientos nos desgarran y se suman a las torturas de la edad para rodear de lágrimas y zarzas la tétrica proximidad del ataúd. ¿o acaso te has entregado al disparate de la eternidad?". Por otra parte, tal actitud es muy propia de una época que busca soluciones en el mundo inmanente y que reniega de toda trascendencia. Encarado según esta óptica, sade es un indicio formidable del proceso que se hace manifiesto en el Renacimiento y que presuntamente está llegando en nuestros días a sus consecuencias finales. Cuando el autor de Justine concibe al hombre no como "lo que es" sino como "lo que puede ser", evidentemente se ubica en la tradición del humanismo secular que interpretaba la naturaleza humana como "posibilidad". Esta idea, en consecuencia, puede trazarse ininterrumpidamente desde las reflexiones renacentistas de dignitate hominis hasta la noción nietscheana de "superhombre", como un derivado aristocratizante del individualismo: las aspiraciones del homo sadicus, deseoso de ejercer una soberanía ilimitada, no constituyen más que una variedad -acaso desorbitada- de esa constante búsqueda de afirmación que se advierte en la sociedad moderna. El aspecto trágico de esta búsqueda -que tanto entusiasma a los protagonistas de Juliette- radica en la circunstancia de que tal empresa se propone la anulación del "otro", de aquel que 
recibe la acción; este hecho, como apunta el mismo sade, es casi inevitable pues "todo gozo participado se debilita"; y Dolmancé reitera una opinión muy similar cuando, en La philosophie dans le boudoir, declara que a la persona utilizada en sus placeres la considera "como algo enteramente nulo" cuyo sufrimiento le resulta desdeñable o, en todo caso estimulante: "¿qué se desea cuando se goza? Que todos aquellos que nos rodean sólo se ocupen de nosotros, no piensen sino en nosotros y sólo a nosotros cuiden. Si los objetos que nos sirven para gozar también gozaran, desde ese mismo instante se preocuparían más de sí mismos que de nosotros y en consecuencia disminuiría nuestro propio placer". De tal modo, los seres humanos sometidos a la voluntad del homo sadicus que ha logrado imponer su soberanía padecen un manifiesto proceso de cosificación; y ello se debe, como observa Hubert Juin, a que la conducta de este personaje apunta hacia la "transformación del otro en objeto". (Por lo demás, el consentimiento popular del que parecen disfrutar algunos regímenes totalitarios hace pensar que vastos sectores desean cosificarse, a fin de que se los exonere de la enojosa tarea que consiste en pensar y en tomar decisiones.) Por consiguiente, en la visión problemática del individualismo tal vez corresponda poner el nombre de Sade junto al de Tetrarca, uno de los primeros escritores modernos que percibió los desasosiegos del humanismo secular, esta vinculación, que quizá sorprenda en un primer momento, no resulta insólita si se piensa que el Divino Marqués, en su condición de presunto descendiente directo de Madonna Laura celebrada en el Canzioniere, siempre se sintió ligado al poeta italiano, a quien leía "con un placer y 
una avidez que no puede comprarse con nada", según confiesa en una carta que en 1781 escribió a su mujer desde Vincennes.

Las observaciones apuntadas, por discutibles que parezcan, nos permiten deslindar ciertos aspectos básicos de la obra de Sade. En especial, facilitan la incorporación de este autor en el cuadro de la literatura licenciosa que ha caracterizado al secularismo burgués. Desde su nacimiento hasta mediados del siglo XVIII -con Cleland, por ejemplo- esta tradición de anécdotas libertinas apuntó hacia efectos placenteros, desprovistos de crueldad. No cabe dudad de que existen excepciones, pero estas sólo vienen a confirmar la regla: del Decamerón a Fanny Hill hallamos un erotismo que en sí mismo se muestra fresco, grato, exento de violencias, porque es una manifestación de la alegría de vivir. Tal comprobación, acaso con algunas reservas, puede hacerse extensiva a Casanova. A partir de Sade, en cambio, el comportamiento perverso y la humillación del objeto erótico parecen expresar el deseo de soberanía mediante la cosificación del otro. Ello no ha variado mayormente hasta nuestros días, según lo ilustra Historie d'O: el propósito de René en esta narración consiste, al parecer, en deshumanizar a su amante, para lo cual trata -lo consiga o no- de privarla hasta del más elemental indicio de amor que pudiera justificarla ante sí misma. En la presente centuria, sólo en escritores como Charles-Louis Philippe o D. H. Lawrence tan diferentes el uno del otro- se advierte un intento de rescatar el valor humano y aún sagrado de la comunicación erótica, pero sin la jovialidad y la despreocupada complacencia que exhibían Bocaccio o Chaucer. No obstante, los equívocos y ambigüedades 
suscitados en torno de sade muy probablemente radiquen en que su producción ha sido considerada un estímulo de la actitud coercitiva más bien que su denuncia y enjuiciamiento, sin advertir que las extravagancias del Divino Marqués fueron concebidas como el desenvolvimiento hasta sus últimos y absurdos resultados de ciertas nociones socialmente respetables y canónicas, a fin de suscitar una toma de conciencia plena -casi delirante- que indujera a revertir el proceso hacia aquella libertad que en opinión de los superrealistas esta insólita figura propició. Por lo tanto, la implacable interdicción que ha pesado sobre sade es, desde tal perspectiva, la respuesta previsible que la sociedad dio a quien se propuso desenmascararla públicamente en su comportamiento feroz y alarmante. En parte, se sostiene que la prohibición también ha sido un exasperado intento de amordazar a uno de los pensadores más audaces de los siglos recientes. Este juicio parece avalado por la tesitura corrosiva que asoma de manera explícita en las teorías políticas, sociales y religiosas de sade, pero que aún con mayor vigor es posible percibir implícita en la dimensión imaginaria, cuyo propósito esencial apuntó a quebrar la atmósfera represiva imperante, engendrada en esa época como secuela de los esquemas intelectuales mecanicistas. En su constante tarea creadora, Sade abrió la caja de Pandora en la que, como bien señalan sus actuales defensores, quedó ese último don que es el pensamiento emancipado de los inflexibles dogmas racionalistas: sabía que el conocimiento no es más que una telaraña de interpretaciones elaboradas por el hombre y que la realidad -sea lo que fuereno se agota en tan estrechos causes; sospechaba la existencia de 
verdades que excedían el mundo de lucidez y vigilia. Estas comprobaciones -tan desconcertantes que se tardó más de cien años en comenzar a valorarlas- constituyen el ingrediente que otorga trabazón sistemática a las fantasías de Sade: la suya -según hubiera juzgado Polonio- era una locura que no carecía de de método. En este último sentido, tal como suponen los críticos franceses que hemos citado, quizá estemos efectivamente en presencia de una "nueva filosofía", cuyo empleo fructífero todavía se halla viciado por la obstinación de nuestros pensamientos, que se aferran a los hábitos engendrados por la doctrina anterior en vías de disgregación. En ese presunto caso, Sade -junto a Goya, a Blake, a Nietszche, a Van Gogh- sería uno de los que vaticinaron el fin de los tiempos modernos, superados por aquella disciplina ya anticipada en Don Quijote y en Hamlet, verdaderos precursores de esta radical transformación del intelecto.

Por otra parte, en respaldo del procedimiento reivindicatorio que tiene lugar en estos días, debemos tomar muy en cuenta que el autor de Justine no propicia en momento alguno una doctrina de acción, sino exclusivamente de la imaginación, por sobre toda interpretación, debemos recordar que la obra de este escritor es un testimonio casi inagotable e humor negro que denuncia las contradicciones del mundo de su época; suponer que meramente era el plan de un desequilibrado deseoso de aplicarlo significaría ignorar ese hecho de tanta importancia literaria que es su obra, al respecto, el mismo Sade escribió: "Concebí todo lo que se puede concebir en la especie, pero no llevé a cabo cuanto he concebido y seguramente nunca lo llevaré a cabo". Una reflexión como esta 
refleja tanta sensatez y claridad intelectual, quizá constituya la clave para interpretar al hombre que la formuló. Quienes ponen en obra las fantasías sádicas y quienes condenan al inventor de esas fantasías no han advertido que Sade, en manifiesto anticipo de los estudios psicológicos modernos, admitió la natural presencia de oscuras corrientes aberrantes en estratos profundos de la conciencia, y propuso satisfacer esas predisposiciones a un nivel imaginario. Su tesis liberadora acaso haya sido la aceptación de la condición humana tal como es y la descarga en una dirección exclusivamente ficticia de las tendencias destructivas o insociales que la recorren. Por hábito mental que podríamos llamar "mimetista", el contemplador de una obra de arte se siente tentado a vincular el mundo creado con el mundo del creador, como si la composición fuese un espejo que permite la prolongación o duplicación -ya sea fiel o deformada- de un ámbito que tiene espesor real, no como la exclusiva construcción de un mundo virtual. Por añadidura, la escritura de sade -a diferencia de la que exhiben Beckford o El monje de Lewis- puede facilitar las confusiones y desconciertos que trasladan al plano de la conducta lo que es básicamente fantasía; pero recordemos que no se trata de un escritor "realista" y que su labor no mezcla el ámbito de la vida cotidiana con la dimensión poco menos que ilimitada cuyo descubrimiento está reservado por completo a la aventura imaginaria.

Sin embargo, sea cual fuere nuestra opinión acerca del Marqués de Sade, cabe reconocer en su obra aspectos de indudable validez objetiva, al margen de toda contingencia interpretativa. Su producción se destaca por la notable relevancia que posee como 
clave para descifrar un intrincado proceso observable en el curso reciente del pensamiento europeo. Para bien o para mal, este proceso consistió en la transición del sobrenaturalismo medieval al secularismo moderno. Tal fenómeno dejó en su momento el saldo sin duda positivo de favorecer un margen más amplio de tolerancia en el campo de las ideas y estimuló una mayor preocupación por el bienestar temporal del hombre. Pero al mismo tiempo, esta mutación ha ido eliminando de la experiencia humana la perspectiva escatológica, el sentido último de la existencia; en definitiva, ello terminó por crear en el horizonte de cada individuo una necesidad inmediata de realización terrenal plena, lo cual ha favorecido el advenimiento de ese clima generalizado de tensión que se percibe en el mundo actual. Ni al historiador ni al crítico literario le corresponde especular acerca de los alcances futuros de este proceso; pero en la medida en que tal suceso ha adquirido magnitud, resulta inevitable prestar atención a las invenciones del Divino Marqués, como significativo documento de la encrucijada intelectual de nuestra época. 


\section{LA FICCIÓN CRÍTICA}

\section{$(1973-1976)$}

LA PERFIDIA DEL LENGUAJE

En el prólogo a The Liberal Imagination -traducido por Enrique Pezzoni en 1956- Lionel Trilling apunta que toda crítica genuinamente preocupada en los intereses del liberalismo debe procurar un sostenimiento pero también un refinamiento las premisas liberales en el contexto de transformación que supone el mundo moderno. Afirma además que, en la consideración de la política «como política de la cultura», la crítica literaria liberal «da por sentada la íntima -si no obvia- relación entre literatura y política». Y, al señalar la condición paradójica del liberalismo -que se obstina siempre en «organizar los elementos de la vida de manera racional» a la vez que se esfuerza por no subestimar «la emoción en toda su variedad y posibilidad»-, sugiere que, cuando está movido por un «espíritu crítico», el liberalismo no tiene más alternativa que enfrentar su propia crítica: es entonces cuando se permite abordar las diferencias y desacuerdos entre lo que sería «la imaginación primordial del liberalismo» y «sus manifestaciones presentes y particulares», reconociendo «su amplitud, su matización y su complejidad» como atributos fundamentales (Trilling 1956: 9-15).

En esa «función de la crítica» bien puede incluirse la producción crítico-literaria de Jaime Rest de mediados de la 
década del setenta. No sólo porque se trata de una intervención crítica que insiste «en restituir en el liberalismo esa primera y esencial concepción de la variedad y la posibilidad», sino fundamentalmente porque parte de la convicción de que «la literatura es la actividad humana que tiene conciencia más precisa e intensa de la variedad, la posibilidad, la complejidad y la dificultad» (Trilling 1956: 15).

Unos versos de Sleep an Poetry de John Keats citados por el autor de The opposing self bien podrían pautar la modalidad específica de intervención de esa «crítica de la imaginación liberal»: «Though no great minist'ring reason sorts / Out of the dark misteries of human souls / To clear conceiving: yet there ever rolls / A vast idea before me, and I glean / Therefore my liberty...» ${ }^{210}$. En primer lugar, porque pone especial énfasis en el contrapunto sobre el que gravita gran parte de la reflexión restiana previa: la emotividad que toca los «oscuros misterios del alma humana» frente a la racionalidad que se erige como fundamento mismo de la libertad. Y, en segundo lugar, porque pone en escena el problema de la relación entre la literatura y las ideas, cuya importancia para la crítica moderna ha sido sin lugar a dudas crucial.

En un contexto de marcado predominio de un modelo crítico ideológico de clara ascendencia sociológica, Rest se impone la tarea de buscar una alternativa a la relación "lineal" entre clase, ideología y literatura sobre la que se construyen las

210 «Aunque ninguna razón administradora ordena / los oscuros misterios del alma humana / en las claras concepciones, no obstante, siempre rueda / ante mí una vasta idea, y recojo / de ella mi libertad...». Traducción de Enrique Pezzoni. 
lecturas inscritas en esa perspectiva. Es por eso que, en vez de enrolarse en el denuncialismo de las ideologías -que, en la perspectiva liberal de Trilling, «no son el producto del pensamiento», sino «el hábito o el ritual de mostrar respeto por ciertas fórmulas a las que (...) nos sentimos atados con lazos de cuyo significado y consecuencias no tenemos en la actualidad una comprensión clara» (Trilling 1956: 321)-, Rest busca pues otras modos de intersección entre las ideas y la literatura, donde los a priori teórico-metodológicos no determinen la lectura antes de la lectura misma.

Es así que, durante la primera mitad de la década del 70, Rest se dedica casi en exclusivo a escribir y publicar, en los números 3, 7 y 11-12 de la revista Hispamérica, una serie de extensos artículos sobre la obra de Jorge Luis Borges. ${ }^{211}$ Corregidos, revisados y completados con un breve prólogo y un importante epílogo, esos mismos trabajos aparecerán publicados a fines de 1976 por Ediciones Librerías Fausto bajo el título de El laberinto del universo. Borges y el pensamiento nominalista $(1976 a)^{212}$. La importancia particular de este texto en el marco del proyecto crítico restiano puede sintetizarse -siguiendo a Bardauil- en tres puntos fundamentales.

A primera vista, el trabajo de Rest pareciera venir a cristalizar una suerte de pasaje: de «un interés dominante en la

211 Los artículos que componen la serie en cuestión son tres: "Borges y el 'pensamiento sistemático'" (1973a). Hispamérica, 3, Buenos Aires, Marzo. pp. 3-23; "Borges y el universo de los signos" (1974b), Hispamérica, 7, Buenos Aires, Julio. pp. 3-24; y "Borges y el espacio literario" (1975e), Hispamérica, 11/12, Buenos Aires, Diciembre. pp. 3-21.

212 Rest, J., El laberinto del universo. Borges y el pensamiento nominalista (1976a). Buenos Aires: Ediciones Librerías Fausto 
década del 50 por la literatura inglesa a una creciente atención por la literatura argentina» (Bardauil 1999: 205). Tal aseveración debe matizarse, sobre todo teniendo en cuenta que, si bien no constituye el núcleo fundamental del trabajo de Rest, la literatura argentina nunca estuvo por completo desligada de sus intereses. Sólo por dar algunos ejemplos cabe mencionar que en 1952, el año mismo en que empieza a publicar, aparece en centro "Borges, Descartes y el obispo Wilkins" (1952C) ${ }^{213}$, su primera nota sobre Borges; unos años más tarde publica en Sur reseñas sobre el teatro y la poesía para niños de Fryda Schultz De Mantovani (1958a) ${ }^{214}$ y los relatos de Federico González Frías ${ }^{215}$; en 1960 aparece en Bahía Blanca su primer trabajo independiente, Cuatro hipótesis de la Argentina (1960a)216, texto íntegramente dedicado a las obras de Domingo Faustino Sarmiento, Ezequiel Martínez Estrada, Eduardo Mallea y Julio Mafud; en ese mismo año escribe en Sur a propósito de la biografía de Ricardo Güiraldes ${ }^{217}$; tiempo después aparecen en el mismo año Notas para una estilística del arrabal (1965a)"218 y "Trayectoria de Ezequiel

\footnotetext{
213 Rest, J., "Borges, Descartes y el obispo Wilkins" (1952c), Centro. Revista del Centro de Estudiantes de Filosofía y Letras, Buenos Aires, Año 2, $\mathrm{N}^{\circ}$ 4, diciembre de 1952. pp. 47-50.

214 Rest, J., "Schultz de Mantovani, F., 'El árbol guardavoces'" (1958a), en Sur $\mathrm{n}^{\circ}$ 251, Bs. As., marzo/abril. pp. 88-96.

215 Rest, J., "Federico González Frías, 'El oficinista Pedreiras y otras pesadillas vulgares"" (1959c), en Sur $\mathrm{n}^{\circ}$ 257, Buenos Aires, marzo/abril, 1959. p. 77-79.

216 Rest, J., Cuatro hipótesis de la Argentina (1960a). UNSur. Bahía Blanca: Cuadernos de Extensión Universitaria.

217 Rest, J., "Presencia de Güiraldes: Última biografía de Dora P. de Etchebarne, Collantes de Terán, Horacio Jorge Becco" (1960c), en Sur nº 263, Buenos Aires, marzo/abril. pp. 55-59.

218 Rest, J., Notas para una estilística del arrabal (1965a). Buenos Aires: Servicio de Extensión Cultural de la Dirección General de Obra Social de la Secretaría de Estado de Obras Públicas.
} 
Martínez Estrada" (1965e) ${ }^{219}$; dos años después da una interesante conferencia bajo el título "Los narradores argentinos y la búsqueda de un idioma nacional" $(1967)^{220}$ donde trata las obras de Echeverría, Sarmiento, Mansilla, Estanislao del Campo, Lugones, Güiraldes, Mallea, Borges, Marechal y Cortázar; tiempo después aparece "A lightning before death: elaboración de un tema en tres cuentistas" (1968d) ${ }^{221}$, un erudito artículo de crítica temática en que estudia textos de Borges y Cortázar; y, al año siguiente, en Los Libros, publica "Las invenciones de Bioy Casares" (1969a)222. En consideración de la prolífica pluma de Rest por esos años, los artículos consignados no son tantos; pero de todos modos revelan a las claras que seguía con cierto interés la literatura argentina. Así mismo, en la época en que Bardauil marca el viraje en el campo de intereses restianos, el número de publicaciones del autor dedicadas a las literaturas inglesas, norteamericanas y francesas es significativamente mayor al dedicado a las producciones vernáculas.

La colocación de Rest tampoco exhibe ningún pasaje sensible. Al contrario: a lo largo del trabajo, lo que se sostiene es justamente la posición liberal, "cosmopolita" y antipopulista que había incorporado en la década del 50, cuando tanto la inteligencia liberal conservadora (de Sur y el suplemento

\footnotetext{
219 Rest, J., "Trayectoria de Ezequiel Martínez Estrada" (1965e). En AAVV. Homenaje a Ezequiel Martínez Estrada. Bahía Blanca: UNS.

220 Rest, J., "La búsqueda de un idioma nacional", Ensayos sobre cultura y literatura nacional (Selección y Estudio preliminar Maximiliano Crespi), Buenos Aires, 17grises editora, 2010. pp. 149-160.

221 Rest, J., "A lightning before death: elaboración de un tema en tres cuentistas" (1968d), en Cuadernos del Sur, 8-9. Bahía Blanca, Unsur. pp. 105-128.

222 Rest, J., "Las invenciones de Bioy Casares" (1969a), en Los Libros, n 2. Buenos Aires, agosto de 1969. pp. 8-10.
} 
cultural del diario La Nación) como la liberal progresista (de Imago Mundi) se definían por su abierta oposición a la promoción de la cultura "nacional y popular" enarbolada por el peronismo. Más cerca de Imago Mundi que de Sur -en la cual siempre ocupó un lugar marginal- Rest se inscribe en esa perspectiva aperturista y universalista defendida por el propio perfil académico de su director, José Luis Romero. Leyera literaturas argentinas o inglesas, tomara como objetos de sus intervenciones letras de Homero Manzi o textos de John Lennon, su colocación crítica respecto de las posturas nacionalistas y populistas fue siempre sostenida desde su perspectiva liberal socialista ${ }^{223}$. Contra el movimiento general de la crítica que, ya a comienzos de los 60 se inclinaba en términos generales y cada vez más definidamente a centrar su objeto de estudio en las literaturas nacionales y latinoamericanas, Rest sostiene su interés por la literatura occidental -sin establecer divisiones coyunturales. Su remisión constante al marco general de la literatura europea y la publicación de artículos de inscripción comparatista como "La crisis contemporánea y el espíritu en el testimonio de dos poetas: T. S. Eliot y Paul Valéry" (1956c) o "A lightning before death: elaboración de un tema en tres cuentistas" (1968d), por ejemplo, ratifican concretamente esta colocación en un sentido abiertamente occidentalista, en clara diferenciación con la tendencia general que -influenciada por el impacto generado por la Revolución cubana y el auge del "boom" latinoamericanopercibía en la "nacionalización" y "latinoamericanización" de sus

223 Cfr. Portantiero 1988: 132-133. 
objetos una suerte de resistencia política e ideológica al cosmopolitismo liberal (King 1989: 218-232).

Al ocuparse de Borges, Rest centra su atención en un autor que, no sólo manifiesta abiertamente su predilección por la literatura anglosajona, sino también por un escritor que comparte su perspectiva cosmopolita al describir -como lo hace en la célebre conferencia sobre "El escritor argentino y la tradición" (1951)- la acentuación de los rasgos nacionalistas o localismos particulares como una superstición que cae en una afectación innecesaria. En este sentido, cabe invertir la argumentación de Bardauil y decir que la importancia específica de este texto radica en la reafirmación y ratificación de su posición universalista y occidentalista ante un contexto que produce un visible y homogéneo viraje, centrando su atención sobre la cultura producida en el continente y rechazando abiertamente los valores cosmopolitas.

Que, «sin ser un especialista en la obra de Borges», Rest afirme su elección a partir de la «fascinación» que le produce la obra y que, por ende, el «Borges leído» corra -como él mismo diría- «por su cuenta y cargo», es también significativo. El crítico se aboca a leer esa obra -que lo ha acompañado «desde los diecisiete años»- entendiendo que en ella es posible retomar el lugar de la experiencia del placer -propiamente estético- de la lectura y la experiencia del trabajo intelectual como una instancia de articulación singular entre literatura y vida. La indagación del modo específico en que la obra evoca esas relaciones no excluye -en la perspectiva de Rest- el placer que 
se desprende de la experiencia de una ejecución literaria calculada y de una formulación intelectual rigurosa, como la que el propio Borges ve y admira en De Quincey. La literatura se funda sobre una erótica: el placer -explica en el prólogo a Mundos de la imaginación- es la única forma de justificar una lectura (1978b: 15-16). Que declare desde el comienzo su afinidad personal y que haga del «deslumbramiento» que la obra borgeana produce sobre él como lector el motivo íntimo de la indagación desarrollada habla menos de una confidencia intimista que de una infidencia causal. Rest reconoce que la fascinación que le produce el texto borgeano se debe a que su ficción toca los filamentos mismos de su dispositivo crítico. En función de esa intuición, y como en un movimiento autoreflexivo, dispone su lectura en un ademán que se enlaza a ciertos enfoques contemporáneos que abordan las producciones estéticas estudiando su capacidad de afecto con relación a «las cualidades subjetivas de las experiencias individuales» -pertenezcan estas al registro de la percepción sensible o al campo de lo estrictamente intelectual. ${ }^{224}$ Resulta en efecto por demás ejemplar en este sentido que Rest escriba: «me impide ver con claridad el hábito, la circunstancia de que lo he seguido en el curso del tiempo y de que [...] estoy deslumbrado por las experiencias pasadas» al punto de que «tal vez escribo este libro para despojarme de tal visión y para poder releerlo en el futuro sin residuos cronológicos»

\footnotetext{
224 En una obra reciente, el filósofo Jean-Claude Milner subraya que uno de los motivos más importantes del proyecto crítico de Roland Barthes era el de "salvar a los qualia, tomar partido por ellos, y constituirse, en sentido propio, como portavoz de la sensibilidad, sin temer en absoluto la anfibología del término" (2004: 36).
} 
(1976a: 23).

Pero sobre este gesto -que lleva a pensar en una «crítica patética» en el sentido en que la entendía Roland Barthes (2005: 163)-, El laberinto del universo traduce además su particular colocación en términos de políticas de lectura. En primera instancia, ejemplifica singularmente la condición excéntrica -si no directamente marginal- del trabajo restiano y expone con nitidez su posicionamiento específico frente a las modulaciones de la crítica sociológica e ideológica vernácula, que siempre exhibió una relación de incomodidad respecto de la producción literaria de Borges. Rest recorta su corpus y construye su objeto de lectura a contrapelo de la agenda crítica de los 70 en más de un sentido. Esa es precisamente una de las razones específicas por las que cuesta reconocer en él una voluntad de inscripción «en el interior de un movimiento general de la crítica que ya desde comienzos de los 60 dedicaría una atención cada vez más creciente a la literatura argentina y latinoamericana» (Bardauil 1999: 206). Al contrario: frente a la tendencia de nacionalización y latinoamericanización de los corpus, Rest configura una propuesta crítica cuya impronta está fuertemente influenciada por las ideas centrales de "El escritor argentino y la tradición" -texto que elogiará incluso por su claridad de perspectiva en las páginas finales de El cuarto en el recoveco, redactado en 1979. Justifica sus corpus no por su procedencia (o por su pertenencia al «imaginario de la literatura nacional») sino por la fascinación del fantasma temático que convoca su mirada. Construye sus objetos situándolos ahí donde la crítica se 
muestra incómoda o -mejor- ahí donde la incomodidad de la crítica es algo que merece ser interrogado. ${ }^{225}$ Pero además, a la superstición sociológica de la "crítica ideológica" -que «en su urgencia por vincular arte y política volvería a saltar por encima de los aspectos específicos de la obra»-, opone un modelo crítico descriptivo que busca «deslindar lo que [Tzvetan] Todorov denomina una poética: una serie de coordenadas en las que puede ser insertado y completado el hecho literario» (1976a: 136-137). El libro se inscribe pues en un antiguo combate: el que se libra desde comienzos del siglo xx contra el desconocimiento o la marginalización de los aspectos formales y específicos de la obra literaria en el proceso de producción de sentidos. Desde el mismo prólogo, Rest define su colocación haciendo blanco en la crítica ideológica al declarar que, si bien «cada artista tiene, incuestionablemente, un compromiso moral con la sociedad en que desenvuelve su actividad -que es su tan mentado compromiso específico», acto seguido aclara que tal compromiso consiste precisamente en no desconocer ni marginar «las características intrínsecas de su oficio», sino más bien en «enfatizarlas». Su tarea -escribe Rest- no es la de «internarse en la resolución de problemas sociales o económicos -en los que, por lo menos, no es

\footnotetext{
225 Es pública la incomodidad que ha producido la obra borgeana a los críticos de la llamada "generación del 55", el desprecio por ese «literato sin literatura» que compartieron Prieto, Jitrik, Viñas y Masotta quien en el quinto de sus "Seis intentos frustrados de escribir sobre Roberto Arlt" dejó expresa esa incomodidad ante la obra de Borges. En una conferencia pronunciada en abril de 2005, con motivo de la presentación del décimo número de Orbis Tertius, Jorge Panesi da cuenta fehaciente de la incomodidad que la obra borgeana ha generado durante años a la crítica literaria desde Contorno y los comienzos de su modernización (Panesi 2005: 3).
} 
especialista-, ni tampoco vociferar solidaridades minoritarias o masivas». Lo que el artista comprometido «debe proponerse es subrayar la naturaleza de su actividad», es decir: hacer resplandecer la producción «en sí misma, pues ese es el motivo de que su labor reciba tal nombre por antonomasia» (1976: 20). De acuerdo a este parámetro, y contra toda presunción de la "crítica ideológica", difícilmente se pueda sostener que Borges no es el escritor más comprometido de su tiempo. Y finalmente, por una suerte de transferencia específica, la propia crítica restiana revela su compromiso concreto al abordar esa obra compleja que visiblemente incomoda a la crítica ideológica y cuya incomprensión es directamente proporcional con el voluntarismo que subyace a las diatribas militantes sostenidas contra el autor de Ficciones.

Las miradas que «con excesiva facilidad» denuncian a Borges por su «falta de permeabilidad a factores circunstanciales» olvidan precisamente la condición misma de un compromiso que, sin caer en una reivindicación en extremo formalista, supone «una exaltación del trabajo como aptitud configuradora por cuyo intermedio cada hombre contribuye, en su campo, al desenvolvimiento de la vida comunitaria» (1976a: 21). Rest vuelve a subrayar aquí un aspecto fundamental que recorre toda su obra y explica muchas veces sus propias colocaciones: el intelectual, como el escritor, ejerce su determinación política al interior de su práctica específica. Es su especificidad lo que da lugar y valor a su praxis configurando una coherencia no siempre visible a golpe de vista. Es por eso que Rest no oculta el sentido 
político de su lectura: su defensa de «un liberalismo de la tolerancia» se carga de significación en una coyuntura histórica en que la violencia autoritaria del poder -sostenido desde una suerte de «mito del orden»- era respondida con más violencia sobre todo a partir del estallido ocurrido en Córdoba en mayo de 1969- por parte de los grupos ideológicamente cada vez más radicalizados que configuraban su resistencia (Romero 2001: 175185). Tampoco borronea lo político de la hipótesis que rige su indagación; al contrario: lo subraya declarando ya desde la primera página del libro que «en el pensamiento moderno existe una estrecha relación subyacente entre nominalismo filosófico, lenguaje místico y concepción liberal de la tolerancia» (1976a: 17). Como la mayor parte de la crítica ideológica, Rest inscribe a Borges en la tradición del pensamiento liberal. Sólo que Rest lee efectivamente esa inscripción política al interior de la literatura, en vez de denunciarla a partir de declaraciones en entrevistas 0 de su no pronunciamiento sobre cuestiones extraliterarias. Pero a su vez, al leerlo al interior de esa «tradición»-entendida «como una continuidad dinámica, no como la reafirmación dogmática de valores ontológicos (y, por lo tanto, inamovibles) que terminan mostrándose rígidos y ahistóricos» (1976a: 25)- se atreve a deducir de esa literatura una gnoseología, una «casi inevitable antropología (y quizá también una ética) de corte existencial» (1976a: 19).

La hipótesis del libro sostiene que la obra literaria borgeana «es el resultado de una concepción orgánica y unitaria, cuya clave debe buscarse en el nominalismo» (1976a: 18). Pero la 
lectura de Rest borra todo prejuicio de abstracción o banalidad al desplegar -en cada uno de los capítulos dispuestos- su lectura sobre la problematización específica de los momentos en que la obra de Borges remite a aspectos concretos de la «crisis que aqueja al hombre moderno» determinando al mundo en el que habita.

"El 'pensamiento sistemático'", publicado originalmente en marzo de 1973, señala la condición errabunda de ese hombre moderno «en perpetua búsqueda», que vive -o sobrevive- «con una ilusión de permanencia», buscando una realización siempre diferida, explorando «una posibilidad de comunicación» siempre frustrada y pugnando por establecer un sentido para su propia vida. Toda afirmación -escribe Rest con tono generosamente pedagógico- y, más aun, «todo esfuerzo por comunicar o imponer certidumbre en los demás apenas es un intento por superar la incertidumbre propia, de ignorar o escamotear la angustia que uno mismo siente» (1976a: 71). Acorralado entre la fugacidad real y la intuición de permanencia, la experiencia humana se descubre arrobada por una «alienación» profunda y característica del mundo moderno que la literatura de Borges no deja de poner al descubierto. Al igual que las de Lewis Carroll y Franz Kafka, la literatura de Borges parece optar por la hipótesis de que «la alienación es y fue siempre inevitable», precisamente porque «emana de una toma de conciencia del desajuste entre las herramientas cognoscitivas de que disponemos y los hechos concretos que debemos afrontar» (1976a: 72). No hay afuera de la ficción. En consecuencia, «el mundo se nos presenta como un laberinto» cuyo «propósito subyacente» y «cuyo sentido se nos 
escapa» en un «caos de datos dispersos» que condenan al hombre «a una visión contradictoria y fragmentada» (1976a: 74). La literatura de Borges se emparenta con la de Kafka, «entre otros rasgos, en un modo análogo de testimoniar, en nuestro tiempo, la condición alienada de los actos humanos» (1976a: 74-75). Tanto uno como otro, y cada cual a su modo, exploran -según explica Rest- «con ánimo crítico» las raíces y los alcances de tal alienación: mientras el hombre kafkiano se resigna a la imposibilidad de conocer las causas de su ajusticiamiento o los motivos que le difieren la entrada al castillo, en Borges «prevalece el homo ludens», acaso «consciente de que el camino está cerrado», pero cínicamente «dispuesto a solazarse con los posibles atajos, con las taumaturgias del pensamiento, tan ilusorias como fascinantes» (1976a: 75).

En "El universo de los signos", la segunda parte del libro (aparecida originalmente en julio de 1974), Rest corrobora que la «preocupación metalingüística» de Borges está siempre orientada a interrogarse por la validez o invalidez de la especulación filosófica y a «indagar el papel relevante de la literatura como plenitud de la gravitación que la palabra ejerce en nuestra existencia». Concluye además que, en su obra, la «renuencia con respecto al pensamiento sistemático» se justifica en que, en sus «deliberadas interpretaciones de la realidad», esta actitud incurre «de manera inevitable en concepciones metafísicas cuyo valor cognoscitivo no excede el de la literatura fantástica» (1976a: 121). Finalmente, confirma que -articulado sobre la tradición filosófica del nominalismo, el empirismo, el 
positivismo, el pragmatismo y el formalismo lógico-, «su recelo con respecto a la herramienta lingüística del conocimiento» confirma sus estrechos y férreos vínculos con «una ideología liberal» de larga data. La conclusión extraída por Rest es sencilla pero contundente: «si no hay acceso cierto y unívoco a la verdad, toda concepción ajena -tal como postulaba John stuart Mill- debe ser examinada con la misma atención que cada uno presta a las propias ideas». Esa articulación de individualismo y relativismo -que el propio Herbert spencer defendió imponiendo una fatal alternativa: «respeto del individuo o tiranía»- sólo cobra sentido y coherencia en el marco de la imaginación liberal que se afirma en la idea de que -como apunta el teórico liberal L. T. Hobhouse- «la única doctrina que cabe rechazar sin contemplaciones es aquella que dogmáticamente rehúsa compartir el principio de tolerancia» (1976a: 122) ${ }^{226}$.

En "El espacio literario" -título en el que reverbera claramente la influencia de Maurice Blanchot- Rest desarrolla la relación entre la tropología de «la experiencia mística» y la tradición nominalista. Señala que la denuncia del «desajuste entre lenguaje y realidad» realizada por los nominalistas coincide con la tradición mística que se desarrolla -por rechazo de las trascripciones literales- en favor de un marco de referencias alusivas y «asedios metafóricos». Como la de San Juan de la Cruz -aunque sin su contenido religioso-, la literatura de Borges desconfía del poder de representación del lenguaje pero confía en la «potencia evocativa de la metáfora». Tanto es así -

226 El subrayado es mío. 
explica Rest- que, «sin la necesidad de experiencias extraordinarias», Borges ha comprendido que «la instrumentación de la materia verbal que perfeccionaron los místicos es apropiada para hablar acerca de una realidad absoluta y concreta con la que el hombre cree haber mantenido constante relación» (1976a: 163164). Con perspicacia y sistematicidad, en textos como "El Aleph", "La Biblioteca de Babel" y "La escritura del Dios" la obra de Borges exhibe -a juicio de Rest- un «empleo actualizado de tales métodos enunciativos» (1976a: 164).

Finalmente, en "El 'silencio privilegiado'", escrito durante la segunda mitad de 1975 para transformarse en el epílogo del libro, Rest recapitula rápidamente lo expuesto a lo largo de los textos precedentes para dedicar -no sin cierta consciencia de la ironía- al silencio las páginas finales. Señala la confluencia de la tradición mística y el nominalismo en su crítica implacable a los límites del lenguaje. Frente a tal situación, el místico descubre en tropos y figuras metafóricas su aproximación a la experiencia de lo inefable; el nominalista, en cambio, vive con turbación su propio descubrimiento (la imposibilidad de ordenar los términos de su experiencia sorteando la arbitrariedad del lenguaje). Cada uno presenta además -como observa Rest- una actitud diversa frente al silencio: «el místico lo asume como el más perfecto testimonio de sabiduría», mientras el nominalista «va a librar en los tiempos modernos una desesperada batalla en el intento de superarlo» (1976a: 172-173). En cualquier caso, los tropos metafóricos y la fuerza connotativa del lenguaje buscan suplir las necesidades: en el primer caso, el lenguaje traduce 
alusivamente una experiencia de lo inefable de la que sólo puede dar cuenta el silencio; en el segundo, la superación de los límites del lenguaje se busca a través de las rupturas en la sintaxis, la ilación narrativa y las técnicas de desviación, digresión narrativa y flujo caótico (como el "monólogo interior") halladas en las experiencias literarias del siglo $\mathrm{XX}$ «en su intento de penetrar niveles profundos de la experiencia» (1976a: 189) .

Pero hay todavía una posición que no considera el silencio como alternativa al lenguaje literario y es precisamente aquella que, más radicalmente, postula la propia «expresión poética como una forma de silencio» -esto es: «como aquel silencio propio de la metáfora cuyos enunciados sólo adquieren sentido en función de lo que no es posible explicitar» (1976a: 191-192). El representante más eximio de esta formulación poética es Maurice Blanchot. En las páginas de la part du feu dedicadas a "la literatura y el derecho de la muerte", Rest cree percibir «la subsistencia de la concepción nominalista según la cual las palabras sólo nos proporcionan flatus vocis, sin que haya un vínculo natural o necesario con la realidad. Bajo su óptica, hablar es siempre hablar sobre nada: «es intentar una declaración del mundo a través de una mediación en el que éste se manifiesta como ausencia» (1976a: 192). Más aún: su propia defensa de lo poético se produce sobre la convicción de que «cuanto escuchamos en el texto literario es aquello que se presenta como un silencio de la existencia» (1976a: 192-193). En función de tales afirmaciones, Rest no duda en hacer de Blanchot un escritor 
radicalmente contemporáneo a Borges, en el sentido de que sus obras comparten las mismas preocupaciones y las mismas reticencias sobre la relación entre lenguaje y realidad. Coteja las ideas presentes en "Borges y yo", el texto espejado del propio Borges, y las reflexiones blanchotianas que dicen: «Pronuncio mi propio nombre y es como si pronunciara mi sentencia de muerte; me separo de mí mismo y dejo de ser mi presencia o mi realidad, para ser la presencia objetiva de mi nombre, que está más allá de mí» (Blanchot 1949: 326-327). Y en ese cotejo revela un parentesco incuestionable. La obra de Borges condena por absurdo el conocimiento discursivo y demuestra la concreta imposibilidad de «ordenar los datos de nuestra percepción e integrarlos en una imagen del mundo» (1976a: 193). Textos como "El idioma analítico de John Wilkins" revelan a las claras que, en su perspectiva, sólo es posible resignarse a una configuración abstracta y arbitraria de la "realidad" mediatizada por el lenguaje. En ese contexto se comprende de manera cabal la lucidez que subyace a su ironía al afirmar que la poesía, la filosofía, la religión y la ciencia «son manifestaciones diversas de un único campo significativo que se denomina literatura y cuya sustancia siempre es fabulosa» (1976a: 194). Pero usando como ejemplo irrecusable el relato "La escritura del Dios", Rest descubre además que en Borges se reúnen los dos silencios sobre los que se ciernen los límites del pensamiento moderno: «está el silencio nominal, la ineptitud del lenguaje para introducirnos en la realidad», y está también «el silencio místico, el carácter inefable que se desprende del trato con Aquello (o Aquel) que 
sustantivamente "es lo que es"». Como bien apunta Rest, la literatura borgeana se mece sobre una afirmación doble y paradójica que no cesa de remitir a la enseñanza taoísta: porque, si «quien habla no dice nada» y si «a quien ha desentrañado la verdadera sabiduría sólo le está permitido callar», la verdad no está muy lejos de la sentencia que reza «Quien habla, no sabe; quien sabe, no habla» (1976a: 195).

En su descripción del pensamiento nominalista borgeano, Rest retoma múltiples experiencias teóricas y literarias modernas que coinciden en alguno de sus momentos con las posiciones más definidas de esta tradición filosófica. Los nombres de Friedrich Hölderlin, Stéphane Mallarmé, Charles Baudelaire, Arthur Rimbaud, Antonin Artaud, Roger Vitrac y Samuel Beckett se unen a los de Roland Barthes, Michel Foucault, Ludwig Wittgenstein, Susan Sontag, Georges Bataille y Pierre Klossowski, y éstos a su vez se suman a los de George Steiner, Hans Mayer, Erich Kahler, Adam Schaff, Karel Kosík, Leszek Kolakowski, Ingmar Bergman, Jean-Luc Godard y Harpo Marx, entre tantos otros. La amplitud y extensión de la serie corrobora -a juicio de Rest- la inscripción de Borges en el abordaje comprometido de una de las cuestiones fundamentales de su tiempo. Afirma que, como aquellas otras intervenciones, su obra subraya deliberadamente «el agotamiento sufrido por un modo de pensamiento particular, por un determinado lenguaje». Pero, cuando -retórica e incluso irónicamente- se pregunta si en esta crisis «está en cuestión el lenguaje, en sus aspectos esenciales y permanentes, o este lenguaje, propio del ciclo histórico específico que denominamos "moderno"», Rest deja 
entrever que, a su juicio, lo agotado no es el lenguaje en sí mismo, sino un determinado modo de suponer su utilidad, su carácter instrumental y su razón de ser. Como si lo que estuviera en juego en esa crisis no fuera más que una redistribución de «los límites y los alcances del lenguaje -juntamente con la significación e importancia del silencio-» sobre los que se empieza a configurar lo que Foucault define como un nuevo «régimen de verdad», en el cual se redisponen y reorganizan las relaciones de poder y de saber, es decir, las condiciones mismas de producción de subjetividades. ${ }^{227}$

Al carearse con esta «contribución singular y apasionada» que se obstina en cuestionar críticamente «la naturaleza de nuestra relación intelectual con la realidad» (1976a: 201)-, la interrogación restiana asume una formulación filosófica. Hace foco en los modos en que los textos literarios se relacionan con el imaginario de la época. Rastrea qué hay en ellos de conflictivo y de conjurado. Se pregunta, finalmente, por los modos en que -enviados a esa tierra de nadie que es la "literatura"- esos textos incomodan, discuten o astillan el «orden de verdad» en que adquieren el valor de acontecimientos. ¿Qué es lo que en la literatura de Borges se vuelve insoportable? ¿Qué es lo que hace que su rechazo ideológico se anteponga incluso a la lectura misma? ¿Qué es lo que se conjura en ese espacio textual en que se miente cuando se dice la verdad

227 Véase sobre este punto quizá sería interesante confrontar algunas reflexiones afines de Michel Foucault publicadas en Les mots et les choses: une archéologie des sciences humaines (Paris, Gallimard, 1966) y "Réponse au Cercle d'Épistémologie" (Cahiers pour l'Analyse, nº 9, verano, 1968. pp. $9-44)$. 
pero también cuando se dice la mentira? Aunque no haga explícitos estos interrogantes, la lectura restiana conduce al cuestionamiento sin dudas del «orden de verdad» en que la obra se produce al plantear su grado de acatamiento o desobediencia respecto de él; pero también remite indirectamente a las condiciones de la propia enunciación crítica, subrayando hasta qué punto ese «orden de verdad» determina el acto mismo de la lectura-definiendo su origen y sus alcances últimos.

Rest lee a Borges como lee a De Quincey, a Gilles de Rais, a Aretino, a Lacenaire, a Jarry o al asalariado cleland. Preguntándose qué desajuste ponen en evidencia sus literaturas, sin dejar de reconocer incluso que -las más de las veces- esas mismas literaturas no saben con certeza adónde se dirigen pero, en cambio, tienen bastante en claro qué es aquello de lo que huyen. Rest escribe sobre Borges como lo hace en torno a Sade: bajo la convicción de que trata con una obra que guarda una relación esencial a la vez con la historia y con el tiempo. En su perspectiva, la historicidad de esas obras asume una condición particular: no son pues la manifestación de una excepcionalidad espiritual que se sustrae a la historia -según la pretensión mistificadora de cierto filisteísmo crítico- ni se reducen a testimoniar un determinismo histórico -según lo constriñe de la arrogancia militante-; son, para decirlo en términos nietzscheanos, intempestivas: en ellas centellea la potencia de lo inactual, lo singular y lo inútil. ${ }^{228}$ Lo que define la

228 La referencia implícita es a la lectura deleuziana de Spinoza. Véase al respecto la concisa y clara descripción realizada por Alberto Giordano en 
historicidad no es pues más que una erótica de la diferencia: como bien señala Rosa, la lectura exhibe «la pasión ardiente de un saber que objetiva lúcidamente a sus objetos de amor (los textos), no los tipifica sino que los muestra en sus diferencias sin desdeñar su inscripción histórica» $y$, en consecuencia, la lectura histórica de esas diferencias que los textos suponen respecto de sus épocas «permite rescatar su profunda historicidad y no las marcas historiográficas de superficie» (Rosa 1981: 373). Sostener la lectura de Borges por un horizonte de interrogación de la literatura en el contexto de una "política general de la verdad" tiene sus costos. El desajuste constitutivo entre las palabras y las cosas que denuncia la obra borgeana leída en el paradigma de la filosofía nominalista afecta el estatuto mismo de la crítica. En el ejercicio mismo de la lectura, lo primero que tambalea y se vuelve realmente inestable, no son sólo las categorías teóricas y los a priori metodológicos que la literatura borgeana pone en cuestionamiento constantemente, sin el propio espacio de enunciación de la crítica, que se descubre ante la ficción de su propio fundamento. En su creciente pretensión de rigurosidad y cientificidad, el metalenguaje de la propia crítica configura otra de las formas de la literatura fantástica.

En su encuentro con la literatura de Borges, la crítica restiana experimenta transformaciones sensibles que sintomáticamente- se traducen ya en apropiaciones, reelaboraciones y/o abandonos conceptuales. La hipótesis -neutra, 
en apariencia- de que la potencia de evocación y persuasión del lenguaje se materializa en Borges sobre una concepción rigurosamente nominalista supone una consecuencia efectiva. En función de lo que lee en la obra borgeana, Rest se ve obligado a revisar y reelaborar las categorías de trabajo de su propio dispositivo crítico. Ejemplos concretos de ello son, por ejemplo, la caída de los ambiguos y altamente discutibles conceptos de «reflejo» y «expresión» -presentes y vagamente definidos en la primera etapa del proyecto crítico restiano- y la incorporación de la categoría de «evocación» que da cuenta más cabalmente de una instancia de mediación insalvable en el contexto de una posible «comunicación» entre la literatura y la vida.

Con relación a la primera categoría teórica, el crítico se ve obligado a desconfiar -como bien apunta Bardauil- del uso rápido y despreocupado de la idea de «reflejo». Esta noción, que hasta aquí aparece sobrevalorada -en una configuración teórica centrada en la autonomía relativa de la literatura- y que en algunos de sus trabajos es usada sin demasiados pruritos y hasta con cierto desprejuicio-como ocurre en su indagación sobre la estilística del arrabal (1965a), en su vindicación del cine (1968b) o en su lectura de la obra de Nathaniel Hawthorne (1978e)-, aparece aquí puesta en discusión, sobre todo en lo que respecta a la supuesta adecuación entre lenguaje y referente o, más precisamente, literatura y "realidad". El nominalismo borgeano -que Rest lee a través de una tradición filosófica que comienza en las reflexiones de Aristóteles y se prolonga hasta la actualidad en las especulaciones teóricas de Fritz Mauthner y Ludwig 
Wittgenstein- pone de relieve el carácter lúdico del lenguaje y el desajuste insalvable entre las palabras y las cosas. Con argumentos filosóficos contundentes, Fritz Mauthner -anota Restafirma que «el lenguaje sólo es un juego, dotado de singular eficacia como tal pero exento de cualquier aptitud para representar, conocer y entender adecuadamente la realidad, sea "interna" o "exterior" al hombre» (1976: 84). La obra borgeana viene pues a corroborar esas hipótesis. Desarticula y pasa a retiro -casi siempre llevándolas al absurdo- las concepciones "miméticas" o "realistas" de la literatura y el lenguaje, poniendo en evidencia que el único carácter "reflejo" que puede concebirse en la relación literatura y realidad es el que devuelve un espejo ustorio. Rest se apropia de la reflexión borgeana y toma un decidido partido por una concepción nominalista del lenguaje y la literatura, al punto que -incluso en sus últimos trabajos- puede leerse su profunda convicción de que «la realidad está ausente del lenguaje» $y$ de que prácticamente «no hay posibilidad alguna de aseverar que un enunciado significativo designe algo que realmente existe» (1982: $77-78)$.

La segunda categoría del dispositivo crítico que Rest se reformula a partir de su reflexión sobre la literatura borgeana es la de "expresión". Esa noción había ocupado en su dispositivo crítico -como bien apunta Bardauil- una importancia capital. Durante el primer período de su trabajo crítico, en muchos puntos próximo al paradigma de la estilística, Rest concibe «la obra de arte y el lenguaje como una arcilla relativamente maleable a los 
pensamientos del autor». Lee considerando el «estilo» como un «conjunto de recursos expresivos que el autor individual recoge de las múltiples posibilidades contenidas en la lengua» (Bardauil 1999: 211) y supone -tal como lo apunta en sus notas sobre la prosa de Thomas De Quincey- que «no puede ser considerado un mero «ropaje o indumento ajeno» sino concretamente la «encarnación de los pensamientos [del autor]» (1958c: 70). La literatura borgeana pone en abierto cuestionamiento estas formulaciones al plantear que, más que "expresar" los pensamientos de una "individualidad creadora", el lenguaje literario los somete a su propia lógica específica. El nominalismo radical sobre el que se construye el texto borgeano rompe de plano con los fundamentos críticos de la estilística al postular que el estilo «no consiste en la mera singularidad expresiva que una obra determinada extrae de las posibilidades ofrecidas por su respectivo idioma», sino más bien en «la forma original en que un texto nos propone ciertos recursos tomados de la lengua poética universal». Tal presupuesto se apoya en la idea de que esa lengua poética universal se rige por leyes combinatorias propias y «permite articular el conjunto de metáforas, de arquetipos imaginativos cuya reiteración o coincidencia se han verificado a través de una continuidad multisecular» (1976a: 141).

Luego de este encuentro con la literatura borgeana, Rest abandonará definitivamente las categorías de «reflejo» y «expresión». Sin embargo, de algún modo, ambas aparecerán fundidas y transformadas en lo que se definirá como una «potencia evocativa» de la palabra literaria; palabra que, en consecuencia, 
sólo podrá abordarse a partir de una lectura conjetural y especulativa. Esas transformaciones suponen, además, consecuencias concretas en los modos de atribución de valor y autoridad en la lectura. Entre ellas, especialmente, la gradual pérdida de valor de los propios enunciados del autor a propósito de las obras: cabe recordar pues en este punto -y a modo de ejemplo- la importancia crucial que daba Rest a las notas de T. S. Eliot en función de la lectura de the Waste Land, en abierta contraposición a afirmaciones como la de que, en la obra literaria borgeana es dable sostener una concepción orgánica y unitaria de cuño nominalista aun «contrariamente a lo que el propio Borges suele mostrarse dispuesto a reconocer de manera explícita» ya que «esa revelación no le incumbe a él como persona sino al "dibujo en el tapiz" que proponen sus escritos por sí mismos» (1976a: 18).

El hecho de que, a lo largo de los cuatro ensayos, Rest no pierda -ni por un momento- el objetivo de subrayar las precisas coordenadas que vinculan la poética de Borges con la tradición del «nominalismo filosófico», habla a las claras de su determinación e importancia. La premisa de que «en el pensamiento moderno existe una estrecha relación subyacente entre nominalismo filosófico, lenguaje místico y concepción liberal de la tolerancia» (2009: 33) supone, no sólo que la obra borgeana se compromete específicamente al acoger esa problemática sustancial al núcleo del pensamiento moderno, sino también que en esa defensa liberal de la tolerancia se juega el destino de la crítica moderna -que, como bien afirma Eagleton, surgió 
precisamente como respuesta al absolutismo (Eagleton 1999). Es claro que tolerancia no supone un relativismo de valores o complicidad sin exigencias. Como sostiene Trilling, «asentimiento intelectual no es lo mismo que acuerdo intelectual», puesto que una literatura o una argumentación -respondiendo a la fuerza o a la gracia intelectual- es capaz de complacer al lector, sin que esto implique necesariamente un acierto de intención o conclusión -si, como solía afirmar Borges, hay argumentos que «no admiten la menor réplica y no producen la menor convicción», también están los que convencen sin más sostén argumental que su pulsión emotiva-: una literatura y una argumentación bien «puede complacernos por una consistencia intelectual, sin que se relacione con un juicio final sobre la corrección de lo que dice» (1956: 326). Bajo la mirada nominalista y liberal de Rest, la afirmación de la crítica depende pues de la propiedad y la consistencia, que se derivan tanto de los contenidos como de la propia retórica. Porque si -como afirma Trilling- «la literatura moderna es peculiarmente política», su particularidad radica en su reticencia a un utilitarismo lineal que se apoya en una idea falsa de la comunicación literaria. En su voluntad de hacer foco en la problemática del lenguaje y la inadecuación constitutiva entre las palabras y las cosas, la literatura moderna exige tanto una reevaluación de las relaciones entre lenguaje y literatura como del propio espacio de enunciación de la crítica literaria. Cuando se afirma en el progresismo, la mirada liberal parte de una premisa básica: una época cae en el empleo de la fuerza o se vale del disfraz de la ideología cuando desespera de sus 
propias ideas. Para revertir la «bancarrota de las ideas» -que es su propia bancarrota, puesto que el liberalismo burgués universaliza su pensamiento y considera que sus crisis y sus logros son los de la humanidad toda-, se erige «contra el impulso conservador y el impulso reaccionario» glosando lo más potable de esas posiciones a las que implícitamente se sabe opositor. Como John Stuart Mill que afirmaba que «la plegaria de todo verdadero liberal debía ser: "Señor, ilumina a nuestros enemigos"...», Rest supone que la inteligencia y la racionalidad son los que hacen progresar el pensamiento en una dirección venturosa. Esa convicción no es inmotivada: el crítico reconoce en este punto el magisterio desinteresado de José Luis Romero -de quien aprendió que el fundamento mismo de continuidad del pensamiento liberal radica en su progresismo, al afirmarse sobre un concepto dinámico y cambiante de «realidad»- cuya singular virtud consistía en constituir casi un paradigma de la pedagogía liberal al «no cuestionar ninguna interpretación ajena, aun las que no compartía», ya que «su única exigencia consistía en que el sustentador de la opinión pudiera demostrar su validez» (1978b: 16).

El doble movimiento en que se inscribe la crítica restina como saber específico y como afirmación ética- no puede menos que articularse sobre una concepción liberal del lenguaje. Como la de F. R. Leavis, la crítica restiana se asienta sobre un presupuesto epistemológico invisibilizado. En apariencia, «el crítico no juzga mediante una norma filosófica externa, sino que llega a una posesión completa e interna de la obra y la coloca luego a una 
altura relativa junto a otras obras» (Jameson 1977: 115). De ese movimiento que supone una apropiación y una asignación de valor, y que sigue una lógica progresiva y acumulativa, la crítica extrae su propia legitimidad operativa. Pero lo que la comunicación que la «disposición interrogativa y tolerante» de la crítica liberal presupone no puede ocultarse demasiado. Exige como precondición concreta un sistema compartido y estable de valores y creencias sobre el que se pautan los sentidos y los valores de las experiencias. Esa base cultural desde la que parte está a su vez aliada a una filosofía de la historia que no admite quiebres o rupturas radicales sino que se fortalece en la revelación de continuidades subrepticias, retornos y recuperaciones (aun -o especialmente- en un espacio cultural en constante transformación a partir de las nuevas tecnologías de comunicación). En este sentido, uno de los rasgos más notables de la crítica restiana es su optimismo -más que su no pesimismorespecto de la progresión dinámica de la cultura, hecho que puede verse ya en la disposición generosa, abierta y no jerarquizada es decir: definidamente antitradicionalista- ante las múltiples y novedosas producciones culturales, ya en su visible determinación de leer rigurosamente -a veces en el despliegue de una suerte de comparatismo heterodoxo- esas producciones con el objeto de elevar el estándar crítico de la propia cultura en la cual las visiones más conservadoras y apocalípticas parecían percibir la crecida de «una nueva barbarie».

Tratando de problematizar y complejizar el paradigma liberal desde el que aborda sus investigaciones, Rest entabla un diálogo 
abierto y desprejuiciado con las posiciones conservadoras y reaccionarias, pero a la vez sostiene una continua subyacente discusión que le permite incorporar puntos de vista y categorías teóricas provenientes del marxismo crítico. No es un dato menor que, en las últimas páginas de El laberinto del universo, Rest ilumine especialmente los aportes del estructuralismo -en su problematización de la «fractura geológica» producida en el lenguaje mismo- a través de la perspectiva crítica de Fredric Jameson en The Prison-House of Language (1972) ${ }^{229}$. Y tampoco lo es -sobre todo considerando la virulencia del contexto histórico que determina su aparición- que, hacia el final del libro, dedique una parte importante de su indagación a evaluar las contribuciones teóricas de la «dialéctica materialista», especialmente en su perspicaz cuestionamiento del residuo idealista que subsiste en las propias posiciones nominalistas. Rest hace especial hincapié en la línea de investigación que considera que, en los escritos del joven Marx, existe ya germinalmente la idea de que «la praxis tenía que operar como vía dialéctica para la superación de la contradicción entre realismo y nominalismo» (1976a: 199). Sin embargo subraya que «esta interesante corriente de investigación» -que Rest reconoce en el Tratado sobre la mortalidad de la razón del polaco Leszek Kolakowski- debe lidiar con la pesada carga de «la restauración metafísica del realismo, ahora sustentado en un fundamento materialista (por oposición al origen idealista, que procedía de

229 Jameson, F., The Prison-House of Language, Princeton University Press, 1972 (La cárcel del lenguaje. Perspectiva crítica del estructuralismo y del formalismo ruso, Barcelona, Ariel, 1980). 
Platón)» desarrollada por el propio Vladimir Lenin. En las páginas de Materialismo y empiriocriticismo (1908) Rest lee un marcado antinominalismo, sobre todo cuando el autor sostiene que «la propiedad específica de la materia consiste en ser una realidad objetiva independiente del sujeto que la conoce (y, por ende, real aun al margen de la praxis humana o de toda dialéctica cognoscitiva)»(1976a: 200). En consecuencia, no duda en sostener pues que sobre este texto se instituyó «un riguroso dogmatismo del que resultó víctima el pensamiento filosófico del área socialista» (1976a: 200). En este sentido, la posición de Rest frente al marxismo es declaradamente crítica en lo que atañe a sus momentos de cristalización dogmática e intolerante; pero no por ello deja de estar siempre muy atento a sus específicas contribuciones teóricas en lo que atañe a las relaciones entre lenguaje y literatura.

Por otra parte, Rest lee en Borges a un «involuntario precursor» de la nouvelle critique. Observa con pertinencia que los temas de sus ficciones reverberan en las indagaciones teóricas de Georges Poulet, Jean-Pierre Richard, Jean Starobinski, Susan Sontag, Michel Foucault, Maurice Blanchot, Roland Barthes, Georges Bataille, Pierre Macherey, Philippe Sollers y Julia Kristeva. En este sentido, El laberinto del universo no oculta su intención de ser una indagación de «la gravitación de la palabra» y «la actualidad y permanencia del silencio» en la modernidad. Su tema son las complejas relaciones entre pensamiento y lenguaje; su objeto, una poética singular que, paradójicamente, se da a conocer afirmando la imposibilidad 
misma del conocimiento discursivo. La ironía borgeana multiplica una y otra vez el fundamento argumental del nominalismo y sus consecuencias: si la imagen del mundo que nos formamos a partir de los datos de la percepción es sólo ordenable e integrable a través del lenguaje, y la organización y la integración que supone el lenguaje se desprenden de su propia estructura y sus funciones fundamentales, el resultado de tal operación es una configuración (abstracta y arbitraria) irreductiblemente mediatizada de la realidad; en consecuencia, el mismo hecho de convocar la realidad en el lenguaje supone reconocer en esa formación dinámica y compleja la presencia activa de la ficción; en consecuencia, la poesía, la filosofía, la religión y la ciencia se articulan siempre sobre una sustancia fabulosa, arbitraria y artificial; en consecuencia, el cuento y la novela no están más distantes de la metafísica de lo que lo está un tratado de biología; en consecuencia, los libros de historia son meros artificios de una construcción verbal que trata de conjurar el hecho de que sólo el presente fáctico (e inexpresable por naturaleza) puede ser considerado plenamente real. El ademán hiperbólico funciona en esas ficciones que ironizan sobre delirantes enciclopedias y mapas del tamaño del propio territorio. El universo (natura naturans) se vuelve laberinto, «lugar en que el hombre se extravía y a la vez queda prisionero» (1976a: 64). En su paso por el lenguaje sólo nos llega de él una imagen (natura naturata) que se traduce en un «caos de datos dispersos» en medio del cual el sujeto moderno se descubre 
«condenado a una visión contradictoria y fragmentada» (1976a: $74)$.

Traducida en tropos singulares de su ficción (i. e.: el aleph, el zahir, la biblioteca, las múltiples hipertrofias de "la escritura del dios") o en el tema recurrente de su ensayística, la «incesante búsqueda filosófica» de Borges -«llámesela discretamente curiosidad o inquisición» (1976a: 50)- admite la frase de San Pablo citada -con proba pertinencia- una y otra vez en el ensayo restiano: «por espejo, en oscuridad» (2009: 55). La oscuridad y el espejo suponen aspectos de la ficción: son los tropos que confinan la imposibilidad del lenguaje pero también su potencia: la arbitrariedad del signo se juega tanto en lo que impide decir como en lo que obliga a decir. ${ }^{230}$ He ahí la perfidia del lenguaje: «el signo es arbitrario porque obliga a ingresar en un juego, pero este juego reviste para nosotros la mayor seriedad porque nuestra capacidad de relación con el prójimo se sustenta casi por entero en él» (1976a: 94).

Que Rest vuelva insistentemente sobre la «condición ficcional» que afecta por igual a la poesía, a la filosofía y a la ciencia, no quita que además reconozca los términos de su alcance en la propia crítica. La «ficción» -Foucault lo ha expuesto con claridad meridiana- no es la «fábula». Ésta es «aquello que es contado»; aquélla, el «régimen del relato»o, más bien, los diversos regímenes según los cuales algo es relatado (Foucault 1994: 213-219). La fábula se hace de elementos situados

230 Cfr. Barthes, R., El placer del texto y La lección inaugural, México, Siglo XXI, 1986. 
en cierto orden; la ficción es la trama de relaciones establecidas en el propio discurso, entre quien habla y aquello de lo que se habla. La ficción es, en fin, el aspecto de la fábula: el movimiento por el cual los discursos son integrados a la literatura. La poesía, la filosofía, la religión e inclusive la ciencia son, en efecto, complejas y diversas configuraciones de «un único campo significativo que se denomina literatura» (1976a: 194), cuyo régimen es el de la ficción y cuya sustancia específica es la de la fábula.

Recortar la lectura del texto borgeano contra el telón de fondo de un «orden de verdad» cuyas capas tectónicas están en pleno movimiento le permite a Rest llegar a conclusiones tan lúcidas como inesperadas. De ese modo, se descubre afirmando que «la razón de ser de la literatura en su condición de tal es la arbitrariedad del signo, la imposibilidad de que el lenguaje pueda trasladar fielmente la realidad al plano conceptual» (1976a: 91) o que el crítico se debe aplicar a «desentrañar la forma en que el texto suscita ese persuasivo impacto» (1976a: 92), esto es, a señalar las estrategias mismas de la ficción: «el encanto fantasmal de las formas» (1976a: 67). Fábula y ficción vuelven pues en el libro de Rest bajo múltiples ropajes, pero siempre para señalar -contra toda la pretensión marxiana- que el conocimiento es una «actividad especulativa», «una labor limitada a imaginar el ámbito en que nos hallamos insertos pero no a interpretarlo» (1976a: 120). Y de algún modo también ambas vienen a subrayar la presencia activa de dos silencios que la modernidad se obstina en conjurar: por un lado, un silencio nominal 
(respecto de la realidad en sus infinitos detalles) y, por otro, simétrico y excesivo, un silencio místico (respecto de la Totalidad)

Sólo el silencio que se abre al «querer asir» la Totalidad y lo Ínfimo se vuelve un límite. La «gravitación de la palabra» que supone una flotación espectral en la que el taumaturgo se funde con la obra- reduce el fantasma a una presencia servil: como ha visto Maurice Blanchot, está allí para apaciguar el fantasma del silencio, de la Noche, del Afuera (Blanchot 1979: 911). Sin embargo, cuando el fantasma acontece, en una pasión ajena a todo «querer asir» (Barthes 2004: 58-59), liberado de las supersticiones de la utilidad, la generalidad y la actualidad, el silencio se vuelve umbral en el espacio abierto por el tropos poético y habla como en la iluminación mística, como hablaba el silencioso canto de las Sirenas que -en la versión de KafkaUlises, sordo de sentido común, creyó no oír.

Con claridad nominalista, Rest intuye que tanto la totalidad como lo ínfimo ponen al lenguaje ante la evidencia de su condición -el artificio, la ficción- y revelan a la vez mucho de la nuestra cuando apelamos a la «voluntaria suspensión de la incredulidad» (1976a: 120). El laberinto del universo supone una meticulosa cartografía de lo que en la literatura borgeana es el imperio de la imagen, el fantasma, el simulacro. Pone en blanco sobre negro que la literatura anida en cada una de las formas en que imaginamos el mundo. Y pone además al lector ante la evidencia trágica de que su verdad no depende de la fábula, sino que se juega siempre y ante todo en el artificio de la ficción. 
Sin embargo, como bien ha visto Bataille, no se puede hablar de algo como la parte maldita sin ser uno mismo también parte de esa maldición. Es por eso que la propia crítica no podrá hablar de la "ficción" sin que ella misma se transforme también en problema y sin que ese problema se resuelva en el reconocimiento de su propia condición ficcional. El laberinto del universo no retacea pues ejemplos de esos momentos de intensidad en que la crítica transforma su propio estatuto y se asume en esa zona de deslinde -que Nicolás Rosa definió como un exceso tanto de la «crítica» como de la «ficción»- que da lugar a una especie de «ficción crítica»: «un relato donde el rastreo de fuentes (recurso filológico) es una tarea de pasión detectivesca (y la metafórica constante es perpetrar, tramar el texto refiriéndose a sí mismo)»y donde el objetivo no es otro que el de «llegar a reconstruir la obra en su experiencia humana traspuesta estéticamente» (Rosa 1981: 374). En la asunción de esa disposición ética que consiste en considerar a «la crítica como una de las bellas artes» -surgida en el pliegue donde la crítica se detiene en su propio umbral para interrogarse por sus propios alcances, sus limitaciones y sus condiciones de existencia e inscripción en el «orden de verdad»-, no es difícil reconocer un saber que Rest ha elaborado a partir de su experiencia de lectura del nominalismo borgeano.

Hacia la década del 40, en textos como "Tlön, Uqbar, Orbis Tertius" y "Examen de la obra de Herbert Quain", Borges borró -a su modo: de una vez y para siempre- las supuestas jerarquías entre literatura y lectura crítica y puso en ridículo la 
arrogancia propia de los metalenguajes: buscar precursores, trazar recorridos, evocar parentelas o proyectar relaciones entre series no es menos complejo en términos de escritura, ni menos ficcional en términos de apuesta creativa, que proyectar un trabajo narrativo o un ejercicio lírico. En todo caso, hay dos cuestiones centrales en las que las formulaciones de la ciencia, las de la filosofía y la poética coinciden indefectiblemente: por un lado, que -en tanto «actos del decir»- entrañan «una trasposición cualitativa del objeto real y del circuito de relaciones en que se halla inserto» (1976a: 104); y, por otro, que el proceso que se juega en cada una de esas actividades es siempre creativo, y no -como suele creerse- descriptivo, reflexivo, hermenéutico o expresivo. Cabe señalar aquí la sorprendente coincidencia con algunas hipótesis de Deleuze, para quien arte, ciencia y filosofía coinciden en la dimensión creativa: «El auténtico objeto de la ciencia -escribe el filósofo francés- es crear funciones, el verdadero objeto del arte crear agregados sensibles, y el objeto de la filosofía es crear conceptos» (Deleuze 1995: 197). ${ }^{231}$

La «ficción crítica» restiana se reconoce pues en una función específica: imaginar relaciones, ecos y resonancias entre actividades creativas. Es por eso que, al pensar sus condiciones de existencia, no es posible simplificar los términos de esa relación en una instancia de absorción de la literatura por parte de la crítica o, viceversa, de la crítica por parte de la literatura. Los términos de la relación no se asimilan ni se

${ }^{231}$ El subrayado es mío. 
funden en ninguna simbiosis. Lo que sucede -y esto es algo que Rest ha sabido leer en Borges e incorporar a su propia experiencia crítica- es que la literatura y la lectura crítica se asumen como «modos de la ficción»; de manera tal que lo que queda fuera de servicio es la lógica jerárquica que determina funciones para "discursos primeros" y "discursos segundos". Lo que Rest descubre es que, asumidos como experiencias de la ficción, ambos textos apelan a la imaginación porque encuentran en ella un modo de aferrarse a la vida: lo literario no es una propiedad de los textos, sino una manera específica de relacionarse con ellos.

Asumida como ficción, la interrogación filosófica de Rest desplaza a la crítica de toda intervención valorativa y la obliga a reconocer, también en la descripción y en la explicación, las argucias de la razón creativa. Se trata de un trabajo paciente y riguroso -tan atento a «la precisión de la forma» como a «la solidez y la coherencia» de sus enunciados. Como tal, presupone una modalidad excepcional del ethos crítico que se niega categóricamente a juzgar el texto literario y que, cuando se ve obligado a hacerlo, lo hace dejando siempre en claro que preferiría no. No evalúa ni dicta sentencias ni sanciones acaso porque intuye -y ésa es su intuición literaria- que, en el Juicio, es la literatura la que se sustrae para afirmarse al margen de todo valor. Se elige, al contrario, haciendo en ella una experiencia capaz de poner en crisis el sistema de valores del imaginario que le determina el lugar del "resto" (el resto que es literatura). Es pues una crítica que se despega de las formas estandarizadas y que ya no busca juzgar sino que se enrola en una función creativa que 
se empeña en hacer existir las obras produciendo en ellas sentidos nuevos.

Pero eso no es todo. Si algo enseña el ethos crítico restiano es quizá el síntoma de su propia inquietud. Esa inquietud se traduce en el derecho y la responsabilidad de desear -y en ese deseo se rinde a su propia verdad histórica- una existencia soberana en el compromiso con una «ficción crítica» generadora e imaginativa, libre de las supersticiones que obligan al Juicio y obstinada con vehemencia -ésa es su obstinación filosófica- en «producir nuevos sentidos» en los pliegues de una escritura capaz de comprender -en sentido intelectual y espacial del término- las razones de la crítica y los vértigos de la literatura.

LOS OTROS MUNDOS DE LA IMAGINACIÓN

Como bien apunta Raúl Antelo, lo ficcional se define siempre «entre la atracción de lo desconocido y la apariencia de ser» (2008: 112). Es por eso que el momento determinante de la «ficción crítica» es el de la invención de sus fantasmas. Los fantasmas -va de suyo- no tienen superficie, son un simulacro fulgurante, un «como si». Los fantasmas de la crítica no son pues los del corpus, pero tampoco son exactamente los del tema de la crítica: son precisamente los objetos -o, para decirlo en términos hegelianos, presencias imaginarias «a medio camino» entre el lenguaje y las cosas. La ficción crítica teje esos 
espectros imaginándolos entre la verticalidad del jeroglífico que es el texto literario y el horizonte, fondo invisible -por naturalizado- que es el régimen de verdad, la lógica histórica que determina la lectura.

Inscrita formalmente en la superposición de verdad política y verdad estética, la crítica restiana supone la experiencia de una imagen (fantasmática) sólo perceptible en el juego de luces y sombras que se abre entre una literatura y un «régimen de verdad» en que ella se apunta como negatividad. La «ficción crítica» es pues un dispositivo capaz de asumir su «función» imaginando -en la propia obra de arte- la interacción de dos fuerzas antitéticas: «la actividad creadora propiamente dicha y la destinación de la obra» (1978b: 212). Y, en el movimiento de un trabajo que busca des-plegar el espacio de este conflicto, procura ofrecer «al lector medios para trascender la inercia de lo creado [la obra de arte misma] y para penetrar en el dinamismo de la configuración del obrar de la obra» (1978b: 213). ${ }^{232}$

Los textos reunidos en Mundos de la imaginación se articulan sobre un movimiento pendular. Publicado en 1978 en Caracas, el volumen -que está dedicado a Carlos Gardini, Luis Gregorich y Héctor Libertella «quienes -bromea Rest- conservaron el sentido del humor pese a la lectura de las páginas que siguen»- el volumen traduce un doble movimiento que, por un lado, busca explicar el funcionamiento visible de la máquina literaria y, por

\footnotetext{
${ }^{232}$ La reflexión en torno a la función crítica, presente en los comienzos de su trabajo crítico (en "Los ensayos de Virginia Woolf", tesis de licenciatura, Facultad de Filosofía y Letras, Universidad de Buenos Aires, mímeo, 1953) y persistente veinticinco años después, en textos como "Virginia Woolf y la función crítica" (1978b: 211-236), revela su inquietud y su constante cuestionamiento de la propia práctica y su imaginario.
} 
otro, las zonas de indeterminación y de umbral, donde la literatura habla en un rodeo de silencio. El libro reivindica su pertenencia «al campo tradicional y prestigioso de los collected papers», que -como apunta Rivera- «recopilan periódicamente una labor extensa, miscelánea y generalmente no dogmática, desde el punto de vista de la teoría literaria» (Rivera 1979: 31). Reúne trabajos escritos y publicados -en diferentes revistas $y$ en circunstancias diversas- a lo largo de casi tres décadas de trabajo ininterrumpido. Y, pese a estar dedicado casi por entero al corpus de la literatura inglesa, constituye ciertamente una suerte de mosaico que da cuenta real de la multiplicidad y complejidad de los intereses y las funciones que la crítica restiana asume en diferentes coyunturas.

El epígrafe de Desmond MacCarthy que encabeza el libro - «The direction of our interests, whether intelectual or aesthetic, is decided by the times in which we live» (1978b: 9)- no deja margen para la ambigüedad: Rest publica estas notas -realizando en ellas apenas leves modificaciones- porque confía que, bajo su apariencia diversa e incluso caótica, están tanto las marcas de las coyunturas históricas y culturales que determinan su producción como la huella persistente de un proyecto de trabajo que se abre paso a través de fantasmas temáticos, problemáticas y perspectivas críticas.

"El príncipe que decidió ser histrión" -escrito originalmente en 1975- dialoga estrictamente con los trabajos dedicados a Borges y el nominalismo filosófico. Problematiza el 
juego «manierista» ensayado por William Shakespeare: «dentro de la "ficción de la realidad" que entraña la acción escénica, hay a su vez una "ficción de la ficción"» (1978b: 25). Rest se aboca a explicar que, tras la crisis del naturalismo dramático, se produce una suerte de «desintegración del espacio escénico» que transforma por completo al teatro moderno. El tablado como «prolongación ficticia de la realidad», como instancia de una escrupulosa verosimilitud, se aparta del verismo y la «ilusión de realidad»y se convierte en «un comentario del mundo» (1978b: 26). Es así que se permite acoger diversos planos o grados de la ficción. La presencia de múltiples representaciones de la representación se fragua sobre la sospecha que Hamlet deja abierta con relación a las múltiples acusaciones improbadas sobre las que se teje la trama dramática. Incluso cabe sostener que el propio «Hamlet es, en definitiva, un hombre de teatro y, si admitimos que su locura es simulada, la totalidad del drama está protagonizada por un príncipe que se comporta como un actor» (1978b: 29-29); esto es: como una ficción de segundo grado.

Pero el carácter histriónico que se superpone a las configuraciones hipócritas y al tejido de simulaciones en que se sostiene la trama de la obra, no es más que la evocación de una presencia real fuera de la escena. La propia «realidad secular afirma Rest- no se diferencia de un inmenso y calidoscópico teatro» (1978b: 31). El orden de las simulaciones articula espacios porque está «mentado en el mundo real» e inscrito en el procedimiento mismo de la «invención dramática». El desdoblamiento -que imprime, a la vez, un distanciamiento y una 
continuidad- permite ver una «actitud» que trasciende «la mera ficción teatral» y que se asienta sobre «ciertas paradojas intelectuales» que inquietaban a los pensadores de la época. El renacentismo empirista que ganaba terreno sobre la escolástica medieval podía leerse ya en los textos de John Donne, el nominalismo de Occam y la inducción baconiana. Se trata de un movimiento paradójico que busca «llegar a la realidad partiendo de la apariencia» (1978b: 32). En ese método -que, a juicio de los tradicionalistas, sólo subrayaba «la separación entre lo que se muestra a nuestros sentidos y el orden verdadero y sustancial que se oculta detrás de esa máscara fantasmal o fenoménica» (1978b: 33)- se presenta en Hamlet como corroboración de que «la conducta aparente de cada uno no es más confiable que la simulación del histrión en el escenario. Esta idea traduce de alguna manera el grado de fascinación que generaba a Shakespeare y sus contemporáneos, como problema metafísico, «el enigma acerca de la relación entre apariencia y realidad» (1978b: 33) .

«El mundo es como un escenario en el que cada cual recita su papel». Esta frase del siglo XII escrita por Juan de Salisbury abre -a juicio de Rest- una serie de manifestaciones que llegarán a convertirse en la «corriente manierista» que se materializa con Cervantes, Gracián y Calderón en la literatura de habla hispana y que, bajo la divisa Totus mundus agit histrionem, se extiende en Inglaterra en el hojaldre ficcional desplegado en el Globe Theatre de Shakespeare. Pero lo que Rest lee en Hamlet no es sólo la presencia irrecusable de esa metáfora manierista, sino la eficacia de un modelo de reflexión paradójica. La tragedia pone 
la verdad del lado de la simulación: «los actores que interpretan el mimo se convierten en únicos personajes que ciertamente son lo que declaran ser» (1978b: 35). Son histriones en la tarea de «poner en escena un espectáculo». La concepción nominalista del lenguaje se impone en Shakespeare como en Borges: en una teoría de la simulación infinita sólo el simulacro, «la máscara fantasmal o fenoménica (adjetivos que, al fin $y$ al cabo, etimológicamente poseen un mismo significado)», puede ser real. O, para resumirlo con un rodeo macedoniano que sin duda no hubiera disgustado a Rest, sólo en la ficción que se asume como tal hay lugar para la verdad.

Escrito con motivo de la rememoración del sesquicentenario de la muerte de Jane Austen y tomando su título de una nota del diario de André Gide, "Un exquisito dominio de cuanto puede ser dominado", da cuenta de otro de los temas claves que pautan el interés crítico de Rest: el origen de la compleja configuración moral de las clases medias burguesas en el proceso de la modernidad. Fechado en 1967, el texto sin embargo no tiene nada de convencional. Jane Austen -quien, como apunta Rest, no hubiera dudado en definirse como «una solterona inglesa de clase media»supone una mirada excepcional en esa inscripción de clase: «sus obras no reflejan prejuicio, ni resentimiento», ni «mojigatería» (1978b: 39). Al contrario: se inscriben en ese territorio afín al liberalismo progresista que se descubre en el camino del «equilibrio», la «tolerancia», «la prudencia» y la moderación. Como bien apunta Rest, de acuerdo con «su temperamento pleno de 
sobriedad, penetración y sentido cómico, sus novelas no pretenden ir más allá del mundo que ella conocía». Pero ese hecho no define un orden de representación o de reflejo del medio social. Su narrativa alude a ese medio «evocando» su presencia, ya fuera señalando los comportamientos ridículos o empleando su «peculiar sensatez» en la observación de las particulares «condiciones de armonía moral, social y económica que, dentro del sistema burgués vigente, permitían transformar los impulsos del afecto en la siempre aguardada serenidad del trato conyugal» (1978b: 42). Ni rebelde ni conformista, Austen es parte vital de esa «época fluida, de rápido y profundo cambio» que interesa sobremanera a Rest. Escribe su obra en un tiempo en que el crecimiento de «la economía capitalista influía de manera decisiva en la modernización de las técnicas agrícolas y en el avance del incipiente industrialismo urbano». Su obra encuentra sus propias condiciones de producción en un período en que profundas trasformaciones afectan «no sólo el volumen y la naturaleza de la producción sino también el ordenamiento moral y social del país» en un contexto histórico cercado por el ciclo de la Revolución Francesa y las guerras napoleónicas. Pero lo que interesa especialmente a Rest es el hecho de que la novelística de Austen se desarrolla en el momento de «consolidación del proceso que a lo largo del siglo XVIII había ido trasladando el poder dinámico a las clases medias» (1978b: 42). Son esas clases - cuyo ascendiente no se basaba en el tradicional usufructo de la propiedad heredada sino en la capacidad personal de trabajo»- las que hablan y son habladas en la superficie anecdótica de esos 
textos en los que las configuraciones épicas y carismáticas son reemplazadas por «criterios fundados en la valoración competitiva del individuo» $y$ «en el exclusivo reconocimiento de las cualidades y virtudes personales» (1978b: 42-43).

Con «inalterable lucidez»y «certera ironía», Austen evoca escenas de esa «existencia cotidiana» particular. Rest explica la eficacia de sus evocaciones apoyándose en una serie de categorías realistas que retoma de las investigaciones de René Wellek. Al considerar los caracteres generales de la obra de Austen, el teórico vienés señala que su narrativa pone de manifiesto una «indiscutible» objetividad, una escrupulosa evocación del ámbito descrito con suma verosimilitud le confiere un alto grado de historicidad y, finalmente, «sus personajes y situaciones tipifican la época, sin que la individualidad concreta del carácter y de la conducta sufra el más leve menoscabo» (1978b: 46). Su relación con la tradición novelística precedente se apoya -como apunta Ian Watt- en los «procedimientos introspectivos» de Samuel Richardson y el «método objetivo» de Henry Fielding; pero su objetivo último es ciertamente -como apunta Rest- el de «elaborar una forma enteramente nueva, centrada en una técnica eminentemente dramática y en el ordenamiento integral del relato en función de un personaje que sirve al novelista como "punto de vista"» (1978b: 47). Que F. R. Leavis le haya asignado el carácter de «fundadora» de la «gran tradición» de la novela inglesa -en la que se inscriben George Eliot, Henry James, Joseph Conrad y D. H. Lawrence-, no es un dato menor. Sus textos son «típicos productos del racionalismo y la mesura dieciochescos» 
aparecidos, «a destiempo, en pleno auge romántico, cuando la exuberancia, el pintoresquismo y el desborde sentimental creaban un tipo de receptividad poco propicia» (1978b: 49). Acaso por eso han recibido una particular atención de la crítica que insiste en señalar a su respecto ciertos puntos fundamentales que han contribuido notablemente al desarrollo de la narrativa realista posterior: 1) la idea de que su literatura permite corroborar que el período más fecundo para la novela inglesa fue el siglo XVIII -y no la época victoriana; 2) el hecho de que su elección de encuadre del punto de vista en un personaje protagónico «confiere mayor verosimilitud narrativa y una coherencia formal más acabada» -de algún modo desechando la técnica omnisciente y estableciendo una relación más firme de los elementos estructuradores del relato-; 3) el preciso modelado de sus personajes, que -por su depurada actitud irónica- «pueden aparecer como figuras cómicas sin caer en la simplificación grotesca, sin perder la riqueza de matices», le permite además no incurrir en tipologías reduccionistas y poco verosímiles; y 4) el acierto de producir un efecto de exclusión o de no intromisión del autor en el curso mismo del relato, empleando el punto de vista del protagonista y el diálogo como elemento central de la función narrativa. Es probable que -como apunta Rest- el crecimiento del interés por los aspectos estructurales de la novela haya derivado el interés de la crítica por la obra de Austen. Su contribución ha sido singular en varios aspectos. Sobre todo porque -como bien apunta el crítico-, acotada a aspectos aparentemente anecdóticos y cotidianos -sin duda menos 
pretenciosos que los de la acción épica embanderada por Defoe, Cervantes, Fielding o Smollett-, no sólo consiguió proyectar «una de las evocaciones más penetrantes de la comedia social que registra la historia de la novela» sino también ampliar y desarrollar el horizonte formal de la técnica narrativa realista.

"Thomas de Quincey, maestro de la prosa" resume un trabajo de 1958, publicado en la revista La Biblioteca. ${ }^{233}$ La recuperación de este texto escrito veinte años atrás de su reedición ratifica el interés de Rest por la magistral prosa ensayística del autor de Revolt of the Tartars (1837), pero también por la amalgama de temas fascinantes y siniestros que condensa en textos como Confessions of an English Opium Eater (1822) o Murder Considered as One of the Fine Arts (1827). Más allá de los rasgos particulares de la vida y la personalidad del autor -a las que Rest dedica varias páginas del artículo-, el acento está puesto en el brillo particular de esa prosa ensayística que se manifiesta «a través de una arquitectura de ritmos verbales que no sólo se interesa en la sonoridad de los términos sino que por añadidura entreteje las ideas mismas en una trama melódica». El «efecto de intemporalidad, quietud y fascinación» que su prosa alcanza en virtud a una melodía hipnótica es conseguida a partir de un procedimiento formal. A partir de una técnica específica, de Quincey consigue como bien explica Rest- sortear la «grandilocuencia» y la «apasionada elevación» que hacía de la prosa isabelina, a decir de

233 Rest, J., "Thomas de Quincey ante el magisterio de la prosa" (1958c), La Biblioteca, IX, 3, Buenos Aires. pp. 144-154. 
Virginia Woolf, una lengua apta para el tratamiento de temas abstractos como la Condición Humana, la Vida, la Muerte, el Amor y la Belleza, pero a la vez absolutamente incapaz de dar cuenta de los asuntos concretos y cotidianos de la existencia.

La historia acompaña una transformación en el propio modo de producción de la prosa. Diversas circunstancias sociales y culturales favorecen durante el siglo XVIII «el avance de tendencias que apuntaban hacia el predominio de una prosa sobria y objetiva» (1978b: 64). El escritor adquiere real conciencia del público al que se dirige su producción y del sentido social de su intervención: «el periodismo literario se difunde» y «la discursividad se torna imperiosa por exigencias de la actitud racionalista que gobierna las ciencias y la filosofía». De ese modo, «se robustece el carácter utilitario del lenguaje»y «se deshecha la elocuencia poética con el propósito de enfatizar la capacidad expositiva» (1978b: 65). Pero durante la primera mitad del siglo XIX, los románticos se imponen y la prosa inglesa vuelve a tornarse «caprichosa y subjetiva» puesto que se justifica en la inspiración de un hálito de imaginación desenfrenada y misterio. Contrariando ese contexto romántico, de Quincey y Lamb se vuelven a la prosa isabelina y la retórica del siglo XVII en busca de modelos para su propia experiencia literaria. A diferencia de Lamb -cuyo estilo es directo y personal, agudo y condensado sobre oraciones cortas-, Rest ve en de Quincey un estilo basado en el «flujo y reflujo», una sintaxis oscilatoria que «posterga el desenlace a través de digresiones y detalles» y cuyo efecto final es una suerte de «atmósfera de ensueño y de espera» que captura la aten- 
ción del lector en «una suerte de fascinación y se demora en la majestad o el espanto del instante» (1978b: 65). El crítico reconoce como una virtud el hecho de que esa prosa se suspenda o se pierda en digresiones justo antes de cerrar un argumento o enunciar una conclusión. Es el ejercicio singular de una prosa ensayística que se constituye como una de las bellas artes, en un rechazo de la mera función utilitaria y en una actitud que, al contrario de la prosa racionalista, no apunta a la exposición de un tema, sino a constituirse ella misma en una experiencia eminentemente creativa en términos estéticos. Despliega su procedimiento, no para describir hechos concretos, sino «para evocar ensueños, visiones, reminiscencias o para crear un efecto de creciente tensión» (1978b: 66) ${ }^{234}$ en una prosa que tampoco escatima pliegues de ironía mordaz y deliberado humor negro.

En la perspectiva restiana, es bajo la influencia de «la poética formalista de Coleridge» que la prosa de de Quincey llega a consolidar su particular e «intrincada artesanía». Bajo la óptica del poeta, «ese gran órgano social que colectivamente llamamos literatura» presenta dos funciones fundamentales en razón de las cuales da dos tipos de literatura diversos. La función pedagógica de enseñar se corresponde con una «Literatura de Conocimiento (Knowledge)»; mientras que de la que tiene por objeto conmover se obtiene una «Literatura de Intensidad (Power)». En el primer caso -escribe el poeta-, «la literatura se dirige al mero conocimiento discursivo; la segunda acaso se dirija en última instancia al más elevado entendimiento o razón pero a través de sentimientos de

234 Las cursivas son nuestras. 
placer o simpatía» (1978b: 68) ${ }^{235}$. Rest percibe en estas ideas -a las que, a su juicio, adhería implícitamente el propio de Quincey- «esa fuerza evocadora, esa capacidad de infundir "intensidad"» ${ }^{236}$ que es para el prosista inglés la propia idea de «estilo»: esa consistencia formal que «tiene un valor absoluto, totalmente distinto del valor del asunto en que es empleado y sin relación con el tema» (1978b: 69) ${ }^{237}$, esto es -continúa de Quincey-: «un producto del arte, el más raro, sutil e intelectual, y al igual que otras producciones de las bellas artes es tanto más perfecto cuanto más eminentemente desinteresado» (1978b: 70).

Rest acentúa con llamativas cursivas el carácter «absoluto» de ese valor formal. Reconoce que ese valor específico se enfatiza cuanto más conspicua es su resistencia a la demanda utilitaria del lenguaje, pero asume que, más de una vez, ese valor se sobrepone incluso a los «groseros usos palpables» a los que es sometida la prosa. Y subraya con especial rigor el hecho de que de Quincey no considere el estilo de la prosa ensayística como «un ropaje o indumento ajeno, sino que [en ella] el estilo se vuelve encarnación de los pensamientos» (1978b: 70). El estilo no es un decorado ni una cobertura de pensamientos preexistentes; es la carne misma del pensamiento en tanto define sus modulaciones, sus matices, su tensión; es decir, su «intensidad». Más aún: en el estilo de la prosa se inscribe algo del orden de la experiencia del pensar mismo. Teniendo en consideración estas conclusiones, Rest no duda en vincular esta experiencia de escritura -que «co-

\footnotetext{
235 Cursivas en el original.

236 La cursiva es nuestra.

237 Cursivas en el original.
} 
necta formas de pasión con ritmos»- con la noción de "forma orgánica" de Herbert Read, según la cual -como se ha explicitado en páginas precedentes- hay que considerar el proceso creativo «como prolongación de la natura naturans» (1978b: 70). Es así como la ensayística defendida por de Quincey permite a Rest pensar en la posibilidad de una experiencia singular, capaz de articular una sutil función pedagógica en el despliegue de una prosa elegante, creativa y plena de intensidad e imaginación, y capaz de incorporar -sin perder rigurosidad- la inflexión paradójica, el humor sutil y la filosa ironía; es decir: los cimientos mismos de su propia «ficción crítica».

Escrito entre 1976 y 1977, "La locura y el método" vuelve a retomar la problematización del lenguaje abordada en El laberinto del universo. Rest despliega su lectura de Lewis Carroll siguiendo la idea del propio Borges, quien no duda en afirmar que «nadie desconfió tanto del lenguaje» como Carroll al advertir que «descubrir un razonamiento no es lo mismo que percibir un objeto crítico» (Borges 1975: 110). En la perspectiva de Rest, la obra de Carroll, y en especial Alice in Wonderland, supone un doble cuestionamiento: en primer lugar, a las palabras -que «son la materia con que construimos nuestra imagen del universo»- y a la lógica «que supuestamente legisla la correcta organización de nuestros razonamientos», al punto que llega a ser considerada la herramienta fundamental para «estructurar una fiel interpretación de los mecanismos que gobiernan no sólo nuestras ideas sino también la realidad misma del mundo en que nos hallamos insertos» (1978b: 
82). Exhibe hasta qué punto Carroll, que sin dudas fue «un apasionado de la lógica», también era consciente de sus límites. A juicio de Rest, toda la obra del autor de Alice in Wonderland está compuesta desde la convicción de que «cuanto se dice está viciado de confusión y cuanto se logra rescatar de la ambigüedad está condenado a ser mero juego», esto es, «una simetría elaborada en el vacío» (1978b: 83-84). En ese sentido toman razón de ser las «humoradas» y el empleo de «la lógica de aspecto más estricto» en la confección de «razonamientos absurdos» que el autor expone -a juicio de un crítico como Henri Parisot- «como si disfrutase de un perverso regocijo en ridiculizar la ciencia que enseñaba» (Parisot 1952: 28). Su desconfianza no era respecto del lenguaje específicamente sino de sus relaciones naturalizadas con las cosas. En su opinión -escribe Rest-, «nada permitía suponer que la res extensa pueda ser sometida a los mismos principios que regulan la res cogitans» (1978b: 84-85). Que Carroll fuera capaz de adelantarse a la interpretación psicoanalítica de los procesos oníricos -considerando que el sueño es, en su propia lógica, «más coherente y significativo que muchos de los fenómenos, explicados - no, que tienen lugar en el mundo material» (1978b: 85)- no es raro. Carroll asume que hay encadenamientos significantes que exceden largamente los preceptos de la lógica. La «presunción de sentido» atraviesa los más disímiles enunciados, desde la proposición formal hasta los limericks de Edward Lear, desde la secuencia de la pesadilla hasta el ritual esquizofrénico.

Los juegos y las desautomatizaciones producidas por los equívocos nacidos de la ambigüedad lingüística o el desliz ocupan en 
esa obra «magistralmente paradójica» un lugar central. Ejemplifican su radical convicción en la perfidia del lenguaje, sobre todo al exhibir que «las palabras suelen seducirnos con valores traslaticios que logran extraviarnos» cosificando «seres inexistentes y nociones abstractas» (1978b: 89). Pero, como bien apunta Rest siguiendo a Roger $W$. Holmes, la obra de Carroll no se reduce a una mera crítica del lenguaje y de la lógica simbólica. Alice in Wonderland presenta un nudo de problemas que compromete en partes iguales a la lógica, la metafísica, la teoría del conocimiento y la ética. La de Carroll es una obra que pone en cuestionamiento los preceptos lógicos, los usos naturalizados de significantes y significados, las funciones de los nombres, las paradojas que el lenguaje crea en relación al tiempo y el espacio, la ficción de la identidad personal, la condición de la sustancia respecto de las cualidades, la relación entre intelección y corporalidad. En este sentido, constituye sin dudas un intenso desafío intelectual en tanto, dejando a un lado todo nihilismo simplista, es paradójicamente- una obra que se afirma en la creencia de que «todo tiene sentido», pese a que no siempre estemos en condiciones de captarlo.

El hecho de que sólo sea posible conocer «una constelación de apariencias» o «fantasmas» no va en desmedro del conocimiento en sí. Lo que hay que borrar es toda mirada ingenua, toda naturalización de la relación entre las palabras y las cosas. En ese punto, la lectura que Rest hace de Carroll se conecta con la realizada en torno a Borges. Lo que esas obras vienen a denunciar es un cerco infranqueable: si «la lógica es la correcta organización 
de las palabras que designan las cosas», no hay otro remedio que errar irremediablemente en la «prisión del lenguaje que sólo permite hablar acerca de las palabras». En cualquier caso, la «alienación» que estas obras denuncian desde la ironía, el absurdo y la paradoja no es «un hecho sociológico que se circunscribe a un determinado período histórico», sino más precisamente la que «se deriva del aislamiento ontológico que en todos los tiempos el hombre padeció en el instante mismo en que se propuso un lenguaje exacto e inequívoco para mentar la realidad» (1978b: 93). De ahí el carácter reflexivamente existencial de la ficción carrolliana que se despliega sobre un «tipo especial de absurdo: el que puede extraerse de nuestra presencia en el mundo». Como en la maquinaria kafkiana o en la ficción de Borges, en el texto de Carroll no se niega la existencia de un sistema capaz de dar orden al caos. Lo que se cuestiona es la vigencia y operatividad de aquel que se acepta como inexorable porque se halla naturalizado. Pero advierte Rest- Alice in Wonderland dispone además de la virtud que sustenta las interrogaciones brechtianas. Pone al lector ante una encrucijada interpretativa: confiar en que «la estricta adecuación de los principios lógicos que gobiernan el País de las Maravillas nos conduce al desatino» o rendirse al hecho de que «la disposición pragmática que prevalece en la realidad cotidiana nos precipita a un compromiso alienante» (1978b: 98). Es probable que -como apunta Rest- ninguna de ellas resulte amena, aunque sin duda la perspectiva más apocalíptica sea la que sostiene que ambas conclusiones son parejamente verdaderas, complementarias y fatalmente determinantes de nuestra propia concepción del mundo. 
"La nostalgia europea de Henry James", fechado en 1969, remite a una problemática -no siempre explícita pero sin dudas presente y constitutiva tanto de la matriz intelectual de la crítica argentina como de su propio proyecto-: la que se articula sobre el par conceptual «nacionalismo y cosmopolitismo». Rest se interesa en el autor de The Europeans sin duda porque «en ningún otro escritor de los Estados Unidos el descubrimiento de Europa engendró una producción de tal abundancia, calidad y hondura como en Henry James» (1978b: 105). Pero también -y sobre todo- porque, pese a su propensa inclinación por «las formas europeas de comportamiento», su actitud exhibe además «una considerable variedad de matices» sobre el tema. Rest recorre rigurosamente las narraciones de James que abordan la problemática y que -salvo excepciones como el relato "The Jolly Corner"- ponen de manifiesto, no sólo un pleno dominio de la cuestión sino también «un gran sentido crítico y un absoluto equilibrio en el análisis de los impulsos encontrados que origina el enfrentamiento de culturas» (1978b: 108). Subraya las «significativas coincidencias» de su perspectiva con la de Nathaniel Hawthorne en The Marble Faun y dedica largos pasajes de su ensayo a explicar y justificar su deseo de cortar lazos definitivamente con Estados Unidos e identificarse totalmente con Europa.

Rest realiza este rastreo considerando la figura del «retorno del peregrino» («Pilgrims' return»), tópico crítico elaborado por Willard Thorp para caracterizar a la literatura norteamericana del período 1850-1900. Sin embargo, la descripción restiana hace 
de James una suerte de «peregrino apasionado» cuyo itinerario poético despliega sobre el tema en cuestión -y en función de una formación simultánea «en las dos márgenes del Atlántico»- un abanico de matices, vericuetos y sorpresas que lo muestran ligado a una «forma íntima del cosmopolitismo -es decir, al desarraigoque nacía de su misma formación» (1978b: 119). Ve a James dirimirse entre «la aspiración de incorporarse a Europa sin retaceos» y la imposibilidad de despojarse por completo de «lo que tal vez sintió como su indeleble estigma americano» (1978b: 119-120). En este vaivén particular que remite a la condición identitaria se dirime -para Rest- el panorama general de la literatura norteamericana en la segunda mitad del siglo XIX y las dos primeras décadas del siglo Xx. Allí se encuentran -tensa y a veces antagónicamente-, por un lado, «la producción que podemos llamar nacionaIista porque busca una forma de expresión propia» (y donde podrían incluirse los poemarios de Walt Whitman y la épica narrativa que va desde Moby Dick hasta Huckleberry Finn); y, por otro, el «deslumbramiento» respecto de la cultura europea que se materializa en el cosmopolitismo, «como manera de alcanzar una elaboración poética acorde con las condiciones de una existencia más compleja tanto en sus relaciones sociales cuanto en sus fundamentos culturales» (1978b: 120-121). Rest percibe, en el primer caso, una suerte de simplificación excluyente y en el segundo una complejización inclusiva -que, pese a todo, corre el riesgo de mitificar idílicamente a Europa. Mark Twain y Henry James serían los dos autores -casi contemporáneos entre sí- que personifican esta polarización. Claramente, la simpatía de Rest se queda con 
el perfil tomado por el autor de The Ambassadors, a quien por ello no deja de criticar en razón de sus posiciones finales -su célebre «civis Britannicus sum», donde llega incluso a declarar su debilidad por «los elementos de elevada civilización, según se manifiestan en otras naciones y están ausentes en la textura de la vida americana» (1978b: 121). En rechazo de estas declaraciones snobs y en abierta oposición respecto de las «utópicas originalidades del nacionalismo», Rest reivindica enfáticamente la complejidad y el carácter inclusivo que el cosmopolitismo adquiere en las configuraciones literarias más importantes y aun las postreras o inconclusas como the Ivory tower o The Sense of the Past.

"Henry James y sus ideas sobre la novela", fechado en 1976, está en plena consonancia con "Virginia Woolf y la función de la crítica", un artículo que resume las conclusiones fundamentales de la tesis de licenciatura de Rest defendida a fines de 1952. Esa consonancia es una prueba de coherencia en lo que refiere al estudio de la relación entre crítica y ficción en el marco del proyecto restiano. Rest lee en James lo que lee en Woolf: la intención de reflexionar sobre las condiciones y posibilidades de su propia práctica en la articulación de literatura y experiencia. Eleva este sentido de la inquietud a un valor específico y apunta que la contribución de Henry James al estudio de la novela presumiblemente tenga un valor análogo a la de T. S. Eliot en el campo de la poesía. Es que -a su juicio- el novelista traza una relación directa entre el valor de las producciones artísticas y 
el horizonte de reflexión en que se inscribe, dando a entender que existe «una íntima conexión entre la capacidad poética y la perspicacia crítica». Y lo hace señalando especialmente que «la desarticulación de ambas tareas -la falta de reflexión crítica en la actividad poética- desemboca en una obra exenta de convicción» (1978b: 126) .

James percibe una «crisis en la novela» que no vacila en ligar a la inminente ruptura de esta relación. De ella se desprenden tanto las concepciones simplificadas de la relación entre ficción y realidad como la intrascendencia de una crítica incompetente. A su juicio, el vínculo de la ficción con la realidad debe interpretarse de acuerdo a una «tesitura dialéctica», según la cual la imaginación literaria se nutre de la "realidad" pero el «proceso de composición»-que se desencadena luego- se inscribe siempre en una «labor autónoma», como una cuestión de ejecución literaria. Es por eso que lo que desdibuja los alcances precisos de la literatura es la falta de coherencia y articulación entre «la diligencia productiva y la actividad crítica» (1978b: 127). Cuando esa articulación no se produce la literatura pierde eficacia atenazada por los prejuicios (de la realidad) y las cristalizaciones (de la ejecución poética). Rest subraya que «en su labor específica, la actividad creadora apunta -en palabras de James- a instaurar "un sistema, una doctrina, una forma"» (1978b: 130). Su intención es enfatizar la «importancia funcional» de la forma y el perjuicio de toda poética aferrada a «normas rígidas» $y$ «preceptos abstractos». 
Del mismo modo, los límites de la comprensión crítica derivan de cierta «proclividad de los comentaristas a disimular sus propias deficiencias metodológicas con el auxilio de una máscara de inflexibilidad y dogmatismo» (1978b: 131). Rest plantea aquí con la concurrencia de James una crítica liberal a las formas dogmatizadas de la enunciación crítica que, sin someter su propio dispositivo a los riesgos de la lectura, califican y descalifican las producciones literarias en un ademán que sólo tiende a ratificar sus prejuicios y posiciones previas. Su perspectiva particular parece en cambio afirmarse sobre la clásica recomendación de Aristóteles en la Poética, retomada por James en "The Art of Fiction". Siguiendo el apunte del novelista, Rest no duda en sostener que «para juzgar con equidad una obra de arte es indispensable desechar las normas establecidas de antemano y concentrarse en el reconocimiento y la descripción del objeto considerado» (1978b: 131). Se trata pues de una suerte de "lectura literal" que con ciertos recaudos y siguiendo a Nicolás Rosa bien podría aproximarse a algunas apreciaciones althusserianas-; es decir, una lectura que presupone una relación de similitud entre el sistema de producción de la escritura y el de la producción del sentido, como si el texto literario fuera de por sí capaz de decir sus propios sistemas de determinaciones y la lógica de su cifra y de dar ella misma, por lo tanto, la clave para su propio desciframiento. ${ }^{238}$

238 Cfr. Rosa, N., La lengua del ausente, Buenos Aires, Biblos, 1997. pp. $79-80$. 
Por otra parte, Rest no duda tampoco en afirmar que lo más notable del pensamiento crítico de James radica precisamente en «la fuerza con que rechaza los preceptos dogmáticos» y en la conciencia liberal con que condena la «rigidez normativa». Pero su evaluación no queda aquí. Rest señala además el valor específico de un "realismo" como el de James -que no se constriñe a los efectos del verismo y la denuncia social-, sino que se aplica a un trabajo formal riguroso que da lugar a «relatos concebidos con un grado casi obsesivo de refinamiento y alusión». Subraya en este sentido especialmente el recurso a una poética alusiva e indirecta que -como la de los pintores impresionistas contemporáneosse afirma en la convicción de que «la realidad no está en las cosas sino que es una imagen que se integra en la conciencia del observador» (1978b: 133). Si el arte del novelista radica en «captar las cualidades visuales de la experiencia», la instauración artística del «mundo imaginario» de la novela se articula pues sobre tres pasos: 1) experiencia para realizar «acopio del caudal más amplio, directo y minucioso de elementos que constituyen la "realidad" del mundo»; 2) libertad para «seleccionar y ordenar la imagen, pero sin incurrir en falsedades y artificios»; y 3) la decisión de componer una articulación poética de la imagen «como un sistema, como un ordenamiento completo, articulado y coherente». Estos tres pasos confirman los términos de una concepción poética rigurosa y políticamente liberal que -como apunta James- se condice con «una comunidad predispuesta a la reflexión y apegada a las ideas». Esa comunidad imaginada puede ensayar genuinos y enriquecedores «experimentos con el "relato" que perma- 
necerán ignorados en comunidades principalmente entregadas a viajar y cazar, promover el comercio y a jugar al fútbol» (1978b: 135). Estas últimas líneas, publicadas en 1978, aluden sin dudas a un contexto de totalitarismo político que implantaba el liberalismo económico a costa de represión autoritaria y demagogia populista en el plano de la propaganda política del propio régimen que superponía su imaginario reaccionario al de la épica deportiva. En ese contexto el Estado represor instaurado a partir del golpe de 1976 se había desdoblado visiblemente en una parte clandestina y terrorista que practicó una represión sistemática sin responsables, eximida de responder a los reclamos; y una parte pública, apoyada en un orden jurídico reaccionario e impuesto facciosamente a la sociedad y que silenciaba cualquier otra voz que no fuera la voz de mando. Como bien apunta Romero, en ese período no sólo se eliminaron todas las esferas institucionales de la Republica, sino que además «fueron clausuradas autoritariamente la confrontación pública de opiniones y su misma expresión». La actividad política y gremial fue disuelta so pena de encarcelamiento, los medios de prensa fueron sometidos a la censura explícita (lo que impedía cualquier mención al terrorismo estatal y sus víctimas) y todo el arco de la producción estética fue sometida a vigilancia estricta y censuras. Con un enemigo imaginario y de límites borrosos todo el mundo era sospechoso o susceptible de sospechas por parte de un aparato represivo que, a la supuesta amenaza de la «subversión apátrida» -lejos de plantear «una alternativa jurídica y consensual, propia de un Estado republicano y de una sociedad democrática»-, opuso un orden de aniquilamiento 
que era en efecto una imagen hipertrofiada de la ecuación violenta y autoritaria que fingía combatir. El terror que cubría la sociedad civil fue tal que el discurso estatal pregnaba en la vida cotidiana hasta traducirse en autocontrol, autocensura y autovigilancia, en la misma medida que la demagogia patriotera buscaba despertar la adhesión y el entusiasmo de la sociedad aterrorizada, ya por el fogoneo mediático de la «gesta épica» del Campeonato Mundial de Fútbol de 1978 -que Argentina ganó y en cuyos fáusticos festejos fue presentado por la propia voz de mando de la Junta Militar directamente como una «victoria nacional»- como por la agitación de un «turbio sentimiento chauvinista» que, ese mismo año, casi desemboca en un conflicto bélico con chile. ${ }^{239}$

En ese contexto, las afirmaciones de Rest toman un matiz sutil pero alusivamente crítico y se suman a la inclusión de cuatro ensayos que sucesivamente reintroducen los «temas góticos» como la amenaza del Mal, el Terror, la Muerte, la delincuencia y las desapariciones inexplicables y las historias de "muertos vivos" a través de literaturas menores, poco prestigiadas, populares o de consumo masivo. Son textos de "presentación" que Rest incorpora a partir de su trabajo como director de colecciones en el sello editorial de Librerías Fausto. Al igual que lo había hecho en Tres autores prohibidos, sólo que más sutilmente (porque Rest ya cuenta con que el volumen publicado por Galerna en 1968 ha sido paradójicamente prohibido), el crítico aprovecha inteligentemente el desvío de esos textos "introductorios" para traficar un número

${ }^{239}$ Cfr. Romero 2001: 207-211. 
importante de alusiones con relación al oscuro contexto sociopolítico.

El primero de ellos, fechado en 1972, es su "Presentación del conde Drácula, vampiro". En él Rest se propone una descripción general del «arquetipo del vampiro» a partir de la obra original de Bram stoker. Busca deshacer la mitificación de un personaje que ha sido «incorporado a nuestro caudal de experiencias» a partir de una serie de factores sociales, entre los que cabe destacar su origen literario y popular -aun perteneciendo a un género «tácitamente incluido en una presunta categoría de subliteratura deleznable» (1978b: 140). En una decena de páginas eruditas y formales, repasa la historia maldita de ese personaje -que «no es un ser viviente, pero tampoco ha ingresado en el mundo de los muertos»y al que «en inglés suele denominárselo undead» (1978b: 142)- ninguneado por la crítica literaria culta, perseguido por los moralistas y los religiosos e interrogado sólo por psicoanalistas, historiadores de las religiones, estudiosos de las supersticiones la teosofía y el ocultismo.

Señala además que el célebre vampiro es el epígono más visible de una larga tradición popular cuyo momento de mayor auge coincide con el advenimiento de la novela "gótica" inglesa. Siguiendo las eruditas investigaciones de Mario Praz y Wilhelm Worringer, Rest compone una constelación de autores que incluye a Cazotte, Beckford y el "Monje" Lewis, pero también a Byron, Polidori, Maturin, Merimée, Nodier, Goethe y Poe. Señala las íntimas relaciones de la producción de Stoker, aparecida en 1897, con algunos de sus precursores, como el voluminoso Varney the Vampire 
(1847) de Preskett Prest, la fábula de Carmilla de Sheridan Le Fanú incluida en In a Glass Darky (1872), Strange Case of Dr. Jekyll and Mr. Hyde (1886) de Robert Stevenson, The Picture of Dorian Gray (1890) de Oscar Wilde y The turn of the Screw (1898) de Henry James. Y subraya especialmente la reciente recuperación por parte de la crítica francesa -Pierre Macherey, Michel Butor y Jean Chesneaux entre otros- de autores y obras considerados "marginales" y habitualmente "arrinconados fuera del perímetro de la dignidad poética» bajo el rótulo de good bad art.

Pero su "presentación" -que se detiene correctamente en la descripción estructural del «diseño novelesco» y en los recursos narrativos de «efectos folletinescos» (de tensión y postergación) que ligan la trama- se aboca especialmente a subrayar el efecto de fascinación que ejerce el personaje central de la narración en los sectores populares, en lo que sería «una contravención evidente» de las «pautas morales de la sociedad». Rest apunta además la gradual carga de erotismo que se ha ido adosando al personaje de la fábula original (que guardaba el recato propio de su época de aparición) y la creciente disposición al triunfo del mal en las versiones posteriores. Tras examinar las interpretaciones psicoanalíticas que «inducen a suponer la existencia de un trasfondo sadomasoquista, que permanece oculto tras una elaborada simbología de aspecto inocuo», busca explicar la fascinación popular por esas figuras demoníacas a partir de una «pugna entre atracción y repulsión». Esos impulsos contradictorios no son casuales ni novedosos en la compleja configuración de la cultura de masas, forjada fundamentalmente en una suerte de tensión entre 
emotividad y racionalidad. Rest sostiene pues que tal fascinación se corresponde con la propia condición de una sociedad que, bajo una «fachada de conformismo y respetabilidad morales», guarda «un profundo desasosiego» producto del cual se pierde en «un estado crónico de agresividad y alienación solapadas» (1978b: 152). En el reemplazo del héroe positivo tradicional por una «suerte de antihéroe siniestro» (como Drácula o Jack el Destripador) se explica pues -en la perspectiva de Rest- la asfixia de «un clima de moralismo exterior [superficial] e intolerante» que es capaz de desatar «un complejo juego entre el rigor manifiesto de las normas sociales y la efervescencia subterránea de las represiones» (1978b: 154). La alusión sutil de estas conclusiones al contexto represivo y a la vez moralista -impuesto de manera autoritaria por el golpe militar sobre la sociedad civil- se vuelve tangible. Más aún, y como si la alusión no fuera suficientemente clara, Rest cierra su "presentación" con una referencia a The Supernatural in Fiction de Peter Pensoldt y apunta un fragmento que sólo una mirada ingenua podría estimar como anodino, puesto que constituye la clave de lectura del propio ensayo y sus condiciones producción y existencia: «el ingrediente fabuloso a menudo sirvió de vehículo -consciente o inconsciente- para declarar en forma velada experiencias o situaciones que los escritores difícilmente se hubieran atrevido a mentar en forma directa» (1978b: 154-155). Una vez más, la crítica restiana se reconoce en la táctica política del escribir entre líneas, es decir, en el desarrollo de esa «peculiar técnica de escritura» alusiva con la que -a juicio de Leo Strauss-, en un contexto de autoritarismo, opresión y perse- 
cución, «un hombre de pensamiento independiente puede emitir sus opiniones en público y permanecer indemne, siempre y cuando se mueva con circunspección» al traficar en sus escritos «la virulencia de la verdad heterodoxa» (Strauss 1988: 21) ${ }^{240}$.

"El doctor James y sus fantasmas", fechado en 1977, apareció originalmente como prólogo a El enigma de las runas y otros cuentos de fantasmas de M. R. James. ${ }^{241}$ En él Rest presenta al prestigioso y erudito anticuario y a su excepcional arte narrativo: la ghost story. Señala sus orígenes y parentesco con narraciones góticas como The Monk de Matthew Lewis y The Mysteries of Udolpho de Ann Radcliffe, y desarrolla -siguiendo en algunos puntos las especulaciones del teórico alemán Wilhelm Worringerun- un minucioso contrapunto entre la producción del doctor James y la de Sheridan Le Fanú. Y marca sus diferencias específicas respecto de las fábulas medievales y los cuentos de hadas donde los elementos explícitamente sobrenaturales están presentados como «hechos normales, autónomos y universalmente asentidos» (1978b: 159).

Sin escatimar énfasis, subraya que las narraciones del doctor James dejan lo sobrenatural «sumido en la penumbra de lo desconocido e incierto» y confieren verosimilitud a la existencia de lo atroz «integrándolo de manera casi furtiva en el acontecer cotidiano» (1978b: 160). Son relatos que trabajan sobre la tensión ambivalente de emotividad y racionalidad presente en el lector, pero sin resolverse ni por la explicación científica o racional ni por la confirmación atávica. La maquinaria alusiva de Rest se

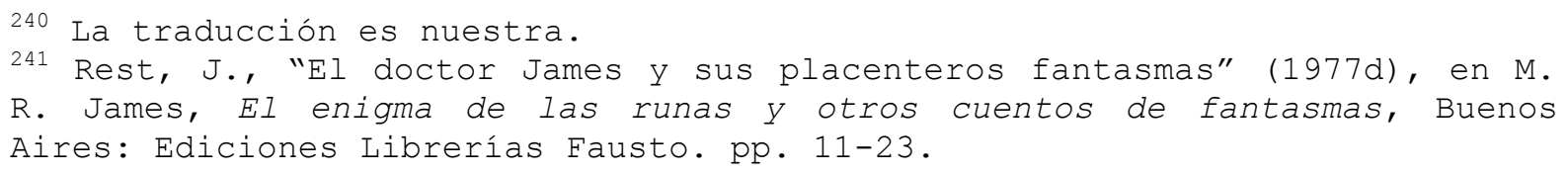
Aires: Ediciones Librerías Fausto. pp. 11-23. 
pone en marcha a partir de la insistencia en que el valor de las narraciones de M. R. James radica en el hecho de descubrir la presencia de lo siniestro «integrado en la vida de todos los días: en calles semejantes a las que recorremos, en parajes análogos a los que conocemos, en domicilios parecidos a los que habitamos» (1978b: 161). La idea de que una fuerza oscura amenaza la consistencia misma de nuestra vida cotidiana produce «un influjo perturbador», «un terror que muchas veces paraliza», sobre todo cuando lo que se generaliza es la idea de que el hombre moderno, «curioso e imprudente», «a menudo paga con su propia vida la insolencia de sus irreflexivos conjuros» (1978b: 161). Las ghost stories -apunta Rest- ponen al lector ante la evidencia de una muerte muchas veces violenta, siniestra e inexplicada y de algún modo permiten al lector conservar la certidumbre o la ilusión de que existe un mundo mucho más ambiguo, amenazante y escurridizo que el «sugerido por el tedio de las obligaciones de cada jornada» (1978b: 163). Advierte que, ni siquiera en el día que se recorta sobre el círculo de la inocencia que va "de la casa al trabajo y del trabajo a la casa", se está por completo libre de la amenaza. Lo atroz e inexplicable se revelará latente y siempre próximo, «cerca de nuestra vida cotidiana, pero no a tal punto como para que la falta de distanciamiento le reste verosimilitud» (1978b: 164). Las «anécdotas que se sustentan en la pura fascinación que engendra en el lector el episodio escalofriante» lo devuelven a una situación de angustia y alienación en la cual «ni siquiera hay una descripción minuciosa del agente que causa el terror en quienes participan de los hechos» (1978b: 167). Final- 
mente, y siguiendo la lógica alusiva, Rest apunta que la singularidad de las representaciones ofrecidas en las narraciones del doctor James radica en su carácter enigmático y absoluto. En la trama de estas historias -escribe el crítico ya en el cierre del artículo- «lo atroz invade nuestro universo cotidiano sin dejar la menor oportunidad para la elucidación apaciguadora»; en ese hecho se afirma la vigencia de lo siniestro y «su naturaleza aterradora» (1978b: 168) .

"La vocación del caballero Raffles", fechado en 1976, constituye originalmente la introducción que Rest preparó para la edición de las Siete aventuras de Raffles de Ernest William Hornung, editada por Librerías Fausto ese mismo año. ${ }^{242}$ En él Rest da cuenta de las condiciones de producción y recepción de Raffles, the Amateur Cracksman (1899), el volumen que reúne las aventuras delictivas de A. J. Raffles, el personaje concebido por el cuñado de Arthur Conan Doyle como el doble oscuro de Sherlock Holmes. Su lectura se desdobla fundamentalmente sobre dos ejes: por un lado, ubica el texto en «el contexto esteticista de su época»y, por otro, desarrolla su «indagación en términos sociológicos» (1978b: 184) .

Al señalar los vínculos entre la producción literaria de Hornung y el esteticismo, Rest tiene en cuenta diversos aspectos, que van desde la imagen de su autor como un «típico representante» de los naughty nineties - «la década en que la moda impuso el tono de corrosiva agudeza difundido por las comedias de Oscar

242 Rest, J., "Introducción" (1976d), en Hornung, E. W., Siete aventuras de Raffles. Buenos Aires: Ediciones Librerías Fausto. 
Wilde, juntamente con el culto del "arte por el arte" y el pregón de veleidades nebulosamente socialistas» (1978b: 177)- al cultivado cinismo, al «hedonismo y el culto por la perversidad» señalado por la historiadora gala Madeleine Cazamian en Le roman et les idées en Angleterre. ${ }^{243}$ Señala sus vínculos con las literaturas de Arthur Machen, Robert Louis Stevenson y Thomas de Quincey. En relación a este último podría decirse que el libro de Hornung es una suerte de ensayo narrativo sobre el robo considerado como una de las bellas artes, puesto que su objetivo es «separar la conducta moralmente reprochable de la evaluación puramente estética que merece un acto cuya perpetración se destaca por la euritmia, por un armonioso equilibrio de sus partes constitutivas». Rest enfatiza el valor de una reivindicación «en el plano de la imaginación, como puro juego, como resultado de un "impulso absolutamente desinteresado", según lo declara el propio héroe» (1978b: 186) .

Siguiendo la intuición de Mario Praz en La carne, la morte e il diavolo nella litteratura romantica, percibe en esta obra particular la presencia residual de mal du siècle, de «bayronismo y decadentismo», de «disposición satánica y bizantina»; rasgos que comparte con el caballero des Esseintes de A rebours de JorisKarl Huysmans y con Dorian Gray y lord Wotton de la célebre obra de Oscar Wilde. Pero eso no es todo. El refinamiento, la morbidez y el dandismo que caracterizan a su personaje principal, coinciden con la agudeza y mordacidad de los héroes del esteticismo. Y

243 Cazamian, M., Le roman et les idées en Angleterre, Paris, Les Belles Lettres, 1935. pp. 42-48. 
el clima de las andanzas es también -como el de las más célebres producciones del decadentismo- la noche: en ella se desarrolla la "doble vida" de ese simpático truhan que ha sido dado por muerto y que, como los personajes más celebrados del folletín, desarrolla su pícara gesta delictiva operando en la clandestinidad.

La segunda perspectiva -que en cierta medida invita a Rest a considerar el texto de Hornung como «un documento de una época» que coincide con «el apogeo del imperialismo británico y el punto de partida de un enfoque crítico y corrosivo de la política expansionista» (1978b: 190)- es la desplegada por George Orwell en el ensayo "Raffles and Miss Blandish" aparecido en Critical Essays de 1946 (traducido por sur en 1948) ${ }^{244}$. Rest sigue al polémico autor de 1984 y afirma que Raffles y Bunny -los dos personajes centrales de la ficción de Hornung- «son dos parias de la alta clase media que han perdido los privilegios de casta en razón de su inconducta»y, por ende, esa «buena sociedad»-sostenida en la apariencia de ser- no los acepta «como sus iguales, sino meramente como integrantes de un sector periférico que es admisible sólo en virtud de una excelente educación y ciertos méritos [culturalmente] relevantes» (1978b: 182).

El delito -dice Rest- es gratuito sólo en apariencia. Lo que lo motiva es «la falta de medios para mantener un nivel social» perdido. Los personajes asumen el riesgo de llevar adelante «una actividad ilegal practicada en la clandestinidad» como «única alternativa posible al ostracismo». La contradicción que Orwell no-

244 Orwell, G., Critical Essays, London, Secker \& Warburg, 1946 (Ensayos críticos, Buenos Aires, Sur, 1948. pp. 192-211). 
ta en esta actitud aparece descrita por Rest en su evidente ambigüedad, al punto que puede ser leída tanto como un modo de alienación o como un revanchismo irónico: los personajes, excluidos de su clase social, respetan los códigos de esa misma clase en su deliberada transgresión: «el robo se tiene que ejercer con la misma distinción con que se participa en la cacería del zorro o en una competencia de tenis» (1978b: 183).

Sin abandonar las argumentaciones de Orwell, Rest señala en esta particular situación los términos de «una curiosa dialéctica». Las frecuentes observaciones circunstanciales acerca del desajuste constitutivo de la sociedad, las duras críticas al arte y la literatura burguesa, y las corrosivas opiniones «sobre la sociedad y la distribución de la riqueza», no consiguen -en su óptica- romper por completo la cristalización ideológica del bon vivant ni llevar a término una crítica radical «del establishment, del orden constituido». Como resultado, el personaje no está en guerra con los fundamentos de la clase que se justifica en la ostentación de la propiedad privada. No busca «cuestionar el sistema sino obtener dentro de él los beneficios que es posible conseguir». En ese punto -como bien dice Orwell- Raffles no difiere de Julien Sorel en Le rouge et le noir, la novela de Stendhal, puesto que «ambos entran en contradicción porque aceptan las reglas del juego y las metas que les propone el contexto social» (1978b: 184). Raffles respeta la hospitalidad de esa clase que lo margina, «no roba a sus anfitriones», «respeta la amistad» y «excluye hasta donde puede el empleo de la violencia». Pero lo más significativo en la perspectiva de Rest son el chauvinismo 
que exhibe el personaje central de la zaga -sólo comparable al de «su contemporáneo Rudyard Kipling, considerado "el poeta del imperio"»- y el carácter xenófobo que se desprende de algunas de las narraciones, donde se ridiculiza a adversarios que «suelen ser marinos alemanes, condes italianos, contrabandistas sudafricanos de diamantes o australianos que se han enriquecido con la especulación territorial» (1978b: 184-185). Desde la perspectiva cosmopolita y el liberalismo tolerante de Rest, estos gestos resultan inadmisibles y contradicen diametralmente la perspectiva crítica del sistema social que en apariencia parece esbozar el personaje de sus aventuras. Y el hecho de que -en el último cuento- Hornung dé a su personaje una muerte heroica, en batalla, y que -«según los preceptos de la buena sociedad»- ese fin conjure su accionar previo y lo rehabilite por completo de su conducta poco respetable, resulta suficiente para que Rest evalúe la producción de Honung como «un pícaro ejercicio de inversión lúdica», satírica -respecto del modelo detectivesco planteado por Conan Doyle-, pero finalmente «conformista» respecto del orden social que -a primera vista- parece venir a criticar.

La lectura que Rest ensaya de las utopías científicas y las ficciones anticipatorias modernas en "Zamiatin y sus herederos ingleses" se despliega sobre los mismos tópicos ideológicos del liberalismo progresista. En su contextualización de la obra ficcional de Ieugueni Zamiatin, no escatima críticas a la rigurosidad dogmática y a la ortodoxia ideológica con que el régimen soviético limita las posibilidades de la imaginación literaria. Que 
Zamiatin sea leído por estudiosos de todo el mundo mientras Nosotros (1920), su obra más representativa, permaneciera inédita durante muchos años en Rusia - a causa de la censura impuesta por el régimen- es, para Rest, un dato irrecusable de «la política represiva sobre la que se sustentaba la permanencia del régimen comunista» (1978b: 197). La ubicación de Nosotros en una línea literaria de ficción científica con un cariz de "utopismo pesimista" permite explicar -aunque no justificar- la censura impuesta sobre ese autor a quien Marc Slonim imaginaba como "el James Joyce ruso" y a quien formalistas de la talla de un Viktor Vinogradov y un Boris Eijenbaum consideraban uno de los narradores más diestros en la técnica del skaz. La lectura de Rest -que está prácticamente centrada en el examen de Nosotros- no se priva de señalar la forma en que Zamiatin procuró responder a la persecución estatal ensayando críticas puntuales y dejando en evidencia su oposición cada vez más radicalizada al régimen: subraya la alusión crítica de Los fuegos de Santo Domingo (1923) en que «la Inquisición española en tiempos de Felipe II era apenas una tenue máscara para denunciar la política represiva del régimen comunista», o textos como Una historia acerca de lo más importante (1923) o Equis (1927) donde «la complejidad artística es instrumentada para mostrar el anquilosamiento y deterioro de la revolución cuya causa había defendido inicialmente» (1978b: 197) .

Atraído por el arte cubista y por la revolución que en el terreno de la física producía la "teoría de la relatividad", Zamiatin no dejó por ello de criticar a las configuraciones sociales que la revolución rusa había añorado derrumbar. Sus sátiras cri- 
tican con mordacidad tanto la sociedad capitalista occidental como las costumbres culturales forjadas en ese contexto -una prueba de ello -apunta Rest- es la sátira Los isleños, donde traza «un cuadro perspicaz de las costumbres británicas dominadas todavía por el orden y la respetabilidad victorianos» (1978b: 196). Sin duda deudora de la línea satírica abierta por El capote y los cuentos ucranianos de Gógol, su literatura se afirmaba pues en el valor del significante para producir variables significativas y daba a la estructuración del relato una importancia capital, lo que lo acercaba al grupo de escritores rusos de inclinación vanguardista a los que León Trotski no dudaba en considerar "compañeros de ruta". En razón de esa resistencia al doblegamiento ideológico y de esa convicción en la potencia específica de la literatura es que Rest transforma a Zamiatin -y en especial a Nosotros- en un antecedente clave para pensar el desarrollo y la función política de las modernas ficciones de anticipación.

Tras un relevamiento minucioso y erudito del material crítico dedicado a la obra de Zamiatin, Rest se detiene en la fascinación que el autor de Nosotros sentía por las ficciones científicas de H. G. Wells. Subraya -con especial interés- el hecho de que las ficciones del inglés trabajasen sobre «el carácter dinámico que debe mantener todo proceso revolucionario» si es que quiere ser fiel a sus propios fundamentos. El hecho de que Wells fuera reticente a idealizar «el armónico funcionalismo de los sistemas perfectamente equitativos» y que, más bien, exhibiera cierto «resquemor o desconfianza con respecto a la eficacia de los "ordenamientos definitivos"», le permitía pensar las condiciones de po- 
sibilidad de su propia literatura sobre la base de dos axiomas no negociables: «1) la necesidad de transformar el mundo por obra de un ciclo revolucionario» y 2) la convicción de que esa revolución en marcha no podía ser otra cosa que «una continuidad renovadora, "una permanencia del cambio"» (1978b: 203). Como bien afirma Rest, a diferencia de Wells, Zamiatin se enfrentaba al fracaso de la utopía posrevolucionaria y comprobaba en carne propia la decepción: «la rueda del cambio daba una sola vuelta y luego era detenida por quienes la impulsaron; no se le permitía seguir girando por propio impulso» (1978b: 204). Y se enfrentaba además a un punto no del todo evaluado en las utopías del escritor inglés: también «el progreso tecnológico podía transformarse en cómplice de las tiranías» (1978b: 204). Es por eso que Nosotros evoca un mundo futuro en que la población es reducida al número y la uniformación y normalización condicionada a una vigilancia extrema aniquila «el derecho a la vida privada, al amor, a la decisión personal» en favor de «un orden de felicidad colectiva» impuesto autoritariamente por un gobierno que considera «delito añorar la vida natural, con su margen de imprevisión y desorden pero también con su irrestricto caudal de libertad» (1978b: 205). Rest toma estos pasajes para establecer una crítica radical al autoritarismo que de alguna manera evoca también las condiciones en que aparece Mundos de la imaginación (1978): en ese mundo en que se practica la "extirpación quirúrgica de la fantasía", hay todavía «la secreta esperanza» de que aún subsistan -en una existencia clandestina capaz de tomar las formas de la revuelta- «seres disconformes», «hombres libres e imaginativos» sobre los cuales es 
posible «soñar un futuro más allá de los condicionamientos» (1978b: 205) .

Al señalar los principales sucesores ingleses de Nosotros como modelo de ficción anticipatoria, Rest reconoce en primer término a Brave New World (1932) de Aldous Huxley, quien a lo largo de su vida -y en trabajos como Science, Liberty and Peace y Ape and Essence- no deja de denunciar que «el progreso tecnológico robustece el autoritarismo y priva al individuo de toda posibilidad de defenderse en un pie de igualdad, cuando su albedrío se ve amenazado por el Estado-agresor» (1978b: 206). En el contrapunto con la novela de Zamiatin, Rest subraya que Huxley «le teme al desarrollo científico y en sus críticas asume la desesperación propia de un humanismo tradicionalista que rechaza de plano la idea de cambio», mientras que el precursor ruso considera el desarrollo técnico de manera más progresista, como parte de «un proceso abierto» e irreversible en términos reales. El segundo de los sucesores de Zamiatin reconocidos por Rest es George Orwell quien, en adhesión a un pensamiento libertario, reivindica a Nosotros por su tematización de «un problema fundamental de la sociedad contemporánea: el estrangulamiento de las decisiones personales» (1978b: 207). Más sagaz que Huxley, Orwell no centra sus cuestionamientos en el progreso científico y tecnológico en sí ni en el cambio social, sino más bien en «el mito de la eficiencia tecnocrática que iba a en camino de menoscabar el albedrío, como herramienta ideológica del totalitarismo» (1978b: 207). La afinidad entre 1984 y Nosotros se puede establecer -según afirma Restsobre dos aspectos esenciales: «el valor que reconoce a las opi- 
niones y decisiones individuales y la importancia que otorga a la conducta amatoria independiente». Pero Orwell suma además un aspecto crítico que Rest considera fundamental -en razón de su actualidad y vigencia-: «el papel que juega la tergiversación del lenguaje como arma de sojuzgamiento». Para Orwell -observa Restla amenaza mayor que debe afrontar el mundo moderno radica caer en el equívoco de confiarse ingenuamente al discurso que busca hacer creer que «la promocionada felicidad de un comunitarismo vertical es equiparable a la realización plena de cada cual» (1978b: 208). Las utopías de A Clockwork Orange (1962) de Antony Burgess como Lord of the Flies (1954) de William Golding radicalizan su pesimismo al percibir una suerte de círculo vicioso muy difícil de romper: «el fenómeno ya está presente en el mundo actual», lo que queda es «evitar que los intentos de restaurar el orden caigan en los mismos procedimientos compulsivos que se tratan de corregir» (1978b: 208-209). Rest parece articular la impronta cristiana implícita en la utopía burgessiana con la mesura y la tolerancia -en cierta medida voluntarista- de su liberalismo progresista al señalar que «de nada sirve utilizar la fuerza para imponer que se haga el bien por temor al castigo»; al contrario, a su juicio, «la única salida consiste en crear una sociedad en la que cada cual se sienta dispuesto a elegir el bien» (1978b: 209). En su conclusión, Rest vacila en ratificar el riesgo implícito en las posiciones unilaterales y antiprogresistas que exhiben un alto grado de «inadaptación al cambio social y técnico», pero confirma también su inclinación antiautoritaria -en consonancia con la tesis de Burgess, para quien «el orden no puede ser 
infligido; sólo admite que se lo asuma voluntariamente» (1978b: 210). En tal colocación se percibe claramente su tolerancia pero también su propia elección en la encrucijada de las dos modulaciones de perspectiva descritas por Raymond Williams en Culture and Society: una fundada en el ideal de servicio-que parte de la idea tradicional, individualista y vertical, de jerarquía, autoridad y subordinación- y otra, en la que sin dudas cabe inscribir a Rest, apoyada en el ideal de solidaridad -sostenida sobre un paradigma horizontal de reciprocidad y responsabilidad mutua y activa, que concibe a la comunidad como un espacio abierto a «un proceso democrático pleno» (Williams 2001: 268-275).

Luego de dos sobrios trabajos dedicados a las narraciones tempranas de Adolfo Bioy Casares (1978b: 263-271) y al proyecto patafísico de Boris Vian (1978b: 273-297) aparece un animoso, extenso y meticuloso ensayo sobre el desarrollo de género policial en el que vale la pena detenerse. "Crímenes de biblioteca" (1978b: 299-325), fechado en 1975 y concebido como una deliberada reivindicación de ese género marginado como «literatura de consumo», retoma algunas de sus investigaciones anteriores -como "Diagnóstico de la novela policial" (1974a) y "Alcances literarios de una dicotomía cultural contemporánea" (1965b), entre otros- y describe el origen, desarrollo y diversificación de las sucesivas modalidades asumidas por el género, desde la escuela francesa -donde prevalecen las formas del suspenso y la aventuraa la escuela norteamericana -donde confluye con un realismo crítico de la sociedad contemporánea en la «novela dura» de la "se- 
rie negra"- y la escuela inglesa -que ha permanecido fiel a las convenciones clásicas del juego de enigma y desciframiento. A partir de perspectivas críticas como la de Claude-Edmond Magny, rebate tenazmente las argumentaciones de Edmund Wilson y Dwight MacDonald contra las diversas configuraciones del género y comprueba que -como otras formas de la literatura en su origen- el género que comenzó siendo considerado «una especie marginal» ha llegado a adquirir -en virtud de una «especial consideración del lector en la construcción del relato» ${ }^{24}$ - un «valor específico» tangible al configurar un universo formal propio e identificable, con personajes y rasgos morfológicos reconocibles, a través de los cuales han conseguido «imponer una óptica singular» (1978b: $324-325)$

"Elocuencia de la noche y del silencio", fechado en 1976, es una suerte de secuela de su investigación sobre el silencio desplegada en El laberinto del universo. Pero exige además un tratamiento específico en función de que en él se materializan los temas (los fantasmas) y las características fundamentales de la «ficción crítica» de Rest. El texto -dedicado a reseñar la super-

\footnotetext{
245 En este texto Rest se encarga específicamente de dejar en claro el lugar central que ocupa el lector en el modo de organización de los materiales que componen el relato-enigma. La forma específica del relato policial está sujeta a dos necesidades básicas que comprometen al lector: 1) proveerlo de los elementos necesarios para que sea capaz de descifrar el enigma por su cuenta; y 2) ocultar deliberadamente estos elementos para que su hallazgo no pueda producirse sino en el tramo final de la narración. De ahí se derivan indefectiblemente dos convenciones puntuales constitutivas del género: a) se trata de narraciones que requieren que el delincuente permanezca todo el tiempo a la vista del lector pero al mismo tiempo oculto entre otros personajes inocentes del delito; y b) en tanto este tipo de relatos es un juego de ingenio a resolver por el lector, la solución del enigma siempre es de índole racional -y excluye, deliberadamente, las soluciones fantásticas o sobrenaturales (1974a).
} 
vivencia de los temas místicos de la noche y el silencio desde el misterioso Corpus Dionysiacum hasta las reivindicaciones del nominalismo filosófico moderno- exhibe en primer lugar el particular interés restiano por los tópicos más exóticos de la cultura medieval. Cabe mencionar sobre este punto que Rest -que fue docente de la cátedra de Lengua y Literatura Medieval en la Facultad de Filosofía y Letras de la Universidad de Buenos Aires entre 1970 y 1972- compartía el interés por estos temas -que remiten a «un objeto no exento de cierto exotismo» (Bardauil 1999: 212)con uno de sus primeros maestros, José Luis Romero, cuya afición a la historiografía liberal constituía, como bien afirma Halperín Donghi, uno de los rasgos característicos de su marginalidad y excentricidad al interior de su propio campo de estudios (Halperín Donghi 1994: 203). Pero el recorte de Rest sobre ese espacio textuario no se reduce al exotismo, sino que responde a un interés estrictamente contemporáneo. Se trata de ver la «perduración actual», en las experiencias estéticas del siglo Xx, de los temas cuyo origen se remite a esos textos atribuidos a Dionisio Areopagita en el siglo V. Lo que se busca es captar su aparición concreta en el contexto de una cultura en que las diversas series discursivas aún no están autonomizadas en un sentido moderno, sino más bien en un espacio de confluencia de saberes, donde el arte y la literatura todavía se encuentran ligados a un conjunto de prácticas políticas, sociales, filosóficas, religiosas e ideológicas. Se trata, en fin, de captar su emergencia en ese contexto para pensar la sobrevivencia y las relaciones vigentes de esos 
tópicos en un mundo (moderno) definido por la autonomización de esas esferas.

En efecto, este tipo de texto permite a Rest desplegar uno de los recursos característicos de su «ficción crítica»: constituir como "objeto" de su análisis un tópico que convoque la influencia recíproca entre las diversas esferas de la producción ideológica y que demande -como lo hacen las producciones de la "cultura de masas"- un enfoque interdisciplinario, capaz de establecer su cabal inscripción en el contexto de un modelo de «historia cultural» de carácter cosmopolita y capaz de desbordar toda delimitación restrictiva, tal y como aparece definida en el programa dispuesto por Romero en el número fundacional de Imago Mundi: como un «intento de reducir a esquemas inteligibles la universalidad del desarrollo histórico, abrazándolo hasta donde sea posible en toda su complejidad y manteniendo una alerta vigilancia para no deslizarse hacia ningún solipsismo» (Romero 1953b: 12) .

Rest trabaja pues sobre un espacio de interferencia de saberes y series discursivas: la serie teológica (el Corpus Dionysiacum), la serie literaria (San Juan de la Cruz) y la serie filosófica (Angelus Silesius). La extensión de estas producciones en el espacio cultural moderno no es menos diversa: va desde las producciones poéticas de T. S. Eliot y Jorge Luis Borges, al cine de Ingmar Bergman y a las reflexiones filosóficas de Ludwig Wittgenstein. Rest parte de los textos que constituyen los fundamentos del misticismo cristiano, cuyo objeto es examinar las posibilidades de transmisión de esa experiencia de lo trascendente que, por naturaleza, «escapa a toda comprensión»y que, incluso si pu- 
diera ser incorporada, no puede ser enunciada directamente ante todo «porque el lenguaje es un instrumento demasiado abstractizante y arbitrario para permitir que se registre la índole concreta e insustituible de un conocimiento que no se presta a equivalencias verbales exactas» (1978b: 331). Pero si la discursividad llana «no sirve a los propósitos del místico», no por ello descarta de plano todos los aspectos del lenguaje. Apela al uso metafórico -es decir: literario- para resolver el escollo de «la inadecuación concreta del lenguaje con respecto a la realidad», tal como lo resolverá luego el nominalismo filosófico a partir del siglo XIV. La teoría del conocimiento místico de Nicolás de Cusa se encuentra así tanto con el nominalismo de Guillermo de Occam como con la inducción baconiana. Pero también se afirma en las experiencias de dos autores que, afirmados en poéticas de intención gnoseológica o expresiva de la experiencia de lo divino, desechan la enunciación literal y adoptan usos alusivos del lenguaje. San Juan de la Cruz y Angelus Silesius son los ejemplos indiscutibles de esa perspectiva que insiste en ampliar los alcances restringidos del lenguaje apelando a la capacidad connotativa de sus estrategias tropológicas. Pero si la alusión metafórica abre la posibilidad de «sugerir por medios de enunciados verbales aquello que resulta discursivamente inefable», la nomenclatura de esos usos estratégicos se apoya sobre dos vocablos que explotan -como apunta el crítico Rudolf Otto- una «fuerza negativa» no exenta de cierta ambigüedad. Tanto «el silencio» como «la noche» exigen, en ese contexto alusivo -para Rest-, una desambiguación necesaria a través de una interpretación compleja y abs- 
trusa». El silencio, por ejemplo, «puede aludir por igual a la inquietud receptiva, al aplacamiento sensorial o la imposibilidad de expresión literal, entre muchas otras cosas»; mientras que la noche puede referir «en algunos casos a la indispensable purificación anímica y en otros apunta a la inexplicable acción que Dios ejerce sobre el alma del contemplativo» (1978b: 334).

Desde diferentes afiliaciones poéticas -explícitamente lírica en el caso del español; despojadamente conceptual en el del alemán- y con diversas elecciones tropológicas -en Silesius «prevalece la poesía del Silencio», mientras que San Juan de la Cruz es justamente considerado «el poeta de la Noche»- ambos autores proporcionan a Rest los elementos necesarios para corroborar «la amplitud y variedad de registros» que es dable observar en el rodeo alusivo por el cual los místicos contemplativos consiguen sortear los límites que impone el desajuste entre el lenguaje instrumental y lo inefable. Pero Rest los retoma, no por su peculiaridad histórica y distante, sino precisamente porque la secularización del mundo moderno no ha conseguido desplazar su gravitación en modo alguno. Al contrario: es un fantasma que retorna «con diversa intensidad y características disímiles en los textos de Aldous Huxley y de Simone Weil»y que -como lo corroboran los trabajos críticos de Evelyn Underhill, R. W. Inge o Jean Barusi- es posible reconocer aun «en variadas manifestaciones artísticas» contemporáneas cuyos «síntomas» específicos pueden remontarse a esa particular elucubración medieval inscripta en el Corpus Dionysiacum. La poesía de Eliot, la narrativa de Borges y el cine de Bergman ilustran -como lo prueba Rest- de manera significativa 
y explicita esta perduración. Del mismo modo -nota el crítico- se pueden vislumbrar vestigios de esta teoría mística en ficciones tan disímiles entre sí como A Passage to India de E. M. Forster y Mrs. Dalloway de Virginia Woolf. Esto es así porque, más que un retorno de las estrategias para dar cuenta de la experiencia de lo inefable, lo que la trae a colación es una actitud crítica y una desilusión respecto de las capacidades del lenguaje para dar cuenta de la experiencia en términos generales.

En efecto, el abordaje multidisciplinario es una constante tangible en los ensayos reunidos en Mundos de la imaginación y se repite cada vez más asiduamente en la ficción crítica restiana en general, ya sea en las introducciones escritas para los volúmenes publicados por CEAL y Ediciones Librerías Fausto ya sea en textos breves como la "Nota preliminar" que acompaña a la edición de Le surmâle de Alfred Jarry en traducción de Juana Bignozzi (1979j) o en el riguroso "Prólogo" que acompaña la edición de Moby Dick o la ballena blanca publicada por el Fondo Nacional de las Artes en traducción de Enrique Pezzoni (1970b). Lo que aquí se exhibe es, sin duda, una tendencia cada vez más marcada en su crítica hacia el estudio de los significados culturales de la literatura. Rest da efectivas pruebas de haber leído e incorporado de los trabajos de Richard Hoggart esa matriz de investigación literaria que el Centro de Estudios Contemporáneos de Birmingham dio a conocer hacia fines de la década del 160 como una articulación dialéctica entre «reading for tone»y «reading for value». La primera instancia busca captar en la lectura misma, tan plenamente como sea 
posible, la textura del escrito, prestando especial atención a los elementos lingüísticos, «al énfasis y a la falta de énfasis, a la repetición y a la omisión, a la imagen, a la ambigüedad y demás, avanzando desde ahí al personaje, al episodio y a la trama», sin perder de vista «los tres elementos principales de una obra literaria: lo estético, lo psicológico y lo cultural»-y sin olvidar que los dos primeros términos de la triada «están en cierta medida condicionados culturalmente y que ninguno es estrictamente separable de los demás» (Hoggart 1974: 193-194)246. Rest dispone sus reconstrucciones críticas y sus selecciones significativas en razón de una finalidad específica: hacer visibles los valores evocados por la obra, esto es, sus significados y contrasignificados culturales. Como bien apunta Hoggart, «reading for value» no se superpone con la idea de juicio valorativo; al contrario, es un momento específico de la lectura en el que se trata de comprender «lo que Weber denomina "la relación del objeto con los valores"», en el marco de una lectura intrínseca que busca develar «lo que ese tipo de obra nos dice de la sociedad, sobre lo que esa sociedad cree, sobre su propia identidad» (Hoggart 1974: 194-195).

A lo largo de los ensayos publicados en la última etapa de su trayectoria crítica, Rest interpola múltiples pasajes en los que los aspectos específicos de los textos literarios son explicados a partir de la confluencia de elementos provenientes del psicoanálisis, la historia social y política, la filosofía, la teolo-

246 Un desarrollo pormenorizado del «reading for tone» puede leerse en Hoggart, R., "The Voices of Lawrence", en New Stateman, 14 de junio de 1968 . 
gía, la sociología y, por supuesto, la estilística y la filología. De algún modo, como lúcidamente apunta Rivera, la indagación restiana está con frecuencia muy próxima «a la sociología del conocimiento, a la erudición literaria, filosófica e histórica» porque su trabajo crítico tiende a ser un intento por «descifrar las relaciones y la interactuación entre especificidad del mundo imaginario y el ámbito particular en que es concebido», esto es: «a establecer los vínculos entre el artista y el mundo, a mensurar las distancias entre la obra de arte y su ámbito vital, a comprender los rasgos generales y los accidentales» (Rivera 1979: 32). Es pues un intento por reponer la complejidad del humus sobre el cual actúa una literatura y del cual extrae su pluralidad de sentido. Si hay una singularidad de la literatura, no es -bajo ningún punto de vista- la del mito que le asigna un valor y una condición metahistórica. Se lee y se escribe en la historia, y es por esa misma razón que la literatura extrae su potencia de la historicidad radical donde -lejos de ser reducida a determinaciones- se carga de una ambigüedad tal que se vuelve irreductible. La función de la crítica es reponer esa complejidad planteando sus hipótesis en un plano conjetural, como parte de un ejercicio especulativo. Si la literatura es el lugar del "como si...", la crítica es el del "y si...". Pero como, de manera inevitable aunque casi siempre sesgada u oblicuamente-, «cada texto declara una manera de aferrarse a la vida», ese "y si..." sólo puede construirse a partir de un énfasis apenas marcado por ciertos componentes dentro del trazado de inscripción de la obra en el tejido de la historia cultural: para decirlo con una frase de Lewis Ca- 
rroll que Rest solía repetir obstinadamente: «Everything's got a moral, if only you can find it».

La compleja capilaridad de las relaciones determina las posibilidades de la lectura. Es por eso que «el objeto del crítico consiste -como nota Rest- en relacionar explícita y esclarecedoramente» los fenómenos estéticos con el mundo en que se insertan, y en ensayar su comprensión «en función de esa compleja circunstancia» (1978b: 15). Para llegar a tal fin, debe no perder de vista que ese mundo particular no es un estado concreto sino un proceso dinámico: es una relación que articula diversos factores, de modo que ese mundo puede ser «social o religioso, social y religioso, y cuantas variantes y combinaciones se puedan concebir» (1978b: 15) 247. En efecto, el crítico no puede tampoco determinar a priori la lectura en función de "métodos" que reduzcan la complejidad de las relaciones sobre las que se compone la lectura. Por el contrario: debe evitar deliberadamente esa tendencia que «consiste en fabricar budineras en que los más variados propósitos artísticos se evalúan de acuerdo con un solo molde». Ello no significa -por cierto- que, en sus esfuerzos por «dominar la perspectiva», el crítico no reconozca la necesaria y concreta incorporación de saberes y herramientas teóricas a su perspectiva de trabajo.

En este sentido, además de una referencia específica a una pléyade de críticos y ensayistas ingleses leídos en su «período de formación y ensayo», Rest reconoce -en las páginas retrospectivas que abren Mundos de la imaginación- la importancia determi-

247 Cursivas en el original. 
nante de cuatro autores argentinos que, ya fuera «a través de sus libros o de una relación personal», «influyeron» en su «actitud crítica» y de alguna manera contribuyeron a la constitución de su perspectiva y modelo de investigación. El primero de ellos es afirma Rest- José Luis Romero quien, «con su excepcional aptitud de historiador del pensamiento», lo ilustró en «la importancia que poseen ciertas ideas matrices dentro de las cuales, en sus respectivos momentos, el artista cumple su acto de creación» y le permitió además tomar genuina dimensión de «la índole cambiante dinámica- que presenta la noción de realidad, sobre la que se ha sustentado toda labor humana a través de las épocas» (1978b: 16). Junto a la productiva exigencia intelectual exhibida por Romero, Rest recuerda la impresión que en sus años de juventud le había causado la forma en que -desde su formación filológica- el erudito hispanista Ángel J. Battistessa diagramaba sus análisis de los textos literarios, donde hizo sus primeras aproximaciones a la tradición del lenguaje místico a través de la obra poética de San Juan de la Cruz. En esas páginas de autoevaluación y reconocimiento que prologan Mundos de la imaginación, Rest cree advertir además en sus propios trabajos recopilados «cierto matiz dialéctico» que remite a «la doble operatividad de la obra de arte (como hecho poético autónomo y como hecho inserto en el mundo)»; matiz que deriva -sin lugar a dudas- de la teoría estética de Luis Juan Guerrero, quien de algún modo determinó su inclinación a emplear «la reflexión filosófica como herramienta crítica». Finalmente, Rest menciona a Jorge Luis Borges en razón de tres motivos fundamentales: en primer lugar, porque ha conservado coherencia e 
integridad ideológica pese a haber atravesado «circunstancias harto complejas que a otros confundieron»; en segundo lugar, porque desde el interior de su obra ha contribuido a «crear una conciencia de la funcionalidad y el valor operativo que debe tener el lenguaje como protagonista de la literatura»; y, en tercer lugar, porque a través de sus ensayos ha sido capaz de relevar una serie de «arquetipos que forman parte del lenguaje universal de la poesía» (1978b: 17).

Más allá de los aportes disciplinarios específicos subrayados por Rest en cada uno de los casos, lo que se pone de relieve es el reconocimiento de una formación teórica liberal, académica y de perfil cosmopolita. A esto habría que sumar la impronta marcadamente antipopulista presente en estos cuatro referentes a quienes Rest agrega a Sarmiento: «un autor del pasado cuya presencia -confiesa el crítico- siento tan viva como si me hablara en este preciso momento», un escritor «mucho más importante de lo que sus admiradores y detractores lograron probar»y a quien Rest no duda en catalogar como «el más formidable prosista de la literatura argentina del siglo pasado» y a cuya obra capital, Facundo, considera sencillamente «la obra narrativa más extraordinaria de su tiempo y lugar, un equivalente nuestro, por así decirlo, de MobyDick» (1978b: 18). Se trata, claramente, de un reconocimiento en el que subyace una afirmación política e ideológica que aparece reafirmada en su opinión sobre la supuesta "misión social y moral" de la literatura. Al respecto, Rest muestra una desconfianza radical ya que, en su óptica, lo que bajo ese requerimiento se da por sentado es que «a los valores poéticos se les ha conferido, 
sin eufemismos, una importancia relativa y puramente secundaria, como meros ornamentos destinados a decorar formas de militancia y compulsión» (1978b: 18). El crítico declara su desconfianza respecto de la determinación de valores y sentidos por reducción a un mero registro ideológico. A su juicio, pese a que prácticamente toda obra literaria «supone algún tipo de interpretación del hombre $y$ de su experiencia» $-y$, por ende, «ninguna puede escapar a su respectivo enfoque extraliterario»-, la tarea específicamente política del crítico «no es alentar responsabilidades ajenas al texto sino comprender las actitudes que están presentes en él» (1978b: 19) ${ }^{248}$. Esta posición no se afirma en ninguna mistificación de neutralidad objetiva. Rest reconoce que «el crítico no puede ser absolutamente neutral» porque eso sería poco menos que identificarse con la indiferencia. Pero no por ello deja de percibir que su función es contribuir a la interpretación de la obra de arte y no manipularla induciendo o alentando «una subordinación a puntos de vista que no son indispensables» en la evaluación del hecho poético. La responsabilidad social del crítico consiste -para Rest- en «utilizar del mejor modo sus propias ideas para examinar o entender la obra y en comunicar ese entendimiento a sus lectores» (1978b: 20). Estima incluso que el hecho de estimular otra actitud puede resultar «contraproducente o peligroso», ya que «lleva a desconocer la autonomía del hecho poético»y ese gesto -de apariencia menor- suele conducir a la confusión de la opinión con «una indebida pretensión de legislar desde fuera la misión de la literatura». Ese hecho -tal y como lo

${ }^{248}$ El subrayado es nuestro. 
atestigua la historia-, siempre amenaza con desembocar en persecuciones y censuras dispuestas por agentes que -ironiza Rest«pueden ser muy sobresalientes en su respectivo campo intelectual pero no por ello dejan de ser jueces improvisados y prejuiciosos en materia poética» y que a veces ni siquiera vacilan en arrogarse «el derecho de injerencia en la literatura» prescribiéndole su deber ser. Frente a estas posiciones, Rest ratifica el ámbito de incumbencia y competencia específica del crítico, planteando que su rol fundamental es el de sostener una «relación adecuada entre el texto significativo y su evaluación literaria» y, por ende, debe afirmar su perspectiva a partir de la colocación del texto «por encima de toda otra consideración» y la utilización de «cualquier conocimiento extrínseco en la medida que ese texto lo admita y justifique para una conveniente interpretación» (1978b: 21) .

La perspectiva crítica restiana no es pues restrictiva. Si la literatura es en efecto esa especie de fe compartida por el escritor y el lector, toda práctica crítica se sostiene en el espacio imaginario de esa relación alimentada por el deseo de reconocer un síntoma, «el afán de escapar al naufragio». El juego que la literatura propone en su «instauración de un orden arbitrario» se dirime pues en un espacio de ilusión que pone en evidencia el carácter también ilusorio del conjunto de convenciones con que una época y un régimen de verdad definen la realidad e «intentan disimular el vértigo que produce el silencio». La posición de Rest se afirma así en la convicción de que la dimensión crítica de una escritura radica en su potencia imaginaria y no en su efi- 
cacia retórica. Es por eso que muchas veces «descubre su camino a lo largo de una línea hilada con sus propios éxitos y fracasos» luego de «tropezar, balbucear» e -incluso- mostrarse a veces «incapaz de un estudio ordenado». Su valor no se desprende pues de sus resultados, sino de su disposición a abrir o ensanchar el espacio de comprensión de la obra frente a los límites determinados por la época o el régimen de verdad.

Lo estrictamente crítico no es en consecuencia un "contenido", sino una "disposición" (de apertura). Lo que define su compromiso no es una política de la atribución (de responsabilidades), sino más bien una ética de imaginación (de posibilidades). En razón de esto, la propia escritura de Rest recusa siempre los modos de enunciación categórica que se superponen con las formas del Juicio o el dictamen: la crítica -escribe a propósito de los ensayos de Virginia Woolf- es «un complemento de la lectura, no su tirano» (1978b: 223). Sobre esta convicción se explica también el hecho de que la suya sea una escritura sutilmente modalizada en sus formulaciones, minuciosamente atenta a los detalles y ante todo consciente de que hay en ella siempre en juego algo del orden de la ficción.

Rest sabe además que aun la obra más crítica de su época no puede evitar pertenecerle. Los elementos que la componen (y la lógica sobre la que ella misma se articula) plantean una coherencia y una organicidad que revelan los modos de su relación, sea para con la tradición precedente como para con el tejido de «series sociales» que configuran las estructuras del presente. En ese sentido, lo que en El laberinto del universo y 
en los textos reunidos en Mundos de la imaginación se entiende por literatura es una suerte de forma no digerida por un contexto que no reenvía a la Historia si no por desvío: esto es, que no remite nunca a un exterior de la obra sino al exterior que la obra presenta en sí misma como umbral hacia ese silencio o esa noche que el orden de verdad intenta conjurar en la interposición de unidades de lo imaginario mediante el dispositivo de la Cultura. En consecuencia, las mismas tensiones a partir de las cuales la obra se define y singulariza -cuestionando el lenguaje sobre el que se sostiene el propio orden de verdad- espacializan una serie de elecciones históricas, de acciones, reacciones y omisiones que acontecen en ella pero en términos de suspensión. ${ }^{249}$ Rest percibe lucidamente que no es improbable que, en tanto «ficción de segundo grado», la crítica misma no sea más que el relato diferido del inaudito encuentro de un paraguas, una máquina de coser y un fantasma sobre una mesa de disección. En efecto: su «ficción crítica» es la primera en asumir que su propio ensayo de lectura quizá hable menos del fantasma que sale a su encuentro, que de su propia inscripción en el mundo y de las marcas indelebles que le enrostran su propia historicidad.

Que, contra toda ilusión y contra toda certeza, la «ficción crítica» manifieste -como la literatura- «una desesperada voluntad de creer en sus propios enunciados», no la vuelve en modo alguno menos lúcida. Si la explicación que ensaya del fantasma que la convoca sólo puede imaginarse como un relato de experiencia de la literatura sobre el orden de verdad, la crítica

${ }^{249}$ Cfr. Sartre, 1982. 
debe necesariamente desplazarse de la enunciación vertical, apodíctica y sentenciosa, incluso a riesgo de transformarse -en función de sus modulaciones concesivas, sus arremolinamientos de saberes, sus desvíos eruditos, sus pliegues comparativos y sus demoras en los ritornelos de la tradición- en una intervención morosa y laberíntica. Pero eso no es todo. Debe además resignar efectismo cambiando la interjección tajante por una modulación especulativa y desplegada a través de una enunciación de corte conjetural -a riesgo incluso de pasar desapercibida ante el fulgor de otros simulacros.

Sólo en el monstruo se revela la monstruosidad de la Norma. La Casa de Asterión es la cárcel del lenguaje. He ahí la sinécdoque extrema la de esta imaginación crítica que se obliga a acceder al mundo por el desvío literario, y al desvío literario por el cuestionamiento del lenguaje; pero que además se obstina en componer su propia dimensión ficcional exponiendo la complejidad y la diversidad matizada del espacio en que el hecho estético acontece y sobre el que se produce la experiencia misma de la lectura. La ficción crítica se construye pues menos como una pesquisa que como un relato conjetural que se suspende siempre un paso antes de la determinación y el resultado. La crítica explica sólo en tanto complica: como la del novelista, la misión del crítico «no consiste en hallar una clave satisfactoria para resolver el conflicto, sino sencillamente en ponerlo de manifiesto» (1978b: 210) . 
APÉNDICE $\mathrm{N}^{\circ} 4$

\title{
LOS NARRADORES ARGENTINOS Y LA BÚSQUEDA DE UN IDIOMA NACIONAL ${ }^{250}$
}

\begin{abstract}
Some work in which the most thorought knowledge of human nature, the happiest delineation of its varieties the liveliest effusions of wit and humor are conveyed to the world in the best chosen lenguaje.
\end{abstract}

JAne Austin

\section{La búsqueda literaria de un lenguaje real}

Con respecto al lenguaje que conviene emplear en la creación literaria, dos fuerzas opuestas se han enfrentado reiteradamente, en el curso de los tiempos modernos: de un lado, se hallan los partidarios de un uso conservador, que propician el exclusivo manejo artístico de las formas cultas ya reconocidas; del otro, se encuentran quienes defienden la vitalidad de la lengua hablada de la lengua coloquial-, en todo caso convenientemente depurada de sus giros más toscos. Esta prolongada contienda se inicia cuando Dante, en el Convivio y en De vulgari eloquentia, expone las ventajas poéticas de escribir en el idioma vernáculo, que permite una comunicación vigorosa y dinámica, por contraste con

250 "Los narradores argentinos y la búsqueda de un idioma nacional" (1967e), ponencia escrita y leída en las Segundas Jornadas de Métodos de Investigación de enseñanza de la Historia y de la Literatura Rioplatense y de los Estados Unidos, Bahía Blanca, junio de 1967. 
la artificialidad erudita de un latín que desde largo tiempo atrás había cesado de expresar la realidad cotidiana y que se iba convirtiendo -pese al afortunado aprovechamiento de algún goliardo- en un conjunto de fórmulas más o menos rígidas y vacías, abstraídas de los autores clásicos por gramáticos y retóricos que desarrollaban una ingente labor de gabinete. En la exposición de sus argumentos, Dante revela una extraordinaria cautela y se mueve con enorme prudencia; su defensa de la legua vulgar pone el acento invariablemente en la facilidad de acceso que su empleo proporciona a todos los sectores del pueblo y en la aptitud que a su juicio posee en lo tocante a elocuencia poética; pero el lector de nuestros días no puede dejar de percibir la subyacente presencia de un motivo adicional: en la medida en que la literatura debe explotar y esclarecer sentimientos y experiencias reales, es indispensable aproximarse al lenguaje más apto y espontáneo para registrar en toda su complejidad los movimientos anímicos estimulados por situaciones actuales. El triunfo de la tesis de Dante puede medirse a través de la madurez y el esplendor literario que alcanzan las lenguas modernas a partir de la Divina Comedia. Pero el conflicto se renueva cuando la irrupción neoclásica tiende a fijar una pauta lingüística para la poesía, con lo cual transforma la literatura en un juego sujeto a reglas estrictas y a menudo constrictivas. En esta ocasión, el paladín de la lengua coloquial fue Wordsworth, quien -en su célebre prefacio a las Lyrical Ballada- expuso al filo del siglo XIX la doctrina de que sólo es legítima la expresión que se nutre del idioma hablado por el pueblo. Esta opinión suscitó una áspera polémi- 
ca, en la que sin duda llevó la mejor parte Coleridge, cuya oposición a las ideas de Wordsworth estaba respaldada en sólidos y elaborados razonamientos; pero en la práctica, la literatura de los últimos ciento cincuenta años no ha cesado de reconocer el acierto de quien defendió el empleo de la "lengua real", de las formas coloquiales que -transformadas en una verdadera estrategia estilística- suelen asomar en los autores más diversos y representativos.

Por lo demás, el asunto no reviste un interés puramente teórico. Múltiples casos podrían servir para ilustrar la aplicación de este argumento tan sostenido y tantas veces renovado en las letras modernas, pero basta con sólo apelar a un par de ejemplos. El primero lo proporciona la literatura inglesa a fines del siglo XVI y en la mitad inicial del XVII: la prosa de este período (Philip Sidney, John Donne, Milton) conformada por lo general a imitación de los modelos clásicos latinos, sin duda logra elegancia y resulta ricamente modulada, pero -como señaló Virginia Woolf- carece de naturalidad para indagar las experiencias humanas concretas y se mueve en el plano de las abstracciones; en cambio, la poesía, que por contraste se maneja al nivel del lenguaje cotidiano y real -en la obra dramática de Shakespeare y en la lírica profana o sagrada del mismo Donne-, admite una vital y minuciosa exploración del hombre, elaborada con intensidad y hondura. La segunda ilustración puede ofrecerla el Quijote, en el prólogo de cuya primera parte Cervantes expone su posición con tal contundencia que sugiere una actitud programática y polémica: puesto que su novela apunta hacia la evocación de la realidad, 
"sólo tiene que aprovecharse de la imitación en lo que fuere escribiendo; que cuanto ella fuere más perfecta, tanto mejor será lo que se escribiere"; por consiguiente, juzga innecesario todo ardid que lo separe de la lengua hablada y que lo introduzca en una prosa artificiosa y falsa, sobrecargada de floreos; el propósito del escritor ha de ser "procurar que a la llana, con palabras significantes, honestas y bien colocadas, salga vuestra oración y período sonoro y festivo, pintando en todo lo que alcanzáredes y fuere posible vuestra intención; dando a entender vuestros conceptos sin intrincarlos y oscurecerlos".

La importancia de estas reflexiones cervantinas no puede ignorarse, si se tiene en cuenta que implícitamente aquí queda declarado cuál habría de ser el estilo conveniente a la narrativa moderna: sencillo, directo, afianzado en el lenguaje hablado. Por añadidura, estas observaciones -tan lúcidas en la descripción del idioma que debe utilizar la novela- ponen también en evidencia los motivos que explican las ventajas de una expresión espontánea y conversacional: desde las postrimerías medievales, la literatura arraiga en una concepción secular de la realidad, de fundamento social y psicológico. En este sentido, se requiere que el instrumento expositivo se aproxime en el mayor grado posible a las características de la constelación imaginaria que se pretende estructurar. Tal es la situación del habla coloquial, con respecto a todo realismo que aspire a indagar artísticamente las relaciones entre a conciencia individual y el mundo cotidiano que la circunda. Lo cual debe servir de advertencia y reconvención a quienes se proponen estudiar el realismo literario: ya se trate 
de adversarios (Wellek) o defensores (Lukács) de esta corriente, con excesiva frecuencia se cae en un exclusivo análisis de "contenidos" (con todo lo que puede tener de equívoco este vocablo). Por el contrario, la raíz específicamente poética de una literatura testimonial quizá deba buscarse, antes que nada, en un idioma que se preste a calar con apropiada hondura en la situación explorada. En consecuencia, por desconcertante que ello pueda parecer, lo primero que corresponde señalar con respecto al realismo literario es aquello que debiera resultar más obvio: la búsqueda del lenguaje real (con sus peculiaridades de dicción, de construcción, de vocabulario, de imaginería). Una vez admitida tal premisa, es inevitable comprobar que esta dimensión inexcusable del realismo ha constituido una de las preocupaciones incesantes de la literatura moderna, según lo demuestra la nómina de autores que hemos mencionado.

\section{La prosa narrativa en la literatura argentina}

La búsqueda de un lenguaje real como medio de expresión se advierte en las letras argentinas desde sus mismos orígenes, cuando Echeverría expuso en sus escritos de teoría poética la necesidad de constituir una literatura nacional con temas e idiomas propios; ello ya se encuentra explicitado en la advertencia de La cautiva, donde surge de manera evidente la importancia de "nombrar las cosas por su nombre" como único criterio recomendable para que las ideas resulten convenientemente claras. Sin embargo no es en su obra en verso donde Echeverría habría de exhibir con 
mayor plenitud el uso de la lengua concreta y actual; demasiado atado a los moldes franceses de su inspiración romántica, tiende a caer en una retórica sentimental y en un pintoresquismo que es por entero inapropiado para lograr un dominio firme de la realidad; en cambio, es en El matadero -un relato en prosa que permaneció inédito hasta veinte años después de morir su autor- donde Echeverría revela un empleo adecuado del lenguaje, eficaz en la descripción de situaciones, a la vez natural y expresivo, inconfundible en sus referencias de época y lugar pero despojado de todo "color local" superfluo y sólo aderezado de giros populares en la justa medida en que lo requiere el coloquio de los matarifes. El ejemplo de Echeverría se reproduce en toda la literatura argentina anterior al modernismo: el verso suele pecar de sensiblería o de aparatosidad; la prosa, por lo contrario, es manejada -las más de las veces intuitivamente- con toda sencillez, eficiencia y expresividad, sin "sobreactuarla". Existe en el siglo XIX, es cierto, un verso de gran vitalidad, encarnado en la poesía gauchesca; pero como ha sido señalado con frecuencia inclusive por Borges-, el idioma empleado no es el que habitualmente utilizaban sus autores, sino un lenguaje que adoptaban y que a veces no está exento de cierto matiz pintoresco; y en este sentido, la ironía con que lo emplea Estanislao del Campo en su Fausto es un verdadero hallazgo porque subraya la distancia a la que se ubica el poeta $-y$ a la que debe situarse el lector-, en lugar de originar la fácil identificación propiciada por un acercamiento excesivo. 
Por lo menos hasta 1880 es difícil hallar en la Argentina una prosa cultivada por la exclusiva complacencia imaginativa y creadora; lo más frecuente es encontrarse con un escritor "comprometido" cuyas incursiones literarias son casi un subproducto de su actividad pública, a menudo vinculada -como en el caso de Sarmiento- a un combativo periodismo político. Pese a esta circunstancia, podemos mencionar dos o tres narradores de primera agua que hacen gala de un lenguaje espontáneo -pleno de naturalidad y de vigor- en el ejercicio de la exposición autobiográfica o doctrinaria. Para comprobarlo, allí tenemos, en primer lugar, las Memorias del general Paz, quizá el testimonio personal literariamente más memorable que haya quedado de los numerosos militares que participaron de las guerras en la independencia y en las contiendas civiles que le siguieron; luego, corresponde mencionar a Lucio V. Mansilla, quien evidentemente escribía del mismo modo que hablaba, pleno de galicismos y sentido del humor, al punto de que su Excursión a los indios ranqueles queda, sin duda alguna, como verdadero clásico de nuestra producción literaria; last but not least, es menester evocar a Sarmiento, cuya genialidad -tan fecunda como arbitraria- está presente en todo momento en sus innumerables prosas, pero muy especialmente en Facundo, donde hace del habla cotidiana un instrumento expresivo de singular eficacia; este "libro extraño, sin pies ni cabeza, informe, verdadero fragmento de roca que se arrojó a la cabeza de los tiranos" -como juzgaba su propio autor- es muchas cosas (biografía, interpretación social, costumbrismo, polémica), pero su material complejoy hasta contradictorio no lo fragmenta ni perjudica su intrínseca 
unidad porque hay una sostenida coherencia de estilo, lograda a través de un idioma cuyo acierta en el realismo de su prosa, en la vigorosa naturalidad expositiva que logra traslucir la entonación misma del lenguaje oral.

Cumplida la etapa de asentamiento institucional y de consolidación cultural (aquello que Pedro Henríquez Ureña denomina en sus Literary Trends el "período de organización"), hacia 1880 surge en la Argentina lo que puede llamarse una literatura propiamente dicha, nacida de la división del trabajo intelectual (como bien puntualiza el mismo Henríquez Ureña). En este nuevo período, la tradición de prosistas narrativos que se venía consolidando a lo largo del siglo XIX es continuada por nuevos autores que documentan un eficaz empleo de nuestra realidad lingüistica, como Fray Mocho, Payró, Lynch, Horacio Quiroga o Roberto Arlt; sin embargo, la preocupación artística de algunos creadores deriva hacia una prosa cuya riqueza lírica -morosa en la pura complacencia verbal-, si bien abre nuevas perspectivas expresivas, se aparta de ese idioma real que exige necesariamente la narrativa; es el caso ilustrado por La guerra gaucha de Lugones y Don Segundo Sombra de Güiraldes (para no mencionar La gloria de Don Ramiro de Larreta) y entraña una brecha abierta entre el lenguaje real y el "estilo literario" que sólo logró superarse con la aparición de Borges, uno de cuyos aportes creativos más valiosos es el logro de una espontaneidad narrativa dotada, al mismo tiempo, de plena eficiencia artística.

Pese a esta feliz síntesis, la bifurcación entre el lenguaje real y el lenguaje literario -originada en nuestra prosa con el 
advenimiento de una conciencia artística- tuvo considerables repercusiones en el desenvolvimiento de la narrativa; ello es particularmente notorio en la obra de Eduardo Mallea, quizá porque es uno de los más representativos y ambiciosos novelistas recientes que ha tenido el país, urgente y honestamente preocupado en enunciar su interpretación de un período crítico de la sociedad argentina. Sea cual fuere nuestra evaluación de la capacidad creadora de Mallea, no cabe duda de que su producción reviste importancia, inclusive por los problemas no resueltos que entraña; uno de ellos -tal vez el de mayor alcance para el análisis literario- es el que proviene de su estilo. Indiscutiblemente, se trata de un gran prosista, muy cuidadoso en el manejo del lenguaje; pero esa misma preocupación - por momentos, demasiado visibleconstituye muchas veces el mayor obstáculo para su desenvolvimiento narrativo; esto ha sido explorado con agudeza en the Writings of Eduardo Mallea, estudio de John H. R. Polt que revela concienzudo conocimiento, minuciosidad y manifiesta simpatía por el escritor examinado. Polt destaca que "el lenguaje de Mallea, pleno de abstracción e imaginería, es por lo tanto puramente literario. Su utilidad en el diálogo se limita a aquellos caracteres que al hablar reflejan la personalidad de su autor: Martín Tregua y Roberto Ricarte son capaces de emplearlo, lo cual no sucede con Ágata Cruz. Puesto que Mallea no desea descuidar este lenguaje suyo o la naturaleza de sus criaturas, a veces se ve forzado a limitar la expresión propia de sus personajes a ocasionales exclamaciones". En lugar del habla real de los caracteres prosigue el mismo crítico-, Mallea apela a "descripciones del au- 
tor, discurso indirecto, o monólogo interior en tercera persona"; todo ello determina que "al escribir en una vena puramente subjetiva, alcance un elevado nivel lírico; en cambio, cuando aplica las misma s técnicas a la narración, se vuelve difuso". La conclusión que extrae Polt consiste en que el "incuestionable talento artístico" de Mallea suele entrar en colisión con los propósitos que este mismo escritor exhibe de ponerlo "al servicio de su mensaje". En síntesis, Mallea -como tantos otros novelistas de significación relevante- es antes que nada un hombre acosado por intensas preocupaciones morales, pero la excesiva elaboración artística de su prosa con frecuencia le impide exponer convenientemente la realidad de los problemas que más lo inquietan.

De aquí la importancia que tiene la observación formulada por Julio Cortázar en 1949, al reseñar Adán Buenosayres de Leopoldo Marechal: "Hacer buena prosa de un buen relato es empresa no infrecuente entre nosotros; hacer ciertos relatos con su prosa era la prueba mayor, y en ella alcanza Adán Buenosayres su más alto logro". Según Cortázar, este libro demuestra que "estamos haciendo un idioma"; se trata de "un idioma turbio y caliente, torpe y sutil, pero de creciente propiedad para nuestra expresión necesaria; un idioma que no necesita del lunfardo (que lo usa, mejor), que puede articularse con la mejor prosa 'literaria' y fusionar cada vez mejor con ella -pero para irla liquidando secretamente y en buena hora". Estas apreciaciones tienen decisiva importancia para valorar el intento de Marechal, que ha suscitado juicios tan contradictorios: acaso ofrece un relato desigual y fracase -como puntualiza Cortázar- en su propósito de unificar "las disímiles 
substancias allí yuxtapuestas"; pero, de todos modos, es un significativo esfuerzo destinado no sólo a crear una prosa asentada en el lenguaje real sino, por añadidura, a rever en su mayor amplitud nuestra gama de posibilidades expresivas, a través de los más diversos ejercicios estilísticos, desde una posible aproximación a los místicos españoles (con todos los riesgos que entraña la comparación con modelos tan cabales) o la exploración de nuestros clásicos (como Mansilla o Payró), hasta la parodia maleva de las letras de tango. Con posterioridad a la aparición de Adán Buenosayres, quizá ha sido el mismo Cortázar quien realizó la mayor contribución al desarrollo de una prosa literaria afianzada en la más plena realidad de nuestro lenguaje, como admirablemente lo pone en evidencia su cuento La salud de los enfermos.

\section{El empleo narrativo del monólogo dramático}

Este relato de Cortázar nos introduce en un aspecto particular de nuestra narrativa: el aprovechamiento del monólogo. A diferencia de lo que habitualmente ha sucedido en el teatro argentino donde, salvo excepciones como la proporcionada por Gregorio de Lafèrrere, se suele utilizar un lenguaje ya convencional, ya caricaturesco, desvinculado de las formas de expresión reales y cotidianas- puede perseguirse a través de los cuentistas rioplatenses una interesante línea técnica que consiste en el empleo del "monólogo dramático en prosa" como aproximación al idioma oral y concreto de la ciudad. Para ejemplificar esta continuidad desde principios de siglo hasta el presente, es posible tomar tres au- 
tores que han utilizado tal procedimiento expositivo: Fray Mocho, Borges y Cortázar. Los tres, cada uno a su manera, han demostrado la plasticidad de este tratamiento para acomodarlo a sus propios objetivos literarios y, al mismo tiempo, el extraordinario acercamiento que permite a las formas de nuestro lenguaje coloquial urbano, en sus distintos niveles. En Fray Mocho, la mayor parte de sus cuentos responde a técnicas dramáticas donde se ha eliminado casi por completo todo material descriptivo y se utiliza exclusivamente el monólogo o el diálogo en su plena espontaneidad idiomática, desde el habla de suburbio o la jeringoza gringa hasta cierto tipo predilecto de este autor, que consiste en una clase muy media pero "con pretensiones", según asoma en viñetas como De baquet'a sacatrapo o Las etcéteras. Borges, por supuesto, emplea el monólogo en Hombre de esquina rosada, una de sus ficciones más memorables donde refiere la historia de un bailongo y un crimen de las orillas a través de un personaje arrabalero cuya individualidad íntegra está evocada por el lenguaje que emplea, presuntamente inspirado en la pendenciera prosa oral ejercida por el impagable Vicente Rossi en Cosas de negros. Sin embargo, ni Fray Mocho ni Borges -en los ejemplos mencionados- logran plenamente el propósito que Cortázar enuncia de manera casi explícita en sus reflexiones sobre Adán Buenosayres: usar el idioma real y cotidiano propio, más bien que el lenguaje un tanto pintoresco (y, por lo tanto, propenso a la convencionalización) de ciertos sectores sociales que el escritor interpreta y asume, pero a los que no pertenece. La gran virtud de Cortázar, en La salud de los enfermos, consiste en emplear un monólogo impersonal que responde 
en todas sus cualidades al término medio de comportamiento social, moral y lingüistico que peculiariza al hombre argentino de ciudad, quizá -a lo más- anticuado en unos veinte o treinta años, pero de ningún modo inverosímil en la actualidad; por sobre todo, se advierte una notable coherencia entre la mentalidad de los personajes, sus formas de vida y el idioma empleado para referir los acontecimientos; de un modo intrincado, se conecta la manera de hablar con la anécdota del cuento, e inclusive el clima resultante de esta circunstancias está íntimamente vinculado a los detalles en apariencia más intrascendentes de la narración, ya sea el decorado de la casa ("unas flores para el jarrón de la cómoda" en el dormitorio de "mamá" o la "carpeta verde en la mesa del comedor" sobre la cual lloraba Carlos), ya las tareas desarrolladas por los personajes (la muchacha de familia respetable que tiene "alumnos de piano y solfeo"), ya los consejos de la medicina casera (con las compresas de hamamelis para la irritación de ojos). En un ensayo sobre la naturaleza del cuento, Cortázar señaló que la mera copia de situaciones y objetos no basta para que el realismo alcance la condición de categoría estética; por contraste, en La salud de los enfermos demuestra en qué medida una historia de fantasmas puede transmitirnos un caudal incuestionable de significación realista; el tema, acaso sugerido por el segundo verso de Les sept vieillards de Baudelaire, se resuelve en la frase postrera del relato, que insinúa la plena incorporación de los espectros a la vida familiar; pese a ello, es posible descubrir, entretejidos en la trama de la narración, varios niveles de innegable realismo: el estilo expositivo -vital, genuino, coti- 
diano- otorga a la anécdota un aspecto de absoluta naturalidad, respaldado por la índole ordinaria y común -nada insólita- de la vida diaria que hallamos evocada; inclusive, si deseamos forzar la introducción de un nivel simbólico e ideológico, podemos interpretar el clima de inercia imperante en la casa como indicio de la parálisis que aqueja a todo un cuerpo social. Pero, en última instancia, la carga realista radica en el hecho de que el autor ha asumido su lenguaje propio con espontaneidad, a la vez que con plena conciencia literaria. En tal sentido, este relato permite suponer el advenimiento de una madurez narrativa, que hoy en día se advierte no sólo en la Argentina sino también en otros lugares de América Latina; y es una madurez proporcionada, ante todo, por la victoria obtenida al cabo de una prolongada lucha, que se libró para conseguir un adecuado dominio del lenguaje; lo cual quizá también signifique, en otro plano, una más lúcida comprensión de nuestra realidad. Por consiguiente, parecería que está a punto de completarse el ciclo -iniciado por Echeverría- en que el escritor buscó un medio de expresión concreto y real, un lenguaje cabalmente artístico construido con los recursos que proporciona el habla coloquial; sin embargo, en el caso de que así fuera, este logro no debe interpretarse como una meta final, ya que apenas es lícito considerarlo el fin del comienzo. 


\section{EDITAR， TRADUCIR， DIVULGAR， ENSEÑAR}

\section{(1976-1979)}

La dictadura implantada el 24 de marzo de 1976 llevó al límite los rasgos autoritarios, represivos y criminales de los regímenes militares previos. Muchos historiadores coinciden en subrayar que el proceso desencadenado por el Golpe encabezado por la Junta de Comandantes de las Fuerzas Armadas -integrada por Jorge Rafael Videla, Eduardo Emilio Massera y Orlando R. Agosti- irrumpió con «rasgos propios» en virtud del extremismo de sus acciones; lo que de algún modo significó una «ruptura traumática respecto de ciertas reglas que habían gobernado la vida política en la Argentina», aun durante los regímenes militares precedentes. Como nunca antes se sometió a la sociedad toda -y sin ningún tipo de vacilaciones- a «una violencia sin límites y hasta entonces desconocida, especialmente por la implantación del aparato clandestino de represión y exterminio» (Vezzetti 2003: 38). Los efectos de tal andanada de violencia fueron tales que -a partir de ella- se instauró una etapa histórica de terror y extrema barbarie que de algún modo definió los rasgos determinantes de la sociedad hasta más de tres décadas después de su retiro formal. Ciertamente, el autodenominado "Proceso de Reorganización Nacional" que se extendió entre los años 1976 y 1982 expuso, ante todo, por supuesto, el uso devastadoramente criminal que del aparado de Estado ejercieron las Fuerzas Armadas. Pero también puso a prueba la capacidad y la voluntad de resistencia de intelectua- 
les, dirigencias e instituciones $y$, en general, acabó por sacar a la luz -junto a un conjunto de gestos heroicos ahogados por la represión- lo peor de la sociedad argentina en una serie de actitudes que van desde la complicidad al colaboracionismo.

Las Fuerzas Armadas en el poder dispusieron la ejecución inmediata de un plan de represión y exterminio, de algún modo sostenido -como apunta Hugo Vezzetti- en «una percepción desviada no sólo de la naturaleza de los conflictos en la escena política y social sino del mundo en el que inscribía la proyección desmesurada de sus combates por la fe y la civilización cristianas» (Vezzetti 2003: 12-13). De algún modo, la dictadura buscaba instaurar su propia legitimidad a través de una identificación de sus acciones con los intereses de «una casta y un sistema de creencias que los ungía como una elite situada más allá del bien y el mal» (Vezzetti 2003: 13). El peso específico de ese sistema de creencias y de un cierto «estado de alienación colectiva» producido por los propios efectos del terror internalizado por los sobrevivientes- hizo imposible comprender la inmediata articulación del "proceso" y los asesinatos masivos y una serie de objetivos o intereses clara y consistentemente racionalizables en una lógica de fines y medios. Como bien apunta Vezzetti, en el caso de la dictadura argentina, los fines expuestos como «razones justificatorias» no permiten en modo alguno explicar la necesidad ni las dimensiones del plan sistemático de exterminio llevado adelante por la dictadura. Si «ni la derrota de la insurgencia armada, ni la imposición de un plan económico, ni el propósito de "disciplinar" a la sociedad o la búsqueda de una recomposición 
política» pueden explicar tal devastación es porque en su aterrador despliegue «hay algo que excede cualquier justificación racional» y que demanda un análisis capaz de incorporar «otros componentes, imaginarios, básicamente culturales», en una perspectiva que contemple «un sustrato determinante de la percepción y la experiencia, hecho de visiones, escenas, creencias y representaciones sociales». (Vezzetti 2003: 14).

Por otra parte, la dictadura no sólo desplegó su plan sistemático de detenciones ilegales, torturas y asesinatos sino que además procuró -y en cierta medida consiguió- mantener un control estricto sobre la información pública de del desarrollo de esas prácticas. Se impuso, en consecuencia, «una lucha por la información y por la verdad» que constituyó un espacio de enfrentamiento decisivo entre la dictadura y la resistencia. Los modos de ese enfrentamiento no se resolvieron, por supuesto, sin matices. Entre el silencio y la denuncia se desarrolló una serie de formas de resistencia sutil que produjo experiencias intelectuales y narrativas específicas cuyo objetivo era enfrentar el silencio y la falsificación de los hechos y a la vez conseguir sortear la censura y sobrevivir a la persecución y a la eventual sanción por parte del poder represivo. ${ }^{251}$ En ese marco de experiencias específicas, la literatura y la crítica literaria argentina ejercieron una resistencia importante en el ejercicio de lo que Leo strauss describe como el arte de «escribir entre líneas» (Strauss 1988).

251 Sobre los modos de esta resistencia en el campo específico de la expresión literaria véase, especialmente, el importante trabajo crítico reunido en: Balderson, Daniel, Foster, William, Halperin Donghi, Tulio; Masiello, Francine; Morello-Frosch, Marta y Sarlo, Beatriz, Ficción y política. La narrativa argentina durante el proceso militar, Buenos Aires, Alianza Estudio, 1987. 
Luego de la prohibición de Tres autores prohibidos por parte de la dictadura -libro donde Rest tematizaba no al mal sino a las consecuencias de la sublimación bajo la cual el mal se volvía en un absoluto impensable-, Rest asume la táctica específica de la escritura entre líneas en el contexto de una estrategia más amplia, que articula un conjunto de actividades culturales desde donde su proyecto intelectual exhibe una coherencia global indiscutible. Desarrolla una «ficción crítica» sutilmente modalizada, que absorbe de sus propias experiencias de lectura -sobre todo de la intensa lectura de la obra borgeana- su modo de inscripción en el presente. Rest apela a la «potencia evocativa» de la crítica. Emplea la evocación como una forma diferida, indirecta pero eficaz de hacer rebotar en el presente los temas y las problemáticas a primera vista distantes. Esa modulación evocativa, que ya a partir de 1976 deja de ser sólo un recurso excepcional y se transforma -merced al contexto represivo que circunda su producción- en la característica fundamental de su «ficción crítica», extrae -coherentemente- su propia eficacia de la potencia connotativa de un lenguaje crítico no exento de suspicacias y rodeos irónicos.

Mientras la dictadura busca disciplinar la fuerza de trabajo -suprimiendo la actividad política- y reforzar los lazos familiares tradicionales -moralizando las costumbres, Rest reafirma su nominalismo crítico, subrayando lo transitorio y lo dinámico de los procesos sociales y de la realidad misma, pronunciándose en favor de los cambios progresivos y repitiendo -cada vez que encuentra ocasión- que el supuesto "orden" no es más que una fic- 
ción consentida y que los mentados "valores" de una sociedad no son más que convenciones precarias. Como Hoggart, Rest está convencido de que, al ser ante todo una incontenible máquina de producir valores, una sociedad no puede evitar que esos valores se transformen ni decidir su significado relativo. Tampoco puede evitar que eso que teóricamente es «un conjunto significativo ordenado» sea raudamente desbaratado por la experiencia social misma. Ni siquiera aquellos momentos en que los significados son capaces de articular las estructuras de valores en sistemas, rituales y formas consensuadas no pueden escapar a la corrupción gradual y a su definitivo reemplazo. La vida de los valores y los significados culturales está -a su juicio- inscrita pues en «un proceso dialéctico, que no se completa nunca, que está siempre sujeto a innovaciones y cambio» (Hoggart 1974: 195).

Es en razón de esto que tanto en su trabajo crítico literario como en sus funciones de editor, traductor, investigador y divulgador de la cultura popular Rest se encargó siempre de situar sus objetos de estudio en momentos de crisis y umbrales de mutación o de cambio. Era su manera de sostener su compromiso en la perspectiva de un arco de pensamiento liberal-progresista antiautoritario y cosmopolita, aun cuando -o quizá debiéramos decir: sobre todo cuando- el poder represivo se hacía presente en su propia vida, como en 1976, el año en que la dictadura decreta la prohibición de Tres autores prohibidos y le abre una causa judicial (bajo la Ley 20.840) por "Actividades subversivas". La estrategia del crítico es clara: desnaturalizar ese orden autoritario donde la dimensión de la política de la vida social era suprimida y 
donde se insistía con vehemencia amenazante en «los valores del trabajo, el hogar y la aspiración a un medio ordenado y estable en la escuela y el ámbito laboral» (Vezzetti 2003: 45). La táctica sobre la que tal estrategia se produce es tan lúcida como sutil. Tanto Mundos de la imaginación como El laberinto del universo revelan que lo político aparece en la crítica de Rest aludido en una táctica evocativa. Tal como el historiador residente en el país totalitario imaginado por strauss, Rest aprovecha la reputación obtenida en el campo específico de su actividad para manifestar sus puntos de vista. No lo hace directamente -en el régimen propio de la denuncia- sino que, para sortear la tenaza de la censura, emplea un recurso indirecto: sostener su posición, no por un ataque frontal a las posiciones opuestas a la suya, sino en la descripción de casos y escenas aparentemente lejanas. No es casual pues que todas las introducciones y presentaciones de textos y autores realizadas por Rest en el arco de este período deslicen sus enunciados críticos bajo un camuflaje que -como el del historiados de Strauss- se corresponde con «un estilo sereno, nada espectacular y algo aburrido, que no parece sino natural», que se materializa en una textualidad plagada de «términos técnicos y numerosas citas»-y que no pocas veces se disgrega «atribuyendo indebida importancia a detalles insignificantes»-, pero cuyo secreto objetivo es llegar a un punto de la argumentación donde inscribir «tres o cuatro oraciones en un estilo terso y vivaz, capaz de atraer la atención de los hombres jóvenes a quienes les gusta pensar» (Strauss 1988: 24) ${ }^{252}$. Pero eso no es todo. Tampoco

252 Strauss, L., Persecution and the Art of Writing, Chicago \& London, The 
son casuales sus elecciones bibliográficas -que gradualmente incorporan los trabajos más importantes del culturalismo inglés-, sus investigaciones sobre las producciones culturales masivas que buscan quebrar el cerco elitista de una «cultura represiva» que, como sostiene Perry Anderson, atendía únicamente a las producciones de la "alta" cultura y reproducía los valores e intereses de la clase hegemónica ${ }^{253}$-, sus trabajos de divulgación en relación a la dinámica de los géneros literarios -enfocados en una perspectiva materialista cultural y desarrollados al interior del impactante proyecto editorial de Centro Editor de América Latina, sus traducciones -en especial, su convicción en la necesidad de contextualizar radicalmente las versiones- y sus elecciones de textos a publicar en el marco del proyecto de Librerías Fausto.

LA DINÁMICA DE LOS GÉNEROS

A mediados de la segunda mitad de la década del 160 puntualmente después de la aparición de Literatura y cultura de masas (1967a) ${ }^{254}$, Rest comienza a colaborar asiduamente con el proyecto editorial de Centro Editor de América Latina (CEAL), dirigido por Boris Spivacow. En ese contexto, encara una serie de investigaciones aplicadas a los orígenes y transformaciones de los géneros literarios, que se abre con sus indagaciones sobre La

University of Chicago Press, 1988. La traducción es nuestra.

253 Anderson, P., "Components of the National Culture", en New Left Review, London, 1967 (La cultura represiva, Barcelona, Anagrama, 1977).

254 Rest, J., Literatura y cultura de masas (1967a). Buenos Aires: CEAL. 
novela tradicional (1967b) ${ }^{255}$ y sobre El teatro moderno (1967c) ${ }^{256}$ y se extiende incluso hasta las reflexiones a propósito del ensayo que desarrollaba al momento de su repentina muerte en el año 1979. ${ }^{257}$ El espíritu de esas primeras intervenciones tiene un cariz divulgador que se superpone con la orientación masiva que vislumbraba el propio proyecto de Spivacow. En el prólogo a Novela, cuento, teatro: apogeo y crisis (1971b)258, aparecido a mediados de 1971, Rest mismo lo confirma al señalar que el volumen reúne tres estudios sobre sendas áreas poéticas, confeccionados con «un criterio eminentemente pragmático» y con el propósito deliberado de «proporcionar -con la mayor claridad posible- un enfoque orgánico de los aspectos y problemas fundamentales que debe tener presente el lector de nuestro tiempo al establecer su relación con tales campos creativos» (1971b: 7).

Rest liga esa serie de trabajos a su propia labor docente en la Universidad de Buenos Aires y en la Universidad Nacional del Sur, espacios de producción de saber de donde -asegura- ha extraído la certidumbre de que uun conocimiento elemental pero sólido del ámbito en que se insertan las obras individuales» es necesario e indispensable «para penetrar con adecuada profundidad en el significado de esa forma singular de producción que constituye la tarea del escritor». Se trata de ofrecer y acercar al «lector común»-«ese common reader que lee por la razón más plausible, antigua y justificada: disfrutar de lo que lee» (1971b:

\footnotetext{
255 Rest, J., La novela tradicional (1967b). Buenos Aires: CEAL.

256 Rest, J., El teatro moderno (1967c). Buenos Aires: CEAL.

257 Rest, J., El cuarto en el recoveco (póstumo, 1982), Buenos Aires: CEAL.

258 Rest, J., Novela, cuento, teatro: apogeo y crisis (1971b). Buenos Aires: CEAL .
} 
9)- un compendio de las múltiples especulaciones teóricas y estudios parciales y generales sobre la novela, el cuento y el teatro en un intento por zanjar la ausencia efectiva de instrumentos objetivos «para interpretar o ubicar los textos concretos en el proceso de constante renovación que se observa a lo largo de la historia literaria» (1971b: 7-8) .

La orientación pedagógica de las investigaciones restianas están en cierta consonancia con la perspectiva de «materialismo cultural» sobre la que, por esos mismos años, trabaja Raymond Williams. ${ }^{259}$ Se afirma en la convicción de que la producción literaria, «cualesquiera sean sus características, entraña una dialéctica entre la autonomía del mundo imaginario y su dependencia con respecto al ámbito circundante en el que fue concebido». Rest asume que incluso la configuración formal de los géneros está ligada a un conjunto de factores y fuerzas culturales que remiten tanto al «momento histórico en el que fue elaborada», como al que configura «la óptica con que el lector o espectador encara la obra de arte. Ese doble condicionamiento cultural es inevitable puesto que -como bien apunta Rest- «la visión de todo individuo está sujeta a un horizonte ideológico, a una concepción de la realidad, cuya importancia es decisiva tanto en la elaboración como en la recepción de la obra de arte» (1971b: 8). Se aparta de toda complacencia con los mitos de la «excepcionalidad» -dejando en claro que «Dante estuvo profundamente comprometido con las contiendas de su época», que «Villón no desdeñó a los seres mar-

259 Cfr. Williams, R., "Base y superestructura en la teoría cultural marxista", en New Left Review, noviembre-diciembre de 1973 (compilado en Cultura y materialismo, Buenos Aires, La Marca, 2012. pp. 50-71). 
ginados que padecieron a su lado» y que «Shakespeare y Lope de Vega no ignoraron las predilecciones populares en materia dramática que tenían vigencia entre sus contemporáneos»- y ensaya cuidadosas explicaciones no metafísicas y no subjetivistas de las mutaciones en las prácticas culturales y géneros emergentes.

Rest se apoya en una afirmación de Ezra Pound para sostener la idea de que el crítico literario debe discriminar el valor de cada composición reconociendo ese doble condicionamiento, ya que su «función» radica, no en «inducir al lector a leer libros indiscriminadamente», sino en facilitarle la selección permitiéndole «leer menos con mayor provecho». De ese modo, los trabajos de Rest se inscriben en un proyecto crítico que se afianza contra todo esoterismo. No se proponen -como apunta Rest-exponer hipótesis novedosas o intrincadas, sino más bien aproximar a los lectores a un conjunto de problemáticas que contribuyen a una comprensión global de los fenómenos literarios en la compleja trama de la historia cultural.

Los tres rigurosos estudios que componen el libro están dedicados a la definición e historia de cada género. Rest proporciona un enfoque orgánico, fuertemente documentado y generoso con el lector, que hace especial hincapié en su relación con el contexto cultural, social e histórico. Plantea con suma agudeza -haciendo pie en Teoría del arte de vanguardia de Renato Poggioli, a quien referencia como bibliografía fundamental en Conceptos de literatura moderna- las coordenadas precisas donde es posible reconocer las zonas de crisis que dan lugar a transformaciones y posibilidades para las nuevas experiencias de la literatura moderna. Y, 
finalmente, termina por corroborar que -en consonancia con los propios conceptos de "literatura" y "realidad"- la configuración formal de los géneros literarios es eminentemente dinámica y está siempre doblemente determinada, tanto por las formas culturales residuales como por las formas culturales emergentes.

Como Georg Luckács y Theodor Adorno, Rest lee el proceso de apogeo de la novela moderna con el de la burguesía como clase dominante. Reconoce que uno de sus rasgos fundamentales es «su estrecho y constante vínculo con la realidad social», casi a la manera de un mapa que traduce «una proyección verbal e imaginaria de la sociedad». Se trata -apunta Rest- de una evocación verbal, porque «no expone presentativamente -como el teatro, el cine y la pintura- las condiciones o las situaciones humanas, sino que las refiere discursivamente a través de descripciones»; pero, a la vez, es una producción imaginaria porque su nudo anecdótico no necesariamente se concentra en sucesos históricos verdaderos sino en «episodios ficticios de que resultan verosímiles» (1971b: 2223). Pero, como bien apunta el crítico, su coincidencia con el afianzamiento de la sociedad burguesa en su carácter capitalista y moderno -cuyo auge se caracteriza por la expansión económica, la elevación del índice de alfabetización, el desarrollo comercial, la decadencia de la manufactura artesanal por el impacto de la producción industrial, la reconfiguración del régimen de propiedad y la conformación moderna de las clases sociales- no pone de manifiesto una actitud conformista, sino más bien eminentemente crítica» respecto de su propio contexto social (1971b: 27). Y es este gesto crítico dispuesto en la evocación de sus mundos 
imaginarios el que termina por agotar el modelo clásico del género que entra en crisis justo en el momento en que la burguesía francesa parece cerrar su ciclo.

La «actitud liberal y empírica» de la burguesía llegó a establecer «un sistema objetivo y universal»-sobre cuyo andamiaje la novela construye el verosímil de sus mundos imaginarios- pero, una vez impuesto, este ordenamiento entra en una crisis que rápidamente repercute en la novela. La imagen tradicional del género -escribe Rest siguiendo a Northrop Frye- se convirtió de ese modo en «una anticuada interpretación ptolemaica cuya vigencia había caducado por obra de la revolución copernicana» (1971b: 48). La narrativa en general -y en particular la novela- se transforma en virtud de dos factores fundamentales: en primer lugar, «una alteración decisiva de las condiciones sociales que estaban relacionadas con el realismo propio de la novela burguesa»-consecuencia de la «repercusión de las guerras mundiales, los cambios estructurales de la sociedad, la desintegración de las pautas morales establecidas» y la incorporación de técnicas narrativas provenientes de la psicología, la ciencia y la sociología-; y, en segundo lugar, «por la irrupción de procedimientos formales y expresivos renovadores» -surgidos al interior de «las nuevas corrientes estéticas y filosóficas: simbolismo, superrealismo, impresionismo, existencialismo, fenomenología husserliana» (1971b: 48-49). Y con relación a eso se orientan las dos direcciones en que se resuelve la evolución del género: por un lado, «hacia la desintegración del individuo (Musil) y hacia la comprobación de que el fondo histórico de la novela tradicional ha invadido el 
primer plano imaginario (Malraux)»; y, por otro, «hacia una revolución estética no desprovista de la perturbadora sensación de que los viejos esquemas se disgregan (Joyce, Virginia Woolf, Faulkner, Robbe-Grillet, Claude Simon)» (1971b: 49). Rest sostiene que el narrador moderno debe afrontar «condiciones de extremada complejidad»y es por eso que no puede producir una imagen ordenada de la "realidad", tal y como se presentaba en la novela tradicional. Pero acaso lo que resulta más transgresor en el recorrido planteado por Rest es su convicción en que, si el género tradicional parece acercarse a su extinción, el hecho coincide no casualmente- con el advenimiento de «nuevas formas narrativas que ya van en camino de suplantarla y que aparentemente están destinadas a diversificar y enriquecer el respectivo campo poético». En este punto cabe subrayar su apuesta sobre la posibilidad de que el cinematógrafo sea el «legítimo heredero de la novela» por su variedad de recursos técnicos y por su capacidad para producir significaciones en virtud a su poder de verosimilización. De ese modo, Rest apuesta por la transformación dinámica de los géneros al reconocer que, aunque la capacidad poética de un género llegue a agotarse -como alguna vez se agotaron la épica popular y el roman courtois-, ello no significa necesariamente el fin de la narrativa, sino más bien «el principio de nuevos procedimientos»y nuevas modalidades de experiencia cultural.

El tratamiento que en el libro se realiza en torno al cuento sigue la misma línea de trabajo. Rest subraya la especial «sutileza expositiva» del cuento moderno -para evitar la «expresión directa y brutal»- que, a su vez, demanda -pero también da cuenta 
de- «un mayor refinamiento en la sensibilidad del lector» (1971b: 105). Ese refinamiento supone una íntegra transformación de la concepción de la realidad a partir de un abandono gradual del «enfoque basado en una noción empírico racionalista del mundo y en una afirmación de la individualidad». Puestas en abierta discusión la solidez del mundo y la exaltación de la individualidad en el régimen de la ficción, se produce un repliegue: la literatura no ataca necesariamente estos conceptos, sino que «simplemente los omite, los ignora». En contraposición -apunta Rest-, en vez de narrar hechos significativos por sí solos, el cuento moderno apunta a recrear una suerte de "clima mental" o «una atmósfera en la que los acontecimientos pueden parecer ínfimos pero se cargan de sentido por la circunstancia de vincularse entre sí hasta formar una trama tenue, una suerte de telaraña que constituye la realidad y el destino» (1971b: 106).

Rest define la particular dinámica del cuento -como género literario original y autónomo- hasta su configuración moderna sobre tres etapas principales: 1) «un entronque con el pasado, con la tradición -especialmente medieval- del relato folklórico»; 2) la «estructuración gradual de una nueva forma cuentística, destinada a captar una realidad evanescente y a darle una apariencia de solidez» -punto en el que gravita la preceptiva de Poe-; y 3) una ruptura con el «excesivo formalismo» impuesto por los decálogos con el objeto de ampliar su horizonte estético y «registrar episodios aún más escurridizos, mucho más cotidianos y decididamente elementales» (1971b: 107). Lo mismo ocurre en sus indagaciones sobre el teatro, donde la dinámica del género en la moder- 
nidad se desenvuelve a través de una polaridad notable: por una parte, se encuentra el «nuevo realismo», indeclinable en «su actitud combativa destinada a colaborar en la transformación de la sociedad»; y por otra, el teatro del absurdo, aferrado a «su pesimista visión de un mundo en el que ya no parece existir lenguaje o comunicación posible» (1971b: 155). Rest plantea una solución sintética entre esas dos corrientes estableciendo los cruces y las posibilidades de conjunción de esas fuerzas dramáticas en apariencia contradictorias. Observa, por ejemplo, que en el teatro de Bernard Shaw y de Bertolt Brecht es fundamental el ejercicio de la exageración - «hasta el disparate»- de determinadas situaciones para «intensificar el enjuiciamiento de la sociedad»; y no deja de mencionar que tanto en Luigi Pirandello, como en Eugène Ionesco y en Samuel Beckett es perceptible una importante dosis de realismo «en la medida en que reflejan con incontrovertible maestría poética la quiebra de esquemas cuyo agotamiento se torna evidente a través del absurdo o de la incomunicación humana»-lo que, como bien apunta Rest, es también un enjuiciamiento de la incapacidad del lenguaje para hacer inteligibles circunstancias sociales nuevas. En la búsqueda de esa síntesis de elementos realistas y absurdos, Rest rescata la triple estructuración diagramada por Edward Albee en The Zoo Story y subraya especialmente la lúcida actitud de Max Frisch y Friedrich Dürrenmatt, cuyas parábolas escénicas «no son ajenas a lo que Brecht consideraba "teatro de instrucción", pero sin desdeñar la utilización didáctica de lo insólito y lo disparatado» (1971b: 156). No obstante, como apuesta más ambiciosa y significativa en ese movi- 
miento sintético de conciliación del realismo crítico y la poética del absurdo, Rest señala a Peter Weiss y a su «complejo y valioso experimento dramático conocido como Marat/Sade». En esa pieza reconoce, no sólo los típicos artificios reflexivos de Shakespeare definidos como «teatro en el teatro» -antes estudiados con relación a Hamlet-, sino también un «giro pirandelliano» a partir de ese final en que uno de los personajes increpa directamente al público - señalándoles su incomprensión de la obra- borrando prácticamente los límites entre la escena de ficción y la "realidad". En ese drama singular, Rest reconoce la articulación eficaz de los dos niveles que se potencian más aún en función del contexto en que se pone en escena. La riqueza específica de Marat-Sade está pues en esa doble articulación, ya que -como apunta el crítico- «el drama tiene un nivel realista y político, referente a las circunstancias que intervienen en la muerte de un gobernante con ideas renovadoras»-Rest señala aquí la coincidencia cronológica del asesinato de John Fitzgerald Kennedy y la reelaboración definitiva del texto de Weiss (1963)-y, por otro lado, exhibe «una dimensión afín al "teatro del absurdo", que incluye flagelaciones (como las de Jean Genet), reclusos de un hospicio y reiteradas confusiones entre el ámbito imaginario y el mundo real» (1971b: 157).

La apuesta reflexiva sobre la dinámica de los géneros es claramente perceptible también en "Panorama del ensayo", un artículo aparecido en forma de fascículo en la colección capítulo del 
$\mathrm{CEAL}^{260}$. El trabajo -que acompañaba la entrega de una edición pocket de El juicio del siglo de Joaquín V. González, cuyo prefacio también estaba a cargo de Rest- constituye sin dudas una versión resumida de las investigaciones que el crítico proyectaba desplegar en El cuarto en el recoveco, cuyo boceto -organizado años después por Virginia Erhart- apareció publicado por CEAL en 1982. El texto está diagramado sobre un esquema de exploración descriptiva que parte del reconocimiento de las dificultades para circunscribir las características del género. Señala de antemano que tal caracterización sólo puede conseguirse merced a «un sacrificio de sus variedades o el olvido intencional de que dentro de un cuadro homogéneo hay infinidad de excepciones y desviaciones» (1979h: 97). Inscribe al ensayo como una prosa de ideas provisionales de naturaleza artística y marca el carácter subjetivo de sus afirmaciones desde su advenimiento, a fines del siglo XVI, cuando Montaigne utilizó por primera vez la denominación, y que apareció quizá como una alternativa a la prosa científica que empezaba a crecer con el avance del pensamiento moderno. Es claro que, tanto por el carácter subjetivo de su punto de vista como por la condición casi íntima de su validez, el ensayo «constituye la otra manera de exponer ideas, la que no se articula con la minuciosa comprobación y verificación, la que otorga más importancia a los atractivos de la presentación poética que a la validez de los juicios enunciados» (1979h: 97) ${ }^{261}$. Pese a sus diferencias de tono y la actitud, tanto Michel de Montaigne como Francis Ba-

\footnotetext{
260 Rest, J., "Panorama del ensayo", Capítulo, La historia de la literatura argentina, 5, Buenos Aires: CEAL, 1979.

261 Subrayado en el original.
} 
con son -a juicio de Rest- los que concretaron la efectiva instauración del género y el reconocimiento moderno de su importancia y singularidad. Pero las múltiples modalidades que va a adoptar dicho género también lo exhiben como una forma dinámica y estrictamente condicionada por su contexto de emergencia y recepción.

Como Adorno, Rest se interesa particularmente por el ensayo porque es la forma de la emergencia, porque su objeto es «lo nuevo en tanto nuevo» (Adorno 2009: 32), esto es, lo desconocido -lo no retraducible a lo viejo de las formas existentes. Pero además porque establece con ese objeto extraño una forma de relación no violenta, en tanto supone un experiencia de escritura que da lugar a un desarrollo de los pensamientos que difiere de la lógica discursiva -porque no se produce ni por inferencia ni por deducción sino que coordina los elementos lógicos en lugar de subordinarlos. Rest se interesa pues por el ensayo precisamente por su carácter híbrido y por su condición dinámica: es decir, por un lado, por el hecho de que, como nota Lukács, es una forma que «sigue hasta ahora sin haber todavía cubierto el camino de autonomización que su hermana, la poesía, hace ya tiempo que ha recorrido: el de la evolución a partir de una unidad primitiva e indiferenciada con la ciencia, la moral y el arte» (Lukács 1975: 29); y, por otro, porque -como apunta Adorno- la versatilidad propia del género permite acoger «la flexibilidad del curso de los pensamientos del ensayista» y promueve la experiencia de una reflexividad -no exenta de intensidad- que se distingue particularmente de la expuesta en el pensamiento discursivo, puesto que 
«el ensayo no procede, como éste, ciega y automáticamente, sino que a cada instante tiene que reflexionar sobre sí mismo» (Adorno 2009: 33).

Rest se demora en subrayar el carácter menor e incluso ancilar atribuido al género en Europa respecto de las «formas "mayores" de la literatura, que corresponden a la actividad imaginativa más bien que a la exposición deliberada de ideas y que incluyen la ficción, el drama y la poesía» (1979h: 98). El gesto no es arbitrario. Rest busca contrastar ese hecho con el caso diametralmente opuesto de Hispanoamérica, donde «la literatura no parece haber nacido de la imaginación sino de la formulación de ideas», «la polémica y la confrontación de opiniones» tal y como lo demuestran las obras de José Enrique Rodó, Alfonso Reyes, Ezequiel Martínez Estrada, Jorge Luis Borges y Octavio Paz entre otros. Rest liga este hecho particular a su función específica en un contexto fundacional, donde las contiendas y el activo enfrentamiento ideológico -tanto en las letras como en la política- se canalizaron a través de una vasta producción ensayística, cuya vigencia deriva de su particular fuerza de convicción. La relevancia excepcional del ensayo argentino «desde los orígenes mismos de la nacionalidad» -relevancia que le ha deparado una posición fundamental en el cuadro de la cultura y ha gravitado en multitud de aspectos del pensamiento y de la acción- radica en su disposición a «interpretar las características de la sociedad, formas del comportamiento y ciertos rasgos observados en la vida cultural del país» (1979h: 99). Rest recorre pues la dinámica deriva del género señalando puntualmente los momentos de transfor- 
mación a partir de sus condicionamientos históricos: desde los iniciales intentos revolucionarios hasta los primeros exámenes de la realidad nacional en formación -originalmente ligados al periodismo- y al ciclo de formulaciones ontológicas -que a través de las formulaciones de Domingo F. Sarmiento, Joaquín V. González, Ezequiel Martínez Estrada, Eduardo Mallea, Ricardo Rojas y Leopoldo Lugones se orientaba a reflexionar sobre el desarrollo de la comunidad y el tipo de organización institucional que se supone más apropiado para asegurar la consolidación y el progreso de la vida nacional-, el artículo de costumbres y crítica moral surgidos a partir de la consolidación de la vida urbana y entre cuyos representantes figuran Fray Mocho, Roberto J. Payró, Mariano José de Larra y Roberto Arlt-, al ensayo especulativo que se produce en el deslinde de ficción y crítica literaria a partir de las inquisiciones de Jorge Luis Borges.

Rest no desconoce que en la Argentina ningún otro aspecto del ensayo exhibe tanta riqueza como la serie orientada a esbozar una interpretación de la realidad social, política y cultural. Al contrario: señala que su importancia es tal que sobre ella se dispone «uno de los troncos principales de nuestro desarrollo literario» (1979h: 114). La dinámica del género se ve así favorecida por el estímulo de contribuciones teóricas de la sociología, la psicología y los estudios literarios sin que el objetivo de producir una manifiesta significación política deje de constituir el centro de la intervención ensayística. Reconoce el «proceso de ruptura» examinado por Emir Rodríguez Monegal en El juicio de los 
parricidas $(1956)^{262}$ y reconoce el valor del cuestionamiento que en la década de 1950 se desató contra la hegemonía de «la generación precedente encabezada por Borges, Martínez Estrada y Mallea» (1971h: 113). Define el gesto como una «especie de sublevación»de la que fue víctima incluso H. A. Murena- que hizo del ensayo un espacio de relación entre cultura, literatura y nación. La reivindicación de nombres como los de David Viñas, Adolfo Prieto, Juan José Sebreli, Noé Jitrik y Tulio Halperín Donghi viene de alguna manera a atemperar el juicio sobre los contornistas vertido -casi veinte años antes- en Cuatro hipótesis de la Argentina (1960). No obstante ello, sostiene su afinidad y admiración por aquellas «figuras que han desechado el tono polémico y han buscado respuestas de mayor equilibrio» (1971h: 114), como Bernardo Canal Feijóo, José Luis Romero, Juan Carlos Mastronardi y el Jorge Luis Borges de "El escritor argentino y la tradición", cuyas opiniones considera fundamentales para todo debate centrado en los vínculos entre literatura y nación.

Sin embargo, Rest reconoce además la existencia de otras orientaciones del ensayo entre las que no duda en destacar la del artículo de costumbres y que la compromete a los estudios especulativos sobre literatura, filosofía y otras disciplinas. Sobre esta última dirección Rest se detiene especialmente, como si tratara de demarcar el espacio de inscripción de su propia práctica crítica, con la intención de definir el lugar y la relación de una escritura especificada por su objeto con una forma caracteri-

262 Rodríguez Monegal, E., El juicio de los parricidas. La nueva generación argentina y sus maestros, Deucalión. Buenos Aires, 1956. 
zada por su voluntad de problematicidad e intervención en el campo cultural. Busca dar cuenta de aquellas experiencias en que «el objeto del ensayo es, por excelencia, la crítica literaria o la exposición de ideas, especialmente aquellas que poseen interés en el campo del arte y de las humanidades» (1971h: 118). Como virtudes de esta especie de ensayismo -en el que parece inscribir su propia «ficción crítica»-, Rest señala el hecho de una doble exigencia, que neutraliza cualquier jerarquización reductiva entre forma y contenido: «el ensayista -escribe- se preocupa tanto por las cualidades y perfección de su prosa cuanto por la solidez y coherencia de sus argumentos» (1971h: 118). De ese modo, su propia articulación se produce en la «tenue y escurridiza frontera que separa la actividad del ensayista de la práctica del investigador O erudito» (1971h: 118). Y es precisamente en este punto donde Rest marca también una clara distancia de la retórica institucionalizada, al afirmar que en el ensayo coinciden la informalidad en los juicios y la formalización en el modo expositivo «por contraste con los trabajos académicos y las tesis universitarias que no reclaman belleza de construcción sino validez demostrativa» (1971h: 118).

En el marco de esta tradición ensayística Rest rescata la «indagación filológica» iniciada por Amado Alonso y continuada por María Rosa Lida de Malkiel, Raimundo Lida y Ana María Barrenechea, la «orientación nacionalista» de Ricardo Rojas, Antonio Pagés Larraya e Ismael Moya, la «investigación folklórica» de Juan Alfonso Carrizo, Augusto Raúl Cortázar y Susana Chertudi, y las contribuciones individuales de Pedro Henríquez Ureña, Juan 
Carlos Ghiano, Enrique Anderson Imbert, Guillermo Ara, Luis Emilio Soto, Arturo Marasso, Ángel J. Batistessa y Raúl H. Castagnino. Subraya las contribuciones en el área de los «estudios filosóficos» abierta por José Ingenieros y Alejandro Korn, y proseguida por Luis Juan Guerrero, Francisco Romero, Carlos Astrada y Vicente Fatone. Y también en las áreas de las artes plásticas y la música, donde sobresalen Julio E. Payró y Juan Carlos Paz, respectivamente. Pero deja especialmente claro que -a su juiciola línea del ensayo literario más acorde con la doble exigencia señalada anteriormente «ha de buscarse no en las aulas o claustros sino principalmente en las revistas literarias», donde se cuenta con una escucha no especializada y donde la enunciación puede prescindir de los efectos de la jerga académica (1971h: 118) .

Rest inscribe su propio trabajo en ese «cuarto en el recoveco» en que «se amontonan en completo desorden nuevos materiales de la especie más dispar, habitualmente marginados y descuidados por los críticos y estudiosos» (1982: 13). Se trata, sin dudas, de un espacio dinámico pero también éxtimo -una dimensión superlativa de lo exter (extraño, extranjero, exterior), capaz de configurar un margen que, paradójicamente, altera las fronteras entre lo externo y lo interno-; lo que le permite definir una articulación relativa, de pertenencia y no de reducción a las formas institucionales de la crítica y la literatura. El «ensayo especulativo» es el horizonte genérico de tal inscripción: el cuarto propio. Es por eso que, como ejemplos de un contexto propicio para esta particular disposición ensayística Rest subraya la «rele- 
vancia singular» de revistas literarias como Nosotros (creada por Roberto F. Giusti) y Sur (dirigida por Victoria Ocampo). Se trata de espacios definidos por su «disposición cosmopolita», es decir, por su resistencia a diversos modos de chauvinismo y por haber funcionado «como instrumentos de contacto con la realidad artística y cultural del mundo contemporáneo» (1982: 74). La importancia de la perspectiva cosmopolita es -en la óptica restiana- determinante en el desarrollo del ensayo especulativo, el ensayo de crítica literaria y de exposición filosófica, ya que muchos de ellos empezaron teniendo por objetivo «incorporar a nuestra vida cultural aportes de distinta procedencia como herramientas útiles de nuestra propia conciencia intelectual» (1982: 75).

Rest señala la importancia decisiva de autores como Luis Juan Guerrero y Roberto Giusti en la línea de un ensayo cuyo origen puede ser remontado hasta Juan María Gutiérrez (1809-1878), quien en Cartas de un porteño -al igual que Sarmiento y Alberdi- defendió la autonomía de la lengua hablada cotidianamente y se opuso a la injerencia española en la tradición poética nacional. Apunta que los tres volúmenes que componen la obra filosófica de Guerrero encuentran su singular valor en la manera en que resuelve dialécticamente «el viejo conflicto entre autonomía y función social del hecho poético», reconociendo la especificidad de las formas creativas y el influjo que, a su vez, el mundo ejerce sobre ellas. Y remarca la importancia de «la labor difusora y esclarecedora» de Giusti en lo referente a ciertos procesos y figuras determinantes de la literatura europea. Pero, como punto culminante de una lista que incluye a Martín García Mérou, Pedro Goye- 
na, Paul Groussac, Calixto Oyuela, Emilio Becher, Rafael Alberto Arrieta, Arturo Capdevila, Pablo Rojas Paz, Fryda Schultz de Mantovani, Eduardo Mallea y Carlos Mastronardi, Rest sitúa la presencia de Borges. El autor de Otras inquisiciones (1952) es sin duda la figura excluyente del ensayo especulativo, puesto que fue él el que «confirió a esta práctica una verdadera trascendencia artística, poniéndola en un pie de igualdad con la poesía o la ficción» (1971h: 119). Ese mismo rango es el que Rest desea para su «ficción crítica»: una colocación no necesariamente subsidiaria respecto de otras series discursivas, sostenida en una interrogación filosófica de sus objetos, legitimada en su disposición francamente imaginativa y articulada sobre una doble exigencia que implica un refinamiento formal tanto en la materia de sus enunciados como en la de su propia enunciación: esto es, «la crítica considerada como una de las bellas artes» (Rosa 1981: 374).

Rest retoma la tesis fundamental de El laberinto del universo (1976a) y sostiene que, sin ser un saussuriano, el pensamiento de Borges se halla en perfecta sintonía con el de las reflexiones teóricas del estructuralismo. A su juicio, Borges es «heredero de la tradición nominalista que se ha desarrollado en el pensamiento moderno a través del empirismo, el positivismo y la filosofía de análisis lógico» (1982: 77), cuyo representante en el campo de la lingüística es precisamente Ferdinand de Saussure. Este último mediante la sistematización de sus cursos realizada por sus discípulos y alumnos-, plantea que todo signo establece «la relación entre una imagen acústica significante y un concepto significativo; es decir, lo que una palabra menta es una idea, no una cosa; 
por ende, la realidad está fuera del lenguaje» (1982: 77-78). Por su parte, el objetivo de muchos de los ensayos de Borges consiste justamente en «demostrar que la verdad está excluida de las posibilidades humanas porque el hombre se maneja con ideas y no con realidades». Rest cita el ejemplo de "El idioma analítico de John Wilkins" para confirmar la intención borgeana de plantear que todo organización de la realidad y todo intento de interpretación derivada o vehiculizada en instrumentos lingüísticos «es necesariamente falsa porque jamás podrá ser verificada, ya que las palabras y las cosas pertenecen a dos órdenes distintos y nunca podrán ser traducidas unas a otras» (1982: 78). La ubicación de Borges en el cuadro general del pensamiento contemporáneo lleva al crítico a subrayar su parentesco con las reflexiones teóricas de Saussure, Wittgenstein y Foucault. Pero además le permite establecer su contribución particular en la distinción de dos categorías de conocimiento: la operativa y la verdadera. Con relación a la «categoría operativa», Borges tiene una posición indiferente e incluso la admite -al señalar que «nada impide que nos manejemos en un mundo con conocimiento operativo, que de ningún modo nos permite saber si el principio rector es la materia o la idea» (1982: 78). Respecto del «conocimiento verdadero», en cambio, Borges presenta -en la perspectiva de Rest- un escepticismo declarado: «todas las formulaciones metafísicas, sean de extracción materialista o idealista, no son admisibles; no son conocimientos valederos sino actos de fe en modo alguno verificables». Como todas las doctrinas se apoyan en algún acto de fe, las demostraciones metafísicas se manifiestan morfológicamente a la manera de 
argumentos policiales: «se elige un desenlace y se procede a construir una rigurosa y articulada demostración de que ese desenlace puede ser verificado» (1982: 79). Si tanto el idealismo como el materialismo son falacias -porque el hombre se mueve en la ilusión de que el lenguaje «funciona como una mera asíntota de la realidad que jamás podrá sustituir al hecho individual y concreto por medio de sus interpretaciones generales y abstractas» (1982: 79)- lo son precisamente porque creen en una gnoseología que trata de exceder la mera operatividad. En consecuencia, «para Borges, la metafísica es una de las más resplandecientes exhibiciones que ha hecho la literatura fantástica en el curso de la historia» (1882: 79) .

En síntesis, Rest resume la perspectiva de Borges en el deslinde entre un conocimiento operativo que sólo tiene utilidad pragmática y, más allá de éste, un espacio discursivo abierto que excede esa operatividad- y cuyo valor se apoya en un «acto de fe». Cuando este «acto de fe» no se sostiene más que provisionalmente -para usar la borgeana frase de Coleridge, como eventual "suspensión de la incredulidad"- las formulaciones caen indefectiblemente en el ámbito de la ficción, donde la literatura tiene la ventaja de admitir, desde su propio fundamento, su carácter de no verdad: la literatura sabe que miente cuando miente pero también sabe que miente cuando dice la verdad. El ensayo especulativo -ya se despliegue sobre el terreno de la filosofía, la religión, el arte o la ciencia- se inscribe en el ámbito inventivo de los mundos de la imaginación. La «ficción crítica» restiana reconoce pues su propia soberanía y su condición creativa en la nive- 
lación que propone la propia perspectiva borgeana, que volatiliza todo intento de jerarquización interdiscursiva y toda organización del lenguaje a partir del lenguaje mismo.

Esta serie de trabajos desarrollados por Rest para Centro Editor de América Latina se propone fundamentalmente dar cuenta de que la dinámica de los géneros se deriva de la dinámica social, de la irrupción de formas nuevas que la cultura alumbra desde sus zonas más marginales. La repercusión de estos trabajos se percibe, en efecto, en la orientación y en el foco de atracción de los trabajos publicados por Rest en esta época. La cultura de masas aparece iluminando nuevas formas de producción cultural o incluso modificando la tendencia de las producciones artísticas provenientes de la "alta cultura". Rest se interesa -como se ha visto en las páginas precedentes- por el modo en que el auge del policial promueve transformaciones en la novela clásica. Pero también percibe en la emergencia de otras nuevas formas y experiencias culturales la presencia de nuevos relatos o nuevas versiones de antiguos relatos producidos en los bordes de una sociedad en plena ebullición. Un ejemplo de ello, es su singular vindicación del trabajo del historietista Jules Ralph Feiffer a quien -apoyándose en las ideas de Oscar Steimberg en Leyendo historietas- en el último texto entregado a la revista Punto de vista antes de su muerte, Rest compara con Quino y reivindica como intelectual en razón de la raíz política, sociológica y filosófica de su humorismo crítico: a su juicio, Feiffer desenmascara «la falsedad a la que se apela para ocultar el vacío mediante el uso de clisés culturales» en «un mundo que todos conocemos demasiado 
bien pero que sólo unos pocos -incluido Feiffer- se atreven a denunciar con apropiado enjuiciamiento», poniendo el humorismo no al servicio del entretenimiento sino al de la crítica: proponiendo «una reflexión despectiva de las debilidades del presente» sin por ello ceder ingenuamente a la ilusión de «la utopía de un cambio indispensable» y a la espera de un necesario «mundo mejor en el futuro» $(1979 \mathrm{k})^{263}$.

Otro ejemplo de esta particular disposición crítica es su "Relectura de Tolstói" (1978a) ${ }^{264}$, aparecida también en Punto de Vista un año antes, donde Rest aprovecha el sesquicentenario del nacimiento de Lev Nikoláyevich Tolstói como excusa oportuna para ensayar en torno a las posibilidades y límites del relato como género. El texto resume las proposiciones centrales de la "Introducción" ${ }^{265}$ a una selección de relatos del escritor ruso -que, en sobria traducción de Galina Tolmacheva, había aparecido en 1977 bajo el sello de Ediciones Librerías Fausto- y es una prueba tangible de la coherencia que caracteriza esta última etapa del proyecto crítico restiano. El texto se inscribe en esa serie de trabajos que tiene por objeto interrogar los modos de producción de sentido a través del dominio, la conciencia y la puesta en práctica de complejos procedimientos narrativos. Rest trabaja desmontando esos procedimientos, descubriendo sus operaciones, subrayando su artificio sobre todo en aquellos momentos en que se pretenden naturalizados en el horizonte de la cultura. Con economía

263 Rest, J., "Jules Feiffer: un Aristófanes de la sociedad de consumo" (1979k), Buenos Aires, Punto de vista, año II/ $N^{\circ} 7 /$ noviembre. pp. 28-29. 264 Rest, J., "Relectura de Tolstoi" (1978a). Buenos Aires: Punto de Vista, año I/ $\mathrm{N}^{\circ} 4 /$ Buenos Aires, noviembre. p. 13.

265 Cfr. Tolstói, L., La muerte de Iván Ilich y otras narraciones, Buenos Aires, Ediciones Librerías Fausto, 1977. 
inglesa -en apenas dos páginas- ensaya una recuperación de Tolstói, no ya como uno de los fundamentales cultores de la novela del siglo XIX, con los ejemplos memorables de Guerra y Paz (18651869), Ana Karénina (1875-1877) y Resurrección (1899); sino, al contrario, por su modernidad literaria. Reconoce en esos textos una auténtica "consciencia de sí" del género novelesco -una conciencia que es, al mismo tiempo, una conciencia de sus potencias y de sus límites-, por su carácter precursor de algunas de las más intensas experiencias narrativas del alto modernismo surgido en la primera mitad del siglo xx. El poder evocativo del texto sólo es estimable en función de su contexto de aparición: es 1978 y se respira un aire de triunfalismo heroico promovido por el monumental despliegue de un relato épico nacionalista, construido y difundido por la última dictadura militar alrededor del Mundial de Fútbol "Argentina '78", pero consentido, aprobado y hasta cierto punto celebrado por una porción no menor de la sociedad argentina. Rest -que, vale la pena recordarlo, viene de sufrir repetidas amenazas de la Triple A durante el gobierno de Isabel Martínez de Perón, y que ha soportado en 1976 no sólo la prohibición de Tres autores prohibidos sino también un procesamiento por "Actividades subversivas" bajo la Ley 20.840- plantea en ese contexto su abierta desconfianza respecto de los "relatos legitimados" y "consagrados" -sobre todo porque sospecha precisamente de sus modos de legitimación. Propone leer los «otros relatos», aquellos en los que late una «incisiva disección de una sociedad en la que el encubrimiento y la simulación se han convertido en exitosos sucedáneos de autenticidad moral y de espíritu crítico» 
(1978a: 13). Es allí donde -a juicio del crítico- se revela el carácter artificial de los relatos sociales en general y donde es posible poner en cuestión aquellos casos en que la monumentalidad se rige por una preceptiva naturalizada -a partir de la cual los relatos se establecen, no sólo como posibles, sino también como efectivos y como deseados. Frente a los relatos que extraen su valor de la extenuada repetición del relato monumental de la cultura y no de su actualidad o su potencia para producir sentidos nuevos, Rest propone pensar a Tolstói a partir de una multiplicidad de los relatos "menores" - de algún modo marginados en favor de los relatos "espectaculares" legitimados- que mantienen -como diría Deleuze- un linaje subterráneo con experiencias narrativas como las de Michel Butor, Alain Robbe-Grillet o Samuel Beckett. El ciclo de nouvelles y cuentos tolstoianos señalados por Rest como merecedores de una revisión crítica pasa por la vestisca (1856), La sonata a Kreutzer (1889), El diablo (póstumo, 1911), El padre Sergeii (1898) y La muerte de Iván Ilich (1886). En esos relatos "menores" de Tolstói sugiere «intentar una relectura de nuestros días», ya que son ésos y no los consagrados los que traducen más intensamente los signos de «nuestra plena actualidad». Siendo ellos mismos «modelos de concepción artística», revelan «otros niveles de significación» y en ese sentido traducen una «singular agudeza» a la hora de evocar un «enfoque de la existencia humana», cuya «vitalidad resulta sorprendente». Como el joven Barthes que -siguiendo la notación de Albert Thibaudet- recupera a los grandes Autores Clásicos a través de sus "obras-límite", aquellas en que ellos mismos han depositado (acaso inconsciente- 
mente) el secreto y la caricatura de su propia creación (como dejando entrever la obra aberrante que no escribieron y que acaso hubiesen deseado escribir), Rest se sale del canon tolstoiano y señala indirectamente hasta qué punto ese canon es un relato cuyo verosímil responde a una lógica histórica de lectura (que se articula sobre la "realidad" de los relatos sociales) y que coincide con intereses sostenidos sobre posiciones cristalizadas respecto de los relatos y sus lenguajes.

Usa a Borges para dejar en evidencia el carácter potencial de los relatos, aduciendo que se trata de textos nunca definitivos sino en la actualización que el lector hace de él a partir de la experiencia del mundo y la literatura. Restablece -a contrapelo de lo predictible- los vínculos formales entre las nouvelles tolstoianas y textos como Watt (1945), Molloy (1951) o El mirón (1955), La celosía (1957) o La modificación (1957). Imagina vasos comunicantes entre los textos tolstoianos y las técnicas narrativas exploradas por autores cuya obra se distingue por funcionar como negatividad radical respecto del texto de la Cultura. Subraya el artificio de la formulación "objetiva" de los sucesos presentes/ausentes en los relatos, los recursos a un narrador protagonista "innominado" - «la mágica incertidumbre de lo desconocido»-, «el efecto calidoscópico de la historia» presentada o sesgada en el relato - «los trineos que aparecen y desaparecen en medio de la tormenta»- y la construcción fragmentaria del relato en que están deliberadamente excluidas las «explicaciones iniciales y finales acerca de la procedencia, destino y propósito de la historia» (1978a: 14). Pero, vista retrospectivamente, lo más im- 
pactante de la nota en cuestión es la lectura restiana de La muerte de Iván Ilich. La densidad que adquiere su reflexión sobre el acontecimiento de la muerte resulta destacable por su lucidez, su precisión y su deliberada ausencia de patetismo -gesto que aparece potenciado por la circunstancia personal del propio crítico, quien por esa época era consciente de que arrastraba una difícil enfermedad que acabaría por vencerlo apenas meses después de la aparición de esta nota. Si la exploración de la incertidumbre y el contrasentido planteados por el relato tolstoiano evocan -para Rest- a autores posteriores como Franz Kafka o Albert Camus, la forma en que la narración examina el advenimiento de la muerte no busca «consolar al lector con simplificaciones fáciles - vanamente alentadoras»; al contrario: la muerte aparece retratada como «un enigma irremediable», «un deslumbramiento en que naufraga cualquier esperanza que se abrigue, convertida en desesperado manoteo en el vacío» (1978a: 14). Lo que Tolstói pone al descubierto es la inutilidad y la vanidad de «promesas o vindicaciones de especie alguna» cuando se esbozan al momento de ese «salto al abismo» que entraña el fin de toda existencia. La posición de Rest es clara y concreta: cuanto se ha escrito respecto del enigma de la muerte no llega más que al umbral señalado por Tolstói en ese relato. En esa certeza se apoya su afirmación de que ningún otro texto «exhibe tal lucidez y precisión al evocar el desamparo que circunda tantos afanes, nada habla en términos tan inequívocos del absurdo en que transcurre esta agitada espera que denominamos vida» (1978a: 14). 
En resumen, Rest presenta un Tolstói crítico y ciertamente problematizador del modo clásico y hegemónico de producción del relato. Lo reivindica por estos textos "menores", que proponen un quiebre de la visión unilateral, homogénea y espectacular de la historia (contenida en el relato) y cuestionan radicalmente toda "objetividad" supuesta, todo privilegio y toda inocencia en el punto de vista -señalando su artificio a partir de un modelo de relato que, deliberadamente, se sustrae a las miserias de la explicación porque reconoce su carácter potencial y el lugar activo del lector a la hora de su actualización. Al igual que Tolstói, Rest deja entrever que ni en la literatura ni en la sociedad hay relatos inocentes. Al contrario: cada uno guarda -cual carta robada- su propia verdad. En lo que a la literatura respecta, lo que parece desprenderse de la reivindicación formal y genéricamente marginal de los textos es que la verdad política de los relatos es su verdad estética. La verdad estética es pues una verdad formal, una verdad técnica, procedimental: la verdad del artificio. Su operatividad no se resuelve por la representación sino por evocación. Los relatos tolstoianos devuelven la imagen de un narrador comprometido con esa verdad política que atañe a su especificidad; un narrador que insta al lector a producir y actualizar el relato, desplazándolo de la posición pasiva en que los disponen los formateos y legitimaciones oficiales; un narrador que pone al lector en situación de producir sentidos y no meramente de aprehenderlos. 
Sin embargo, pese a la estructura descriptiva de su «plan inicial» ${ }^{266}$, El cuarto en el recoveco excede largamente los límites de la exploración genérica. Como ya anticipaba en Cuatro hipótesis de la Argentina (1960), el libro reafirma la acertada intuición restiana de que lo nacional de una cultura no es una esencia sino una construcción -que, como tal, compromete un tratamiento específico de la propia lengua. Prefigura en gran medida lo que constituye el nudo crítico de las últimas investigaciones. En ese sentido, más que las discusiones y problemas que comprometen al ensayo como género, lo que busca subrayar en Sarmiento, Lucio V. González, Ezequiel Martínez Estrada, Mafud, Mallea, Borges y Arlt es una suerte de "disposición ética" de la escritura que se manifiesta en el ensayo y que define su función por su destino social y sus modos de elección (política) en términos de moral de lenguaje $-y$ en este punto se articula coherentemente con textos como Notas para una estilística del arrabal (1965a) o en su conferencia sobre "Los narradores argentinos y la búsqueda de

\footnotetext{
${ }^{266}$ El índice provisional sobre el que Rest trabajaba bajo el nombre "Aspectos del ensayo argentino" define la fisonomía del proyecto centrándolo en cuatro secciones fundamentales: I. El ensayo entre la Organización nacional y la Generación del 80 [1. Significación general del ensayo; 2. Preeminencia del ensayo en la literatura argentina; 3. El Facundo de Sarmiento y su valor operativo en la organización del país; 4. Las consecuencias de la Organización nacional: Mansilla y el ensayismo del 80], II. El ensayo de interpretación nacional [1. El ensayo como instrumento definidor de los problemas nacionales; 2. Radiografía de la pampa de Martínez Estrada y las crisis del 30; 3. Evaluación de Martínez Estrada: alcances y límites del ensayo como instrumento de interpretación sociológical, III. El ensayo periodístico y la visión mitológica de Buenos Aires [1. Desarrollo y consolidación del periodismo en la Argentina; 2. El periodismo de Roberto Arlt: sus Aguafuertes porteñas; 3. Aspectos de la tradición mítica de Buenos Aires: la Relación parcial de Buenos Aires de Alberto Salas] y IV. La revista literaria y el advenimiento del ensayo especulativo [1. La revista literaria y su función cosmopolita; 2. La revista literaria en la Argentina: Nosotros y Sur; 3. El ensayo crítico y filosófico; 4. Borges y el ensayo especulativo]." (El cuarto en el recoveco, ed. cit. pp. 7-8.).
} 
un idioma nacional" $(1967 e)^{267}$. Los ensayos e hipótesis sobre "lo argentino" abordados por Rest en sus últimos trabajos se desplazan pues desde la trajinada dicotomía sarmientina y la profunda reflexión de Joaquín V. González sobre «las condiciones de nuestra identidad cultural» a las evocaciones de una imagen -la de un desgarramiento nacional trasfigurado en dolor personal y soledaden Martínez Estrada. Confrontan y examinan la irónica tesis cosmopolita de "El escritor argentino y la tradición" y las consideraciones arltianas sobre el idioma de los argentinos, el tango de Homero Manzi, y la búsqueda de una lengua nacional y popular emprendida por los escritores argentinos menos nacionalistas y menos populistas (de Echeverría a Cortázar). Se trata de ensayos que piensan y asumen la relación de la cultura y la literatura argentinas con lo "nacional" entendido como esa forma discursiva de lo colectivo que configura identidad y pertenencia, y permite pensar tradiciones y proyecciones. Como cada uno de los hilos de esa compleja trama en que se va configurando la siempre encomillada "nacionalidad" de la cultura, la propia ensayística restiana puede ser leída como un nuevo avatar en esa serie; pero también como la traducción del protocolo de experiencia de una insistente reflexión teórico-crítica -en torno al ensayo como género nacional-y, a la vez, ético-política -en torno a lo nacional como problema constitutivo del ensayo.

Con ciertos recaudos, un ensayo como Cuatro hipótesis de la Argentina (1960), por ejemplo, bien podría ser incluido en esa 267 "Los narradores argentinos y la búsqueda de un idioma nacional" (1967e), conferencia escrita y leída en las "Segundas Jornadas de Métodos de Investigación de enseñanza de la Historia y de la Literatura Rioplatense y de los Estados Unidos", en Bahía Blanca, en junio de 1967. 
serie de textos que no dejan de ser interpelados, recorridos, glosados y examinados -sin la perentoria presencia de la superstición o el prejuicio- en función de los modos en que se colocan y pronuncian sobre los dilemas cruciales de la tradición de la ensayística nacional. Las conferencias reunidas en El cuarto en el recoveco hacen del ensayo y de lo nacional los motivos cribados de un complejo tejido de problemas que -quiéralo o no- involucran y comprometen al escritor argentino. Que el lugar de ese compromiso se resuelva -en la perspectiva restiana- menos por la disposición de los escritores a abrazar "causas nacionales" que por su disposición ética de escritura, no es un dato menor. Rest parece intuir la verdad íntima de la tradición del ensayo nacional: componer una lengua, una retórica y un estilo es inventar una forma de percepción de ese proceso dinámico que es la "realidad". Es en la escritura -en esa elección política pero a la vez específica que, como apunta Barthes, se realiza «entre el horizonte de la lengua y la verticalidad del estilo» (Barthes 1973: 21)- donde los escritores se debaten en la compleja tarea de resolver una obra narrativa o poética sin perder de vista las condiciones de producción y recepción a las que se ligan por su destino social. Es, por ende, en sus elecciones -lexicales, sintácticas y tonales- donde cada escritura despliega su apuesta política y define su identidad.

En su función de historiador literario, el crítico intercepta de ese modo, al nivel de la conformación misma de las escrituras, las errantes derivas de lo "nacional" -que casi siempre aparece recortado sobre la fisonomía de una contradicción sin solución 
dialéctica o sobre la mueca exasperante de la fatalidad maniquea. La indagación restiana explora pues en el ensayo -esa forma singular que «se ocupa de lo que hay de ciego en los objetos», como si en efecto deseara secretamente «descerrajar con conceptos lo que no entra en los conceptos» (Adorno 2009: 33)- las capas geológicas en que lo "nacional" convoca una mezcolanza de formas y semblantes. Hace foco en los momentos en que la tradición se constituye como imagen de su pasado y la incertidumbre de un destino se establece, si no como proyecto, al menos como tópico en discusión para el «espíritu crítico». Y se define también ella misma como una intervención específica en la ineludible faena de reflexionar sobre su propia condición, su propio derecho a la existencia, comprometiéndose a tejer -en el revés de trama del propio ensayo- la urdimbre de un horizonte de comprensión donde se hace posible deslindar problemas y definir posiciones en función de proyectos sociales.

\section{LA TRADUCCIÓN COMO PROBLEMA}

Tres meses antes del Golpe de estado del 24 de marzo de 1976, en el número doble 338-39, aparece "Reflexiones de un traductor", la última colaboración importante de Jaime Rest en la revista Sur. ${ }^{268}$ Después de más de seis años de no aparecer en las páginas

268 Rest, J., "Reflexiones de un traductor" (1976c) en Sur, n 338-39, Buenos Aires, enero-diciembre de 1976. pp. 133-144. 
de la revista fundada por Victoria Ocampo -y siendo ya pieza fundamental en los proyectos editoriales de CEAL y Ediciones de Librerías Fausto, proyectos en los que trabaja de manera activa y orgánicamente ya en coordinación general, ya en redacción de fascículos, libros de divulgación e incluso en la traducción y revisión de los materiales publicados-, Rest es consultado en su función de traductor. El texto resulta realmente significativo a la hora de evaluar la distancia ideológica que exhiben sus opiniones con relación a las sostenidas por el grueso del grupo que nuclea la revista. Rest no comparte ya con sus integrantes la mirada consensuada en un espacio de diálogo y publicación asidua, pero tampoco se reconoce en sus intereses críticos. Sur es para Rest un espacio extraño. Ni Tres autores prohibidos (1968b) ni El laberinto del universo (1976a) serán reseñados o comentados en la revista. Pero tampoco el campo de problemas que azuzaban su interés teórico y temático son los de la publicación que -como bien apunta Judith Podlubne- ya a comienzos de la década del '60, había quedado anacrónica por las dificultades teóricas e ideológicas que exhibía para enfrentar tanto las profundas transformaciones históricas y sociales suscitadas en la segunda mitad del siglo XX como los efectos culturales de dichas transformaciones (Podlubne 2012: 48). Sin embargo, acaso como una suerte de cierre en su relación con la revista, Rest coordina el dossier de ese número doble y anual descriptivamente titulado "Problemas de la traducción". Se encarga de seleccionar -el grueso del volumen compila textos importantes sobre el tema aparecidos previamentey traducir la mayor parte de las colaboraciones de traductores 
extranjeros (como Elsa Gress, B. J. Chute, Thomas Lask y John L. Mosh, entre otros), extraídas en su mayoría de The World of Translation, un volumen -que reunía una serie de ponencias presentadas en el Congreso de Traductores que se llevó a cabo en Nueva York en 1970- publicado por el P.E.N. American Center en 1971. El especial agradecimiento de Victoria Ocampo, en las últimas líneas de la introducción, deja en claro que el trabajo de Rest empieza a ser reconocido por la dirección de la revista precisamente cuando él comienza a distanciarse de su radio de inferencia.

Rest piensa el «problema de la traducción» a la luz de un contexto cultural y en un proceso dinámico de transformación social. Su perspectiva contempla, ante todo, el carácter determinante que la continua revolución tecnológica-«desencadenada en la era industrial»- toma sobre el extenso ámbito de lo cultural en el horizonte de un mundo globalizado y cosmopolita, donde la traducción es una práctica social clave en la construcción y el desarrollo progresista de cada cultura. Se apoya en la hipótesis de que, si ese complejo proceso de transformaciones y de pérdidas que es la modernidad afecta y condiciona fuertemente el grueso de la producción cultural contemporánea, el problema de la traducción no puede estar ajeno a sus efectos, ni puede ser tratado como un asunto restringido a los estrechos límites e intereses de la "alta" cultura -en tanto ésta se ve constantemente asediada, penetrada y transformada por el propio desarrollo incesante de la "cultura de masas". Si el problema de la traducción «se ha convertido en uno de los asuntos más importantes para la cultura de 
nuestro siglo» es precisamente porque todos los problemas de la cultura están presentes en ella: en la traducción están comprometidos los problemas de la lengua pero «también la época jugará un papel decisivo, con sus gustos literarios, sus influencias y corrientes estéticas, sus audacias o interdicciones sociales y morales» (1976c: 134). Es por eso que el proceso de la traducción el arte de llevar un significado situado en un contexto cultural preciso a otro- implica tanto un desplazamiento como una transformación de los sistemas culturales en los que se incorporan los nuevos elementos. El proceso de la traducción no es pues -en este enfoque abiertamente culturalista- complementario a las culturas modernas sino plenamente constitutivo de su propia y cambiante identidad.

Por entonces, Rest es un traductor versátil y atento a estas cuestiones. Es capaz de pasar de la traducción de una caudalosa biografía de Edgar Alan Poe como la de Philip Lindsay ${ }^{269}$ a la de un farragoso tratado de filosofía del lenguaje como el de Sussanne Langer ${ }^{270}$. Pero sus virtudes técnicas en materia de traducción no se reducen al género ensayístico. Ha traducido -unos años antes, no al español, sino deliberadamente «al lenguaje popular de Buenos Aires»- las "prosas experimentales" de John Lennon ${ }^{271}$, acaba de entregar a los editores una versión de las siete aventuras

\footnotetext{
269 Lindsay, Ph., El poseso. Retrato de Edgar Allan Poe, de Philip Lindsay, Buenos Aires: Sur, 1956 (Traducción: Jaime Rest).

270 Langer, S., Nueva clave de la filosofía. Un estudio acerca del simbolismo de la razón, del rito y del arte. Buenos Aires: Sur, 1958 (Traducción: Jaime Rest y Virginia Erhart).

271 Lennon, J., John Lennon en su tinta, Buenos Aires, Bocarte, 1967. pp. 13-18. (Traducción, prólogo y notas de Jaime Rest)
} 
de Raffles de William Hornung ${ }^{272}$ y prepara una traducción The Twilight of the Gods de Richard Garnett ${ }^{273}$, una versión del relato "La casa encantada" de Virginia Woolf ${ }^{274}$, traduce -primero para Ediciones Librerías Fausto y, luego, junto a Idea Vilariño, para la prestigiosa Biblioteca Ayacucho- tres textos fundamentales de Guillermo Enrique Hudson ${ }^{275}$ y se compromete en numerosas traducciones de narrativa y poesía medieval y moderna para sucesivas antologías y selecciones publicadas por Centro Editor de América Latina ${ }^{276}$.

En este contexto, Rest -que había abordado el problema de la traducción en otras ocasiones en el contexto de la misma revista ${ }^{277}$ - desplaza esta vez el eje de la cuestión. No se trata ya de volver -como en un círculo vicioso- sobre el trajinado adagios de la factibilidad o la «imposibilidad del traducir»; tampoco de repetir las presuposiciones en torno al «valor del texto traducido en relación con el original»; ni siquiera de argumentar en favor o en contra de la mentada «libertad que pueda ejercer el traductor en su trato con la obra que está vertiendo» (1976c: 133) en

272 Hornung, E. W., Siete aventuras de Raffles, Buenos Aires: Ediciones Librerías Fausto (Traducción Jaime Rest).

273 Garnett, R., El ocaso de los dioses y otros relatos, Buenos Aires: Ediciones Librerías Fausto (Traducción Jaime Rest).

274 Aparecida finalmente en AAVV., Antología del cuento tradicional y moderno, Centro Editor de América Latina, Buenos Aires, 1978.

275 Hudson, G. E., Allá lejos y hace tiempo, Buenos Aires: Ediciones Librerías Fausto (Traducción Jaime Rest). Hudson, G. E., La tierra purpúrea. Allá lejos y hace tiempo. Buenos Aires, Biblioteca Ayacucho, 1980 (Prólogo y cronología: Jean Franco. Traducción: Idea Vilariño y Jaime Rest).

276 AAVV., Antología del cuento tradicional y moderno, Centro Editor de América Latina, Buenos Aires, 1978 (Selección y estudio preliminar: Jaime Rest); AAVV., Poesía medieval inglesa (selección), Centro Editor de América Latina, Buenos Aires, 1970 (Selección, versión y comentarios: Jaime Rest); y AAVV., Los románticos ingleses (selección), Centro Editor de América Latina, Buenos Aires, 1968 (Selección, versión y notas: Jaime Rest).

277 Rest, J., "Una traducción de William Blake" (1958e), en Sur, n² 253, Buenos Aires, julio-agosto. pp. 59-65. 
el contexto de sus condiciones de producción efectiva. Rest ya no se siente interpelado por tales interrogantes. Más aún: acabando rápidamente con cualquier prurito purista sobre la intraducibilidad, se muestra terminante al sostener que la traducción no sólo es posible sino también es «necesaria»y «urgente». Tiene incluso la cabal convicción de que «el hecho práctico consiste en que la traducción resulta inevitable» (1976c: 133). Aún tres años después -en la brevísima entrada dedicada al tema en Conceptos de literatura moderna- no dudará en afirmar que «aunque no haya criterios definitivos y unívocos para encarar estas cuestiones, la tarea del traductor debe proseguir realizándose porque así lo exige el intercambio cultural de nuestras presentes condiciones mundiales» (1979a: 153-154).

Bajo su óptica, si hay algo que merece ser discutido, son precisamente las condiciones de producción de la traducción misma. Por ello, para pensar los términos de esa problemática, Rest apela a una serie de autores y traductores que han abordado el tema desde perspectivas diversas pero coincidentes en su consideración de la inscripción cultural concreta. Los nombres de George Steiner, Walter Benjamin, Georges Munin y Maurice Blanchot se unen así por su consideración contextual de la práctica a los de Octavio Paz, Jorge Luis Borges y Alfonso Reyes. Sin embargo, el peso de esos nombres no es simétrico. La constelación compuesta por Rest gira fundamentalmente en torno a dos referentes fundamentales: Borges y Benjamin.

El crítico devenido traductor se apoya en "Las versiones homéricas" (1932) y "Los traductores de las 1001 Noches" (1935), 
para ajustar cuentas con dos posiciones extremas: por un lado, la de ciertas concepciones puristas, que procuran «una versión literal o servil»-que se remite sólo a las funciones denotativas del texto a traducir-mitificadora del "original", y que se aferran a la suposición de que el lector accederá al sistema de connotación en la hipotética circunstancia de que llegue a dominar la lengua del "original"; por el otro, la de quienes sostienen la necesidad de practicar una traducción literaria, capaz de subsistir por sí misma y de comunicar plenamente los recursos del original, «aun a costa de sacrificar la escrupulosa literalidad» (1976c: 135). En esos extremos Rest ve una cristalización de posiciones que se funda en «motivos justificados y dignos de consideración», pero incapaces -por su propio extremismo- de plantear, a través de «un equilibrio justo», la real y compleja dimensión del problema de la traducción.

La primera postura, «de índole erudita», es -apunta el crítico- la que suelen asumir algunos filólogos y lingüistas que buscan hacer prevalecer el valor del texto "original". En la perspectiva de Rest, esta posición abreva frecuentemente en el lugar común de «la superstición de la inferioridad de las traducciónes» (Borges 1998: 130). Y, en ciertas ocasiones, deja traslucir también la situación alienada de un traductor que enfrenta a un texto que se le impone como "sublime", como "grandioso", como "intocable", es decir, como absolutamente otro. En tal situación, el traductor corre el riesgo de capitular ante un modelo de lector sumiso que casi no se habilita otro margen que el de la postración, y se ve tentado a adoptar una actitud piadosa y a someterse 
a las "supersticiones" de una tradición que no sólo desconoce, sino que además se niega a cuestionar. Apoyándose en la ironía crítica del texto borgeano, Rest se opone de plano a la disposición filológica que privilegia los "originales" por sobre la traducción recordando que, en realidad, nadie puede decir a ciencia cierta cuál de todos los originales es el original de la Ilíada o de la Odisea y que ese origen perdido no menoscaba los efectos de lectura del texto. Según su hipótesis, no hay texto intraducible: el texto que presupone tal condición circunscribe su valor no a la experiencia de la lectura sino a la referencia de su origen, como aquellos que justifican el valor de la Biblia no en su textualidad sino en su procedencia -el sádico lápiz del Espíritu Santo que, como recuerda Bacon, «se ha demorado más en las aflicciones de Job que en las felicidades de Salomón». Como el Barthes de la década del 70, Rest intuye que la felicidad del texto es su negación a las reclusiones que para él prevén los puristas y guardianes de la tradición. Sabe que sólo una experiencia de lectura desprejuiciada e incluso "irreverente" -capaz de tratar al texto de igual a igual (sin la imposición de jerarquías eclesiásticas)- puede disponer una valoración del o de los textos de la tradición y definir cuáles de ellos tienen todavía algo inaudito por decir. Y sabe que esa lectura es también la que justifica la indiscutible necesidad de la traducción. Es ella la que pone en escena, paradójicamente, la verdad literaria del texto al prolongar su existencia sin dejar de reconocer su diferencia -al tiempo que pone en evidencia la actitud miserable de aquellas posturas 
que pretenden hacer del "original" un todo completo, cerrado, siempre idéntico a sí mismo y sacralizadamente definitivo.

Respecto de la segunda posición, «de carácter poético», Rest no es menos crítico. Pese a que parece reconocer que es probable que cada pieza tenga una particular intensidad en su propia lengua no por ello admite que a priori su traducción pueda ser depreciada. No es justo -sostiene Rest-menospreciar de antemano el valor de la traducción por la ausencia de las cualidades imaginativas que exhibió en su advenimiento inicial. Semejante perspectiva cae en el error de establecer -implícitamente- una infundada relación jerárquica entre las lenguas a partir del señalamiento particular de un acontecimiento poético. Más allá del yerro de plantear la equívoca imagen de una relación jerárquica entre las lenguas cuando, en lo concreto, esa relación es una relación de diferencia, lo que este tipo de simplificación olvida -u omitees que la traducción es, como apunta Benjamin, «ante todo una forma» (Benjamin 1971: 128) ${ }^{278}$ y que en ella se juega -según puede deducirse de la posición restiana- un hecho fundamental y casi siempre elidido en los debates sobre el tema: el traductor debe ser un escritor.

Si lo que en la traducción se manifiesta es «cierta significación inherente al original» (Benjamin 1971: 129) el tránsito de esa significación no puede darse más que como una operación de escritura por medio de la cual «la vida del original alcanza en ellas su expansión póstuma más vasta y siempre renovada» (Benja-

278 Benjamin, W., "La tarea del traductor", Angelus Novus, Edhasa, 1971. pp. $127-143$. 
min 1971: 130). Se trata, por cierto, de «un procedimiento transitorio y provisional para interpretar lo que tiene de singular cada lengua» (Benjamin 1971: 134). En la perspectiva de Rest, la traducción es en efecto una forma particular de escritura, acaso -como sostiene Borges- justamente su «etapa más avanzada» (Borges 1975: 12) ${ }^{279}$. El traductor traduce tratando de encontrar en la propia lengua la significación inherente al original y es por eso que se condena a escribir siempre tratando de entrar en aquella que no cesa de tratarlo como un extranjero. Como en una pesadilla kafkiana, el traductor está siempre entre lenguas. Pero no-como suele creerse- entre dos lenguas hechas; sino entre una que se deshace y otra que está por hacerse. El traductor está siempre a medio camino entre la lengua perdida de lo dicho y el habla incierto del porvenir. Es así un mediador en un acto de transferencia cultural que busca llevar una significación particular de una lengua a otra. Que tal transferencia llegue a concretarse sólo depende de algo: que el traductor pueda sostenerse lo suficiente en esa tensión, en ese «tembladeral» que es el estar entre lenguas. Es allí donde descubre los «particulares matices emocionales y culturales» que singularizan a las lenguas y a sus modos de percibir el mundo.

La relación entre traducción y erudición es, por su parte, necesaria pero no determinante por sí misma. En la perspectiva restiana, «la traducción literaria tiene que ser vital, no meramente erudita: debe sustentarse por sí misma» (1976c: 142). Pero,

279 Borges, J. L., El escritor y su obra (Entrevistas de Georges Charbonnier), Siglo XXI Editores, México, 1975. 
al mismo tiempo, Rest reconoce que hay una responsabilidad intelectual del traductor y se juega en los momentos en que se aparta del original: cuando lo hace, «debe hacerlo a sabiendas, no por simple ignorancia» (1976c: 142). Debe ser consciente de que lo hace para saltar los límites de la propia lengua, no por desconocimiento o carencia de recursos propios. El traductor de un texto literario debe -para Rest- «conocer en su totalidad la literatura de donde procede, con el objeto de captar alusiones y referencias que se han incorporado al texto» (1976c: 142). Pero también debe conocer exhaustivamente el circuito de relaciones textuales en que la obra se inscribe, pertenezcan éstas o no al sistema de la lengua del original. No obstante ello, la condición fundamental para la traducción supone -para Rest- una inversión de la lógica según la cual la mayor atención está puesta en la lengua de la que se traduce en menoscabo de la lengua a la que se traduce-so pretexto de que «el traductor vierte el texto a su lengua materna, adquirida espontáneamente, y que el idioma del que traduce lo ha aprendido por los procedimientos artificiales de un estudio sistemático» (1976c: 136). El traductor debe en cambio ser -o hacerse- escritor. Debe asumir que la traducción debe depender del texto original sólo «en lo que respecta a la trama de recursos que se pretende reproducir, pero que una vez completada valga por sus propios méritos artísticos, por su íntima vitalidad» (1976c: 139). Debe encontrar pues la voz del texto a traducir en el horizonte de su propia lengua. Si es preciso, debe llevar su propia lengua más allá de su límite para experimentar esa misma voz, pero tratando de que el lector que enfrenta la traducción olvide 
«la existencia del original en virtud de su propia intensidad; de tal modo llegue a ser plenamente fiel al texto que ha sustituido» (1976c: 140). Aunque también puede acoger alguno de esos hallazgos en que la propia voz del original es potenciada por la traducción, como ocurre en el caso del título The Turn of the Screw en manos de un traductor avezado y sagaz como José Bianco.

No es un trabajo sencillo: «el terreno que pisa el traductor -escribe lúcidamente Rest- con frecuencia es un tembladeral»; tanto es así que ni siquiera «el esfuerzo por alcanzar una presunta exactitud ideal» es garantía de éxito; menos aun si el texto a traducir «ha tenido significativa gravitación por espacio de generaciones» o si «ha dejado su impronta en una determinada cultura a través de anteriores traducciones» (1976c: 135). Pero tampoco es imposible. Las pruebas contundentes que Rest acredita en el orden vernáculo casi no dejan margen de duda: además de otra vuelta de tuerca en traducción de José Bianco-«que sigue siendo la más prodigiosa trasposición castellana de Henry James»-, cita El troquel de T. E. Lawrence, traducido por Victoria Ocampo «con notable minuciosidad y aptitud literaria», Moby Dick en la notable versión de Enrique Pezzoni y la Divina Comedia de Ángel J. Battistessa, así como las numerosas y logradas traducciones del propio Borges y Julio Cortázar.

Rest exhibe pues una perspectiva culturalista de la traducción. En su óptica, traducir no se reduce a una mera translación lingüística, sino que, al contrario, supone en un principio un ejercicio crítico, una interpretación contextual de la situación emocional y cultural que el acontecimiento literario crea en su 
propio contexto para recrearlo en el contexto de la propia traducción. Es en virtud a ese proceso reconstructivo que conseguirá presentar al lector no el contenido estricto de una emisión lingüística, sino el campo emocional de una situación dada en otro lenguaje. En su perspectiva, la traducción es un proceso creativo y erudito que implica la evaluación de las posibilidades de transferencia lingüística de fenómenos, situaciones y experiencias culturales. En ese sentido, su deliberada decisión de traducir las prosas y poemas de John Lennon al lenguaje popular de Buenos Aires se vuelve razonable ya que implica un trabajo previo de evaluación rigurosa de la propia vida de esos textos en su cultura (sus relaciones específicas con la propia lengua y con la tradición de las letras inglesas) y un intento de reposición de tales circunstancias en el contexto cultural vernáculo. La traducción supone -para Rest- no sólo problemas prácticos y operativos, sino también -y sobre todo- un haz de relaciones culturales complejas y dinámicas, que suponen -a su vez- un orden de coexistencia con otras culturas y un modo de vida de las propias identidades culturales. Es sobre todo la traducción la que pone a la cultura en la tensión entre coherencia y alternabilidad desde la que germinan las formaciones culturales modernas: su propia inferencia en el mundo actual condiciona significativamente la sensibilidad, la percepción -como explica Rest: una lengua es una manera de percibir el mundo-, las formas de lectura y de escritura; es decir: la propia matriz de las configuraciones culturales. 
UNA POLÍTICA DE LA EDICIÓN, LA DIVULGACIÓN Y LA ENSEÑANZA

Pese a ser frecuentemente referenciado como «uno de los grandes críticos argentinos» -perteneciente a los llamados "años dorados de la crítica"-, no existen trabajos específicos ni relevamientos minuciosos de la obra crítica de Rest. Lo común es que las pocas y parciales evaluaciones de su trabajo acaben por decretar que "descentramiento y dispersión" sean los atributos más recurrentes de un proyecto crítico-intelectual desperdigado en múltiples actividades. La fisonomía misma de su producción parece traducir una dinámica de constante descentramiento (tanto en función de sus intereses de investigación como en el despliegue de sus modos y sus retóricas -entre el ensayo y la crítica académica, entre la cultura popular y la "alta" literatura, entre la ordenada literatura inglesa y las siempre improvisadas letras argentinas). En ese movimiento, el proyecto restiano viborea y vuelve superflua - y también endeble- toda etiqueta y toda caracterización que no acabe por rendirse al elogio de su "excentricidad". Por otra parte, la dispersión y la diversidad de soportes en que se materializa su actividad suelen inducir -en un puro efecto de superficie- la imagen de un trabajo escrito casi en un presente absoluto, como respuesta urgente a requerimientos estrictamente coyunturales. Si bien ambos atributos son en buena medida precisos, también es cierto que, a través de ese descentramiento y esa dispersión, lo que se teje es un proyecto de trabajo intelectual que exhibe una coherencia y una organicidad sorprendentes. Más aún: vista con atención, esa 
misma "multiplicidad de aristas" revela su profunda coherencia programática como un ejercicio de dispersión calculada.

En este sentido, una apuesta de recuperación integral que tome por objeto a este problemático proyecto no puede soslayar ni desestimar la sólida articulación entre el trabajo crítico restiano y su singular labor como docente, divulgador, editor, traductor, coordinador de colecciones y supervisor editorial, sobre todo en la última etapa de su vida. Tales actividades mayormente desestimadas en los exámenes que abordan su trabajo crítico- sólo son objeto de menciones laterales que las presentan como poco más que curiosidades o contingencias poco significativas. Sin embargo, en estudios dedicados exclusivamente al campo de la industria cultural y editorial (Bueno y Taroncher 2006; De Diego 2010) se señala su efectiva -aunque "esporádica" y casi siempre subterránea- participación, a comienzos de los '60, en la primera época del proyecto de la Editorial de la Universidad de Buenos Aires (EUDEBA) junto a Boris Spivacow (cfr. Maunás, 1995), su participación activa y fundamental en el proyecto del Centro Editor de América Latina (CEAL) y su determinante trabajo en el proyecto editorial de Ediciones Librerías Fausto.

En efecto, en el contexto del CEAL, el fastuoso proyecto cultural dirigido por Boris spivacow, Rest trabaja -como la mayoría de sus miembros- a destajo, desde mediados del '67 hasta fines de 1979, el año de su muerte. Los testimonios de Beatriz Sarlo, Aníbal Ford y Jorge Lafforgue -en su mayoría reunidos por 
Patricia Somoza y Elena Vinelli en el volumen Centro Editor de América Latina. Capítulos para una historia (Bueno y Taroncher 2006)- permiten corroborar que, si bien Rest no estaba estrictamente "adentro" del CEAL, las suyas eran «Colaboraciones importantes y permanentes». Es así que Rest no sólo llegó a desempeñar -como apunta Susana Santos- un «papel protagónico» y determinante en el proyecto y la realización final de la colección "Capítulo Universal" -donde Rest escribe y/o supervisaba la mayor parte de los fascículos-, sino que además en virtud a su erudición bibliográfica, su responsabilidad y capacidad de trabajo- llegó a constituir una suerte de salvavidas infalible al que se solía acudir para cubrir huecos en todas las colecciones: «contábamos -apunta Lafforgue-, por ejemplo, con Jaime Rest, que era fantástico y tenía una biblioteca fenomenal, como he visto pocas. Vos le decías: "Jaime, se me cayó el prólogo de no sé quién". Y él te respondía: "Bueno, yo lo hago". "Pero lo necesito ya: mañana". "No, no, mañana no: pasado mañana". Y era puntual e impecable: el día prometido te entregaba un trabajo muy bueno» (citado en Bueno y Taroncher 2006: 298).

CEAL era el resultado de un desprendimiento -o, mejor, una suerte de "continuación" por otros medios- del proyecto iniciado por Spivacow en EUDEBA y, en algún punto, su comienzo coincidía con el momento más álgido de lo que Amelia Aguado marca como el período de consolidación de un «mercado interno» [1956-1975], que entraría en una crisis profunda ttal y como lo demuestra De Diego- en el período posterior [1976-1989], tanto por la presión de la censura sobre la edición dispuesta por la última dictadura 
militar como por el exilio obligado al que se vieron empujados muchos de sus más activos agentes y, más adelante, por la endeble situación económica bajo el alfonsinismo (De Diego 2010). Su objetivo fundamental apuntaba a una intervención concreta en el mercado editorial, que ciertamente contribuiría a transformar en unos pocos años. Se trataba, claramente, de un obligado pasaje de la órbita estatal a la esfera privada. Tal pasaje estaba lógicamente motivado por la hostilidad y la ofensiva antiintelectual abierta por la serie de disposiciones reaccionarias ejecutadas en el amplio contexto del "shock autoritario" implementado por el onganiato a partir de 1966 -y en la que resultan claramente significativos algunos acontecimientos de violencia explícita e inusitada como los de la denominada "Noche de los Bastones Largos" (Romero 2001: 169-175). Como bien señala Oscar Fernández, «CEAL nace cuando la utopía cultural se hace privada». Es, en cierto sentido, «el emprendimiento personal de un grupo de intelectuales» que, trabajando a destajo y muchas veces cobrando por su trabajo -casi siempre con retraso- sumas irrisorias, se compromete en la continuación del proyecto iniciado en EUDEBA con el financiamiento estatal (Bueno y Taroncher 2006: 59). La prueba sintomática de tal continuidad está dada por la coincidencia entre la nómina de colaboradores iniciales del CEAL y la de los que integraban el proyecto de EUDEBA. Por ello no es sólo un signo de ironía el hecho de que el mentor de ambos proyectos dejara impresa tal continuidad en los respectivos lemas: el "Libros para todos" que funcionaba como acápite comercial en EUDEBA aparece resignificado -y en cierta 
medida potenciado- en "Más libros para más" con que se subtitulaba a CEAL.

Pero, como parecen sugerir esos mismos lemas, más que una continuidad, lo que se desprende del cotejo de ambos proyectos es la ratificación de un curso y la radicalización de un perfil. Las políticas de divulgación y extensión cultural visibles ya en EUDEBA se enfatizaron en CEAL. En este último proyecto se dispuso abierta y determinadamente una política cultural de ampliación del público lector sin precedentes en el país. Tal política se desarrolló a partir de un gigantesco programa de reedición que proyectaba una diversificación de la lectura de textos tradicionales y que contemplaba como uno de sus puntos fundamentales la actualización de géneros y la incorporación de formatos nuevos, ofrecidos en ediciones populares pero cuidadas, de bajo costo, y disponibles en quioscos de diarios y revistas lo que ya era llevar al límite la incipiente idea de "los quiosquitos de EUDEBA"-, es decir, tratando de trasvasar el marco clásico de divulgación en librerías con el objeto de incorporar más y nuevos lectores. CEAL buscaba pues llegar a todos los sectores sociales a nivel nacional y en este punto resultaba sin dudas seductor a la perspectiva democrática y liberal de quienes -como Rest- estaban realmente convencidos de que «el derecho a pensar no debe ( $\mathrm{ni}$ puede) ser regulado discrecionalmente por los gobiernos; sino que es el pueblo quien (puede y) debe hacer a diario profesión de renovar sus ansias de libertad» (1958b: 24). Sin embargo, es probable que lo que más atrajera a Rest fuera el cálculo de la magnitud de los efectos que el proyecto buscaba 
producir al introducir y circular un discurso modernizador que no se acotaba ya al módico espacio de la literatura y la crítica literaria, sino que apelaba a producir efectos concretos en la cultura entendida en un sentido mucho más amplio (la colección "Siglomundo", por ejemplo, incluía discos, mapas y sobres con fotos). Esta perspectiva no era ajena en modo alguno a la orientación que Rest daba a su propio proyecto crítico. Él mismo, con un sentido divulgador pero a la vez riguroso, dirigiéndose a un «lector enterado, no necesariamente especialista» (1979: 7a), había escrito numerosos trabajos que no aspiraban «a exponer hipótesis novedosas o intrincadas» sino a subrayar «problemas presentes en los textos» (1971b: 8). Pero eso no es todo. También su propia obra crítica daba cuenta de una articulación de intereses y objetos de estudio: escribía sobre "alta literatura", del mismo modo que lo hacía sobre las voces del tango, la historieta de Quino, el cine de Bergman, las prosas hilarantes de Lennon o la historia de la Pena de Muerte.

No es de sorprender pues que muchos de los proyectos particulares de Rest encontraran en el marco del CEAL sus condiciones objetivas de realización. En él llegó a publicar casi siempre corregidos, ampliados y actualizados bibliográficamente- muchos de sus primeros trabajos exploratorios como Literatura y cultura de masas (1967a), La novela tradicional (1967b), El teatro moderno (1967c), El teatro inglés (1969b), Novela, cuento, teatro: apogeo y crisis (1971b), Conceptos de literatura moderna (1979a). Y allí aparecieron incluso, dos años después de su muerte, sus investigaciones sobre los diversos 
aspectos del ensayo nacional bajo el título de El cuarto en el recoveco (1982). Allí compiló y prologó también varios volúmenes entre los que cabe destacar especialmente Antología del cuento universal (1968a), Los románticos ingleses (1968c), Poesía y prosa de John Milton (1969b) y Poesía medieval inglesa (1970a). Escribió además eruditos fascículos para la historia de la literatura mundial, donde se encargó de presentar tanto "temas clásicos" -como en "Orígenes y desarrollo de la novela" (1970c), "El apogeo de la novela" (1970d) y "Boccacio y el apogeo del cuento" (1970e)- como aportes sin lugar a dudas precursores en temas específicos y novedosos -como "Las literaturas marginales" (1972b) y "Panorama del ensayo" (1979h). Pero además escribió minuciosos estudios introductorios a Ivanhoe de Walter scott (1978c), Tiempos difíciles de Charles Dickens (1978d), Relatos de Nathaniel Hawthorne y Herman Melville (1978e), Las nuevas Mil y Una Noches de Robert L. Stevenson (1979b), Feria de vanidades de William M. Thackeray (1979c), Hojas de hierba de Walt Whitman (1979d), La importancia de llamarse Ernesto y Salomé de Oscar Wilde (1979e) y El juicio del siglo de Joaquín V. González (1979b). Fue además el supervisor general de más de una treintena de fascículos aparecidos en las diversas colecciones de la editorial, se encargó de redactar y corregir un sinnúmero de recuadros, biografías y "sueltos" que completaban los célebres fascículos, con el mismo compromiso y la misma seriedad con que encaraba la escritura de los rigurosos fascículos sobre literatura europea medieval y moderna que eran materia de su especialización académica y donde, como apuntara uno de sus 
discípulos, «se hallaba como pez en el agua» (Gregorich 1987: $82)$.

En términos concretos, lo que trazaba una solidaridad irrecusable entre el proyecto restiano y el coordinado por Spivacow era una serie de obsesiones que se ajustaban tanto a la disposición ética del crítico como a los objetivos prácticos del divulgador: «la claridad y la discreción del tono, la justeza en la exposición, el respeto al lector y la devoción por un tesoro verbal que no admitía fronteras» (Gregorich 1987: 80). Como el propio Rest, el proyecto de CEAL era liberal, progresista, pluralista, democrático y cosmopolita. Se comprometía cabalmente con el proceso de modernización cultural a través de la divulgación de problemas y perspectivas propios de la industria cultural, sin que esto implicara un desdén por la tradición letrada. No es improbable conjeturar pues que quizá Rest valorara estos aspectos particulares del proyecto pergeñado por spivacow, en la misma medida en que éste se nutría lúcida y operativamente de los numerosos trabajos restianos «que cumplían tan eficazmente con su función didáctica, a la vez que establecían una inmediata complicidad con el lector» (Gregorich 1987: 84).

En 1981, en la colección "Biblioteca Básica Universal", el CEAL publica una edición de Vathek de William Beckford que en una breve "Nota del editor" se subraya especialmente una arista plenamente significativa de las coincidencias entre el proyecto crítico restiano y la empresa cultural de Spivacow. La nota en cuestión deja constancia de que, con ese "“cuento oriental", surgido de uno de los periódicos impactos de la cultura oriental 
sobre la europea», «se cierra la sexta serie de la Biblioteca Básica Universal -íntegramente dedicada a las literaturas "marginales" o géneros "menores" o textos "olvidados"-» (1981b: $\mathrm{XVI})^{280}$. Las comillas, sutilmente dispuestas sobre los términos marginalidad, minoridad y olvido, son claramente los signos de una irónica manera de cuestionar los mecanismos de constitución de un canon "oficial" pero también de subrayar el aporte específico de la editorial y del propio Rest en la revalorización de esas formas despreciadas. Es claro que, ya para 1981, en proyectos editoriales como CEAL y Ediciones Librerías Fausto -que vienen de publicar una cantidad significativa de textos "marginales" en los que la participación de Rest es determinantela idea de minoridad o de marginalidad remiten sin lugar a dudas a un modo de estructuración perimido y las comillas sobre esos términos, más que remitir a las series, aluden a un registro de valoración que la propia obra crítica de Rest no cesa de cuestionar en la práctica. Tal cuestionamiento puede rastrearse en el hecho de que tomara por objeto de sus investigaciones críticas por igual «al cine, la crisis del lenguaje, la relación entre la política y el oficio del artista, o las nuevas formas de religiosidad» (Gregorich 1987: 82), pero también se vislumbra en deliberada atención que el crítico pone en las formas culturales situadas en «los márgenes del pensamiento oficial y consagrado» en el despliegue de una generosa indagación capaz de «enseñar mucho acerca de los goliardos, y explicar por qué René Guénon era y a la vez no era reaccionario, o hablar con la misma autoridad

${ }^{280}$ En: Beckford, W., Vathek, cuento árabe, Buenos Aires, CEAL, 1981. 
de autores de novelas libertinas y del sentido de la ciencia ficción» (Gregorich 1987: 82-83). Tanto la ironía de la nota editorial como la insistencia en la modalidad y el campo de intervención de la crítica restiana revelan, sin duda, el sinsentido de las taxonomía verticalistas tradicionales; pero también dan cuenta de la emergencia y el establecimiento de un nuevo modo de restructuración del estatuto de legitimidad y la puesta en valor de los textos y materiales excluidos del canon, sobre un modelo crítico que, en el contexto de la crítica argentina, continuarán -con previsibles y valiosas diferenciaslas investigaciones de Jorge Rivera, Aníbal Ford, Eduardo Romano y Jorge Lafforgue, entre otros.

No es raro pues que la nota editorial se cierre con una sencilla aclaración que ratifica lo dicho anteriormente respecto de la actuación de Rest en CEAL y permite vislumbrar ciertos aspectos de lo que será su labor en contexto del proyecto editorial de Librerías Fausto. «Esta edición -se apunta allí- fue posible gracias a Ediciones Librerías Fausto, que había preparado los originales, ahora cedidos gentilmente para su inclusión en la Biblioteca Básica Universal». Tras esa aclaración, la nota se cierra explicitando un agradecimiento conjunto: «Asimismo, Ediciones Librerías Fausto y Centro Editor de América Latina rinden de esta forma homenaje a quien fuera uno de sus más asiduos colaboradores y uno de los más lúcidos intelectuales argentinos de los últimos tiempos: Jaime Rest.» (1981b: XVI). Inscripta precisamente en ese texto que, además de dos prólogos célebres -uno de Stéphane Mallarmé y otro de Jorge Luis Borges-, 
incluía dos importantes estudios preliminares -uno del propio Rest y otro del traductor, su amigo personal Carlos Gardini-, la nota permite vislumbrar el lugar central y el peso específico de Rest en el desarrollo de ambos proyectos editoriales, pero también da cuenta de un estado de un campo cultural que articulaba su resistencia al autoritarismo a partir de puntos de coincidencia y estrategias solidarias libradas en el plano de la especificidad.

Es indudable que el proyecto de CEAL exige ser pensado y evaluado en función del contexto histórico en que se inscribe [1966-1982], especialmente porque -como bien apuntan Somoza y Vinelli-, al tratarse de un proyecto pensado y «fundado como respuesta a las acciones de una dictadura, su condición de empresa cultural resistente es percibida como una marca de origen» (2006). Pero tampoco es del todo descabellado pensar que Ediciones Librerías Fausto -fundada en 1963- se propuso en un momento como una suerte de respuesta a un contexto cultural que empieza a volverse gradualmente más y más autoritario hacia fines del 74 y se define categóricamente por la violencia con el golpe del 76. Pero mientras CEAL se inclina -como sostienen Somoza y Vinelli- hacia una actitud más «combativa»-al punto de tener que poner fin a sus colecciones más arriesgadas y comprometidas en términos de crítica social, como "Transformaciones" y "Siglomundo"-, hacia mediados de la década del '70, con la incorporación de Jaime Rest como asesor literario y director de la colección "Biblioteca de Cuento y Novela" -dedicada casi 
integralmente a la publicación de literatura europea y norteamericana-, Ediciones Librerías Fausto responde a su contexto desde un perfil singular que se afianza en una política de edición de textos "menores", "marginados" u "olvidados" y que, alusivamente, casi entre líneas, lleva adelante un contrapunto sutil respecto del régimen represivo que asolaba el campo de la cultura.

Hasta mediados de la década del setenta, Ediciones Librerías Fausto, el pequeño sello editorial fundado por el mítico librero Gregorio Schvartz -quien ya en su paso por Siglo Veinte, junto a Rafael Zorrilla, había sido el primero en traducir a Sartre y Simone de Beauvoir-, seguía la senda que había sido trazada por el legendario proyecto editorial de Spivacow en EUDEBA, publicando casi únicamente excelentes traducciones de célebres narradores y poetas del canon occidental. Dentro de la colección denominada "Los Poetas" había publicado, en cuidadas ediciones bilingües, prologadas y anotadas rigurosamente por especialistas selecciones de la obra poética de los franceses stéphane Mallarmé y Pierre Jean Jouve, la poesía completa de Blaise Cendrars, La vida en los pliegues de Henry Michaux y hasta llegó a traducir y publicar hacia 1974, en edición bilingüe, Les armes miraculeuses del escritor y pensador martiniqués Aimé Césaire. En consonancia con esto, en el catálogo en que hacia 1976 aparecían clásicos como Hojas de hierba o la célebre Antología de Spoon River -a cargo del poeta, biógrafo y dramaturgo Edgar Lee Masters- de Walt Whitman y una antología poética de Hermann Hesse, se publicaba a los tres grandes poetas italianos del siglo XX: Huesos de jibia y 
Las ocasiones, del Premio Nobel Eugenio Montale; La alegría y La tierra prometida de Giuseppe Ungaretti, y la poesía completa del también Nobel Salvatore Quasimodo. Tradujo la obra poética del célebre novelista italiano Cesare Pavese y, en la colección Poesía Universal, aparecieron publicadas diversas obras poéticas contemporáneas, sin contar que -en cuidadas ediciones bilingües, seleccionadas y traducidas por especialistas- vieron la luz antologías de poesía francesa (a cargo de Raúl G. Aguirre), italiana (a cargo de Horacio Armani), estadounidense e inglesa (a cargo de L. Revol) y alemana (a cargo de Rodolfo E. Modern). Pero es en el terreno narrativo -y muy especialmente en la colección "Biblioteca de Cuento y Novela"- donde la apuesta de Ediciones Librerías Fausto se radicaliza y se superpone en intereses y elecciones con la última etapa del proyecto crítico restiano.

En un principio, la colección "Biblioteca de Cuento y Novela" del pequeño proyecto editorial llevó adelante una importante política de divulgación de la obra de grandes novelistas que aún no contaban con gran difusión en otros catálogos en lengua hispana. En este sentido, apostó inicialmente por narradores italianos del siglo XX al publicar El castillo de los destinos cruzados, de quien hoy muchos consideran el más importante escritor italiano del siglo pasado, Italo Calvino; pero también al traducir la luego celebrada Crónica de mi familia de Vasco Pratolini y El simplón guiña el ojo al frejus del escritor y traductor Elio Vittorini. Por otra parte, Ediciones Librerías Fausto publicó una serie de narradores italianos menos conocidos: la novelista Natalia Ginzburg; el escritor y periodista Carlo 
Laurenzi; la novelista y dramaturga Dacia Maraini; Carlo Bernari y su novela Tres obreros, que le daría renombre dentro de las letras italianas, y, por último, el escritor neorrealista Beppe Fenoglio de quien en 1976 publicó la que es aún hoy considerada su mejor novela, Una cuestión privada.

Pero es en el ámbito de divulgación de la narrativa británica donde la inferencia de Rest resulta determinante, al punto que visto en perspectiva- el catálogo "Biblioteca de Cuento y Novela" de Fausto parece venir a complementar esa provocativa tendencia del proyecto crítico restiano, perfilada ya desde trabajos como Tres autores prohibidos y otros ensayos (1968), El marqués de Sade y la crisis del racionalismo (1971b) y sus publicaciones en Los libros, Crisis y Punto de Vista como una deliberada exégesis de la transgresión en la literatura que afirma la función negativa y transgresiva de la literatura misma. No casualmente el catálogo diseñado por Rest se define por una puesta en circulación de literaturas "malditas", marginales o marginadas que constituyen un irrecusable contrapunto al "proyecto moral" que la dictadura buscaba restaurar e imponer a fuerza de represión y censura. En ese sentido, se comprende que -junto a las traducciones de Lord Jim, El negro del Narciso, Tifón o El agente secreto de Joseph Conrad y los textos del prolífico Gilbert Keith Chesterton- en el catálogo de Ediciones Librerías Fausto vean la luz textos como Extraña Alianza de Hugh S. Walpole y la polémica y muchas veces catalogada de "obscena" novela gótica El monje, del escritor, dramaturgo y político Matthew Gregory Lewis. En la misma línea, y en el marco de la misma 
colección, la editorial publica -por decisión del propio Rest-, apenas meses después del golpe militar del 76, En el camino y El ángel subterráneo del bohemio narrador beatnik Jack Kerouac, cuya controvertida producción gira alrededor de una moral licenciosa que une la filosofía, el pensamiento automático, las religiones orientales, la libertad sexual, las drogas y el jazz. Correlativamente, meses después, aparecerían en el mismo sello Stern, un hombre perseguido, la primera obra del novelista y dramaturgo Bruce Jay Friedman -dedicada Günther Stern, perseguido por el régimen nazi por su colaboración con Bertolt Brecht-, y luego Desesperación, del controvertido escritor y profesor ruso Vladimir Nabokov que había afrontado ya sucesivas censuras y acusaciones de inmoralidad por Lolita, su obra más conocida. Sin abandonar el ámbito específico de la narrativa anglosajona, Ediciones Librerías Fausto publicó también por decisión de Rest al dramaturgo y novelista irlandés Lord Dunsany, cuya narrativa se caracteriza por la fusión de las tradiciones populares, la épica celta y el exotismo oriental, y que es considerado el precursor de la narrativa de "terror fantástico" o "terror cósmico materialista" de H. P. Lovecraft; y, en el año del golpe de Estado, puso en circulación -en traducción del propio RestSiete aventuras de Raffles, del australiano de origen británico Ernest William Hornung, libro que quizá haya pasado el cerco de la censura merced a la lúcida decisión restiana de omitir en la traducción el adjetivo "delictivas" del título del libro. Y, en la misma línea de edición, se toma la estratégica decisión de publicar otros dos textos que están en estrecha relación con la 
tematización del mal a que se orienta la última etapa de las investigaciones restianas: el célebre A rebours -Al revés- del decadentista francés Joris-Karl Huysmans, considerado como "la Biblia del decadentismo" -donde Des Esseintes, su protagonista, un dandy y esteta rebelde, se debate entre el cinismo ético y la perversidad moral-; y El Nuevo Decameron, del historiador y narrador polaco Jan Potocki, que completa la edición del Manuscrito encontrado en Zaragoza preparado por Roger Caillois años antes, y que constituye -a juicio de Rest- una «obra maestra de la literatura fantástica de todos los tiempos» por su capacidad para articular de forma singular «historias en las que predominan lo macabro y lo sobrenatural, anticipando así la gran literatura de terror romántica», y las narraciones ocultistas «que hunde sus raíces en la vieja tradición de la cábala y la hechicería» (1977e: 13-14).

Asimismo, junto a varios volúmenes de Hermann Hesse, vieron la luz Vladimiro, pintor de nubes de Rainer Maria Rilke, relatos de Henry James y León Tolstoi, y Las hormigas del escritor y músico francés Boris Vian, autores a quienes Rest dedicaría su atención en las páginas de Mundos de la imaginación. La política de publicación de relatos cortos que impulsó Ediciones Librerías Fausto le permitió además incorporar a su catálogo textos como Hombres sin mujeres del norteamericano Ernest Hemingway, Aguafuertes norteamericanas de su compatriota O. Henry, seudónimo de William Sidney Porter, considerado un maestro del relato breve, y traducir también La orgullosa hermana muerte, volumen en que sin duda -en razón de sus obvias connotaciones- merece ser 
destacado el relato "Los cuatro desaparecidos" del influyente novelista Thomas Clayton Wolfe, cuya obra anticipa en los años posteriores a 1936 -mediante observaciones interesantes sobre aspectos culturales y cotidianos de Inglaterra, Francia y Alemania que a menudo pasan desapercibidos a los propios europeos- los signos latentes de la discriminación racista e ideológica sobre la que germinaría el nazismo.

En el ámbito del cuento y el relato breve, la editorial publicó -bajo estricta recomendación de Rest- a notables autores y obras, empezando por la compilación de Cuentos populares italianos, editado durante 1977 en cuatro volúmenes al cuidado del propio Italo Calvino; pero también textos de fuerte impronta política antiautoritaria como Los veintitrés días de la ciudad de Alba, del citado novelista itálico Giuseppe "Beppe" Fenoglio, un texto perteneciente a la llamada "Resistencia italiana" -también llamada "Resistencia partisana"-, un movimiento armado de oposición al fascismo y a las tropas de ocupación nazis instaladas en Italia durante la Segunda Guerra Mundial.

Por otro lado, en lo que respecta a la recuperación de literaturas excluidas, "marginales" o "menores" también cabe subrayar la decisión de publicar -en cuidadas ediciones y casi siempre acompañadas de minuciosos estudios críticos- los textos capitales de cuentistas del siglo XIX de temática fantástica o de terror. Es el caso El enigma de las runas y otros cuentos de fantasmas, del anticuario, medievalista y escritor Montague Rhodes James; El ocaso de los dioses, del librero y poeta inglés Richard Garnett; Carmilla y otras alucinaciones del irlandés 
Joseph Sheridan Le Fanu; El rey de la máscara de oro y otros cuentos fantásticos del crítico, traductor y escritor francés Marcel Schwob; y Kwaidan y otros relatos del profesor y orientalista grecoirlandés nacionalizado japonés Lafcadio Hearn.

Rest trabajó pues activamente en el diseño y la realización del singular catálogo de Ediciones Librerías Fausto, pero además contribuyó específicamente en él, ya fuera prologando, introduciendo o traduciendo autores poco conocidos con el rigor que lo caracterizó siempre en el marco institucional. En ello también cabe reconocer la medida exacta de su compromiso con el proyecto y con el trabajo específico que requiere su materialización. Lleva su firma la puntillosa introducción a Carmilla y otras alucinaciones de Joseph Sheridan Le Fanu (1975c), del que además es traductor -junto a su esposa Virginia Erhart-, y también lleva su nombre la selección, traducción e introducción que él mismo preparó de The Raffles' Adventures de Ernest William Hornung (1976d). Es suya la justiciera vindicación de A rebours de Joris-Karl Huysmans, que Ediciones Librerías Fausto publica en 1977 en traducción de Rodrigo Escudero. Le pertenecen además la versión al español y el prefacio que lleva adelante la singular puesta en valor de The Twilight of the Gods de Richard Garnett (1977) y la brillante introducción a la ajustada traducción de Floreal Mazia de El monje de Matthew G. Lewis (1977), y la no menos erudita introducción a El Nuevo Decámeron de Jan Potocki (1977), que completa la edición aparecida por Minotauro -una década antes- en impecable traducción de José Bianco. 
El contenido particular dispuesto en el diseño del catálogo "Biblioteca de Cuento y Novela" de Ediciones Librerías Fausto guarda pues -como se ha visto- estrecha relación con la última etapa del proyecto crítico restiano, a la vez que constituye un enclave de resistencia a la moral reaccionaria en que se funda la embestida autoritaria desplegada por las sucesivas dictaduras. Como se ha desarrollado en las páginas precedentes, el proyecto crítico de Rest -que comenzó en concreta filiación con la llamada "crítica tradicional" burguesa y que en esa óptica escribió numerosos textos sobre el valor literario de las obras y los autores consagrados del canon- comienza, hacia mediados de la década del '60, un silencioso pero riguroso trabajo de restructuración de intereses que incluye la problematización de textos, autores y materiales culturales marginados por el canon implícitamente sostenido por la crítica "oficial". Su intención está lejos de ser la de reemplazar ese canon por otro que finalmente funcione excluyendo. Busca, al contrario-como se ha señalado en las páginas precedentes-, ensanchar el horizonte de comprensión de las experiencias culturales, esto es, abrir el espacio de lo literario en función de un reconocimiento de la diversidad y la tolerancia coherente con un proyecto intelectual progresista y liberal.

El diálogo entre el catálogo de Ediciones Librerías Fausto y la serie de indagaciones críticas que Rest desarrolla entre 1965 y 1979 se vuelve más nítido a medida que el autoritarismo 
político radicaliza sus formas represivas. Rest relee, cita y pone en discusión en ese contexto una serie particular de trabajos teórico-críticos -entre los que cabe mencionar a La carne, la morte e il diavolo nella litteratura romantica y Il patto col serpente de Mario Praz, Lautreamont et Sade de Maurice Blanchot, La littèrature et le mal de Georges Bataille y Histoire de la folie à l'âge classique de Michel Foucault-; escribe textos como Tres autores prohibidos (1968b), "Retrato del moralista como cínico" (1970f), "Satanás, sus obras y sus pompas" (1970h), "Las agonías del romanticismo" (1971a) y El marqués de Sade y la crisis del racionalismo (1971b) en la elaboración de una suerte de "canon del mal y la transgresión"; estudia la ascendencia decadentista del gótico; releva los orígenes de los cuentos de fantasmas y aparecidos; rastrea la historia del relato de horror y el terror fantástico; y subraya lúcidamente el morbo sobre el que se construye la ascendencia popular del policial negro. Lee y relee a Blake, a Sade, a Jarry, a Cleland, a Aretino, a Lawrence y a Lacenaire, y articula esas singulares lecturas -reeditándolas en un mismo libro- con ensayos como "Emotividad verbal y totalitarismo" (1958b) y "El retorno del realismo" (1964c). Es consciente de que, reeditados en Tres autores prohibidos, junto a textos que tematizan la censura hasta ponerla en ridículo, todos los enunciados antiautoritarios resultan claramente resignificados. Allí aparece un orwell demostrando hasta qué punto «todas las dictaduras apelan necesariamente a tácticas lingüísticas», puesto que su poder y perduración se afirman tanto en «un abierto empleo de la fuerza» -que busca reprimir las 
diferencias- como en «un clima de fanatismo y temor que se impone por medio de un recurso primordialmente lingüístico: la propaganda» (1968b: 199). No es casual pues que luego del Golpe de Estado de 1976, la dictadura impuesta prohibiera categóricamente ese libro, que exhibía la articulación entre terrorismo autoritario y propaganda, acusándolo de «apología de la literatura pornográfica». Lo que en realidad incomodaba ese libro era, sin embargo, la manera en la que se describía cómo, haciendo uso de la propaganda, el poder autoritario consigue encubrir y naturalizar su violencia cuando, por ejemplo, «excluye por completo cualquier referencia a la condición humana de quienes han sido castigados por el atropello y la persecución». Rest no duda en afirmar allí que «la instauración plena del totalitarismo requiere la eliminación del pensamiento libre» que pone en cuestión la verdad de los enunciados emitidos" por la propaganda con que el «totalitarismo se naturaliza» (1968b: 202). Y expone hasta qué punto las estrategias verbales del totalitarismo «no están desvinculadas de las interdicciones artísticas, en la medida en que la censura es uno de los recursos más utilizados para imponer regulaciones intelectuales y para coartar el juicio independiente» (1968:8), ratificando así su interés por los textos y "autores prohibidos", censurados y excomulgados del canon de lo políticamente correcto.

El catálogo de la colección "Biblioteca de Cuento y Novela" de Ediciones Librerías Fausto es estratégico y a la vez íntimo. Tal y como ha quedado claramente registrado entre sus papeles personales, Rest se siente atraído por una creciente «fascinación 
por lo diabólico, lo marginal y lo maldito» ${ }^{281}$. Sus últimos textos dan cuenta de ello, y de su intento por comprender el sentido de esas fuerzas destructivas que señalan un más allá de la razón o la atrocidad misma de la razón llevada al extremo, hasta sus últimas consecuencias. Rest articula políticamente sus investigaciones y su irrenunciable disposición ética en favor de la "libertad del hombre", en la afirmación de un «liberalismo progresista, entendido como un ejercicio constante de tolerancia y devoto, ante todo, de la libertad de los demás» (Gregorich 1987: 83). Su curiosidad por las literaturas marginadas y su preferencia por aquellos textos alusivos que trafican lenguajes y temas que involucran el orden de lo delictivo, lo pecaminoso y lo repudiable desde el plano moral se inscribe también en la órbita de una estrategia política. Rest sabe que el poder autoritario se afirma en una moral rigurosa pero perimida e incluso insostenible. Busca, en efecto, exhibir sus limitaciones y su evidente margen de hipocresía. Pero, sobre todo, está convencido de que «eliminar la clandestinidad» de estos temas "prohibidos" y «trasladarlos a la superficie» es clave para hacer comprensibles sus causas, «neutralizar a sus frecuentes imitadores (especialmente los prosélitos de las prácticas totalitarias)» y a la vez poner fin al maniqueísmo irracional que suele circundarlos. Que la violencia, el terror, el mal sean tematizados es fundamental porque su reconocimiento constituye el

281 Debo el hallazgo de esta nota a la Licenciada Silvana Piga, actualmente encargada de ordenar los papeles personales de Jaime Rest en el sector "Colecciones Especiales y Archivo" de la Universidad de San Andrés, donados por Guillermo Erhart del Campo (cuñado y heredero de Rest) a dicha casa de altos estudios. 
primer paso para ensayar la comprensión de sus causas. Y viceversa: lo que garantiza su continuidad amenazante es el silenciamiento y la censura que se impone desde los agentes que sacan provecho de sus efectos.

La estrategia de Rest es lúcida y las funciones del crítico y el editor se muestran sólidamente articuladas -aun durante el gradual crescendo autoritario. Pero la violencia sin atenuantes con que la dictadura extermina todo intento de resistencia emergente lo obliga a sutilizar su tramoya. Es pues comprensible que Rest no impulse directamente la publicación en el catálogo de Fausto de las obras de los nombres más virulentos en esta tendencia y a los que ha tratado específica o lateralmente en la década precedente -es decir: aquellos que, como Gilles de Rais, Guilleri, Cartouche, Sade y Lacenaire, causan «espanto o escándalo» precisamente «a causa de los recuerdos abominables que han dejado, de las maldades que se les atribuyen, del terror que han inspirado» (Foucault 1990: 184-185). El «fervor de la inteligencia»-que, como afirma Luis Gregorich, «no lo abandonó ni siquiera en los momentos más dolorosos de su vida, cuando la orgía represora que se había instalado en la Argentina lo expulsó de sus cátedras universitarias» (Gregorich 1987: 81)- le hizo sencilla una inteligente lectura de las condiciones históricas objetivas para el sostenimiento de semejante empresa. En primer lugar, percibió con claridad que, a diferencia de CEAL, el pequeño proyecto de Ediciones Librerías Fausto difícilmente soportaría las pérdidas económicas ocasionadas por un eventual pero previsible secuestro de las ediciones. Por otro lado, para 
ese entonces era más que consciente de que su accionar estaba ya bajo la lupa del poder represivo. Rest no era ajeno a esas circunstancias: venía de recibir reiteradas amenazas e intimidaciones por parte de la "Triple A" bajo el gobierno de Isabel Martínez de Perón, pero luego de 1976 debió soportar, no sólo -como tantos otros autores durante el período (Invernizzi y Gociol 2003)- la arbitraria prohibición de Tres autores prohibidos, sino también que la misma dictadura lo asediara con sucesivas amenazas e incluso le abriera una causa judicial por "Actividades subversivas" bajo la Ley 20.840.282 En razón de ello, decidió sutilizar estratégicamente su proyecto crítico y publicar una serie de autores menos radicales que, inscritos lateralmente en la misma línea literaria, eran aún desconocidos en el país y algunos inclusive en habla hispana. Los elegidos le permitieron además trazar -en sus sobrias introducciones críticasfiliaciones temáticas incluso con aquellos textos y autores prohibidos que no podía publicar directamente.

En vez de trabajar sobre los textos más radicales e ir a una confrontación directa de la que había pocas posibilidades de salir con vida, Rest optó por redefinir sutilmente el perfil del catálogo a su cargo. Visto en perspectiva, la configuración de tal catálogo, devuelve no obstante una imagen que lejos está de parecer inocente: los textos que lo componen tematiza obreros irascibles, bandidos desencantados del régimen de acumulación de capital, delincuentes simpáticos, hombres perseguidos por

\footnotetext{
282 Una copia del documento de la causa judicial se encuentra entre los papeles personales de Rest conservados en el sector "Colecciones Especiales y Archivo" de la Universidad de San Andrés.
} 
regímenes autoritarios, "desaparecidos" de los que nadie habla, vagabundos que cuestionan irónicamente el orden social, marginales que reniegan de las convenciones, sociedades represivas en las que se organizan agrupaciones secretas y fuerzas parapoliciales que actúan impunemente incluso a veces en complicidad con las "fuerzas de la ley". Pero eso no es todo. El catálogo diagramado por Rest pone indirectamente en escena formas literarias que describen el terror, la amenaza de muerte y el control psicológico impuesto a través del miedo, e incluso ciertas formas de resistencia a situaciones signadas por la hostilidad, la opresión y la violencia. Y, articulado con su trabajo en CEAL, reafirma los dos núcleos de atención fundamentales de la última etapa del proyecto crítico restiano: explora una particular serie de textos que -temáticamente- se instituyen como una suerte de "canon del mal y la transgresión" y atiende, a la vez, a un "canon marginal", que introduce -en un plano de igualdad con los de la "alta literatura"- géneros excluidos o no del todo legitimados (como el relato de terror, la novela gótica, el policial negro o el aguafuerte), formas alternas a la lógica utilitarista del logocentrismo (como el nonsense, el absurdo y el silencio místico), autores cuestionados por quebrantar las normas en que se apoya el régimen de verdad y textos que abiertamente se constituyen sobre lo que Michel Foucault denominó saberes bajos, marginados o sometidos descalificados o no calificados- en que se cifra el saber histórico de las luchas, la memoria de los combates silenciados y la llama ahogada de la insurrección. 
APÉNDICE $\mathrm{N}^{\circ} 5$

\section{REFLEXIONES DE UN TRADUCTOR ${ }^{283}$}

\section{La libertad y los límites de interpretación}

El problema de la traducción entraña aspectos muy controvertidos que difícilmente logren jamás resolverse de común acuerdo. Se ha debatido hasta el cansancio la posibilidad de traducir, el valor del texto traducido en su relación con el original, la libertad que puede ejercer el traductor en su trato con la obra que está vertiendo. Esta disputa es valedera sin lugar a dudas en un plano teórico, pero el hecho práctico consiste en que la traducción resulta inevitable, en que su ausencia limitaría exageradamente nuestra posible inserción en el mundo de las ideas; y en nuestro tiempo este hecho se hace cada día más urgente. Cuando Livio Andrónico trasladaba la odisea o cuando Catulo imitaba a Safo, todo parecía reducirse a un par de lenguas confrontadas: el griego, del que se traducía, y el latín, al que se traducía. Cuando el asunto volvió a plantearse, por gravitación del humanismo renacentista, el cuadro era bastante complejo; no sólo existían las dos lenguas clásicas de la cultura occidental, sino también el diversificado mapa lingüistico de la Europa moderna con aportes literarios que no podían desconocerse: Boscán tradu-

\footnotetext{
283 "Reflexiones de un traductor" (1976c) en Sur, n 338-39, Buenos Aires, enero-diciembre de 1976. pp. 133-144.
} 
cía a Castiglione, en España; Florio vertía a Montaigne, en Inglaterra. Durante varios siglos esta situación se mantuvo sin mayores variantes: Gallard introdujo el árabe, con su versión francesa de las Mil y una noches; el descubrimiento del sánscrito abrió un nuevo campo; desde el siglo XVIII existió un interés, a menudo impreciso y confuso, por el Extremo Oriente, con la incorporación de Japón y China. Por añadidura, de vez en cuando se exploraba la literatura de alguna región lingüística previamente omitida: Edward FitzGerald ponía de moda la poesía persa; los novelistas rusos del siglo XIX irrumpían en Europa occidental. Por contraste, quien haya leído The World of Traslation, el volumen que en el P.E.N. American Center reunió las ponencias presentadas en el congreso de traductores que se llevó a cabo en Nueva Cork en 1970, sabe que al presente esta situación se ha tornado infinitamente más intrincada, a causa de la precipitada emergencia de innúmeras culturas y lenguas anteriormente casi desconocidas.

El problema de la traducción, por consiguiente, se ha convertido en uno de los asuntos más importantes para la cultura de nuestro siglo. Basta ensayar una brevísima e incompleta nómina de quienes lo han encarado o estudiado para advertir la intensidad de la preocupación: George Steiner, Walter Benjamin, Georges Munin, Maurice Blanchot, Octavio Paz, Jorge Luis Borges, Alfonso Reyes; es decir, críticos, traductores, poetas, lingüistas, filósofos. Las opiniones, como es previsible, no coinciden. Hay, empero, ciertas ideas que parecen haber servido de fundamento común a tales reflexiones: la traducción es inevitable pero, ¿hasta qué punto posee validez un texto literario traspuesto de una lengua a 
otra? De algún modo ha surgido, como respuesta, una metáfora de procedencia musical: el texto original es siempre una partitura que atesora en su silencio la forma ideal de la composición; el traductor no en vano es un intérprete, un ejecutante de la partitura. Ello significa que inclusive en una misma lengua son admisibles diferentes traducciones de un mismo texto extranjero, porque la interpretación de una partitura acepta un razonable margen de variaciones en el que se manifiesta la personalidad artística de cada uno de los ejecutantes. Esta personalidad, en la traducción literaria tal vez mucho más que en la interpretación musical, está condicionada por una tradición: necesariamente, las formas de verter un texto se diferenciarán si el traductor es español, mexicano o argentino, cada uno con sus propios usos lingüísticos dentro del ámbito hispanohablante; y así como la lengua a que traduce o la nación a la que pertenece, en el intérprete también la época jugará un papel decisivo, con sus gustos literarios, sus influencias y corrientes estéticas, sus audacias o interdicciones sociales y morales. Esto último Borges lo ha señalado lúcidamente en el ensayo sobre los traductores de las Mil y una noches que incluyó en su Historia de la eternidad.

De cualquier modo, los perfiles del antagonismo en la disputa acerca de las fronteras de la traducción pueden trazarse a lo largo de dos posiciones extremas. De un lado se hallan los que consideran que la versión debe ser literal o servil y sólo tiene que proporcionarnos un andamiaje que permita recorrer las denotaciones de la obra, a la espera de que el lector obtenga un acceso pleno a las connotaciones en la hipotética circunstancia de que 
llegue a dominar la lengua original; es una posición que suelen asumir los filólogos y los lingüistas, más interesados en la exacta indagación del texto original que en la vitalidad de la traducción. Del otro, encontramos a los hombres de letras encabezados en nuestro siglo por Ezra Pound- que sostienen la necesidad de practicar una traducción literaria, capaz de subsistir por sí misma y de comunicar plenamente los recursos del original, aún a costa de de sacrificar la escrupulosa literalidad. Cada una de estas posiciones se funda en motivos justificados y dignos de consideración: el primer enfoque, de índole erudita, es un llamado de atención a quienes deforman el texto original por mera ignorancia; el segundo, de carácter poético, nos advierte que una pieza que posee incomparable intensidad en su propia lengua no puede ser depreciada en la traducción por ausencia de las cualidades imaginativas que exhibió en su advenimiento inicial. La dificultad consiste en hallar el equilibrio justo que conviene en el tratamiento de cada composición. Borges ha sugerido que Néstor Ibarra, al traducir Le cimetiére marin, logró en un determinado verso convertirse en el autor original al sobrepujar le changement des rives en rumeur, de Valéry, por medio de una muy feliz recreación española: "la pérdida en rumor de la rivera".

Por lo demás, el terreno que pisa el traductor con frecuencia es un tembladeral. El esfuerzo por alcanzar una presunta exactitud ideal puede, inclusive, resultar contraproducente; en especial, cuando se trata de un texto que ha tenido significativa gravitación por espacio de generaciones y que ha dejado su impronta en una determinada cultura a través de anteriores traduc- 
ciones. Al respecto, cabe recordar un episodio que suscitó un ardoroso debate en Inglaterra hacia 1960. Un conjunto de especialistas había sido encargado por las iglesias reformadas de la Gran Bretaña de que preparara una nueva traducción oficial de la Biblia. Al completarse la versión del nuevo Testamento, ésta fue publicada por separado y de inmediato se desató la controversia. En San Lucas, I, 27 la nueva versión decía: For a girl betrothed to a man named Joseph, a descendant of David; the girl's name was Mary. E este pasaje, girl vertía la palabra griega parthénos, cuyo significado primordial es "virgen". Por afán de polémica teológica o por considerar que la palabra presuntamente utilizada en textos que precedieron a la definitiva redacción griega significaba "muchacha" y no "virgen", los traductores de la New English Bible provocaron un conflicto en el que inclusive participó T. S. Eliot, en defensa de la lectura tradicional. Sin entrar a indagar el asunto en vericuetos, el hecho evidente consiste en que, sea cual fuere el nivel de exactitud que se habían propuesto los nuevos traductores, su versión quebraba de manera inopinada una concepción que había arraigado hondamente en la cultura cristiana y que se hallaba convalidada por una multitud de antecedentes. La Vulgata registra: Ad virginem desposatam viro, qui nomen erat Ioseph, et nomen virginis Maria. La versión española de Casiodoro de la Reina y Cipriano de Valera utiliza "virgen". la versión alemana de Martín Lucero escoge Jungfrau (el mismo término que, de paso, designa el signo zodiacal de Virgo). En inglés, Wycliffe y Purvey, en la década de 1380, emplearon maidyn y maydun, en 
tanto que la King James Version, de 1611, adopta sin vacilaciones virgin.

\section{La traducción al español}

Habitualmente se presta mayor atención a la lengua de la que se traduce que a la lengua a la que se traduce; la razón es bastante comprensible: se supone que el traductor vierte el texto a su lengua materna, adquirida espontáneamente, y que el idioma del que traduce lo ha aprendido por los procedimientos artificiales de un estudio sistemático. Sin desestimar lo que pueda tener de verdad esta suposición, conviene empero no descuidar el enfoque opuesto. Por ejemplo, Julio Cortázar señaló alguna vez que la mala calidad de la prosa exhibida por los narradores de habla castellana en los siglos XIX y XX debe atribuirse a la influencia ejercida por el pésimo dominio de su propia lengua que caracterizó a quienes traducían al español las novelas europeas de la centuria pasada, lectura casi exclusiva en los juveniles años formativos de los escritores. España estuvo entre las naciones que más afianzaron en el Renacimiento la práctica de la traducción, con Fray Luis de León, con Quevedo y con otros autores notables; pero entre las vicisitudes históricas y artísticas que sufrió este país debe contarse la ulterior pérdida de la tradición literaria que hace de la traslación poética un acto creativo. Mientras en Inglaterra Dryden, Pope, Shelley, y los Browning y Dante Gabriel Rossetti traducían las obras de distintos idiomas y épocas, en el 
área hispanohablante casi no hubo nombres significativos. A causa de ello, no existen en castellano traducciones reconocidamente clásicas, a diferencia de lo que sucede en inglés, donde Benjamin Jowett es sinónimo de Platón, donde Garnett y Aylmer Maude son nombres asociados a Dostoieviski, Chéjov o Tolstoi, donde C. K. Scott-Monerieff significa A la recherche du temps perdu y Arthur Waley es poco menos que el autor de la narrativa oriental, con The Tale of Grnji y Monkey. Una consecuencia de esta situación se pone de manifiesto en el hecho de que el área de habla hispana simula un cosmopolitismo que sólo encubre tenuemente una actitud parroquial: mientras los más eminentes críticos ingleses o norteamericanos -como F. R. Leavis y Wayne C. Booth- no vacilan en citar las traducciones a su lengua, casi ningún crítico del ámbito hispanohablante que deba mencionar algún párrafo de una obra extranjera acudirá a una versión ya existente en su idioma, sino que apelará a la transcripción (o traducción propia) del texto original; esta práctica no deja de ser justa, si se toma en cuenta las galimatías en que el traductor convirtió, no hace mucho tiempo, ciertas partes de El hombre sin cualidades de Robert Musil. Es curioso observar que en Inglaterra tanto Homero como los dramaturgos griegos son autores vivos; la explicación consiste en la calidad y en la abundancia de las traducciones concebidas con fuerza y actualidad literarias, incluida la Odisea de T. E. Lawrence (que a juicio de Maurice Bowra es el testimonio de un esfuerzo por hacer "claro y vívido" el relato homérico para el lector actual). En los países hispanohablantes estos eminentes poetas en el mejor de los casos son mirados con suspicacia, cuando 
no se los considera cadáveres conservados por la idolatría de anticuarios sin imaginación; la causa de ello tiene que buscarse, como bien lo saben quienes debieron soportarlas, en las puntillosas y discretas versiones que publicaba la Biblioteca Clásica de la casa editorial Hernando en las postrimerías del siglo XIX (y sus ulteriores reediciones), la únicas pergeñadas por doctos y eruditos helenistas, quienes dominaban plenamente el griego y sabían disimular las impropiedades de Aristófanes con ayuda de pasajes en latín, si bien nunca supieron nada acerca del placer en que se sustentan la lectura y la experiencia literaria. Lo mismo ha sucedido con Shakespeare: Luis Astrana Marín prodigó su traducción con abundantes notas a menudo seudoeruditas, pero no supo qué hacer (y lo hizo mal) cuando enfrentó los equívocos -muy del período manierista- que se observan en el lenguaje de Launcelot Gobbo, criado de Shylock en El mercader de Venecia; en un parlamento en que este personaje le confiesa a su padre que el emperador lo alimenta tan mal que you may tell every finger I have with my ribs -cómica inversión del dicho tan difundido de que uno está tan flaco que es posible "contarle las costillas con los dedos"-, el traductor español opta por la ambigüedad y hasta la inexactitud al verter: "podéis contarme todos los dedos que tengo en las costillas"

Por cierto, desde hace algunos años, hay promisorios síntomas de que esta situación está cambiando, tanto en España cuanto en Hispanoamérica: casi todos los grandes poetas y muchos de los mejores prosistas han practicado la traducción, a menudo de calidad óptima, y hasta podemos disfrutar de una excelente versión de Lí- 
ricos griegos arcaicos debida a Juan Ferraté. Importante ha sido la contribución de Alfonso Reyes, que ha traducido a Homero, a Mallarmé y a prosistas ingleses (Sterne, Stevenson, Chesterton). En la Argentina es posible mencionar trabajos de índole memorable: alguna versión que realizó Julio Cortázar; Otra vuelta de tuerca en traducción de José Bianco, que sigue siendo la más prodigiosa trasposición castellana de Henry James; El troquel de T. E. Lawrence, reelaborado en nuestro idioma por Victoria Ocampo con notable minuciosidad y aptitud literaria. Cabe una referencia especial para la fugaz colección de Obras Maestras que publicó el Fondo Nacional de las Artes y en la que deben subrayarse los méritos notables de Moby Dick y de la Divina Comedia, respectivamente vertidos por Enrique Pezzoni y por Ángel J. Battistessa.

Una dificultad que se plantea al traductor es la fragmentación de la lengua española. Traducir al francés significa incontestablemente traducir a la lengua que se habla en Francia. Traducir al inglés es más problemático porque, como dirían los franceses, hay versiones de anglais y versiones de americain. Pero nada es tan dificultoso como la traducción al castellano, lengua que tiene múltiples centros de irradiación tanto en España misma cuanto en América Latina, cada uno de ellos con sus peculiaridades expresivas propias. El acuerdo tácito entre los traductores consiste en utilizar una suerte de lingua communis, cuyos rasgos más notorios son el empleo del tuteo (aún en aquellos lugares donde prevalece el voseo) y de un vocabulario neutro. Por supuesto, no siempre esta solución puede aplicarse fácilmente: para un escritor rioplatense saco y pollera son, respectivamente, térmi- 
nos más naturales que chaqueta y falda; además, se compra cigarrillos en el quiosco, no en el estanco. Por otra parte, hay casos muy particulares: el teatro actual que se traduce suele estar escrito en una lengua coloquial en que las palabrotas tienen un valor expletivo, más bien que expresivo: pero si en un escenario de Buenos Aires se conserva este vocabulario acompañado de envarado tuteo el efecto es contraproducente y los términos que tienen por misión exclusiva dar énfasis y color reales recuperan su valor significativo y pueden disgustar injustamente a los espectadores. En tales circunstancias quizá convenga manejarse con dos versiones: una destinada a la representación, en lenguaje local, y otra en lingua communis, que esté destinada a ser impresa y pueda circular por toda el área hispanohablante inteligiblemente; no parece haber otra solución. Un tropiezo análogo suele presentarse en la novela de "serie negra", ese tipo de narración policial norteamericana en la que se destacó Raymond Chandler; el texto tiende a ser en su propia lengua intensamente coloquial y, por consiguiente, se lo suele verter a las formas conversacionales del lugar en que se publica originalmente la traducción; pero la mayoría de los lectores rioplatenses ha comprobado que en la versión circulante de Adios, muñeca de Chandler sería necesaria una ulterior traducción, del caló español a la lengua que ellos son capaces de entender.

\section{La traducción de poesía}


Teóricamente, la poesía lírica es intraducible. Al comienzo de la introducción de su antología titulada The Penguin Book of Modern Verse Translation, Georges Steiner recuerda los argumentos esgrimidos al respecto:

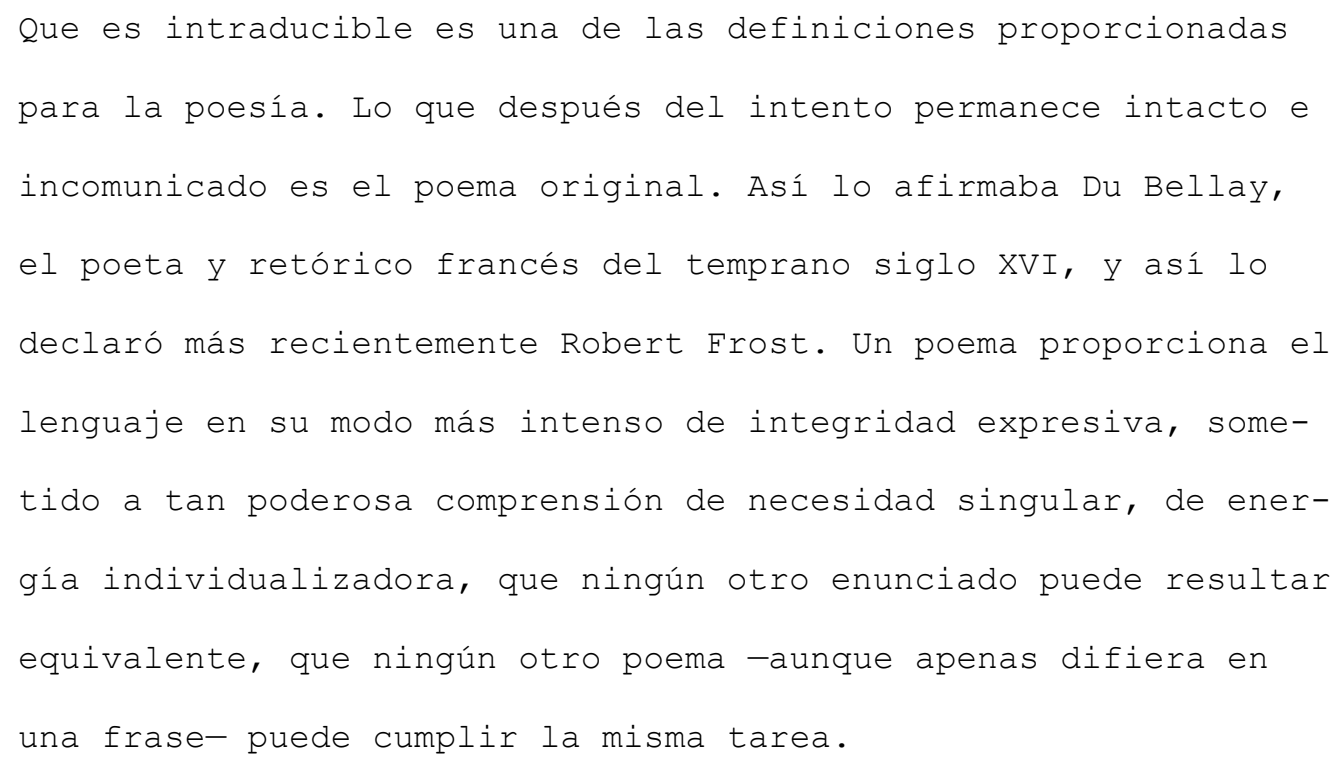

Christian Morgenstern, el efectivamente casi intraducible autor de los Galgenlieder, alguna vez suscribió que es imposible verter poesía: "No existe cosa semejante a una buena o mejor traducción de poesía de otra lengua; sólo hay pobres y más pobres interpretaciones". Susanne K. Langer, en su Nueva clave de la filosofía, intentó una certera explicación de la insalvable dificultad que en principio supone esta especie de traslación; a su juicio:

...los símbolos artísticos son intraducibles; su sentido está sujeto a la forma particular que haya tomado. Ese sentido es siempre implícito y no puede explicarse mediante ninguna interpretación. Esto es válido aún para la poesía; pues aunque el 
material de la poesía verbal, su significación no es el aserto literal formulado con palabras sino la manera en que se formula dicho aserto, y esto implica el sonido, el tempo, el efluvio de asociaciones verbales, las breves y prolongadas secuencias de ideas, el caudal o pobreza de transitoria imaginería que las contiene, la repentina contención de la fantasía mediante la realidad pura o de la realidad familiar mediante la súbita fantasía, la suspensión del significado literal mediante una sostenida ambigüedad que se resuelve en una palabra clave largamente esperada, el artificio unificado y plenamente comprensivo del ritmo.

No obstante, en la práctica es posible traducir poesía, si se tienen en cuenta -e inclusive si se aplican- las consideraciones que acabamos de transcribir como refutaciones del procedimiento. Cada poema es una estructura insustituible, unitaria e intrincada que se propone suscitar una impresión total. No basta con trasladar un cúmulo de palabras y giros si no es indispensable y primordial para conservar el efecto. En consecuencia, sólo es lícito traducir poesía por medio de una nueva composición que se sustente a sí misma: que la elaboración dependa del texto original en lo que respecta a la trama de recursos que se pretende reproducir, pero que una vez completada valga por sus propios méritos artísticos, por su íntima vitalidad. Cuando el lector enfrenta la traducción de un poema, ésta debe hacerle olvidar la existencia del original en virtud de su propia intensidad; de tal modo llega a ser plenamente fiel al texto que ha sustituido. Ello es lo que en el Renacimiento hizo admirablemente Fray Luis de León al ver- 
ter Beatus ille de Horacio: no dudó en aprovechar al máximo las rimas, los metros, las estrofas y todas las restantes posibilidades que le ofrecía el español, a diferencia del latín; así consiguió dar a sus compatriotas una experiencia viva de lo que había sido el original en su propia lengua, no una mera trasposición servil y burocrática. La traducción poética es, ante todo, un acto de creación. Tal criterio ha sido sustentado enérgicamente por Octavio Paz en su ensayo Traducción: literatura y literalidad:

Traducción y creación son operaciones gemelas. Por una parte, según lo muestran los casos de Baudelaire y Pound, la traducción es indistinguible muchas veces de la creación; por otra, hay un incesante reflujo entre las dos, una continua y mutua fecundación. Los grandes periodos creadores de la poesía de Occidente, desde su origen en Provenza hasta nuestros días, han sido precedidos o acompañados por entrecruzamientos entre diferentes tradiciones poéticas. Estos entrecruzamientos a veces adoptan la forma de la imitación y otras las de la traducción. Desde este punto de vista, la historia de la poesía europea podría verse como la historia de las conjunciones de las diversas tradiciones que componen lo que se llama la literatura de Occidente, para no hablar de la presencia árabe en la lírica provenzal la del haiku y la poesía china en la poesía moderna. Los críticos estudian las "influencias" pero ese término es equívoco; más cuerdo sería considerar la literatura de Occidente como un todo unitario en el que los personajes centrales no son las tradiciones nacionales -la poesía inglesa, la francesa, la portuguesa, la alemana- sino los estilos y las tendencias. Ningún estilo y ninguna tendencia han sido nacionales, ni siquiera el llamado "nacionalismo artístico". Todos los estilos han sido 


\begin{abstract}
translingüísticos: Donne está más cerca de Wordsworth; entre Góngora y Marino hay una evidente afinidad en tanto que nada, salvo la lengua, une a Góngora con el Arcipreste de Hita que, a su vez, hace pensar por momentos en Chaucer. Los estilos son colectivos y pasan de una lengua a otra; las obras, todas arraigadas a su suelo verbal, son únicas... Únicas pero no aisladas: cada una de ellas nace y vive en relación con otras obras de lenguas distintas. Así, ni la pluralidad de las lenguas ni la singularidad de las obras significan heterogeneidad irreductible o confusión sino lo contrario: un mundo de relaciones hecho de contradicciones y correspondencias, uniones y separaciones.
\end{abstract}

Por lo demás, esta certidumbre de que la traducción poética sólo admite plasmarse como un acto creador es lo que ha convertido a Ezra Pound en un influjo a la vez tan polémico y tan fecundo en la materia. Desde la rigurosa perspectiva de la traducción servil, sus versiones han sido cuestionadas por la libertad con que eran tratados los textos originales, pero el propósito del poeta no era reproducir en otra lengua una mera sucesión de palabras que se combinaban en una serie de enunciados, sino penetrar una forma de pensamiento y sentimiento, asumir y comunicar plenamente una determinada experiencia, aunque ellos significase alguna transgresión circunstancial de la exactitud. El valor de esta técnica ha sido destacado por Hugh Kenner en su introducción a The traslations of Ezra Pound:

Si el traductor no se limita a verter palabras, permanece fiel a la secuencia de imágenes del poeta original, a sus ritmos o a 
los efectos producidos por sus ritmos, a su tono. En la medida en que conserva esta fidelidad, rinde homenaje al conocimiento profesional de su predecesor, a la eficacia que exhibió de un extremo a otro en su dominio de las imágenes y gestos precisos requeridos para corporizar una visión que no es la suya propia ni la del traductor. La pedantería cosiste en suponer que la relevancia de un instante de pensamiento o sentimiento radica en los términos que otra persona halló para registrarlos. El homenaje que intenta Pound consiste en tomar a un poeta del pasado como guía que nos conduzca a secretos lugares de la imaginación.

En última instancia, el movimiento se demuestra andando. La prueba irrefutable de que la traducción poética es posible en la práctica, como un nuevo acto creador, la proporcionan las versiones francesas de Edgar Allan Poe que realizó Charles Baudelaire y las traslaciones italianas de los líricos griegos que ensayó Salvatore Quasimodo. Pero hay una traducción casi prodigiosa, digna de ser reproducida íntegramente; consiste en los tres cuartetos en que el juvenil William Butler Yeats reprodujo en inglés el memorable soneto de Rosard, Quand vous serez bien vieille, au soir, á la chandelle:

\footnotetext{
When you are old and grey and full of sleep, And nodding by the fire, take down this book, And slowly read, and dream of the soft look Your eyes had once, and of their shadows deep;
}

How many loved your moments of glad grace, 


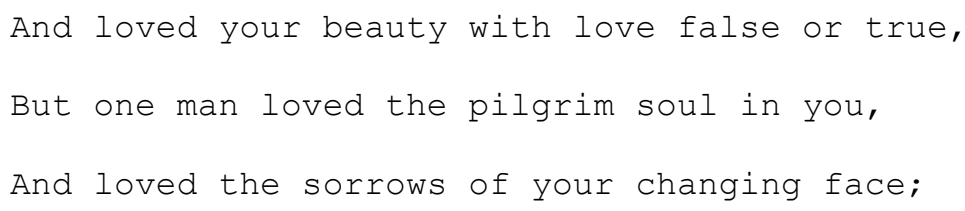

And bending down beside the glowing bars, Murmur, a little sadly, how Love fled And paced upon the mountains overhead And hid his face amid a crowd of stars.

\title{
4. Traducción y erudición
}

\begin{abstract}
La traducción literaria tiene que ser vital, no meramente erudita: debe sustentarse por sí misma. Pero una vez que este precepto ha quedado convincentemente afianzado, es oportuno recordar que también tiene que ser erudita. Si el traductor se apartad del original, debe hacerlo a sabiendas, no por simple ignorancia. En el seminario de traducción que Frank MacShane organizó en la Universidad de Columbia, Richard Wilbur sostuvo muy sensatamente que le traductor de un poema está obligado a conocer en su totalidad la literatura de donde procede, con el objeto de captar alusiones y referencias que se han incorporado al texto. Sería lícito agregar que para verter una composición debemos explorar exhaustivamente la totalidad del circuito de relaciones literarias en que se halla inserta, pertenezcan o no a la lengua del original. Esto resulta muy evidente cuando intentamos trasladar la poesía de T. S. Eliot, sobrecargada con toda especie de
\end{abstract}


reverberaciones. Por ejemplo, en The Waste Land el mismo autor ha proporcionado algunas notas aclaratorias (por cierto, bastante elusivas), que amplió John Hayward para la traducción francesa de Pierre Leyris y que se pueden completar por añadidura con el casi enciclopédico catálogo de Grover Smith, T. S. Eliot's Poetry and Plays: a study in Sources and Meaning. Pero hay datos que acaso podrían resultar útiles al traductor, si bien por lo general no aparecen incluidos en los repertorios de fuentes; entre ellos cabe mencionar el hecho de que la leyenda de Tiresias, tal como la utilizó Eliot, procede de la Biblioteca de Apolodoro, donde se refiere que el mítico vidente obtuvo el don profético al adquirir -como Sigfrido- la aptitud de interpretar las voces de las aves, cuyos gorjeos se renuevan en The Waste Land a través de incesantes onomatopeyas: Apolodoro dice que los oídos de Tiresias fueron "limpiados" (Biblioteca, III, vi, 7), en tanto que el poema de Eliot menciona a los dirty ears del hombre común que no entiende el mensaje oculto en el canto de los pájaros (verso 103).

Esta composición de Eliot -como los principales textos de James Joyce- tal vez presente un caso extremo en cuanto a las dificultades que debe superar el traductor, pero por esa misma circunstancia resulta muy ilustrativa: los errores de interpretación cometidos son un severo llamado de atención. Para ejemplificar los tropiezos sufridos por los traductores tomaremos en consideración solamente dos breves pasajes y verificaremos cómo fueron resueltos en las dos primeras versiones españolas, aparecidas casi simultáneamente en 1930: la de Ángel Flores, publicada en Es- 
paña, y la de Enrique Munguía, que se incluyó en el número 26/27 de la revista mexicana Contemporáneos.

El primero de los pasajes mencionados procede de la parte I del poema "The burial of the Dead", y corresponde al presagio de la "muerte por agua": I do not find the Hanged Man. Fear death by water (versos 54-55). Ángel Flores y Enrique Munguía traducen, respectivamente, "No encuentro al ahorcado" y "No logro dar aún con el ahorcado". En sus notas, el mismo Eliot indicó que ésta era una referencia a la correspondiente lámina del Tarot, la que tiene inscripto el número 12; si bien el autor declaraba en su explicación que no se hallaba suficientemente familiarizado con la exacta composición del mazo de láminas del Tarot, los significados esotéricos que se atribuyen a esta figura se muestran tan apropiados al significado del poema que resulta dudosa tal afirmación. Sea como fuere, no se trata de un "Ahorcado", como dicen ambas versiones, pues es la imagen de un hombre que no ha sido ajusticiado colgándolo del cuello sino que pende cabeza abajo, atado por su pie derecho a la rama de un árbol. La interpretación exacta es, en consecuencia, el Colgado. En la traducción de Pierre Leyris no fue posible incurrir en este error, pues la palabra francesa "pendu" -al igual que la denominación inglesa- admite ambos sentidos: colgado y ahorcado. En cambio, la interpretación inexacta vuelve a darse en la traducción italiana de The Waste Land que realizó Luigi Berti, quien utiliza el término Impiccato ("Ahorcado"), si bien en dicha lengua la respectiva lámina del Tarot se denomina inconfundiblemente el Appeso ("Colgado") . 
El segundo de los pasajes indicados corresponde al final de la parte III, "The Fire Sermon":

To Carthage then I came

Burning burning burning burning

o Lord Thou pluckest me out

O Lord Thou pluckest

burning

Sin duda, O Lord Thou pluckest me out puede resultar, en una primera consideración, bastante ambiguo, en virtud de que el verbo compuesto admite variadas elucidaciones. El problema no resulta tan arduo si se toma en cuenta la precedente referencia a Cartago y se verifica la nota de Eliot que remite a las Confesiones de san Agustín: "Llegué a Cartago, y por todas partes crepitaba en torno de mí un hervidero de amores impuros". La clave de la alusión puede buscarse, en consecuencia, en el libro III de la obra que escribió el obispo de Hipona; en efecto, en las Confesiones, III, 19, leemos: Et misisti manum ex alto et de hac profunda caligine eruisti animan meam. Vale la pena comprobar que entre las versiones del verbo eruo que incluye el viejo diccionario latino-inglés de Sir William Smith (reimpresión 1929), una de las primeras es pluck out. De cualquier modo, el texto de san Agustín no presenta mayores dificultades de interpretación: "Y enviaste tu mano desde lo alto y arrancaste mi alma de esta profunda tiniebla". Por lo tanto, el verso correspondiente de The 
Waste Land debe traducirse: "Oh, Señor, tú me arrancas". Sin embargo, ninguno de los dos traductores castellanos acertó la solución correcta. Enrique Munguía se refugió en una discreta imprecisión: "Oh, Señor, tú que me deshojaste". Pero Ángel Flores logró, sin querer, un irresistible efecto cómico: Oh, Señor, Tú me estás desplumando". Porque ciertamente pluck out significa además "desplumar", como puede comprobarse en cualquier diccionario inglés-español. 


\section{CONSIDERACIONES FINALES SOBRE EL PROYECTO INTELECTUAL}

En una conferencia pronunciada en la Universidad de París 8, en medio de un largo y sinuoso inventario de «las generaciones argentinas», Horacio González ubica el nombre de Jaime Rest en «la del 55», junto a los de León Rozitchner, David e Ismael Viñas, Tulio Halperin Donghi, Osvaldo Bayer, Juan José Sebreli, Ramón Alcalde, Noé Jitrik, Carlos Correas y Oscar Masotta (González 2002: 75). Cronológicamente, la ubicación es irrecusable: Rest nació y empezó a publicar casi en los mismos años que lo hicieron los integrantes del grupo Contorno. Sin embargo, la inclusión del nombre de Rest en esa serie resulta tan extraña, tan arbitraria y, en cierto sentido, tan forzada que, de algún modo, deshace la idea misma de "generación", reduciéndola a la mera coexistencia en un mismo tiempo cronológico y despojándola de su principal valor: el de traducir la experiencia compartida de un sentido histórico.

El caso presenta un problema teórico particular puesto que la incomodidad que produce la colocación del nombre de Jaime Rest en esa lista obliga a pensar la contemporaneidad del autor y su proyecto crítico, no ya como efecto de la mera coincidencia cronológica, sino más bien -según la perspectiva trazada por Hans Gadamer- en virtud a su modalidad de acción y toma de posición respecto del pasado, la tradición y su sentido. Sin caer en el señuelo de una simplificación, el problema podría ser puesto en estos términos: en rigor, los nombres impresos en la lista de Gon- 
zález pertenecen a la misma generación pero ello no los transforma necesariamente en contemporáneos. O, dicho de otro modo: la contemporaneidad histórica de los sujetos biográficos que la componen no puede de ningún modo subordinar, desconocer o borrar las diferencias específicas de obras y proyectos intelectuales que, bajo ningún punto de vista, pueden ser asimilados a un mismo sentido de la historia (Dosse 269-287).

No obstante ello, aun en la discutible contemporaneidad que atribuye, la serie planteada por González deja entrever algo interesante respecto de esta obra crítica tan esquiva como atópica: que su condición descentrada y su dispersión espacial constituyen si no un impedimento, por lo menos un problema concreto a la hora de intentar situar su proyecto intelectual. E incluso permite reconocer además, por contraste, dos modos de temporalidad en los que Rest difiere de los demás autores incluidos en la serie y a partir de los cuales singulariza su propio programa: su temporalidad teórica y su temporalidad política.

Dos argumentos fundamentales permiten distinguir a Rest y a su proyecto intelectual del que podría llamarse -abusando quizá aquí también de la generalización del crítico uruguayo Emir Rodríguez Monegal- la de «los parricidas de Contorno»: el primero remite al importante desacuerdo formal y sustancial entre su obra y la de aquéllos; el segundo, a la singularidad característica del modelo intelectual por el que Rest opta frente al modelo que caracterizan y promocionan sus "contemporáneos generacionales". Porque, si bien es cierto que -vista en perspectiva- la producción crítica restiana dibuja una trayectoria de pronunciada "de- 
riva progresista", ya en sus intereses y temas de investigación como en su perspectiva crítica -deriva que, gradualmente, se superpone con una serie de transformaciones visibles en su proyecto político-intelectual-, su proyecto de trabajo no sólo no se alinea nunca ni teórica ni metodológicamente al de aquéllos, sino que un cotejo cuerpo a cuerpo bien podría corroborar que en todo momento Rest se empeña deliberadamente en tomar distancia tanto de sus posiciones políticas específicas como de sus modalidades de intervención.

La diferencia específica entre Rest y el grueso de los autores incluidos en esa lista se da, en principio, por el modo de intervención en que éste plantea su práctica específica, definiendo un ethos singular a partir de la construcción de su punto de vista y su modo de disponer e iluminar sus objetos de investigación. Mientras los contornistas apoyan su intervención específica sobre un modelo agonístico -visiblemente expuesto en la determinación parricida- e inscriben su percepción del mundo en una lógica dialéctica y combativa; la mirada liberal-progresista de Rest se erige sobre una lógica estratégica, que busca en la difícil tarea de hacer existir $-y$ coexistir- formas de experiencia y sentidos culturales heterogéneos. Mientras aquéllos se ejercitan en un modelo denuncialista que acciona a partir de la polémica ${ }^{284}$

284 Quizá sea justo recordar que la polémica no surge primigeniamente del discurso bélico, sino en el contexto de una Teología dogmática, en el contexto de las guerras de religión. Como apunta Raúl Antelo, «señala fundamentalmente la continuación del combate con otras armas, proponiendo algo así como una praxis argumentativa portátil y fulminante, más cómoda que las costumbres lentas o duraderas de la dialéctica clásica, activada siempre para defender el dogma ante la irrupción de estrategias que no se duda en proclamar irrisorias e impertinentes". (Antelo, R., "La teoría y sus ventosas", NELIC, Boletim de pesquisa, vol. V, $\mathrm{n}^{\circ}$ 6/7, Florianópolis, 
y que lucha por imponer la (única) verdad -en una espacio de encubrimientos y complicidades- disponiendo valoraciones y juicios concretos y urgentes en función de esos intereses, Rest opta por una intervención moderada y erudita en que la valoración ocupa un lugar marginal, cuando no inexistente. Mientras los parricidas se hacen un lugar de enunciación a partir de la polémica, con intervenciones directas y de coyuntura, Rest rechaza el efectismo de la polémica -donde la confrontación encapsula posicionamientos, donde el otro deja de ser un «interlocutor en la búsqueda de la verdad», y es rápidamente convertido en «un adversario, un enemigo que es culpable, es nocivo y, por ende, es alguien cuya propia existencia constituye una amenaza» (Foucault 1999: 353-354) ${ }^{285}-$ y opta por una enunciación gravada en la sobriedad de lo específico y en la mesura de lo sugerido alusiva e irónicamente, bajo una ejercicio de erudición no ostentadora ni autoritaria: la erudición de Rest -apunta Luis Gregorich- era ajena a todo matiz de compulsión y de autoritarismo con que a menudo suelen disfrazarse «el subdesarrollo y la nostalgia del saber metropolitano» y no aspiraba al poder en modo alguno sino que «sólo era el libre e irónico despliegue de las infinitas relaciones, de los secretos vínculos que recorren la cultura y el lenguaje, y cuyo develamiento vale por sí mismo» (Gregorich 1987: 83).

$2003)$.

285 Para el polemista -agrega Foucault- «el juego no consiste, por tanto, en reconocer al otro como sujeto que tiene derecho a la palabra, sino en anularlo como interlocutor de todo diálogo posible, y su objetivo final no será el de acercar tanto como se pueda una difícil verdad, sino el hacer triunfar la causa justa de la que desde el comienzo es el portador manifiesto. El polemista se apoya en una legitimidad de la que, por definición, es excluido su adversario» (Foucault 1999: 354). 
Mientras la lógica dialéctica se alimenta de la polarización, haciendo intervenir -como bien nota Foucault en El nacimiento de la biopolítica- términos contradictorios en el elemento de lo homogéneo, la lógica estratégica no hace valer términos contradictorios en un elemento o momento de lo homogéneo (que es promesa de su resolución en una unidad sintética), sino que su función es la de establecer «las conexiones posibles entre términos dispares y que siguen dispares» (Foucault 2006a: 62). Rest trabaja sobre esta lógica de la estrategia. Se niega a reducir el espacio de lo cultural a un "campo de batalla" y opta por asumirlo deliberadamente como un espacio de ficciones e impregnaciones heterogéneo y dinámico. ${ }^{286}$ Sobre ese criterio, construye una perspectiva crítica que se afirma en un ethos liberal progresista que hace del cosmopolitismo y la tolerancia sus puntales fundamentales; un ethos crítico que tiene el valor de no ceder a los principios de exclusión y que por el contrario fomenta la coexistencia, la unión y la conexión de lo diverso -y en muchos casos incluso se empeña en ponerlo en evidencia al trazar, por ejemplo, sutiles relaciones entre las manifestaciones populares o masivas de la "baja" cultura y los recursos y tópicos de la "alta" literatura, así como también al poner en evidencia los orígenes populares y siempre impuros de las formas legitimadas de la "alta" Cultura.

\footnotetext{
286 A fines de la década del 70 en sus cursos del collège de France, Foucault propondría a su auditorio sustituir la lógica dialéctica por una lógica de la estrategia afirmando que «una lógica de la estrategia no hace valer términos contradictorios en un elemento de lo homogéneo que promete su resolución en una unidad. La función de la lógica de la estrategia es establecer las conexiones posibles entre términos dispares y que siguen dispares. La lógica de la estrategia es la lógica de la conexión de lo heterogéneo y no la lógica de la homogenización de lo contradictorio» (Foucault 2006a: 62).
} 
En segundo lugar, en el contexto del llamado «proceso de modernización de la crítica en la Argentina», consolidado -según la hipótesis de Carlos Mangone y Jorge Warley- hacia mediados de la década del 50 a través de un grupo de escritores con cierta «unidad de formación» nucleados alrededor de las revistas centro y Contorno, Rest contrasta particularmente en razón de una diferencia importante en la configuración de su función intelectual. La diferencia es tanto de orden teórico e ideológico como de inscripción social. Mientras los contornistas se inscriben en una colocación de izquierda sartreano-marxista y antiliberal que les permite producir tanto una revisión del peronismo como una tímida adscripción al proyecto frondizista, el horizonte de formación y el espacio de inscripción de sus primeros trabajos de Rest remite a un complejo proceso de afiliación ${ }^{287}$ teórica y política antipopulista y antinacionalista que lo enmarcan en una perspectiva liberal y cosmopolita. Es por eso que, pese a compartir con los integrantes de Contorno un horizonte de filiación (pertenencia a una clase media ascendente de origen pequeñoburguesa y una formación profesional en el ámbito de la misma universidad peronista), y aun cuando su trabajo crítico siempre esté más emparentado con la refinada escritura de figuras como José "Pepe" Bianco, la precisión erudita de Ángel Batistessa, la consistencia filológica de

\footnotetext{
287 En un trabajo de desnaturalización de lo cultural, la conciencia crítica se rebela -como bien explicita Edward W. Said en El mundo, el texto, el crítico- contra los procesos de filiación (natural e intuitiva) a determinados esquemas ideológicos y redistribuye compromisos y responsabilidades en función de procesos de afiliación (electiva, voluntaria e intencional) a esos u otros esquemas. Este proceso afiliatorio determina pues la conciencia crítica: el escritor se elige haciendo lo que hace (y del modo en que lo hace) y esa elección se conjuga en las preguntas sartreanas: qué, para qué y para quién se escribe (Said 2004: 30-47).
} 
María Rosa Lida de Malkiel o la lucidez repentina de Daniel Devoto, la formación inicial de Rest se produce en la periferia de la llamada "Crítica tradicional" y su afiliación política se encuentra fuertemente influenciada, no por el modelo ideológico liberal militado en la revista Sur y el diario La Nación -con los que colaboró eventualmente-, sino por el que caracterizaba a los espacios más laxos y de cierta permisividad o ascendencia progresista, como el Colegio Libre de Estudios Superiores, la Sociedad Científica Argentina o las revistas Realidad e Imago Mundi. Sin los estertores de la radicalización de izquierda, la colocación de Rest irá orientándose en una pendiente progresista, de un liberalismo demócrata hacia lo que, con ambigua precisión, Beatriz Sarlo definió como un «socialismo liberal»o, mejor aún, como un «socialismo fabiano» ${ }^{288}$. Esto es: «un liberalismo a la inglesa, pero sin el Imperio, sin las colonias, sin la City, sin la flota, sin la intención de imponer ese liberalismo a quienes no lo comparten ni entienden» (Gregorich 1987: 83); lo que lo convertía en liberal genuino, «un liberal que en realidad es un hombre libre y que quiere la libertad de los demás» (Gregorich 1987: 84).

Por otra parte, la recurrencia casi obstinada a los atributos de discontinuidad, dispersión y excentricidad cada vez que su obra reclama adjetivación, no deja de ser también significativa en términos críticos. Remite a una lectura y a un modo de evaluación de la función intelectual ligados a un paradigma definido por la continuidad, la coherencia y la consistencia. En una pala288 Aporte de Beatriz Sarlo quien participó desde el público en la Mesa debate: "Rest en su laberinto", actividad organizada por la editorial Eterna Cadencia, en mayo de 2009 (cfr. Crespi, M. J. Laforgue y J. Monteleone). 
bra: se juzga así el proyecto intelectual restiano, no por lo que es, sino -precisamente- por lo que no es. En el sustrato de esas valoraciones está la figura del "intelectual universal" (comprometido u orgánicol como horizonte de lectura. Se juzga la consistencia del proyecto o la performatividad del discurso crítico intelectual sin interrogar esa discontinuidad, esa dispersión y esa excentricidad en su valor específico, y siempre atribuyéndolas a una deficiencia -producida ya por las condiciones de producción objetiva del proyecto o ya por propia incapacidad del intelectual para resolver sus contradicciones internas. En cualquier caso, nunca se la piensa como una modalidad efectiva de acción estratégica. No se sospecha siquiera del hecho de que la discontinua, dispersa y excéntrica obra de Rest haya sido objeto de la misma persecución y censura que la de intelectuales que hacían de la continuidad, la coherencia y la consistencia los valores fundamentales de sus proyectos intelectuales.

La exploración precedente ha permitido observar que es precisamente en su discontinuidad, su dispersión y su excentricidad donde radica la estrategia fundamental del proyecto intelectual restiano. Es ahí donde ejerce su función política y donde el proyecto exhibe sus apuestas más arriesgadas y efectivas. Y para corroborarlo sólo ha bastado con prestar atención a los momentos en que definía su configuración formal, su espacio de intervención y sus enunciados específicos, considerándolos -por supuesto- en su historicidad, como respuesta a un campo de fuerzas complejo pero preciso y en una articulación sutil con una serie de objetivos defi- 
nidos en perspectiva -es decir: de acuerdo a sus propias condiciones de producción y posibilidad.

Pero eso no es todo. La exploración además ha devuelto una imagen particular de la función intelectual inscrita en el proyecto restiano. Es por ello que, a partir de su modalidad específica, ha sido posible descartar de plano -por simplistas, pero también por falaces- las lecturas que sugerían circunscribir su proyecto a una forma rezagada y epigonal de la "Crítica tradicional", así como también despegarlo de una rápida inclusión en el contexto de una perspectiva generacional a la cual lo une poco más que la arbitrariedad cronológica. Más aún, en el curso mismo de esta investigación, ha encontrado sus propias condiciones objetivas una nueva hipótesis, surgida de un análisis de la modalidad específica de intervención del trabajo intelectual restiano sobre la base de un proceso de transformación del rol del intelectual y la reconfiguración de funciones.

\section{INTELECTUAL ESPECÍFICO}

En una caracterización muy general -que sin dudas corre el riesgo de comportar un reduccionismo-, podría decirse que la "generación del '55" responde al modelo del intelectual universal comprometido, inaugurado por Émile Zola a partir del célebre "caso Dreyfus" y consolidado en las primeras décadas del siglo XX en la figura emblemática de Jean-Paul Sartre. El proyecto intelectual de Rest, en cambio, no sólo se sustrae a las características genera- 
les de ese modelo, sino que además parece encauzarse en una tendencia que cierra ese clásico paradigma. En "Les intellectuels et le pouvoir" (un diálogo con Gilles Deleuze de 1972) y "Vérité et pouvoir" (una entrevista que le realizara Alessandro Fontana en 1977), Michel Foucault delinea con claridad la colocación y las funciones precisas del modelo intelectual universal frente a las que empiezan a vislumbrarse en el nuevo intelectual específico. Un examen atento de las distinciones planteadas por Foucault en estas intervenciones permite comprender hasta qué punto el proyecto intelectual restiano -fascinado por la naturaleza dinámica de lo social- estaba también inscrito en el proceso de una transformación singular.

En la primera de esas conversaciones, reflexionando en torno a la relación entre teoría y práctica en la función intelectual, Foucault plantea la inminencia de un cambio en el modo en que se materializa la politización del intelectual llamado "de izquierdas" o -en un sentido más abierto, pero a la vez más concretodel intelectual "progresista". Tradicionalmente -sostiene el filósofo- esa politización estaba dada en función de dos factores: su posición en la sociedad burguesa, en el sistema de la producción capitalista, y en la ideología que producía o imponía su propio discurso en tanto era capaz de revelar una cierta verdad y de descubrir relaciones políticas allí donde no se percibían. Por lo demás -como irónicamente apunta Foucault-, esas dos formas de politización no eran ajenas una a la otra, aunque tampoco coincidieran necesariamente. En todo caso, el intelectual era objeto de aprecio o desprecio, de adhesión o rechazo, de protección o per- 
secución, en el mismo momento en que la "realidad" aparecía en su "verdad". Su función social era pues, en efecto, la de decir «la verdad a los que todavía no la veían y en nombre de los que no podían decirla: conciencia y elocuencia» (Foucault 1992: 80).

La transformación que nota el filósofo no está determinada por esa conciencia preclara que representa el intelectual clásico. Al contrario: en su óptica, los intelectuales no han tenido más remedio que enfrentarse al hecho de que, en cierto punto de la historia, las masas ya no necesitaran de su discurso para saber ni para decir. Las masas -sostiene Foucault en un enunciado que no hubiera dudado en ratificar el propio Rest- saben y dicen por sí mismas. El hecho de que aun así no consigan romper el cerco de opresión que se les impone se explica por la existencia de un sistema de poder que intercepta, prohíbe, invalida o deslegitima ese discurso y ese saber popular. Lo que Foucault pone en evidencia es, finalmente, que el poder no se encuentra tan sólo inscrito en las instancias superiores de la censura, la prohibición o la represión; sino que también penetra de un modo profundo -muy sutilmente y de manera activa- en toda la red social, a través de los discursos. Deja en claro entonces que los intelectuales -en tanto agentes de la "conciencia" y del discurso- forman parte de ese mismo sistema de poder, en el que sólo pueden intervenir efectivamente si se deciden a luchar contra las formas del poder precisamente ahí donde su ejercicio es a la vez su objeto e instrumento: en el orden del "saber", de la "verdad", de la "conciencia", del "discurso". Si quiere ser efectivo y no malograrse en voluntarismos, su grado de intervención deberá ser pues local, 
regional, y no totalizador. En consecuencia, la lucha del intelectual-concluye el autor de Les mots et les choses- debe darse pues en el sistema de lo específico y no en el de lo universal.

Un lustro después, en diálogo con Alessandro Fontana, Foucault retoma estos argumentos y precisa más aún su análisis de dicha transformación. Plantea que si durante mucho tiempo el intelectual llamado "de izquierda" tomó la palabra y experimentó el reconocimiento de su derecho a hablar en tanto propietario de la verdad, si se lo escuchaba -o él pretendía que se lo escuchaseen calidad de "representante de lo universal", si "ser intelectual" era por entonces ser de algún modo un poco "la conciencia de todos" (de esos "todos" que a su vez eran portadores inmediatos, inconscientes- de lo universal), esto se debió fundamentalmente a una suerte de mistificación de la práctica intelectual. De esta mistificación habrían sido -según explica el filósofo- un poco responsables también los propios intelectuales, quienes -en contraprestación de una «elección moral, teórica y política» en favor de los intereses de «los sin voz»- se habrían arrogado el derecho a ser considerados portadores conscientes y voceros de esa universalidad. De este modo, el intelectual habría hecho de sí «la figura clara e individual de una universalidad de la que el proletariado sería la forma gris y colectiva» (Foucault 1997: 138). Que la crisis de ese modelo intelectual se superponga no sólo con una pérdida de credibilidad sino también -y sobre todo- con una transformación específica en el modo de producción de la práctica (su profesionalización), lleva la cuestión a una instancia irreversible. En efecto, es un nuevo modo de concebir la 
relación entre teoría y práctica lo que -como bien afirma Foucault- ha impulsado la transformación en el rol del intelectual en la historia. Por diversas razones, gradualmente, desde comienzos de la década del '60, ha empezado a ganar peso -hasta imponerse casi definitivamente- la función del intelectual específico. El trabajo intelectual ha dejado de definirse por su intervención sobre lo universal, lo "ejemplar", lo "justo-y-verdaderopara-todos", para comenzar a operar de manera efectiva en sectores puntuales, determinados específicamente: en los «puntos precisos donde los situaban sus condiciones de trabajo, o bien sus condiciones de vida (la vivienda, el hospital, el asilo, el laboratorio, la universidad, los vínculos familiares o sexuales)» (Foucault 1997: 139).

Esta transformación puede ser leída en dos sentidos diferentes: por un lado, negativamente, como en Representaciones del intelectual lo hace Edward W. Said, quien interpreta ese pasaje como resultado de una serie de presiones que la sociedad capitalista imprime sobre la práctica intelectual -a través de la especialización, la experticia, la burocratización y el mercado- y cuya única salida sería -según la ironía de Foucault- una suerte de retorno forzado al amateurismo (Foucault 1997: 139); por otra parte, la transformación puede ser interpretada también en términos positivos, como lo hace el propio Foucault al examinarla como correlato específico del pasaje de la sociedad regida por los dispositivos disciplinarios a la gobernada en función de dispositivos de seguridad (Foucault 2006b: 15-71), y para quien el hecho de tener que enfrentarse a problemas no universales sino especí- 
ficos -distintos a veces a los del proletariado o las masas- permite al intelectual ganar «una conciencia mucho más concreta e inmediata de las luchas»y, a la vez, acercarse a esas masas de una manera distinta: a través de la experiencia de hallarse él mismo inmerso en «una red de luchas reales, concretas, cotidianas», en las que finalmente debe enfrentar, de otro modo, al mismo poder que oprime al «proletariado, el campesinado o las masas (las multinacionales, el aparato judicial y policial, la especulación inmobiliaria)» (Foucault 1997: 139).

El surgimiento de la figura del intelectual específico tiene, por lo demás, una precisa significación política y compromete sustancialmente lo que respecta a su lugar de procedencia y actuación efectiva. El nuevo paradigma hace que el intelectual no se reconozca más en la autoridad del «jurista notable» -esto es: que deje de ser ya por excelencia el escritor en tanto «conciencia universal», sujeto libre, solitario, iluminado y "maldito", siempre "fuera de lugar", cuya función esencial es la de «hablarle claro al poder» (Said 1996: 93-108)- y que empiece a reconocerse más bien en la actividad del «sabio experto» ${ }^{289}$. Si el poder

\footnotetext{
${ }^{289}$ Foucault clasifica los dos tipos intelectuales a partir del modelo en el que abrevan. El intelectual universal deriva de la figura histórica del «hombre de justicia, el hombre de ley, aquel que al poder, al despotismo, a los abusos, a la arrogancia de la riqueza opone la universalidad de la justicia, la equidad de una ley ideal». Su figura prototípica es Voltaire, cuya actividad aún está ligada a la del jurista o, mejor aún, a la «del hombre que se reclamaba de la universalidad de la ley justa», aún contra los profesionales del derecho. En una palabra, deriva del «jurista-notable» y encuentra su expresión más plena en el escritor, portador de significaciones y de valores en los que todos pueden reconocerse. El intelectual específico deriva, al contrario, del «sabio-experto». Este modelo intelectual tiene como antecedente célebre a Darwin y a los evolucionistas post-darwinianos: «las relaciones tormentosas entre el evolucionismo y los socialistas, los efectos muy ambiguos del evolucionismo (por ejemplo sobre la sociología, la criminología, la psiquiatría, el eugenismo), señalan el momento importante en el que, en nombre de una verdad científica "local" -
} 
no se reduce a una función negativa -y si su localización no puede ser determinada por el simplismo de «quienes lo ejercen y quienes lo padecen»-, los espacios de intervención en las mallas del poder son mucho más específicos, más capilares, más diversificados pero también más concretos y más próximos y menos voluntaristas que los imaginados por el intelectual universal. Si el paso de la Política a la política implica una comprensión más lúcida de la localización del poder, el intelectual específico por fin reconoce que su actividad no está por encima de otras, sino ligada a otras por su acción microfísica. En consecuencia, el intelectual específico es siempre y ante todo un especialista que vive una relación de dependencia y a la vez de incomodidad con los poderes, las instituciones y los espacios que lo legitiman: porque trabajan para el Estado o para el Capital, los intelectuales específicos -sean ingenieros, magistrados, profesores, periodistas, etc.- tienen la posibilidad concreta de actuar sobre ellos. Más aún, si «desde el momento en que la politización se opera a partir de la actividad específica de cada uno, el umbral de la escritura, como marca sacralizante del intelectual, desaparece», lo que en la práctica se pone en juego es, en efecto, una red de fuerzas que hace posible los lazos transversales entre saberes específicos y crea vasos comunicantes que se activan de un punto de politización a otros: así «los magistrados y los psiquiatras, los médicos y los trabajadores sociales, los trabajadores de laboratorio y los sociólogos pueden, cada uno en su lugar

sea lo importante que sea-, se da la intervención del sabio en las luchas políticas que le son contemporáneas» (Foucault 1997: 141). 
propio y mediante intercambios y ayudas, participar en una politización global de los intelectuales» (Foucault 1997: 140).

En este proceso desmontado por Foucault, el "escritor" tiende a desaparecer como figura de proa; pero el divulgador, el profesor y la universidad aparecen, no ya como como elementos principales de la verdad, sino como efectivos "ejes de transmisión", puntos privilegiados en el cruzamiento que la compone. Frente a la actitud del intelectual universal, que rechazaba la especialización y la academia como formas y espacios válidos para su intervención política, el intelectual específico comprende que la universidad y la enseñanza son regiones políticamente cruciales. Es en esos espacios donde sus intervenciones se refuerzan y donde se multiplican exponencialmente sus efectos de poder.

Lo que Foucault percibe es pues que la transformación de los modelos intelectuales es el correlato de un cambio de estatuto en los dispositivos de verdad. Si el intelectual no es ya el «portador de valores universales», sino más bien alguien que «ocupa una posición específica» en la trama social, que su especificidad esté directamente ligada a las funciones generales del dispositivo de verdad -que rige los enunciados a partir de los cuales la sociedad define su organización, sus modalidades de inclusión y exclusión- es lo que ratifica la politicidad indeclinable de sus intervenciones. En este sentido, el intelectual específico de izquierdas evidencia una «triple especificidad» que lo posiciona en una encrucijada difícil: 1) «la especificidad de su posición de clase (pequeño burgués al servicio del capitalismo, intelectual "orgánico" del proletariado)»; 2) la de «sus condiciones de vida 
y de trabajo, ligadas a su condición de intelectual (su campo de investigación, su puesto en un laboratorio, las exigencias económicas y políticas a las que se somete o contra las que se rebela en la universidad, en el hospital, etc.)»; y, por último, 3) «la especificidad de la política de verdad» en que se apoya la estructura de legitimación y legitimidad misma de las sociedades contemporáneas. Y es justamente en esta última instancia donde su posición puede cobrar una significación general, donde sus estrategias de lucha y su combate local o específico son capaces de producir efectos concretos, cuya implicancia no se reduce simplemente al ámbito profesional o sectorial. El intelectual específico lucha en consecuencia a nivel general haciendo transformaciones específicas al interior del régimen de verdad -ya sea desplazando sus límites o transgrediendo sus naturalizaciones. El suyo es un combate en torno a la verdad pero entendiendo esa verdad, no ya como «ese conjunto de cosas verdaderas que hay que descubrir y hacer aceptar» (Foucault 1997: 144), sino más bien como el conjunto de reglas según las cuales se discrimina lo verdadero de lo falso, lo valioso de lo despreciable, lo conveniente de lo condenable. El valor de su trabajo no se asocia, en consecuencia, al coraje que -en determinadas circunstancias- exige el «juicio ideológico», sino más bien a la inteligencia que precede a la descripción y al desencubrimiento de los mecanismos por los cuales determinados efectos políticos son ligados a lo verdadero, a lo valioso, a lo conveniente para una sociedad determinada. El suyo no es pues un combate «en favor de la verdad», sino «en torno al estatuto de la verdad y al rol económico-político que la 
verdad juega» en un determinado espacio práctico y discursivo (Foucault 1997: 144-145).

El modo de intervención elegido por Jaime Rest prefigura en muchos aspectos el modelo del "intelectual específico", característico de lo que podría entenderse como el proceso de modernización de la función intelectual. El mosaico que compone su trabajo da cuenta no de su excentricidad, diversificación y su dispersión, sino de una estrategia que dispone de esas cualidades específicas. No hay un solo texto de Rest que se pronuncie directamente sobre aspectos de la política coyuntural. Pero eso no significa que no las haya. Como se ha visto, en cada una de sus intervenciones específicas, Rest se pronuncia siempre de manera mediata sobre aspectos que exceden los límites de su especificidad. La estrategia de la alusión o la evocación es, en su intervención crítica, una posición de narrador particular. Pone siempre en escena de escritura una serie de indicios que demandan del lector una función activa. De un modo siempre muy sutil, siembra en el lector la sospecha: da un texto denotativo que convida siempre una proliferación connotativa. Al trabajar una escritura que se afirma como un cierto arte de lo indirecto, de lo mediato, de lo oblicuo, su texto se presenta al lector declarando que siempre hay una especie de hiato entre lo que allí se afirma y la referencia eventual de tales afirmaciones en un contexto preciso y determinado. Lo mismo ocurre con sus clases, sus conferencias y los materiales que promueve y divulga en su gestión editorial. Se trata, por supuesto, de la irónica disposición ética del nominalista -presente en la literatura borgeana- convertida en táctica 
crítica efectiva: entre lo dicho y aquello de lo que se habla hay, en todo caso, siempre una veladura que confirma la existencia de algo que impide ver el horizonte o el límite preciso y definitivo de aquello está siendo dicho.

Sus intervenciones políticas están pues siempre enmarcadas por su especificidad y guardan una relación directa y localizada con el mercado, con las instituciones y con el saber científico en que se legitiman $-y$ en virtud a lo cual se desarrollan en términos prácticos. Pero, al mismo tiempo, se articulan sutil y estratégicamente con intereses y luchas que reverberan más allá de esos espacios específicos. Los ejemplos, como se ha visto, son múltiples y en algunas ocasiones el poder de intervención de lo específico en lo político se potencia contextualmente y se revela (irrecusable) tanto en su labor estrictamente crítica como en sus intervenciones en otras funciones culturales como la docencia, edición, la traducción y la divulgación.

La lectura longitudinal de su producción no deja dudas de que sus intervenciones políticas se encuentran impresas al nivel de la especificidad de su experticia o en un doblez alusivo de su discurso crítico-como sucede, por ejemplo, en sus notas y conferencias sobre autores prohibidos y marginales. Es por ello que su dimensión y función (su política) se definen dentro de lo que podría pensarse como una microfísica de la resistencia tópica a los poderes. En esa perspectiva se orientan sus lecturas gramscianas del policial y la novela negra norteamericana, su reivindicación de las "literaturas del mal y la trasngresión" y de literaturas, géneros y autores "malditos", sus indagaciones sobre la relación 
entre la función emotiva del lenguaje, la demagogia y el autoritarismo, sus particulares opiniones sobre la censura y la traducción, su insistente puesta en valor y promoción de la novela gótica, la literatura de fantasmas y la narrativa de terror desarrolladas específicamente en el diseño del catálogo de Librerías Fausto. En esa micropolítica, se tejían también sus magistrales y recordadas clases sobre el teatro y la novela inglesa tanto en las aulas de la Universidad de Buenos Aires como en las de la Universidad Nacional del Sur, donde -desde un marco teórico constituido por los primeros trabajos de Raymond Williams y Richard Hoggart- Rest reactualizaba el enfoque sobre las formas de relación entre "literatura y política". En el marco de esa insistencia puede leerse también su esmerado intento de secularización del saber literario a partir de sus precisas colaboraciones con las colecciones del proyecto de Centro Editor de América Latina (CEAL), comandado por Boris Spivacow; no sólo en tanto redactor y supervisor de numerosos fascículos sino también desde trabajos específicos como Novela, teatro, cuento: apogeo y crisis (1971b) - Conceptos de literatura moderna (1979a) que buscaban poner a disposición de un público más amplio y diverso una caja de herramientas conceptuales para comprender el proceso dinámico de las formaciones culturales. Y algo análogo puede decirse aun con relación a sus investigaciones sobre la "Situación del arte en la era tecnológica" (1961a) o sobre la compleja relación entre "literatura y cultura de masas" (1965b), donde se revalorizan las formas de la cultura popular sin caer en el populismo -desde las letras de tango (1965a) a la historieta (1979k)- y donde los gé- 
neros considerados "menores" -littérature de colportage, folletín, novela policial, ciencia ficción, literatura radial, letras de rock, cine comercial, etc.- son interpelados con la misma intensidad con que se abordan las "altas" literaturas sobre la base de los aportes teórico-culturalistas como los de Mathew Arnold, F. R. Leavis, Arnold Hauser, George Orwell, Walter Benjamin, Herbert Read, Edmund Wilson, Richard Hoggart, Raymond Williams, Edward P. Thompson y Stuart Hall. Es en esos trabajos donde nace y se pone de manifiesto su inquietud por las relaciones entre arte e ideología y arte y propaganda, cuyo debate se proyecta radicalizándose sin duda- en los textos reunidos en Tres autores prohibidos (1968b) y, más adelante, en Conceptos de literatura moderna (1979a).

Rest opera deliberada y estratégicamente: sus temas no son nunca casuales y sus intervenciones siempre se relacionan alusivamente con el contexto en que se inscriben. Un caso ejemplar es su investigación en clave histórico-cultural del «problema de actualidad candente» de "La Pena de muerte" (1962): una investigación histórica rigurosa, iniciada en 1956, con posterioridad a los fusilamientos dispuestos por el gobierno militar del general Eugenio Aramburu, y publicada en la Revista de la Universidad de Buenos Aires -por entonces dirigida por José Luis Romero- luego del Golpe liderado por el general Raúl Poggi, el 29 de marzo de 1962, contra el gobierno de Arturo Frondizi. En ese texto singular, Rest ratifica su convicción en que el hecho de que los fundamentos de la pena capital sean discutidos públicamente -y no dispuestos autoritariamente- constituye un «avance de un espíritu 
de tolerancia más profundo y de una mayor preocupación por la equidad judicial»; pero, a la vez, da a entender que en su apología se traducen «hondos y ocultos» factores psicológicos «que determinan la conducta humana, principalmente en sus manifestaciones de índole anormal y asocial» (1962: 487). En la síntesis de ese texto puntilloso, Rest se aboca criteriosa y estratégicamente a subrayar la «categórica lucidez» de los argumentos abolicionistas en razón de que resultan incontestables al referir el componente de sadismo que supone la defensa misma de la pena capital; pero también al dar pruebas fehacientes -sobre el ejemplo de las condenas de los anarquistas Sacco y Vanzetti- de la imposibilidad de los jueces para evaluar objetivamente hechos que serán penados con un castigo irreversible; y aun por el hecho probado de que su imposición social, no sólo no amedrenta las eventuales transgresiones, sino que además potencia sustancialmente la agresividad de las acciones delictivas. Finalmente, el texto -que se abre con una irónica descripción del código Hammurabi que es algo así como una versión macabra y aterradora de la Enciclopedia china descrita por Borges en "El idioma analítico de John Wilkins"290- se cierra con una significativa declaración de Rest donde señala que,

\footnotetext{
290 «En el código Hammurabi -escribe Rest al comienzo de su artículo- la pena capital es el explícito castigo para quien maldice injustificadamente (art. 1), para quien obra encantamientos en perjuicio de terceros (2), para quien presta falso testimonio (3), para quienes comenten diversos delitos contra la propiedad (6 a 11), para quien ofrece refugio a un esclavo evadido (19), para quien se introduce sin autorización en propiedad ajena y comete en su recinto un acto punible (21 y 22), para quien se apodera ilegalmente de objetos rescatados de un incendio (25), para quien se insubordina durante el cumplimiento de una misión oficial (26), para quien encubre a facciosos (109), para quien comete violencia contra la mujer de un desconocido (130), para quienes perpetran delitos sexuales o descuidan obligaciones maritales (143, 153, 155 y 157), para quienes son culpables de grave deslealtad en el ejercicio comercial o profesional (227 y 229)» (1962: 487-488).
} 
«cuando se impone por causa política o mediante juicio sumario, a través de cortes marciales o de disposiciones excepcionales» la pena capital no sólo carece de legitimidad sino que, en lo concreto, se superpone con la acción delictiva misma -ya que, «desde el punto de vista legal es inútil atribuir la más mínima pátina de justicia» con relación a acciones que encubren su «vicio de procedimiento y conducen a toda suerte de arbitrariedad» (1962: $501-502)$.

Es claro que, como intelectual específico, Rest ocupa finalmente una plaza singular y es ella misma la que garantiza y legitima el fondo político (liberal) de sus enunciados teóricos. Su trabajo crítico busca hacer visibles los mecanismos del poder represivo precisamente ahí donde son ejercidos solapadamente, desarticulando mitos y desactivando prejuicios naturalizados en su propio espacio de saber (Foucault 1975: 30-31). No es casual pues que, tal y como ocurriera con los casos del destacado ingeniero y físico Walter Enrique Daub o el eximio matemático Antonio Aniceto Monteiro, Rest y su trabajo crítico fueran perseguidos, censurados y fustigados -mediante recurrentes y diversas intimidaciones - mediante amenazas directas- por el Poder (represivo), no en función de un discurso general sobre lo político, sino precisamente por intervenir lo político desde el espacio de saber en que su voz hallaba legitimidad. El carácter específico y estrictamente localizado en un dominio que excedía largamente la competencia de los censores resultó determinante para que sus intervenciones pasaran muchas veces desapercibidas a los ojos de un Poder represivo que, a partir de mediados de la década del 170, ya hacía 
blanco fijo en los intelectuales universales comprometidos -a los que acabó por someter en la encrucijada del silencio, el exilio o la muerte (Gilman 2003). Y fue ese procedimiento estratégico sutil pero a la vez efectivo, apoyado en la alusión para pronunciarse contra la escalada de violencia que llegaría a su clímax de represión y autoritarismo en el período 1976-1983, lo que finalmente le permitió - «cuando la orgía represora que se había instalado en la Argentina lo expulsó de sus cátedras universitarias» (Gregorich 1987: 81)- seguir trabajando, como bien recuerda Luis Gregorich en La utopía democrática, «casi en forma anónima, en cursos, conferencias, artículos, prólogos, traducciones y libros que eran un hermoso ejemplo de integridad intelectual en medio de la corrupción y la mediocridad que nos rodeaba» (Gregorich 1987: 81-82) .

Jaime Rest falleció de manera repentina, mientras redactaba una colaboración para la revista Vigencia, el 8 de noviembre de 1979, en un gabinete de investigación de la Universidad de Belgrano, en la ciudad de Buenos Aires. Para ese entonces su nombre ya no aparecía desde hacía casi 10 años en la lista de colaboradores de Sur; se lo leía en cambio asiduamente en revistas como Crisis, Los libros y Punto de Vista. Lejana estaba ya su renuncia a la cátedra compartida con Borges en la UBA y más reciente era su actividad como Profesor titular de las cátedras de Literatura Europea Medieval, Literatura Europea Moderna y Literatura Europea Contemporánea en la Universidad Nacional del Sur de Bahía Blanca, donde había vivido y trabajado desde 1959 hasta 1975, cuando fue cesanteado por "recomendación" de autoridades militares de la Ba- 
se Naval Puerto Belgrano ${ }^{291}$. Como motivo de la "recomendación" respaldada por la división de inteligencia del V Cuerpo del Ejército (comandado por Carlos Guillermo "Pajarito" Suárez Mason y Ramón Genaro Díaz Bessone)- el comunicado militar alegaba, sencilla y significativamente, una «conducta sospechosa en sus actividades extra-académicas». Según el testimonio de sus alumnos y compañeros de trabajo, con esto se hacía referencia al hecho de que -después de dictar sus magistrales clases en las aulas de la UNSur- Rest solía subir a su bicicleta y pedalear junto a un puñado de alumnos -muchos de ellos militantes de la Juventud Peronista- hasta alguna de las villas bahienses, donde dictaba «exactamente la misma clase que había ofrecido en la universidad». ${ }^{292}$ El testimonio no es anecdótico. Da cuenta de la persecución que se acentuaría más aún después del 24 de marzo de 1976, cuando un nuevo golpe de Estado cívico-militar encabezado por los comandantes de las tres Fuerzas Armadas, autonominado "Proceso de Reorganización Nacional", derrocara al ya insostenible gobierno de María Estela Martínez de Perón. Pero además ratifica su confianza

\footnotetext{
291 Tal como lo prueban, entre otras, las recientes e importantes investigaciones del periodista Diego Martínez y las de Gattari y Visotsky, Rest fue dejado cesante bajo la gestión del Rector Interventor Dionisio Remus Tetu ("un rumano colaboracionista nazi y reconocido colaborador orgánico de la Alianza Anticomunista Argentina impulsada por el lopezrreguismo"), en el marco de la administración Ivanisevich. En este oscuro período represivo fueron cesanteados además 225 profesores y otros tantos trabajadores no docentes y fue asesinado, dentro del propio edificio de la Universidad Nacional del Sur, a manos del "Cuerpo de seguridad del Rectorado", el estudiante David Nolver Cilleruelo, apenas días después de las referidas cesantías.

292 Testimonio oral de la profesora Silvia Capelli, auxiliar de Investigación en el Instituto de Humanidades que dirigía Héctor Ciocchini y cuyo vicedirector era Jaime Rest, que también tenía a su cargo la sección de Literatura Inglesa, en la que, además de Capelli, trabajaban Virginia Erhart y Necha Giorgetti de Rábano.
} 
plena en un discurso complejo -autorizado pero no autoritarioque es capaz de convocar sentidos en diferentes ámbitos.

Las reiteradas intimidaciones, las amenazas continuas y las sucesivas censuras por parte del poder represivo no consiguieron amedrentarlo. Al contrario: lo convencieron más aún de la eficacia política de su trabajo específico. Sin ser militante, su afirmación política fue progresista tanto en su disposición ética como en el contenido concreto de sus enunciados. Su socialismo liberal lo puso más cerca de las gestiones de la reforma que de los avatares de la revolución. Su convicción de que lo social y lo cultural se han conformado históricamente como una red de tensas imposiciones y subterráneas resistencias afirmó su convicción de que éstas mismas son tanto más reales o eficaces cuanto se forman en el preciso espacio en que se ejercen esas relaciones de poder, ante todo porque de esa manera las resistencias locales se integran a estrategias globales. Dispuso así todas sus energías en interrogar la especificidad de acción de los mecanismos de poder y resistencias en su propio espacio de saber, reparando en sus enlaces, sus extensiones y modificaciones propias. Sus investigaciones en torno a la condición maldita, la marginalidad y la exclusión de textos, autores o géneros, y su específica atención a la raíz formal y sustancial de su virulencia o incomodidad respecto de una época (o un régimen de verdad), exhiben sin duda su convicción de que es sobre las zonas malditas, proscritas, sublimadas o tabuadas del imaginario burgués donde asoma el fundamento último de la barbarie represiva y autoritaria. 
Sin embargo, su colocación de algún modo desconcertaba a los fichajes. Al quitarse deliberadamente a la lógica maniquea de la contradicción, su propio trabajo se definía hacia una nueva modalidad de lucha intelectual -aún a riesgo de ser acusado tanto de "sospechoso" (por parte del Poder hegemónico) como de "tibio" (por parte de una resistencia radicalizada al extremo, y no exenta de una lógica de acción e impugnación microterrorista). Durante la larga noche de la dictadura, Rest coordinó pues -tanto en Buenos Aires como en Bahía Blanca- pequeños grupos de lectura clandestina, donde se abordaban textos como el monumental The Making of the English Working Class de Edward Palmer Thompson, The Uses of Literacy: Aspects of Working Class Life -el «admirable trabajo» de Richard Hoggart-y Drama from Ibsen to Eliot, Culture and Society, 1780-1950 y Britain in the Sixties: Communications de Raymond Williams. Pero es no es todo. Mientras daba a conocer en el país a los textos y autores que, a la postre, serían considerados los founding fathers de los "estudios culturales", a través de sus escritos -académicos o de estricta divulgación-, sus selectivas traducciones y sus memorables conferencias, se encargaba además de vehiculizar puntos de vista progresistas alternativos en un contexto signado por la violencia y el terror, desarrollando hipótesis reflexivas donde no se privaba en modo alguno de hacer referencias -sutiles pero precisas- a las investigaciones de Stuart Hall, Fredric Jameson, Northrop Frye, Kenneth Burke, Leszek Kołakowski, William Empson y H. E. Bates. Contaba como escribió Leo Strauss- con la ignorancia de los censores y la curiosidad de su auditorio. Aferrándose al valor ético de la to- 
lerancia como quien se aferra a la vida, Rest ratificaba la decisión de proseguir y profundizar su programa crítico e intelectual, centrado en la interpelación estratégica del discurso del poder en su propio espacio de intervención, ya fuera desnudando el funcionamiento de sus dispositivos de exclusión en el ámbito específico de la literatura y la cultura, ya señalando -como desde el otro lado del espejo- la deriva inexorablemente catastrófica de un orden racional impuesto sobre una lógica represiva, arbitraria e intolerante (1971c), o ya poniendo al descubierto las concretas operaciones ideológicas, propagandísticas, intimidatorias y autoritarias implícitas en los dispositivos de censura y de pedagogía social (1968b: 105-161) o en los diversos modos de expresión y enunciación performativa dispuestos sobre el recurso a la "emotividad verbal" con que el discurso totalitario procuraba perversamente imponer efectos de verdad (1968b: 183-203).

Difícilmente pueda atribuirse a Rest una conciencia plena de la inminencia de un cambio de modelo en la función intelectual. Lo que no puede negarse es que su perfil se ajusta cabalmente al de este nuevo tipo de intelectual crítico que redescubre y concreta su criba política en su propio espacio de intervención específica. En atención a su vocación liberal y democrática, dejó de lado en sus operaciones críticas la valoración ideológicopolítica de los objetos abordados y orientó estratégicamente sus energías al desencubrimiento de las operaciones que naturalizan una ideología autoritaria al interior de la serie de prácticas específicas y en apariencia inocentes que constituyen la trama misma de la cultura. De ese modo, se inscribía también en la lí- 
nea de una política progresista que -según los términos establecidos por Foucault- se afirma en el reconocimiento de sus propias condiciones históricas y las de las reglas específicas de su práctica, frente a otras modalidades de la política "de izquierda" que sólo reconocen necesidades ideales, determinaciones unívocas o la arbitrariedad de un libre juego de iniciativas individuales y voluntaristas (Foucault 1985: 84-85). Sorteando el dualismo de un callejón sin salida -cuyas trágicas consecuencias históricas son ya tristemente conocidas-, y en un examen lúcido de sus condiciones históricas y sus posibilidades objetivas, la producción de Rest se revela estratégicamente dispuesta como un mosaico de intervenciones específicas que define una sutil pero efectiva colocación política. En el ejercicio de esa práctica situada-que extrae su potencia de su propia especificidad- pueden visualizarse, como sugiere la presente exploración, tanto las transformaciones históricas de la función intelectual como el juego de dependencias y condicionamientos a través de los cuales una obra crítica de apariencia discontinua, dispersa y excéntrica se afirma en un proyecto intelectual de política concreta y efectiva. 
APÉNDICE $\mathrm{N}^{\circ} 6$

TIERRA BALDÍA (DE T. S. ELIOT) ${ }^{293}$

\author{
A Ezra Pound \\ il miglior fabbro.
}

Nam Sibyllam quidem Cumis

ego ipse oculis meis vidi in

ampulla pendere, et cum illi

pueri dicerent: $\Sigma i ́ \beta u \lambda \lambda \alpha$ tí $\theta \dot{\varepsilon} \lambda \varepsilon\llcorner$ s;

respondebat illa: $\alpha \dot{\Pi} \circ \theta \alpha \nu \varepsilon \tilde{\imath} \nu$ $\theta \dot{\varepsilon} \lambda \omega$.

[Entonces yo, con mis propios ojos, oí a la sibila de Cumas suspendida en una botella, y cuando los niños preguntaron «Sibila, ¿qué quieres?», ella respondió «Quiero morir».]

-Petronius, Satyricon [El Satiricón de Petronio, apartado XLVIII]

I. EL ENTIERRO DE LOS MUERTOS

Abril es el mes más cruel; engendra

293 Traducción inédita de Jaime Rest. 
lilas de la tierra muerta, mezcla

memorias y anhelos, remueve

raíces perezosas con lluvias primaverales.

El invierno nos mantuvo cálidos, cubriendo

la tierra con olvidadiza nieve, nutriendo

una pequeña vida con tubérculos secos.

Nos sorprendió el verano, cuando llegó sobre el Starnberger-

see

con un chaparrón; nos detuvimos bajo la columnata,

y seguimos luego, bajo el sol, dentro de Hofgarten,

y tomamos café, y hablamos durante una hora.

«Bin gar keine Russin, stamm'aus Litauen, echt deutsch».

Y cuando éramos niños, pasando una temporada en casa de mi

primo el archiduque,

él me sacó en trineo.

Y yo tenía miedo, y él me dijo: María,

María, agarrate fuerte. Y nos deslizamos cuesta abajo.

En las montañas, allí sí que se siente uno libre.

Leo durante gran parte de la noche y en el invierno parto hacia el sur.

¿Cuáles son las raíces que arraigan, qué ramas crecen

en estos escombros pétreos? Hijo del hombre,

tú no puedes decirlo, ni adivinarlo; pues tú tan sólo conoces

un montón de imágenes rotas, donde el sol bate.

El árbol muerto no cobija, el grillo no consuela

y reseca la piedra no mana agua. Sólo 
hay sombra bajo esta roca roja.

(Ven a cobijarte bajo la sombra de esta roca roja),

y te enseñaré algo diferente

de tu sombra que te sigue a zancadas por la mañana

- de tu sombra que al atardecer se levanta para encontrarte;

te mostraré lo que es el miedo en un puñado de polvo.

\author{
Frisch weht der Wind \\ der Heimat zu \\ mein Irisch Kind, \\ Wo weilest du?
}

«Me diste jacintos por primera vez hace un año;

me llamaban la niña de los jacintos».

- Mas cuando regresamos, tarde, del jardín de los jacintos,

Tus brazos cargados, y tus cabellos húmedos, no pude

hablar, mis ojos se me nublaron, no estaba ni

vivo ni muerto, y no sabía nada,

mirando en el corazón de la luz, el silencio.

«Oed'und leer das Meer».

Madame Sosostris, famosa clarividente,

tenía un mal catarro, sin embargo.

Se la conoce como la mujer más sabia de Europa,

con una maldita baraja. Aquí, dice ella,

está su carta, el Marino y Fenicio que pereció ahogado,

(Los que eran ojos son perlas. ¡Fíjense!) 
Aquí está Bella Donna, la Dama de las Rocas,

la dama de las situaciones.

Aquí está el hombre de los tres bastos, y aquí la Rueda,

y aquí el comerciante tuerto, y esta carta en blanco

es algo que lleva sobre la espalda, que no puedo ver. No en-

cuentro

al Ahorcado. Tema la muerte por agua.

Veo un tropel de gente, rondando en círculo.

Gracias. Si ve usted a la estimadísima señora Equitone,

dígale que yo misma le llevaré el horóscopo:

¡una tiene que ser tan precavida en estos días!

Ciudad Irreal,

bajo la parda niebla de un amanecer de invierno,

tal multitud fluía sobre el puente de Londres

que nunca hubiera yo creído ser tantos los que la muerte arrebatara.

Llevaban todos los ojos clavados

delante de sus pies y exhalaban [cortos y rápidos] suspiros

Cuesta arriba y luego calle King William abajo

hacia donde Santa María Woolnoth guarda las horas

con un sonido mortecino al final de la novena campanada.

Allí vi a un conocido, y le detuve, llamándole: «iStetson!, ¡tú, que estabas conmigo en los barcos de Mylae!

¿Aquel cadáver que plantaste el año pasado en tu jardín,

ha comenzado a germinar? ¿Florecerá este año?

¿O la repentina escarcha perturba su lecho? 
¡Oh, aleja de allí al Perro, que es amigo de los hombres, que si no, lo desenterrará de nuevo con sus uñas! Tú, hypocrite lecteur! - mon semblable, - mon frère!»

II. UNA PARTIDA DE AJEDREZ

La Silla en que estaba sentada, como un bruñido trono, relucía sobre el mármol, donde el espejo soportado por estantes labrados con viñas cargadas de racimos desde las cuales un Cupido dorado se asomaba (otro ocultaba sus ojos bajo el ala) multiplicaba las llamas de los candelabros de siete brazos que reflejaban su luz sobre la mesa mientras el esplendor de sus joyas, desparramadas en rica profusión en estuches de raso, saló a encontrarla. En redomas de marfil y vidrio policromo, destapadas, acechaban sus raros perfumes sintéticos, ungüentos, polvos, líquidos -inquietando, confundiendo y ahogando los sentidos en olor; movidos por el aire que soplaba de la ventana, ascendían nutriendo las prolongadas llamas de las velas, que esparcían sus humos por la laquaría, y animaban los diseños del artesonado techo. Enormes leños recogidos de la playa, patinados de cobre, ardían verdes y anaranjados, en su marco de piedra policroma, y en esa luz triste nadaba un delfín tallado. 
Sobre la repisa de la chimenea estaba representada

-como ventana abierta a una escena silvestre-

la metamorfosis de Filomela, forzada tan rudamente

por el bárbaro rey; todavía allí el ruiseñor

llenaba todo el desierto con inviolable voz

y todavía gritaba, y aún el mundo sigue persiguiendo

«Yag Yag» para oídos sucios.

Y otros tarugos marchitos del tiempo

Estaban trazados en las paredes; formas llamativas

sobresalían, inclinándose, silenciando el ámbito de la alcoba.

Se oyó un taconeo en la escalera.

A la luz del hogar, bajo el cepillo, los cabellos de ella fulguraban en puntos lumínicos,

encendiéndose en palabras, permaneciendo luego salvajemente quietos.

«Mis nervios están agitados esta noche. Sí, descompuestos. Quédate conmigo,

háblame. ¿Por qué nunca hablas? Habla.

¿En qué piensas? ¿Qué piensas? ¿Qué?

Nunca sé lo que piensas. Piensa.»

Me parece que estamos en el callejón de las ratas

donde los muertos perdieron sus huesos.

«¿Qué ruido es ése?» 
El viento bajo la puerta.

«¿Qué ruido es ése ahora? ¿Qué hace el viento?»

Nada, otra vez nada.

« No

sabes nada? ¿No ves nada? ¿No te acuerdas

de nada?»

Recuerdo

que lo que fueron sus ojos ahora son perlas.

«¿Estás vivo o no? ¿No hay nada en tu cabeza?»

Pero

o o o ese rag shakespeaheriano:

es tan elegante

tan inteligente...

«¿Qué haré ahora? ¿Qué haré?

¿Me apresuraré a salir tal y como estoy, y andaré por las calles

Así, con el pelo suelto? ¿Qué haremos mañana?

(¿Qué haremos jamás?»

Agua caliente a las diez.

Y si llueve, un coche cerrado a las cuatro.

y jugaremos una partida de ajedrez,

fatigando nuestros ojos sin párpados, esperando que llamen a

la puerta. 
Cuando licenciaron del servicio activo al marido de Lil, yo dije

-y no me comí las palabras-, lo dije sin subterfugios:

Dense prisa, por favor, que ya es hora.

Ahora Alberto va a regresar, embellécete un poco.

Él querrá saber qué has hecho con el dinero que te dio

para arreglarte los dientes. Y que te lo dio de veras, yo estaba allí.

Extráetelos todos, Lil, y cómprate una buena dentadura, dijo, juro que no puedo mirarte cara a cara.

Ni yo tampoco, dije, y piensa en el pobre Alberto, que ha estado en el ejército cuatro años, quiere divertirse, y si tú no lo haces, ya habrá otras que lo hagan, dije yo. ¡Oh hay otras!, dijo ella. Algo por el estilo, dije yo. Entonces ya sé a quién agradecérselo, dijo mirándome de arriba abajo.

Dense prisa, por favor, que ya es hora.

Si esto no te gusta, trágatelo, dije.

Otras gozarán de lo bueno si tú no puedes.

Pero si Alberto se larga, será tuya la culpa, pues ha habido ya quien te ha prevenido.

Debes avergonzarte, dije, de parecer tan anticuada

(Ella no tiene más que treinta y un años).

No es culpa mía, dijo, poniendo una cara atribulada. 
Son esas malditas píldoras que tomé para abortar, dijo.

(Ella había alumbrado ya cinco, y a poco se muere en el parto de Jorge) .

El boticario me dijo que no sería nada, pero yo nunca he vuelto a ser la misma.

Eres una verdadera tonta, le dije.

Pues si Alberto no te deja quieta, ése es el resultado, dije.

¿Para qué te casaste si no querías tener hijos?

Dense prisa, por favor, que ya es hora.

Pues bien, aquel domingo Alberto estaba en casa, tenían jamón curado,

y me invitaron a cenar, para que saboreara aquel jamoncito caliente.

Dense prisa, por favor, que ya es hora.

Dense prisa, por favor, que ya es hora.

Buenas noches Bill. Buenas noches, Lou. Buenas noches, May. Buenas

/ noches.

Adiós, adiós. Buenas noches. Buenas noches.

Buenas noches, señoras, buenas noches, simpáticas señoras, buenas noches, buenas noches.

III. EL SERMÓN DEL FUEGO 
Se ha roto la tienda de campaña del río: los últimos dedos de las hojas

se agarran y se hunden en la barranca húmeda. El viento cruza la parda llanura, silenciosamente. Las ninfas se han marchado.

Dulce Támesis, fluye suavemente, hasta que termine mi cantar. El río no arrastra botellas vacías, papeles de sandwiches, pañuelos de seda, cajas de cartón, colillas de cigarrillos u otros testimonios de noches estivales. Las ninfas se han marchado.

Y sus amigos, perezosos herederos de potentados comerciales, se fueron, no han dejado sus nuevas direcciones. A orillas del Leman me senté y lloré... Dulce Támesis, fluye suavemente, hasta que termine mi cantar. Dulce Támesis, fluye suavemente, pues no hablaré recia ni luengamente

pero a mi espalda en el viento frío oigo sacudimiento de huesos y risas ahogadas.

Un ratón se deslizó blandamente entre los matorrales arrastrando su viscosa barriga por la orilla mientras yo pescaba en el apacible canal en una noche de invierno detrás de la fábrica de gas, meditando sobre el naufragio de mi hermano rey y sobre la muerte anterior de mi padre rey. Blancos cuerpos desnudos sobre la baja tierra húmeda y huesos abandonados en una fría guardilla de techo bajo, 
sacudidos sólo por la pata del ratón, año tras año.

Pero a mi espalda de vez en cuando oigo

bocinas y autos, que llevarán a Sweeney.

En la primavera adonde la señora Porter.

Oh, la luna fulguraba radiantemente sobre la señora Porter

y sobre su hija.

Ellas se lavan los pies con agua gaseosa.

Et O ces voix d'enfants, chantant dans la coupole!

Tuit tuit tuit

Yag yag yag yag yag yag

forzada tan rudamente,

Tereo.

Ciudad Irreal,

bajo la parda niebla de un mediodía invernal.

El señor Eugenides, comerciante de Esmirna,

sin afeitar, con un bolsillo lleno de pasas

T.a.g. Londres: documentos a la vista,

me invitó en francés popular

a almorzar en el Hotel Cannon Street

y a pasarme el fin de semana en el Metropole.

A la hora violeta, cuando alzamos del escritorio los ojos y las espaldas,

cuando la máquina humana aguarda

como un taxímetro espera vibrando,

yo, Tiresias, aunque ciego, palpitando entre dos vidas, 
viejo, con arrugadas tetas de mujer, puedo ver

a la hora violeta, a esa hora de la tarde que nos empuja hacia el hogar y el mar envía al marinero a casa,

y la mecanógrafa, para tomar el té de la tarde, levanta la mesa del desayuno, enciende

su estufa, y saca alimentos en conserva.

Fuera de la ventana, peligrosamente puestas a secar, están sus combinaciones, tocadas por los postreros rayos del sol. Sobre el diván (que por la noche le sirve de cama) están amontonadas

medias, chinelas, enaguas y sostenes.

Yo, Tiresias, un viejo de ubres arrugadas

vi la escena, y predije el resto-

Yo también aguardaba la esperada visita.

El joven de manchada tez, llega,

secretario de un agente de una pequeña casa mercantil, de mirada altanera,

uno de esos bribones sobre quien el descaro se asienta como una chistera sobre un millonario de Bradford.

La hora es propicia, y tal como él imaginó,

La cena ha concluido, ella está aburrida y cansada,

él trata de excitarla con caricias

que, aunque no rechazadas, tampoco se las desea.

Congestionado y decidido, él la asalta enseguida;

sus manos exploradoras no encuentran resistencia;

su vanidad no necesita respuesta,

y hasta se alegra de su indiferencia. 
(Y yo, Tiresias, he tolerado todo

lo ocurrido en este mismo diván o lecho.

Yo, que estuve sentado bajo los muros de Tebas

y anduve entre lo más bajo de los muertos.)

Le otorga un beso patronizante y final,

y baja a tientas por la escalera oscura...

Ella se vuelve y se mira en el espejo, sin preocuparse de su amante recién marchado;

su cerebro consigue formular un pensamiento borroso:

«Bueno, asunto concluido, me alegro que ya haya terminado».

Cuando una mujer hermosa comete tales locuras y

vuelve a pasearse por su cuarto, sola,

se alisa los cabellos con mano automática

y pone un disco en el gramófono.

«Esta música se deslizó junto a mí sobre las ondas»

y a lo largo del strand, calle Reina Victoria arriba.

Oh, ciudad, ciudad, a veces puedo escuchar

cerca de un bar de la calle Lower Thames,

el agradable lamento de una mandolina

y el murmullo y la charla que sale del interior

donde los vendedores de pescado descansan al mediodía; donde

los muros

de Magnus Mártir guardan

un inexplicable esplendor de jónica blancura y oro. 
El río suda

aceite y brea.

Lanchones se van

con la cambiante marea

Velas rojas

anchas,

a sotavento, se mecen sobre los mástiles.

Los lanchones

sumergen maderos a la deriva

Navegando hacia el sur de Greenwich,

más allá de la Isla de los Perros.

\author{
Weialala leia \\ Wallala leialala
}

Elizabeth y Leicester

remando

la proa era

dorado casco

rojo y oro

rizó ambas orillas

el viento del sudoeste

cargó aguas abajo

las campanas de las

torres blancas

Weialala leia 
Wallala leialala.

«Tranvías y polvorientos árboles.

Highbury me vio nacer. Richmond y Kew

me deshicieron. Al pasar por Richmond alcé

las rodillas

acostada boca arriba en el fondo de una an-

gosta canoa.»

«Mis pies están en Moorgate y mi corazón

bajo mis pies. Después de lo ocurrido

él lloró. Me prometió "empezar de nuevo"

No contesté nada. ¿Para qué guardarle ren-

cor?»

«Mis pies están en Moorgate, y mi corazón

Bajo mis pies. Después de lo ocurrido

él lloró. Me prometió "empezar de nuevo".

Yo no dije nada. ¿Para qué guardarle rencor?

Sobre Margate Sands.

No puedo coordinar

nada con nada.

Las uñas rotas de manos sucias.

Mi gente, humilde gente, que no espera

nada.»

la la. 


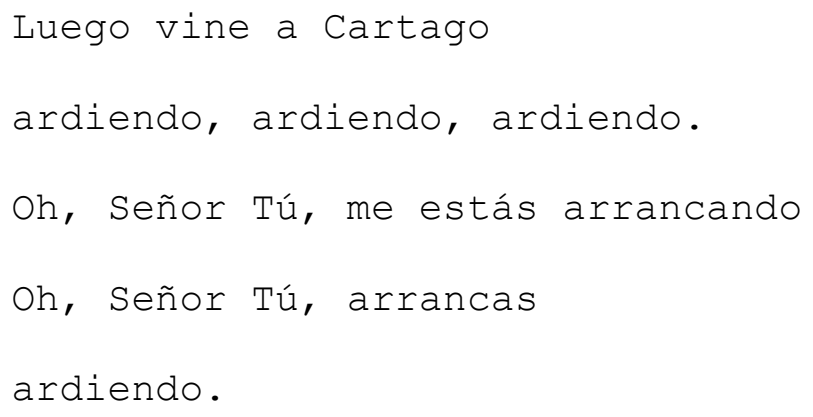

IV. MUERTE POR AGUA

Flebas el Fenicio, muerto hace una quincena, olvidó el grito de las gaviotas y el hondo mar de leva y las ganancias y las pérdidas.

Una corriente submarina recogió sus huesos en susurro. Pasó todas las etapas de su edad y juventud mientras flotaba y se hundía entrando en el remolino.

Gentil judíoOh, tú, que volteas la rueda del timón y miras a barlovento, acuérdate de Flebas, que una vez fue bello y robusto como tú.

V. LO QUE DIJO EL TRUENO

Tras la roja luz de las antorchas sobre rostros sudorosos, tras el helado silencio en los jardines tras la agonía en lugares pétreos y el griterío y el llanto, 
prisión y palacio y reverberación

de trueno primaveral sobre lejanos montes.

Aquel que antes vivía ha muerto ya.

Nosotros que vivíamos antes estamos ahora muriendo

con un poco de paciencia.

Aquí no hay agua, sólo roca,

roca y no agua, y el camino arenoso.

El camino sube serpenteando las montañas,

que son montañas de roca sin agua.

Si hubiese agua nos detendríamos a beber.

Entre las rocas no puede uno ni pararse ni pensar.

El sudor es seco y los pies se hunden en la arena;

si sólo hubiera agua entre las rocas

muerta montaña, boca de cariosos dientes que no puede escupir.

Aquí no puede uno ni pararse, ni acostarse, ni sentarse.

No hay ni silencio siquiera en las montañas,

sino el seco estéril trueno sin lluvia.

No hay ni silencio siquiera en las montañas,

sino ceñudos rostros rojos que gruñen entre dientes

desde los umbrales de casas de tierra apisonada.

Si hubiera

agua
y no roca,
si hubiese roca
y también agua, 


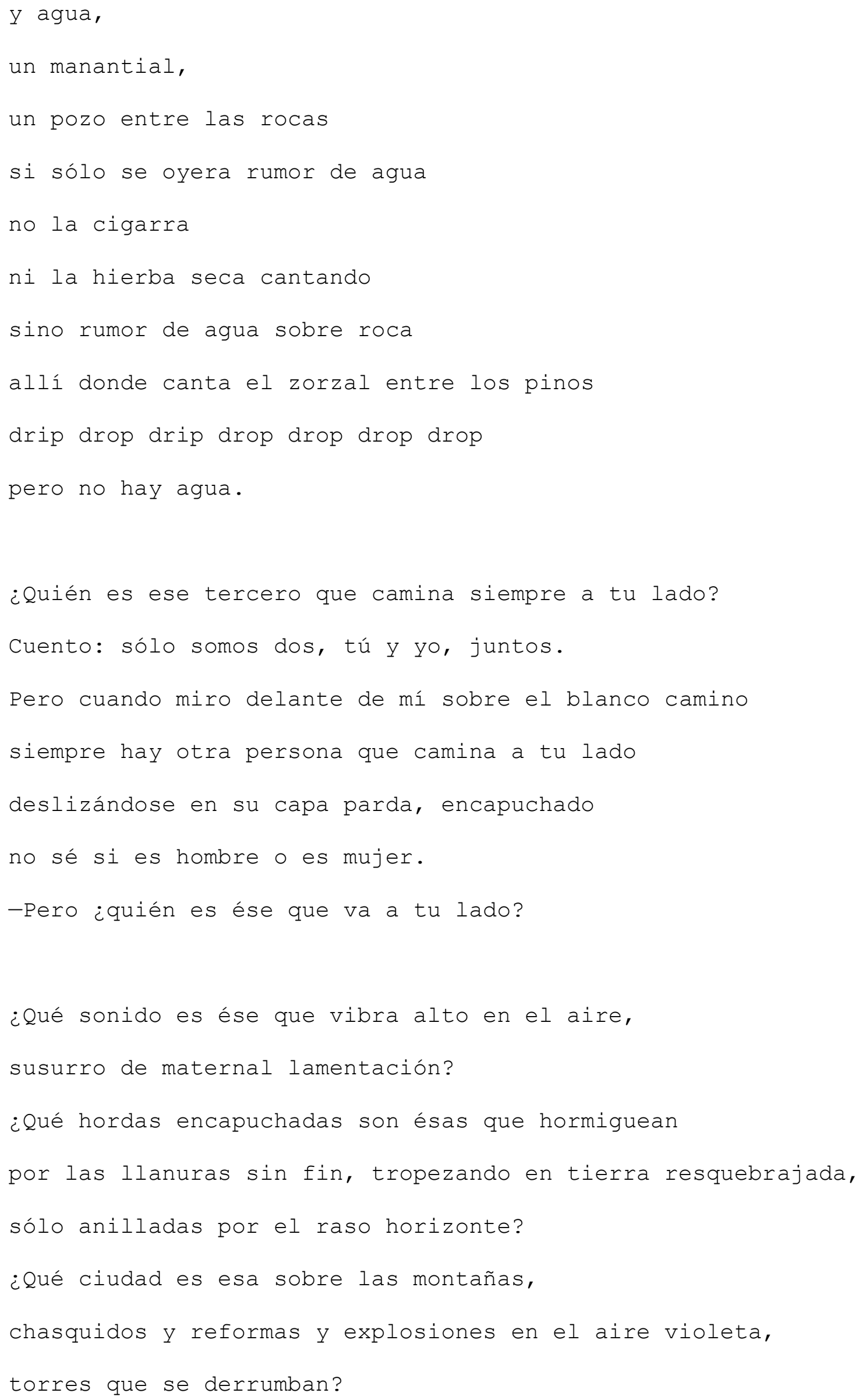


¿Jerusalén, Atenas, Alejandría,

Viena, Londres?

Irreales.

Una mujer se soltó la luenga cabellera negra

y extrajo susurradora música al tañer esas cuerdas.

Y murciélagos de caras infantiles silbaban en la luz violeta,

y batían sus alas,

y se escurrieron cabeza abajo por el negruzco muro,

y de torres inversas en el aire

salían toques de reminiscentes campanas, que guardaban las horas,

y cánticos de cisternas vacuas y agotados aljibes.

En esta corrupta cavidad de las montañas

bajo el lánguido clarear de luna, la hierba canta

sobre las tumbas derruidas, en torno a la capilla.

Allí está la desierta capilla, solitario hogar del viento.

No tiene ventanas y la puerta se mece en sus goznes,

huesos secos a nadie hacen daño.

Sólo un gallo se alzaba en la cumbrera

Quiquiriquí, quiquiriquí,

bajo el relámpago. Luego, una brisa húmeda

anunciando lluvia.

Ganga estaba hundido y las débiles hojas

aguardaban la lluvia, mientras los nubarrones 
se amontonaban en la distancia, sobre Himavant.

Los matorrales se agacharon, encorvados en el silencio.

Entonces habló el trueno

$\mathrm{Da}$

Datta: ¿qué hemos dado?

Amigo, la sangre se me agolpa en el corazón.

Al pensar que es por el tremendo atrevimiento de entregarse

un momento

que un siglo de prudencia no nos podrá hacer retractar

por eso y sólo eso es por lo que hemos existido,

cosa que no ha de hallarse en nuestros obituarios

ni en las memorias por la benéfica araña

ni bajo los sellos que el flaco procurador romperá

en nuestras alcobas vacías.

$\mathrm{Da}$

Dayadhwam: he oído la llave

voltear en la cerradura una vez y sólo una vez.

Pensamos en la llave, cada cual en su prisión

Pensando en la llave, cada cual confirma la existencia de una prisión.

Al anochecer, sólo rumores etéreos

reaviven por un momento a un Coriolano roto.

$\mathrm{Da}$

Damyata: la barca obedeció

alegremente, a la mano hábil con vela y remo.

Sereno estaba el mar, tu corazón podía haber respondido

alegremente, a la invitación, obediente palpitando 
a las manos diestras.

\section{Yo me senté en la orilla}

a pescar, con la llanura árida a mi espalda.

¿Debo al menos poner mis asuntos al día?

El Puente de Londres se está cayendo, cayendo, cayendo.

Poi s'ascose nel foco che gli affina

quando fiam uti chelidon -Oh, golondrina, golondrina.

Le Prince d’Aquitaine à la tour abolie.

Estos fragmentos he amontonado sobre mis ruinas

Ea! entonces os puedo ser útil: Hieronymo ha vuelto a enloquecer.

Datta. Dayadhvam. Damyata.

Shantih shantih shantih. 


\section{BIBLIOGRAFÍA}

A) PUBLICACIONES DE JAIME REST (POR ORDEN CRONOLÓGICO)

- "Nota sobre la poesía de T. S. Eliot" (1952a), Centro. Revista del Centro de Estudiantes de Filosofía y Letras, Buenos Aires, Año 2, $\mathrm{N}^{\circ}$ 2, abril de 1952. pp. 48-51.

- "La poesía de T. S. Eliot: Formación" (1952b), Centro. Revista del Centro de Estudiantes de Filosofía y Letras, Buenos Aires, Año 2, $\mathrm{N}^{\circ}$ 3, setiembre de 1952. pp. 1-8.

- "Borges, Descartes y el obispo Wilkins" (1952c), Centro. Revista del Centro de Estudiantes de Filosofía y Letras, Buenos Aires, Año 2, $\mathrm{N}^{\circ}$ 4, diciembre de 1952. pp. 47-50.

- "George Santayana" (necrológica) (1953a), Centro. Revista del Centro de Estudiantes de Filosofía y Letras, Buenos Aires, Año 3, $N^{\circ}$ 5, mayo de 1953. p. 57.

- "Los ensayos de Virginia Woolf" (1953b). Tesis de licenciatura presentada en la Facultad de Filosofía y Letras de la Universidad de Buenos Aires, mimeo.

- Notas sobre Virginia Woolf (1953c). Buenos Aires: separata del Boletín de Estudios Germánicos, $\mathrm{N}^{\circ} 10$

- "Sir Herbert Read y el estudio del romanticismo inglés" (1953d), en Imago Mundi, 2, Buenos Aires: pp. 72-76.

- "Coleridge y las teorías artísticas del romanticismo inglés" (1954a), Imago Mundi, Buenos Aires: pp. 76-77. 
- "Acerca del teatro de J. B. Priestley" (1954b), en Zohna, 3-4, Buenos Aires. pp. 33-38.

- "Virginia Woolf y Victoria Ocampo" (1954c), en Oeste. Revista Literaria, Año $\mathrm{X}, \mathrm{N}^{\circ}$ 17, Buenos Aires, setiembre de 1954. [sin paginar].

- "La poesía de T. S. Eliot: The Waste Land", Centro. Revista del Centro de Estudiantes de Filosofía y Letras, Buenos Aires, Año 5, N 9, setiembre de 1955. pp. 11-29.

- "Chaucer y el concepto de poesía: lo medieval y lo moderno" (1955a), Imago Mundi, 8, Buenos Aires: pp. 13-34.

- "Wycliffe y los lolardos" (1955b), en Imago Mundi, 9, Buenos Aires. pp. 68-71.

- "La cárcel corporal: una imagen y su perduración en las concepciones antropológicas" (1955c), en Imago Mundi, 10, Buenos Aires. pp. 19-53.

- "Virginia Woolf y la función crítica" (1956a), en Sur nº 238, enero/febrero. pp. 45-59.

- "Forster y su 'Paso a la India'" (1956b), en Sur, 239, Buenos Aires, pp. 52-77.

- "La crisis contemporánea y el espíritu en el testimonio de dos poetas: T. S. Eliot y Paul Valéry" (1956c), en Imago Mundi, 11-12, Buenos Aires. pp. 134-182.

- "Bibliografía chauceriana en el siglo XX" (1956d), en RUBA, 4, Buenos Aires. pp. 569-573.

- "Synge y el renacimiento literario irlandés" (1957), en La Biblioteca, IX, 2, Buenos Aires. pp. 93-103. 
- "Geografía ultramundana del medioevo" (1957b), en Sur nº 245, mar/abr, Buenos Aires: 1957. pp. 82-99.

- "Howard Match, 'El otro mundo en la literatura medieval'" (1957c), en Sur $n^{\circ}$ 245, mar/abr, Buenos Aires: 1957. pp. 8299.

- "Ingmar Bergman: presencia humana y dimensión imaginaria del cine sueco" (1957d), en Sur, n²46, Buenos Aires, mayo/junio. pp. 80-89.

- "Schultz de Mantovani, 'El árbol guardavoces'" (1958a), en Sur $\mathrm{n}^{\circ}$ 251, Buenos Aires: marzo/abril. pp. 88-96.

- "Emotividad verbal y totalitarismo" (1958b), en Sur n²55, Buenos Aires: noviembre/diciembre. pp. 14-24.

- "Thomas de Quincey ante el magisterio de la prosa" (1958c), en La Biblioteca, IX, 3, Buenos Aires: pp. 144-154.

- "La 'reconciliación' de la filosofía moderna (con motivo de un libro de Sussane K. Langer)." (1958d), en Sur n² 252, Buenos Aires, mayo/junio de 1958. pp. 106-108.

- "Una traducción de William Blake" (1958e), en Sur, n² 253, Buenos Aires, julio/agosto. pp. 59-65.

- Thomas Taylor: influjo platónico en el romanticismo inglés (1959). Buenos Aires, Revista de la Universidad de Buenos Aires, 5 ta época, Año IV, N 1 (separata).

- "Helen Ferro, 'Los testigos"" (1959b), en Sur n²57, Buenos Aires, marzo/abril. pp. 77-79. 
- "Federico González Frías, 'El oficinista Pedreiras y otras pesadillas vulgares" " (1959c), en Sur n²57, Buenos Aires, marzo/abril, 1959. p. 77.

- "Susana Bombal, 'Green Wings"" (1959d), en Sur n²58, Buenos Aires, mayo/junio. pp. 79-85.

- "El caso 'Lolita' (Encuesta)" (1959e), en Sur n²60, Buenos Aires, setiembre/octubre. pp. 44-75.

- Cuatro hipótesis de la Argentina (1960a). UNSur. Bahía Blanca: Cuadernos de Extensión Universitaria.

- Cartomancia y poesía (1960b). Bahía Blanca: Cuadernos del Sur (separata).

- "Presencia de Güiraldes: Última biografía Dora P. de Etchebarne, Collantes de Terán, Horacio Jorge Becco" (1960c), en Sur $n^{\circ}$ 263, Buenos Aires, marzo/abril. pp. 55-59.

- "Sobre las hadas; ensayos de literatura infantil" (1960d), en Sur $\mathrm{n}^{\circ}$ 263, Buenos Aires: mar/abr. pp. 62-64.

- "Fernando de Elizalde, 'El camino'" (1960e), en Sur n²66, Buenos Aires, set/oct. pp. 70-71.

- "Carmelo Bonet, 'La crítica literaria"" (1960f), en Sur nº 266, Buenos Aires, set/oct. pp. 71-73.

- "Emilio Sosa López, 'La novela y el hombre"" (1960g), en Sur $n^{\circ}$ 266, Buenos Aires, set/oct. pp. 74-75.

- "Situación del arte en la era tecnológica" (1961a) . RUBA, 5ta época, $\mathrm{N}^{\circ}$ 2: 297-338, Buenos Aires, abril-junio. pp. 297338 . 
- "Peter G. Earle, 'Unamuno and English Literature'" (1961b), en Sur $n^{\circ}$ 273, Buenos Aires, noviembre/diciembre pp. 57-58.

- "María Rosa Vacaro, 'Los maestros de antes, hoy: Chaplin, Reoir, Clair, John Ford"" (1961c), en Sur n² 273, Buenos Aires, noviembre/diciembre. pp. 82-83.

- "La Pena de muerte" (1962). Revista de la Universidad de Buenos Aires, 5ta ép, Año VII, $N^{\circ} 3$, Buenos Aires.

- "Un Shakespeare para nuestro tiempo" (1964a), en Sur nº 289-290, Buenos Aires, julio/agosto. pp. 102-116.

- Un Shakespeare para nuestro tiempo (1964b). Buenos Aires: Servicio de Extensión Cultural de la Dirección General de Obra Social de la Secretaría de Estado de Obras Públicas.

- "El retorno del realismo" (1964c), en Marcha, n 1233, Montevideo, 27 de noviembre. pp. 29-31.

- "John Cleland y ese librito tan divertido" (1964d), en Marcha, $\mathrm{n}^{\circ}$ 1211, Montevideo, 26 de junio. pp. 27-33.

- "Inadvertencia preliminar" (1964e), John Lennon en su tinta (Traducción, prólogo y notas de Jaime Rest), Buenos Aires, Bocarte. pp. 13-18.

- Notas para una estilística del arrabal (1965a). Buenos Aires: Servicio de Extensión Cultural de la Dirección General de Obra Social de la Secretaría de Estado de Obras Públicas.

- "Alcances literarios de una dicotomía cultural contemporánea" (1965b), en Revista de la Universidad de La Plata, 19, La Plata. pp. 23-52. 
- Wesker y su trilogía dramática (1965c), Buenos Aires, Edición Teatro del Buen Aire.

- "Evocación de Martínez Estrada" (1965d) en Sur n² 295, Buenos Aires, julio/agosto, 1965. pp. 69-72.

- "Trayectoria de Ezequiel Martínez Estrada" (1965e). En AAVV. Homenaje a Ezequiel Martínez Estrada. Bahía Blanca: UNS. - "Shaskespeare y la imaginación impersonal" (1966), en Cuadernos del Sur, 5, Bahía Blanca. pp. 16-22.

- Literatura y cultura de masas (1967a). Buenos Aires: CEAL.

- La novela tradicional (1967b). Buenos Aires: CEAL.

- El teatro moderno (1967c). Buenos Aires: CEAL.

- "Función del mito clásico en The Weste Land": Tiresias como 'persona' del poeta" (1967d), en Cuadernos del Sur, 6-7, Bahía Blanca. pp. 90-100.

- "John Lennon en su tinta" (1967d), en Lennon, J., John Lennon en su tinta, Buenos Aires: Bocarte.

- "Los narradores argentinos y la búsqueda de un idioma nacional" (1967e), conferencia escrita y leída en las "Segundas Jornadas de Métodos de Investigación de enseñanza de la Historia y de la Literatura Rioplatense y de los Estados Unidos", en Bahía Blanca, en junio de 1967.

- Antología del cuento universal (comp. 1968a). Buenos Aires: CEAL .

- Tres autores prohibidos y otros ensayos (1968b). Buenos Aires: Galerna.

- Los románticos ingleses (comp. 1968c). Buenos Aires: CEAL. 
- "A lightning before death: elaboración de un tema en tres cuentistas" (1968d), en Cuadernos del Sur, 8-9. Bahía Blanca, UNSur. pp. 105-128.

- "Las invenciones de Bioy Casares" (1969a), en Los Libros, $\mathrm{n}^{\circ}$ 2. Buenos Aires, agosto de 1969. pp. 8-10.

- El teatro inglés (1969b). Buenos Aires: CEAL.

- Poesía y prosa. John Milton (comp. 1969b). Buenos Aires: CEAL .

- Poesía medieval inglesa (comp. 1970a). Buenos Aires: CEAL. - "Prólogo a Moby Dick o la ballena blanca" (1970b), en Herman Melville, Moby Dick o la ballena blanca. Buenos Aires: Fondo Nacional de las Artes.

- "Orígenes y desarrollo de la novela" (1970c), Capítulo, La historia de la literatura mundial, 1, Buenos Aires: CEAL.

- "El apogeo de la novela" (1970d), Capítulo, La historia de la literatura mundial, 2, Buenos Aires: CEAL.

- "Boccacio y el apogeo del cuento" (1970e), Capítulo, La historia de la literatura mundial, 2, Buenos Aires, CEAL.

- "Retrato del moralista como cínico" (1970f), en Los Libros, $\mathrm{n}^{\circ}$ 8. Buenos Aires, mayo de 1970. pp. 10 y 26.

- "El trasfondo religioso de Ingmar Bergman" (1970g), en Sur, número 324, Buenos Aires, mayo-junio, pp. 102-105

- "Satanás, sus obras y sus pompas" (1970h), en Los Libros, $\mathrm{n}^{\circ}$ 14. Buenos Aires, diciembre de 1970. pp. 10 y 26.

- "Las agonías del romanticismo" (1971a), en Los Libros, nº 17. Buenos Aires, marzo de 1971. 
- Novela, cuento, teatro: apogeo y crisis (1971b). Buenos Aires: CEAL.

- El marqués de Sade y la crisis del racionalismo (1971c). Bahía Blanca: Alianza Francesa.

- "El teatro de habla inglesa" (1972a). En AAVV. Arte contemporáneo. Bahía Blanca: Alianza Francesa.

- "Las literaturas marginales" (1972b), Capítulo, La historia de la literatura mundial, 2, Buenos Aires: CEAL.

- "Borges y el 'pensamiento sistemático'" (1973a). Hispamérica, 3, Buenos Aires, Marzo. pp. 3-23.

- "Ángel Rama, La generación crítica: 1939-1969. I: Panoramas" (1973b). Hispamérica, R 4/5, Buenos Aires, Diciembre. pp. 134-36.

- "Diagnóstico de la novela policial" (1974a), Crisis, XV, Buenos Aires. pp. 30-39.

- "Borges y el universo de los signos" (1974b), Hispamérica, 7, Buenos Aires, Julio. pp. 3-24.

- María Luisa Bastos, Borges ante la crítica argentina, 1923-1960" (1975a), Hispamérica, R 7, Buenos Aires, R 9, Febrero. pp. 105-06.

- "Marcelo Pichón Riviëre, Territorios" (1975b), Hispamérica, R 7, Buenos Aires, R 10, Abril. pp. 100-101.

- "Prólogo a Carmilla y otras alucinaciones" (1975c), en J. Sheridan Le Fanú, Carmilla y otras alucinaciones, (Traducción: Virginia Erhart y Jaime Rest). Buenos Aires: Ediciones Librerías Fausto. 
- "Introducción a El monje" (1975d), en Matthew G. Lewis, El monje, Buenos Aires, Ediciones Librerías Fausto.

- "Borges y el espacio literario" (1975e), Hispamérica, 11/12, Buenos Aires, Diciembre. pp. 3-21.

- El laberinto del universo. Borges y el pensamiento nominaIista (1976a). Buenos Aires: Ediciones Librerías Fausto.

- "Ese incomparable Max" (1976b), en La Opinión cultural, Buenos Aires, 24-10-76.

- "Reflexiones de un traductor" (1976c) en Sur, n³38-39, Buenos Aires, enero-diciembre de 1976. pp. 133-144.

- "Introducción a Siete aventuras de Raffles" (1976d), en Hornung, E. W., Siete aventuras de Raffles. Buenos Aires: Ediciones Librerías Fausto (Traducción Jaime Rest).

- "Introducción a Aguafuertes norteamericanas" (1976e), en Henry, O., Aguafuertes norteamericanas. Buenos Aires: Ediciones Librerías Fausto (Traducción Virginia Erhart).

- "Introducción a Allá lejos y hace tiempo" (1977a), en Hudson, Guillermo Enrique Allá lejos y hace tiempo, Buenos Aires: Ediciones Librerías Fausto. (Traducción Jaime Rest).

- "Introducción a El ocaso de los dioses" (1977b), en Garnett, R., El ocaso de los dioses y otros relatos, Buenos Aires: Ediciones Librerías Fausto (Traducción Jaime Rest).

- "Introducción a La muerte de Iván Ilich y otras narraciones" (1977c), en Tolstoi, L., La muerte de Iván Ilich y otras narraciones. Buenos Aires: Ediciones Librerías Fausto (Traducción Galina Tolmacheva). 
- "El doctor James y sus placenteros fantasmas" (1977d), en M. R. James, El enigma de las runas y otros cuentos de fantasmas, Buenos Aires: Ediciones Librerías Fausto. pp. 11-23.

- "Estudio preliminar a El Nuevo Decamerón" (1977e), en Potoki, J., El Nuevo Decamerón, Buenos Aires: Ediciones Librerías Fausto. pp. 11-23.

- "Relectura de Tolstoi" (1978a). Buenos Aires: Punto de Vista, año I/ $N^{\circ} 4 /$ Buenos Aires, nov. p. 13.

- Mundos de la imaginación (1978b). Caracas: Monte de Ávila.

- "Estudio preliminar a Ivanhoe de Walter Scott" (1978c), en Walter Scott, Ivanhoe. Buenos Aires: CEAL.

- "Estudio preliminar a Tiempos difíciles de Charles Dickens" (1978d), en Charles Dickens, Tiempos difíciles. Buenos Aires: CEAL .

- "Estudio preliminar a Relatos de Nathaniel Hawthorne y Herman Melville" (1978e), en Nathaniel Hawthorne y Herman Melville, Relatos. Buenos Aires: CEAL.

- Conceptos de literatura moderna (1979a). Buenos Aires: CEAL .

- "Prólogo a El juicio del siglo" (1979b), en J. V. González, El juicio del siglo. Buenos Aires: CEAL.

- "La neurastenia de Franny y el budismo Zen de Zooey" (1979c). Buenos Aires: Punto de vista, año II/ $N^{\circ} 5 /$ marzo. pp. 18-19. 
- "Estudio preliminar a Las nuevas Mil y Una Noches de Robert L. Stevenson" (1979b), en Robert L. Stevenson, Las nuevas Mil y Una Noches. Buenos Aires: CEAL.

- "Estudio preliminar a Feria de vanidades de William M. Thackeray" (1979c), en William M. Thackeray, Feria de vanidades. Buenos Aires: CEAL.

- "Estudio preliminar a Hojas de hierba de Walt Whitman" (1979d), en Walt Whitman, Hojas de hierba. Buenos Aires, CEAL. - "Estudio preliminar a La importancia de llamarse Ernesto y Salomé de Oscar Wilde" (1979e), en Oscar Wilde, La importancia de llamarse Ernesto y Salomé. Buenos Aires, CEAL.

- "Estudio preliminar: Poesía inglesa del siglo XIX" (1979f), Buenos Aires, CEAL.

- "Estudio preliminar: Antología del cuento tradicional y moderno" (1979g), en AAVV, Antología del cuento tradicional y moderno. Buenos Aires, CEAL.

- "Panorama del ensayo" (1979h), Capítulo, La historia de la Iiteratura argentina, 5, Buenos Aires, CEAL.

- "Vicente Rossi y los orígenes del tango" (1979i), en Sur n 258, Buenos Aires, mayo/junio. pp. 79-85.

- "Estudio preliminar a El Supermacho de Alfred Jarry" (1979j), en Alfred Jarry, El Supermacho. Buenos Aires, Stilman Editores. pp. 7-26.

- "Jules Feiffer: un Aristófanes de la sociedad de consumo" (1979k), Buenos Aires, Punto de vista, año II/ No $7 /$ noviembre. pp. 28-29. 
- "Introducción a Allá lejos y hace tiempo" (1981a), en Nicolás Rosa (comp.), La crítica literaria contemporánea, vol II, Buenos Aires, CEAL. pp. 87-103.

- "Estudio preliminar a Vathek, cuento árabe" (1981b), en Beckford, W., Vathek, cuento árabe, Buenos Aires, CEAL. pp. IXV .

- El cuarto en el recoveco (póstumo, 1982). Buenos Aires, CEAL .

- Arte, literatura y cultura popular (2006). Víctor Pesce (comp.), Buenos Aires: Norma.

- Hipótesis y ensayos argentinos (2008). Buenos Aires, Las Cuarenta. Selección, Introducción y Notas a cargo de Maximiliano Crespi.

- El laberinto del universo. Borges y el pensamiento nominalista (2009). Buenos Aires, Eterna Cadencia. Prólogo de Maximiliano Crespi.

- Ensayos sobre cultura y literatura nacional (2010). Buenos Aires, 17grises Editora. Selección y Estudio preliminar: Maximiliano Crespi.

B) BIBLIOGRAFÍA SOBRE JAIME REST (EN ORDEN CRONOLÓGICO)

- Jurado, Alicia, "Jaime Rest, 'Cartomancia y poesía'", Sur nº 271, julio/agosto, 1961. pp. 82-83. 
- Rivera, Jorge B., "Solitarios avatares de la crítica literaria", Punto de vista, Año 2, n 6, julio, 1979. pp. 31-32.

- Rosa, Nicolás, "La crítica literaria contemporánea" (1981) en Zanetti, Susana (coord.) Capítulo, La historia de la literatura argentina, 113, Buenos Aires: CEAL. Reeditado bajo el título de "La crítica literaria argentina actual. Convergencias/Divergencias", en Rosa, N., Los fulgores del simulacro. Santa Fe: Cuadernos de extensión universitaria de la Universidad Nacional del Litoral, 1987.

- Gregorich, Luis, "Evocación de Jaime Rest", en La utopía democrática, Cuadernos de Extensión Universitaria, Universidad Nacional del Litoral, 1987. pp. 79-86.

- Bardauil, Pablo, "El excéntrico Jaime Rest", en Nicolás Rosa (comp.), Políticas de la crítica. Historia de la crítica literaria en la Argentina. Buenos Aires: Biblos, 1999. pp. 183-215.

- Torre, María Elena, "Jaime Rest, un cuarto propio" (2000) en Boletín/8 del Centro de Estudios de Teoría y Crítica Literaria, Rosario. pp. 125-134.

- Torre, María Elena, "Pensar en el límite. Sobre algunos ensayos de Jaime Rest" (2002), en Voz y Escritura, $N^{\circ} 11$. pp. 157-170.

- Pesce, Victor, "Introducción", en Arte, literatura y cultura popular (2006). Buenos Aires: Norma.

- De Santis, Pablo, "Jaime Rest, hacia la reafirmación del hecho literario" (2006), en La Biblioteca, n² 4/5, Buenos Aires: verano de 2006. pp. 174-179. 
C) BIBLIOGRAFÍA TEÓRICO-CRÍTICA GENERAL

- Adorno, Theodor W. Crítica cultural y sociedad. Barcelona, Ariel, $1969 a$.

- Adorno, Theodor W. Dialéctica del Iluminismo. Buenos Aires: Sur, $1969 b$.

- Adorno, Theodor W. Notas de literatura. Barcelona, Ariel, 1962 .

- Albéres, R. M. Historia de la novela moderna. Mexico, UTEHA, 1966.

- Albéres, R. M. Metamorfosis de la novela. Madrid, Taurus, 1971.

- Altamirano, C. (Ed.) La Argentina en el siglo XX. Buenos Aires: Ariel/UNQ, 1999.

- Altamirano, C. y Sarlo, B. (comp.) Literatura y sociedad. Buenos Aires: Hachette, 1983.

- Altamirano, C., "Raymond Williams, 1921-1988", en Punto de vista, XI, 33, set-dic. 1988, pp. 1-2.

- Altamirano, Carlos, "De la historia política a la historia intelectual", en Prismas. Revista de Historia Intelectual, año 9, $\mathrm{N}^{\circ}$ 9, Buenos Aires, Universidad Nacional de Quilmes, 2005 .

- Altamirano, Carlos, "La fundación de la literatura argentina", Punto de vista, Buenos Aires: II, 7, noviembre 1979. 
- Altamirano, Carlos, "Lo imaginario como campo del análisis histórico y social" en Punto de vista, XIII, 38, octubre 1990, Buenos Aires: pp. 11 a 14.

- Altamirano, Carlos, "Proposiciones para una teoría social de la cultura", en Prismasunto de vista, IV, 11, marzo-junio 1981, p. 20 y ss.

- Altamirano, Carlos, Bajo el signo de las masas, Buenos Aires, Ariel, 2001.

- Altamirano, Carlos, Peronismo y cultura de izquierda, Buenos Aires, Temas, 2001.

- Anderson, Benedict, Comunidades imaginadas. Reflexiones sobre el origen y la difusión del nacionalismo, México, FCE, 1994.

- Antelo, Raúl (2008). Crítica acéfala, Buenos Aires, Grumo.

- Arias, Martín - Hadis, Martín (ed.), Borges profesor, Buenos Aires: Emecé, 2000.

- Aristóteles. Poética. Buenos Aires: Emecé, 1947.

- Auerbach, Erich. Mimesis. Mexico, FCE, 1950.

- Avaro, N., "Sur en debate: moral y literatura", ponencia presentada en el III Congreso Internacional de Teoría y Crítica Literaria, Rosario, Agosto de 2002 (mimeo).

- Avaro, N. y A. Capdevila, Denuncialistas. Literatura y polémica en los '50, Buenos Aires, Santiago Arcos, 2004. 
- Balderston, Daniel et al., Ficción y política. La narrativa argentina durante el proceso militar, Buenos Aires, Alianza Estudio, 1987.

- Bardauil, Pablo. "El excéntrico Jaime Rest", Políticas de la crítica. Historia de la crítica literaria en la Argentina. Nicolás Rosa (Comp.) Buenos Aires: Biblos, 1999. 183-215.

- Barthes, Roland (2004). Lo Neutro, Buenos Aires, Siglo XXI.

- Barthes, Roland (2005). La preparación de la novela, Buenos Aires, Siglo XXI.

- Barthes, Roland, El grado cero de la escritura, México: Siglo XXI, 1973.

- Benjamin, Walte, Angelus Novus, Barcelona, Edhasa, 1971.

- Benjamin, Walter, Discursos interrumpidos I, Taurus, Buenos Aires: 1989.

- Benjamin, Walter, el concepto de crítica de arte en el romanticismo alemán, Madrid, Península, 1988.

- Benjamin, Walter, El origen del drama barroco alemán, Madrid, Taurus, 1990.

- Benjamin, Walter, Para una crítica de la violencia y otros ensayos. Iluminaciones IV. Taurus, Madrid, 1991.

- Benjamin, Walter, Sobre el programa de la filosofía futura, Barcelona, Planeta, 1986.

- Benjamin, Walter, Tentativas sobre Brecht. Iluminaciones III. Taurus, Madrid, 1975. 
- Bergman, Ingmar. Four Screenplays of Ingmar Berman. Londres, Secker and Warburg, 1960.

- Bianco, José, Ficción y reflexión, México, Fondo de Cultura Económica, 1988.

- Blanchot, Maurice (1978). El libro que vendrá, Caracas, Monte Ávila Editores.

- Boileau-Narcejac. La novela policial. Buenos Aires: Paidós, 1968.

- Booth, Wayne C. The Retoric of Fiction. Chicago, Chicago University Press, 1965.

- Borges, Jorge Luis, Discusión, Buenos Aires: Alianza, 1998.

- Borges, Jorge Luis, El idioma de los argentinos, Buenos Aires: Alianza, 1998.

- Borges, Jorge Luis, el tamaño de mi esperanza, Buenos Aires: Alianza, 1998 .

- Borges, Jorge Luis, Otras inquisiciones, Buenos Aires: Alianza, 1998 .

- Boudieu, Pierre, Campo intelectual y campo de poder. Buenos Aires: Folios, 1983.

- Bourdieu, Pierre, Homo Academicus, París, Minuit, 1984.

- Bourdieu, Pierre, La distinción. Crítica social del juicio, Madrid, Taurus, 1988.

- Bourdieu, Pierre, Las reglas del arte, Barcelona, Anagrama, 1995 
- Bourdieu, Pierre, Razones prácticas. Sobre la teoría de la acción, Barcelona, Anagrama, 1997.

- Bourdieu, Pierre. "Campo intelectual y proyecto creador", en Pouillon y otros. Problemas del estructuralismo. México, Siglo XXI, 1967.

- Bourdieu, Pierre. Intelectuales, política y poder. Buenos Aires: Eudeba, 2000.

- Bowra, C. M. From Virgil to Milton. Londres, Macmillan, 1967 .

- Bowra, C. M. Heroic Poetry. Londres, Macmillan, 1964.

- Buchbinder, P. La Facultad de Filosofía y Letras 1943-1965. s/d., mimeo, Universidad Nacional de Buenos Aires: Boletín del Instituto de Sociología, Boletín de Informaciones, Departamento de Sociología.

- Buchbinder, P., La Facultad de Filosofía y Letras 1943-1965. s/d., mimeo, Universidad Nacional de Buenos Aires: Boletín del Instituto de Sociología, Boletín de Informaciones, Departamento de Sociología.

- Buchrucker, C. Nacionalismo y Peronismo. La Argentina en la crisis ideológica mundial (1927-1955). Buenos Aires: Sudamericana, 1987.

- Bueno, Mónica y Miguel Angel Taroncher, Centro Editor de América Latina. Capítulos de una historia, Buenos Aires: SigloXXI, 2006.

- Burke, Kenneth. The Philosopy of Literary Form. Baton Rouge, Luiciana State University, 1941. 
- Calveiro, Pilar. Política y/o violencia. Una aproximación a la guerrilla de los años 70, Buenos Aires, Norma, 2005.

- Castagnino, Raúl H. ¿Qué es literatura? Buenos Aires: Nova, 1954.

- Castagnino, Raúl H. El análisis literario. Buenos Aires: Nova, 1953.

- Castagnino, Raúl H. Teoría del teatro. Buenos Aires: Nova, 1959.

- Casullo, Nicolás. "Investigaciones culturales y pensamiento crítico". En: Sociedad, n 5, UBA, oct-nov. 1994.

- Casullo, Nicolás. Modernidad y cultura crítica, Buenos Aires: Paidos, 1998.

- Croce, Benedetto. Breviario di estetica. Bari, Latersa, 1913.

- Croce, Marcela, Contorno. Izquierda y proyecto cultural. Buenos Aires: Colihue, 1996.

- Dalmaroni, Miguel, La palabra justa. Literatura, crítica y memoria en. Argentina (1960-2002). Santiago de Chile, Melusina / RIL editores, 2004 .

- David, Guillermo, Carlos Astrada. La filosofía argentina, Buenos Aires: El Cielo por Asalto, 2004.

- Deleuze, Gilles (1995). Conversaciones, Valencia, Pretextos.

- Djament, Leonora, La vacilación afortunada. H. A. Murena: un intelectual subversivo, Buenos Aires, Colihue, 2007. 
- Dosse, François. La marcha de las ideas. Valencia: Universitat de Valencia, 2007.

- During, S., (ed.), The Cultural Studies Reader. London, New York: Routledge, 1993.

- Eagleton, Terry, Marxism and Literary Criticism, University of California Press, California, 1976.

- Eagleton, Terry, The Ideology of the Aesthetic, Oxford, Blackwell, 1990.

- Eagleton, Terry, Una introducción a la teoría literaria, MéXiCO, FCE, 1988.

- Eagleton, Terry, Walter Benjamin. Or Towards A Revolutionary Criticism, Londres, Verso Editions, 1981.

- Eagleton, Terry. Criticism and Ideology. Londres, New Left Review Editions, 1978.

- Eagleton, Terry. Ideology. An Introduction, London, Verso, 1991.

- Eagleton, Terry. The Function of Criticism. Londres, Verso, 1980.

- Erlich, Victor. El formalismo ruso. Barcelona, Seix Barral, 1975.

- Escarpit, Robert. L'humor. Paris, PUF, 1958.

- Escarpit, Robert. Sociologie de la littérature. Paris, PUF, 1960.

- Ferrater Mora, J. Diccionario de filosofía. 2 tomos. Buenos Aires: Sudamericana, 1975. 
- Foucault, Michel (1994). De lenguaje y literatura, Barcelona, Paidós.

- Foucault, Michel. "Hospicios, sexualidad, prisiones". Revista Versus 1 (1975): 30-31.

- Foucault, Michel. "Les intellectuels et le pouvoir". L'Arc 49 (1972): 3-10 ("Los intelectuales y el poder" Microfísica del poder. Madrid: La Piqueta, 1992. 78-88).

- Foucault, Michel. "Respuesta a Esprit". El discurso del poder. Oscar Terán (Comp.). México: Folios, 1985. 84-85.

- Foucault, Michel. "Vérité et pouvoir". L'Arc 70 (1977): 1626. ("Verdad y poder". Un diálogo sobre el poder. Madrid: Alianza, 1997. 128-145).

- Foucault, Michel. Nacimiento de la biopolítica. Buenos Aires: Fondo de Cultura Económica, 2006a.

- Foucault, Michel. Seguridad, territorio, población. Buenos Aires: Fondo de Cultura Económica, 2006b.

- Gadamer, Hans-Gerg. Verdad y método. Salamanca: Ediciones Sígueme, 1991.

- Gattari, Verónica, y Jessica Visotsky. Recordar en el olvido. Dictadura adelantada en la universidad argentina: la represión en la Universidad Nacional del Sur (1975), 2002. Mimeo.

- Germani, Gino, Política e massa. Estudo sôbre a integração das massas na vida politica dos paises em desenvolvimento, Belo Horizonte, Facultad de Dereito - Universidade de Minas Gerais, 1960 . 
- Germani, Gino, Política y sociedad en una época de transición, Buenos Aires, Paidós, 1966.

- Gilman, Claudia. Entre la pluma y el fusil, Buenos Aires, Siglo XXI, 2003.

- Giraud, P. La estilística. Buenos Aires: Nova, 1970.

- González, Horacio. Restos pampeanos. Ciencia, ensayo y política en la cultura argentina del siglo XX. Buenos Aires: Colihue, 1999.

- González, Horacio. Retórica y locura. Para una teoría de la cultura argentina. Buenos Aires: Colihue, 2002.

- González, Horacio. Retórica y locura. Para una teoría de la cultura argentina. Buenos Aires: Colihue, 2002.

- Gramsci, Antonio. Literatura y vida nacional. Buenos Aires: Lautaro, 1961 .

- Gramsci, Antonio. Los intelectuales y la organización de la cultura. Buenos Aires: Nueva Visión, 2000.

- Gramuglio, María Teresa, "Sur: constitución del grupo y proyecto cultural", Punto de Vista, año 6, n 17, 1983.

- Gramuglio, María Teresa, "Sur en la década del treinta. Una revista política", Punto de vista, n²8, 1986.

- Gramuglio, María Teresa, "Bioy, Borges y Sur. Diálogos y duelos", Punto de vista, $\mathrm{n}^{\circ} 34,1989$.

- Gramuglio, María Teresa. "Las minorías y la defensa de la cultura. Proyecciones de un tópico de la crítica literaria inglesa en Sur", Boletín/7 del Centro de Estudios de Teoría y Crítica Literaria, Rosario, octubre de 1999. pp. 71-77. 
- Gramuglio, María Teresa. "Una década dinámica. Transformaciones, posiciones y debates en la literatura argentina en los años treinta", Nueva Historia argentina, tomo 7. Buenos Aires: Sudamericana, 2001.pp. 333-380.

- Gramuglio, María Teresa, "Posiciones de Sur en el espacio literario. Una política de la cultura", en Sylvia Saítta (directora), El oficio se afirma, tomo 9, Historia de la literatura argentina, Buenos Aires, Emecé, 2004.

- Gramuglio, María Teresa. (Ed.) "Sur, una minoría cosmopolita en la periferia occidental", Altamirano, C., (ed.), Historia de los intelectuales en América Latina, Buenos Aires, Katz, 2010. pp. 192-209.

- Guerrero, Luis Juan. ¿Qué es la belleza? Buenos Aires: Columba, 1954.

- Guerrero, Luis Juan. Estética operatoria en tres direcciones. I. Revelación y acogimiento de la obra de arte. Estética de las manifestaciones artísticas. Buenos Aires: Losada, 1956.

- Guerrero, Luis Juan. Estética operatoria en tres direcciones. II. Creación y ejecución de la obra de arte. Estética de las potencias artísticas. Buenos Aires: Losada, 1957.

- Guerrero, Luis Juan. Estética operatoria en tres direcciones. Promoción y requerimiento de la obra de arte. Estética de las tareas artísticas. Buenos Aires: Losada, 1967. 
- Hall, Stuart. "Notas sobre la deconstrucción de 'lo popular"", en Samuel, Raphael (comp.) Historia popular y teoría socialista, Barcelona, Grijalbo, 1984.

- Halperin Donghi, Tulio. El espejo de la historia. Buenos Aires: Sudamericana, 1987.

- Halperín Donghi, Tulio. Historia de la Universidad de Buenos Aires:. Buenos Aires: Eudeba, 1962.

- Halperin Donghi, Tulio. La larga agonía de la Argentina peronista. Buenos Aires: Ariel, 1994.

- Hauser, Arnold. El manierismo. Madrid, Guadarrama, 1965.

- Hauser, Arnold. Historia social de la literature y el arte. 3 Vols. Madrid, Guadarrama, 1974.

- Hauser, Arnold. Sociología del arte. 2 Vols. Madrid, Guadarrama, 1975.

- Hernández Arregui, J. J. Imperialismo y Cultura. Buenos Aires: Hachea, 1964 .

- Hobsbawm, Eric, La era del imperio, Madrid, Cátedra, 1998.

- Hobsbawm, Eric, Naciones y nacionalismo desde 1780, Barcelona, Crítica, 1991.

- Hobsbawm, Eric. "La fabricación de naciones" en La era del capitalismo, Madrid, Guadarrama, 1977.

- Hoggart, Richard. Speaking to each other. 2 Vols. Londres, Penguin Books, 1973.

- Hoggart, Richard. The uses of Iiteracy. Middlesex, Penguin Books, 1962 . 
- Holub, Robert, Reception Theory. A Critical Introduction, London-New York, Methuen, 1984.

- Huyssen, Andreas, After the Great Divide, Modernism, Mass Culture, Postmodernism, Bloomington, Indiana University Press, 1986.

- Huyssen, Andreas, En busca del futuro perdido. Cultura y memoria en tiempos de globalización, México, Fondo de Cultura Económica, 2002 .

- James, Daniel, Resistencia e integración, Buenos Aires, sudamericana, 1990 .

- James, Daniel (director), Violencia, proscripción y autoritarismo: 1955-1976, tomo IX, Nueva Historia Argentina, Buenos Aires, Sudamericana, 2003.

- Jameson, Frederic. Documentos de cultura, documentos de barbarie. Madrid, Visor, 1990.

- Jameson, Frederic. Marxism \& Form. Princeton, Princeton University Press, 1974 .

- Jameson, Frederic. The Prison-House of Language. A Critical Account of Structuralism and Russian Formalism. Princeton, Princeton University Press, 1972.

- Jameson, Fredric, Ensayos sobre el posmodernismo, Buenos Aires: Imago Mundi, 1991.

- Jameson, Fredric, La cárcel del lenguaje. Perspectiva crítica del estructuralismo y del formalismo ruso, Ariel, Barcelona, 1980. 
- Jameson, Fredric, The Ideologies of Theory, Minneapolis, University of Minnesotta Press, 1988, 2 vol.

- Jauss, Hans Robert, Experiencia estética y hermenéutica literaria, Madrid, Taurus, 1982.

- Jauss, Hans Robert, Pour une esthétique de la réception, Gallimard, París, 1975.

- Jay, Martin, Adorno, Madrid, Siglo XXI, 1988.

- Jay, Martin, Campos de fuerza. Entre historia intelectual y Crítica cultural, Paidós, Buenos Aires, 2003

- Jay, Martin, Cantos de experiencia. Variaciones modernas sobre un tema universal, Buenos Aires, Paidos, 2009.

- Jay, Martin, Socialismo fin-de-siècle, Buenos Aires, Nueva Visión, 1990.

- Jitrik, Noé (director). Historia crítica de la literatura argentina. Vol. 10. La irrupción de la crítica (coordinado por Cella, Susana). Buenos Aires: Emecé, 1999.

- Jolles, A., Formas simples, Sao Paulo, Cultrix, 1976,

- Kafka, Franz (1988). "El silencio de las Sirenas", Obra completa, vol. IV, Madrid, Edicomunicación.

- Katra, William H., Contorno: Literary Engagement in PostPeronist Argentina, London and Toronto: Associated University Presses, 1988 .

- Kayser, Wolfgang. Interpretación y análisis de la obra literaria. Madrid, Gredos, 1954. 
- Kermode, Frank, "El valor literario considerado a cierta distancia", en Historia y valor. Ensayos sobre literatura y sociedad, Barcelona, Península, 1990.

- King, John, Sur. Estudio de la revista argentina y de su papel en el desarrollo de una cultura. 1931-1970, México, FCE, 1989.

- Kołakowski, Leszek, La presencia del mito, Buenos Aires, Amorrortu, 1975.

- Krieger, Murray, Teoría de la crítica, Madrid, Visor, 1992.

- Leavis, F. R. The Great Tradition. Londres, Chatto \& Windus, 1948 .

- Leavis, Q. D. Fiction and the Reading People. Londres, Chatto \& Windus, 1965.

- Lewis, C. S. La alegoría del amor. Buenos Aires: Eudeba, 1969.

- Link, Daniel, El juego de los cautos. La literatura policial: de Poe al caso Giubileo, Buenos Aires: La Marca, 1992.

- Link, Daniel, Leyenda. Literatura argentina en cuatro cortes, Buenos Aires: Entropía, 2006.

- Luhn, E., Marxismo y modernismo. Un estudio histórico de Lukács, Benjamin y Adorno, México, FCE, 1986.

- Mafud, Julio, El desarraigo argentino: clave argentina para un estudio americano. Buenos Aires, Américalee, 1959.

- Magny, Claude-Edmond, Littérature et critique, Paris: Payot, 1971. 
- Mangone, C. y Warley, J. A. Universidad y peronismo (19461955). Buenos Aires: CEAL, 1984.

- Mangone, Carlos, y Jorge Warley. "La modernización de la crítica. La revista Contorno". Historia de la Literatura Argentina. Buenos Aires: Centro Editor de América Latina, 1982. Vol. 122. 433-460.

- Martínez Estrada, Ezequiel, Radiografía de la Pampa, Buenos Aires, Babel, 1933.

- Martínez, Diego. "Con los puntos sobre las AAA de Bahía Blanca". Página/12 (3 mayo 2007). Web.

- Martínez, Diego. "De cómo Madueño 'limpió' la facultad de 'subversivos'". Página/12 (30 mayo 2005). Web.

- Martínez, Diego. "Primero acusado y después acusador". Página/12 (18 abril 2007). Web.

- Martínez, Diego. "Una historia olvidada que se reabre". Página/12 (9 abril 2007). Web.

- Milner, Jean-Claude (1996), La obra clara. Lacan, la Ciencia, la filosofía, Buenos Aires, Manantial.

- Narcejac, T., Una máquina de leer: la novela policial, MéxiCO, FCE, 1986.

- Navarro Gerasi, Marysa, Los nacionalistas, Buenos Aires: Jorge Álvarez, 1969.

- Nicolet, Le Goff, Duby, Romano, Tenenti y otros. Niveles de cultura y grupos sociales. Edición preparada por Louis Bergeron. Mexico, Siglo XXI, 1977. 
- Otero, José M., 30 años de revistas literarias argentinas (1960-1989), Buenos Aires: Catedral al Sur Editores, 1990.

- Panesi, Jorge (2005). "Los dos tiempos de la crítica", Orbis Tertius, año $\mathrm{x}, \mathrm{n}^{\circ}$ 11, La Plata. Publicación online en el sitio web de la revista: http://163.10.30.238:8080/OrbisTertius/numeros/numero-11/1panesi-los-dos-tiempos-de-la-critica.pdf.

- Pastormerlo, Sergio, Borges crítico, Buenos Aires: Fondo de Cultura Económica, 2007.

- Perloff, M., Radical Artifices. Writing Poetry in the age of Media, Chicago, University of Chicago Press, 1994.

- Pezzoni, Enrique, El texto y sus voces, Buenos Aires: Sudamericana, 1986 .

- Phillips, Katharine, "Borges as concomitant critic", en Latin American Literary Review, n³, Pittsburgh, 1973.

- Piglia, Ricardo, Crítica y ficción, Buenos Aires: Siglo Veinte, 1990.

- Podlubne, J., "Sur en los 60. Hacia una nueva sensibilidad crítica", en Badebec. Revista del Centro de Estudios de Teoría y Crítica Literaria, $\mathrm{N}^{\circ}$ 2, marzo de 2012. On-line en: http://www.badebec.org/badebec 2/sitio/pdf/Podlubne.pdf

- Podlubne, J., Escritores de Sur. Los inicios literarios de José bianco y Silvina Ocampo, Rosario, Beatriz Viterbo editora / Universidad Nacional de Rosario, 2011. 
- Podlubne, J., "Moral y literatura en Sur: un debate tardío", en Boletín/11 del Centro de Estudios de Teoría y Crítica Literaria, Rosario, Diciembre de 2003. pp. 42-58.

- Poggioli, Renato, Teoría de la vanguardia, Madrid, Revista de Occidente, 1964.

- Portantiero, Juan Carlos, La producción del orden. Ensayos sobre la democracia entre el Estado y la sociedad, Buenos Aires, Nueva Visión, 1988.

- Praz, Mario (1948), La carne, la morte e il diavolo nella litteratura romantica, Firense, Sansoni [La carne, la muerte y el diablo (en la literatura romántica), Caracas, Monte Ávila, 1969. Trad. Jorge Cruz].

- Praz, Mario (1972), Il patto col serpente. Paralipomeni di La carne, la morte e il diavolo nella litteratura romantica, Milan, Mondadori, [El pacto con la serpiente. Paralipómenos de La carne, la muerte y el diablo en la literatura romántiCa, México, FCE, 1988. Trad. Ida Vitale].

- Prieto, Adolfo, Sociología del público, Buenos Aires, Leviatán: 1956.

- Richards, I. A. Practical Criticism. Londres, Routledge and Kegan Paul, 1929.

- Richards, I. A. Principles of Literacy Criticism. Londres, Routledge and Kegan Paul, 1925.

- Rivera, J. Apogeo y crisis de la industria del libro: 19551970. Buenos Aires: CEAL, 1980. 
- Rivera, J. El auge de la industria cultural (1930-1955). Buenos Aires: CEAL, 1981.

- Rivera, Jorge, El folletín y la novela popular, Buenos Aires: CEAL, 1967.

- Rock, David, Argentina 1516-1987: De la colonización española hasta Raúl Alfonsín, Alianza, Buenos Aires: 1989.

- Romero, José Luis, Argentina: imágenes y perspectivas, Buenos Aires, Raigal, 1956.

- Romero, José Luis, El ciclo de la revolución contemporánea, Buenos Aires, Argos, 1948.

- Romero, José Luis. "Presentación y Programa", Jornadas de Extensión Universitaria, Buenos Aires, Imprenta de la Universidad de Buenos Aires, 1958.

- Romero, José Luis. El desarrollo de las ideas en la sociedad argentina del siglo XX. Buenos Aires: Del Solar, 1983.

- Romero, José Luis. La cultura occidental, Buenos Aires, Columba, 1953.

- Romero, José Luis. Las ideologías de la cultura nacional y otros ensayos. Buenos Aires: CEAL, 1982.

- Rosa, N., Los fulgores del simulacro. Santa Fe: Cuadernos de extensión universitaria de la UNL, 1987.

- Rosa, Nicolás, "Borges y la crítica", Los libros, Buenos Aires: $n^{\circ} 26,1972$.

- Rosa, Nicolás, "La crítica literaria contemporánea" (1981) en Zanetti, Susana (coord.) Capítulo, La historia de la literatura argentina, 113, Buenos Aires: : CEAL. 
- Said, Edward. Beginnings. Intention and Method, New York, Columbia University Press, 1985.

- Said, Edward. El mundo, el texto, el crítico, Buenos Aires: Debate, 2004 .

- Said, Edward. Representaciones del intelectual. Barcelona, Paidós, 1996.

- Sarlo, B., "¿Arcaicos o marginales? Situación de los intelectuales en el fin de siglo", en Punto de vista, n 47, diciembre 1993.

- Sarlo, B., La batalla de las ideas, Buenos Aires, Ariel, 2001.

- Sarlo, Beatriz, "Crítica de la lectura: ¿un nuevo canon?", en Punto de vista, $\mathrm{n}^{\circ}$ 28, Buenos Aires: 1985.

- Sarlo, Beatriz, "Raymond Williams: una relectura", en Punto de vista, XVI, 45, abril 1993, p. 12 y ss.

- Sarlo, Beatriz. "Lo popular en la historia de la cultura", en Punto de vista, XII, 35, set-nov. 1989.

- Sarlo, Beatriz. "Raymond Williams y Richard Hoggart: cultura y sociedad", en Punto de vista, II, 6, julio 1979.

- Sarmiento, Domingo Faustino, Facundo (Prólogo de Noé Jitrik y Notas de Nora Dottori y Susana Zanetti), Buenos Aires, Hyspamerica, 1986.

- Sartre, Jean Paul, ¿Qué es la literatura?, Buenos Aires: Losada, 1950 .

- Sayer, D., Capitalismo y modernidad, Buenos Aires: Losada, 1995. 
- Schücking, Levin. El gusto literario. Mexico, FCE, 1950.

- Shklovski, Víctor. Sobre la prosa literaria. Barcelona, Planeta, 1971.

- Shua, Ana María, "Dictadura 76-83: efectos de lectura" (2006) . Web.

- Shumaker, Wayne. Literature and the Irrational. Nueva Cork, Washington Square Press, 1966.

- Sigal, Silvia. Intelectuales y poder en Argentina. La década del sesenta. Buenos Aires: Siglo XXI, 2002.

- Steiner, George, Presencias reales, Barcelona, Destino, 1991.

- Steiner, George. Languaje and Silence. Londres, Penguin Books, 1969 .

- Strada, Vittorio (comp.), Problemi di teoria del Romanzo. G. Lukács, M.Bachtin e altri, Torino, Einaudi, 1976.

- Strauss, L., Persecution and the Art of Writing, Chicago \& London, The University of Chicago Press, 1988.

- Suasnabar, Claudio. Universidad e intelectuales: educación y política en la argentina (1955-1976). Buenos Aires: Manantial, 2004 .

- Terán, Oscar, En busca de la ideología argentina. Buenos Aires: Catálogos Editora, 1986.

- Terán, Oscar, Nuestros años sesentas. La formación de la nueva izquierda intelectual argentina. Buenos Aires: El cie10 por Asalto, 1993. 
- Thompson, E. P., The Making of the English Working Class, London: Victor Gollancz, 1963 (ed. española: La formación de la clase obrera en Inglaterra, Madrid: Crítica, 1989).

- Thorp, Willard. "Pilgrims' Return", en Spiller, Robert E. et alt., Literary History of the United States: History, New York: Macmillan, 1974. pp. 827-842.

- Todorov, Les genres du discours, Paris, Seuil, 1978.

- Todorov, T. "Los géneros literarios", en Introducción a la literatura fantástica, México, Premia, 1980.

- Todorov, T., "Tipología de la novela policial", en Fausto, $\mathrm{n}^{\circ}$ 4, Buenos Aires: marzo-abril de 1974.

- Todorov, T., "Typologie du roman policier", en Poétique de la prose, Paris, Du Seuil, 1966.

- Todorov, Tzevan. (Comp.) Teoría de los formalistas rusos. Mexico, Siglo XXI, 1973.

- Todorov, Tzevan. Introducción a la literatura fantástica. Buenos Aires: Tiempo contemporáneo, 1972.

- Tomachevski, Boris, Teoría de la literatura, Madrid, Akal, 1982.

- Trilling, Lionel, Imágenes del Yo romántico. Buenos Aires: Sur, 1956.

- Trilling, Lionel, La imaginación liberal. Ensayos sobre la Iiteratura y la sociedad. Buenos Aires: Sudamericana, 1956. Trad. Enrique Pezzoni. 
- Vázquez, M. C. y Pastormerlo, S. (comps.), Literatura argentina. Perspectivas de fin de siglo, Buenos Aires: Eudeba, 2001.

- Walzer, Michael, La compañía de los críticos, Buenos Aires, Nueva Visión, 1988.

- Warley, Jorge, "Un acuerdo de orden ético", en Punto de Vista, $\mathrm{N}^{\circ}$ 17, Buenos Aires, Abril-Junio de 1983. pp. 12-14.

- Watt, Ian. The Rice of the Novel. Studies in Defoe, Richardson and Fielding. Londres, Penguin Books, 1972.

- Weber, Alfred, Historia de la cultura, México, Fondo de Cultura Económica, 1941.

- Wellek, René y Warren, Austin. Teoría literaria. Madrid, Gredos, 1953.

- Wellek, René. Concepts of criticism. New Heaven, Yale University Press, 1963.

- Wellek, René. Historia de la crítica moderna: 1750-1950. Madrid, Gredos, 1959.

- Williams, Raymond, Solos en la ciudad. La novela inglesa de Dickens a D. H. Lawrence, Debate, 1997.

- Williams, Raymond. Cultura y materialismo, Buenos Aires: La Marca Editora, 2012.

- Williams, Raymond. Culture and Society. 1780-1950. Londres, Penguin Books, 1971a (Cultura y sociedad 1780-1950. De Coleridge a Orwell, Buenos Aires, Nueva Visión, 2001). 
- Williams, Raymond. Marxism and literature. Oxford, Oxford University, 1977 (Marxismo y literatura. Barcelona, Península/Biblos, 2000).

- Williams, Raymond. Palabras clave: un vocabulario de la cultura y la sociedad. Buenos Aires: Nueva Visión, 2003.

- Williams, Raymond. The Long Revolution. Londres, Penguin Books, 1971b (La larga revolución, Buenos Aires, Nueva visión, 2003).

- Willson, Patricia, La Constelación Sur. Traductores y traducciones en la literatura argentina del siglo XX, Buenos Aires: Siglo XXI, 2004.

- Wilson, Edmund. El Castillo de Axel. Madrid, CUPSA, 1969.

- Wilson, Edmund. Literatura y sociedad. Buenos Aires: Sur, 1957.

- Wismann, Heinz (ed), Walter Benjamin et Paris, París, Cerf, 1986.

En las diversas etapas del desarrollo de la presente investigación fueron consultadas además publicaciones periódicas importantes como Centro, Imago Mundi, Sur, RUBA, Revista de la Universidad de La Plata, Cuadernos del Sur, Marcha, Hispamérica, Los Libros, Punto de Vista, Crisis y Vigencia, entre otras. 